\title{
Site Selective Acceptorless Dehydrogenation of Aliphatics Enabled by Organophotoredox/Cobalt Dual Catalysis
}

\author{
Min-Jie Zhou, ${ }^{\dagger},+$ Lei Zhang, ${ }^{\S}$ Guixia Liu, ${ }^{\ddagger}$ Chen Xu, ${ }^{*}{ }^{\dagger}$ Zheng Huang ${ }^{*}, \dagger, \star \S$ \\ †Shenzhen Grubbs Institute and Department of Chemistry, Southern University of Science and \\ Technology, Shenzhen 518055, China \\ the State Key Laboratory of Organometallic Chemistry, Shanghai Institute of Organic Chemistry, \\ University of Chinese Academy of Sciences, Chinese Academy of Sciences, 345 Lingling Road, \\ Shanghai 200032, China \\ ${ }^{\S}$ School of Chemistry and Material Sciences, Hangzhou Institute of Advanced Study, University of \\ Chinese Academy of Sciences, 1 Sub-lane Xiangshan, Hangzhou 310024, China
}

\section{Table of Contents}

1) General Information..................................................S2

2) Preparation of Catalysts and Substrates....................................S3

3) Reaction Setup.........................................................S11

4) Reaction Optimization and Control Experiments........................S12

5) Analysis of the Side Products and the PC Decomposition Products.........S16

6) Detection of $\mathrm{H}_{2}$ for the Dehydrogenation of S18.........................S18

7) General Procedure for the Acceptorless Dehydrogenation of Aliphatics...S19

8) Intermolecular and Intramolecular Competitive Experiments..............S20

9) Synthesis of Pharmaceutical Intermediates...............................S23

10) Gram-Scale Synthesis of Compound P100.............................S25

11) Mechanistic Investigation..........................................S26

12) Analytic Data of Products...........................................S41

13) Supplementary References...........................................S68

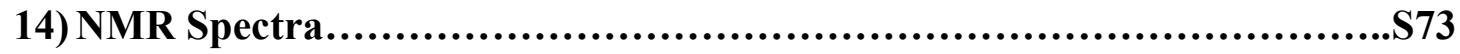




\section{General Information}

Unless otherwise noted, all solvents used in the reactions were distilled from appropriate drying agent prior to use. ${ }^{1}$ Solvents used for acceptorless dehydrogenation of alkane were degassed by three cycles of freeze-pump-thaw cycling. All cobalt complexes were prepared following literature procedures. 2-Chloroanthraquinone (99\%) was purchased from TCI and used without further purification. Uncommercial available substrates were synthesized according to literature. The visible lights (400-415 nm LED, $20 \mathrm{~W}$ ) were purchased from Facai LED Zhaoming Co. Ltd. (website: https://shop358870690.taobao.com). ${ }^{1} \mathrm{H}$ NMR and ${ }^{13} \mathrm{C}$ NMR spectra were recorded with a Brucker AV 400 or 600 spectrometer at 400 or $600 \mathrm{MHz}\left({ }^{1} \mathrm{H}\right.$ NMR) and 101 or $125 \mathrm{MHz}\left({ }^{13} \mathrm{C}\right.$ NMR). Chemical shifts for ${ }^{1} \mathrm{H}$ NMR spectra were reported in ppm down field from internal $\mathrm{Me}_{4} \mathrm{Si}(\delta 0.0)$ and relative to the signal of chloroform- $d(\delta 7.26$, singlet). Chemical shifts for ${ }^{13} \mathrm{C}$ NMR spectra were reported in ppm relative to the signal of chloroform- $d$ ( $\delta 77.00$, triplet). Multiplicities were given as: s (singlet); brs (broad singlet); d (doublet); t (triplet); q (quartet); dd (doublets of doublet); m (multiplets) and etc. HRMS were recorded on an IonSpec FT-ICR mass spectrometer with ESI resource. All GC-MS analyses were performed on an Agilent 7980A GC system equipped with a 5977B MS detector. All GC analyses were performed on Agilent 7980A gas chromatograph equipped with $(30 \mathrm{~m} \times 320 \mu \mathrm{m} \times 0.25 \mu \mathrm{m})$ HP-5 column and a flame-ionization detector. GC yields were determined using standard curves with $n-\mathrm{C}_{16} \mathrm{H}_{34}$ as internal standard. For all analyses following method has been employed throughout the study: $\mathrm{N}_{2}$ carrier gas, Inlet temperature: $300{ }^{\circ} \mathrm{C}$, Inlet Pressure: $104.4 \mathrm{KPa}$, Injection Volume: $1.0 \mu \mathrm{L}$, Split ratio: 20:1, Split flow: $20.0 \mathrm{~mL} / \mathrm{min}$, Flow rate: $1.0 \mathrm{~mL} / \mathrm{min}$, Temperature: $70{ }^{\circ} \mathrm{C}$ was increased to $300{ }^{\circ} \mathrm{C}$ at 20 ${ }^{\circ} \mathrm{C} / \mathrm{min}$ rate and holds for further $1.5 \mathrm{~min}$, Detector temperature: $280{ }^{\circ} \mathrm{C}$, Hydrogen flow: 30 $\mathrm{mL} / \mathrm{min}$, Air flow: $300 \mathrm{~mL} / \mathrm{min}$, Makeup nitrogen flow: $25 \mathrm{~mL} / \mathrm{min}$. Hydrogen gas content was analyzed by gas chromatography (Agilent 7890A, argon as a carrier gas and $5 \AA$ molecular sieve column, a thermal conductivity detector). Stern-Volmer luminescence quenching analyses were conducted using a Jasco FP-8300 spectrofluorometer. All ${ }^{1} \mathrm{H}$ NMR yields were determined using 1,3,5-trimethoxybenzene as internal standard. 


\section{Preparation of Catalysts and Substrates}

\section{Preparation of $\mathrm{Co}(\mathrm{dmgH})_{2} \mathrm{pyCl}([\mathrm{Co}]-\mathrm{A})$.}

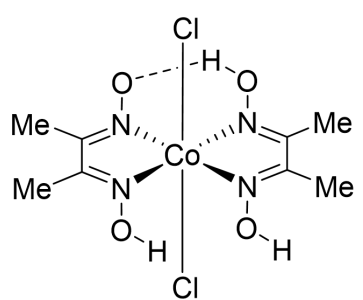

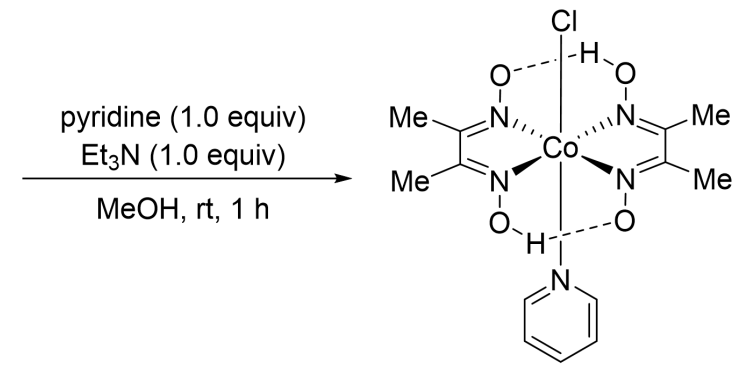

Following literature procedure, ${ }^{2}$ to a suspension of $\mathrm{Co}(\mathrm{dmgH})\left(\mathrm{dmgH} \mathrm{H}_{2}\right) \mathrm{Cl}_{2}(542 \mathrm{mg}, 1.5 \mathrm{mmol})$ in $\mathrm{MeOH}, \mathrm{Et}_{3} \mathrm{~N}(208 \mu \mathrm{L}, 1.5 \mathrm{mmol})$ was added at room temperature. The mixture was allowed to stir for 30 minutes until the mixture turned from green to clear dark brown solution. Then, pyridine $(121 \mu \mathrm{L}, 1.5 \mathrm{mmol})$ was added to the solution and the reaction mixture was allowed to stir for 1 hour at room temperature. After that, the flask was placed on ice for about 4 hours. The suspension was filtered and the precipitate was washed with cold water $(5 \mathrm{~mL})$, ethanol $(5 \mathrm{~mL})$, and diethyl ether $(5 \mathrm{~mL})$ to afford $\mathrm{Co}(\mathrm{dmgH})_{2} \mathrm{PyCl}(426 \mathrm{mg}, 79 \%$ yield $)$ as a brown solid. ${ }^{1} \mathrm{H}$ NMR data matches previously reported data. ${ }^{2} \mathrm{H}_{\mathrm{NMR}}\left(400 \mathrm{MHz}, \mathrm{CDCl}_{3}\right): \delta 8.27(\mathrm{~d}, J=6.0 \mathrm{~Hz}$, 2H), $7.70(\mathrm{t}, J=7.5 \mathrm{~Hz}, 1 \mathrm{H}), 7.23(\mathrm{t}, J=6.7 \mathrm{~Hz}, 2 \mathrm{H}), 2.40(\mathrm{~d}, J=0.9 \mathrm{~Hz}, 12 \mathrm{H})$.

\section{2-(4-Ethylphenoxy)pyridine (S13)}

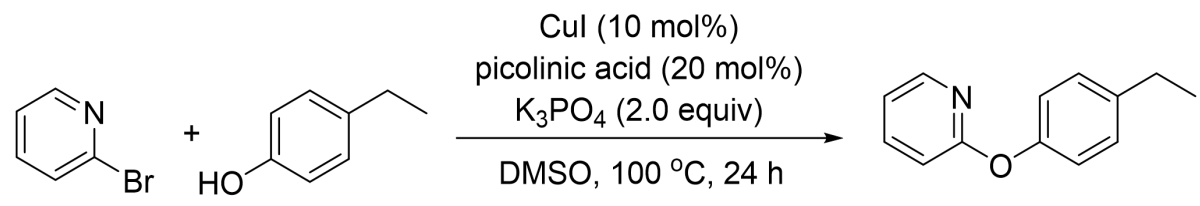

Following literature procedure, ${ }^{3}$ an oven-dried flask was charged with 4-ethyl phenol $(610.8 \mathrm{mg}$, $5.0 \mathrm{mmol}), \mathrm{K}_{3} \mathrm{PO}_{4}(2.12 \mathrm{~g}, 10.0 \mathrm{mmol}), \mathrm{CuI}(95.2 \mathrm{mg}, 0.5 \mathrm{mmol})$, and picolinic acid (123.1 $\mathrm{mg}$, $1.0 \mathrm{mmol})$. The flask was evacuated and backfilled with argon. DMSO (10 mL) and 2-bromopyridine $(572 \mu \mathrm{L}, 6.0 \mathrm{mmol})$ were added to the flask and then the mixture was heated at $100{ }^{\circ} \mathrm{C}$ for 24 hours. EtOAc $(5 \mathrm{~mL})$ and $\mathrm{H}_{2} \mathrm{O}(5 \mathrm{~mL})$ were added, and the mixture was filtered through a Celite pad. The organic layer was separated, and the aqueous layer was extracted twice with EtOAc. The combined organic layers were washed with water, dried over anhydrous $\mathrm{Na}_{2} \mathrm{SO}_{4}$, and filtered. The filtrate was concentrated, and the residue was purified by column chromatography using petroleum ether/EtOAc $=20: 1$ to give the product as a yellow oil $(746 \mathrm{mg}$, 74\% yield). ${ }^{1} \mathrm{H}$ NMR $\left(600 \mathrm{MHz}, \mathrm{CDCl}_{3}\right): \delta 8.20(\mathrm{dd}, J=5.0,2.0 \mathrm{~Hz}, 1 \mathrm{H}), 7.69-7.63(\mathrm{~m}, 1 \mathrm{H})$, 
7.24-7.19 (m, 2H), 7.08-7.02 (m, 2H), $6.97(\mathrm{dd}, J=7.1,5.0 \mathrm{~Hz}, 1 \mathrm{H}), 6.88(\mathrm{~d}, J=8.3 \mathrm{~Hz}, 1 \mathrm{H})$, $2.66(\mathrm{q}, J=7.6 \mathrm{~Hz}, 2 \mathrm{H}), 1.25(\mathrm{t}, J=7.6 \mathrm{~Hz}, 3 \mathrm{H}) ;{ }^{13} \mathrm{C} \mathrm{NMR}\left(101 \mathrm{MHz}, \mathrm{CDCl}_{3}\right): \delta 164.0,151.9$, $147.8,140.5,139.3,129.0,121.0,118.2,111.3,28.2,15.5$; ESI-HRMS calcd for $\left[\mathrm{C}_{13} \mathrm{H}_{14} \mathrm{NO}, \mathrm{M}+\right.$ $\mathrm{H}]^{+}: 200.1070$, Found: 200.1071.

2-(Phenethylthio)pyrimidine (S42)

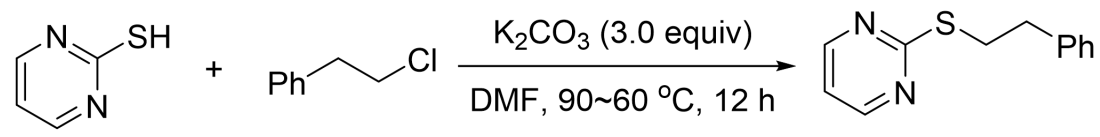

Following literature procedure, ${ }^{4}$ to a mixture of pyrimidine-2-thiol $(561 \mathrm{mg}, 5.0 \mathrm{mmol})$ and DMF $(10.0 \mathrm{~mL})$ was added $\mathrm{K}_{2} \mathrm{CO}_{3}(2.07 \mathrm{~g}, 15.0 \mathrm{mmol})$. The mixture was stirred at $90{ }^{\circ} \mathrm{C}$ for $1 \mathrm{~h}$, cooled to $60{ }^{\circ} \mathrm{C}$ and followed by addition of a solution of (2-chloroethyl)benzene (1.32 mL, 10.0 $\mathrm{mmol}) / \mathrm{DMF}(10.0 \mathrm{~mL})$. The reaction mixture was stirred at $60^{\circ} \mathrm{C}$ for 12 hours. Then, the reaction mixture was cooled to room temperature, poured into saturated ammonium chloride solution and extracted with $\mathrm{Et}_{2} \mathrm{O}$. The organic phase was dried over anhydrous $\mathrm{Na}_{2} \mathrm{SO}_{4}$ and filtered. The filtrate was evaporated and purified by flash column chromatography using petroleum ether/EtOAc $=$ 10:1 to give the product as a collorless oil $\left(1.0 \mathrm{~g}, 92 \%\right.$ yield). ${ }^{1} \mathrm{H}$ NMR $\left(600 \mathrm{MHz}, \mathrm{CDCl}_{3}\right): \delta 8.52$ (d, $J=4.8 \mathrm{~Hz}, 2 \mathrm{H}), 7.33-7.26(\mathrm{~m}, 4 \mathrm{H}), 7.24-7.19(\mathrm{~m}, 1 \mathrm{H}), 6.95(\mathrm{t}, J=4.8 \mathrm{~Hz}, 1 \mathrm{H}), 3.42-3.35(\mathrm{~m}$, 2H), 3.08-3.00 (m, 2H); ${ }^{13} \mathrm{C}$ NMR (151 MHz, $\left.\mathrm{CDCl}_{3}\right): \delta$ 172.4, 157.2, 140.4, 128.6, 128.4, 126.4, 116.4, 35.7, 32.2; ESI-HRMS calcd for $\left[\mathrm{C}_{12} \mathrm{H}_{13} \mathrm{~N}_{2} \mathrm{OS}, \mathrm{M}+\mathrm{H}\right]^{+}:$: 217.0794, Found: 217.0796 .

\section{4-Ethylbenzyl 2-(2-fluoro-[1,1'-biphenyl]-4-yl)propanoate (S87)}<smiles>CCOc1ccccc1-c1ccc(-c2ccc(CC)cc2)c(F)c1</smiles>

To a stirred solution of acid (1.35 g, $5.5 \mathrm{mmol})$, DCC (1.13 g, $5.5 \mathrm{mmol})$, and DMAP (123 $\mathrm{mg}, 1.0 \mathrm{mmol})$ in $\mathrm{CH}_{2} \mathrm{Cl}_{2}(10 \mathrm{~mL})$ was added a solution of alcohol $(681 \mathrm{mg}, 5.0 \mathrm{mmol})$ in $\mathrm{CH}_{2} \mathrm{Cl}_{2}$ $(3 \mathrm{~mL})$ at ice bath. The reaction mixture was gradually warmed to room temperature and stirred for 12 hours. After completion, the mixture was concentrated under reduced pressure, dissolved in EtOAc and filtered through a Celite pad. The filtrate was evaporated and purified by flash column chromatography using petroleum ether/EtOAc $=20: 1$ to give the product as a collorless oil $(1.56 \mathrm{~g}$, $86 \%$ yield). ${ }^{1} \mathrm{H}$ NMR (600 MHz, $\left.\mathrm{CDCl}_{3}\right): \delta 7.52(\mathrm{dt}, J=8.2,1.5 \mathrm{~Hz}, 2 \mathrm{H}), 7.43-7.39(\mathrm{~m}, 2 \mathrm{H})$, 
7.37-7.30 (m, 2H), 7.22-7.06 (m, 6H), $5.12(\mathrm{~d}, J=12.3 \mathrm{~Hz}, 1 \mathrm{H}), 5.06$ (d, $J=12.2 \mathrm{~Hz}, 1 \mathrm{H}), 3.77$ (q, $J=7.2 \mathrm{~Hz}, 1 \mathrm{H}), 2.61(\mathrm{q}, J=7.6 \mathrm{~Hz}, 2 \mathrm{H}), 1.52(\mathrm{~d}, J=7.2 \mathrm{~Hz}, 3 \mathrm{H}), 1.20(\mathrm{t}, J=7.6 \mathrm{~Hz}, 3 \mathrm{H}) ;{ }^{13} \mathrm{C}$ $\operatorname{NMR}\left(101 \mathrm{MHz}, \mathrm{CDCl}_{3}\right): \delta 173.8,159.6\left(\mathrm{~d}, J_{\mathrm{CF}}=249.5 \mathrm{~Hz}\right), 144.4,141.7\left(\mathrm{~d}, J_{\mathrm{CF}}=7.8 \mathrm{~Hz}\right), 135.5$, $133.0,130.7\left(\mathrm{~d}, J_{\mathrm{CF}}=4.2 \mathrm{~Hz}\right), 128.9\left(\mathrm{~d}, J_{\mathrm{CF}}=2.9 \mathrm{~Hz}\right), 128.4,128.2,128.0,127.8\left(\mathrm{~d}, J_{\mathrm{CF}}=13.2\right.$ $\mathrm{Hz}), 127.6,123.6\left(\mathrm{~d}, J_{\mathrm{CF}}=3.4 \mathrm{~Hz}\right), 115.3\left(\mathrm{~d}, J_{\mathrm{CF}}=23.6 \mathrm{~Hz}\right), 66.7,45.0,28.6,18.3,15.5 ;{ }^{19} \mathrm{~F}$ NMR (376 MHz, $\mathrm{CDCl}_{3}$ ): $\delta$-117.5; ESI-HRMS calcd for $\left[\mathrm{C}_{24} \mathrm{H}_{22} \mathrm{FO}_{2}, \mathrm{M}-\mathrm{H}\right]^{-}: 361.1609$, Found: 361.1610.

\section{Phenyl 2-(4-((2-oxocyclopentyl)methyl)phenyl)propanoate (S88)}

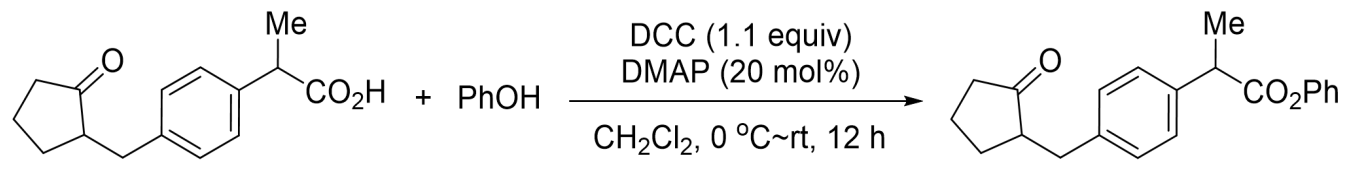

To a stirred solution of acid (1.35 g, $5.5 \mathrm{mmol})$, DCC (1.13 g, $5.5 \mathrm{mmol})$, and DMAP (123 $\mathrm{mg}$, $1.0 \mathrm{mmol})$ in $\mathrm{CH}_{2} \mathrm{Cl}_{2}(10 \mathrm{~mL})$ was added a solution of phenol $(471 \mathrm{mg}, 5.0 \mathrm{mmol})$ in $\mathrm{CH}_{2} \mathrm{Cl}_{2}(3$ $\mathrm{mL}$ ) at ice bath. The reaction mixture was gradually warmed to room temperature and stirred for 12 hours. After completion, the mixture was concentrated under reduced pressure, dissolved in EtOAc and filtered through a Celite pad. The filtrate was evaporated and purified by flash column chromatography using petroleum ether/EtOAc $=20: 1$ to give the product as a collorless oil $(1.64 \mathrm{~g}$, 93\% yield). ${ }^{1} \mathrm{H}$ NMR (400 MHz, $\mathrm{CDCl}_{3}$ ): $\delta$ 7.38-7.27 (m, 4H), 7.22-7.12 (m, 3H), 7.03-6.94 (m, 2H), $3.93(\mathrm{q}, J=7.2 \mathrm{~Hz}, 1 \mathrm{H}), 3.14(\mathrm{dd}, J=13.9,4.1 \mathrm{~Hz}, 1 \mathrm{H}), 2.53(\mathrm{dd}, J=13.9,9.5 \mathrm{~Hz}, 1 \mathrm{H})$, 2.42-2.28 (m, 2H), 2.18-2.02 (m, 2H), 2.01-1.89 (m, 1H), 1.80-1.66 (m, 1H), 1.62-1.50 (m, 4H); ${ }^{13} \mathrm{C}$ NMR (101 MHz, $\left.\mathrm{CDCl}_{3}\right): \delta 220.0,173.0,150.8,139.1,137.8,129.2$ (2C), 127.5, 125.7, 121.3, 50.9, 45.2, 38.1, 35.1, 29.1, 20.5, 18.5; ESI-HRMS calcd for $\left[\mathrm{C}_{21} \mathrm{H}_{22} \mathrm{NaO}_{3}, \mathrm{M}+\mathrm{Na}\right]^{+}: 345.1461$, Found: 345.1458 .

\section{2-(2,5-Dichlorophenoxy)-1-thiomorpholinoethan-1-one (S91)}

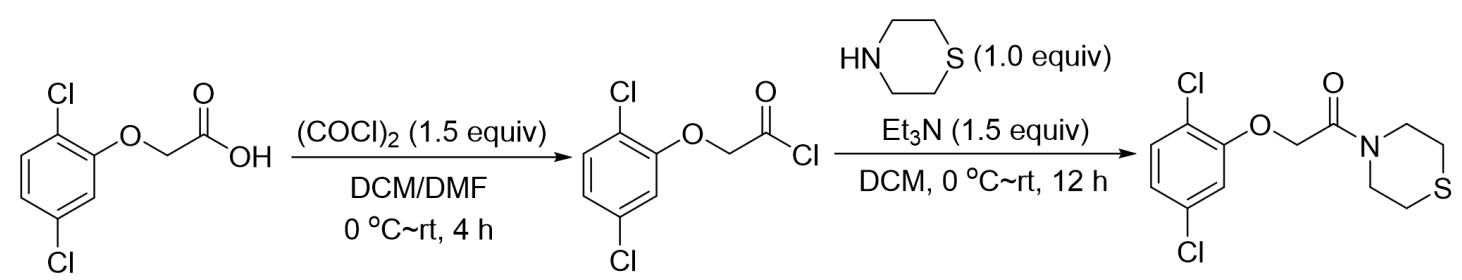

Following a reported procedure, ${ }^{5}$ oxalyl chloride $(317.3 \mu \mathrm{L}, 3.75 \mathrm{mmol})$ was added slowly to a stirred solution of the carboxylic acid $(552.5 \mathrm{mg}, 1.1 \mathrm{mmol})$ in $\mathrm{CH}_{2} \mathrm{Cl}_{2}(50 \mathrm{~mL})$ and DMF $(0.25$ 
$\mathrm{mL}$ ) at $0{ }^{\circ} \mathrm{C}$. The obtained mixture was stirred at $0{ }^{\circ} \mathrm{C}$ for 1 hour and continued further at room temperature for another 3 hours. After that, solvents were evaporated in vacuo and the corresponding crude acid chloride was used directly used for the next step without any purification. The solution of acid chloride in dichloromethane $(15 \mathrm{~mL})$ was added dropwise to a solution of thiomorpholine $(251 \mu \mathrm{L}, 2.5 \mathrm{mmol})$ and $\mathrm{Et}_{3} \mathrm{~N}(521 \mu \mathrm{L}, 3.75 \mathrm{mmol})$ in $\mathrm{CH}_{2} \mathrm{Cl}_{2}(35 \mathrm{~mL})$ at $0{ }^{\circ} \mathrm{C}$ and stirred continued at room temperature for 12 hours. The completion of the reaction was monitored by TLC and the reaction was quenched with water after dilution with $\mathrm{CH}_{2} \mathrm{Cl}_{2}$, washed successively with saturated aqueous $\mathrm{NaHCO}_{3}$ and brine. The organic layer was dried over $\mathrm{MgSO}_{4}$ and and filtered. The filtrate was evaporated and purified by flash column chromatography using petroleum ether/EtOAc $=3: 1$ to give the product as a white solid $(620 \mathrm{mg}, 81 \%$ yield $) .{ }^{1} \mathrm{H}$ NMR (400 MHz, $\left.\mathrm{CDCl}_{3}\right): \delta 7.39$ (d, $\left.J=2.5 \mathrm{~Hz}, 1 \mathrm{H}\right), 7.19(\mathrm{dd}, J=8.8,2.5 \mathrm{~Hz}, 1 \mathrm{H}), 6.95$ (d, $J=8.9 \mathrm{~Hz}$, 1H), 4.75 (s, 2H), 3.94-3.81 (m, 4H), 2.71-2.52 (m, 4H); ${ }^{13} \mathrm{C}$ NMR (101 MHz, $\left.\mathrm{CDCl}_{3}\right): \delta$ 165.6, 152.0, 130.3, 127.8, 127.0, 123.5, 114.3, 68.9, 48.4, 44.8, 28.2, 27.4; ESI-HRMS calcd for $\left[\mathrm{C}_{12} \mathrm{H}_{14} \mathrm{Cl}_{2} \mathrm{NO}_{2} \mathrm{~S}, \mathrm{M}+\mathrm{H}\right]^{+}:$306.0117, Found: 306.0115 .

\section{2-((1-(2-Morpholino-2-oxoethyl)cyclohexyl)methyl)isoindoline-1,3-dione (S92)}
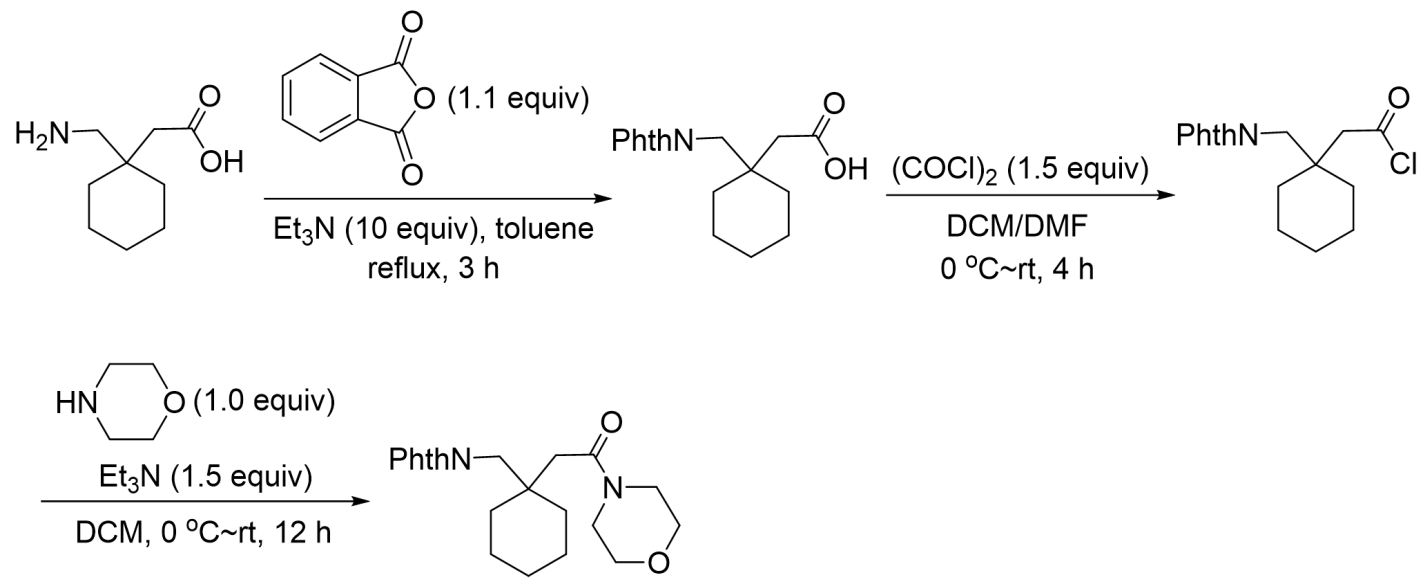

Phthalic anhydride $(988 \mathrm{mg}, 6.6 \mathrm{mmol})$ and $\mathrm{Et}_{3} \mathrm{~N}(8 \mathrm{~mL}, 59 \mathrm{mmol})$ were added to a suspension of the acid in toluene. The mixture was heated under reflux for 3 hours. After evaporated of the solvent, cold water $(12 \mathrm{~mL})$ and concentrated $\mathrm{HCl}(0.12 \mathrm{~mL})$ were added to the crude solid. After stirring for 3 hours at room temperature, filtration, then washing with cold water and dring under vacuum afforded the product 2-(1-((1,3-dioxoisoindolin-2-yl)methyl)cyclohexyl)acetic acid (1.55 g, 97\%). 
Oxalyl chloride (317 $\mu \mathrm{L}, 3.75 \mathrm{mmol})$ was added slowly to a stirred solution of 2-(1-((1,3-dioxoisoindolin-2-yl)methyl)cyclohexyl)acetic acid (331 mg, $1.1 \mathrm{mmol})$ in $\mathrm{CH}_{2} \mathrm{Cl}_{2}(50$ $\mathrm{mL})$ and DMF $(0.25 \mathrm{~mL})$ at $0{ }^{\circ} \mathrm{C}$. The obtained mixture was stirred at $0{ }^{\circ} \mathrm{C}$ for 1 hour and continued further at room temperature for another 3 hours. After that, solvents were evaporated in vacuo and the corresponding crude acid chloride was used directly used for the next step without any purification. The solution of acid chloride in dichloromethane $(15 \mathrm{~mL})$ was added dropwise to a solution of thiomorpholine $(251 \mu \mathrm{L}, 2.5 \mathrm{mmol})$ and $\mathrm{Et}_{3} \mathrm{~N}(521 \mu \mathrm{L}, 3.75 \mathrm{mmol})$ in $\mathrm{CH}_{2} \mathrm{Cl}_{2}(35$ $\mathrm{mL})$ at $0{ }^{\circ} \mathrm{C}$ and stirred continued at room temperature for 12 hours. The completion of the reaction was monitored by TLC and the reaction was quenched with water after dilution with $\mathrm{CH}_{2} \mathrm{Cl}_{2}$, washed successively with saturated aqueous $\mathrm{NaHCO}_{3}$ and brine. The organic layer was dried over $\mathrm{MgSO}_{4}$ and and filtered. The filtrate was evaporated and purified by flash column chromatography using petroleum ether/EtOAc $=2: 1$ to give of the product as a white solid (297 $\mathrm{mg}, 73 \%$ yield). ${ }^{1} \mathrm{H}$ NMR (600 MHz, $\left.\mathrm{CDCl}_{3}\right): \delta 7.87-7.80(\mathrm{~m}, 2 \mathrm{H}), 7.74-7.69(\mathrm{~m}, 2 \mathrm{H}), 3.90(\mathrm{~s}$, 2H), 3.74-3.58 (m, 6H), 3.52-3.42 (m, 2H), $2.33(\mathrm{~s}, 2 \mathrm{H}), 1.81-1.73(\mathrm{~m}, 2 \mathrm{H}), 1.71-1.61(\mathrm{~m}, 2 \mathrm{H})$, $1.50-1.37(\mathrm{~m}, 6 \mathrm{H}) ;{ }^{13} \mathrm{C}$ NMR $\left(151 \mathrm{MHz}, \mathrm{CDCl}_{3}\right): \delta 170.0,169.2,133.9,132.0,123.1,66.9,66.4$, 46.4, 45.6, 41.6, 38.7, 37.3, 33.8, 25.8, 21.7; ESI-HRMS calcd for $\left[\mathrm{C}_{21} \mathrm{H}_{27} \mathrm{~N}_{2} \mathrm{O}_{4}, \mathrm{M}+\mathrm{H}\right]^{+}$: 371.1965, Found: 371.1963.

Benzyl 4-(2-((2,4-dimethylphenyl)thio)phenyl)piperazine-1-carboxylate (S93)

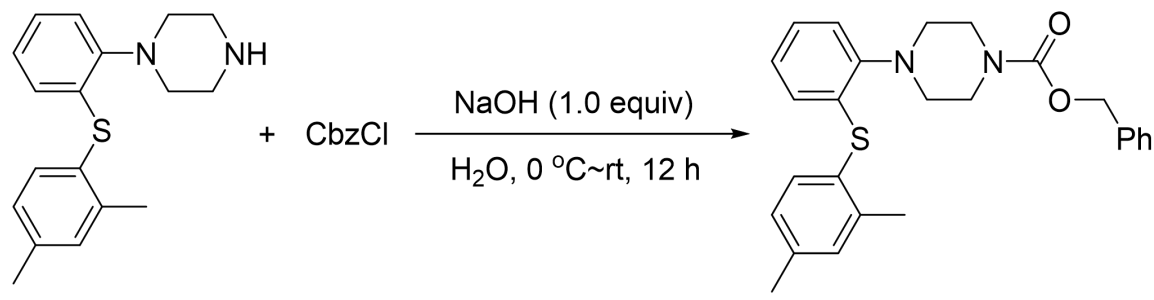

Following literature procedure, ${ }^{6}$ vortioxetine $(289 \mathrm{mg}, 1.0 \mathrm{mmol})$ was added to an aqueous solution of $\mathrm{NaOH}\left(40 \mathrm{mg}\right.$ in $1 \mathrm{ml}$ of water). At $0{ }^{\circ} \mathrm{C}$, benzyl chloroformate $(141 \mu \mathrm{L}, 1.0 \mathrm{mmol})$ was added over 15 minutes. The reaction was then warmed to room temperature and was stirred for 2 hours. The mixture was then extracted with $\mathrm{CH}_{2} \mathrm{Cl}_{2}(2 \times 3 \mathrm{ml})$, dried over $\mathrm{MgSO}_{4}$ and evaporated in vacuo to give the required carbamate as a yellow oil (343 mg, 79\% yield). ${ }^{1} \mathrm{H}$ NMR (400 MHz, $\left.\mathrm{CDCl}_{3}\right): \delta 7.43-7.28(\mathrm{~m}, 6 \mathrm{H}), 7.18-7.12(\mathrm{~m}, 1 \mathrm{H}), 7.11-6.97(\mathrm{~m}, 3 \mathrm{H}), 6.88(\mathrm{ddd}, J=$ 8.5, 7.2, $1.5 \mathrm{~Hz}, 1 \mathrm{H}), 6.53$ (dd, $J=8.0,1.5 \mathrm{~Hz}, 1 \mathrm{H}), 5.17$ (s, 2H), 3.70 (t, $J=4.9 \mathrm{~Hz}, 4 \mathrm{H}), 3.03$ 
(brs, 4H), 2.36 (s, 3H), 2.31 (s, 3H); ${ }^{13} \mathrm{C}$ NMR (101 MHz, $\left.\mathrm{CDCl}_{3}\right): \delta 155.4,148.8,142.3,139.3$, $136.8,136.1,134.6,131.7,128.5,128.0,127.9,127.8,127.7,126.3,125.5,124.7,119.9,67.2$, 51.5, 44.4, 21.2, 20.6; ESI-HRMS calcd for $\left[\mathrm{C}_{26} \mathrm{H}_{29} \mathrm{~N}_{2} \mathrm{O}_{2} \mathrm{~S}, \mathrm{M}+\mathrm{H}\right]^{+}: 433.1944$, Found: 433.1943.

\section{4-Ethylphenyl}

4-((5S,8R,9S,10S,13R,14S)-10,13-dimethyl-3,7,12-trioxohexadecahydro-1 $H$-cyclopenta[a]phe nanthren-17-yl)pentanoate (S96)

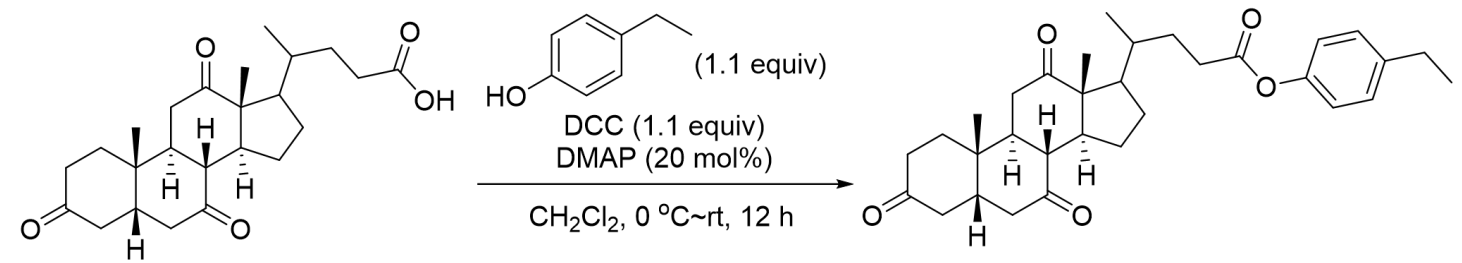

To a stirred solution of acid (2.01 g, $5.0 \mathrm{mmol})$, DCC (1.13 g, $5.5 \mathrm{mmol})$, and DMAP (123 mg, $1.0 \mathrm{mmol}, 20 \mathrm{~mol} \%)$ in $\mathrm{CH}_{2} \mathrm{Cl}_{2}(10 \mathrm{~mL})$ was added a solution of 4-ethylphenol $(672 \mathrm{mg}, 5.5$ mmol) in $\mathrm{CH}_{2} \mathrm{Cl}_{2}(3 \mathrm{~mL})$ at ice bath. The reaction mixture was slowed to gradually warm to room temperature and stirred for 12 hours. After completion, the mixture was concentrated under reduced pressure, dissolved in EtOAc and filtered through a Celite pad. The filtrate was evaporated and purified by flash column chromatography using petroleum ether/EtOAc $=1: 1$ to give the product as a collorless oil $\left(2.18 \mathrm{~g}, 86 \%\right.$ yield). ${ }^{1} \mathrm{H}$ NMR $\left(600 \mathrm{MHz}, \mathrm{CDCl}_{3}\right): \delta 7.19(\mathrm{~d}, J=$ $8.2 \mathrm{~Hz}, 2 \mathrm{H}), 6.97(\mathrm{~d}, J=8.5 \mathrm{~Hz}, 2 \mathrm{H}), 2.97-2.81(\mathrm{~m}, 3 \mathrm{H}), 2.68-2.59(\mathrm{~m}, 3 \mathrm{H}), 2.55-2.48(\mathrm{~m}, 1 \mathrm{H})$, 2.38-2.20 (m, 6H), 2.18-2.02 (m, 5H), 2.01-1.94 (m, 2H), 1.91-1.83 (m, 1H), $1.62(\mathrm{td}, J=14.5$, 4.6 Hz, 1H), 1.55-1.47 (m, 1H), 1.40 (s, 5H), 1.30-1.20 (m, 4H), 1.09 (s, 3H), 0.92 (d, $J=6.6 \mathrm{~Hz}$, 3H); ${ }^{13} \mathrm{C}$ NMR (151 MHz, $\left.\mathrm{CDCl}_{3}\right): \delta 211.9,209.0,208.6,172.7,148.6,141.6,128.7,121.2,56.9$, 51.7, 49.0, 46.8, 45.7, 45.5, 45.0, 42.8, 38.6, 36.5, 36.0, 35.5, 35.3, 31.6, 30.4, 28.2, 27.6, 25.1, 21.9, 18.7, 15.5, 11.9; ESI-HRMS calcd for $\left[\mathrm{C}_{34} \mathrm{H}_{42} \mathrm{NaO}_{5}, \mathrm{M}+\mathrm{Na}\right]^{+}:$429.2925, Found: 429.2926.

$(1 S, 8 R, 9 S, 10 S, 13 S, 14 S, 17 S)$-1,10,13-trimethyl-3-oxohexadecahydro-1H-cyclopenta[a]phenan thren-17-yl 2-(4-(ethylthio)phenyl)acetate (S97)

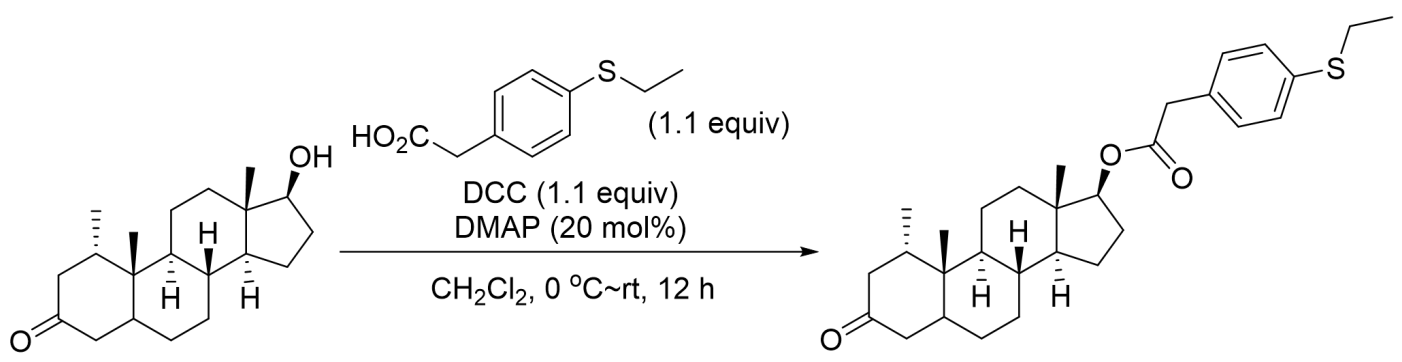


To a stirred solution of acid (216 mg, $1.1 \mathrm{mmol})$, DCC (227 mg, $1.1 \mathrm{mmol})$, and DMAP (123 $\mathrm{mg}, 0.2 \mathrm{mmol})$ in $\mathrm{CH}_{2} \mathrm{Cl}_{2}(2 \mathrm{~mL})$ was added a solution of mesterolone (305 $\left.\mathrm{mg}, 1.0 \mathrm{mmol}\right)$ in $\mathrm{CH}_{2} \mathrm{Cl}_{2}(2 \mathrm{~mL})$ at ice bath. The reaction mixture was gradually warmed to room temperature and stirred for 12 hours. After completion, the mixture was concentrated under reduced pressure, dissolved in EtOAc and filtered through a Celite pad. The filtrate was evaporated and purified by flash column chromatography using petroleum ether/EtOAc $=10: 1$ to give the product as a collorless oil (440 mg, 91\% yield). ${ }^{1} \mathrm{H}$ NMR (600 MHz, $\left.\mathrm{CDCl}_{3}\right): \delta 7.28(\mathrm{~d}, J=8.2 \mathrm{~Hz}, 2 \mathrm{H}), 7.20$ (d, $J=8.2 \mathrm{~Hz}, 2 \mathrm{H}), 4.61(\mathrm{t}, J=8.5 \mathrm{~Hz}, 1 \mathrm{H}), 3.57(\mathrm{~s}, 2 \mathrm{H}), 2.93(\mathrm{q}, J=7.3 \mathrm{~Hz}, 2 \mathrm{H}), 2.69$ (dd, $J=$ 14.6, $6.1 \mathrm{~Hz}, 1 \mathrm{H}), 2.22(\mathrm{t}, J=14.2 \mathrm{~Hz}, 1 \mathrm{H}), 2.18-2.03(\mathrm{~m}, 4 \mathrm{H}), 1.82-1.74(\mathrm{~m}, 1 \mathrm{H}), 1.70-1.59(\mathrm{~m}$, $3 \mathrm{H}), 1.52-1.42(\mathrm{~m}, 3 \mathrm{H}), 1.37-1.25(\mathrm{~m}, 7 \mathrm{H}), 1.14(\mathrm{dd}, J=12.9,4.2 \mathrm{~Hz}, 1 \mathrm{H}), 1.11(\mathrm{~s}, 3 \mathrm{H})$, 1.09-1.02 (m, 1H), 0.99-0.93 (m, 1H), 0.90-0.82 (m, 4H), 0.73 (s, 3H); ${ }^{13} \mathrm{C}$ NMR (151 MHz, $\left.\mathrm{CDCl}_{3}\right): \delta 212.1,171.5,135.1,132.1,129.7,129.3,83.1,50.6,48.5,45.9,44.9,42.9,41.2,39.8$, 39.5, 37.8, 36.8, 35.2, 31.0, 28.7, 27.8, 27.4, 23.5, 20.0, 14.7, 14.4, 14.4, 12.1; ESI-HRMS calcd for $\left[\mathrm{C}_{30} \mathrm{H}_{42} \mathrm{NaO}_{3} \mathrm{~S}, \mathrm{M}+\mathrm{Na}\right]^{+}:$505.2747, Found: 505.2749.

\section{4-(ethyl-1,1- $\left.d_{2}\right)$ phenyl benzoate $\left(S 7-D_{2}\right)$}

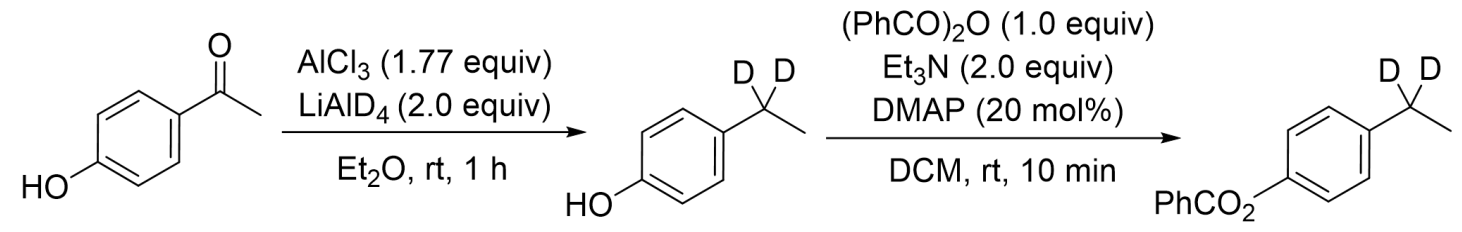

Following a reported procedure, ${ }^{7}$ a flame-dried vial was charged with water free $\mathrm{AlCl}_{3}(236 \mathrm{mg}$, $1.77 \mathrm{mmol})$ and lithium aluminum deuteride $(84 \mathrm{mg}, 2.0 \mathrm{mmol})$ under nitrogen atmosphere. The mixture was carefully suspended in dry ether $(10 \mathrm{~mL})$. 1-(4-Hydroxyphenyl)ethan-1-one (136.2 $\mathrm{mg}, 1.0 \mathrm{mmol}$ ) was carefully added to the suspension. The mixture was stirred for 1 hour at room temperature, diluted with ether and quenched by the addition of aqueous $\mathrm{HCl}(1 \mathrm{M})$. The phases were separated, and the aqueous phase was extracted with ether $(3 \times 10 \mathrm{~mL})$. The organic phase was dried over sodium sulfate and filtered. The filtrate was evaporated and purified by flash column chromatography using petroleum ether/EtOAc $=10: 1$ to give 4-(ethyl-1,1- $\left.d_{2}\right)$ phenol as a white solid ( $86 \mathrm{mg}, 69 \%$ yield). 
An oven-dried $50 \mathrm{~mL}$ Schlenk tube was charged with 4-(ethyl-1,1- $\left.d_{2}\right)$ phenol ( $\left.86 \mathrm{mg}, 0.7 \mathrm{mmol}\right)$ and DCM $(10 \mathrm{~mL})$. Then, Et $3 \mathrm{~N}(200 \mu \mathrm{L}, 1.4 \mathrm{mmol})$, DMAP (17 mg, $0.14 \mathrm{mmol})$, and $(\mathrm{PhCO})_{2} \mathrm{O}$ (158 $\mathrm{mg}, 0.7 \mathrm{mmol}$ ) were added successively to the mixture. The reaction mixture was allowed to stir at room temperature for 10 minutes. After completion, the mixture was poured into water, extracted with EtOAc $(3 \times 10 \mathrm{~mL})$ and dried over sodium sulfate and filtered. The filtrate was evaporated and purified by flash column chromatography using petroleum ether/EtOAc $=50: 1$ to give 4-(ethyl-1,1- $\left.d_{2}\right)$ phenyl benzoate as a white solid (125 mg, 78\% yield). ${ }^{1} \mathrm{H}$ NMR (600 MHz, $\left.\mathrm{CDCl}_{3}\right): \delta 8.23-8.18(\mathrm{~m}, 2 \mathrm{H}), 7.66-7.61(\mathrm{~m}, 1 \mathrm{H}), 7.51(\mathrm{t}, J=7.7 \mathrm{~Hz}, 2 \mathrm{H}), 7.24(\mathrm{~s}, 2 \mathrm{H}), 7.15-7.10$ (m, 2H), $1.24(\mathrm{~s}, 3 \mathrm{H}) ;{ }^{13} \mathrm{C}$ NMR $\left(151 \mathrm{MHz}, \mathrm{CDCl}_{3}\right): \delta 165.4,148.9,141.8,133.5,130.2,129.7$, $128.8,128.5,121.4,121.4,27.6\left(\mathrm{p}, J_{\mathrm{C}-\mathrm{D}}=19.6 \mathrm{~Hz}\right), 15.4$; ESI-HRMS calcd for $\left[\mathrm{C}_{15} \mathrm{H}_{13} \mathrm{D}_{2} \mathrm{O}_{2}, \mathrm{M}+\right.$ $\mathrm{H}]^{+}:$229.1192, Found: 229.1195 .

\section{4-(Ethyl-1,1-d 2$)-1,1$ '-biphenyl (S9-D 2$)$}

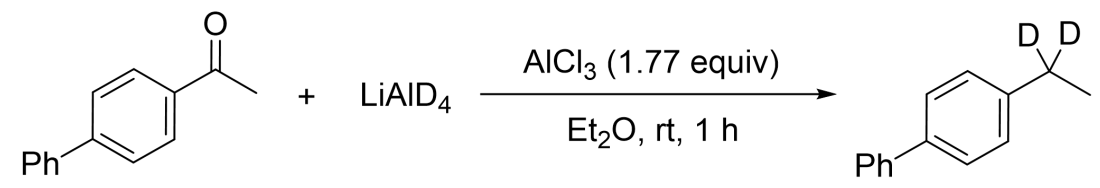

Following a reported procedure, ${ }^{7}$ a flame-dried vial was charged with water free $\mathrm{AlCl}_{3}(945 \mathrm{mg}$, $4.0 \mathrm{mmol})$ and lithium aluminum deuteride $(168 \mathrm{mg}, 4.0 \mathrm{mmol})$ under nitrogen atmosphere. The mixture was carefully suspended in dry ether $(10 \mathrm{~mL})$. 4-Acetylbiphenyl (785 mg, $4.0 \mathrm{mmol})$ was carefully added to the suspension. The mixture was stirred for 1 hour at room temperature, diluted with ether and quenched by the addition of aqueous $\mathrm{HCl}(1 \mathrm{M})$. The phases were separated, and the aqueous phase was extracted with ether $(3 \times 20 \mathrm{~mL})$. The organic phase was dried over sodium sulfate and filtered. The filtrate was evaporated and purified by flash column chromatography using $n$-hexane to give the product as a white solid (670 mg, 90\% yield). ${ }^{1} \mathrm{H}$ NMR and ${ }^{13} \mathrm{C}$ NMR data match previously reported data. ${ }^{7} \mathrm{H}$ NMR $\left(600 \mathrm{MHz}, \mathrm{CDCl}_{3}\right): \delta 7.58(\mathrm{~d}, J=8.3 \mathrm{~Hz}, 2 \mathrm{H})$, $7.52(\mathrm{~d}, J=7.9 \mathrm{~Hz}, 2 \mathrm{H}), 7.42(\mathrm{t}, J=7.7 \mathrm{~Hz}, 2 \mathrm{H}), 7.32(\mathrm{t}, J=7.4 \mathrm{~Hz}, 1 \mathrm{H}), 7.27$ (d, $J=7.9 \mathrm{~Hz}, 2 \mathrm{H})$, $1.26(\mathrm{~s}, 3 \mathrm{H}) ;{ }^{13} \mathrm{C} \mathrm{NMR}\left(151 \mathrm{MHz}, \mathrm{CDCl}_{3}\right): \delta 143.3,141.2,138.6,128.7,128.3,127.1,127.0$, $127.0,27.8\left(\mathrm{p}, J_{\mathrm{C}-\mathrm{D}}=19.0 \mathrm{~Hz}\right), 15.4$. 


\section{Reaction Setup}

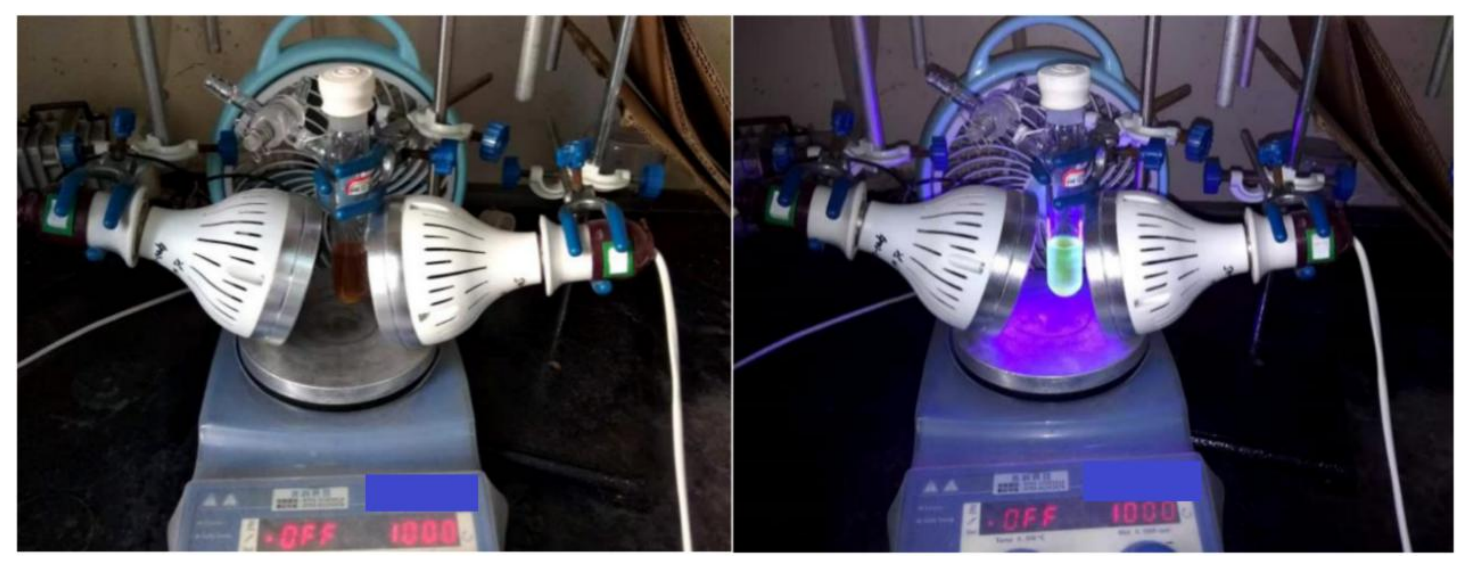

Figure S1. Reaction setup (0.1 mmol scale)

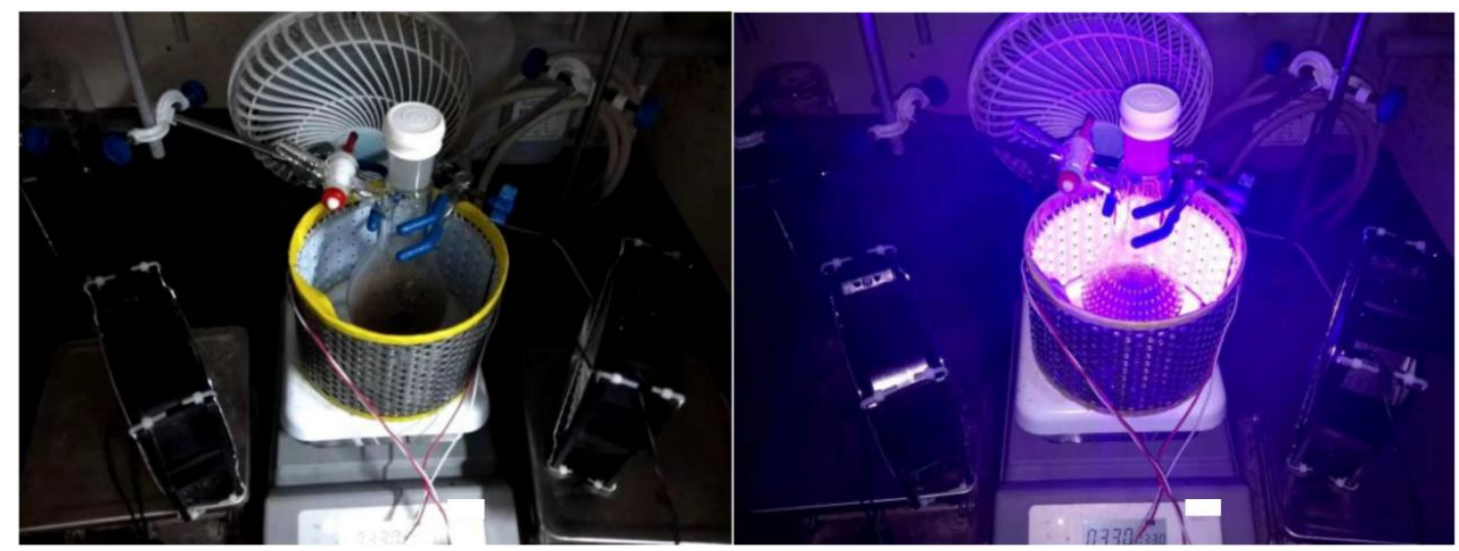

Figure S2. Reaction setup (gram scale) 


\section{Reaction Optimization and Control Experiments}

Table S1. Evaluation of $\mathrm{PC}^{a}$

$$
\underset{\text { S1 }}{\stackrel{\mathrm{PC}(20 \mathrm{~mol} \%)}{\mathrm{Co}(\mathrm{dmgH})_{2} \mathrm{pyCl}(3 \mathrm{~mol} \%)}} \frac{\mathrm{DCE}, \text { visible light, rt, } 16 \mathrm{~h}}{\mathrm{Ph}} \underset{\mathrm{P1}}{\curvearrowright}
$$

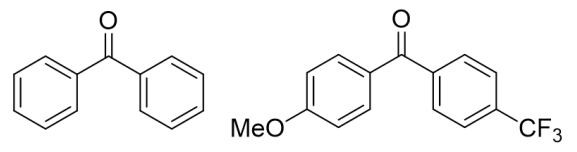

$0 \%$ conv.; $0 \%$ yield<smiles>O=C1c2ccccc2C(=O)c2ccccc21</smiles>

$48 \%$ conv.; $24 \%$ yield
$5 \%$ conv.; $<1 \%$ yield<smiles>CC(C)(C)c1ccc2c(c1)C(=O)c1ccccc1C2=O</smiles>

$48 \%$ conv.; $12 \%$ yield

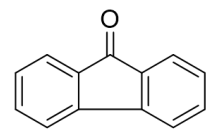

0\% conv.; 0\% yield

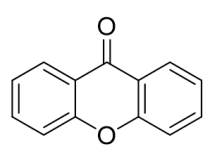

$0 \%$ conv.; $0 \%$ yield

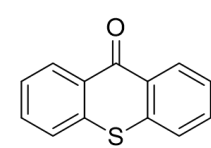

$0 \%$ conv.; $0 \%$ yield<smiles>O=C1c2ccccc2C(=O)c2cc(-c3ccccc3)ccc21</smiles>

$11 \%$ conv.; $6 \%$ yield<smiles>O=C1c2ccccc2C(=O)c2cc(Cl)ccc21</smiles>

$58 \%$ conv.; $31 \%$ yield<smiles>O=C1c2ccccc2C(=O)c2cc(Br)ccc21</smiles>

$27 \%$ conv.; $19 \%$ yield<smiles>COc1ccc2c(c1)C(=O)c1ccccc1C2=O</smiles>

$25 \%$ conv.; $8 \%$ yield $52 \%$ conv.; $27 \%$ yield $\quad 45 \%$ conv.; $31 \%$ yield $\quad 19 \%$ conv.; $5 \%$ yield $9 \%$ conv.; $1 \%$ yield<smiles>O=C1c2ccccc2C(=O)c2c(Cl)cccc21</smiles><smiles>O=C1c2ccc(Br)cc2C(=O)c2cc(Br)ccc21</smiles><smiles>O=C1c2ccc(Br)cc2C(=O)c2cc(Br)ccc21</smiles>

$19 \%$ conv.; $16 \%$ yield

$23 \%$ conv.; $14 \%$ yield

$19 \%$ conv.; $9 \%$ yield

(1)

${ }^{a}$ Reaction conditions: A solution of S1 $(0.1 \mathrm{mmol}), \mathrm{PC}(20 \mathrm{~mol} \%)$ and $\mathrm{Co}(\mathrm{dmgH})_{2} \mathrm{pyCl}(3 \mathrm{~mol} \%)$ in DCE (4 mL) was irradiated with $20 \mathrm{~W} 400-415 \mathrm{~nm}$ LEDs for 16 hours at room temperature under argon atmosphere. Conversions and yields were determined by $\mathrm{GC}$ analysis using ${ }^{n} \mathrm{C}_{16} \mathrm{H}_{34}$ as an internal standard.

Table S2. Evaluation of the additives $^{a}$

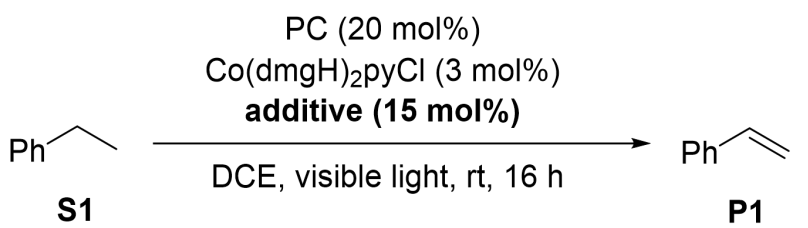

S1<smiles>O=C1c2ccccc2C(=O)c2ccccc21</smiles>

PC

\begin{tabular}{ccccc}
\hline entry & additive $(15 \mathrm{~mol} \%)$ & conv. $(\%)^{b}$ & ${\text { Yield }(\%)^{b}}^{b}$ & PC recovery $(\%)^{b}$ \\
\hline 1 & $\mathrm{PhCO}_{2} \mathrm{Na}$ & 50 & 38 & 46 \\
2 & $\mathrm{~K}_{3} \mathrm{PO}_{4}$ & 45 & 34 & 12 \\
3 & $\mathrm{KH}_{2} \mathrm{PO}_{4}$ & 53 & 21 & 16 \\
4 & $\mathrm{Na}_{2} \mathrm{HPO}_{4}$ & 56 & 30 & 14 \\
5 & pyridine & 48 & 23 & 20
\end{tabular}




\begin{tabular}{|c|c|c|c|c|}
\hline 6 & $\mathrm{NaOH}$ & 55 & 34 & 31 \\
\hline 7 & $\mathrm{Na}_{2} \mathrm{CO}_{3}$ & 51 & 32 & 12 \\
\hline 8 & $\mathrm{NaHCO}_{3}$ & 56 & 31 & 17 \\
\hline 9 & KOAc & 39 & 31 & 26 \\
\hline 10 & $\mathrm{KF}$ & 52 & 34 & 15 \\
\hline 11 & $\mathrm{PhCO}_{2} \mathrm{H}$ & 38 & 32 & 20 \\
\hline 12 & HOAc & 61 & 31 & 23 \\
\hline 13 & $\mathrm{NH}_{4} \mathrm{Cl}$ & 55 & 30 & 21 \\
\hline 14 & $\mathrm{HNO}_{3}$ & 24 & 33 & 25 \\
\hline 15 & $\mathrm{dmgH}_{2}$ & 60 & 43 & 31 \\
\hline
\end{tabular}

Table S3. Evaluation of the solvents ${ }^{a}$

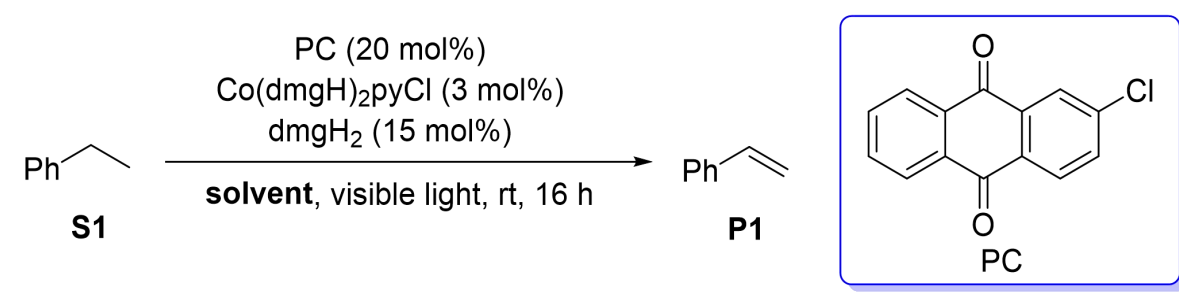

\begin{tabular}{ccccc}
\hline entry & solvent & conv. $(\%)^{b}$ & ${\text { Yield }(\%)^{b}}$ & ${\text { PC recovery }(\%)^{b}}^{b}$ \\
\hline 1 & $\mathrm{CH}_{3} \mathrm{CN}$ & 53 & 34 & 24 \\
2 & EtOAc & 27 & 6 & 25 \\
3 & acetone & 14 & 5 & 36 \\
4 & benzene & 36 & 33 & 57 \\
5 & $\mathrm{PhCF}_{3}$ & 41 & 30 & 21 \\
6 & $\mathrm{PhCl}$ & 23 & 18 & 17 \\
7 & $\mathrm{PhCN}_{8}$ & 31 & 29 & 37 \\
9 & ${ }^{\mathrm{BuOH}}$ & 39 & 31 & 42 \\
10 & $\mathrm{DCM}$ & 14 & 7 & 18 \\
\hline
\end{tabular}

${ }^{a}$ Reaction conditions: A solution of $\mathbf{S 1}(0.1 \mathrm{mmol}), \mathrm{PC}(20 \mathrm{~mol} \%), \mathrm{Co}(\mathrm{dmgH})_{2} \mathrm{pyCl}(3 \mathrm{~mol} \%)$ and $\mathrm{dmgH}_{2}(15 \mathrm{~mol} \%)$ in solvent $(4 \mathrm{~mL})$ was irradiated with $20 \mathrm{~W} 400-415 \mathrm{~nm}$ LEDs for 16 hours at room temperature under argon atmosphere. ${ }^{b}$ Conversions and yields were determined by GC analysis using ${ }^{n} \mathrm{C}_{16} \mathrm{H}_{34}$ as an internal standard. 
Table S4. Evaluation of the amounts of PC, [Co], $\mathrm{dmgH}_{2}$ and $\mathrm{DCE}^{a}$

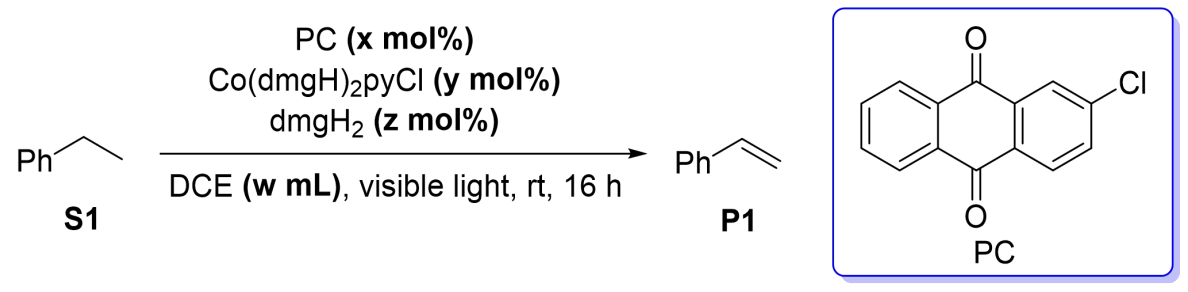

\begin{tabular}{|c|c|c|c|c|c|c|c|}
\hline entry & $\begin{array}{c}\mathrm{PC} \\
(\mathrm{x} \mathrm{mol} \%)\end{array}$ & $\begin{array}{c}{[\mathrm{Co}]} \\
(\mathrm{y} \mathrm{mol} \%)\end{array}$ & $\begin{array}{c}\text { DCE } \\
(\mathrm{w} \mathrm{mL})\end{array}$ & $\begin{array}{c}\mathrm{dmgH}_{2} \\
\text { (z mol\%) }\end{array}$ & conv. $(\%)^{b}$ & $\begin{array}{l}\text { Yield } \\
(\%)^{b}\end{array}$ & $\begin{array}{c}\mathrm{PC} \\
\text { recovery } \\
(\%)^{b}\end{array}$ \\
\hline 1 & 10 & 3 & 4 & 15 & 43 & 33 & 31 \\
\hline 2 & 15 & 3 & 4 & 15 & 47 & 36 & 23 \\
\hline 3 & 20 & 3 & 4 & 15 & 60 & 43 & 32 \\
\hline 4 & 20 & 5 & 4 & 15 & 55 & 45 & 30 \\
\hline 5 & 20 & 10 & 4 & 15 & 61 & 47 & 52 \\
\hline 6 & 20 & 10 & 6 & 15 & 58 & 47 & 37 \\
\hline 7 & 20 & 10 & 8 & 15 & 60 & 48 & 24 \\
\hline 8 & 20 & 10 & 8 & 25 & 61 & 48 & 33 \\
\hline 9 & 20 & 10 & 8 & 50 & 65 & 49 & 28 \\
\hline 10 & 25 & 10 & 8 & 50 & 65 & 51 & 43 \\
\hline
\end{tabular}


Table S5. Evaluation of the transition-metal catalysts ${ }^{a}$

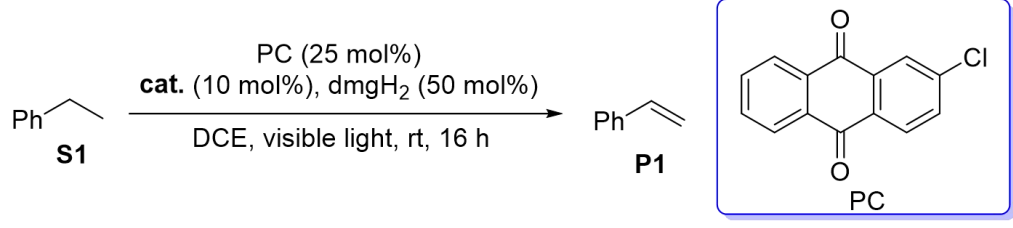

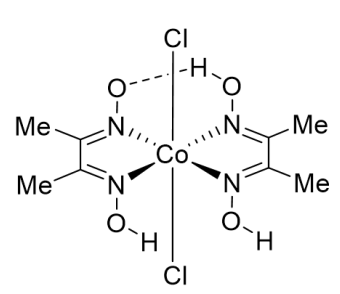

$87 \%$ conv.; $23 \%$ yield

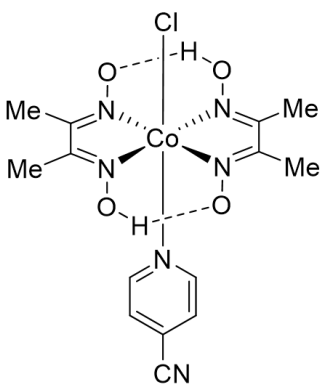

$69 \%$ conv.; $53 \%$ yield

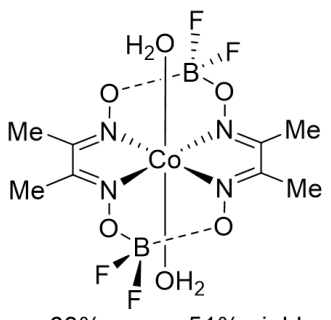

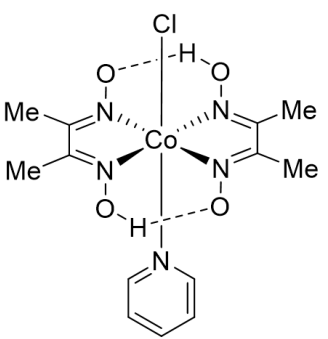

$65 \%$ conv.; $51 \%$ yield

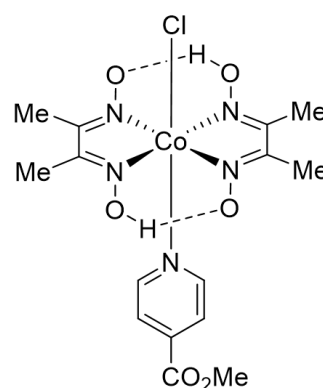

$73 \%$ conv.; $48 \%$ yield

$\mathrm{Co}(\mathrm{acac})_{2}$

$70 \%$ conv.; $64 \%$ yield

$\mathrm{Co}(\mathrm{OAc})_{2}-4 \mathrm{H}_{2} \mathrm{O}$

$71 \%$ conv.; $65 \%$ yield

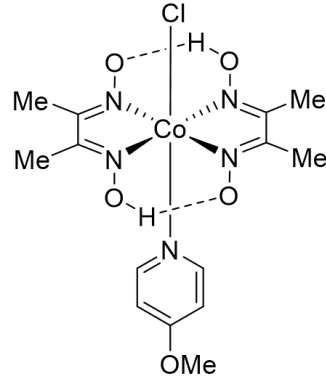

$71 \%$ conv.; $48 \%$ yield

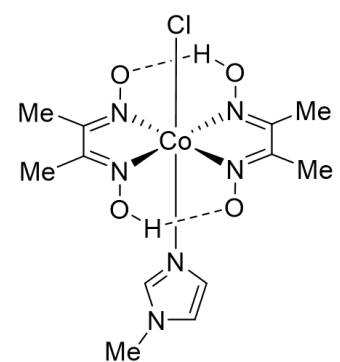

$75 \%$ conv.; $22 \%$ yield

$\mathrm{CoCl}_{2} \cdot 6 \mathrm{H}_{2} \mathrm{O}$

$77 \%$ conv.; $22 \%$ yield

$\mathrm{Ni}(\text { acac })_{2}$

$66 \%$ conv.; $16 \%$ yield

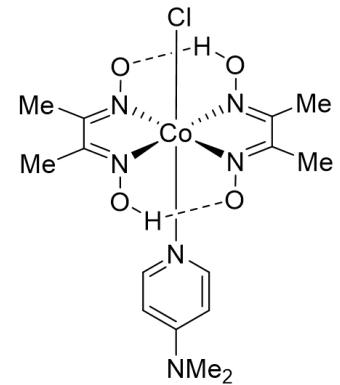

$76 \%$ conv.; $47 \%$ yield

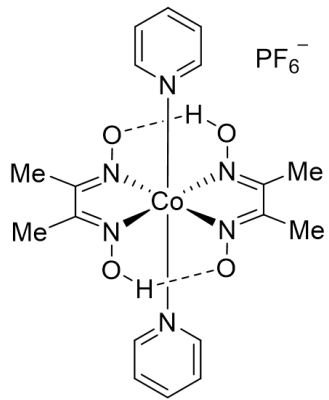

$68 \%$ conv.; $54 \%$ yield

$\mathrm{FeCl}_{3}$

$40 \%$ conv.; $14 \%$ yield

$\mathrm{MnCl}_{2}$

$78 \%$ conv.; $10 \%$ yield

$63 \%$ conv.; $51 \%$ yield

${ }^{a}$ Reaction conditions: A solution of $\mathbf{S 1}(0.1 \mathrm{mmol}), \mathrm{PC}(25 \mathrm{~mol} \%)$, cat. (10 mol\%) and $\mathrm{dmgH}_{2}(50$ mol\%) in DCE $(8 \mathrm{~mL})$ was irradiated with $20 \mathrm{~W} 400-415 \mathrm{~nm}$ LEDs for 16 hours at room temperature under argon atmosphere. Conversions and yields were determined by $\mathrm{GC}$ analysis using ${ }^{n} \mathrm{C}_{16} \mathrm{H}_{34}$ as an internal standard.

Table S6. Control experiment ${ }^{a}$

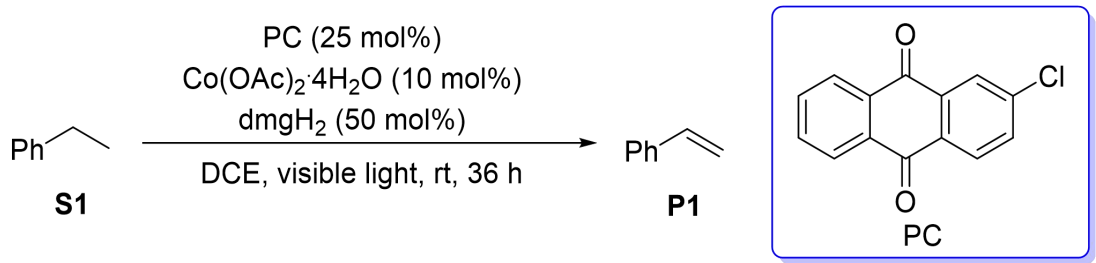

\begin{tabular}{ccccc}
\hline entry & Variation from standard condition & Conv. $(\%)^{b}$ & Yield $(\%)^{b}$ & PC recovery $(\%)^{b}$ \\
\hline 1 & no & 86 & 71 & 61 \\
2 & no photocatalyst & 0 & 0 & --
\end{tabular}


${ }^{a}$ Reaction conditions: A solution of $\mathbf{S 1}(0.1 \mathrm{mmol}), \mathrm{PC}(25 \mathrm{~mol} \%)$, cat. $(10 \mathrm{~mol} \%)$ and $\mathrm{dmgH}_{2}(50$ mol\%) in DCE $(8 \mathrm{~mL})$ was irradiated with $20 \mathrm{~W} 400-415 \mathrm{~nm}$ LEDs for 36 hours at room temperature under argon atmosphere. ${ }^{b}$ Conversions, yields and PC recoveries were determined by GC analysis using ${ }^{n} \mathrm{C}_{16} \mathrm{H}_{34}$ as an internal standard.

\section{Analysis of the Side Products and the PC Decomposition Products}

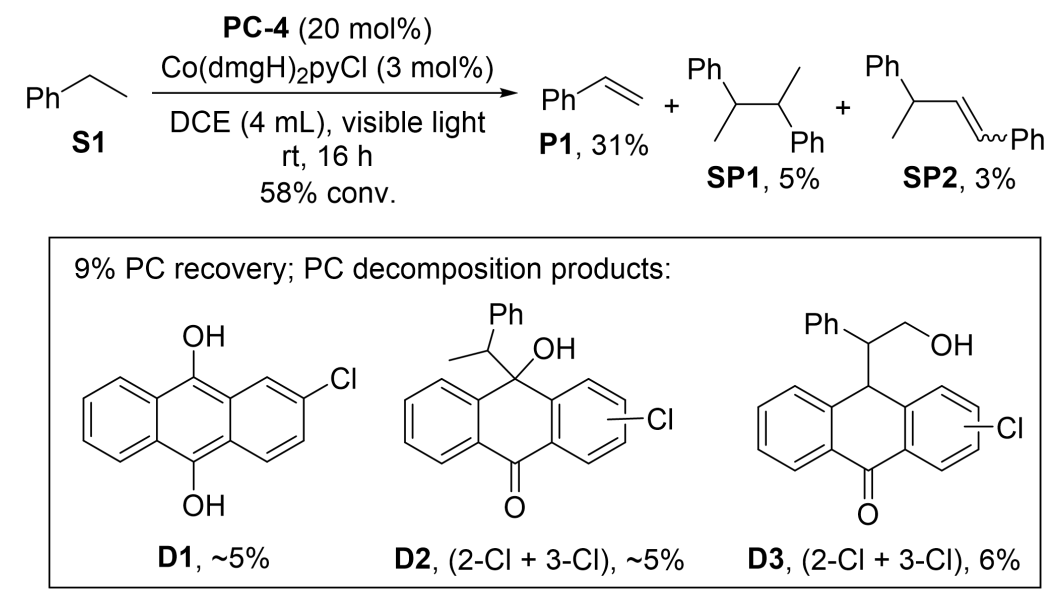

In argon-filled glovebox, to an oven-dried $10 \mathrm{~mL}$ Schlenk tube equipped with a stir bar was added 2-chloroanthraquinone $(0.02 \mathrm{mmol}, 4.9 \mathrm{mg}), \mathrm{Co}(\mathrm{dmgH})_{2} \mathrm{pyCl}(0.003 \mathrm{mmol}, 1.2 \mathrm{mg})$, ethylbenzene $\mathbf{S 1}(0.1 \mathrm{mmol}, 12.2 \mu \mathrm{L})$ and DCE $(4 \mathrm{~mL})$. The reaction mixture was sealed and irradiated with two $20 \mathrm{~W}$ 400-415 $\mathrm{nm}$ LEDs for 16 hours (tube $2 \mathrm{~cm}$ away from lights, fans for cooling, 20-30 $\left.{ }^{\circ} \mathrm{C}\right)$. After that, the reaction mixture was diluted with EtOAc $(2 \mathrm{~mL})$ and $n-\mathrm{C}_{16} \mathrm{H}_{34}$ was added as an internal standard. About $500 \mu \mathrm{L}$ of the mixture was taken and filtered through a short pad of silica gel with EtOAc as eluent. The sample was subjected to GC and GC-MS analysis and the GC yields of P1, SP1 and SP2 were determined based on an internal standard. The decomposition products of PC-4 (D1, D2 and D3) were isolated by column chromatography on silica gel and isolated yields were given. $\sim 5 \%$ Yield of D1 $(0.2 \mathrm{mg})$ was isolated as a yellow solid, ${ }^{1} \mathrm{H}$ NMR (400 MHz, $\left.\mathrm{CDCl}_{3}\right): \delta 8.39-8.30(\mathrm{~m}, 2 \mathrm{H}), 7.66-7.59(\mathrm{~m}, 1 \mathrm{H}), 7.57(\mathrm{dd}, \mathrm{J}=8.2,2.4$ $\mathrm{Hz}, 1 \mathrm{H}), 7.51-7.46(\mathrm{~m}, 2 \mathrm{H}), 7.44(\mathrm{~d}, J=8.3 \mathrm{~Hz}, 1 \mathrm{H}), 4.34(\mathrm{~s}, 2 \mathrm{H}) . \sim 5 \%$ Yield of D2 (0.3 mg, two isomers) were isolated as yellow solids, for one isomer: ${ }^{1} \mathrm{H} \mathrm{NMR}\left(600 \mathrm{MHz}, \mathrm{CDCl}_{3}\right): \delta 8.11-8.02$ (m, 1H), 8.01-7.87 (m, 2H), 7.69-7.54 (m, 1H), 7.53-7.38 (m, 3H), 7.17-7.14 (m, 1H), 7.05-6.99 (m, 2H), $6.38(\mathrm{t}, J=7.0 \mathrm{~Hz}, 2 \mathrm{H}), 3.26(\mathrm{dq}, J=14.1,7.2 \mathrm{~Hz}, 1 \mathrm{H}), 2.50(\mathrm{~d}, J=6.1 \mathrm{~Hz}, 1 \mathrm{H}), 1.16$ 
(dd, $J=8.9,7.2 \mathrm{~Hz}, 3 \mathrm{H}$ ); ESI-HRMS calcd for $\left[\mathrm{C}_{22} \mathrm{H}_{18} \mathrm{ClO}_{2}, \mathrm{M}+\mathrm{H}\right]^{+}:$349.0990, Found: 349.0993; for another isomer: ${ }^{1} \mathrm{H}$ NMR $\left(600 \mathrm{MHz}, \mathrm{CDCl}_{3}\right): \delta 8.12-8.04(\mathrm{~m}, 1 \mathrm{H}), 7.99-7.86(\mathrm{~m}, 2 \mathrm{H})$, 7.70-7.58 (m, 2H), 7.53-7.47 (m, 1H), 7.39-7.34 (m, 1H), 7.16-7.11 (m, 1H), 7.04-6.98 (m, 2H), $6.36(\mathrm{dd}, J=32.5,7.7 \mathrm{~Hz}, 2 \mathrm{H}), 3.25(\mathrm{p}, J=7.3 \mathrm{~Hz}, 1 \mathrm{H}), 2.49$ (s, 1H), $1.16(\mathrm{dd}, J=25.6,7.2 \mathrm{~Hz}$, 3H); ESI-HRMS calcd for $\left[\mathrm{C}_{22} \mathrm{H}_{18} \mathrm{ClO}_{2}, \mathrm{M}+\mathrm{H}\right]^{+}:$349.0990, Found: 349.0991. 6\% Yield of D3 (0.4 mg, two isomers) were isolated as yellow oils, for one isomer: ${ }^{1} \mathrm{H}$ NMR $\left(600 \mathrm{MHz}, \mathrm{CDCl}_{3}\right): \delta$ 8.06-7.86 (m, 2H), 7.64-7.54 (m, 2H), 7.52-7.33 (m, 3H), 7.13-7.07 (m, 1H), 6.95-6.88 (m, 2H), 6.09-5.99 (m, 2H), 4.87-4.77 (m, 1H), 4.05-3.97 (m, 1H), 3.95-3.86 (m, 1H), 3.39-3.31 (m, 1H), $1.78-1.59(\mathrm{~m}, 1 \mathrm{H}) ;{ }^{13} \mathrm{C}$ NMR $\left(151 \mathrm{MHz}, \mathrm{CDCl}_{3}\right): \delta 183.0,182.9,145.9,143.7,142.6,140.2$, 138.7, 138.2, 135.0, 134.9, 134.0, 133.2, 132.8, 132.7, 132.0, 128.94, 128.88, 128.8, 128.4, 128.2, 128.0, 127.9, 127.8, 127.6, 127.5, 127.2, 126.8, 126.6, 62.8, 62.8, 58.2, 58.1, 44.7; ESI-HRMS calcd for $\left[\mathrm{C}_{22} \mathrm{H}_{18} \mathrm{ClO}_{2}, \mathrm{M}+\mathrm{H}\right]^{+}:$349.0990, Found: 349.0992; for another isomer: ${ }^{1} \mathrm{H}$ NMR (600 $\left.\mathrm{MHz}, \mathrm{CDCl}_{3}\right): \delta 8.08-7.88(\mathrm{~m}, 2 \mathrm{H}), 7.62-7.36(\mathrm{~m}, 5 \mathrm{H}), 7.14-7.05(\mathrm{~m}, 1 \mathrm{H}), 6.97-6.86(\mathrm{~m}, 2 \mathrm{H})$, $6.04(\mathrm{dd}, J=7.9,2.7 \mathrm{~Hz}, 2 \mathrm{H}), 4.89-4.82(\mathrm{~m}, 1 \mathrm{H}), 4.04-3.95(\mathrm{~m}, 1 \mathrm{H}), 3.94-3.86(\mathrm{~m}, 1 \mathrm{H})$, 3.37-3.30 (m, 1H), 1.75-1.58 (m, 1H); ${ }^{13} \mathrm{C}$ NMR (151 MHz, $\left.\mathrm{CDCl}_{3}\right): \delta 182.8,144.1,142.5,140.6$, 139.0, 135.6, 135.01, 134.99, 134.8, 133.9, 133.7, 133.3, 133.0, 132.8, 132.4, 132.1, 131.7, 130.5, $129.5,129.0,128.93,128.86,128.0,127.83,127.81,127.5,127.2,126.9,126.7,126.6,126.3,63.0$, 62.8, 58.1, 58.1, 44.5, 44.4; ESI-HRMS calcd for $\left[\mathrm{C}_{22} \mathrm{H}_{18} \mathrm{ClO}_{2}, \mathrm{M}+\mathrm{H}\right]^{+}: 349.0990$, Found: 349.0990.
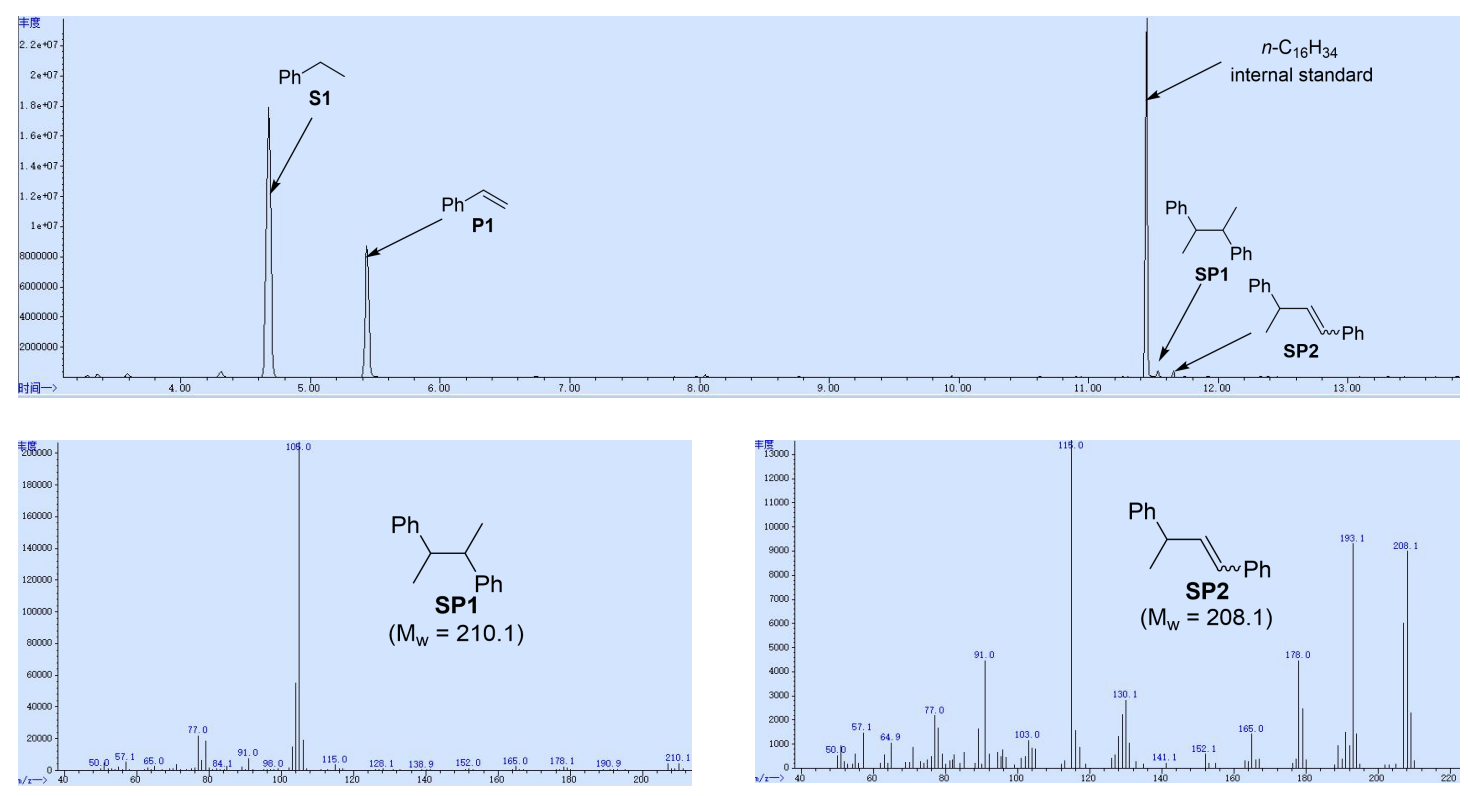

Figure S3 Side products SP1 and SP2 detected on GC-MS 


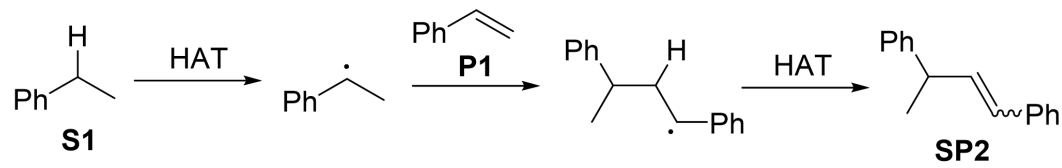

Figure S4 Proposed pathway for SP2

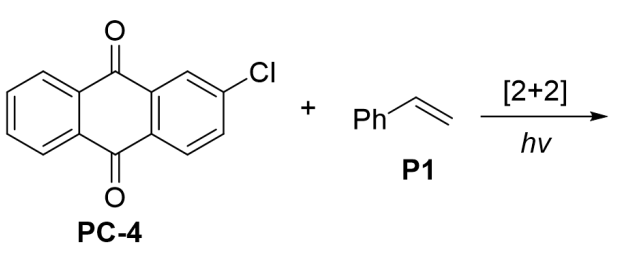<smiles>O=C1c2ccccc2C2(OCC2c2ccccc2)c2cc(Cl)ccc2C1c1ccc(Cl)cc1</smiles>

D3 (2-Cl)<smiles>O=C1c2ccccc2C(=O)c2cc(Cl)ccc21</smiles><smiles>CCCC(C=Cc1ccccc1)CC</smiles><smiles>O=C1c2ccccc2C2(c3ccccc3)COC12c1ccccc1</smiles>
reduction PC-4<smiles>O=C1c2ccccc2C(C(CO)c2ccccc2)c2cc(Cl)ccc21</smiles>

D3 (3-Cl)

Figure S5. Proposed pathway for D3 $(2-\mathrm{Cl}+3-\mathrm{Cl})$

\section{Detection of $\mathrm{H}_{2}$ for the Dehydrogenation of $\mathrm{S} 18$}<smiles>c1ccc2c(c1)CCCC2</smiles>

S18
PC-4 (25 mol\%) $\mathrm{Co}(\mathrm{OAc})_{2} \cdot 4 \mathrm{H}_{2} \mathrm{O}(10 \mathrm{~mol} \%)$ $\underset{\text { DCE, visible light, } \mathrm{rt}, 36 \mathrm{~h}}{\stackrel{\mathrm{dmgH}_{2}(50 \mathrm{~mol} \%)}{\longrightarrow}}$

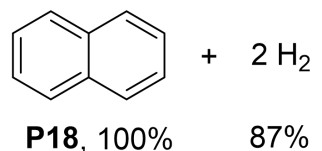

In argon-filled glovebox, to an oven-dried $25 \mathrm{~mL}$ Schlenk tube equipped with a stir bar was added 2-chloroanthraquinone $(0.025 \mathrm{mmol}, 6.1 \mathrm{mg}), \mathrm{Co}(\mathrm{OAc})_{2} \cdot 4 \mathrm{H}_{2} \mathrm{O}(0.01 \mathrm{mmol}, 2.5 \mathrm{mg})$, $\mathrm{dmgH}_{2}(0.05 \mathrm{mmol}, 5.8 \mathrm{mg})$, 1,2,3,4-tetrahydronaphalene $\mathbf{S 1 8}(0.1 \mathrm{mmol})$ and DCE $(8 \mathrm{~mL})$. The reaction mixture was sealed and stirred in dark for 30 minutes at room temperature. Then, the reaction was irradiated with two $20 \mathrm{~W} 400-415 \mathrm{~nm}$ LEDs for 36 hours (tube $2 \mathrm{~cm}$ away from lights, fans for cooling, 20-30 ${ }^{\circ} \mathrm{C}$ ). After reaction, methane was injected as an internal standard for analysis of generated $\mathrm{H}_{2}$ by GC-TCD. After that, the reaction mixture was diluted with EtOAc (2 $\mathrm{mL}$ ) and $n-\mathrm{C}_{16} \mathrm{H}_{34}$ was added as an internal standard. About $500 \mu \mathrm{L}$ of the mixture was taken and filtered through a short pad of silica gel with EtOAc as eluent. The sample was subjected to GC-FID analysis and the yield of P18 was determined based on the internal standard. 


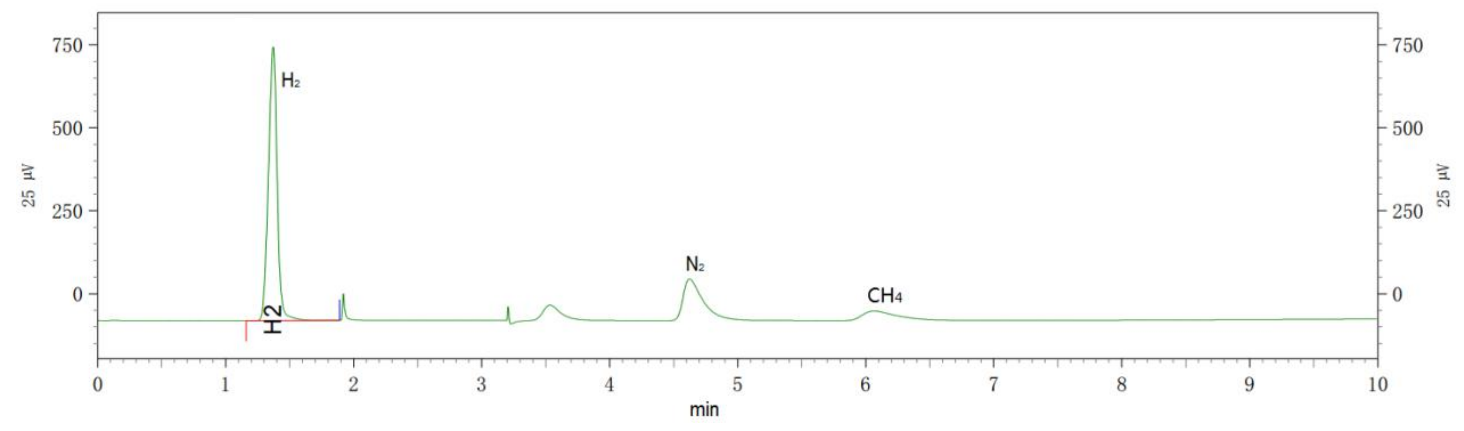

Figure S6. GC spectrum for the detection of $\mathrm{H}_{2}$ under optimized condition

\section{General Procedure for the Acceptorless Dehydrogenation of Aliphatics}

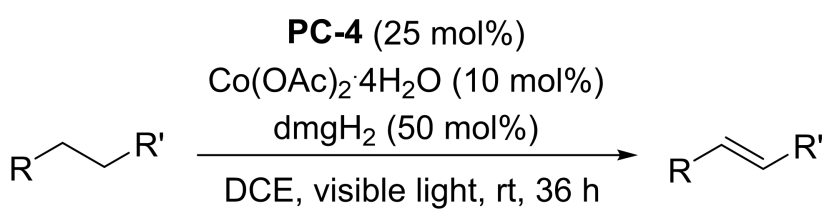

General procedure for the acceptorless dehydrogenation of volatile substrates (P1 and P18-23):

In argon-filled glovebox, to an oven-dried $10 \mathrm{~mL}$ Schlenk tube equipped with a stir bar was added 2-chloroanthraquinone $(0.025 \mathrm{mmol}, 6.1 \mathrm{mg}), \mathrm{Co}(\mathrm{OAc})_{2} \cdot 4 \mathrm{H}_{2} \mathrm{O}(0.01 \mathrm{mmol}, 2.5 \mathrm{mg})$, $\mathrm{dmgH}_{2}(0.05 \mathrm{mmol}, 5.8 \mathrm{mg})$, alkane substrate $(0.1 \mathrm{mmol})$ and DCE $(8 \mathrm{~mL})$. The reaction mixture was sealed and stirred in dark for 30 minutes at room temperature. Then, the reaction was irradiated with two $20 \mathrm{~W} 400-415 \mathrm{~nm}$ LEDs for 36 hours (tube $2 \mathrm{~cm}$ away from lights, fans for cooling, $\left.20-30{ }^{\circ} \mathrm{C}\right)$. After that, the reaction mixture was diluted with EtOAc $(2 \mathrm{~mL})$ and $n-\mathrm{C}_{16} \mathrm{H}_{34}$ was added as an internal standard. About $500 \mu \mathrm{L}$ of the mixture was taken and filtered through a short pad of silica gel with EtOAc as eluent. The sample was subjected to GC analysis and the yield was determined based on the internal standard.

\section{General procedure for the acceptorless dehydrogenation of other aliphatics:}

In argon-filled glovebox, to an oven-dried $10 \mathrm{~mL}$ Schlenk tube equipped with a stir bar was added 2-chloroanthraquinone (0.025 mmol, $6.1 \mathrm{mg}), \mathrm{Co}(\mathrm{OAc})_{2} \cdot 4 \mathrm{H}_{2} \mathrm{O}(0.01 \mathrm{mmol}, 2.5 \mathrm{mg})$, $\mathrm{dmgH}_{2}(0.05 \mathrm{mmol}, 5.8 \mathrm{mg})$, alkane substrate $(0.1 \mathrm{mmol})$ and DCE $(8 \mathrm{~mL})$. The reaction mixture was sealed and stirred in dark for 30 minutes at room temperature. Then, the reaction was irradiated with two $20 \mathrm{~W}$ 400-415 nm LEDs for 36 hours (tube $2 \mathrm{~cm}$ away from lights, fans for cooling, 20-30 ${ }^{\circ} \mathrm{C}$ ). After that, the solvent of the reaction mixture was removed on a rotary evaporator under reduced pressure and the residue was purified by column chromatography on 
silica gel.

\section{Intermolecular and Intramolecular Competitive Reactions}

\subsection{Intermolecular competitive reactions}
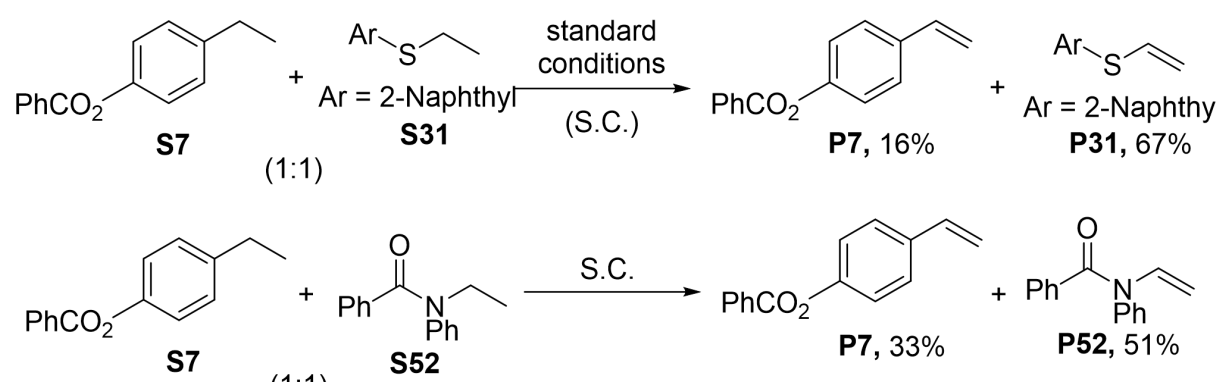

$(1: 1)$<smiles>CCc1ccccc1</smiles>

S1

$(1: 1)$

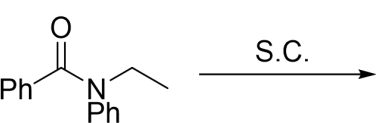

S52<smiles>C=Cc1ccccc1</smiles>

P1, 26\%<smiles>C=C[PH+](C=C)C(=O)c1ccccc1</smiles>

P52, 50\%<smiles>CC[AsH][AsH]</smiles><smiles>Cc1ccccc1</smiles><smiles>C=CN(C)C(=O)c1ccccc1</smiles>

$(1: 1)$<smiles>CCCc1ccc(OC(C)C)cc1</smiles>

S7

$(1: 1)$

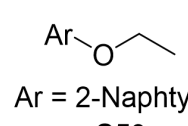<smiles></smiles><smiles>C=Cc1ccc(OCC)cc1</smiles>

P7, 61\%<smiles>C=CO[Al]</smiles>

$+\operatorname{Ar}=2-\mathrm{Naphtyl}$ P50, $3 \%$<smiles>CCOC(=O)Oc1ccc(CC)cc1</smiles>

$(1: 1)$<smiles>C1CCCCCC1</smiles>

S19<smiles>C1C[13CH2]1</smiles>

$\mathrm{PhCO}_{2}$<smiles>C1=CCCCCC1</smiles>

P19, 6\%

In argon-filled glovebox, to an oven-dried $10 \mathrm{~mL}$ Schlenk tube equipped with a stir bar was added 2-chloroanthraquinone (0.025 mmol, $6.1 \mathrm{mg}), \mathrm{Co}(\mathrm{OAc})_{2} \cdot 4 \mathrm{H}_{2} \mathrm{O}(0.01 \mathrm{mmol}, 2.5 \mathrm{mg})$, $\mathrm{dmgH}_{2}(0.05 \mathrm{mmol}, 5.8 \mathrm{mg})$, two aliphatic substrates $(0.1 \mathrm{mmol}+0.1 \mathrm{mmol})$ and DCE $(8 \mathrm{~mL})$. The reaction mixture was sealed and stirred in dark for 30 minutes at room temperature. Then, the reaction was irradiated with two $20 \mathrm{~W}$ 400-415 nm LEDs for 36 hours or 2 hours (for S7 + S19) (tube $2 \mathrm{~cm}$ away from lights, fans for cooling, 20-30 ${ }^{\circ} \mathrm{C}$ ). After that, the reaction mixture was diluted with EtOAc and internal standard was added. For volatile products (P1 and P19), about $500 \mu \mathrm{L}$ of the mixture was taken and filtered through a short pad of silica gel with EtOAc as eluent. The sample was subjected to GC analysis. For other products, sample was taken out of the reaction mixture and solvent was removed on a rotary evaporator under reduced pressure. ${ }^{1} \mathrm{H}$ 
NMR yields of P7, P31, P50 and P52 were given based on the internal standard. GC yields of styrene $\mathbf{P 1}$ and $\mathbf{P 1 9}$ were given based on the internal standard.

\subsection{Intramolecular competitive reactions}

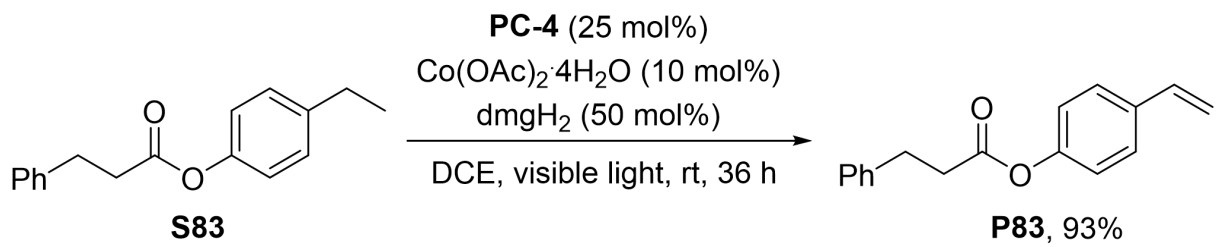

In argon-filled glovebox, to an oven-dried $10 \mathrm{~mL}$ Schlenk tube equipped with a stir bar was added 2-chloroanthraquinone $(0.025 \mathrm{mmol}, 6.1 \mathrm{mg}), \mathrm{Co}(\mathrm{OAc})_{2} \cdot 4 \mathrm{H}_{2} \mathrm{O}(0.01 \mathrm{mmol}, 2.5 \mathrm{mg})$, $\mathrm{dmgH}_{2}(0.05 \mathrm{mmol}, 5.8 \mathrm{mg})$, 4-ethylphenyl 3-phenylpropanoate $\mathbf{S 8 3}(0.1 \mathrm{mmol}, 25.4 \mathrm{mg})$ and DCE $(8 \mathrm{~mL})$. The reaction mixture was sealed and stirred in dark for 30 minutes at room temperature. Then, the reaction was irradiated with two $20 \mathrm{~W}$ 400-415 nm LEDs for 36 hours (tube $2 \mathrm{~cm}$ away from lights, fans for cooling, $20-30{ }^{\circ} \mathrm{C}$ ). After that, the solvent of the reaction mixture was removed on a rotary evaporator under reduced pressure and the residue was purified by silica gel column chromatography using petroleum ether/EtOAc $=20: 1$ to give $93 \%$ yield $(23.5$ $\mathrm{mg})$ of the product as a colorless oil. ${ }^{1} \mathrm{H}$ NMR $\left(400 \mathrm{MHz}, \mathrm{CDCl}_{3}\right): \delta 7.40(\mathrm{~s}, 2 \mathrm{H}), 7.35-7.28(\mathrm{~m}$, 2H), 7.27-7.19 (m, 2H), $6.97(\mathrm{~d}, J=8.6 \mathrm{~Hz}, 2 \mathrm{H}), 6.68(\mathrm{dd}, J=17.6,10.9 \mathrm{~Hz}, 1 \mathrm{H}), 5.69(\mathrm{~d}, J=$ $17.6 \mathrm{~Hz}, 1 \mathrm{H}), 5.23(\mathrm{~d}, J=10.9 \mathrm{~Hz}, 1 \mathrm{H}), 3.07(\mathrm{t}, J=7.7 \mathrm{~Hz}, 2 \mathrm{H}), 2.92-2.84(\mathrm{~m}, 2 \mathrm{H}) ;{ }^{13} \mathrm{C}$ NMR $\left(101 \mathrm{MHz}, \mathrm{CDCl}_{3}\right): \delta 171.4,150.2,140.1,135.9,135.3,128.6,128.4,127.1,126.5,121.6,114.0$, 36.0, 31.0; ESI-HRMS calcd for $\left[\mathrm{C}_{17} \mathrm{H}_{17} \mathrm{O}_{2}, \mathrm{M}+\mathrm{H}\right]^{+}:$253.1223, Found: 253.1225.

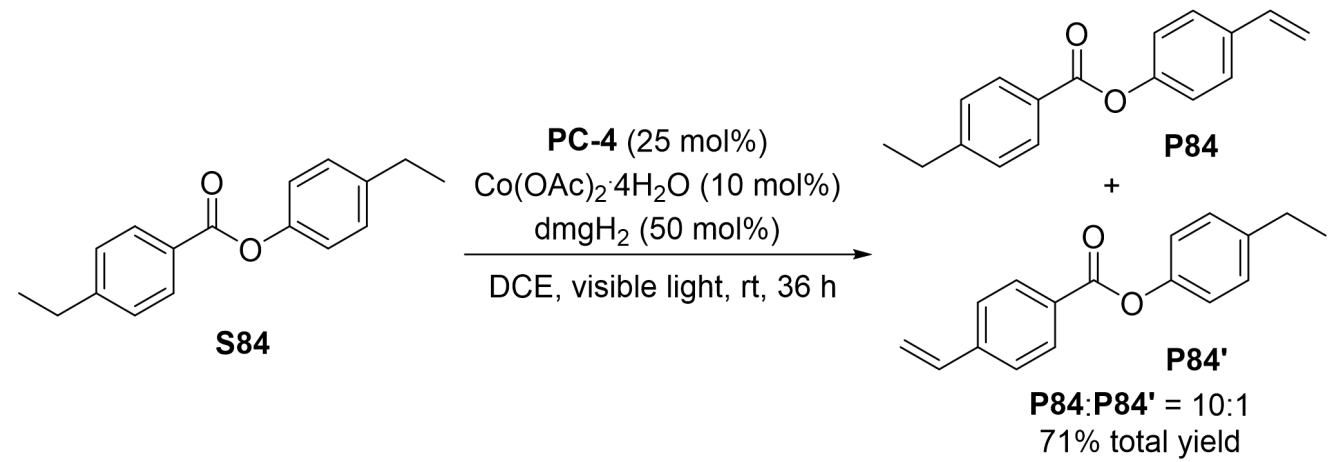

In argon-filled glovebox, to an oven-dried $10 \mathrm{~mL}$ Schlenk tube equipped with a stir bar was added 2-chloroanthraquinone $(0.025 \mathrm{mmol}, 6.1 \mathrm{mg}), \mathrm{Co}(\mathrm{OAc})_{2} \cdot 4 \mathrm{H}_{2} \mathrm{O}(0.01 \mathrm{mmol}, 2.5 \mathrm{mg})$, $\mathrm{dmgH}_{2}$ (0.05 mmol, $\left.5.8 \mathrm{mg}\right)$, 4-ethylphenyl 4-ethylbenzoate $\mathbf{S 8 4}(0.1 \mathrm{mmol}, 25.4 \mathrm{mg})$ and DCE (8 
$\mathrm{mL}$ ). The reaction mixture was sealed and stirred in dark for 30 minutes at room temperature. Then, the reaction was irradiated with two $20 \mathrm{~W}$ 400-415 nm LEDs for 36 hours (tube $2 \mathrm{~cm}$ away from lights, fans for cooling, $20-30{ }^{\circ} \mathrm{C}$ ). After that, the solvent of the reaction mixture was removed on a rotary evaporator under reduced pressure and the residue was purified by silica gel column chromatography using petroleum ether/EtOAc $=20: 1$ to give $71 \%$ yield $(17.9 \mathrm{mg})$ of the product $\mathbf{P 8 4}+\mathbf{P 8 4}^{\prime}$ as a yellow solid. The two isomers $\mathbf{P 8 4}$ and $\mathbf{P 8 4}$ ' can not be isolated, and the ratio (10:1) of these two isomers was determined by ${ }^{1} \mathrm{H}$ NMR.

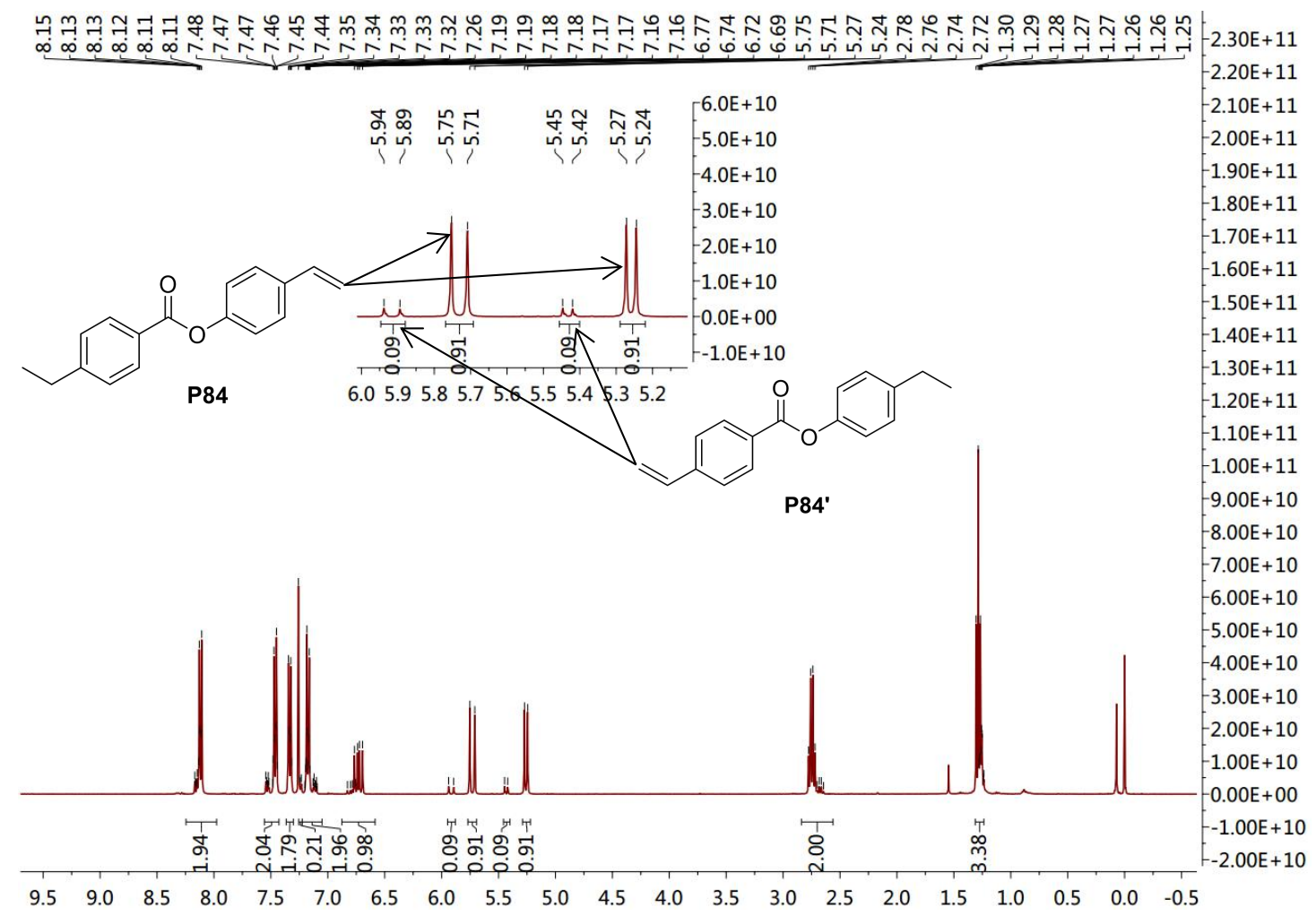

Figure S7. ${ }^{1} \mathrm{H}$ NMR of P84 + P84'

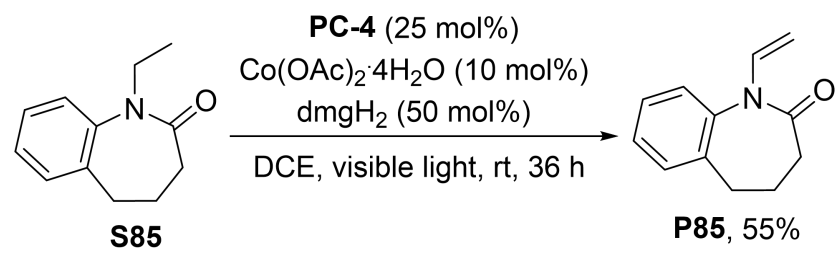

In argon-filled glovebox, to an oven-dried $10 \mathrm{~mL}$ Schlenk tube equipped with a stir bar was added 2-chloroanthraquinone $(0.025 \mathrm{mmol}, 6.1 \mathrm{mg}), \mathrm{Co}(\mathrm{OAc})_{2} \cdot 4 \mathrm{H}_{2} \mathrm{O}(0.01 \mathrm{mmol}, 2.5 \mathrm{mg})$, $\mathrm{dmgH}_{2}(0.05 \mathrm{mmol}, 5.8 \mathrm{mg})$, 1-ethyl-1,3,4,5-tetrahydro-2H-benzo[b]azepin-2-one $\mathbf{S 8 5}$ (0.1 mmol, $19.0 \mathrm{mg})$ and DCE $(8 \mathrm{~mL})$. The reaction mixture was sealed and stirred in dark for 30 minutes at room temperature. Then, the reaction was irradiated with two $20 \mathrm{~W}$ 400-415 nm LEDs for 36 
hours (tube $2 \mathrm{~cm}$ away from lights, fans for cooling, 20-30 ${ }^{\circ} \mathrm{C}$ ). After that, the solvent of the reaction mixture was removed on a rotary evaporator under reduced pressure and the residue was purified by silica gel column chromatography using petroleum ether/EtOAc $=10: 1$ to give $55 \%$ yield $\left(10.3 \mathrm{mg}\right.$ ) of the product as a yellow oil. ${ }^{1} \mathrm{H} \mathrm{NMR}\left(400 \mathrm{MHz}, \mathrm{CDCl}_{3}\right): \delta 7.57$ (dd, $J=16.1$, $9.1 \mathrm{~Hz}, 1 \mathrm{H}), 7.33-7.27(\mathrm{~m}, 3 \mathrm{H}), 7.26(\mathrm{~s}, 1 \mathrm{H}), 4.50(\mathrm{dd}, J=9.1,0.7 \mathrm{~Hz}, 1 \mathrm{H}), 4.42$ (dd, $J=16.1$, $0.6 \mathrm{~Hz}, 1 \mathrm{H}), 2.70$ (brs, $2 \mathrm{H}), 2.29$ (brs, 3H), 2.00 (brs, $1 \mathrm{H}) ;{ }^{13} \mathrm{C} \mathrm{NMR}\left(101 \mathrm{MHz}, \mathrm{CDCl}_{3}\right): \delta 171.5$, 138.2, 136.6, 131.8, 129.4, 127.6, 127.1, 126.3, 97.2, 33.2, 29.3, 28.2; ESI-HRMS calcd for $\left[\mathrm{C}_{12} \mathrm{H}_{14} \mathrm{NO}, \mathrm{M}+\mathrm{H}\right]^{+}:$188.1070, Found: 188.1070 .

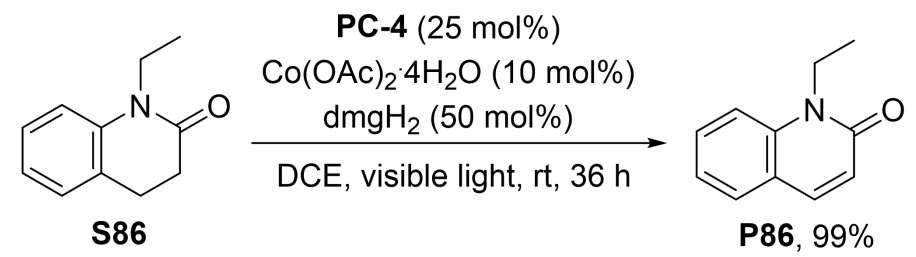

In argon-filled glovebox, to an oven-dried $10 \mathrm{~mL}$ Schlenk tube equipped with a stir bar was added 2-chloroanthraquinone $(0.025 \mathrm{mmol}, 6.1 \mathrm{mg}), \mathrm{Co}(\mathrm{OAc})_{2} \cdot 4 \mathrm{H}_{2} \mathrm{O}(0.01 \mathrm{mmol}, 2.5 \mathrm{mg})$, $\mathrm{dmgH}_{2}(0.05 \mathrm{mmol}, 5.8 \mathrm{mg})$, 1-ethyl-3,4-dihydroquinolin-2(1H)-one $\mathbf{S 8 6}(0.1 \mathrm{mmol}, 17.5 \mathrm{mg})$ and DCE $(8 \mathrm{~mL})$. The reaction mixture was sealed and stirred in dark for 30 minutes at room temperature. Then, the reaction was irradiated with two $20 \mathrm{~W}$ 400-415 nm LEDs for 36 hours (tube $2 \mathrm{~cm}$ away from lights, fans for cooling, 20-30 ${ }^{\circ} \mathrm{C}$ ). After that, the solvent of the reaction mixture was removed on a rotary evaporator under reduced pressure and the residue was purified by silica gel column chromatography using petroleum ether/EtOAc $=5: 1$ to give $99 \%$ yield $(17.1$ $\mathrm{mg}$ ) of the product as an orange solid. ${ }^{1} \mathrm{H}$ NMR and ${ }^{13} \mathrm{C}$ NMR data match previously reported data. ${ }^{8}{ }^{1} \mathrm{H} \mathrm{NMR}\left(600 \mathrm{MHz}, \mathrm{CDCl}_{3}\right): \delta 7.67(\mathrm{~d}, J=9.4 \mathrm{~Hz}, 1 \mathrm{H}), 7.60-7.54(\mathrm{~m}, 2 \mathrm{H}), 7.39(\mathrm{~d}, J=8.9$ $\mathrm{Hz}, 1 \mathrm{H}), 7.25-7.18(\mathrm{~m}, 1 \mathrm{H}), 6.70(\mathrm{~d}, J=9.3 \mathrm{~Hz}, 1 \mathrm{H}), 4.38(\mathrm{q}, J=7.2 \mathrm{~Hz}, 2 \mathrm{H}), 1.37$ (t, $J=7.2 \mathrm{~Hz}$, $3 \mathrm{H}) ;{ }^{13} \mathrm{C} \mathrm{NMR}\left(151 \mathrm{MHz}, \mathrm{CDCl}_{3}\right): \delta 161.9,139.0,138.9,130.5,129.0,121.8,121.0,114.0,37.2$, 12.7 .

\section{Synthesis of Pharmaceutical Intermediates}

1-(5H-dibenzo[b,f]azepin-5-yl)ethan-1-one (P98) 


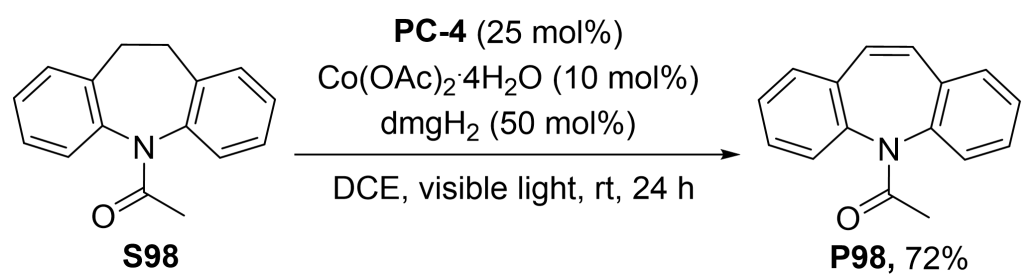

In argon-filled glovebox, to an oven-dried $10 \mathrm{~mL}$ Schlenk tube equipped with a stir bar was added 2-chloroanthraquinone (0.025 mmol, $6.1 \mathrm{mg}), \mathrm{Co}(\mathrm{OAc})_{2} \cdot 4 \mathrm{H}_{2} \mathrm{O}(0.01 \mathrm{mmol}, 2.5 \mathrm{mg})$, $\mathrm{dmgH}_{2}(0.05 \mathrm{mmol}, 5.8 \mathrm{mg}), 1$-(10,11-dihydro-5H-dibenzo[b,f]azepin-5-yl)ethan-1-one $\mathbf{S 9 8}(0.1$ mmol, $23.7 \mathrm{mg})$ and DCE $(8 \mathrm{~mL})$. The reaction mixture was sealed and stirred in dark for 30 minutes at room temperature. Then, the reaction was irradiated with two $20 \mathrm{~W}$ 400-415 nm LEDs for 24 hours (tube $2 \mathrm{~cm}$ away from lights, fans for cooling, 20-30 ${ }^{\circ} \mathrm{C}$ ). After that, the solvent of the reaction mixture was removed on a rotary evaporator under reduced pressure and the residue was purified by silica gel column chromatography using petroleum ether/EtOAc $=5: 1$ to give $72 \%$ (16.9 mg) yield of the product as a light yellow solid. ${ }^{1} \mathrm{H}$ NMR and ${ }^{13} \mathrm{C}$ NMR data match previously reported data. ${ }^{9}{ }^{1} \mathrm{H}$ NMR $\left(400 \mathrm{MHz}, \mathrm{CDCl}_{3}\right): \delta 7.48-7.27(\mathrm{~m}, 8 \mathrm{H}), 7.01-6.88(\mathrm{~m}, 2 \mathrm{H})$, $1.86(\mathrm{~s}, 3 \mathrm{H}) ;{ }^{13} \mathrm{C}$ NMR $\left(101 \mathrm{MHz}, \mathrm{CDCl}_{3}\right): \delta 170.8,140.5,140.3,134.7,133.5,131.5,129.34$, $129.29,129.26,129.25,129.1,128.5,127.91,127.87,127.4,22.1$.

\section{Carbamazepine (P99)}

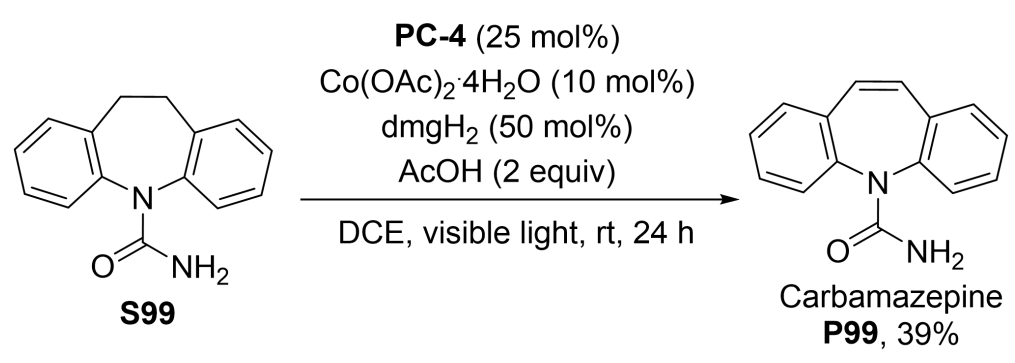

In argon-filled glovebox, to an oven-dried $10 \mathrm{~mL}$ Schlenk tube equipped with a stir bar was added 2-chloroanthraquinone (0.025 mmol, $6.1 \mathrm{mg}), \mathrm{Co}(\mathrm{OAc})_{2} \cdot 4 \mathrm{H}_{2} \mathrm{O}(0.01 \mathrm{mmol}, 2.5 \mathrm{mg})$, $\left.\begin{array}{llllllll}\mathrm{dmgH}_{2} & (0.05 \quad \mathrm{mmol}, & 5.8 & \mathrm{mg}\end{array}\right), \quad \mathrm{AcOH} \quad(0.2 \quad \mathrm{mmol}, \quad 12 \quad \mu \mathrm{L})$, 10,11-dihydro-5H-dibenzo[b,f]azepine-5-carboxamide $\mathbf{S 9 9}(0.1 \mathrm{mmol}, 23.8 \mathrm{mg})$ and DCE $(8 \mathrm{~mL})$. The reaction mixture was sealed and stirred in dark for 30 minutes at room temperature. Then, the reaction was irradiated with two $20 \mathrm{~W} 400-415 \mathrm{~nm}$ LEDs for 24 hours (tube $2 \mathrm{~cm}$ away from lights, fans for cooling, $20-30^{\circ} \mathrm{C}$ ). After that, the solvent of the reaction mixture was removed on a rotary evaporator under reduced pressure and the residue was purified by silica gel column 
chromatography using EtOAc (with a small amount of $\mathrm{Et}_{3} \mathrm{~N}$ ) to give $39 \%$ yield $(9.2 \mathrm{mg}$ ) of the product as a light yellow solid. ${ }^{1} \mathrm{H}$ NMR and ${ }^{13} \mathrm{C}$ NMR data match previously reported data. ${ }^{10}{ }^{1} \mathrm{H}$ NMR (400 MHz, $\left.\mathrm{CDCl}_{3}\right): \delta 7.50-7.40(\mathrm{~m}, 4 \mathrm{H}), 7.40-7.30(\mathrm{~m}, 4 \mathrm{H}), 6.94(\mathrm{~s}, 2 \mathrm{H}), 4.54$ (brs, 2H); ${ }^{13} \mathrm{C}$ NMR (101 MHz, $\left.\mathrm{CDCl}_{3}\right): \delta 156.9,140.0,135.0,130.5,129.6,129.5,128.7,127.8$.

\section{7-(4-Chlorobutoxy)quinolin-2(1H)-one (P100)}

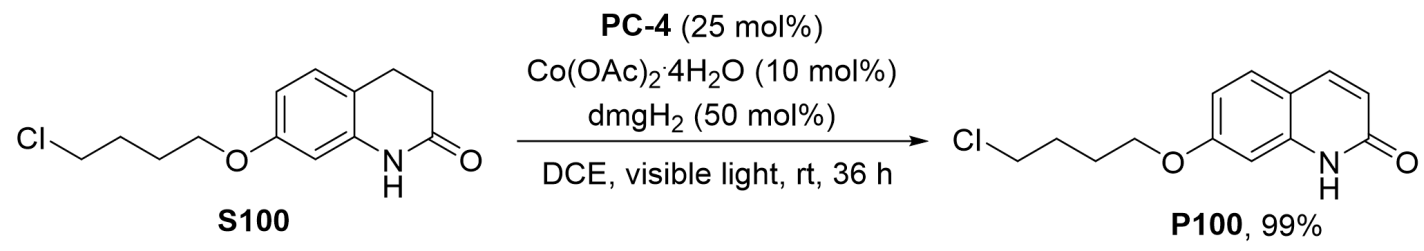

In argon-filled glovebox, to an oven-dried $10 \mathrm{~mL}$ Schlenk tube equipped with a stir bar was added 2-chloroanthraquinone (0.025 mmol, $6.1 \mathrm{mg}), \mathrm{Co}(\mathrm{OAc})_{2} \cdot 4 \mathrm{H}_{2} \mathrm{O}(0.01 \mathrm{mmol}, 2.5 \mathrm{mg})$, $\mathrm{dmgH}_{2}$ (0.05 mmol, $\left.5.8 \mathrm{mg}\right)$, 7-(4-chlorobutoxy)-3,4-dihydroquinolin-2(1H)-one S100 (0.1 mmol, $25.4 \mathrm{mg})$ and DCE $(8 \mathrm{~mL})$. The reaction mixture was sealed and stirred in dark for 30 minutes at room temperature. Then, the reaction was irradiated with two $20 \mathrm{~W} \mathrm{400-415} \mathrm{nm}$ LEDs for 36 hours (tube $2 \mathrm{~cm}$ away from lights, fans for cooling, 20-30 ${ }^{\circ} \mathrm{C}$ ). After that, the solvent of the reaction mixture was removed on a rotary evaporator under reduced pressure and the residue was purified by silica gel column chromatography using EtOAc to give 99\% yield (25.0 $\mathrm{mg}$ ) of the product as a yellow solid. ${ }^{1} \mathrm{H}$ NMR and ${ }^{13} \mathrm{C}$ NMR data match previously reported data. ${ }^{11}{ }^{1} \mathrm{H}$ NMR (600 MHz, $\left.\mathrm{CDCl}_{3}\right): \delta 12.57$ (brs, $\left.1 \mathrm{H}\right), 7.74(\mathrm{~d}, J=9.3 \mathrm{~Hz}, 1 \mathrm{H}), 7.45(\mathrm{~d}, J=8.7 \mathrm{~Hz}, 1 \mathrm{H}), 6.85(\mathrm{~d}, J$ $=2.4 \mathrm{~Hz}, 1 \mathrm{H}), 6.80(\mathrm{dd}, J=8.6,2.4 \mathrm{~Hz}, 1 \mathrm{H}), 6.57(\mathrm{~d}, J=9.3 \mathrm{~Hz}, 1 \mathrm{H}), 4.10(\mathrm{t}, J=5.4 \mathrm{~Hz}, 2 \mathrm{H})$, $3.63(\mathrm{t}, J=6.0 \mathrm{~Hz}, 2 \mathrm{H}), 2.05-1.93(\mathrm{~m}, 4 \mathrm{H}) ;{ }^{13} \mathrm{C} \mathrm{NMR}\left(151 \mathrm{MHz}, \mathrm{CDCl}_{3}\right): \delta 165.1,161.2,140.9$, $140.4,129.0,118.0,114.3,112.6,99.0,67.4,44.7,29.2,26.5$.

\section{Gram-Scale Synthesis of Compound P100}

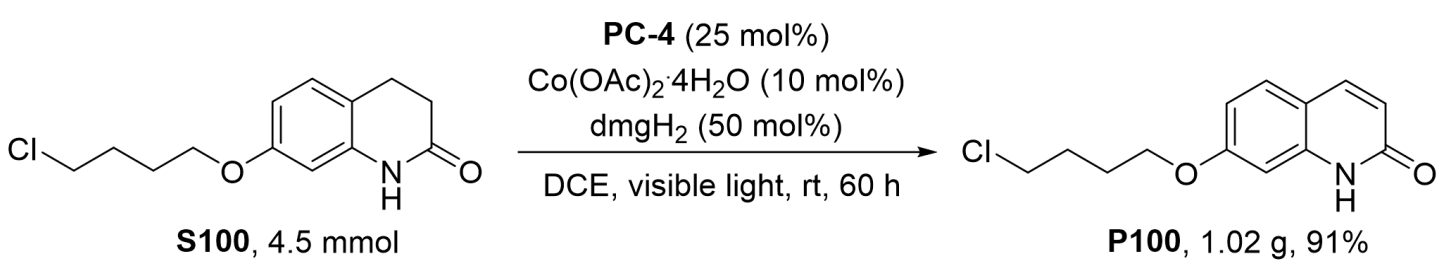

In argon-filled glovebox, to an oven-dried $250 \mathrm{~mL}$ Schlenk tube equipped with a stir bar was added 2-chloroanthraquinone (1.125 mmol, $273 \mathrm{mg}), \mathrm{Co}(\mathrm{OAc})_{2} \cdot 4 \mathrm{H}_{2} \mathrm{O}(0.45 \mathrm{mmol}, 112 \mathrm{mg})$, $\mathrm{dmgH}_{2}(2.25 \mathrm{mmol}, 5.8 \mathrm{mg})$, alkane $(4.5 \mathrm{mmol}, 1.14 \mathrm{~g})$ and DCE $(90 \mathrm{~mL})$. The reaction mixture 
was sealed and stirred in dark for 30 minutes at room temperature. Then, the reaction was irradiated with two $20 \mathrm{~W} 400-415 \mathrm{~nm}$ LEDs for 60 hours. After that, the solvent of the reaction mixture was removed on a rotary evaporator under reduced pressure and the residue was purified by silica gel column chromatography using EtOAc to give $91 \%$ yield (1.02 g) of the product P100 as a yellow solid.

\section{Mechanistic Investigation}

\subsection{Radical trapping experiments}

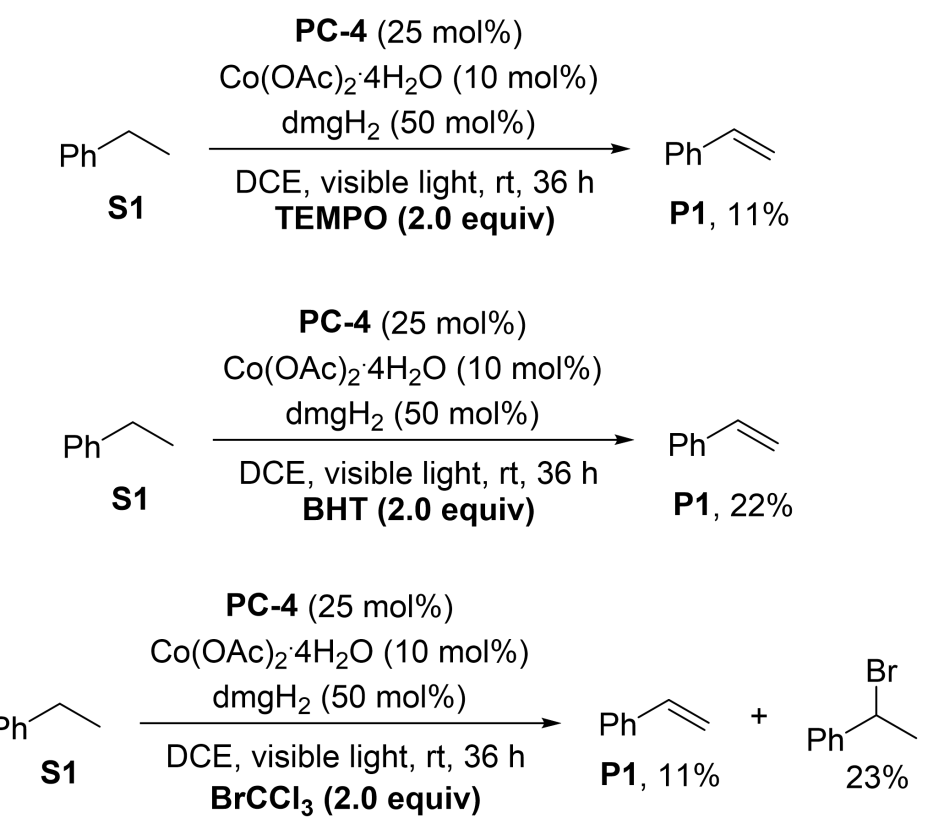

In argon-filled glovebox, to an oven-dried $10 \mathrm{~mL}$ Schlenk tube equipped with a stir bar was added 2-chloroanthraquinone $(0.025 \mathrm{mmol}, 6.1 \mathrm{mg}), \mathrm{Co}(\mathrm{OAc})_{2} \cdot 4 \mathrm{H}_{2} \mathrm{O}(0.01 \mathrm{mmol}, 2.5 \mathrm{mg})$, $\mathrm{dmgH}_{2}(0.05 \mathrm{mmol}, 5.8 \mathrm{mg})$, ethylbenzene $\mathbf{S 1}(0.1 \mathrm{mmol}, 12.2 \mu \mathrm{L})$, additive (TEMPO, BHT, or $\left.\mathrm{BrCCl}_{3}\right)(0.2 \mathrm{mmol})$ and DCE $(8 \mathrm{~mL})$. The reaction mixture was sealed and stirred in dark for 30 minutes at room temperature. Then, the reaction was irradiated with two $20 \mathrm{~W}$ 400-415 nm LEDs for 36 hours (tube $2 \mathrm{~cm}$ away from lights, fans for cooling, 20-30 ${ }^{\circ} \mathrm{C}$ ). After that, the reaction mixture was diluted with EtOAc $(2 \mathrm{~mL})$ and $n-\mathrm{C}_{16} \mathrm{H}_{34}$ was added as an internal standard. About $500 \mu \mathrm{L}$ of the mixture was taken and filtered through a short pad of silica gel with EtOAc as eluent. The sample was subjected to GC analysis and the yield of styrene P1 was determined based on the internal standard. For reaction with $\mathrm{BrCCl}_{3}$ as an additive, $23 \%$ yield $(4.3 \mathrm{mg})$ of (1-bromoethyl)benzene was isolated by silica gel column chromatography with $n$-hexane as eluent. ${ }^{1} \mathrm{H}$ NMR data of (1-bromoethyl)benzene matches previously reported data. ${ }^{12} \mathrm{H}$ NMR $(400 \mathrm{MHz}$, 
$\left.\mathrm{CDCl}_{3}\right): \delta 7.48-7.41(\mathrm{~m}, 2 \mathrm{H}), 7.37-7.27(\mathrm{~m}, 3 \mathrm{H}), 5.21(\mathrm{q}, J=6.9 \mathrm{~Hz}, 1 \mathrm{H}), 2.05(\mathrm{~d}, J=6.9 \mathrm{~Hz}$, $3 \mathrm{H})$.

\subsection{Light on-off experiments}
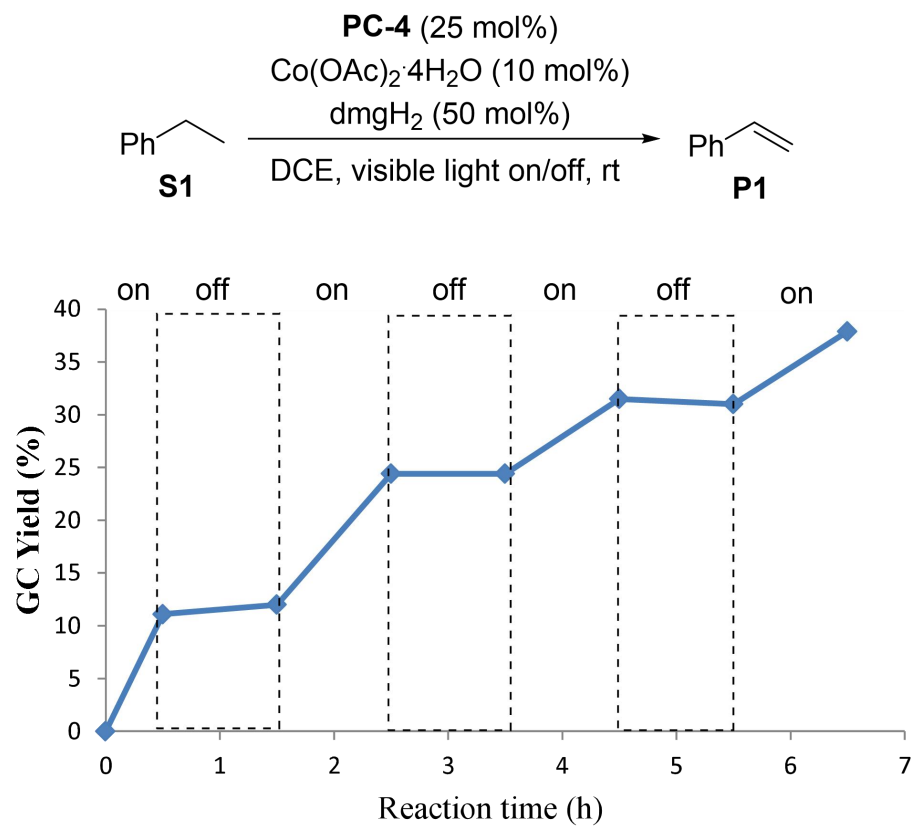

In argon-filled glovebox, to an oven-dried $10 \mathrm{~mL}$ Schlenk tube equipped with a stir bar was added 2-chloroanthraquinone (0.025 mmol, $6.1 \mathrm{mg}), \mathrm{Co}(\mathrm{OAc})_{2} \cdot 4 \mathrm{H}_{2} \mathrm{O}(0.01 \mathrm{mmol}, 2.5 \mathrm{mg})$, $\mathrm{dmgH}_{2}(0.05 \mathrm{mmol}, 5.8 \mathrm{mg})$, ethylbenzene $\mathbf{S 1}(0.1 \mathrm{mmol}, 12.2 \mu \mathrm{L})$ and DCE $(8 \mathrm{~mL})$. The reaction mixture was sealed and stirred in dark for 30 minutes at room temperature. Then, the reaction was irradiated with two $20 \mathrm{~W}$ 400-415 nm LEDs for 30 minutes (tube $2 \mathrm{~cm}$ away from lights, fans for cooling, $\left.20-30{ }^{\circ} \mathrm{C}\right)$. After that, lights were turned off, sample $(200 \mu \mathrm{L})$ was taken with a syringe and filtered through a short pad of silica gel with EtOAc as eluent. $n-\mathrm{C}_{16} \mathrm{H}_{34}$ was added to the sample as an internal standard. Then, the reaction mixture was continued to stir in dark for 1 hour. Another sample $(200 \mu \mathrm{L})$ was taken with a syringe and filtered through a short pad of silica gel with EtOAc as eluent. $n$ - $\mathrm{C}_{16} \mathrm{H}_{34}$ was added to the sample as an internal standard. After an additional 1 hour of irradiation, lights were turned off again, sample $(200 \mu \mathrm{L})$ was taken with a syringe and filtered through a short pad of silica gel with EtOAc as eluent. $n$ - $\mathrm{C}_{16} \mathrm{H}_{34}$ was added to the sample as an internal standard. The above light on-off experiments were conducted for another two times. All samples were analyzed by GC to determine the yields of styrene $\mathbf{P 1}$ based on the internal standard. 


\subsection{Acceptorless dehydrogenation of $S 9-\mathrm{D}_{2}$}

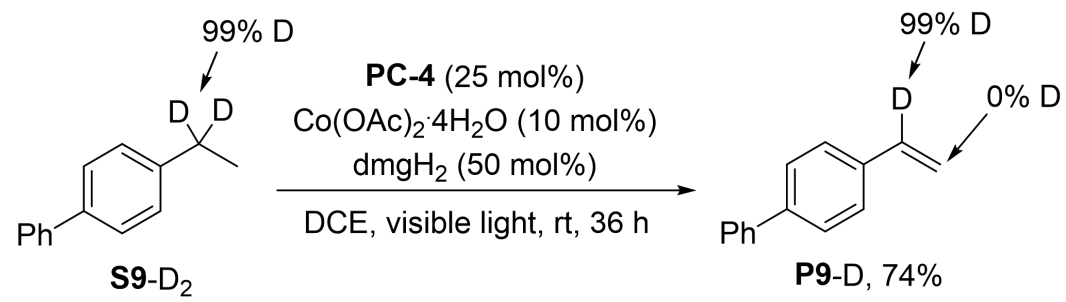

In argon-filled glovebox, to an oven-dried $10 \mathrm{~mL}$ Schlenk tube equipped with a stir bar was added 2-chloroanthraquinone $(0.025 \mathrm{mmol}, 6.1 \mathrm{mg}), \mathrm{Co}(\mathrm{OAc})_{2} \cdot 4 \mathrm{H}_{2} \mathrm{O}(0.01 \mathrm{mmol}, 2.5 \mathrm{mg})$, $\mathrm{dmgH}_{2}(0.05 \mathrm{mmol}, 5.8 \mathrm{mg}), 4$-(ethyl-1,1- $\left.d_{2}\right)$-1,1'-biphenyl $\mathbf{S 9}-\mathrm{D}_{2}(0.1 \mathrm{mmol}, 18.4 \mathrm{mg})$ and DCE $(8 \mathrm{~mL})$. The reaction mixture was sealed and stirred in dark for 30 minutes at room temperature. Then, the reaction was irradiated with two $20 \mathrm{~W}$ 400-415 nm LEDs for 36 hours (tube $2 \mathrm{~cm}$ away from lights, fans for cooling, $20-30{ }^{\circ} \mathrm{C}$ ). After that, the solvent of the reaction mixture was removed on a rotary evaporator under reduced pressure and the residue was purified by silica gel column chromatography using $n$-hexane to give $74 \%$ yield $(13.5 \mathrm{mg})$ of the product P9-D as a white solid. ${ }^{1} \mathrm{H}$ NMR (400 MHz, $\left.\mathrm{CDCl}_{3}\right): \delta 7.62-7.41(\mathrm{~m}, 8 \mathrm{H}), 7.38-7.29(\mathrm{~m}, 1 \mathrm{H}), 5.80-5.76(\mathrm{~m}$, $1 \mathrm{H}), 5.27(\mathrm{~s}, 1 \mathrm{H}) ;{ }^{13} \mathrm{C} \mathrm{NMR}\left(151 \mathrm{MHz}, \mathrm{CDCl}_{3}\right): \delta 140.7,140.6,136.5,136.1\left(\mathrm{t}, J_{\mathrm{C}-\mathrm{D}}=24.2 \mathrm{~Hz}\right)$, 128.8, 127.3, 127.2, 127.0, 126.6, 113.7; ESI-HRMS calcd for $\left[\mathrm{C}_{14} \mathrm{H}_{12} \mathrm{D}, \mathrm{M}+\mathrm{H}\right]^{+}: 182.1075$, Found: 182.1075 .

\subsection{Crossover experiment 1}

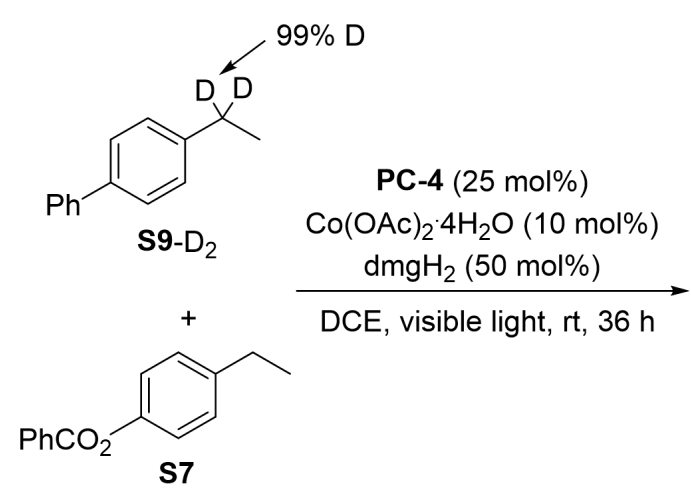

$(1: 1)$

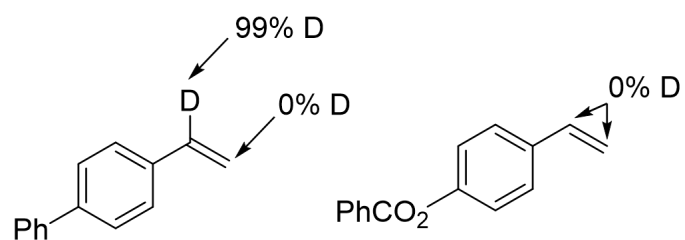

P9-D, $79 \% \quad$ P7, 30\%<smiles>Oc1ccc(C2C3C(O)C23)cc1</smiles>

$61 \%$ S7 recovered

In argon-filled glovebox, to an oven-dried $10 \mathrm{~mL}$ Schlenk tube equipped with a stir bar was added 2-chloroanthraquinone (0.025 mmol, $6.1 \mathrm{mg}), \mathrm{Co}(\mathrm{OAc})_{2} \cdot 4 \mathrm{H}_{2} \mathrm{O}(0.01 \mathrm{mmol}, 2.5 \mathrm{mg})$, $\mathrm{dmgH}_{2}$ (0.05 mmol, $\left.5.8 \mathrm{mg}\right)$, 4-(ethyl-1,1- $\left.d_{2}\right)-1,1$ '-biphenyl S9-- 2 (0.1 mmol, $\left.18.4 \mathrm{mg}\right)$, 4-ethylphenyl benzoate $\mathbf{S} 7(0.1 \mathrm{mmol}, 22.6 \mathrm{mg})$ and DCE $(8 \mathrm{~mL})$. The reaction mixture was sealed and stirred in dark for 30 minutes at room temperature. Then, the reaction was irradiated 
with two $20 \mathrm{~W}$ 400-415 nm LEDs for 36 hours (tube $2 \mathrm{~cm}$ away from lights, fans for cooling, 20-30 ${ }^{\circ} \mathrm{C}$ ). After that, the solvent of the reaction mixture was removed on a rotary evaporator under reduced pressure and the residue was purified by silica gel column chromatography to give $79 \%$ yield $(14.3 \mathrm{mg}$ ) of the product $\mathbf{P 9}$-D and $30 \%$ yield $(6.7 \mathrm{mg})$ of the product $\mathbf{S} 7$. At the same time, $61 \%(13.8 \mathrm{mg})$ of start material $\mathbf{S} 7$ was recovered.

\subsection{Crossover experiment 2}

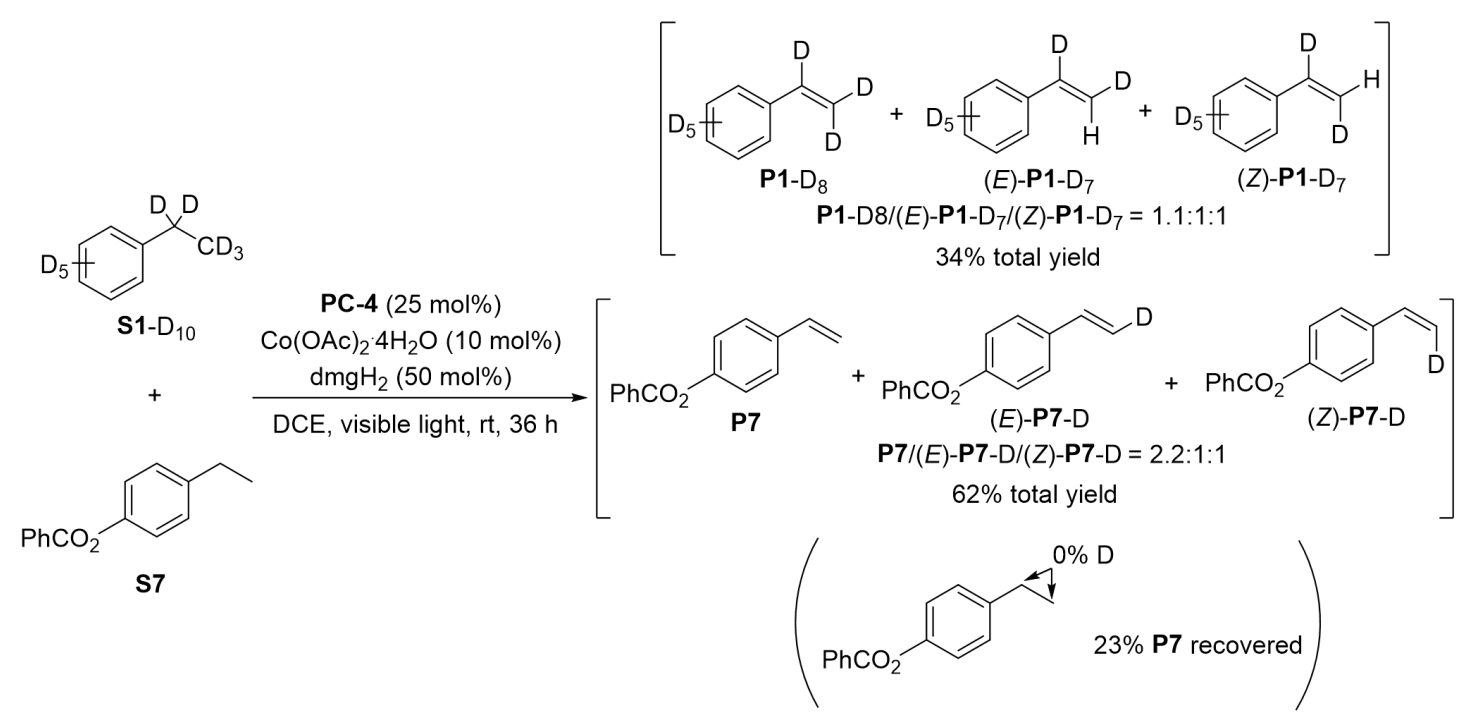

In argon-filled glovebox, to an oven-dried $10 \mathrm{~mL}$ Schlenk tube equipped with a stir bar was added 2-chloroanthraquinone $(0.025 \mathrm{mmol}, 6.1 \mathrm{mg}), \mathrm{Co}(\mathrm{OAc})_{2} 4 \mathrm{H}_{2} \mathrm{O}(0.01 \mathrm{mmol}, 2.5 \mathrm{mg})$, $\mathrm{dmgH}_{2}(0.05 \mathrm{mmol}, 5.8 \mathrm{mg})$, 1-(ethyl- $\left.d_{5}\right)$ benzene-2,3,4,5,6- $d_{5}$ S1-D $\mathrm{D}_{10}(0.1 \mathrm{mmol}, 11.6 \mathrm{mg})$, 4-ethylphenyl benzoate $\mathbf{S} 7(0.1 \mathrm{mmol}, 22.6 \mathrm{mg})$ and DCE $(8 \mathrm{~mL})$. The reaction mixture was sealed and stirred in dark for 30 minutes at room temperature. Then, the reaction was irradiated with two $20 \mathrm{~W}$ 400-415 nm LEDs for $36 \mathrm{~h}$ (tube $2 \mathrm{~cm}$ away from lights, fans for cooling, 20-30 $\left.{ }^{\circ} \mathrm{C}\right)$. The reaction mixture was diluted with EtOAc $(2 \mathrm{~mL})$ and $n-\mathrm{C}_{16} \mathrm{H}_{34}$ was added as an internal standard. About $500 \mu \mathrm{L}$ of the mixture was taken and filtered through a short pad of silica gel with EtOAc as eluent. The sample was subjected to GC analysis and the yield of $\left[\mathbf{P} 1-\mathrm{D}_{8}+(E)-\mathbf{P} 1-\mathrm{D}_{7}+\right.$ (Z)-P1- $\left.\mathrm{D}_{7}\right]$ was determined based on the internal standard. Then, the sample was subjected to GC-MS analysis and the ratio of $\left[\mathbf{P} 1-\mathrm{D}_{8}\right] /\left[(E)-\mathbf{P} 1-\mathrm{D}_{7}+(Z)-\mathbf{P} 1-\mathrm{D}_{7}\right]$ was determined (1.1:2) base on mass spectrometry abundance. After that, the reaction mixture was removed on a rotary evaporator under reduced pressure and the residue was purified by silica gel column chromatography to give a mixture of $\left[(E)-\mathbf{P} 1-\mathrm{D}_{7}+(Z)-\mathbf{P} 1-\mathrm{D}_{7}\right]$ (crude), and a mixture of $\left[\mathbf{P} 7-\mathrm{D}_{8}+\right.$ (E)-P7-D + (Z)-P7-D + S7 + PC-4] (24.0 mg). Analysis of crude ${ }^{1} \mathrm{H}$ NMR spectra of [(E)-P1-D $7+$ 
(Z)-P1-D 7 showed that the ratio of $(E)-\mathbf{P 1}-\mathrm{D}_{7}$ and $(Z)-\mathbf{P 1}-\mathrm{D}_{7}$ is $1: 1$. Analysis of ${ }^{1} \mathrm{H}$ NMR spectra of $\left[\mathbf{P 7}-\mathrm{D}_{8}+(E)-\mathbf{P} 7-\mathrm{D}+(Z)-\mathbf{P} 7-\mathrm{D}+\mathbf{S} 7+\mathbf{P C}-4\right]$ showed that: $(1)$ the total yield of $\left[\mathbf{P} 7-\mathrm{D}_{8}+\right.$ (E)-P7-D + (Z)-P7-D] is 62\%; (2) the ratio of $\mathbf{P 7}-\mathrm{D}_{8} /(E)-\mathbf{P} 7-\mathrm{D} /(Z)-\mathbf{P} 7-\mathrm{D}$ is $2.2: 1: 1 ;(3) 23 \%$ of $\mathbf{S} 7$ was recovered and no deuteration was found in recovered $\mathbf{S 7}$.

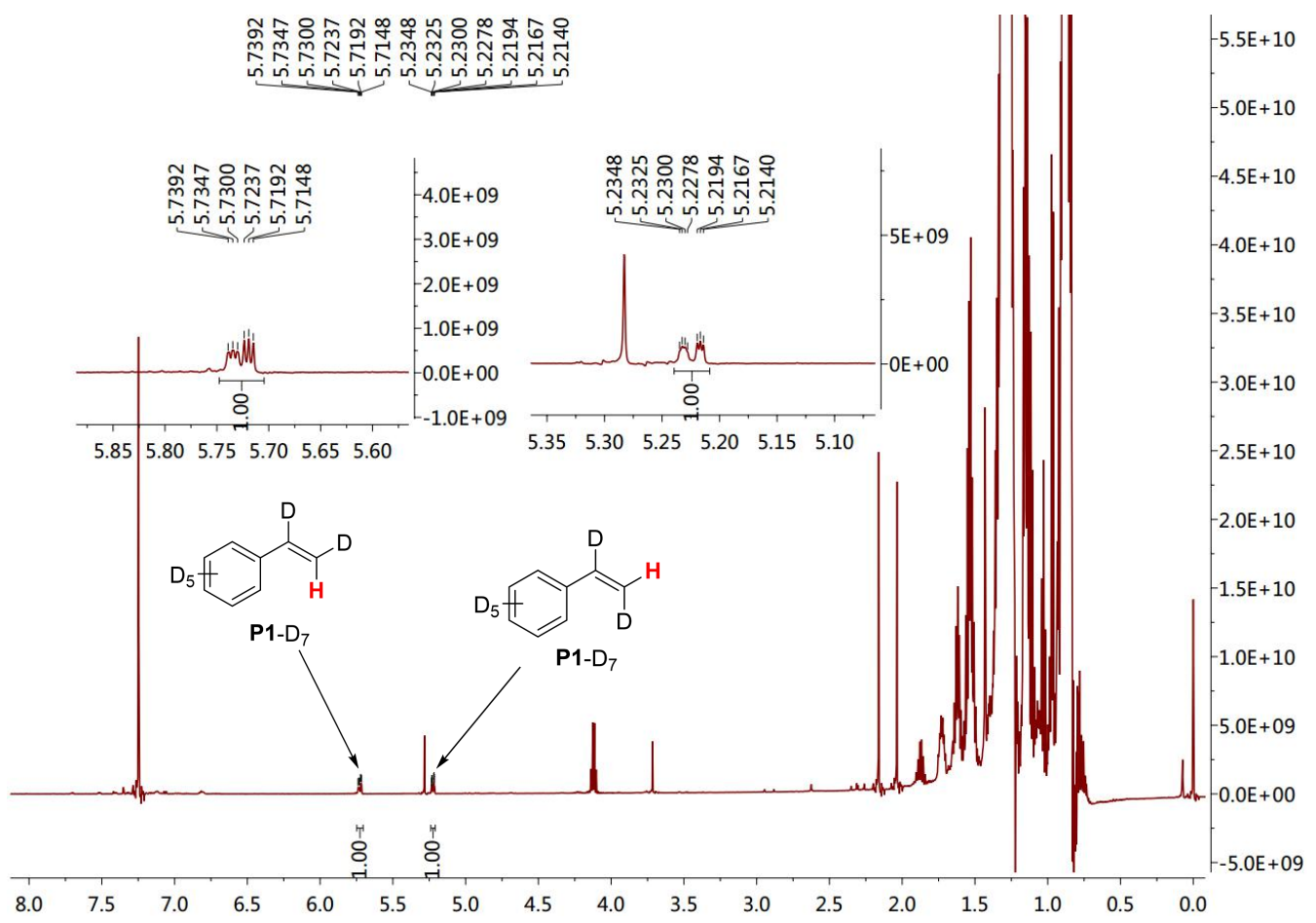

Figure S8. Crude ${ }^{1} \mathrm{H}$ NMR of $\left[(E)-\mathbf{P 1}-\mathrm{D}_{7}+(Z)-\mathbf{P} 1-\mathrm{D}_{7}\right]$

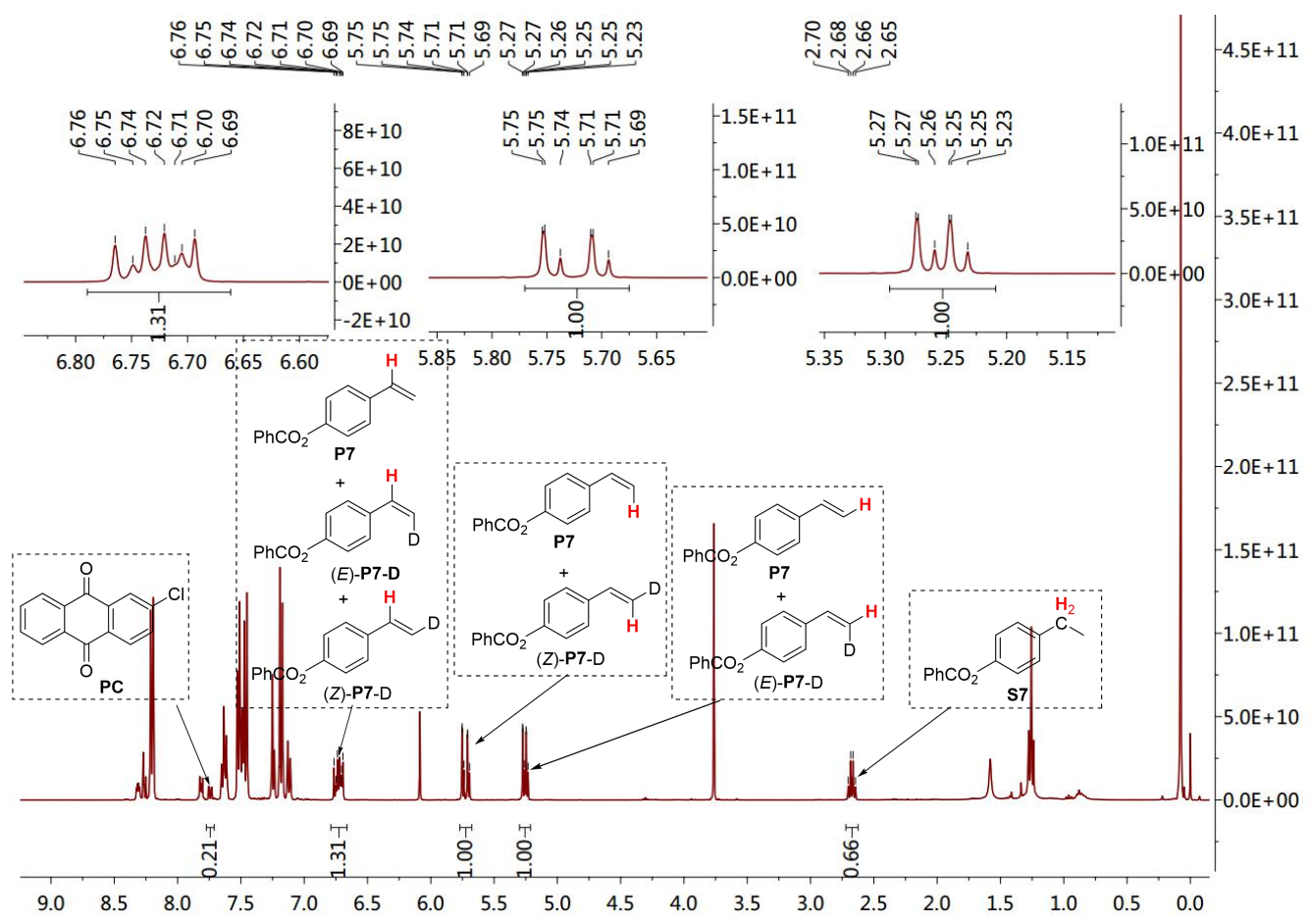

Figure S9. ${ }^{1} \mathrm{H}$ NMR of $\left[\mathbf{P 7}-\mathrm{D}_{8}+(E)-\mathbf{P 7}-\mathrm{D}+(Z)-\mathbf{P 7}-\mathrm{D}+\mathbf{S 7}+\mathbf{P C}-4\right]$ 
11.6 Experiments for photoisomerization of P38

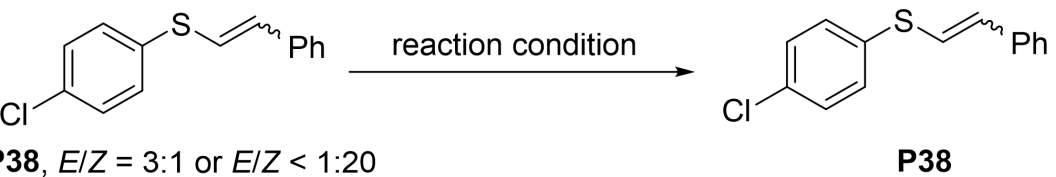

P38, $E / Z=3: 1$ or $E / Z<1: 20$

P38

\begin{tabular}{ccc}
\hline S.M & reaction conditions ${ }^{a}$ & results $^{b}$ \\
\hline $\mathbf{P 3 8}(E / Z=3: 1)$ & standard condition & $70 \%$ yield, P38 $(E / Z=1: 1.4)$ \\
$\mathbf{P 3 8}(E / Z<1: 20)$ & standard condition & $75 \%$ yield, P38 $(E / Z=1: 1.4)$ \\
$\mathbf{P 3 8}(E / Z=3: 1)$ & standard condition without 2-ClAQ & $98 \%$ yield, P38 $(E / Z=3: 1)$ \\
$\mathbf{P 3 8}(E / Z<1: 20)$ & standard condition without 2-ClAQ & $99 \%$ yield, P38 $(E / Z<1: 20)$ \\
$\mathbf{P 3 8}(E / Z=3: 1)$ & standard condition without $[\mathrm{Co}]$ & $66 \%$ yield, $\mathbf{P 3 8}(E / Z=1: 1.3)$ \\
$\mathbf{P 3 8}(E / Z<1: 20)$ & standard condition without $[\mathrm{Co}]$ & $70 \%$ yield, P38 $(E / Z=1: 1.2)$ \\
$\mathbf{P 3 8}(E / Z=3: 1)$ & standard condition without light & $100 \%$ yield, $\mathbf{P 3 8}(E / Z=3: 1)$ \\
$\mathbf{P 3 8}(E / Z<1: 20)$ & standard condition without light & $99 \%$ yield, P38 $(E / Z<1: 20)$ \\
\hline
\end{tabular}

${ }^{a}$ Standard condition: See section 7. A solution of P38 (0.1 mmol), PC-4 (25 mol\%), $\mathrm{Co}(\mathrm{OAc})_{2} \cdot 4 \mathrm{H}_{2} \mathrm{O}(10 \mathrm{~mol} \%)$ and $\mathrm{dmgH}_{2}(50 \mathrm{~mol} \%)$ in DCE $(8 \mathrm{~mL})$ was irradiated with $20 \mathrm{~W}$ 400-415 nm LEDs for 36 hours at room temperature under argon atmosphere. ${ }^{b 1} \mathrm{H}$ NMR yields were determined using 1,3,5-trimethoxybenzene as an internal standard. E/Z ratios were determined by crude ${ }^{1} \mathrm{H}$ NMR.

\subsection{Kinetic experiments}

For reaction order of ethylbenzene S1. In argon-filled glovebox, to an oven-dried $10 \mathrm{~mL}$ Schlenk tube equipped with a stir bar was added 2-chloroanthraquinone $(0.025 \mathrm{mmol}, 6.1 \mathrm{mg})$, $\mathrm{Co}(\mathrm{OAc})_{2} \cdot 4 \mathrm{H}_{2} \mathrm{O}(0.01 \mathrm{mmol}, 2.5 \mathrm{mg}), \mathrm{dmgH}_{2}(0.05 \mathrm{mmol}, 5.8 \mathrm{mg})$, ethylbenzene $\mathbf{S 1}(0.05 \mathrm{mmol}$, $0.1 \mathrm{mmol}, 0.15 \mathrm{mmol}$, or $0.2 \mathrm{mmol})$ and DCE $(8 \mathrm{~mL})$. The reaction mixture was sealed and stirred in dark for 30 minutes at room temperature. Then, the reaction was irradiated with two $20 \mathrm{~W}$ 400-415 nm LEDs (tube $2 \mathrm{~cm}$ away from lights, fans for cooling, 20-30 $\left.{ }^{\circ} \mathrm{C}\right)$. Samples $(200 \mu \mathrm{L})$ were taken with a syringe and filtered through a short pad of silica gel with EtOAc as eluent. $n-\mathrm{C}_{16} \mathrm{H}_{34}$ was added to the sample as the internal standard. All samples were analyzed by GC to determine the yield based on the internal standard. Every reaction rates of different [S1] were measured for more than two times. The experimental results show that the reaction rates for dehydrogenation of ethylbenzene is a first-order dependence on [S1]. 
$[\mathrm{S} 1]=0.00625 \mathrm{M}$

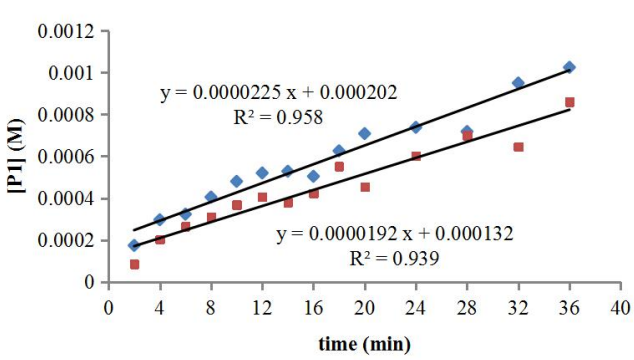

$[\mathrm{S} 1]=\mathbf{0 . 0 1 8 7 5} \mathrm{M}$

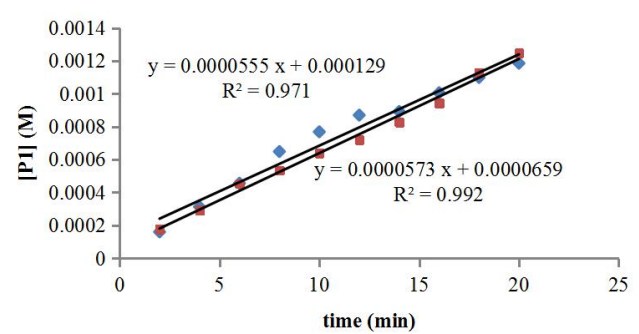

$[\mathrm{S} 1]=\mathbf{0 . 0 1 2 5} \mathrm{M}$

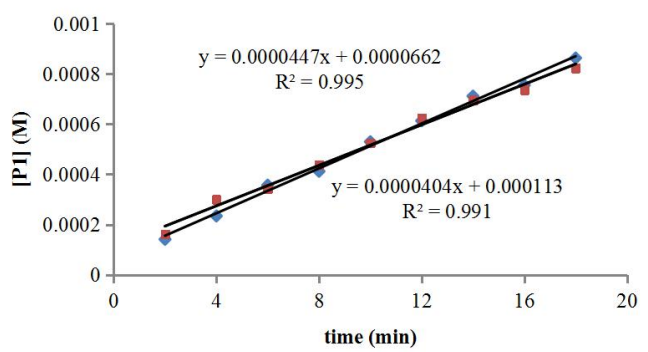

$[\mathrm{S} 1]=0.025 \mathrm{M}$

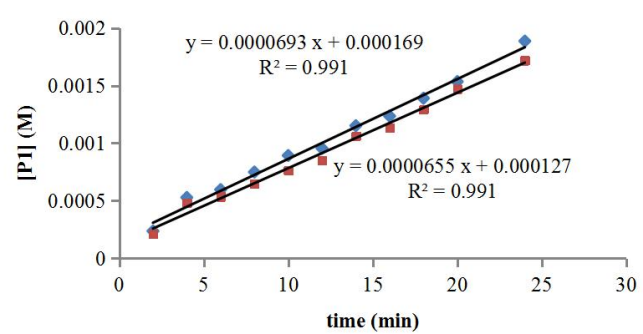

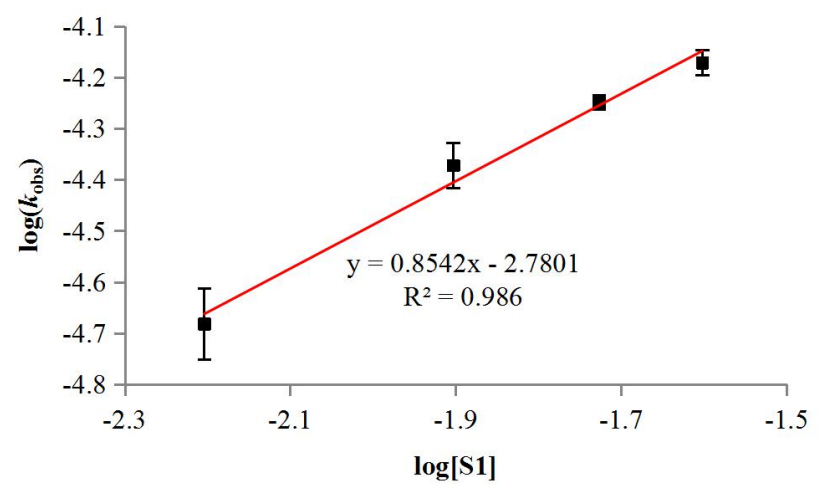

Figure S10. Dependence of the reaction rate on concentration of S1

For reaction order of 2-CIAQ (PC-4). In argon-filled glovebox, to an oven-dried $10 \mathrm{~mL}$ Schlenk tube equipped with a stir bar was added 2-chloroanthraquinone $(0.015 \mathrm{mmol}, 0.02 \mathrm{mmol}, 0.025$ mmol or $0.03 \mathrm{mmol}), \mathrm{Co}(\mathrm{OAc})_{2} 4 \mathrm{H}_{2} \mathrm{O}(0.01 \mathrm{mmol}, 2.5 \mathrm{mg})$, dmgH $\mathrm{H}_{2}(0.05 \mathrm{mmol}, 5.8 \mathrm{mg})$, ethylbenzene $\mathbf{S 1}(0.1 \mathrm{mmol})$ and DCE $(8 \mathrm{~mL})$. The reaction mixture was sealed and stirred in dark for 30 minutes at room temperature. Then, the reaction was irradiated with two $20 \mathrm{~W} 400-415 \mathrm{~nm}$ LEDs (tube $2 \mathrm{~cm}$ away from lights, fans for cooling, 20-30 $\left.{ }^{\circ} \mathrm{C}\right)$. Samples $(200 \mu \mathrm{L})$ were taken with a syringe and filtered through a short pad of silica gel with EtOAc as eluent. $n-\mathrm{C}_{16} \mathrm{H}_{34}$ was added to the sample as the internal standard. All samples were analyzed by GC to determine the yield based on the internal standard. Every reaction rates of different $[\mathbf{P C}]$ were measured for more than 
two times. The experimental results show that the reaction rates for dehydrogenation of ethylbenzene is a first-order dependence on [PC-4].
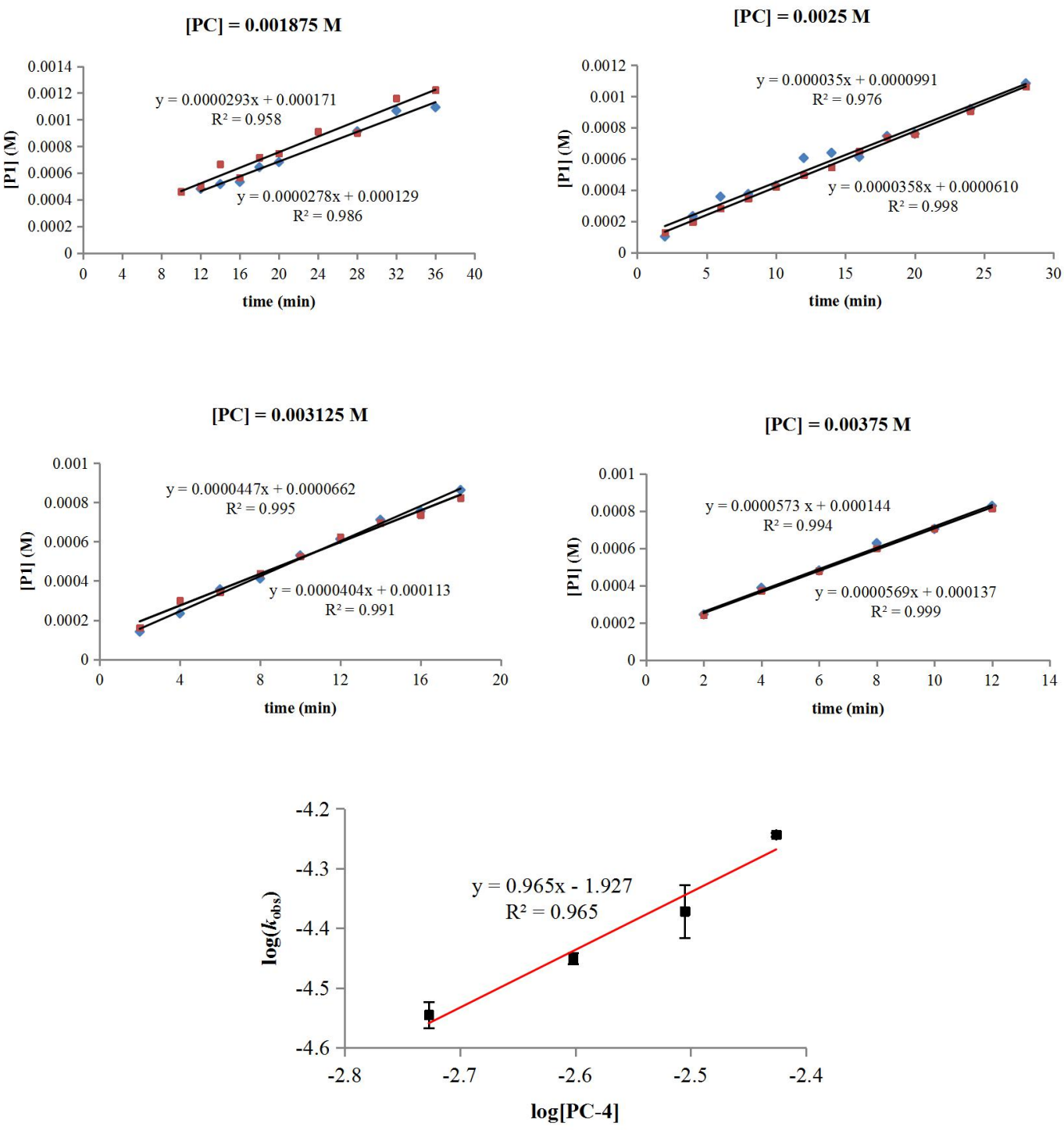

Figure S11. Dependence of the reaction rate on concentration of PC-4

For reaction order of cobalt catalyst. In argon-filled glovebox, to an oven-dried $10 \mathrm{~mL}$ Schlenk tube equipped with a stir bar was added 2-chloroanthraquinone $(0.025 \mathrm{mmol}), \mathrm{Co}(\mathrm{OAc})_{2} \cdot 4 \mathrm{H}_{2} \mathrm{O}$ (0.2 mg, $0.5 \mathrm{mg}, 0.8 \mathrm{mg}, 1.0 \mathrm{mg}, 1.3 \mathrm{mg}, 1.9 \mathrm{mg}, 2.5 \mathrm{mg}, 3.7 \mathrm{mg}$, or $5.0 \mathrm{mg}), \mathrm{dmgH} \mathrm{H}_{2}(0.5 \mathrm{mg}, 1.2$ $\mathrm{mg}, 1.9 \mathrm{mg}, 2.3 \mathrm{mg}, 2.9 \mathrm{mg}, 4.4 \mathrm{mg}, 5.8 \mathrm{mg}, 8.7 \mathrm{mg}$, or $11.6 \mathrm{mg})$, ethylbenzene $\mathbf{S 1}(0.1 \mathrm{mmol})$ and DCE $(8 \mathrm{~mL})$. The reaction mixture was sealed and stirred in dark for 30 minutes at room temperature. Then, the reaction was irradiated with two $20 \mathrm{~W}$ 400-415 nm LEDs (tube $2 \mathrm{~cm}$ away from lights, fans for cooling, $\left.20-30{ }^{\circ} \mathrm{C}\right)$. Samples $(200 \mu \mathrm{L})$ were taken with a syringe and filtered through a short pad of silica gel with EtOAc as eluent. $n-\mathrm{C}_{16} \mathrm{H}_{34}$ was added to the sample as the 
internal standard. All samples were analyzed by GC to determine the yield based on the internal standard. Every reaction rates of different $[\mathbf{C o}]$ were measured for more than two times. The experimental results are shown in Figure S12 and the reaction orders of cobalt catalyst are complicated.

$[\mathrm{Co}]=0.0001 \mathrm{M}$

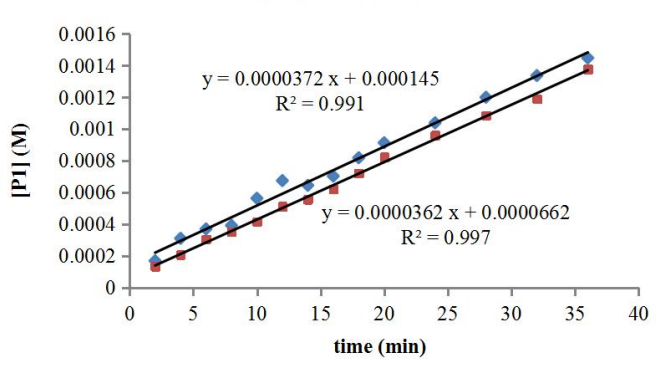

$[\mathrm{Co}]=0.0004 \mathrm{M}$

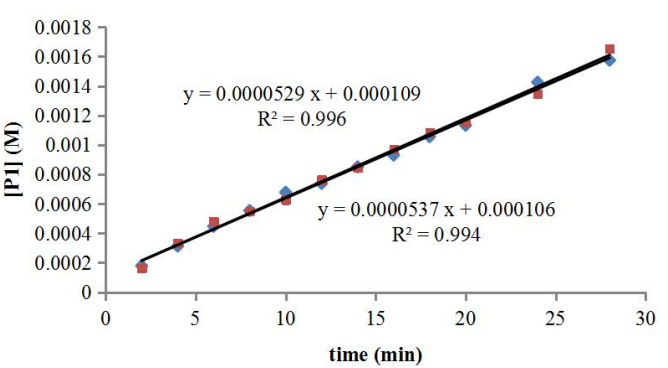

$[\mathrm{Co}]=\mathbf{0 . 0 0 0 6 5} \mathrm{M}$

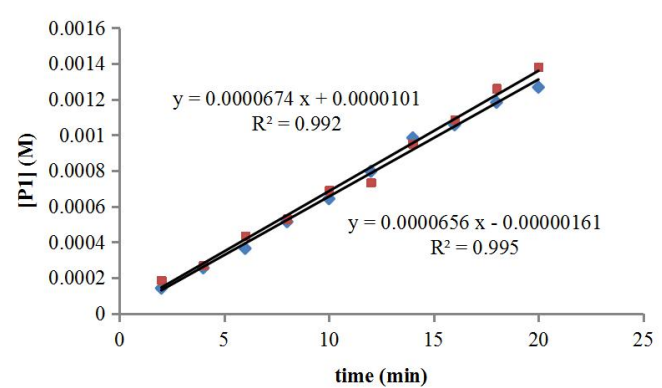

$[\mathrm{Co}]=0.00125 \mathrm{M}$

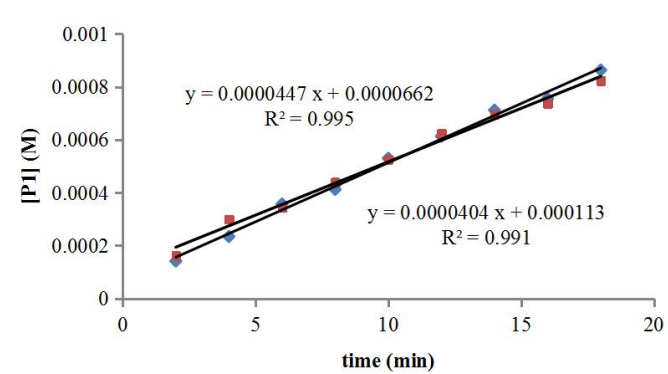

$[\mathrm{Co}]=0.00025 \mathrm{M}$

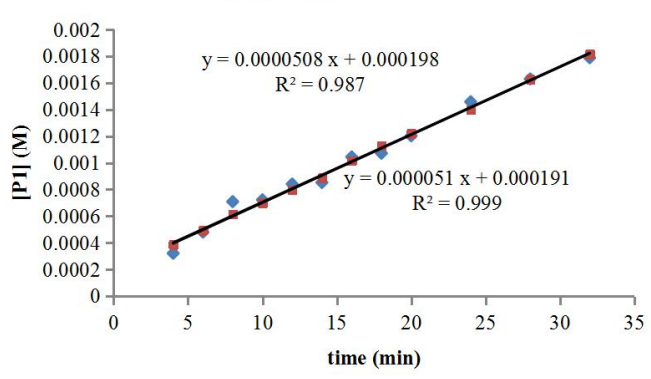

$[\mathrm{Co}]=\mathbf{0 . 0 0 0 5} \mathrm{M}$

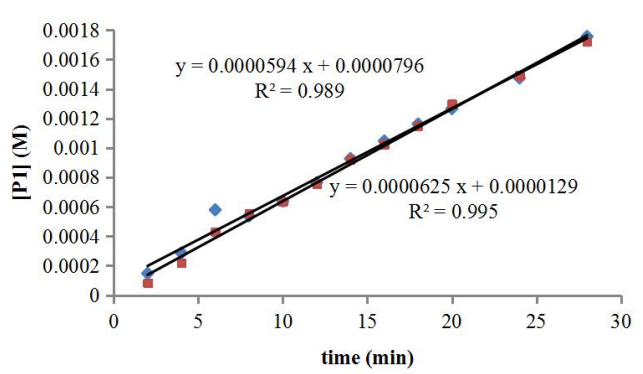

$[\mathrm{Co}]=0.00095 \mathrm{M}$

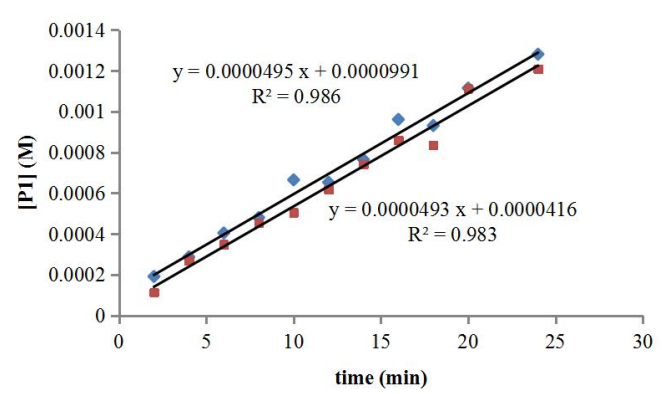

$[\mathrm{Co}]=0.00185 \mathrm{M}$

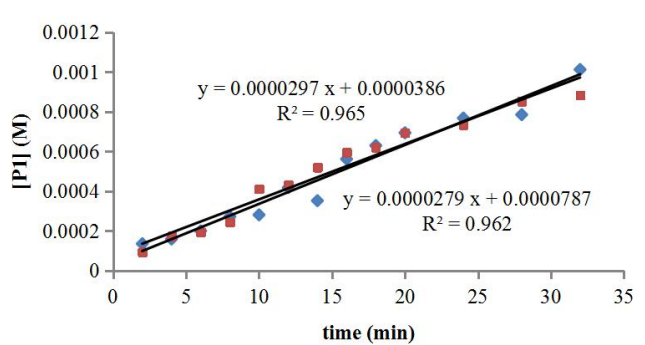




\section{$[\mathrm{Co}]=\mathbf{0 . 0 0 2 5}$}
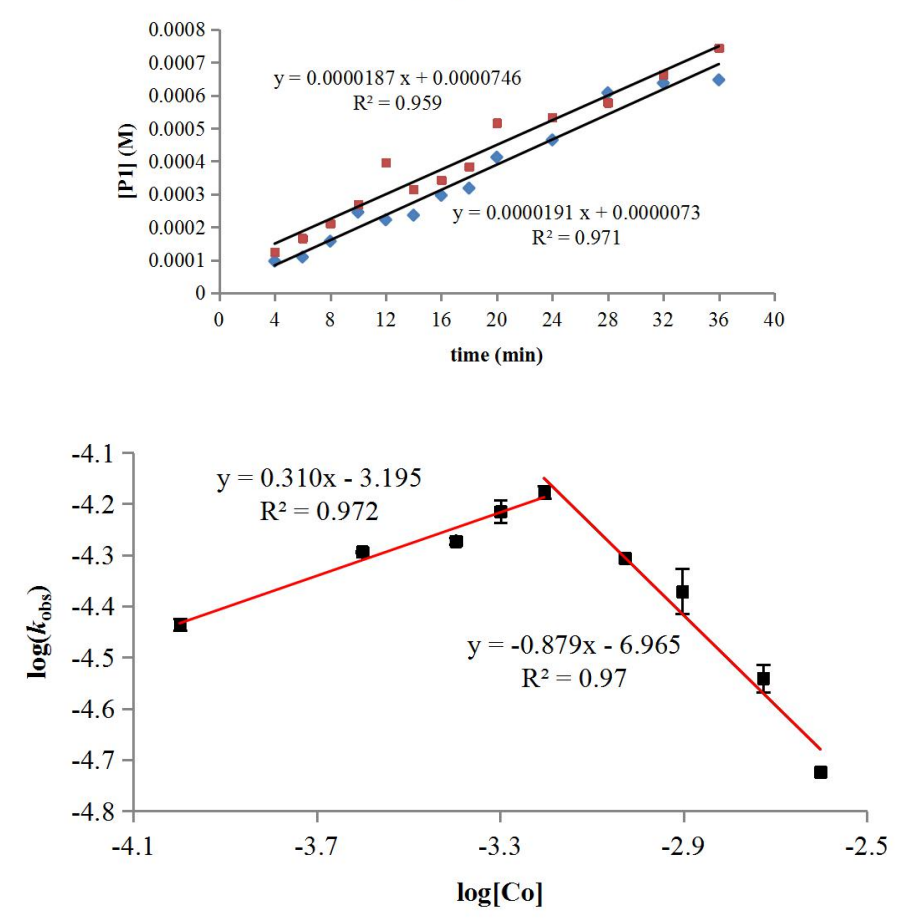

Figure S12. Dependence of the reaction rate on concentration of cobalt catalysts

\subsection{Intermolecular competitive KIE experiment}

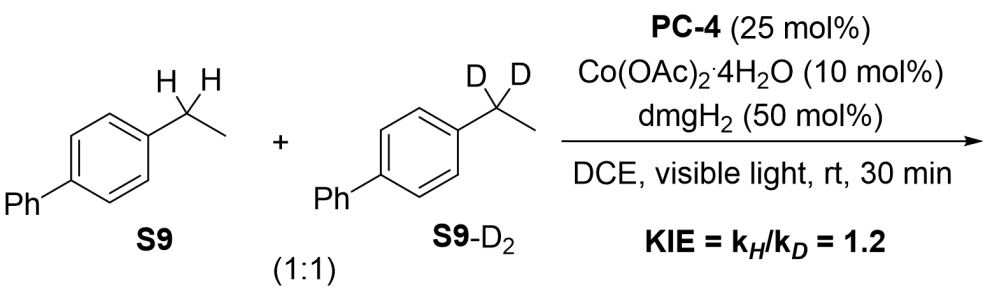

$(1: 1)$
\% total conversion $23 \%$ total yield

In argon-filled glovebox, to an oven-dried $10 \mathrm{~mL}$ Schlenk tube equipped with a stir bar was added 2-chloroanthraquinone $(0.025 \mathrm{mmol}, 6.1 \mathrm{mg}), \mathrm{Co}(\mathrm{OAc})_{2} \cdot 4 \mathrm{H}_{2} \mathrm{O}(0.01 \mathrm{mmol}, 2.5 \mathrm{mg})$, $\mathrm{dmgH}_{2} \quad(0.05 \quad \mathrm{mmol}, \quad 5.8 \quad \mathrm{mg}), \quad$ 4-ethyl-1,1'-biphenyl $\quad \mathbf{S 9} \quad(0.1 \quad \mathrm{mmol}, \quad 18.2 \quad \mathrm{mg})$, 4-(ethyl-1,1- $\left.d_{2}\right)-1,1$ '-biphenyl S9-D $2(0.1 \mathrm{mmol}, 18.4 \mathrm{mg})$ and DCE $(8 \mathrm{~mL})$. The reaction mixture was sealed and stirred in dark for 30 minutes at room temperature. Then, the reaction was irradiated with two $20 \mathrm{~W}$ 400-415 nm LEDs for 30 minutes (tube $2 \mathrm{~cm}$ away from lights, fans for cooling, 20-30 ${ }^{\circ} \mathrm{C}$ ). After that, the solvent of the reaction mixture was removed on a rotary evaporator under reduced pressure and the residue was purified by silica gel column chromatography using $n$-hexane to give mixture of product and start material. The yield and the deuterium distribution of the products were determined by ${ }^{1} \mathrm{H}$ NMR of $[\mathbf{P 9}+\mathbf{P 9}-\mathrm{D}+\mathbf{S 9}]$. 


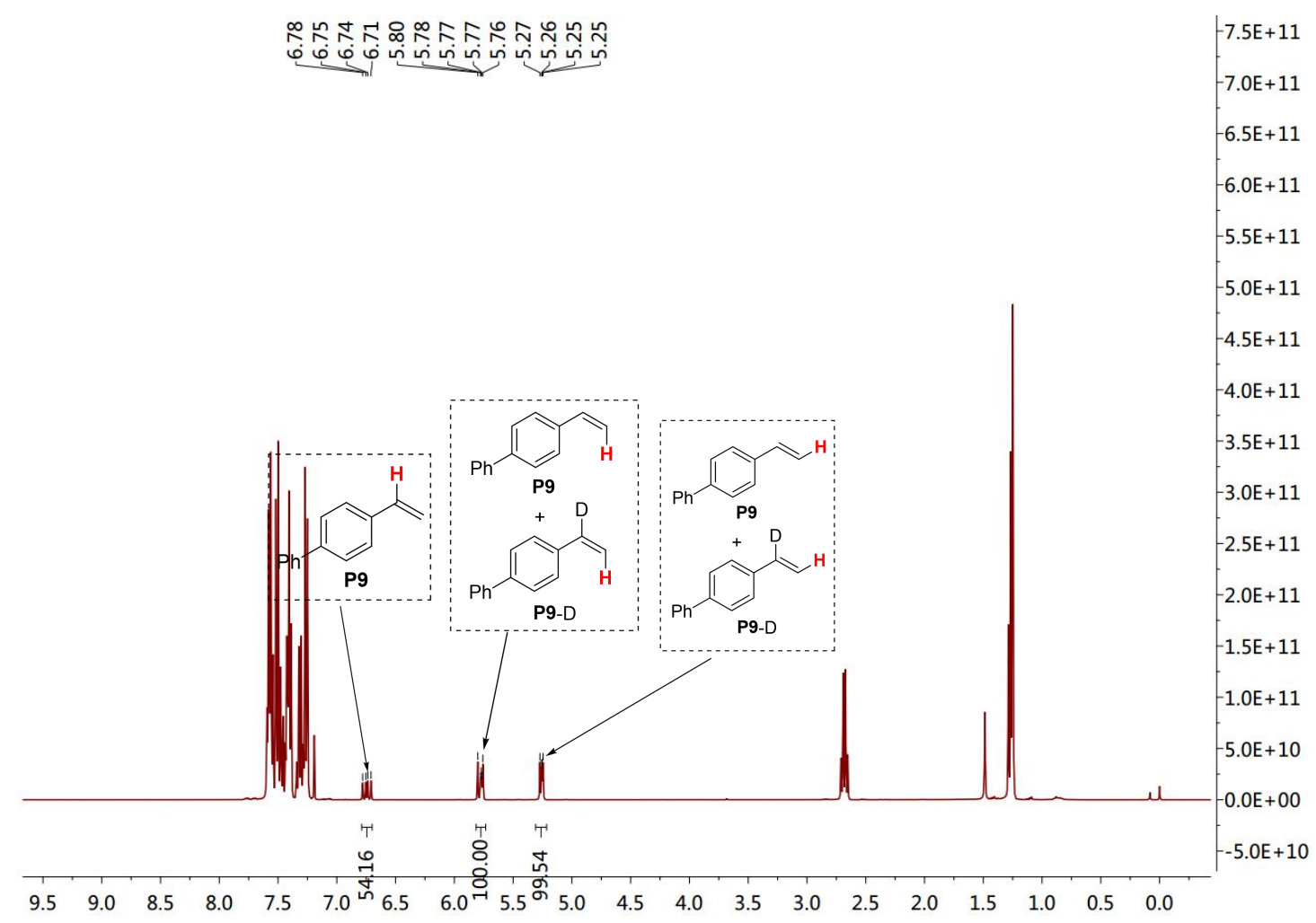

Figure S13. ${ }^{1} \mathrm{H}$ NMR of $[\mathbf{P 9}+\mathbf{P 9}-\mathrm{D}+\mathbf{S 9}]$

\subsection{Independent-rate KIE experiments of S9 or S9- $\mathrm{D}_{2}$}

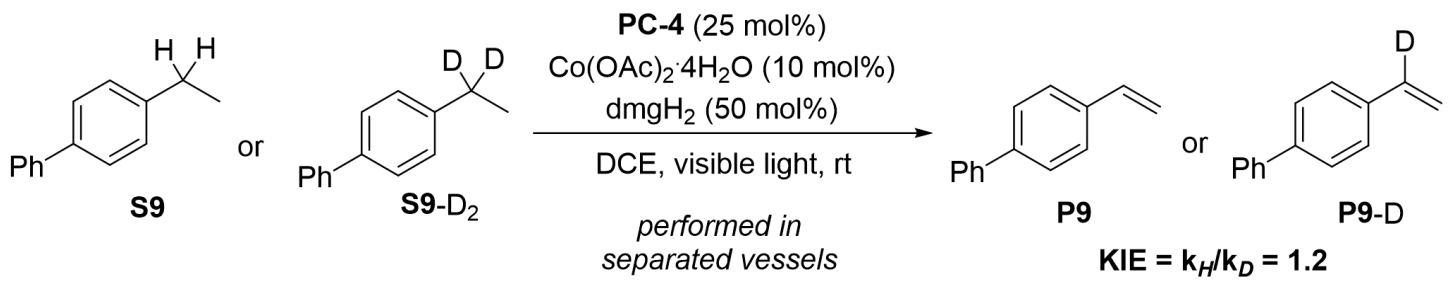

In argon-filled glovebox, to an oven-dried $10 \mathrm{~mL}$ Schlenk tube equipped with a stir bar was added 2-chloroanthraquinone $(0.025 \mathrm{mmol}, 6.1 \mathrm{mg}), \mathrm{Co}(\mathrm{OAc})_{2} \cdot 4 \mathrm{H}_{2} \mathrm{O}(0.01 \mathrm{mmol}, 2.5 \mathrm{mg})$, $\mathrm{dmgH}_{2} \quad(0.05 \quad \mathrm{mmol}, \quad 5.8 \mathrm{mg}), \quad$ 4-ethyl-1,1'-biphenyl $\quad \mathbf{S 9} \quad(0.1 \quad \mathrm{mmol}, \quad 18.2 \mathrm{mg}) \quad$ or 4-(ethyl-1,1- $\left.d_{2}\right)$-1,1'-biphenyl S9- $\mathrm{D}_{2}(0.1 \mathrm{mmol}, 18.4 \mathrm{mg})$ and DCE $(8 \mathrm{~mL})$. The reaction mixture was sealed and stirred in dark for 30 minutes at room temperature. Then, the reaction was irradiated with two $20 \mathrm{~W}$ 400-415 nm LEDs (tube $2 \mathrm{~cm}$ away from lights, fans for cooling, 20-30 $\left.{ }^{\circ} \mathrm{C}\right)$. Samples $(200 \mu \mathrm{L})$ were taken with a syringe and filtered through a short pad of silica gel with EtOAc as eluent. $n-\mathrm{C}_{16} \mathrm{H}_{34}$ was added to the sample as the internal standard. All samples were analyzed by GC to determine the yield based on the internal standard. 


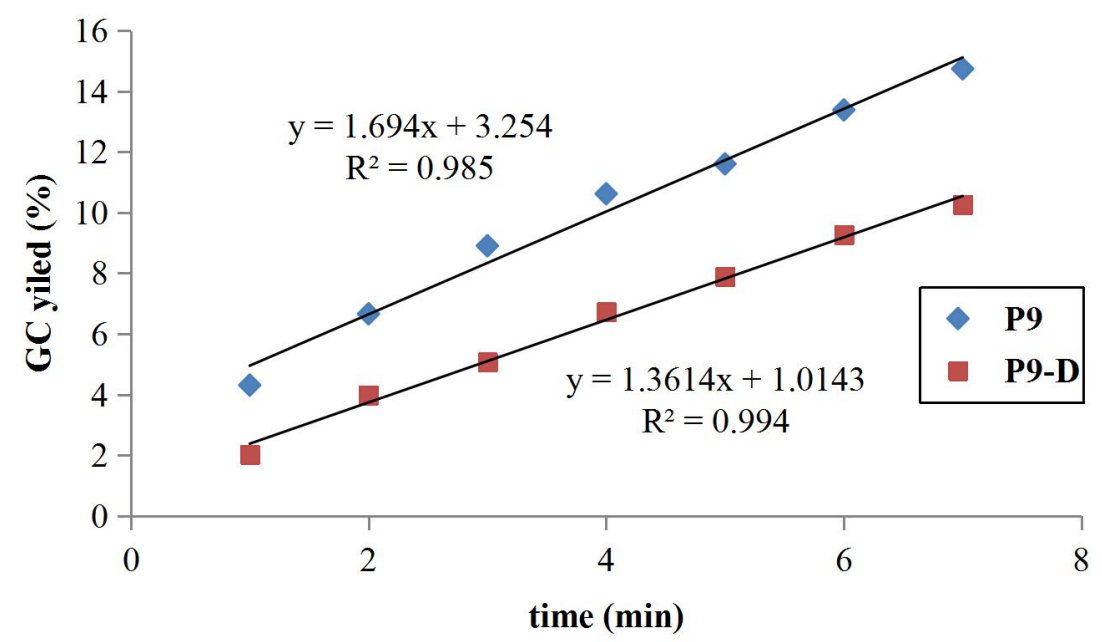

Figure S14. Reaction time-course data for independent rate KIE of $\mathbf{P 9}$ and P9-D
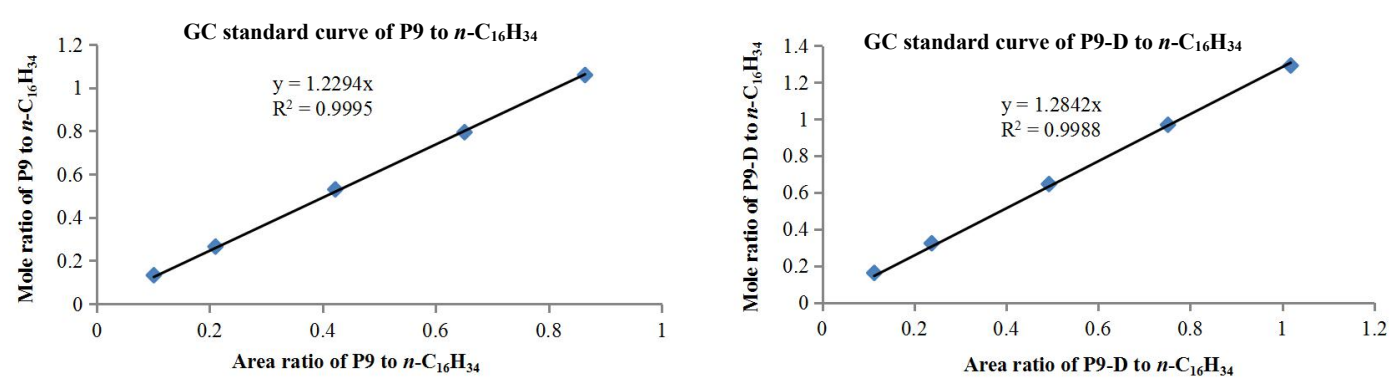

Figure S15. GC standard cure of $\mathbf{P 9}$ and $\mathbf{P 9}-\mathrm{D}$ to $n-\mathrm{C}_{16} \mathrm{H}_{34}$

11.10 Independent-rate KIE experiments of $S 7$ or $S 7-D_{2}$

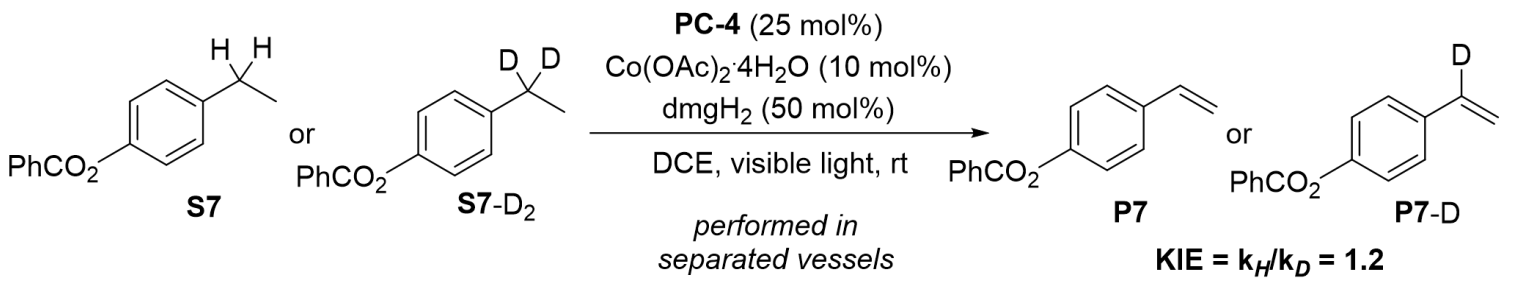

In argon-filled glovebox, to an oven-dried $10 \mathrm{~mL}$ Schlenk tube equipped with a stir bar was added 2-chloroanthraquinone $(0.025 \mathrm{mmol}, 6.1 \mathrm{mg}), \mathrm{Co}(\mathrm{OAc})_{2} \cdot 4 \mathrm{H}_{2} \mathrm{O}(0.01 \mathrm{mmol}, 2.5 \mathrm{mg})$, $\mathrm{dmgH}_{2} \quad(0.05 \mathrm{mmol}, \quad 5.8 \mathrm{mg})$, 4-ethylphenyl benzoate $\mathbf{S 7}(0.1 \mathrm{mmol}, 22.6 \mathrm{mg})$ or 4-(ethyl-1,1- $\left.d_{2}\right)$ phenyl benzoate $\mathbf{S} 7-\mathrm{D}_{2}(0.1 \mathrm{mmol}, 22.8 \mathrm{mg})$ and DCE $(8 \mathrm{~mL})$. The reaction mixture was sealed and stirred in dark for 30 minutes at room temperature. Then, the reaction was irradiated with two $20 \mathrm{~W}$ 400-415 nm LEDs (tube $2 \mathrm{~cm}$ away from lights, fans for cooling, 20-30 $\left.{ }^{\circ} \mathrm{C}\right)$. Samples $(200 \mu \mathrm{L})$ were taken with a syringe and filtered through a short pad of silica gel with 
EtOAc as eluent. $n-\mathrm{C}_{16} \mathrm{H}_{34}$ was added to the sample as the internal standard. All samples were analyzed by GC to determine the yield based on the internal standard.

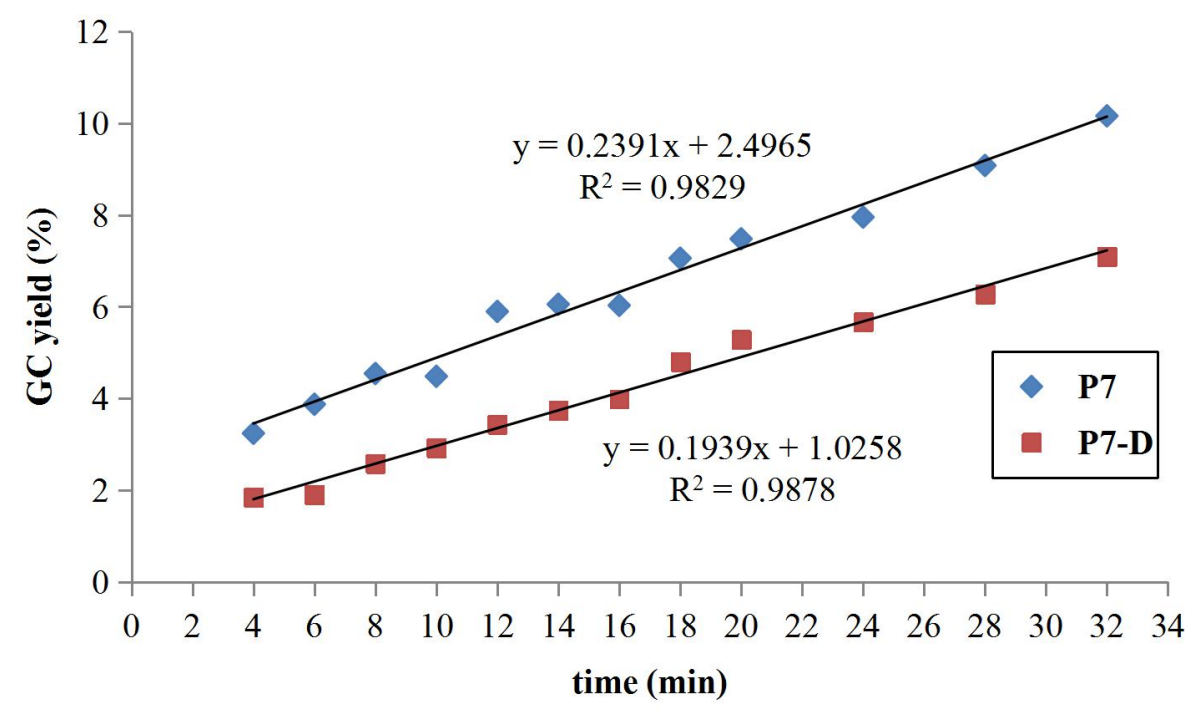

Figure S16. Reaction time-course data for independent rate KIE of P7 and P7-D
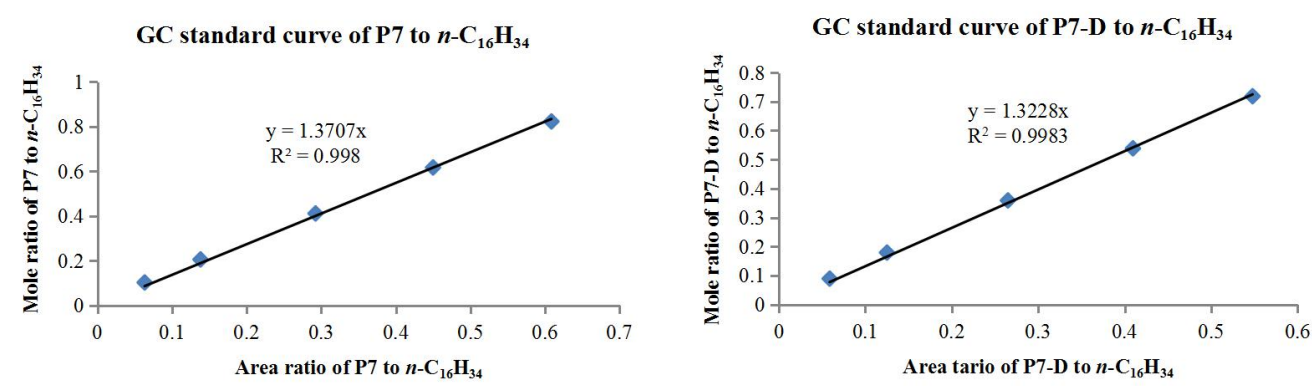

Figure S17. GC standard cure of $\mathbf{P 7}$ and $\mathbf{P 7}-\mathbf{D}$ to $n-\mathrm{C}_{16} \mathrm{H}_{34}$

\subsection{Independent-rate KIE experiments of S1 or S1- $\mathrm{D}_{10}$}

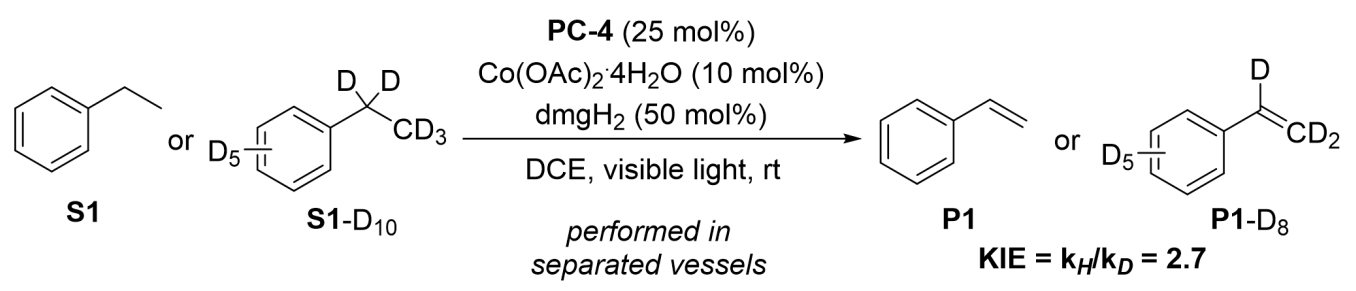

In argon-filled glovebox, to an oven-dried $10 \mathrm{~mL}$ Schlenk tube equipped with a stir bar was added 2-chloroanthraquinone $(0.025 \mathrm{mmol}, 6.1 \mathrm{mg}), \mathrm{Co}(\mathrm{OAc})_{2} \cdot 4 \mathrm{H}_{2} \mathrm{O}(0.01 \mathrm{mmol}, 2.5 \mathrm{mg})$,

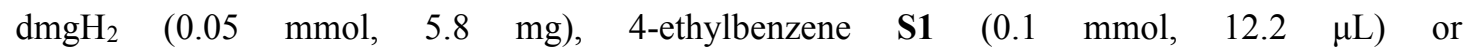


1-(ethyl- $\left.d_{5}\right)$ benzene-2,3,4,5,6- $d_{5} \mathbf{S}$ S1- $\mathrm{D}_{10}(0.1 \mathrm{mmol}, 11.6 \mathrm{mg})$ and DCE $(8 \mathrm{~mL})$. The reaction mixture was sealed and stirred in dark for 30 minutes at room temperature. Then, the reaction was irradiated with two $20 \mathrm{~W}$ 400-415 nm LEDs (tube $2 \mathrm{~cm}$ away from lights, fans for cooling, 20-30 $\left.{ }^{\circ} \mathrm{C}\right)$. Samples $(200 \mu \mathrm{L})$ were taken with a syringe and filtered through a short pad of silica gel with EtOAc as eluent. $n-\mathrm{C}_{16} \mathrm{H}_{34}$ was added to the sample as the internal standard. All samples were analyzed by GC to determine the yield based on the internal standard.

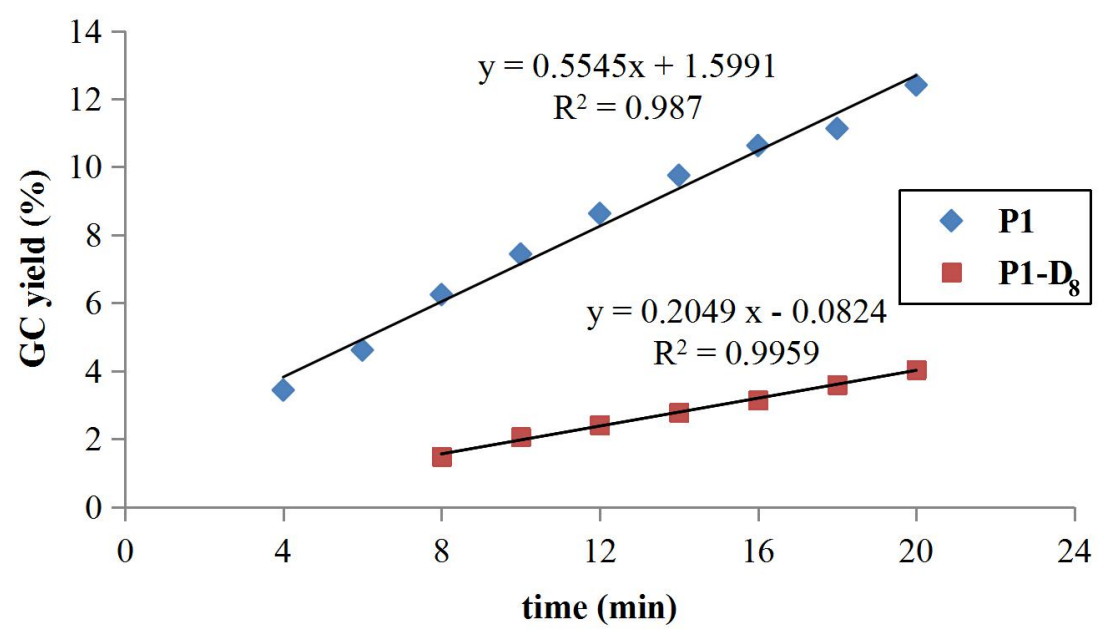

Figure S18. Reaction time-course data for independent rate KIE of P1 and P1-D8
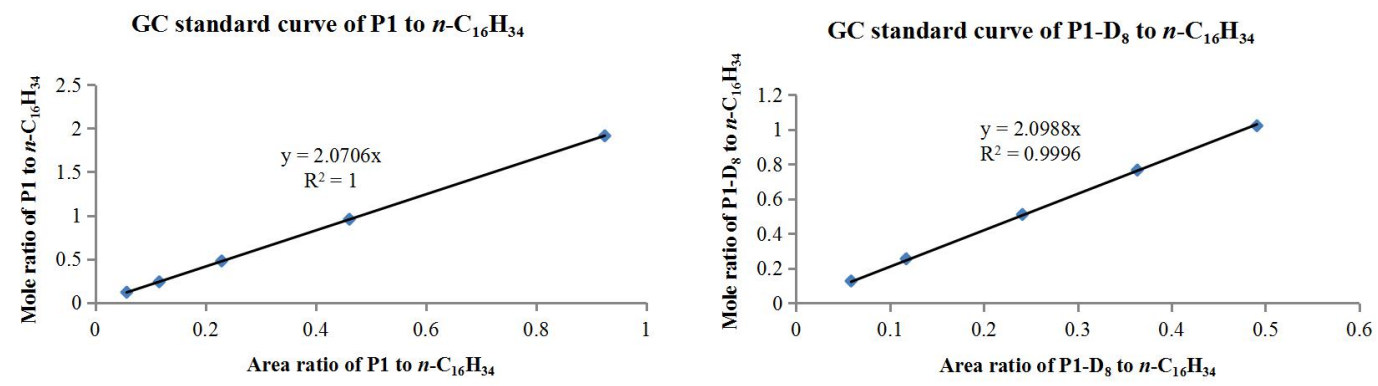

Figure S19. GC standard cure of $\mathbf{P 1}$ and $\mathbf{P 1} 1-\mathrm{D}_{8}$ to $n-\mathrm{C}_{16} \mathrm{H}_{34}$

\subsection{Stern-Volmer fluorescence quenching experiments}

All solutions for analyzing were prepared in the glovebox. The solutions were irradiated at 400 $\mathrm{nm}$ and the luminescence was measured at $600 \mathrm{~nm}$. Fluorescence quenching experiments were carried out using a $3.125 \mathrm{mM}$ solution of 2-chloroanthraquinone (2-ClAQ) in DCE upon addition of different concentrations of Co catalyst varying from 0.3125 to $2.5 \mathrm{mM}$. 


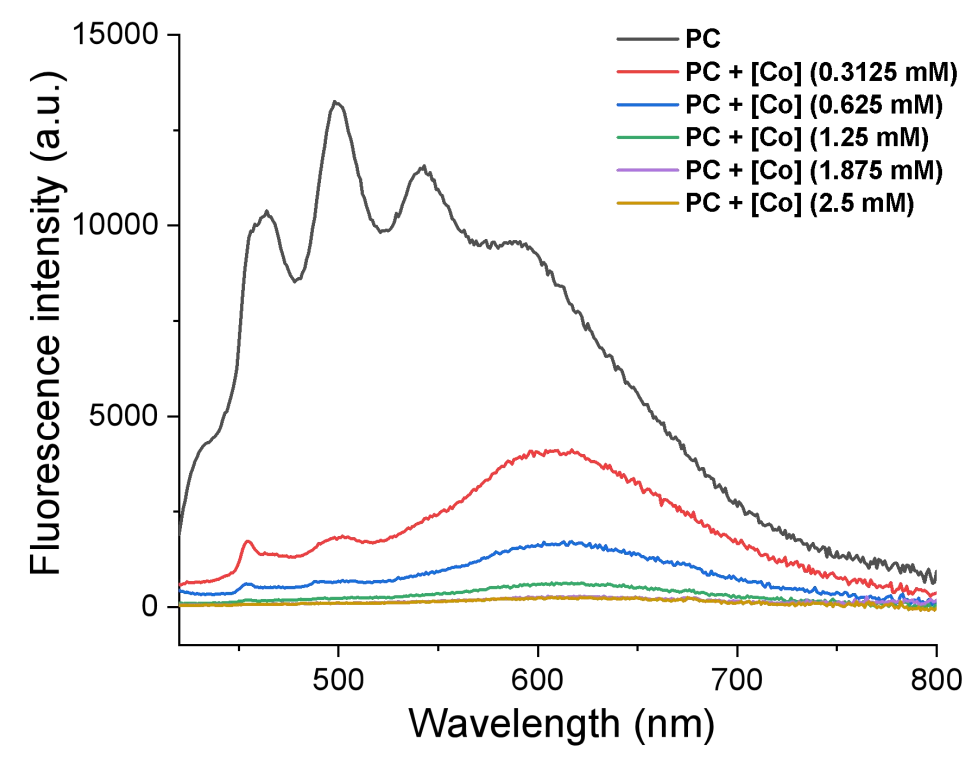

Figure S20. Fluorescence quenching experiments

Stern-Volmer constant was determined using Stern-Volmer kinetic analysis (eq S1).

$$
\begin{gathered}
\mathrm{I}_{0} / \mathrm{I}=1+K s v[\text { quencher }] \\
K s v=k q \tau_{0}
\end{gathered}
$$

As shown in eq $\mathrm{S} 1, \mathrm{I}_{0}$ is the luminescence intensity in the absence of the quencher; $\mathrm{I}$ is the intensity in the presence of the quencher; $K s v$ is the Stern-Volmer constant. Form eq S2, the actual bimolecular rate of quenching $(\mathrm{kq})$ can be calculated from Ksv using the lifetime $\left(\tau_{0}\right)$ of the photocatalyst.

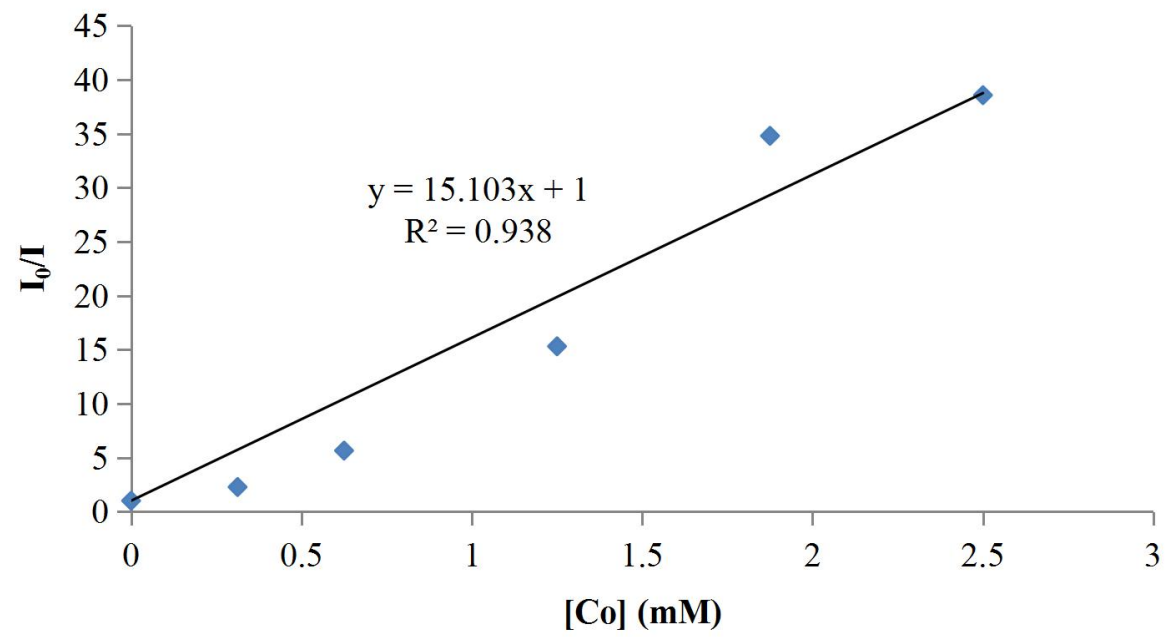

Figure S21. Stern-Volmer kinetic analysis 


\subsection{Trap of benzylic cation intermediate}

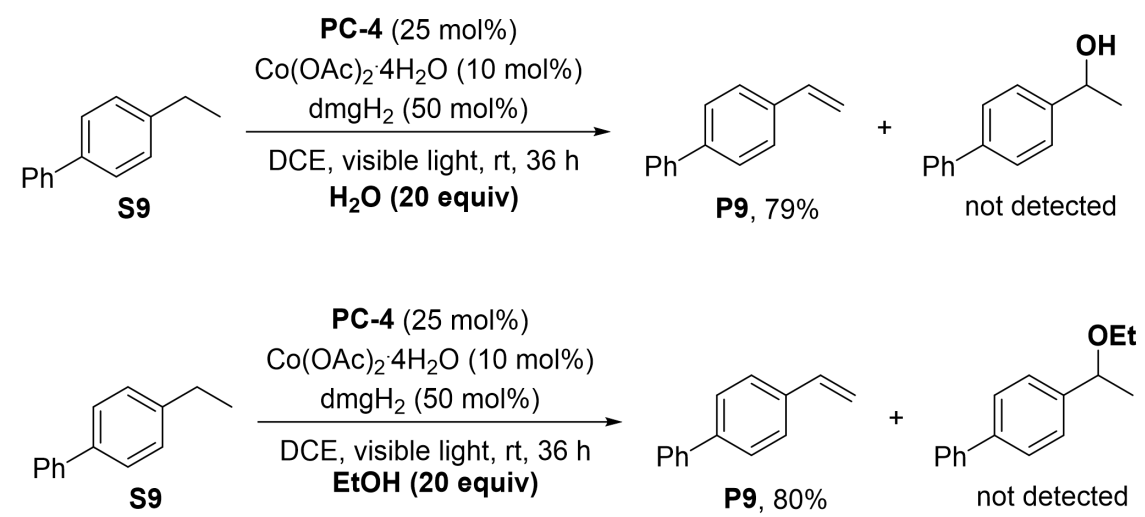

In argon-filled glovebox, to an oven-dried $10 \mathrm{~mL}$ Schlenk tube equipped with a stir bar was added 2-chloroanthraquinone (0.025 mmol, $6.1 \mathrm{mg}), \mathrm{Co}(\mathrm{OAc})_{2} \cdot 4 \mathrm{H}_{2} \mathrm{O}(0.01 \mathrm{mmol}, 2.5 \mathrm{mg})$, $\mathrm{dmgH}_{2}(0.05 \mathrm{mmol}, 5.8 \mathrm{mg})$, 4-ethyl-1,1'-biphenyl $\mathbf{S 9}(0.1 \mathrm{mmol}, 18.2 \mathrm{mg})$ and DCE $(8 \mathrm{~mL})$. The reaction mixture was sealed and stirred in dark for 30 minutes at room temperature. At this time, nucleophile $\left(\mathrm{H}_{2} \mathrm{O}\right.$ or EtOH, 20 equiv) was added to the reaction mixture by syringe. Then, the reaction was irradiated with two $20 \mathrm{~W} \mathrm{400-415} \mathrm{nm}$ LEDs for $36 \mathrm{~h}$ (tube $2 \mathrm{~cm}$ away from lights, fans for cooling, $20-30^{\circ} \mathrm{C}$ ). After that, the solvent of the reaction mixture was removed on a rotary evaporator under reduced pressure and the residue was purified by silica gel column chromatography. $79 \%$ or $80 \%$ yield of product $\mathbf{P 9}$ was isolated. However, no alcohol or ether product was detected, which indicated that benzylic cation intermediates might not be involved in reaction.

\section{Analytic Data of Products}

\section{4-Vinylphenol (P2)}<smiles>C=Cc1ccc(O)cc1</smiles>

Prepared as described above. Purified by silica gel column chromatography using petroleum ether/EtOAc $=10: 1 \rightarrow 6: 1$ to give $72 \%$ yield $(8.6 \mathrm{mg})$ of the product as a yellow oil. ${ }^{1} \mathrm{H}$ NMR and ${ }^{13} \mathrm{C}$ NMR data match previously reported data. ${ }^{13}{ }^{1} \mathrm{H}$ NMR $\left(600 \mathrm{MHz}, \mathrm{CDCl}_{3}\right): \delta 7.30(\mathrm{~d}, J=8.6 \mathrm{~Hz}, 2 \mathrm{H}), 6.79(\mathrm{~d}, J=8.6 \mathrm{~Hz}, 2 \mathrm{H}), 6.65(\mathrm{dd}, J=17.6,10.9$ $\mathrm{Hz}, 1 \mathrm{H}), 5.60(\mathrm{dd}, J=17.6,0.9 \mathrm{~Hz}, 1 \mathrm{H}), 5.12(\mathrm{dd}, J=10.9,0.9 \mathrm{~Hz}, 1 \mathrm{H}), 4.73-4.66(\mathrm{~m}, 1 \mathrm{H}) ;{ }^{13} \mathrm{C}$ NMR (101 MHz, $\left.\mathrm{CDCl}_{3}\right): \delta 155.2,136.1,130.7,127.6,115.4,111.7$. 


\section{1-Methoxy-4-vinylbenzene (P3)}

赵

Prepared as described above. Purified by silica gel column chromatography using $n$-hexane to give $71 \%$ yield $(9.5 \mathrm{mg})$ of the product as a colorless oil.

${ }^{1} \mathrm{H}$ NMR and ${ }^{13} \mathrm{C}$ NMR data match previously reported data. ${ }^{14} \mathrm{H}$ NMR $\left(600 \mathrm{MHz}, \mathrm{CDCl}_{3}\right): \delta 7.34$ $(\mathrm{d}, J=7.8 \mathrm{~Hz}, 2 \mathrm{H}), 6.85(\mathrm{~d}, J=7.8 \mathrm{~Hz}, 2 \mathrm{H}), 6.65(\mathrm{dd}, J=17.6,10.9 \mathrm{~Hz}, 1 \mathrm{H}), 5.60(\mathrm{~d}, J=17.6 \mathrm{~Hz}$, 1H), $5.11(\mathrm{~d}, J=10.9 \mathrm{~Hz}, 1 \mathrm{H}), 3.79(\mathrm{~s}, 3 \mathrm{H}) ;{ }^{13} \mathrm{C} \mathrm{NMR}\left(151 \mathrm{MHz}, \mathrm{CDCl}_{3}\right): \delta 159.4,136.2,130.4$, $127.3,113.9,111.5,55.2$

\section{1-Phenoxy-4-vinylbenzene (P4)}<smiles>C=Cc1ccc(O)cc1</smiles>

Prepared as described above. Purified by silica gel column chromatography using $n$-hexane to give $77 \%$ yield $(15.1 \mathrm{mg})$ of the product as a colorless oil.

${ }^{1} \mathrm{H}$ NMR and ${ }^{13} \mathrm{C}$ NMR data match previously reported data. ${ }^{15} \mathrm{H}$ NMR $\left(600 \mathrm{MHz}, \mathrm{CDCl}_{3}\right): \delta 7.38$ (d, $J=8.6 \mathrm{~Hz}, 2 \mathrm{H}), 7.35-7.30(\mathrm{~m}, 2 \mathrm{H}), 7.13-7.07(\mathrm{~m}, 1 \mathrm{H}), 7.07-6.99(\mathrm{~m}, 2 \mathrm{H}), 6.99-6.92(\mathrm{~m}, 2 \mathrm{H})$, $6.69(\mathrm{dd}, J=17.6,10.9 \mathrm{~Hz}, 1 \mathrm{H}), 5.66(\mathrm{~d}, J=17.5 \mathrm{~Hz}, 1 \mathrm{H}), 5.19(\mathrm{~d}, J=10.9 \mathrm{~Hz}, 1 \mathrm{H}) ;{ }^{13} \mathrm{C} \mathrm{NMR}$ $\left(151 \mathrm{MHz}, \mathrm{CDCl}_{3}\right): \delta 157.1,157.0,136.0,132.8,129.8,127.6,123.3,118.9,118.8,112.8$.

\section{tert-Butyldimethyl(4-vinylphenoxy)silane (P5)}

Prepared as described above. Purified by silica gel column
chromatography using $n$-hexane to give $70 \%$ yield $(16.4 \mathrm{mg})$ of the product as a colorless oil. ${ }^{1} \mathrm{H}$ NMR and ${ }^{13} \mathrm{C}$ NMR data match previously reported data. ${ }^{16}{ }^{1} \mathrm{H}$ NMR $\left(400 \mathrm{MHz}, \mathrm{CDCl}_{3}\right): \delta 7.33-7.26(\mathrm{~m}, 2 \mathrm{H}), 6.84-6.74(\mathrm{~m}, 2 \mathrm{H}), 6.65(\mathrm{dd}, J=17.6,10.9 \mathrm{~Hz}, 1 \mathrm{H})$, $5.60(\mathrm{dd}, J=17.6,1.0 \mathrm{~Hz}, 1 \mathrm{H}), 5.12(\mathrm{dd}, J=10.9,1.0 \mathrm{~Hz}, 1 \mathrm{H}), 0.98(\mathrm{~s}, 9 \mathrm{H}), 0.20(\mathrm{~s}, 6 \mathrm{H}) ;{ }^{13} \mathrm{C}$ NMR (101 MHz, $\left.\mathrm{CDCl}_{3}\right): \delta 155.5,136.3,131.0,127.3,120.1,111.7,25.7,18.2,-4.4$.

\section{$N$-(4-vinylphenyl)acetamide (P6)}<smiles>C=Cc1ccc(NC(C)C)cc1</smiles>

Prepared as described above. Purified by silica gel column chromatography using petroleum ether/EtOAc $=4: 1 \rightarrow 2: 1$ to give $77 \%$ yield $(12.4 \mathrm{mg})$ of the product as a colorless oil. ${ }^{1} \mathrm{H}$ NMR and ${ }^{13} \mathrm{C}$ NMR data match previously reported data. ${ }^{17}{ }^{1} \mathrm{H}$ NMR (400 MHz, $\left.\mathrm{CDCl}_{3}\right): \delta 7.47(\mathrm{~d}, J=8.6 \mathrm{~Hz}, 2 \mathrm{H}), 7.37(\mathrm{~d}, J=8.6 \mathrm{~Hz}, 2 \mathrm{H}), 7.18(\mathrm{~s}, 1 \mathrm{H}), 6.67$ 
$(\mathrm{dd}, J=17.6,10.9 \mathrm{~Hz}, 1 \mathrm{H}), 5.68(\mathrm{~d}, J=17.6 \mathrm{~Hz}, 1 \mathrm{H}), 5.19(\mathrm{~d}, J=10.9 \mathrm{~Hz}, 1 \mathrm{H}), 2.18(\mathrm{~s}, 3 \mathrm{H}) ;{ }^{13} \mathrm{C}$ NMR (101 MHz, $\left.\mathrm{CDCl}_{3}\right): \delta 168.1,137.4,136.1,133.7,126.8,119.7,113.0,24.7$.

\section{4-Vinylphenyl benzoate (P7)}

Prepared as described above. Purified by silica gel column
chromatography using petroleum ether/EtOAc $=40: 1$ to give $95 \%$ yield (21.3 mg) of the product as a colorless oil. ${ }^{1} \mathrm{H}$ NMR and ${ }^{13} \mathrm{C}$ NMR data match previously reported data. ${ }^{18}{ }^{1} \mathrm{H}$ NMR $\left(600 \mathrm{MHz}, \mathrm{CDCl}_{3}\right): \delta 8.24-8.17(\mathrm{~m}, 2 \mathrm{H}), 7.68-7.60(\mathrm{~m}, 1 \mathrm{H}), 7.55-7.49(\mathrm{~m}, 2 \mathrm{H})$, 7.49-7.45 (m, 2H), 7.22-7.16 (m, 2H), $6.73(\mathrm{dd}, J=17.6,10.9 \mathrm{~Hz}, 1 \mathrm{H}), 5.74(\mathrm{dd}, J=17.6,0.8 \mathrm{~Hz}$ 1H), $5.27(\mathrm{dd}, J=10.8,0.8 \mathrm{~Hz}, 1 \mathrm{H}) ;{ }^{13} \mathrm{C}$ NMR (151 MHz, $\left.\mathrm{CDCl}_{3}\right): \delta 165.2,150.5,135.9,135.4$, 133.6, 130.2, 129.5, 128.6, 127.3, 121.8, 114.1.

\section{1-Phenyl-2-(4-vinylphenoxy)ethan-1-one (P8)}<smiles>C=Cc1ccc(OCC(=O)c2ccccc2)cc1</smiles>

Prepared as described above. Purified by silica gel column chromatography using EtOAc to give $76 \%$ yield $(18.1 \mathrm{mg})$ of the product as a colorless oil. ${ }^{1} \mathrm{H}$ NMR $\left(400 \mathrm{MHz}, \mathrm{CDCl}_{3}\right): \delta 8.07-7.94$ (m, 2H), 7.68-7.58 (m, 1H), 7.55-7.45 (m, 2H), 7.39-7.30 (m, 2H), 7.95-7.85 (m, 2H), $6.65(\mathrm{dd}$, $J=17.6,10.9 \mathrm{~Hz}, 1 \mathrm{H}), 5.61(\mathrm{dd}, J=17.6,0.9 \mathrm{~Hz}, 1 \mathrm{H}), 5.27$ (s, 2H), $5.14(\mathrm{dd}, J=10.9,0.9 \mathrm{~Hz}$, 1H); ${ }^{13} \mathrm{C}$ NMR (101 MHz, $\left.\mathrm{CDCl}_{3}\right): \delta 194.4,157.7,136.0,134.6,133.9,131.4,128.8,128.1,127.5$, 114.8, 112.1, 70.84; ESI-HRMS calcd for $\left[\mathrm{C}_{16} \mathrm{H}_{15} \mathrm{O}_{2}, \mathrm{M}+\mathrm{H}\right]^{+}:$239.1067, Found: 239.1069 .

\section{4-Vinyl-1,1'-biphenyl (P9)}

Prepared as described above. Purified by silica gel column chromatography
using $n$-hexane to give $78 \%$ yield $(14.1 \mathrm{mg})$ of the product as a white solid. ${ }^{1} \mathrm{H}$ NMR and ${ }^{13} \mathrm{C}$ NMR data match previously reported data. ${ }^{19}{ }^{1} \mathrm{H}$ NMR $\left(400 \mathrm{MHz}, \mathrm{CDCl}_{3}\right): \delta$ 7.63-7.52 (m, 4H), 7.52-7.39 (m, 4H), 7.38-7.31 (m, 1H), 6.76 (dd, $J=17.6,10.9 \mathrm{~Hz}, 1 \mathrm{H}), 5.79$ $(\mathrm{d}, J=17.6 \mathrm{~Hz}, 1 \mathrm{H}), 5.27(\mathrm{~d}, J=10.9 \mathrm{~Hz}, 1 \mathrm{H}) ;{ }^{13} \mathrm{C} \mathrm{NMR}\left(101 \mathrm{MHz}, \mathrm{CDCl}_{3}\right): \delta 140.7,140.6$, $136.6,136.4,128.8,127.3,127.2,127.0,126.6,113.9$.

\section{4-Bromo-4'-vinyl-1,1'-biphenyl (P10)}


<smiles>C=Cc1ccc(-c2ccc(Br)cc2)cc1</smiles>

Prepared as described above. Purified by silica gel column chromatography using $n$-hexane to give $72 \%$ yield $(18.6 \mathrm{mg})$ of the product as a white solid. ${ }^{1} \mathrm{H}$ NMR and ${ }^{13} \mathrm{C}$ NMR data match previously reported data. ${ }^{20} \mathrm{H}$ NMR $\left(400 \mathrm{MHz}, \mathrm{CDCl}_{3}\right): \delta 7.65-7.34(\mathrm{~m}, 8 \mathrm{H}), 6.75(\mathrm{dd}, J=17.6$, $10.9 \mathrm{~Hz}, 1 \mathrm{H}), 5.80(\mathrm{dd}, J=17.6,0.9 \mathrm{~Hz}, 1 \mathrm{H}), 5.29(\mathrm{dd}, J=10.8,0.9 \mathrm{~Hz}, 1 \mathrm{H}) ;{ }^{13} \mathrm{C}$ NMR $(101$ $\left.\mathrm{MHz}, \mathrm{CDCl}_{3}\right): \delta 139.6,139.3,137.0,136.2,131.9,128.5,127.0,126.8,121.6,114.2$.

\section{4-Iodo-4'-vinyl-1,1'-biphenyl (P11)}<smiles>C=Cc1ccc(-c2ccc(I)cc2)cc1</smiles>

Prepared as described above. Purified by silica gel column chromatography using $n$-hexane to give $68 \%$ yield $(20.8 \mathrm{mg})$ of the product as a white solid. ${ }^{1} \mathrm{H}$ NMR $\left(400 \mathrm{MHz}, \mathrm{CDCl}_{3}\right): \delta 7.75(\mathrm{~d}, J=$

$8.4 \mathrm{~Hz}, 2 \mathrm{H}), 7.49$ (q, $J=8.4 \mathrm{~Hz}, 4 \mathrm{H}), 7.32(\mathrm{~d}, J=8.4 \mathrm{~Hz}, 2 \mathrm{H}), 6.74$ (dd, $J=17.6,10.9 \mathrm{~Hz}, 1 \mathrm{H})$, $5.79(\mathrm{~d}, J=17.6 \mathrm{~Hz}, 1 \mathrm{H}), 5.28(\mathrm{~d}, J=10.9 \mathrm{~Hz}, 1 \mathrm{H}) ;{ }^{13} \mathrm{C} \mathrm{NMR}\left(101 \mathrm{MHz}, \mathrm{CDCl}_{3}\right): \delta 140.2,139.3$, 137.9, 137.0, 136.2, 128.8, 127.0, 126.8, 114.2, 93.0; ESI-HRMS calcd for $\left[\mathrm{C}_{14} \mathrm{H}_{12} \mathrm{I}, \mathrm{M}+\mathrm{H}\right]^{+}$: 306.9978, Found: 306.9976.

\section{6-Methyl-2-(4-vinylphenyl)-1,3,6,2-dioxazaborocane-4,8-dione (P12)}

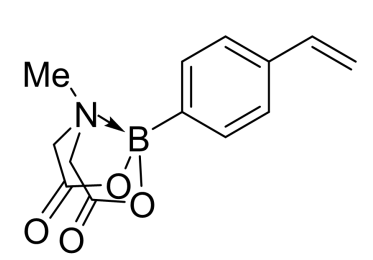

Prepared as described above. Purified by silica gel column chromatography using EtOAc to give $78 \%$ yield $(20.2 \mathrm{mg})$ of the product as a white solid. ${ }^{1} \mathrm{H}$ NMR $\left(400 \mathrm{MHz}, \mathrm{CDCl}_{3}\right): \delta 7.48(\mathrm{~d}, J=8.0$ $\mathrm{Hz}, 2 \mathrm{H}), 7.43(\mathrm{~d}, J=8.1 \mathrm{~Hz}, 2 \mathrm{H}), 6.72(\mathrm{dd}, J=17.6,10.9 \mathrm{~Hz}, 1 \mathrm{H}), 5.80$ (dd, $J=17.6,0.9 \mathrm{~Hz}, 1 \mathrm{H}), 5.29(\mathrm{dd}, J=10.9,0.9 \mathrm{~Hz}, 1 \mathrm{H}), 3.95(\mathrm{~d}, J=16.4 \mathrm{~Hz}, 2 \mathrm{H}), 3.77(\mathrm{~d}, J=$ $16.4 \mathrm{~Hz}, 2 \mathrm{H}), 2.56(\mathrm{~s}, 3 \mathrm{H}) ;{ }^{13} \mathrm{C}$ NMR $\left(151 \mathrm{MHz}, \mathrm{CDCl}_{3}\right): \delta 167.3,139.1,136.5,132.5,126.2$, 114.8, 61.8, 47.4; ESI-HRMS calcd for $\left[\mathrm{C}_{13} \mathrm{H}_{15} \mathrm{BNO}_{4}, \mathrm{M}+\mathrm{H}\right]^{+}:$260.1089, Found: 260.1086 .

\section{2-(4-Vinylphenoxy)pyridine (P13)}<smiles>C=Cc1ccc(Oc2ccccn2)cc1</smiles>

Prepared as described above. Purified by silica gel column chromatography using petroleum ether/EtOAc $=20: 1$ to give $73 \%$ yield $(14.4 \mathrm{mg})$ of the product as a colorless oil. ${ }^{1} \mathrm{H}$ NMR $\left(400 \mathrm{MHz}, \mathrm{CDCl}_{3}\right): \delta 8.20(\mathrm{ddd}, J=5.0,2.1$, $0.8 \mathrm{~Hz}, 1 \mathrm{H}), 7.75-7.61(\mathrm{~m}, 1 \mathrm{H}), 7.44(\mathrm{~d}, J=8.6 \mathrm{~Hz}, 2 \mathrm{H}), 7.15-7.06(\mathrm{~m}, 2 \mathrm{H}), 6.99$ (ddd, $J=7.2$, 
5.0, $1.0 \mathrm{~Hz}, 1 \mathrm{H}), 6.91(\mathrm{dt}, J=8.3,0.9 \mathrm{~Hz}, 1 \mathrm{H}), 6.71(\mathrm{dd}, J=17.5,10.9 \mathrm{~Hz}, 1 \mathrm{H}), 5.69(\mathrm{dd}, J=17.6$, $0.9 \mathrm{~Hz}, 1 \mathrm{H}), 5.22(\mathrm{dd}, J=10.9,0.9 \mathrm{~Hz}, 1 \mathrm{H}) ;{ }^{13} \mathrm{C} \mathrm{NMR}\left(101 \mathrm{MHz}, \mathrm{CDCl}_{3}\right): \delta 163.7,153.8,147.8$, 139.4, 136.1, 134.2, 127.5, 121.2, 118.5, 113.4, 111.6; ESI-HRMS calcd for $\left[\mathrm{C}_{13} \mathrm{H}_{12} \mathrm{NO}, \mathrm{M}+\mathrm{H}\right]^{+}$: 198.0913, Found: 198.0915.

\section{1-(4-Vinylphenyl)-1 H-pyrazole (P14)}<smiles>C=Cc1ccc(-n2cccn2)cc1</smiles>

Prepared as described above. Purified by silica gel column chromatography using petroleum ether/EtOAc $=50: 1$ to give $68 \%$ yield (11.6 mg) of the product as a white solid. ${ }^{1} \mathrm{H}$ NMR and ${ }^{13} \mathrm{C}$ NMR data match previously reported data. ${ }^{21}{ }^{1} \mathrm{H}$ NMR $\left(400 \mathrm{MHz}, \mathrm{CDCl}_{3}\right): \delta 7.92(\mathrm{~d}, J=2.5 \mathrm{~Hz}, 1 \mathrm{H}), 7.73(\mathrm{~d}$, $J=1.8 \mathrm{~Hz}, 1 \mathrm{H}), 7.69-7.62(\mathrm{~m}, 2 \mathrm{H}), 7.54-7.44(\mathrm{~m}, 2 \mathrm{H}), 6.73(\mathrm{dd}, J=17.6,10.9 \mathrm{~Hz}, 1 \mathrm{H}), 6.47$ (t, $J$ $=2.2 \mathrm{~Hz}, 1 \mathrm{H}), 5.76(\mathrm{~d}, J=17.6 \mathrm{~Hz}, 1 \mathrm{H}), 5.28(\mathrm{~d}, J=10.9 \mathrm{~Hz}, 1 \mathrm{H}) ;{ }^{13} \mathrm{C} \mathrm{NMR}\left(101 \mathrm{MHz}, \mathrm{CDCl}_{3}\right)$ : $\delta 141.1,139.5,135.8(2 \mathrm{C}), 127.2,126.6,119.1,114.1,107.7$.

\section{1-Phenoxy-3-vinylbenzene (P15)}<smiles>C=Cc1cccc(Oc2ccccc2)c1</smiles>

Prepared as described above. Purified by silica gel column chromatography using $n$-hexane to give $76 \%$ yield $(14.9 \mathrm{mg})$ of the product as a colorless oil.

${ }^{1} \mathrm{H}$ NMR and ${ }^{13} \mathrm{C}$ NMR data match previously reported data. ${ }^{22}{ }^{1} \mathrm{H}$ NMR $\left(600 \mathrm{MHz}, \mathrm{CDCl}_{3}\right): \delta$ 7.38-7.31 (m, 2H), 7.28 (t, $J=7.9 \mathrm{~Hz}, 1 \mathrm{H}), 7.15(\mathrm{dt}, J=7.7,1.4 \mathrm{~Hz}, 1 \mathrm{H}), 7.13-7.08(\mathrm{~m}, 1 \mathrm{H}), 7.07$ $(\mathrm{t}, J=2.1 \mathrm{~Hz}, 1 \mathrm{H}), 7.02(\mathrm{dd}, J=8.7,1.1 \mathrm{~Hz}, 2 \mathrm{H}), 6.92-6.88(\mathrm{~m}, 1 \mathrm{H}), 6.67(\mathrm{dd}, J=17.6,10.8 \mathrm{~Hz}$, 1H), $5.72(\mathrm{dd}, J=17.6,0.8 \mathrm{~Hz}, 1 \mathrm{H}), 5.25(\mathrm{dd}, J=10.9,0.8 \mathrm{~Hz}, 1 \mathrm{H}) ;{ }^{13} \mathrm{C} \mathrm{NMR}\left(151 \mathrm{MHz}, \mathrm{CDCl}_{3}\right)$ : $\delta 157.5,157.2,139.5,136.3,129.8,129.7,123.2,121.3,118.8,118.3,116.5,114.6$.

\section{1-Phenoxy-2-vinylbenzene (P16)}

Prepared as described above. Purified by silica gel column chromatography using
$n$-hexane to give $78 \%$ yield $(15.3 \mathrm{mg})$ of the product as a colorless oil. ${ }^{1} \mathrm{H}$ NMR
and ${ }^{13} \mathrm{C}$ NMR data match previously reported data. ${ }^{23}{ }^{1} \mathrm{H}$ NMR $\left(600 \mathrm{MHz}, \mathrm{CDCl}_{3}\right)$ : $\delta 7.61(\mathrm{~d}, J=7.7 \mathrm{~Hz}, 1 \mathrm{H}), 7.35-7.27(\mathrm{~m}, 2 \mathrm{H}), 7.25-7.19(\mathrm{~m}, 1 \mathrm{H}), 7.13(\mathrm{t}, J=17.7 \mathrm{~Hz}, 1 \mathrm{H})$, 7.08-7.03 (m, 1H), $6.99(\mathrm{dd}, J=17.7,11.1 \mathrm{~Hz}, 1 \mathrm{H}), 6.95-6.88(\mathrm{~m}, 3 \mathrm{H}), 5.79(\mathrm{dt}, J=17.7,1.2 \mathrm{~Hz}$, 
1H), $5.27(\mathrm{dt}, J=11.1,1.1 \mathrm{~Hz}, 1 \mathrm{H}) ;{ }^{13} \mathrm{C} \mathrm{NMR}\left(101 \mathrm{MHz}, \mathrm{CDCl}_{3}\right): \delta 157.9,153.6,131.0,129.8$, $129.7,129.0,126.6,124.1,122.7,120.1,117.8,115.4$.

\section{2-Vinylnaphthalene (P17)}<smiles>C=Cc1ccc2ccccc2c1</smiles>

Prepared as described above. Purified by silica gel column chromatography using $n$-hexane to give $59 \%$ yield $(9.1 \mathrm{mg})$ of the product as a white solid. ${ }^{1} \mathrm{H}$

NMR and ${ }^{13} \mathrm{C}$ NMR data match previously reported data. ${ }^{24}{ }^{1} \mathrm{H}$ NMR $\left(400 \mathrm{MHz}, \mathrm{CDCl}_{3}\right): \delta$ 7.84-7.73 (m, 4H), $7.64(\mathrm{dd}, J=8.6,1.8 \mathrm{~Hz}, 1 \mathrm{H}), 7.50-7.39(\mathrm{~m}, 2 \mathrm{H}), 6.89(\mathrm{dd}, J=17.6,10.9 \mathrm{~Hz}$, 1H), $5.87(\mathrm{~d}, J=17.6 \mathrm{~Hz}, 1 \mathrm{H}), 5.34(\mathrm{~d}, J=10.9 \mathrm{~Hz}, 1 \mathrm{H}) ;{ }^{13} \mathrm{C} \mathrm{NMR}\left(101 \mathrm{MHz}, \mathrm{CDCl}_{3}\right): \delta 136.9$, $135.0,133.6,133.2,128.1,128.0,127.7,126.4,126.2,125.9,123.2,114.2$.

\section{Naphthalene (P18)}<smiles>c1ccc2ccccc2c1</smiles>

Prepared as described above. When using 1,2,3,4-tetrahydronaphthalene as substrate, yield was determined to be $100 \%$ based on GC analysis using an internal standard before purification. Purified by silica gel column chromatography using $n$-hexane to give $67 \%$ yield $(8.6 \mathrm{mg})$ of the product as a white solid. When using decahydronaphthalene as substrate, yield was determined to be $20 \%$ based on GC analysis using an internal standard. ${ }^{1} \mathrm{H}$ NMR and ${ }^{13} \mathrm{C}$ NMR data match previously reported data. ${ }^{25}{ }^{1} \mathrm{H}$ NMR $\left(600 \mathrm{MHz}, \mathrm{CDCl}_{3}\right): \delta 7.84(\mathrm{dt}, J=6.1$, $3.3 \mathrm{~Hz}, 4 \mathrm{H}), 7.48(\mathrm{td}, J=6.3,3.0 \mathrm{~Hz}, 4 \mathrm{H}) ;{ }^{13} \mathrm{C} \mathrm{NMR}\left(151 \mathrm{MHz}, \mathrm{CDCl}_{3}\right): \delta 133.4,127.9,125.8$.

\section{1,1'-Biphenyl (P21)}<smiles>c1ccc(-c2ccccc2)cc1</smiles>

Prepared as described above. Before purification, yield was determined to be $37 \%$ based on GC analysis using an internal standard. Purified by silica gel column chromatography using $n$-hexane to give $32 \%$ yield $(5.0 \mathrm{mg})$ of the product as a white solid. ${ }^{1} \mathrm{H}$ NMR and ${ }^{13} \mathrm{C}$ NMR data match previously reported data. ${ }^{26}{ }^{1} \mathrm{H}$ NMR $\left(600 \mathrm{MHz}, \mathrm{CDCl}_{3}\right): \delta 7.59(\mathrm{~d}$, $J=7.8 \mathrm{~Hz}, 4 \mathrm{H}), 7.44(\mathrm{t}, J=7.5 \mathrm{~Hz}, 4 \mathrm{H}), 7.34(\mathrm{t}, J=7.3 \mathrm{~Hz}, 2 \mathrm{H}) ;{ }^{13} \mathrm{C} \mathrm{NMR}\left(151 \mathrm{MHz}, \mathrm{CDCl}_{3}\right): \delta$ $141.2,128.7,127.24,127.16$. 
NoBz

Prepared as described above. Purified by silica gel column chromatography using petroleum ether/EtOAc $=50: 1$ to give $59 \%$ yield $(14.0 \mathrm{mg})$ of the product $(E / Z=1: 1)$ as a white solid. ${ }^{1} \mathrm{H} \mathrm{NMR}\left(400 \mathrm{MHz}, \mathrm{CDCl}_{3}\right): \delta 8.08(\operatorname{td}, J=$ 8.4, $1.4 \mathrm{~Hz}, 2 \mathrm{H}), 7.61-7.53(\mathrm{~m}, 1 \mathrm{H}), 7.50-7.26(\mathrm{~m}, 7 \mathrm{H}), 6.80-6.70(\mathrm{~m}, 1 \mathrm{H}), 6.41(\mathrm{dt}, J=15.9,6.4$ $\mathrm{Hz}, 0.5 \times 1 \mathrm{H}), 5.96(\mathrm{dt}, J=11.8,6.6 \mathrm{~Hz}, 0.5 \times 1 \mathrm{H}), 5.10(\mathrm{dd}, J=6.6,1.7 \mathrm{~Hz}, 1 \mathrm{H}), 4.99(\mathrm{dd}, J=$ 6.4, $1.4 \mathrm{~Hz}, 1 \mathrm{H}) ;{ }^{13} \mathrm{C} \mathrm{NMR}\left(101 \mathrm{MHz}, \mathrm{CDCl}_{3}\right): \delta 166.43,166.40,136.2,136.1,134.3,133.2$, 133.0 (2C), 130.22, 130.15, 129.66, 129.65, 128.8, 128.6, 128.43, 128.37, 128.36, 128.1, 127.6, 126.6, 125.8, 123.3, 65.5, 61.9 ; ESI-HRMS calcd for $\left[\mathrm{C}_{16} \mathrm{H}_{15} \mathrm{O}_{2}, \mathrm{M}+\mathrm{H}\right]^{+}: 239.1067$, Found: 239.1066 .

\section{2-Vinylbenzo[b]thiophene (P25)}<smiles>C=Cc1cc2ccccc2s1</smiles>

Prepared as described above. Purified by silica gel column chromatography using $n$-hexane to give $46 \%$ yield $\left(7.4 \mathrm{mg}\right.$ ) of the product as a yellow solid. ${ }^{1} \mathrm{H}$ NMR and ${ }^{13} \mathrm{C}$ NMR data match previously reported data. ${ }^{15}{ }^{1} \mathrm{H}$ NMR $\left(400 \mathrm{MHz}, \mathrm{CDCl}_{3}\right): \delta$ 7.80-7.71 (m, 1H), 7.71-7.62 (m, 1H), 7.34-7.26 (m, 2H), $7.16(\mathrm{~s}, 1 \mathrm{H}), 6.91(\mathrm{dd}, J=17.2,10.8$ $\mathrm{Hz}, 1 \mathrm{H}), 5.66(\mathrm{~d}, J=17.3 \mathrm{~Hz}, 1 \mathrm{H}), 5.30(\mathrm{~d}, J=10.8 \mathrm{~Hz}, 1 \mathrm{H}) ;{ }^{13} \mathrm{C} \mathrm{NMR}\left(151 \mathrm{MHz}, \mathrm{CDCl}_{3}\right): \delta$ $143.1,140.0,138.8,130.6,124.8,124.4,123.5,123.0,122.3,115.9$.

\section{2-Styrylfuran (P26)}

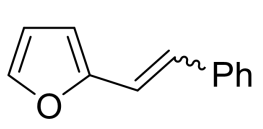

Prepared as described above. Purified by silica gel column chromatography using $n$-hexane to give $85 \%$ yield $(22.9 \mathrm{mg})$ of the product $(E / Z=2.3: 1)$ as a light yellow oil. ${ }^{1} \mathrm{H}$ NMR and ${ }^{13} \mathrm{C}$ NMR data match previously reported data. ${ }^{27}{ }^{1} \mathrm{H}$ NMR (600 $\left.\mathrm{MHz}, \mathrm{CDCl}_{3}\right): \delta$ 7.49-7.43 (m, 2H), 7.42-7.26 (m, 3H), 7.25-7.21 (m, 1H), $7.04(\mathrm{~d}, J=16.2 \mathrm{~Hz}$, $0.7 \times 1 \mathrm{H}), 6.90(\mathrm{~d}, J=16.3 \mathrm{~Hz}, 0.7 \times 1 \mathrm{H}), 6.48(\mathrm{~d}, J=12.6 \mathrm{~Hz}, 0.3 \times 1 \mathrm{H}), 6.42(\mathrm{dd}, J=3.3,1.8$ $\mathrm{Hz}, 0.7 \times 1 \mathrm{H}), 6.37(\mathrm{~d}, J=12.5 \mathrm{~Hz}, 0.3 \times 1 \mathrm{H}), 6.35(\mathrm{~d}, J=3.3 \mathrm{~Hz}, 0.7 \times 1 \mathrm{H}), 6.31(\mathrm{dd}, J=3.4$, $1.9 \mathrm{~Hz}, 0.3 \times 1 \mathrm{H}), 6.24(\mathrm{~d}, J=3.4 \mathrm{~Hz}, 0.3 \times 1 \mathrm{H}) ;{ }^{13} \mathrm{C} \mathrm{NMR}\left(151 \mathrm{MHz}, \mathrm{CDCl}_{3}\right): \delta 153.3,152.1$, $142.1,141.5,137.4,137.0,128.7,128.7,128.1,128.0,127.6,127.3,127.1,126.3,118.0,116.5$, $111.6,111.2,109.9,108.5$. 
$\left\langle\|_{S}^{m} \mathrm{Ph}\right.$

Prepared as described above. Purified by silica gel column chromatography using $n$-hexane to give $92 \%$ yield $(17.1 \mathrm{mg})$ of the product $(E / Z=1: 1)$ as a

white solid. ${ }^{1} \mathrm{H}$ NMR and ${ }^{13} \mathrm{C}$ NMR data match previously reported data. ${ }^{28}{ }^{1} \mathrm{H}$ NMR (400 MHz, $\left.\mathrm{CDCl}_{3}\right): \delta 7.46(\mathrm{~d}, J=7.6 \mathrm{~Hz}, 1 \mathrm{H}), 7.39-7.24(\mathrm{~m}, 4 \mathrm{H}), 7.23-7.15(\mathrm{~m}, 1 \mathrm{H}), 7.10-7.03(\mathrm{~m}, 1 \mathrm{H})$, $6.99(\mathrm{dd}, J=5.1,3.5 \mathrm{~Hz}, 0.5 \times 1 \mathrm{H}), 6.97-6.89(\mathrm{~m}, 1 \mathrm{H}), 6.87(\mathrm{dd}, J=5.1,3.6 \mathrm{~Hz}, 0.5 \times 1 \mathrm{H}), 6.69$ $(\mathrm{d}, J=12.0 \mathrm{~Hz}, 0.5 \times 1 \mathrm{H}), 6.57(\mathrm{~d}, J=12.0 \mathrm{~Hz}, 0.5 \times 1 \mathrm{H}) ;{ }^{13} \mathrm{C} \mathrm{NMR}\left(101 \mathrm{MHz}, \mathrm{CDCl}_{3}\right): \delta 142.9$, $139.8,137.3,137.0,128.9,128.8,128.7,128.5,128.3,128.1,127.6,127.5,126.4,126.3,126.1$, $125.5,124.3,123.3,121.8$.

\section{tert-Butyl 2-styryl-1H-pyrrole-1-carboxylate (P28)}

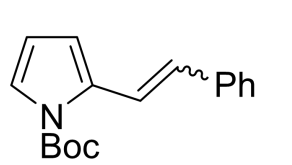

Prepared as described above. Purified by silica gel column chromatography using petroleum ether/EtOAc $=40: 1$ to give $94 \%$ yield $(25.3 \mathrm{mg})$ of the product $(E / Z=1.1: 1)$ as a yellow oil. ${ }^{1} \mathrm{H}$ NMR $\left(400 \mathrm{MHz}, \mathrm{CDCl}_{3}\right): \delta 7.75(\mathrm{~d}, J$

$=16.3 \mathrm{~Hz}, 0.52 \times 1 \mathrm{H}), 7.50-7.44(\mathrm{~m}, 1 \mathrm{H}), 7.36-7.24(\mathrm{~m}, 3 \mathrm{H}), 7.23-7.16(\mathrm{~m}, 2 \mathrm{H}), 6.88(\mathrm{~d}, J=$ $16.3 \mathrm{~Hz}, 0.52 \times 1 \mathrm{H}), 6.81(\mathrm{~d}, J=12.3 \mathrm{~Hz}, 0.48 \times 1 \mathrm{H}), 6.57-6.43(\mathrm{~m}, 1 \mathrm{H}), 6.18(\mathrm{t}, J=3.4 \mathrm{~Hz}, 0.52$ $\times 1 \mathrm{H}), 6.10-5.99(\mathrm{~m}, 1 \mathrm{H}), 1.64-1.58(\mathrm{~m}, 9 \mathrm{H}) ;{ }^{13} \mathrm{C} \mathrm{NMR}\left(101 \mathrm{MHz}, \mathrm{CDCl}_{3}\right): \delta 149.5,149.3,137.6$, $137.5,134.3,131.2,129.1,128.60,128.57,128.16,128.13,127.2,127.0,126.3,122.2,121.3$, 121.2, 119.7, 114.0, 111.1, 110.8, 110.7, 83.9, 83.8, 28.1, 28.0; ESI-HRMS calcd for $\left[\mathrm{C}_{17} \mathrm{H}_{20} \mathrm{NO}_{2}\right.$, $\mathrm{M}+\mathrm{H}]^{+}: 270.1489$, Found: 270.1491.

\section{2-Syrylbenzofuran (P29)}

chromatography using $n$-hexane to give $41 \%$ yield $(9.0 \mathrm{mg})$ of the
che product $(E / Z=4.6: 1)$ as a white solid. ${ }^{1} \mathrm{H}$ NMR $\left(400 \mathrm{MHz}, \mathrm{CDCl}_{3}\right): \delta 7.59-7.42(\mathrm{~m}, 4 \mathrm{H})$, 7.41-7.35 (m, 2H), 7.35-7.26 (m, 3H), 7.24-7.14 (m, 1H), $7.01(\mathrm{~d}, J=16.2 \mathrm{~Hz}, 0.82 \times 1 \mathrm{H})$, 6.73-6.57 (m, 1H), 6.49 (d, $\left.J=12.8 \mathrm{~Hz}, 0.18 \times 1 \mathrm{H}) ;{ }^{13} \mathrm{C} \mathrm{NMR} \mathrm{(101} \mathrm{MHz,} \mathrm{CDCl}_{3}\right): \delta$ 155.1, 154.9, $154.2,153.9,137.0,136.6,131.7,130.2,129.1,128.84,128.76,128.6,128.2,128.1,127.8,126.7$, 124.6, 124.5, 122.9, 122.8, 120.8 (2C), 118.1, 116.4, 111.0, 110.9, 106.1, 105.2; ESI-HRMS calcd for $\left[\mathrm{C}_{16} \mathrm{H}_{13} \mathrm{O}, \mathrm{M}+\mathrm{H}\right]^{+}:$221.0961, Found: 221.0967. 


\section{Nphtho[2,1-b]benzofuran (P29')}

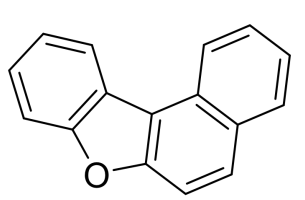

Prepared as described above. Purified by silica gel column chromatography using $n$-hexane to give $9 \%$ yield $(2.0 \mathrm{mg})$ of the product as a colorless oil. ${ }^{1} \mathrm{H}$ NMR data matches previously reported data. ${ }^{29}{ }^{1} \mathrm{H}$ NMR $(400 \mathrm{MHz}$, $\left.\mathrm{CDCl}_{3}\right): \delta 8.68-8.60(\mathrm{~m}, 1 \mathrm{H}), 8.44-8.36(\mathrm{~m}, 1 \mathrm{H}), 8.08-8.00(\mathrm{~m}, 1 \mathrm{H}), 7.94(\mathrm{~d}, J=8.9 \mathrm{~Hz}, 1 \mathrm{H})$, $7.78(\mathrm{~d}, J=8.9 \mathrm{~Hz}, 1 \mathrm{H}), 7.75-7.67(\mathrm{~m}, 2 \mathrm{H}), 7.59-7.53(\mathrm{~m}, 1 \mathrm{H}), 7.52-7.44(\mathrm{~m}, 2 \mathrm{H})$.

\section{2-Styrylbenzo $[b]$ thiophene (P30)}

chromatography using $n$-hexane to give $59 \%$ yield $(13.9 \mathrm{mg})$ of the
(1) Prepared as described above. Purified by silica gel column product $(E / Z=3: 1)$ as a yellow solid. ${ }^{1} \mathrm{H}$ NMR $\left(600 \mathrm{MHz}, \mathrm{CDCl}_{3}\right): \delta 7.79-7.74(\mathrm{~m}, 0.75 \times 1 \mathrm{H})$, 7.70-7.61 (m, 1H), 7.52-7.25 (m, 8H), 7.24-7.19 (m, 1H), $6.99(\mathrm{~d}, J=16.0 \mathrm{~Hz}, 0.75 \times 1 \mathrm{H}), 6.78$ $(\mathrm{d}, J=12.0 \mathrm{~Hz}, 0.25 \times 1 \mathrm{H}), 6.72(\mathrm{~d}, J=12.0 \mathrm{~Hz}, 0.25 \times 1 \mathrm{H}) ;{ }^{13} \mathrm{C}$ NMR $\left(151 \mathrm{MHz}, \mathrm{CDCl}_{3}\right): \delta$ $142.9,140.2,140.1,140.0,139.0,138.9,136.8,136.6,131.2,130.8,129.0,128.7,128.5,128.0$, $127.8,126.6,125.1,124.7,124.51,124.48,124.2,123.8,123.4,123.27,123.25,122.3,122.2$, 122.0; ESI-HRMS calcd for $\left[\mathrm{C}_{16} \mathrm{H}_{13} \mathrm{~S}, \mathrm{M}+\mathrm{H}\right]^{+}:$237.0733, Found: 237.0730 .

\section{Benzo[b]naphtho[1,2-d] thiophene (P30')}<smiles>c1ccc2c(c1)ccc1sc3ccccc3c12</smiles>

Prepared as described above. Purified by silica gel column chromatography using $\mathrm{n}$-hexane to give $5 \%$ yield $(1.2 \mathrm{mg})$ of the product as a yellow solid. ${ }^{1} \mathrm{H}$ NMR data matches previously reported data. ${ }^{30} \mathrm{H}$ NMR $(600 \mathrm{MHz}$, $\left.\mathrm{CDCl}_{3}\right): \delta 9.02(\mathrm{~d}, J=8.5 \mathrm{~Hz}, 1 \mathrm{H}), 8.87(\mathrm{~d}, J=8.3 \mathrm{~Hz}, 1 \mathrm{H}), 8.06-7.98(\mathrm{~m}, 2 \mathrm{H}), 7.91(\mathrm{q}, J=8.6$ $\mathrm{Hz}, 2 \mathrm{H}), 7.74$ (ddd, $J=8.5,6.9,1.4 \mathrm{~Hz}, 1 \mathrm{H}), 7.64-7.56(\mathrm{~m}, 2 \mathrm{H}), 7.51$ (ddd, $J=8.0,7.0,1.1 \mathrm{~Hz}$, $1 \mathrm{H})$.

\section{Naphthalen-2-yl(vinyl)sulfane (P31)}

Prepared as described above. Purified by silica gel column
chromatography using $n$-hexane to give $68 \%$ yield $(12.7 \mathrm{mg})$ of the product as a light yellow solid. ${ }^{1} \mathrm{H}$ NMR and ${ }^{13} \mathrm{C}$ NMR data match previously reported data. ${ }^{31}{ }^{1} \mathrm{H}$ $\operatorname{NMR}\left(400 \mathrm{MHz}, \mathrm{CDCl}_{3}\right): \delta 7.85-7.75(\mathrm{~m}, 4 \mathrm{H}), 7.51-7.44(\mathrm{~m}, 3 \mathrm{H}), 6.63(\mathrm{dd}, J=16.6,9.6 \mathrm{~Hz}, 1 \mathrm{H})$, 
5.44-5.37 (m, 2H); ${ }^{13} \mathrm{C}$ NMR (101 MHz, $\left.\mathrm{CDCl}_{3}\right): \delta 133.8,132.3,131.7,131.6,129.0,128.7$, $128.1,127.7,127.3,126.6,126.2,115.9$.

\section{Naphthalen-2-yl(prop-1-en-2-yl)sulfane (P32)}<smiles>C=C(C)Sc1ccc2ccccc2c1</smiles>

Prepared as described above. Purified by silica gel column chromatography using $n$-hexane to give $31 \%$ yield $(6.2 \mathrm{mg})$ of the product as a colorless oil. ${ }^{1} \mathrm{H}$ NMR $\left(400 \mathrm{MHz}, \mathrm{CDCl}_{3}\right): \delta 7.94(\mathrm{~s}, 1 \mathrm{H}), 7.87-7.73(\mathrm{~m}, 3 \mathrm{H}), 7.55-7.41(\mathrm{~m}, 3 \mathrm{H})$, $5.17(\mathrm{~d}, J=1.5 \mathrm{~Hz}, 1 \mathrm{H}), 4.94(\mathrm{~s}, 1 \mathrm{H}), 2.05-1.97(\mathrm{~m}, 3 \mathrm{H}) ;{ }^{13} \mathrm{C} \mathrm{NMR}\left(101 \mathrm{MHz}, \mathrm{CDCl}_{3}\right): \delta 141.1,133.7$, 132.6, 132.3, 130.5, 130.3, 128.6, 127.7, 127.6, 126.5, 126.5, 113.7, 23.3; ESI-HRMS calcd for $\left[\mathrm{C}_{13} \mathrm{H}_{13} \mathrm{~S}, \mathrm{M}+\mathrm{H}\right]^{+}:$201.0733, Found: 201.0730.

\section{Naphthalen-2-yl(prop-1-en-1-yl)sulfane (P33)}

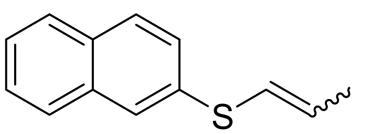

Prepared as described above. Purified by silica gel column product $(E / Z=1.8: 1)$ as a colorless oil. ${ }^{1} \mathrm{H}$ NMR $\left(600 \mathrm{MHz}, \mathrm{CDCl}_{3}\right): \delta 7.79-7.71(\mathrm{~m}, 4 \mathrm{H})$, $7.49-7.38(\mathrm{~m}, 3 \mathrm{H}), 6.32(\mathrm{dq}, J=9.3,1.6 \mathrm{~Hz}, 0.36 \times 1 \mathrm{H}), 6.24(\mathrm{dq}, J=14.6,1.5 \mathrm{~Hz}, 0.64 \times 1 \mathrm{H})$, $6.07(\mathrm{dq}, J=15.0,6.7 \mathrm{~Hz}, 0.63 \times 1 \mathrm{H}), 6.00-5.93(\mathrm{~m}, 0.34 \times 1 \mathrm{H}), 1.88(\mathrm{dd}, J=6.7,1.6 \mathrm{~Hz}, 3 \mathrm{H})$; ${ }^{13} \mathrm{C}$ NMR (151 MHz, $\left.\mathrm{CDCl}_{3}\right): \delta 134.1,133.81,133.80,133.76,132.9,131.8(2 \mathrm{C}), 128.6,128.5$, 128.4, 127.7 (2C), 127.09, 127.08, 126.9, 126.64, 126.59, 126.5 (2C), 126.2, 125.7, 125.6, 123.3, 121.5, 18.6, 14.8; ESI-HRMS calcd for $\left[\mathrm{C}_{13} \mathrm{H}_{13} \mathrm{~S}, \mathrm{M}+\mathrm{H}\right]^{+}:$201.0733, Found: 201.0731.

\section{But-1-en-2-yl(naphthalen-2-yl)sulfane (P34)}

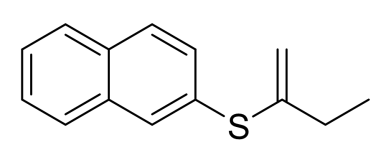

Prepared as described above. Purified by silica gel column product as a colorless oil. ${ }^{1} \mathrm{H}$ NMR $\left(600 \mathrm{MHz}, \mathrm{C}_{6} \mathrm{D}_{6}\right): \delta 7.93(\mathrm{~d}, J=1.6 \mathrm{~Hz}, 1 \mathrm{H}), 7.54-7.49(\mathrm{~m}$, 2H), 7.48-7.43 (m, 2H), 7.20-7.17 (m, 2H), 5.09-5.07 (m, 1H), $5.06(\mathrm{~s}, 1 \mathrm{H}), 2.20(\mathrm{q}, J=7.4 \mathrm{~Hz}$, 2H), $1.04(\mathrm{t}, J=7.4 \mathrm{~Hz}, 3 \mathrm{H}) ;{ }^{13} \mathrm{C}$ NMR $\left(151 \mathrm{MHz}, \mathrm{C}_{6} \mathrm{D}_{6}\right): \delta 148.0,134.4,133.1,132.7,131.3$, 130.6, 129.1, 128.3, 128.0, 126.7, 126.6, 112.4, 30.2, 13.5; ESI-HRMS calcd for $\left[\mathrm{C}_{14} \mathrm{H}_{15} \mathrm{~S}, \mathrm{M}+\right.$ $\mathrm{H}]^{+}:$215.0889, Found: 215.0892 . 
(4-Chlorophenyl)(phenyl)sulfane (P35)<smiles>Clc1ccc(Sc2ccccc2)cc1</smiles>

Prepared as described above. Purified by silica gel column chromatography using $n$-hexane to give $58 \%$ yield $(12.8 \mathrm{mg})$ of the product as a colorless oil. ${ }^{1} \mathrm{H}$ NMR and ${ }^{13} \mathrm{C}$ NMR data match previously reported data. ${ }^{32}{ }^{1} \mathrm{H}$ NMR $\left(600 \mathrm{MHz}, \mathrm{CDCl}_{3}\right): \delta 7.36-7.28(\mathrm{~m}, 4 \mathrm{H}), 7.27-7.22(\mathrm{~m}, 5 \mathrm{H}) ;{ }^{13} \mathrm{C}$ NMR $\left(151 \mathrm{MHz}, \mathrm{CDCl}_{3}\right): \delta 135.1,134.6,133.0,132.0,131.3,129.33,129.31,127.4$.

\section{Phenyl(3-phenylprop-1-en-1-yl)sulfane (P36)}<smiles>Clc1ccc(S/C=C/Cc2ccccc2)cc1</smiles>

Prepared as described above. Purified by silica gel column chromatography using $n$-hexane to give $80 \%$ yield $(20.9 \mathrm{mg}$ ) of the product $(E / Z=2.3: 1)$ as a colorless oil. ${ }^{1} \mathrm{H}$ NMR $(400 \mathrm{MHz}$, $\left.\mathrm{CDCl}_{3}\right): \delta 7.35-7.26(\mathrm{~m}, 4 \mathrm{H}), 7.25-7.15(\mathrm{~m}, 5 \mathrm{H}), 6.27(\mathrm{dt}, J=9.1,1.4 \mathrm{~Hz}, 0.3 \times 1 \mathrm{H}), 6.20-6.07$ $(\mathrm{m}, 0.7 \times 2 \mathrm{H}), 6.03(\mathrm{dt}, J=9.1,7.3 \mathrm{~Hz}, 0.3 \times 1 \mathrm{H}), 3.61(\mathrm{dd}, J=7.4,1.3 \mathrm{~Hz}, 0.7 \times 2 \mathrm{H}), 3.50(\mathrm{~d}, J$ $=5.4 \mathrm{~Hz}, 1 \mathrm{H}) ;{ }^{13} \mathrm{C} \mathrm{NMR}\left(101 \mathrm{MHz}, \mathrm{CDCl}_{3}\right): \delta 139.7,139.0,135.4,134.64,134.58,132.5,132.4$, $132.3,130.14,130.07,129.2,129.1,128.6(2 \mathrm{C}), 128.5,128.4,126.4,126.3,123.3,122.4,39.3$, 35.4; ESI-HRMS calcd for $\left[\mathrm{C}_{15} \mathrm{H}_{14} \mathrm{ClS}, \mathrm{M}+\mathrm{H}\right]^{+}:$261.0499, Found: 261.0497.

\section{Phenyl(3-phenylprop-1-en-1-yl)sulfane (P37)}

$\mathrm{PhS} \backslash \mathrm{w}_{2} / \mathrm{Ph}$ Prepared as described above. Purified by silica gel column chromatography using $n$-hexane to give $71 \%$ yield $(16.0 \mathrm{mg})$ of the product $(E / Z=2.7: 1)$ as a yellow oil. ${ }^{1} \mathrm{H}$ NMR and ${ }^{13} \mathrm{C}$ NMR data match previously reported data. ${ }^{33}{ }^{1} \mathrm{H}$ NMR (600 MHz, $\left.\mathrm{CDCl}_{3}\right): \delta 7.39-7.28(\mathrm{~m}$, $6 \mathrm{H}), 7.25-7.16(\mathrm{~m}, 4 \mathrm{H}), 6.33(\mathrm{~d}, J=9.1 \mathrm{~Hz}, 0.27 \times 1 \mathrm{H}), 6.21(\mathrm{~d}, J=14.8 \mathrm{~Hz}, 0.73 \times 1 \mathrm{H})$, $6.15-6.05(\mathrm{~m}, 0.73 \times 1 \mathrm{H}), 6.02-5.96(\mathrm{~m}, 0.27 \times 1 \mathrm{H}), 3.61(\mathrm{~d}, J=7.4 \mathrm{~Hz}, 0.27 \times 2 \mathrm{H}), 3.49(\mathrm{~d}, J=$ $6.8 \mathrm{~Hz}, 0.73 \times 2 \mathrm{H}) ;{ }^{13} \mathrm{C}$ NMR $\left(151 \mathrm{MHz}, \mathrm{CDCl}_{3}\right): \delta 139.9,139.3,136.1,136.0,134.4,131.6$, 129.02, 128.98 (2C), 128.9, $128.6(3 \mathrm{C}), 128.5,126.4,126.33,126.32,126.2,124.0,123.0,39.3$, 35.4 .

\section{(4-Chlorophenyl)(styryl)sulfane (P38)}<smiles>Clc1ccc(SC=Cc2ccccc2)cc1</smiles>

Prepared as described above. Purified by silica gel column chromatography using $n$-hexane to give $92 \%$ yield $(22.7 \mathrm{mg})$ of the 
product $(E / Z=1: 1.3)$ as a colorless oil. ${ }^{1} \mathrm{H}$ NMR and ${ }^{13} \mathrm{C}$ NMR data match previously reported data. ${ }^{34}{ }^{1} \mathrm{H}$ NMR (400 MHz, $\left.\mathrm{CDCl}_{3}\right): \delta 7.54-7.48(\mathrm{~m}, 1 \mathrm{H}), 7.42-7.25(\mathrm{~m}, 8 \mathrm{H}), 6.82(\mathrm{~d}, J=15.4 \mathrm{~Hz}$, $0.44 \times 1 \mathrm{H}), 6.74(\mathrm{~d}, J=15.4 \mathrm{~Hz}, 0.44 \times 1 \mathrm{H}), 6.62(\mathrm{~d}, J=10.7 \mathrm{~Hz}, 0.56 \times 1 \mathrm{H}), 6.42(\mathrm{~d}, J=10.7$ $\mathrm{Hz}, 0.56 \times 1 \mathrm{H}) ;{ }^{13} \mathrm{C}$ NMR $\left(101 \mathrm{MHz}, \mathrm{CDCl}_{3}\right): \delta 136.3,136.2,134.7,133.8,133.3,133.0,132.8$, 131.2, 131.0, 129.3 (2C), 128.8, 128.7, 128.3, 128.0, 127.8, 127.3, 126.1, 125.2, 122.5.

\section{2-(2-((4-Chlorophenyl)thio)vinyl)pyridine (P39)}<smiles>Clc1ccc(SC=Cc2ccccn2)cc1</smiles>

Prepared as described above. Purified by silica gel column chromatography using petroleum ether/EtOAc $=3: 1 \rightarrow 1: 1$ to give $Z$-isomer as a yellow oil and $E$-isomer as a yellow oil in $38 \%$ total yield $(9.4 \mathrm{mg}, E / Z=1.4: 1)$. For $Z$-isomer, ${ }^{1} \mathrm{H}$ NMR $\left(400 \mathrm{MHz}, \mathrm{CDCl}_{3}\right): \delta 8.78-8.66(\mathrm{~m}, 1 \mathrm{H}), 7.66$ (td, $J=7.7,1.9 \mathrm{~Hz}, 1 \mathrm{H}), 7.47(\mathrm{~d}, J=8.5 \mathrm{~Hz}, 2 \mathrm{H}), 7.33(\mathrm{~d}, J=8.5 \mathrm{~Hz}, 2 \mathrm{H}), 7.26-7.22(\mathrm{~m}, 1 \mathrm{H})$, $7.12(\mathrm{ddd}, J=7.6,4.8,1.2 \mathrm{~Hz}, 1 \mathrm{H}), 6.75(\mathrm{~d}, J=10.4 \mathrm{~Hz}, 1 \mathrm{H}), 6.57(\mathrm{~d}, J=10.4 \mathrm{~Hz}, 1 \mathrm{H}) ;{ }^{13} \mathrm{C}$ NMR $\left(151 \mathrm{MHz}, \mathrm{CDCl}_{3}\right): \delta 155.4,148.7,136.9,136.1,133.6,133.0,132.1,129.3,123.6,123.3$, 120.9; ESI-HRMS calcd for $\left[\mathrm{C}_{13} \mathrm{H}_{11} \mathrm{ClNS}, \mathrm{M}+\mathrm{H}\right]^{+}: 248.0295$, Found: 248.0293 ; for $E$-isomer, ${ }^{1} \mathrm{H}$ $\operatorname{NMR}\left(600 \mathrm{MHz}, \mathrm{CDCl}_{3}\right): \delta 8.54-8.48(\mathrm{~m}, 1 \mathrm{H}), 7.60(\mathrm{td}, J=7.7,1.8 \mathrm{~Hz}, 1 \mathrm{H}), 7.51(\mathrm{~d}, J=15.2 \mathrm{~Hz}$, $1 \mathrm{H}), 7.41(\mathrm{~d}, J=8.5 \mathrm{~Hz}, 2 \mathrm{H}), 7.33(\mathrm{~d}, J=8.5 \mathrm{~Hz}, 2 \mathrm{H}), 7.13-7.08(\mathrm{~m}, 2 \mathrm{H}), 6.59(\mathrm{~d}, J=15.1 \mathrm{~Hz}$, $1 \mathrm{H}) ;{ }^{13} \mathrm{C}$ NMR $\left(151 \mathrm{MHz}, \mathrm{CDCl}_{3}\right): \delta 154.4,149.6,136.6,133.8,132.4,132.2,129.7,129.5,128.4$, 121.9, 121.5; ESI-HRMS calcd for $\left[\mathrm{C}_{13} \mathrm{H}_{11} \mathrm{ClNS}, \mathrm{M}+\mathrm{H}\right]^{+}: 248.0295$, Found: 248.0294 .

\section{(2-Chlorophenyl)(styryl)sulfane (P40)}<smiles>Clc1ccccc1S/C=C/c1ccccc1</smiles>

Prepared as described above. Purified by silica gel column chromatography using $n$-hexane to give $82 \%$ yield $(20.3 \mathrm{mg})$ of the product $(E / Z=1: 1.1)$ as a colorless oil. ${ }^{1} \mathrm{H}$ NMR $\left(400 \mathrm{MHz}, \mathrm{CDCl}_{3}\right): \delta 7.57(\mathrm{dd}, J=7.6,1.7 \mathrm{~Hz}, 1 \mathrm{H}), 7.47-7.12(\mathrm{~m}, 8 \mathrm{H})$, $6.89(\mathrm{~d}, J=15.4 \mathrm{~Hz}, 0.49 \times 1 \mathrm{H}), 6.82(\mathrm{~d}, J=15.4 \mathrm{~Hz}, 0.49 \times 1 \mathrm{H}), 6.74(\mathrm{~d}, J=10.7 \mathrm{~Hz}, 0.51 \times$ $1 \mathrm{H}), 6.42(\mathrm{~d}, J=10.7 \mathrm{~Hz}, 0.51 \times 1 \mathrm{H}) ;{ }^{13} \mathrm{C} \mathrm{NMR}\left(101 \mathrm{MHz}, \mathrm{CDCl}_{3}\right): \delta 136.2,136.1,135.43$, $135.36,135.2,134.0,133.0,130.5,129.84,129.77,129.4,128.9,128.8,128.3,128.1,127.9,127.5$, 127.41, 127.37, 127.3, 126.3, 123.4, 120.5; ESI-HRMS calcd for $\left[\mathrm{C}_{14} \mathrm{H}_{12} \mathrm{ClS}, \mathrm{M}+\mathrm{H}\right]^{+}: 247.0343$, Found: 247.0342 . 
(4-(tert-Butyl)phenyl)(styryl)sulfane (P41)

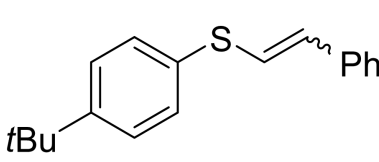

Prepared as described above. Purified by silica gel column chromatography using $n$-hexane to give $65 \%$ yield $(17.4 \mathrm{mg})$ of the product $(E / Z=1: 1.4)$ as a colorless oil. ${ }^{1} \mathrm{H}$ NMR and ${ }^{13} \mathrm{C}$ NMR data match previously reported data. ${ }^{35}{ }^{1} \mathrm{H}$ NMR $\left(600 \mathrm{MHz}, \mathrm{CDCl}_{3}\right): \delta 7.55-7.51(\mathrm{~m}, 1 \mathrm{H}), 7.42-7.35(\mathrm{~m}$, 5H), 7.34-7.25 (m, 2H), 7.24-7.19 (m, 1H), $6.88(\mathrm{~d}, J=15.5 \mathrm{~Hz}, 0.41 \times 1 \mathrm{H}), 6.69(\mathrm{~d}, J=15.5 \mathrm{~Hz}$, $0.41 \times 1 \mathrm{H}), 6.54(\mathrm{~d}, J=10.7 \mathrm{~Hz}, 0.59 \times 1 \mathrm{H}), 6.49(\mathrm{~d}, J=10.8 \mathrm{~Hz}, 0.59 \times 1 \mathrm{H}), 1.32(\mathrm{~s}, 9 \mathrm{H}) ;{ }^{13} \mathrm{C}$ NMR (151 MHz, $\left.\mathrm{CDCl}_{3}\right): \delta 150.6,150.4,136.7,136.6,132.7,131.4,130.7,130.2,130.1,128.7$, 128.6, 128.3, 127.4, 127.0, 126.9, 126.5, 126.2 (2C), 125.9, 124.3, 34.6, 31.3.

\section{2-(Styrylthio)pyrimidine (P42)}<smiles>C(=Cc1ncccn1)c1ccccc1</smiles>

Prepared as described above. Purified by silica gel column chromatography using petroleum ether/EtOAc $=10: 1$ to give $71 \%$ yield $(15.2 \mathrm{mg})$ of the product $(E / Z=1.1: 1)$ as a colorless oil. ${ }^{1} \mathrm{H} \mathrm{NMR}\left(400 \mathrm{MHz}, \mathrm{CDCl}_{3}\right): \delta 8.58(\mathrm{dd}, J=12.2,4.8 \mathrm{~Hz}$, 2H), 7.64-7.32 (m, 5H), 7.30-7.22 (m, 1H), $7.04(\mathrm{dt}, J=10.5,4.8 \mathrm{~Hz}, 1 \mathrm{H}), 6.86(\mathrm{~d}, J=16.2 \mathrm{~Hz}$, $0.47 \times 1 \mathrm{H}), 6.77(\mathrm{~d}, J=11.0 \mathrm{~Hz}, 0.53 \times 1 \mathrm{H}) ;{ }^{13} \mathrm{C} \mathrm{NMR}\left(101 \mathrm{MHz}, \mathrm{CDCl}_{3}\right): \delta 170.8,169.7,157.54$ $157.50,136.4,136.3,131.1,128.8,128.6,128.4,128.0,127.8,127.3,126.3,119.6,119.5,117.4$, 117.1; ESI-HRMS calcd for $\left[\mathrm{C}_{12} \mathrm{H}_{11} \mathrm{~N}_{2} \mathrm{~S}, \mathrm{M}+\mathrm{H}\right]^{+}:$215.0638, Found: 215.0636.

\section{(4-Bromophenyl)(2,2-diphenylvinyl)sulfane (P43)}

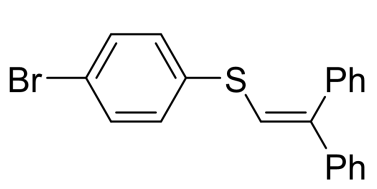

Prepared as described above. Purified by silica gel column chromatography using $n$-hexane to give $75 \%$ yield $(27.5 \mathrm{mg})$ of the product as a light yellow solid. ${ }^{1} \mathrm{H}$ NMR and ${ }^{13} \mathrm{C}$ NMR data match previously reported data. ${ }^{36} \mathrm{H}$ NMR $\left(600 \mathrm{MHz}, \mathrm{CDCl}_{3}\right): \delta 7.46-7.40(\mathrm{~m}, 4 \mathrm{H}), 7.38-7.32(\mathrm{~m}, 3 \mathrm{H})$, $7.31-7.25(\mathrm{~m}, 6 \mathrm{H}), 7.24(\mathrm{~d}, J=2.5 \mathrm{~Hz}, 1 \mathrm{H}), 6.77(\mathrm{~s}, 1 \mathrm{H}) ;{ }^{13} \mathrm{C} \mathrm{NMR}\left(151 \mathrm{MHz}, \mathrm{CDCl}_{3}\right): \delta 142.2$, $141.2,139.0,135.8,132.2,130.9,129.7,128.41,128.35,128.0,127.5,127.2,122.9,120.7$.

\section{(4-(tert-Butyl)phenyl)(2,2-diphenylvinyl)sulfane (P44)}<smiles>CC(C)(C)c1ccc(SC=C(c2ccccc2)c2ccccc2)cc1</smiles>

Prepared as described above. Purified by silica gel column chromatography using $n$-hexane to give $85 \%$ yield $(29.3 \mathrm{mg})$ of the product as a light yellow solid. ${ }^{1} \mathrm{H}$ NMR and ${ }^{13} \mathrm{C}$ NMR data match 
previously reported data. ${ }^{36} \mathrm{H}$ NMR (600 MHz, $\left.\mathrm{CDCl}_{3}\right): \delta$ 7.44-7.33 (m, 9H), 7.29-7.25 (m, 3H), 7.25-7.21 (m, 2H), $6.85(\mathrm{~s}, 1 \mathrm{H}), 1.32(\mathrm{~s}, 9 \mathrm{H}) ;{ }^{13} \mathrm{C} \mathrm{NMR}\left(151 \mathrm{MHz}, \mathrm{CDCl}_{3}\right): \delta 150.2,141.6,140.2$, $139.3,132.9,129.8,129.7,128.4,128.3,127.7,127.1,126.2,125.1,34.5,31.3$.

\section{(4-Chlorophenyl)(2,2-diphenylvinyl)sulfane (P45)}

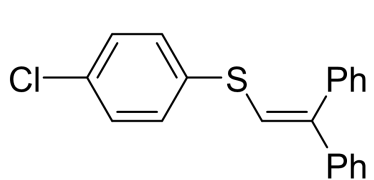

Prepared as described above. Purified by silica gel column chromatography using $n$-hexane to give $85 \%$ yield $(27.5 \mathrm{mg})$ of the product as a light yellow solid. ${ }^{1} \mathrm{H}$ NMR and ${ }^{13} \mathrm{C}$ NMR data match previously reported data. ${ }^{36}{ }^{1} \mathrm{H}$ NMR $\left(400 \mathrm{MHz}, \mathrm{CDCl}_{3}\right): \delta 7.45-7.37(\mathrm{~m}, 3 \mathrm{H}), 7.37-7.26(\mathrm{~m}, 10 \mathrm{H})$, 7.26-7.22 (m, 3H), $6.77(\mathrm{~s}, 1 \mathrm{H}) ;{ }^{13} \mathrm{C} \mathrm{NMR}\left(101 \mathrm{MHz}, \mathrm{CDCl}_{3}\right): \delta$ 142.0, 141.2, 139.0, 135.1, 132.8, $130.7,129.7,129.3,128.42,128.35,128.0,127.5,127.2,123.2$.

\section{(4-Chlorophenyl)(2-phenylprop-1-en-1-yl)sulfane (P46)}

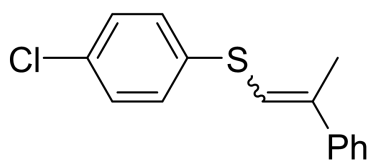

Prepared as described above. Purified by silica gel column chromatography using $n$-hexane to give $E$-isomer as a colorless solid and $Z$-isomer as a colorless oil in $53 \%$ total yield $(13.8 \mathrm{mg}, E / Z=$ 1:2.1). For $E$-isomer, ${ }^{1} \mathrm{H}$ NMR (400 MHz, $\left.\mathrm{CDCl}_{3}\right): \delta$ 7.43-7.38 (m, 2H), 7.36-7.24 (m, 7H), 6.49 $(\mathrm{q}, J=1.1 \mathrm{~Hz}, 1 \mathrm{H}), 2.25(\mathrm{~d}, J=1.1 \mathrm{~Hz}, 3 \mathrm{H}) ;{ }^{13} \mathrm{C} \mathrm{NMR}\left(151 \mathrm{MHz}, \mathrm{CDCl}_{3}\right): \delta 141.5,138.4,135.0$, $132.4,130.2,129.2,128.5,127.4,125.5,120.5,17.8$; ESI-HRMS calcd for $\left[\mathrm{C}_{15} \mathrm{H}_{14} \mathrm{ClS}, \mathrm{M}+\mathrm{H}\right]^{+}$: 261.0493, Found: 261.0491; For Z-isomer, ${ }^{1} \mathrm{H}$ NMR (400 MHz, $\left.\mathrm{CDCl}_{3}\right): \delta 7.41-7.33(\mathrm{~m}, 4 \mathrm{H})$, $7.33-7.28(\mathrm{~m}, 1 \mathrm{H}), 7.27-7.22(\mathrm{~m}, 4 \mathrm{H}), 6.20(\mathrm{q}, J=1.4 \mathrm{~Hz}, 1 \mathrm{H}), 2.22(\mathrm{~d}, J=1.4 \mathrm{~Hz}, 3 \mathrm{H}) ;{ }^{13} \mathrm{C}$ NMR $\left(151 \mathrm{MHz}, \mathrm{CDCl}_{3}\right): \delta 140.1,139.4,135.7,132.2,130.0,129.0,128.2,127.63,127.58$, 119.1 , 25.23; ESI-HRMS calcd for $\left[\mathrm{C}_{15} \mathrm{H}_{14} \mathrm{ClS}, \mathrm{M}+\mathrm{H}\right]^{+}: 261.0493$, Found: 261.0492.

\section{3-((4-Chlorophenyl)thio)-1,3-diphenylprop-2-en-1-one (P47)}

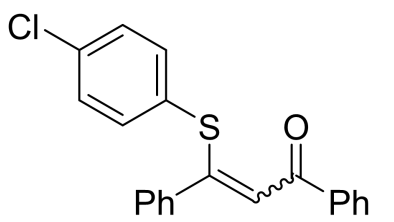

Prepared as described above. Purified by silica gel column chromatography using petroleum ether/EtOAc $=3: 1 \rightarrow 1: 1$ to give $Z$-isomer as a yellow solid and $E$-isomer as a yellow solid in $71 \%$ total yield $(24.9 \mathrm{mg}, E / Z=1: 1.8)$. For $Z$-isomer, ${ }^{1} \mathrm{H}$ NMR $\left(400 \mathrm{MHz}, \mathrm{CDCl}_{3}\right): \delta 8.08-8.01(\mathrm{~m}, 2 \mathrm{H})$, 7.60-7.54 (m, 1H), 7.52-7.46 (m, 2H), $7.24(\mathrm{~s}, 1 \mathrm{H}), 7.22-7.15(\mathrm{~m}, 5 \mathrm{H}), 7.14-7.07(\mathrm{~m}, 2 \mathrm{H})$, 
7.05-6.99 (m, 2H); ${ }^{13} \mathrm{C}$ NMR (101 MHz, $\left.\mathrm{CDCl}_{3}\right): \delta 188.6,161.2,138.5,138.3,135.3,134.2$, $132.6,131.5,128.9,128.7,128.64,128.57,128.2,128.0,120.3$; ESI-HRMS calcd for $\left[\mathrm{C}_{21} \mathrm{H}_{16} \mathrm{ClOS}, \mathrm{M}+\mathrm{H}\right]^{+}: 351.0605$, Found: 351.0602; for $E$-isomer, ${ }^{1} \mathrm{H}$ NMR (400 MHz, $\left.\mathrm{CDCl}_{3}\right): \delta$ 7.70-7.65 (m, 2H), 7.57-7.53 (m, 2H), 7.47-7.36 (m, 5H), 7.35-7.28 (m, 5H), $6.41(\mathrm{~s}, 1 \mathrm{H}) ;{ }^{13} \mathrm{C}$ NMR (101 MHz, $\left.\mathrm{CDCl}_{3}\right): \delta 189.1,159.2,138.4,136.6,136.3,136.2,132.5,130.1,129.4,129.1$, 128.7, 128.4, 128.3, 128.2, 118.9; ESI-HRMS calcd for $\left[\mathrm{C}_{21} \mathrm{H}_{16} \mathrm{ClOS}, \mathrm{M}+\mathrm{H}\right]^{+}: 351.0605$, Found: 351.0601 .

3-((4-Chlorophenyl)thio)cyclohex-2-en-1-one (P48)<smiles>O=C1C=C(Sc2ccc(Cl)cc2)CCC1</smiles>
Prepared as described above. Purified by silica gel column chromatography using petroleum ether/EtOAc $=20: 1 \rightarrow 10: 1$ to give $55 \%$ yield $(13.2 \mathrm{mg})$ of the product as a yellow solid. ${ }^{1} \mathrm{H}$ NMR $(600 \mathrm{MHz}$, $\left.\mathrm{CDCl}_{3}\right): \delta 7.45-7.37(\mathrm{~m}, 4 \mathrm{H}), 5.46-5.43(\mathrm{~m}, 1 \mathrm{H}), 2.52(\mathrm{t}, J=5.8 \mathrm{~Hz}, 2 \mathrm{H}), 2.41-2.36(\mathrm{~m}, 2 \mathrm{H})$, $2.06(\mathrm{p}, J=6.3 \mathrm{~Hz}, 2 \mathrm{H}) ;{ }^{13} \mathrm{C} \mathrm{NMR}\left(151 \mathrm{MHz}, \mathrm{CDCl}_{3}\right): \delta 195.9,166.1,136.7,130.2,126.4,121.1$, 37.2, 30.2, 22.9; ESI-HRMS calcd for $\left[\mathrm{C}_{12} \mathrm{H}_{12} \mathrm{ClOS}, \mathrm{M}+\mathrm{H}\right]^{+}:$239.0292, Found: 239.0293.

\section{6-Chloro-4H-thiochromen-4-one (P49)}<smiles>O=c1ccsc2ccc(Cl)cc12</smiles>

Prepared as described above. Purified by silica gel column chromatography using petroleum ether/EtOAc $=8: 1 \rightarrow 5: 1$ to give $75 \%$ yield $(14.8 \mathrm{mg})$ of the product as a yellow solid. ${ }^{1} \mathrm{H}$ NMR and ${ }^{13} \mathrm{C}$ NMR data match previously reported data. ${ }^{37}{ }^{1} \mathrm{H} \mathrm{NMR}\left(600 \mathrm{MHz}, \mathrm{CDCl}_{3}\right): \delta 8.53(\mathrm{dd}, J=2.0,0.8 \mathrm{~Hz}, 1 \mathrm{H}), 7.84(\mathrm{~d}, J=10.5 \mathrm{~Hz}$, 1H), 7.60-7.54 (m, 2H), $\left.7.02(\mathrm{~d}, J=10.5 \mathrm{~Hz}, 1 \mathrm{H}) ;{ }^{13} \mathrm{C} \mathrm{NMR} \mathrm{(151} \mathrm{MHz,} \mathrm{CDCl}_{3}\right): \delta 178.5,137.8$, 135.6, 134.5, 133.4, 131.9, 128.3, 128.2, 125.7 .

\section{2-(Vinyloxy)naphthalene (P50)}

Prepared as described above. Purified by silica gel column
chromatography using $n$-hexane to give $5 \%$ yield $(1.0 \mathrm{mg})$ of the product as a colorless oil. ${ }^{1} \mathrm{H}$ NMR and ${ }^{13} \mathrm{C}$ NMR data match previously reported data. ${ }^{38}{ }^{1} \mathrm{H}$ NMR (400 $\left.\mathrm{MHz}, \mathrm{CDCl}_{3}\right): \delta 7.86-7.70(\mathrm{~m}, 3 \mathrm{H}), 7.50-7.43(\mathrm{~m}, 1 \mathrm{H}), 7.39(\mathrm{t}, J=7.4 \mathrm{~Hz}, 1 \mathrm{H}), 7.32(\mathrm{~d}, J=2.4$ $\mathrm{Hz}, 1 \mathrm{H}), 7.25-7.18(\mathrm{~m}, 1 \mathrm{H}), 6.77(\mathrm{dd}, J=13.7,6.0 \mathrm{~Hz}, 1 \mathrm{H}), 4.85(\mathrm{~d}, J=13.7 \mathrm{~Hz}, 1 \mathrm{H}), 4.51(\mathrm{~d}, J$ 
$=6.1 \mathrm{~Hz}, 1 \mathrm{H}) ;{ }^{13} \mathrm{C} \mathrm{NMR}\left(101 \mathrm{MHz}, \mathrm{CDCl}_{3}\right): \delta 154.6,148.1,134.2,130.1,129.8,127.7,127.1$, 126.6, 124.6, 118.9, 111.6, 95.6.

\section{(2-Phenoxyvinyl)benzene (P51)}

$\mathrm{PhO} / \mathrm{m}_{\mathrm{Ph}}$

Prepared as described above. Purified by silica gel column chromatography using $n$-hexane to give $14 \%$ yield $(2.7 \mathrm{mg})$ of the product $(E / Z=2.3: 1)$ as a colorless oil. ${ }^{1} \mathrm{H}$ NMR and ${ }^{13} \mathrm{C}$ NMR data match previously reported data. ${ }^{39}{ }^{1} \mathrm{H}$ NMR $(400 \mathrm{MHz}$, $\left.\mathrm{CDCl}_{3}\right): \delta 7.68(\mathrm{~d}, J=7.7 \mathrm{~Hz}, 0.6 \times 1 \mathrm{H}), 7.37-7.29(\mathrm{~m}, 5.4 \mathrm{H}), 7.22-7.04(\mathrm{~m}, 4.7 \mathrm{H}), 6.60(\mathrm{~d}, J=$ $6.9 \mathrm{~Hz}, 0.3 \times 1 \mathrm{H}), 6.34(\mathrm{~d}, J=12.4 \mathrm{~Hz}, 0.7 \times 1 \mathrm{H}), 5.61(\mathrm{~d}, J=6.9 \mathrm{~Hz}, 0.3 \times 1 \mathrm{H}) ;{ }^{13} \mathrm{C} \mathrm{NMR}(101$ $\left.\mathrm{MHz}, \mathrm{CDCl}_{3}\right): \delta 157.3,157.2,143.4,141.7,135.1,134.9,129.7$ (2C), 128.7 (2C), 128.3, 126.6 (2C), 125.7, 123.3, 123.2, 116.0, 116.9, 113.6, 110.4 .

\section{$N$-Phenyl- $N$-vinylbenzamide (P52)}

Prepared as described above. Purified by silica gel column chromatography using

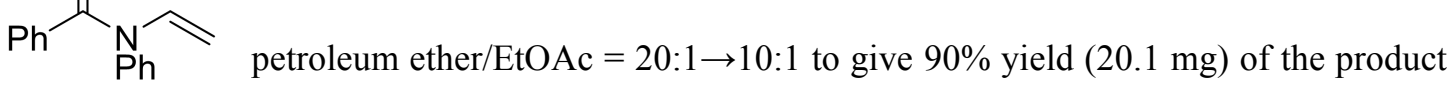
as a yellow solid. ${ }^{1} \mathrm{H}$ NMR and ${ }^{13} \mathrm{C}$ NMR data match previously reported data. ${ }^{40}{ }^{1} \mathrm{H}$ NMR (400 $\left.\mathrm{MHz}, \mathrm{CDCl}_{3}\right): \delta 7.62(\mathrm{dd}, J=15.8,9.0 \mathrm{~Hz}, 1 \mathrm{H}), 7.39-7.30(\mathrm{~m}, 4 \mathrm{H}), 7.29-7.26(\mathrm{~m}, 2 \mathrm{H}), 7.25-7.18$ (m, 2H), 7.16-7.10 (m, 2H), $4.52(\mathrm{dd}, J=8.9,0.8 \mathrm{~Hz}, 1 \mathrm{H}), 4.18(\mathrm{dd}, J=15.8,0.8 \mathrm{~Hz}, 1 \mathrm{H}) ;{ }^{13} \mathrm{C}$ NMR (101 MHz, $\left.\mathrm{CDCl}_{3}\right): \delta 169.1,139.2,135.4,135.1,130.0,129.4,129.2,128.6,127.9,127.8$, 97.6.

\section{$N$-phenyl- $N$-vinylfuran-2-carboxamide (P53)}

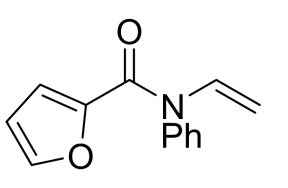

Prepared as described above. Purified by silica gel column chromatography using petroleum ether/EtOAc $=10: 1$ to give $45 \%$ yield $(9.5 \mathrm{mg})$ of the product as a yellow solid. ${ }^{1} \mathrm{H}$ NMR $\left(400 \mathrm{MHz}, \mathrm{CDCl}_{3}\right): \delta 7.82(\mathrm{dd}, J=15.8,8.9$ $\mathrm{Hz}, 1 \mathrm{H}), 7.54-7.46(\mathrm{~m}, 3 \mathrm{H}), 7.40(\mathrm{dd}, J=1.8,0.7 \mathrm{~Hz}, 1 \mathrm{H}), 7.26-7.21(\mathrm{~m}, 2 \mathrm{H}), 6.20(\mathrm{dd}, J=3.6,1.8$ $\mathrm{Hz}, 1 \mathrm{H}), 5.58(\mathrm{~d}, J=3.6 \mathrm{~Hz}, 1 \mathrm{H}), 4.53(\mathrm{dd}, J=8.9,0.8 \mathrm{~Hz}, 1 \mathrm{H}), 4.07(\mathrm{dd}, J=15.9,0.8 \mathrm{~Hz}, 1 \mathrm{H}) ;{ }^{13} \mathrm{C}$ NMR (101 MHz, $\left.\mathrm{CDCl}_{3}\right): \delta$ 157.1, 146.4, 145.3, 138.5, 134.5, 129.9, 129.6, 129.1, 117.6, 111.2, 97.6; ESI-HRMS calcd for $\left[\mathrm{C}_{13} \mathrm{H}_{12} \mathrm{NO}_{2}, \mathrm{M}+\mathrm{H}\right]^{+}:$214.0863, Found: 214.0866. 


\section{$N$-Styrylacetamide (P54)}

$\mathrm{Me}_{\mathrm{H}}^{\mathrm{O}} \overbrace{\mathrm{r}} \mathrm{Ph}$

Prepared as described above. Purified by silica gel column chromatography using petroleum ether/EtOAc $=3: 1 \rightarrow 1: 1$ to give $Z$-isomer as a yellow oil and $E$-isomer as a white solid in $61 \%$ total yield $(9.8 \mathrm{mg}, E / Z=1.5: 1) .{ }^{1} \mathrm{H}$ NMR and ${ }^{13} \mathrm{C}$ NMR data match previously reported data. ${ }^{41}$ For $Z$-isomer, ${ }^{1} \mathrm{H}$ NMR $(400 \mathrm{MHz}$, $\left.\mathrm{CDCl}_{3}\right): \delta 7.58$ (brs, $\left.1 \mathrm{H}\right), 7.44-7.36(\mathrm{~m}, 2 \mathrm{H}), 7.32-7.26(\mathrm{~m}, 3 \mathrm{H}), 6.97(\mathrm{dd}, J=11.3,9.6 \mathrm{~Hz}, 1 \mathrm{H})$, $5.75(\mathrm{~d}, J=9.6 \mathrm{~Hz}, 1 \mathrm{H}), 2.07(\mathrm{~s}, 3 \mathrm{H}) ;{ }^{13} \mathrm{C} \mathrm{NMR}\left(101 \mathrm{MHz}, \mathrm{CDCl}_{3}\right): \delta$ 167.5, 135.7, 129.1, 127.9, 127.0, 122.0, 109.7, 23.5; For $E$-isomer: $\delta 7.70$ (brs, $1 \mathrm{H}), 7.52$ (dd, $J=14.6,10.8 \mathrm{~Hz}, 1 \mathrm{H})$, 7.34-7.24 (m, 4H), 7.21-7.12 (m, 1H), $6.10(\mathrm{~d}, J=14.6 \mathrm{~Hz}, 1 \mathrm{H}), 2.12(\mathrm{~s}, 3 \mathrm{H}) ;{ }^{13} \mathrm{C}$ NMR $(101$ $\left.\mathrm{MHz}, \mathrm{CDCl}_{3}\right): \delta 167.3,136.0,128.7,126.7,125.6,122.7,112.4,23.4$.

\section{Benzyl 1H-pyrrole-1-carboxylate (P55)}<smiles>O=C(O)n1cccc1</smiles>

Prepared as described above. Purified by silica gel column chromatography using petroleum ether/EtOAc $=50: 1$ to give $77 \%$ yield $(15.5 \mathrm{mg})$ of the product as a yellow oil ${ }^{1} \mathrm{H}$ NMR and ${ }^{13} \mathrm{C}$ NMR data match previously reported data. ${ }^{42}{ }^{1} \mathrm{H}$ NMR $(600 \mathrm{MHz}$, $\left.\mathrm{CDCl}_{3}\right): \delta 7.46-7.35(\mathrm{~m}, 5 \mathrm{H}), 7.32-7.26(\mathrm{~m}, 2 \mathrm{H}), 6.24(\mathrm{t}, J=2.4 \mathrm{~Hz}, 2 \mathrm{H}), 5.37(\mathrm{~s}, 2 \mathrm{H}) ;{ }^{13} \mathrm{C} \mathrm{NMR}$ $\left(101 \mathrm{MHz}, \mathrm{CDCl}_{3}\right): \delta 150.3,134.9,128.71,128.69,128.4,120.1,112.5,68.9$.

\section{1-Benzyl 2-methyl 1H-pyrrole-1,2-dicarboxylate (P56)}

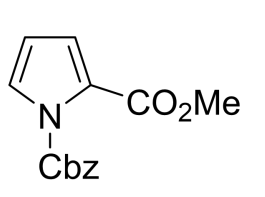

Prepared as described above. Purified by silica gel column chromatography reported data. ${ }^{43}{ }^{1} \mathrm{H} \mathrm{NMR}\left(600 \mathrm{MHz}, \mathrm{CDCl}_{3}\right): \delta 7.45-7.34(\mathrm{~m}, 6 \mathrm{H}), 6.88(\mathrm{dd}, J=3.5,1.7 \mathrm{~Hz}, 1 \mathrm{H})$, $6.19(\mathrm{t}, J=3.3 \mathrm{~Hz}, 1 \mathrm{H}), 5.37(\mathrm{~s}, 2 \mathrm{H}), 3.76(\mathrm{~s}, 3 \mathrm{H}) ;{ }^{13} \mathrm{C} \mathrm{NMR}\left(151 \mathrm{MHz}, \mathrm{CDCl}_{3}\right): \delta 161.1,149.7$, $134.4,128.9,128.69,128.67,126.6,125.5,121.5,110.8,69.8,51.9$.

\section{Benzyl 2,3-dihydro-4H-1,4-oxazine-4-carboxylate (P58)}

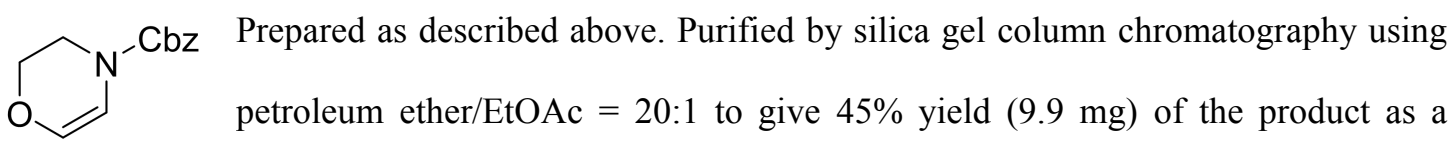
yellow oil. ${ }^{1} \mathrm{H}$ NMR and ${ }^{13} \mathrm{C}$ NMR data match previously reported data. ${ }^{44}{ }^{1} \mathrm{H}$ NMR $(600 \mathrm{MHz}$, 
$\left.\mathrm{CDCl}_{3}\right): \delta 7.46-7.29(\mathrm{~m}, 5 \mathrm{H}), 6.35-6.17(\mathrm{~m}, 1 \mathrm{H}), 6.06-5.86(\mathrm{~m}, 1 \mathrm{H}), 5.21-5.16(\mathrm{~m}, 2 \mathrm{H})$, 4.11-4.00 (m, 2H), 3.77-3.72 (m, 2H); ${ }^{13} \mathrm{C}$ NMR (151 MHz, $\left.\mathrm{CDCl}_{3}\right): \delta 152.1,151.8,136.12$, 136.08, 130.2, 129.0, 128.6, 128.3, 128.2, 128.2, 128.1, 106.1, 105.6, 67.6, 67.6, 64.7, 64.2, 42.1, 41.5.

\section{Benzyl 2,3-dihydro-4H-1,4-thiazine-4-carboxylate (P59)}

$\mathrm{N}^{-\mathrm{Cbz}}$ Prepared as described above. Purified by silica gel column chromatography using
petroleum ether/EtOAc $=20: 1$ to give $78 \%$ yield $(18.3 \mathrm{mg})$ of the product as a yellow oil. ${ }^{1} \mathrm{H}$ NMR $\left(400 \mathrm{MHz}, \mathrm{CDCl}_{3}\right): \delta 7.37(\mathrm{~d}, J=4.6 \mathrm{~Hz}, 5 \mathrm{H}), 7.01(\mathrm{dd}, J=46.9,8.6 \mathrm{~Hz}$, $1 \mathrm{H}), 5.29(\mathrm{dd}, J=42.0,8.6 \mathrm{~Hz}, 1 \mathrm{H}), 5.19(\mathrm{~s}, 2 \mathrm{H}), 4.07-3.91(\mathrm{~m}, 2 \mathrm{H}), 3.05-2.87(\mathrm{~m}, 2 \mathrm{H}) ;{ }^{13} \mathrm{C}$ NMR (101 MHz, $\left.\mathrm{CDCl}_{3}\right): \delta 153.0,135.9,128.6,128.3,128.1,121.8,121.2,99.8,99.6,68.0,43.1$, 42.2, 25.4, 25.2; ESI-HRMS calcd for $\left[\mathrm{C}_{12} \mathrm{H}_{14} \mathrm{NO}_{2} \mathrm{~S}, \mathrm{M}+\mathrm{H}\right]^{+}: 236.0240$, Found: 236.0335 .

\section{Dibenzyl 2,3-dihydropyrazine-1,4-dicarboxylate (P60)}<smiles>O=C(O)N1C=CN(C(=O)OCc2ccccc2)CC1</smiles>

Prepared as described above. Purified by silica gel column chromatography using petroleum ether/EtOAc $=10: 1 \rightarrow 6: 1$ to give $60 \%$ yield $(21.1 \mathrm{mg})$ of the product as a yellow oil. ${ }^{1} \mathrm{H}$ NMR $\left(400 \mathrm{MHz}, \mathrm{CDCl}_{3}\right): \delta 7.61-7.26(\mathrm{~m}$, 10H), 6.46-6.10 (m, 2H), $\left.5.19(\mathrm{~s}, 4 \mathrm{H}), 3.82-3.68(\mathrm{~m}, 4 \mathrm{H}) ;{ }^{13} \mathrm{C} \mathrm{NMR} \mathrm{(101} \mathrm{MHz,} \mathrm{CDCl}_{3}\right): \delta 152.3$, 135.9, 128.6, 128.4, 128.3, 128.2, 128.1, 108.7, 107.9, 67.8, 43.4, 41.5, 41.0, 40.7; ESI-HRMS calcd for $\left[\mathrm{C}_{20} \mathrm{H}_{21} \mathrm{~N}_{2} \mathrm{O}_{3}, \mathrm{M}+\mathrm{H}\right]^{+}:$337.1547, Found: 337.1549 .

\section{Benzyl 4-oxo-3,4-dihydropyridine-1(2H)-carboxylate (P61)}<smiles>O=C1C=CN(C(=O)OCc2ccccc2)CC1</smiles>

Prepared as described above. Purified by silica gel column chromatography using petroleum ether/EtOAc $=5: 1 \rightarrow 3: 1$ to give $59 \%$ yield $(13.6 \mathrm{mg})$ of the product as a yellow solid. ${ }^{1} \mathrm{H}$ NMR and ${ }^{13} \mathrm{C}$ NMR data match previously reported data. ${ }^{45}{ }^{1} \mathrm{H}$ NMR (400 MHz, $\mathrm{CDCl}_{3}$ ): $\delta 7.85$ (brs, 1H), 7.46-7.34 (m, 5H), 5.42-5.29 (m, 1H), $5.26(\mathrm{~s}, 2 \mathrm{H}), 4.04(\mathrm{t}, J=7.3 \mathrm{~Hz}, 2 \mathrm{H}), 2.56(\mathrm{t}, J=7.3 \mathrm{~Hz}, 2 \mathrm{H}) ;{ }^{13} \mathrm{C} \mathrm{NMR}\left(101 \mathrm{MHz}, \mathrm{CDCl}_{3}\right)$ : $\delta 193.3,152.5,143.4,134.9,128.8,128.7,128.5,107.7,69.1,42.6,35.6$. 
$\overbrace{\substack{N \\ 1 \\ P h}}$

Prepared as described above. Purified by silica gel column chromatography using petroleum ether $/$ EtOAc $=1: 1 \rightarrow 1: 2$ to give $97 \%$ yield $(16.6 \mathrm{mg})$ of the product as a yellow solid. ${ }^{1} \mathrm{H}$ NMR and ${ }^{13} \mathrm{C}$ NMR data match previously reported data. ${ }^{46}{ }^{1} \mathrm{H}$ NMR (400 MHz, $\left.\mathrm{CDCl}_{3}\right): \delta$ 7.54-7.46 (m, 2H), 7.45-7.36 (m, 4H), 7.34 (ddd, $\left.J=6.9,2.1,0.8 \mathrm{~Hz}, 1 \mathrm{H}\right)$, $6.66(\mathrm{dt}, J=9.2,1.1 \mathrm{~Hz}, 1 \mathrm{H}), 6.24(\mathrm{td}, J=6.7,1.4 \mathrm{~Hz}, 1 \mathrm{H}) ;{ }^{13} \mathrm{C} \mathrm{NMR}\left(101 \mathrm{MHz}, \mathrm{CDCl}_{3}\right): \delta 162.4$, $140.9,139.8,138.0,129.3,128.5,126.5,121.9,105.9$.

\section{1-Benzylpyridin-2(1H)-one (P63)}<smiles>O=c1ccccn1Cc1ccccc1</smiles>
Prepared as described above. Purified by silica gel column chromatography using petroleum ether/EtOAc $=2: 1 \rightarrow 1: 1$ to give $87 \%$ yield $(16.1 \mathrm{mg})$ of the product as a yellow solid. ${ }^{1} \mathrm{H}$ NMR and ${ }^{13} \mathrm{C}$ NMR data match previously reported data. ${ }^{47} \mathrm{H}$ NMR $\left(400 \mathrm{MHz}, \mathrm{CDCl}_{3}\right): \delta 7.39-7.28(\mathrm{~m}, 6 \mathrm{H}), 7.26-7.23(\mathrm{~m}, 1 \mathrm{H}), 6.62(\mathrm{dt}, J=9.0,1.1 \mathrm{~Hz}, 1 \mathrm{H}), 6.14$ (td, $J=6.7,1.4 \mathrm{~Hz}, 1 \mathrm{H}), 5.15(\mathrm{~s}, 2 \mathrm{H}) ;{ }^{13} \mathrm{C}$ NMR $\left(151 \mathrm{MHz}, \mathrm{CDCl}_{3}\right): \delta 162.7,139.4,137.2,136.3$, $128.9,128.1,128.0,121.2,106.2,51.9$.

\section{Isoquinolin-1(2H)-one (P64)}<smiles>O=c1[nH]ccc2ccccc12</smiles>

Prepared as described above. Purified by silica gel column chromatography using petroleum ether/EtOAc $=2: 1 \rightarrow 1: 1$ to give $99 \%$ yield $(14.4 \mathrm{mg})$ of the product as a yellow solid. ${ }^{1} \mathrm{H}$ NMR and ${ }^{13} \mathrm{C}$ NMR data match previously reported data. ${ }^{48}{ }^{1} \mathrm{H}$ NMR $\left(600 \mathrm{MHz}, \mathrm{CDCl}_{3}\right): \delta 11.62(\mathrm{~s}, 1 \mathrm{H}), 8.43(\mathrm{dd}, J=8.2,1.2 \mathrm{~Hz}, 1 \mathrm{H}), 7.68(\mathrm{ddd}, J=$ 8.2, 7.1, 1.3 Hz, 1H), 7.57 (d, $J=7.8 \mathrm{~Hz}, 1 \mathrm{H}), 7.52$ (ddd, $J=8.1,7.0,1.2 \mathrm{~Hz}, 1 \mathrm{H}), 7.20$ (d, $J=7.1$ $\mathrm{Hz}, 1 \mathrm{H}), 6.58(\mathrm{~d}, J=7.1 \mathrm{~Hz}, 1 \mathrm{H}) ;{ }^{13} \mathrm{C} \mathrm{NMR}\left(101 \mathrm{MHz}, \mathrm{CDCl}_{3}\right): \delta 164.5,138.2,132.6,127.7$, $127.3,126.8,126.2,126.1,106.7$.

\section{3-Phenyloxazol-2(3H)-one (P65)}<smiles>O=c1occn1-c1ccccc1</smiles>

Prepared as described above. Purified by silica gel column chromatography using petroleum ether/EtOAc $=10: 1 \rightarrow 5: 1$ to give $81 \%$ yield $(13.1 \mathrm{mg})$ of the product as a yellow solid. ${ }^{1} \mathrm{H}$ NMR and ${ }^{13} \mathrm{C}$ NMR data match previously reported data. ${ }^{49}{ }^{1} \mathrm{H}$ NMR $\left(600 \mathrm{MHz}, \mathrm{CDCl}_{3}\right): \delta$ 7.59-7.54 (m, 2H), 7.48-7.42 (m, 2H), 7.32-7.28 (m, 1H), $6.95(\mathrm{~s}, 2 \mathrm{H}) ;{ }^{13} \mathrm{C}$ NMR (151 MHz, $\left.\mathrm{CDCl}_{3}\right): \delta 153.3,135.5,129.5,128.5,126.7,121.0,115.0$. 


\section{1-Phenyl-1,5-dihydro-2H-pyrrol-2-one (P66)}

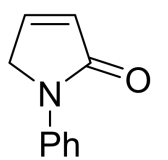

Prepared as described above. Purified by silica gel column chromatography using petroleum ether $/$ EtOAc $=4: 1$ to give $73 \%$ yield $(11.6 \mathrm{mg})$ of the product as an orange solid. ${ }^{1} \mathrm{H}$ NMR and ${ }^{13} \mathrm{C}$ NMR data match previously reported data. ${ }^{50}{ }^{1} \mathrm{H}$ NMR (400 $\left.\mathrm{MHz}, \mathrm{CDCl}_{3}\right): \delta 7.74-7.68(\mathrm{~m}, 2 \mathrm{H}), 7.42-7.33(\mathrm{~m}, 2 \mathrm{H}), 7.21-7.09(\mathrm{~m}, 2 \mathrm{H}), 6.28(\mathrm{dt}, J=6.1,1.9$ $\mathrm{Hz}, 1 \mathrm{H}), 4.45(\mathrm{t}, J=1.9 \mathrm{~Hz}, 2 \mathrm{H}) ;{ }^{13} \mathrm{C}$ NMR $\left(151 \mathrm{MHz}, \mathrm{CDCl}_{3}\right): \delta 170.2,142.1,139.1,129.3$, $129.1,124.2,118.9,53.2$.

\section{1-Phenyl-1,7-dihydro-2H-azepin-2-one (P67)}<smiles>O=C1C=CC=CCN1Pc1ccccc1</smiles>

Prepared as described above. Purified by silica gel column chromatography using petroleum ether/EtOAc $=10: 1$ to give $59 \%$ yield $(10.9 \mathrm{mg})$ of the product as a yellow oil. ${ }^{1} \mathrm{H}$ NMR (400 MHz, $\left.\mathrm{CDCl}_{3}\right): \delta$ 7.45-7.36 (m, 2H), 7.34-7.27 (m, 1H), 7.26-7.20 (m, 2H), 6.38-6.24 (m, 2H), 5.95 (dd, $J=8.9,5.0 \mathrm{~Hz}, 1 \mathrm{H}), 5.84-5.72(\mathrm{~m}, 1 \mathrm{H}), 3.14(\mathrm{~d}$, $J=6.8 \mathrm{~Hz}, 2 \mathrm{H}) ;{ }^{13} \mathrm{C}$ NMR $\left(151 \mathrm{MHz}, \mathrm{CDCl}_{3}\right): \delta 166.0,141.4,131.0,129.1,127.4,127.1,126.9$, 123.1, 115.2, 38.2; ESI-HRMS calcd for $\left[\mathrm{C}_{12} \mathrm{H}_{12} \mathrm{NO}, \mathrm{M}+\mathrm{H}\right]^{+}$: 186.0913, Found: 186.0914 .

\section{Naphthalen-1-ol (P68)}<smiles>Oc1cccc2ccccc12</smiles>

Prepared as described above. Purified by silica gel column chromatography using petroleum ether/EtOAc $=15: 1 \rightarrow 8: 1$ to give $92 \%$ yield $(13.2 \mathrm{mg})$ of the product as a white solid. ${ }^{1} \mathrm{H}$ NMR and ${ }^{13} \mathrm{C}$ NMR data match previously reported data. ${ }^{51}{ }^{1} \mathrm{H}$ NMR (600 MHz, $\left.\mathrm{CDCl}_{3}\right): \delta 8.21-8.12(\mathrm{~m}, 1 \mathrm{H}), 7.86-7.77(\mathrm{~m}, 1 \mathrm{H}), 7.52-7.46(\mathrm{~m}, 2 \mathrm{H}), 7.44(\mathrm{~d}, J$ $=8.3 \mathrm{~Hz}, 1 \mathrm{H}), 7.30(\mathrm{t}, J=7.9 \mathrm{~Hz}, 1 \mathrm{H}), 6.81(\mathrm{~d}, J=7.4 \mathrm{~Hz}, 1 \mathrm{H}) ;{ }^{13} \mathrm{C} \mathrm{NMR}\left(151 \mathrm{MHz}, \mathrm{CDCl}_{3}\right): \delta$ $151.3,134.7,127.7,126.4,125.8,125.3,124.3,121.5,120.7,108.6$.

\section{Naphthalen-2-ol (P69)}<smiles>Oc1ccc2ccccc2c1</smiles>

Prepared as described above. Purified by silica gel column chromatography using petroleum ether/EtOAc $=10: 1$ to give $96 \%$ yield $(13.9 \mathrm{mg})$ of the product as a pink solid. ${ }^{1} \mathrm{H}$ NMR and ${ }^{13} \mathrm{C}$ NMR data match previously reported data. ${ }^{51}{ }^{1} \mathrm{H}$ NMR (400 MHz, $\left.\mathrm{CDCl}_{3}\right): \delta 7.80-7.72(\mathrm{~m}, 2 \mathrm{H}), 7.68(\mathrm{~d}, J=8.2 \mathrm{~Hz}, 1 \mathrm{H}), 7.46-7.38(\mathrm{~m}, 1 \mathrm{H}), 7.36-7.27$ 
(m, 1H), $7.15(\mathrm{~d}, J=2.5 \mathrm{~Hz}, 1 \mathrm{H}), 7.10(\mathrm{dd}, J=8.8,2.6 \mathrm{~Hz}, 1 \mathrm{H}), 4.88(\mathrm{~s}, 1 \mathrm{H}) ;{ }^{13} \mathrm{C}$ NMR $(101$ $\left.\mathrm{MHz}, \mathrm{CDCl}_{3}\right): \delta 153.3,134.6,129.9,129.0,127.8,126.5,126.4,123.6,117.7,109.5$.

\section{4-Hydroxybiphenyl (P70)}<smiles>Oc1ccc(-c2ccccc2)cc1</smiles>

Prepared as described above. Purified by silica gel column chromatography using petroleum ether/EtOAc $=10: 1 \rightarrow 5: 1$ to give $61 \%$ yield $(10.4 \mathrm{mg})$ of the product as a white solid. ${ }^{1} \mathrm{H}$ NMR and ${ }^{13} \mathrm{C}$ NMR data match previously reported data. ${ }^{52}{ }^{1} \mathrm{H}$ NMR $\left(600 \mathrm{MHz}, \mathrm{CDCl}_{3}\right): \delta 7.56-7.52(\mathrm{~m}, 2 \mathrm{H}), 7.50-7.47(\mathrm{~m}, 2 \mathrm{H}), 7.41(\mathrm{dd}, J$ $=8.5,7.0 \mathrm{~Hz}, 2 \mathrm{H}), 7.33-7.28(\mathrm{~m}, 1 \mathrm{H}), 6.93-6.88(\mathrm{~m}, 2 \mathrm{H}), 4.72(\mathrm{~s}, 1 \mathrm{H}) ;{ }^{13} \mathrm{C}$ NMR $(151 \mathrm{MHz}$, $\left.\mathrm{CDCl}_{3}\right): \delta 155.0,140.7,134.1,128.7,128.4,126.7(2 \mathrm{C}), 115.6$.

\section{Chalcone (P72)}

O Prepared as described above. Purified by silica gel column chromatography $\mathrm{Ph}$ Ph using petroleum ether/EtOAc $=50: 1$ to give $59 \%$ yield $(12.3 \mathrm{mg})$ of the product $(E / Z=1: 1.2)$ as a yellow oil. ${ }^{1} \mathrm{H}$ NMR and ${ }^{13} \mathrm{C}$ NMR data match previously reported data. ${ }^{53}{ }^{1} \mathrm{H}$ NMR $\left(400 \mathrm{MHz}, \mathrm{CDCl}_{3}\right): \delta 8.08-7.89(\mathrm{~m}, 2 \mathrm{H}), 7.81(\mathrm{~d}, J=15.7 \mathrm{~Hz}, 0.45 \times 1 \mathrm{H})$, 7.66-7.17 (m, $8.45 \times 1 \mathrm{H}), 7.00(\mathrm{~d}, J=12.8 \mathrm{~Hz}, 0.55 \times 1 \mathrm{H}), 6.61(\mathrm{~d}, J=12.9 \mathrm{~Hz}, 0.55 \times 1 \mathrm{H}) ;{ }^{13} \mathrm{C}$ NMR (101 MHz, $\left.\mathrm{CDCl}_{3}\right): \delta$ 194.7, 190.5, 144.8, 139.4, 138.2, 137.1, 135.1, 134.9, 133.2, 132.8 , $130.5,129.4,129.0,128.9,128.8,128.6,128.50,128.48,128.4,128.2,126.7,122.1$.

\section{H-chromen-4-one (P74)}<smiles>O=c1ccoc2ccccc12</smiles>

Prepared as described above. Purified by silica gel column chromatography using petroleum ether/EtOAc $=10: 1 \rightarrow 6: 1$ to give $98 \%$ yield $(14.3 \mathrm{mg})$ of the product as a yellow solid. ${ }^{1} \mathrm{H}$ NMR and ${ }^{13} \mathrm{C}$ NMR data match previously reported data. ${ }^{54}{ }^{1} \mathrm{H}$ NMR (400 MHz, $\left.\mathrm{CDCl}_{3}\right): \delta 8.22(\mathrm{dd}, J=8.0,1.8 \mathrm{~Hz}, 1 \mathrm{H}), 7.86(\mathrm{~d}, J=6.0 \mathrm{~Hz}, 1 \mathrm{H}), 7.68(\mathrm{ddd}, J=$ 8.7, 7.1, 1.7 Hz, 1H), 7.49-7.38 (m, 2H), $6.35(\mathrm{~d}, J=6.1 \mathrm{~Hz}, 1 \mathrm{H}) ;{ }^{13} \mathrm{C}$ NMR $\left(151 \mathrm{MHz}, \mathrm{CDCl}_{3}\right): \delta$ $177.6,156.5,155.3,133.8,125.8,125.3,124.9,118.2,113.0$.

\section{2-Phenyl-4H-chromen-4-one (P75)}<smiles>O=c1cc(-c2ccccc2)oc2ccccc12</smiles>

Prepared as described above. Purified by silica gel column chromatography using petroleum ether/EtOAc $=10: 1 \rightarrow 6: 1$ to give $95 \%$ yield $(21.1 \mathrm{mg})$ of the 
product as a yellow solid. ${ }^{1} \mathrm{H}$ NMR and ${ }^{13} \mathrm{C}$ NMR data match previously reported data. ${ }^{54}{ }^{1} \mathrm{H}$ NMR $\left(600 \mathrm{MHz}, \mathrm{CDCl}_{3}\right): \delta 8.24(\mathrm{dd}, J=7.9,1.7 \mathrm{~Hz}, 1 \mathrm{H}), 7.93(\mathrm{dd}, J=7.8,1.9 \mathrm{~Hz}, 2 \mathrm{H}), 7.70(\mathrm{ddd}, J=$ 8.6, 7.1, 1.7 Hz, 1H), $7.57(\mathrm{~d}, J=8.3 \mathrm{~Hz}, 1 \mathrm{H}), 7.55-7.50(\mathrm{~m}, 3 \mathrm{H}), 7.45-7.40(\mathrm{~m}, 1 \mathrm{H}), 6.83(\mathrm{~s}, 1 \mathrm{H})$; ${ }^{13} \mathrm{C}$ NMR $\left(151 \mathrm{MHz}, \mathrm{CDCl}_{3}\right): \delta 178.4,163.4,156.2,133.7,131.8,131.6,129.0,126.3,125.7$, $125.2,123.9,118.1,107.6$.

\section{H-chromen-2-one (P76)}<smiles>O=c1ccc2ccccc2o1</smiles>

Prepared as described above. Purified by silica gel column chromatography using petroleum ether/EtOAc $=10: 1$ to give $20 \%$ yield $(2.9 \mathrm{mg})$ of the product as a yellow oil. ${ }^{1} \mathrm{H}$ NMR and ${ }^{13} \mathrm{C}$ NMR data match previously reported data. ${ }^{55}{ }^{1} \mathrm{H}$ NMR $(400 \mathrm{MHz}$, $\left.\mathrm{CDCl}_{3}\right): \delta 7.71(\mathrm{dd}, J=9.6,0.7 \mathrm{~Hz}, 1 \mathrm{H}), 7.57-7.46(\mathrm{~m}, 2 \mathrm{H}), 7.37-7.32(\mathrm{~m}, 1 \mathrm{H}), 7.32-7.27(\mathrm{~m}$, 1H), $6.43(\mathrm{~d}, J=9.5 \mathrm{~Hz}, 1 \mathrm{H}) ;{ }^{13} \mathrm{C} \mathrm{NMR}\left(151 \mathrm{MHz}, \mathrm{CDCl}_{3}\right): \delta 160.8,154.1,143.4,131.8,127.8$, $124.4,118.8,116.9,116.7$.

\section{Phenyl 3-phenylacrylate (P77)}

O Prepared as described above. Purified by silica gel column chromatography $\mathrm{Ph}$ OPh using petroleum ether/EtOAc $=50: 1$ to give $42 \%$ yield $(9.4 \mathrm{mg})$ of the product $(E / Z=1: 1.2)$ as a colorless oil. ${ }^{1} \mathrm{H}$ NMR and ${ }^{13} \mathrm{C}$ NMR data match previously reported data. ${ }^{56}{ }^{1} \mathrm{H}$ NMR $\left(400 \mathrm{MHz}, \mathrm{CDCl}_{3}\right): \delta 7.88(\mathrm{~d}, J=16.0 \mathrm{~Hz}, 0.46 \times 1 \mathrm{H}), 7.72-7.55(\mathrm{~m}, 2 \mathrm{H})$, 7.49-7.29 (m, 5H), 7.27-7.08 (m, $3.54 \times 1 \mathrm{H}), 6.64(\mathrm{~d}, J=16.0 \mathrm{~Hz}, 0.46 \times 1 \mathrm{H}), 6.17(\mathrm{~d}, J=12.6$ $\mathrm{Hz}, 0.54 \times 1 \mathrm{H}) ;{ }^{13} \mathrm{C} \mathrm{NMR}\left(101 \mathrm{MHz}, \mathrm{CDCl}_{3}\right): \delta 165.4,164.4,150.8,150.5,146.5,145.7,134.4$, $134.1,130.7,130.1,129.5,129.42,129.35,129.0,128.3,128.1,125.76,125.75,121.6,121.5$, 118.6, 117.3.

\section{Phenyl benzoate (P79)}<smiles>O=C(Oc1ccccc1)c1ccccc1</smiles>

Prepared as described above. Purified by silica gel column chromatography using petroleum ether/EtOAc $=20: 1$ to give $66 \%$ yield $(13.1 \mathrm{mg})$ of the product as a white solid. ${ }^{1} \mathrm{H}$ NMR and ${ }^{13} \mathrm{C}$ NMR data match previously reported data. ${ }^{57}$ ${ }^{1} \mathrm{H}$ NMR (600 MHz, $\left.\mathrm{CDCl}_{3}\right): \delta 8.24-8.18(\mathrm{~m}, 2 \mathrm{H}), 7.67-7.60(\mathrm{~m}, 1 \mathrm{H}), 7.52(\mathrm{t}, J=7.8 \mathrm{~Hz}, 2 \mathrm{H})$, 
7.47-7.40 (m, 2H), 7.30-7.26 (m, 1H), 7.24-7.20 (m, 2H); ${ }^{13} \mathrm{C}$ NMR (151 MHz, $\left.\mathrm{CDCl}_{3}\right): \delta 165.2$, $150.9,133.6,130.2,129.6,129.5,128.6,125.9,121.7$.

\section{7-Phenyl-7-azabicyclo[4.2.0]oct-4-en-8-one (P80)}<smiles>O=C1C2CCC=CC2N1c1ccccc1</smiles>

Prepared as described above. Purified by silica gel column chromatography using petroleum ether $/$ EtOAc $=5: 1$ to give $35 \%$ yield $(7.0 \mathrm{mg})$ of the product as a light yellow oil. ${ }^{1} \mathrm{H}$ NMR (600 MHz, $\left.\mathrm{CDCl}_{3}\right): \delta 7.55-7.47(\mathrm{~m}, 2 \mathrm{H}), 7.40-7.31(\mathrm{~m}, 2 \mathrm{H})$, 7.16-7.08 (m, 1H), 6.53-6.42 (m, 1H), 5.82-5.72 (m, 1H), $4.23(\mathrm{t}, J=5.2 \mathrm{~Hz}, 1 \mathrm{H}), 2.98-2.91(\mathrm{~m}$, 1H), 2.50-2.41 (m, 3H), 2.08-2.02 (m, 1H); ${ }^{13} \mathrm{C}$ NMR (101 MHz, $\left.\mathrm{CDCl}_{3}\right): \delta$ 176.2, 138.4, 130.7, $128.9,128.7,124.2,119.5,54.9,41.4,33.7,28.3$; ESI-HRMS calcd for $\left[\mathrm{C}_{13} \mathrm{H}_{14} \mathrm{NO}, \mathrm{M}+\mathrm{H}\right]^{+}$: 200.1070, Found: 200.1069 .

\section{Quinolin-2(1H)-one (P81)}<smiles>O=c1ccc2ccccc2[nH]1</smiles>

Prepared as described above. Purified by silica gel column chromatography using petroleum ether/EtOAc $=2: 1 \rightarrow 1: 1$ to give $99 \%$ yield $(14.4 \mathrm{mg})$ of the product as a yellow solid. ${ }^{1} \mathrm{H}$ NMR and ${ }^{13} \mathrm{C}$ NMR data match previously reported data. ${ }^{58}{ }^{1} \mathrm{H} \mathrm{NMR}\left(400 \mathrm{MHz}, \mathrm{CDCl}_{3}\right): \delta 12.62(\mathrm{~s}, 1 \mathrm{H}), 7.82(\mathrm{~d}, J=9.4 \mathrm{~Hz}, 1 \mathrm{H}), 7.57$ (dd, $J$ $=7.8,1.3 \mathrm{~Hz}, 1 \mathrm{H}), 7.55-7.43(\mathrm{~m}, 2 \mathrm{H}), 7.25-7.18(\mathrm{~m}, 1 \mathrm{H}), 6.73(\mathrm{~d}, J=9.5 \mathrm{~Hz}, 1 \mathrm{H}) ;{ }^{13} \mathrm{C} \mathrm{NMR}$ $\left(101 \mathrm{MHz}, \mathrm{CDCl}_{3}\right): \delta 164.7,141.0,138.5,130.7,127.7,122.7,121.4,119.9,116.2$.

\section{$N, N, 3-$ triphenylacrylamide (P82)}

Prepared as described above. Purified by silica gel column chromatography
$\mathrm{NPh}_{2}$ using petroleum ether/EtOAc $=50: 1$ to give $E$-isomer as a yellow solid and $Z$-isomer as a yellow oil in $43 \%$ total yield $(12.7 \mathrm{mg}, E / Z=1: 1.1) .{ }^{1} \mathrm{H}$ NMR and ${ }^{13} \mathrm{C}$ NMR data match previously reported data. ${ }^{59}$ For $E$-isomer, ${ }^{1} \mathrm{H}$ NMR (400 MHz, $\mathrm{CDCl}_{3}$ ): $\delta 7.77$ (d, $J=15.6$ $\mathrm{Hz}, 1 \mathrm{H}), 7.41-7.25(\mathrm{~m}, 15 \mathrm{H}), 6.48(\mathrm{~d}, J=15.5 \mathrm{~Hz}, 1 \mathrm{H}) ;{ }^{13} \mathrm{C}$ NMR $\left(151 \mathrm{MHz}, \mathrm{CDCl}_{3}\right): \delta 166.2$, 142.8, 142.6, 135.1, 129.7, 129.2, 128.7, 128.0, 127.6-126.5 (br), 119.8; For $Z$-isomer, ${ }^{1} \mathrm{H}$ NMR $\left(400 \mathrm{MHz}, \mathrm{CDCl}_{3}\right): \delta 7.53-7.45(\mathrm{~m}, 2 \mathrm{H}), 7.36-7.20(\mathrm{~m}, 11 \mathrm{H}), 7.12-6.92(\mathrm{~m}, 2 \mathrm{H}), 6.52(\mathrm{~d}, J=$ $12.6 \mathrm{~Hz}, 1 \mathrm{H}), 5.95(\mathrm{~d}, J=12.6 \mathrm{~Hz}, 1 \mathrm{H}) ;{ }^{13} \mathrm{C} \mathrm{NMR}\left(151 \mathrm{MHz}, \mathrm{CDCl}_{3}\right): \delta 167.5,142.42,136.6$, $135.4,129.3,129.0,128.6,128.2,127.5-127.0$ (br), 126.3, 124.2. 


\section{4-Vinylbenzyl 2-(2-fluoro-[1,1'-biphenyl]-4-yl)propanoate (P87)}<smiles>C=Cc1ccc(COC(=O)C(C)c2ccc(-c3ccccc3)c(F)c2)cc1</smiles>

Prepared as described above. Purified by silica gel column chromatography using petroleum ether/EtOAc $=40: 1$ to give $58 \%$ yield $(20.9 \mathrm{mg})$ of the product as a colorless oil.

${ }^{1} \mathrm{H}$ NMR (600 MHz, $\left.\mathrm{CDCl}_{3}\right): \delta 7.57-7.51(\mathrm{~m}, 2 \mathrm{H}), 7.44(\mathrm{t}, J=7.6 \mathrm{~Hz}, 2 \mathrm{H}), 7.40-7.34(\mathrm{~m}, 4 \mathrm{H})$, $7.24(\mathrm{~d}, J=7.9 \mathrm{~Hz}, 2 \mathrm{H}), 7.17-7.08(\mathrm{~m}, 2 \mathrm{H}), 6.70(\mathrm{dd}, J=17.6,10.9 \mathrm{~Hz}, 1 \mathrm{H}), 5.74(\mathrm{~d}, J=17.6 \mathrm{~Hz}$, $1 \mathrm{H}), 5.26(\mathrm{~d}, J=10.8 \mathrm{~Hz}, 1 \mathrm{H}), 5.16-5.07(\mathrm{~m}, 2 \mathrm{H}), 3.80(\mathrm{q}, J=7.2 \mathrm{~Hz}, 1 \mathrm{H}), 1.55(\mathrm{~d}, J=7.2 \mathrm{~Hz}$, $3 \mathrm{H}) ;{ }^{13} \mathrm{C}$ NMR $\left(151 \mathrm{MHz}, \mathrm{CDCl}_{3}\right): \delta 173.8,159.7\left(\mathrm{~d}, J_{\mathrm{CF}}=248.7 \mathrm{~Hz}\right), 141.6\left(\mathrm{~d}, J_{\mathrm{CF}}=7.7 \mathrm{~Hz}\right)$, $137.6,136.3,135.5,135.3,130.8\left(\mathrm{~d}, J_{\mathrm{CF}}=3.2 \mathrm{~Hz}\right), 128.9\left(\mathrm{~d}, J_{\mathrm{CF}}=3.2 \mathrm{~Hz}\right), 128.4,128.3,127.8(\mathrm{~d}$, $\left.J_{\mathrm{CF}}=14.0 \mathrm{~Hz}\right), 127.7,126.3,123.6\left(\mathrm{~d}, J_{\mathrm{CF}}=3.2 \mathrm{~Hz}\right), 115.3\left(\mathrm{~d}, J_{\mathrm{CF}}=23.9 \mathrm{~Hz}\right), 114.3,66.4,45.0$, 18.3; ${ }^{19} \mathrm{~F}$ NMR (376 $\left.\mathrm{MHz}, \mathrm{CDCl}_{3}\right): \delta$-117.7; ESI-HRMS calcd for $\left[\mathrm{C}_{24} \mathrm{H}_{22} \mathrm{FO}_{2}, \mathrm{M}+\mathrm{H}\right]^{+}$: 361.1598, Found: 361.1599.

\section{Phenyl (E)-2-(4-((2-oxocyclopentylidene)methyl)phenyl)propanoate (P88)}<smiles>CC(C(=O)Oc1ccccc1)c1ccc(C=C2CCCC2=O)cc1</smiles>

Prepared as described above. Purified by silica gel column chromatography using petroleum ether/EtOAc $=10: 1$ to give $40 \%$ yield $(12.8 \mathrm{mg})$ of the product as a white solid. ${ }^{1} \mathrm{H}$ NMR $\left(600 \mathrm{MHz}, \mathrm{CDCl}_{3}\right): \delta 7.59-7.53(\mathrm{~d}, J=8.3 \mathrm{~Hz}, 2 \mathrm{H}), 7.46(\mathrm{~d}, J=8.3 \mathrm{~Hz}, 2 \mathrm{H}), 7.39(\mathrm{t}, J=2.9 \mathrm{~Hz}$, 1H), 7.37-7.30 (m, 3H), 7.23-7.18 (m, 1H), 7.01-6.97 (m, 2H), 4.00 (q, J=7.1 Hz, 1H), 2.99 (td, $J=7.3,2.7 \mathrm{~Hz}, 2 \mathrm{H}), 2.42(\mathrm{t}, J=7.9 \mathrm{~Hz}, 2 \mathrm{H}), 2.05$ (p, $J=7.6 \mathrm{~Hz}, 2 \mathrm{H}), 1.63(\mathrm{~d}, J=7.2 \mathrm{~Hz}, 3 \mathrm{H})$; ${ }^{13} \mathrm{C}$ NMR (101 MHz, $\left.\mathrm{CDCl}_{3}\right): \delta 208.1,172.6,150.7,141.3,136.2,134.7,131.7,130.9,129.4$, 127.9, 125.9, 121.3, 45.5, 37.8, 29.3, 20.2, 18.4; ESI-HRMS calcd for $\left[\mathrm{C}_{21} \mathrm{H}_{20} \mathrm{O}_{3}, \mathrm{M}+\mathrm{H}\right]^{+}$: 321.1485, Found: 321.1482 .

\section{1-(6-(tert-Butyl)-1,1-dimethyl-1H-inden-4-yl)ethan-1-one (P89)}<smiles>CC(=O)c1cc(C(C)(C)C)cc2c1C=CC2(C)C</smiles>

Prepared as described above. Purified by silica gel column chromatography using petroleum ether/EtOAc $=20: 1$ to give $76 \%$ yield $(18.4 \mathrm{mg})$ of the product as a yellow solid. ${ }^{1} \mathrm{H} \mathrm{NMR}\left(600 \mathrm{MHz}, \mathrm{CDCl}_{3}\right): \delta 7.73(\mathrm{~d}, J=1.8 \mathrm{~Hz}$, 1H), $7.51(\mathrm{~d}, J=1.8 \mathrm{~Hz}, 1 \mathrm{H}), 7.37(\mathrm{~d}, J=5.5 \mathrm{~Hz}, 1 \mathrm{H}), 6.52(\mathrm{~d}, J=5.6 \mathrm{~Hz}$, 
1H), $2.64(\mathrm{~s}, 3 \mathrm{H}), 1.38(\mathrm{~s}, 9 \mathrm{H}), 1.32(\mathrm{~s}, 6 \mathrm{H}) ;{ }^{13} \mathrm{C} \mathrm{NMR}\left(101 \mathrm{MHz}, \mathrm{CDCl}_{3}\right): \delta 200.1,155.0,150.2$, 148.2, 140.1, 130.3, 127.7, 124.4, 122.3, 49.0, 34.8, 31.6, 28.4, 24.3; ESI-HRMS calcd for $\left[\mathrm{C}_{17} \mathrm{H}_{22} \mathrm{O}, \mathrm{M}+\mathrm{H}\right]^{+}:$243.1743, Found: 243.1742 .

\section{4-(3-(Cyclopentyloxy)-4-methoxyphenyl)-1,5-dihydro-2H-pyrrol-2-one (P90)}<smiles>COc1ccc(C2=CC(=O)NC2)cc1OC1CCCC1</smiles>

Prepared as described above. Purified by silica gel column chromatography using EtOAc/ $\mathrm{MeOH}=20: 1$ to give $88 \%$ yield (24.0 mg) of the product as a white solid. ${ }^{1} \mathrm{H}$ NMR and ${ }^{13} \mathrm{C}$ NMR data match previously reported data. ${ }^{60}{ }^{1} \mathrm{H}$ NMR $\left(400 \mathrm{MHz}, \mathrm{CDCl}_{3}\right): \delta 7.13-6.96(\mathrm{~m}, 3 \mathrm{H}), 6.88(\mathrm{~d}$, $J=8.3 \mathrm{~Hz}, 1 \mathrm{H}), 6.29(\mathrm{~s}, 1 \mathrm{H}), 4.86-4.74(\mathrm{~m}, 1 \mathrm{H}), 4.40(\mathrm{~s}, 2 \mathrm{H}), 3.88(\mathrm{~s}, 3 \mathrm{H}), 2.05-1.75(\mathrm{~m}, 6 \mathrm{H})$, $1.72-1.54(\mathrm{~m}, 2 \mathrm{H}) ;{ }^{13} \mathrm{C}$ NMR $\left(101 \mathrm{MHz}, \mathrm{CDCl}_{3}\right): \delta 175.6,157.6,152.1,147.9,124.8,119.0$, $118.2,112.7,111.7,80.9,56.1,48.3,32.8,24.1$.

\section{2-(2,5-Dichlorophenoxy)-1-(2,3-dihydro-4H-1,4-thiazin-4-yl)ethan-1-one (P91)}<smiles>O=C(COc1cc(Cl)ccc1Cl)N1C=CSCC1</smiles>

Prepared as described above. Purified by silica gel column chromatography using petroleum ether/EtOAc $=8: 1 \rightarrow 4: 1$ to give $58 \%$ yield $(17.5 \mathrm{mg})$ of the product as a white solid. ${ }^{1} \mathrm{H}$ NMR $(600 \mathrm{MHz}$, $\left.\mathrm{CDCl}_{3}\right): \delta 7.39(\mathrm{t}, J=1.9 \mathrm{~Hz}, 1 \mathrm{H}), 7.25-7.14(\mathrm{~m}, 1 \mathrm{H}), 6.97-6.82(\mathrm{~m}$, 2H), 5.60-5.45 (m, 1H), 4.89-4.78 (m, 2H), 4.13-4.03 (m, 2H), 3.07-2.99 (m, 2H); ${ }^{13} \mathrm{C}$ NMR $\left(151 \mathrm{MHz}, \mathrm{CDCl}_{3}\right): \delta 164.6,164.2,152.2,151.8,130.3,127.9,127.6,127.2,124.2,120.2,119.9$, $115.0,114.5, \quad 104.5,104.3,68.8,68.2,44.1,39.8,25.7,25.6$; ESI-HRMS calcd for $\left[\mathrm{C}_{12} \mathrm{H}_{12} \mathrm{Cl}_{2} \mathrm{NO}_{2} \mathrm{~S}, \mathrm{M}+\mathrm{H}\right]^{+}:$303.9960, Found: 303.9963.

\section{2-((1-(2-(2,3-Dihydro-4H-1,4-oxazin-4-yl)-2-oxoethyl)cyclohexyl)methyl)isoindoline-1,3-dion e (P92)}<smiles>O=C(CC1(CN2C(=O)c3ccccc3C2=O)CCCCC1)N1C=COCC1</smiles>
Prepared as described above. Purified by silica gel column chromatography using petroleum ether/EtOAc $=5: 1 \rightarrow 2: 1$ to give $48 \%$ yield $(17.7 \mathrm{mg})$ of the product as a white solid. ${ }^{1} \mathrm{H}$ NMR $(600$ $\left.\mathrm{MHz}, \mathrm{CDCl}_{3}\right): \delta 9.20(\mathrm{~s}, 1 \mathrm{H}), 8.03(\mathrm{~s}, 1 \mathrm{H}), 7.82(\mathrm{dd}, J=5.4,3.1 \mathrm{~Hz}$, 2H), $7.72(\mathrm{dd}, J=5.5,3.0 \mathrm{~Hz}, 2 \mathrm{H}), 4.35(\mathrm{t}, J=5.6 \mathrm{~Hz}, 2 \mathrm{H}), 4.08(\mathrm{t}, J=5.6 \mathrm{~Hz}, 2 \mathrm{H}), 3.91(\mathrm{~s}, 2 \mathrm{H})$, 
$2.64(\mathrm{~s}, 2 \mathrm{H}), 1.75-1.65(\mathrm{~m}, 4 \mathrm{H}), 1.59-1.53(\mathrm{~m}, 2 \mathrm{H}), 1.52-1.47(\mathrm{~m}, 1 \mathrm{H}), 1.46-1.37(\mathrm{~m}, 3 \mathrm{H}) ;{ }^{13} \mathrm{C}$ $\operatorname{NMR}\left(151 \mathrm{MHz}, \mathrm{CDCl}_{3}\right): \delta 171.9,169.4,162.3,160.8,134.1,131.8,123.3,61.0,45.0,39.4,38.6$, 38.3, 34.0, 25.8, 21.4; ESI-HRMS calcd for $\left[\mathrm{C}_{21} \mathrm{H}_{25} \mathrm{~N}_{2} \mathrm{O}_{4}, \mathrm{M}+\mathrm{H}\right]^{+}$: 369.1809, Found: 369.1809.

Benzyl 4-(2-((2,4-dimethylphenyl)thio)phenyl)-3,4-dihydropyrazine-1(2H)-carboxylate (P93)

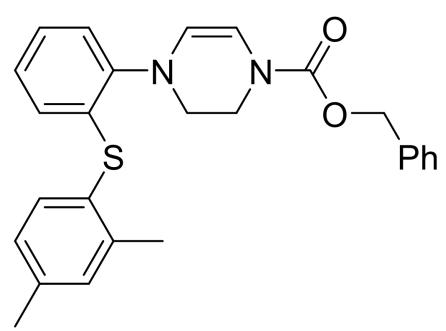

Prepared as described above. Purified by silica gel column chromatography using petroleum ether/EtOAc $=25: 1$ to give $63 \%$ yield $(27.2 \mathrm{mg})$ of the product as a colorless oil. ${ }^{1} \mathrm{H}$ NMR $\left(400 \mathrm{MHz}, \mathrm{CDCl}_{3}\right): \delta 7.46-7.29(\mathrm{~m}, 5 \mathrm{H}), 7.28(\mathrm{~d}, J=8.0 \mathrm{~Hz}, 1 \mathrm{H})$, 7.13-7.02 (m, 3H), 7.00 (d, $J=7.8 \mathrm{~Hz}, 1 \mathrm{H}), 6.96-6.89(\mathrm{~m}, 1 \mathrm{H})$, $6.67(\mathrm{~d}, J=7.8 \mathrm{~Hz}, 1 \mathrm{H}), 6.27(\mathrm{dd}, J=49.3,6.5 \mathrm{~Hz}, 1 \mathrm{H}), 5.73(\mathrm{dd}, J=46.3,6.5 \mathrm{~Hz}, 1 \mathrm{H}), 5.21(\mathrm{~d}, J$ $=6.1 \mathrm{~Hz}, 2 \mathrm{H}), 3.88-3.74(\mathrm{~m}, 2 \mathrm{H}), 3.62-3.51(\mathrm{~m}, 2 \mathrm{H}), 2.34(\mathrm{~s}, 3 \mathrm{H}), 2.31(\mathrm{~s}, 3 \mathrm{H}) ;{ }^{13} \mathrm{C} \mathrm{NMR}(101$ $\left.\mathrm{MHz}, \mathrm{CDCl}_{3}\right): \delta 152.5,145.4,141.6,139.0,136.4,135.1,133.3,131.7,128.5,128.1,128.05$, 128.00, 127.8, 126.0, 125.3, 124.1, 118.4, 117.6, 105.9, 104.9, 67.5, 67.4, 47.9, 47.8, 41.8, 41.2, 21.1, 20.5; ESI-HRMS calcd for $\left[\mathrm{C}_{26} \mathrm{H}_{27} \mathrm{~N}_{2} \mathrm{O}_{2} \mathrm{~S}, \mathrm{M}+\mathrm{H}\right]^{+}: 431.1788$, Found: 431.1787.

Ethyl-(E)-4-(8-chloro-5,6-dihydro-11H-benzo[5,6]cyclohepta[1,2-b]pyridin-11-ylidene)-3,4-di hydropyridine-1 $(2 H)$-carboxylate (P94) and ethyl (Z)-4-(8-chloro-5,6-dihydro-11H-benzo[5,6]cyclohepta[1,2-b]pyridin-11-ylidene)-3,4-dihydro pyridine-1(2H)-carboxylate (P94')

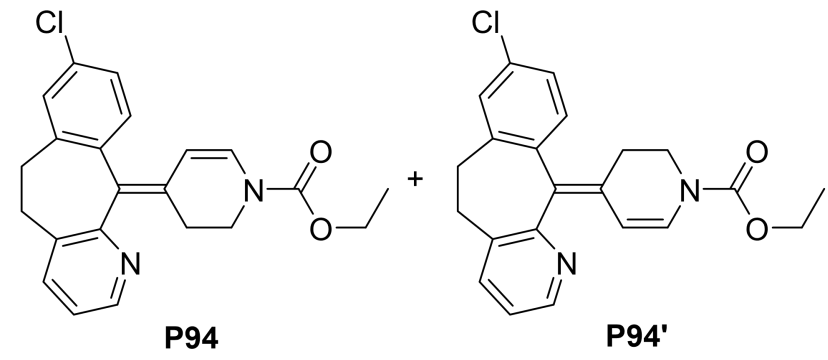

Prepared as described above. Purified by silica gel column chromatography using petroleum ether/EtOAc $=3: 1$ to give $82 \%$ total yield $(31.2 \mathrm{mg}, \mathbf{P 9 4} / \mathbf{P 9 4}$ ' = 1.5:1) of the product as a yellow oil. ${ }^{1} \mathrm{H}$ NMR (600 MHz, $\left.\mathrm{CDCl}_{3}\right): \delta 8.49-8.38(\mathrm{~m}, 1 \mathrm{H}), 7.48-7.40(\mathrm{~m}, 1 \mathrm{H}), 7.27-7.13(\mathrm{~m}, 3 \mathrm{H}), 7.12-7.06$ (m, 1H), 7.03-6.94 (m, $0.4 \times 1 \mathrm{H}), 6.92-6.82(\mathrm{~m}, 0.6 \times 1 \mathrm{H}), 5.87-5.63(\mathrm{~m}, 0.4 \times 1 \mathrm{H}), 5.63-5.46$ $(\mathrm{m}, 0.6 \times 1 \mathrm{H}), 4.32-4.12(\mathrm{~m}, 2 \mathrm{H}), 4.02-3.74(\mathrm{~m}, 1 \mathrm{H}), 3.68-3.42(\mathrm{~m}, 1 \mathrm{H}), 3.39-3.23(\mathrm{~m}, 2 \mathrm{H})$, 3.09-2.65 (m, 3H), 2.49-2.25 (m, 1H), 1.36-1.26 (m, 3H); ${ }^{13} \mathrm{C}$ NMR (151 MHz, $\left.\mathrm{CDCl}_{3}\right): \delta 156.9$, 156.7, 153.5, 153.0, 146.6, 146.5, 139.9, 137.6, 137.5, 133.8, 133.6, 132.8, 131.5, 130.9, 130.7, 
$130.5,128.9,128.2,128.0,127.6,127.4,126.0,122.2,122.1,106.6,106.2,105.8,62.2,42.1,41.8$, 31.71, 31.68, 31.5, 26.8, 26.2, 14.5; ESI-HRMS calcd for $\left[\mathrm{C}_{22} \mathrm{H}_{22} \mathrm{ClN}_{2} \mathrm{O}_{2}, \mathrm{M}+\mathrm{H}\right]^{+}: 381.1364$, Found: 381.1361 .

\section{4-Vinylphenyl 2-(4-(4-chlorobenzoyl)phenoxy)-2-methylpropanoate (P95)}<smiles>C=Cc1ccc(OC(=O)C(C)(C)Oc2ccc(C(=O)c3ccc(Cl)cc3)cc2)cc1</smiles>

Prepared as described above. Purified by silica gel column chromatography using petroleum ether/EtOAc $=60: 1 \rightarrow 30: 1$ to give $78 \%$ yield $(32.8 \mathrm{mg})$ of the product as a white solid. ${ }^{1} \mathrm{H}$ NMR (600 MHz, $\left.\mathrm{CDCl}_{3}\right): \delta 7.79(\mathrm{~d}, J=8.5 \mathrm{~Hz}, 2 \mathrm{H}), 7.72(\mathrm{~d}, J=8.0 \mathrm{~Hz}, 2 \mathrm{H}), 7.46(\mathrm{~d}, J=8.1 \mathrm{~Hz}$, 2H), $7.39(\mathrm{~d}, J=8.2 \mathrm{~Hz}, 2 \mathrm{H}), 7.00(\mathrm{~d}, J=8.5 \mathrm{~Hz}, 2 \mathrm{H}), 6.95(\mathrm{~d}, J=8.2 \mathrm{~Hz}, 2 \mathrm{H}), 6.68(\mathrm{dd}, J=17.5$, $10.8 \mathrm{~Hz}, 1 \mathrm{H}), 5.70(\mathrm{~d}, J=17.6 \mathrm{~Hz}, 1 \mathrm{H}), 5.25(\mathrm{~d}, J=10.8 \mathrm{~Hz}, 1 \mathrm{H}), 1.83(\mathrm{~s}, 6 \mathrm{H}) ;{ }^{13} \mathrm{C}$ NMR $(151$ $\left.\mathrm{MHz}, \mathrm{CDCl}_{3}\right): \delta 194.2,172.4,159.5,149.9,138.5,136.3,135.8,135.7,132.1,131.2,130.7,128.6$, 127.3, 121.2, 117.3, 114.4, 79.5, 25.4; ESI-HRMS calcd for $\left[\mathrm{C}_{25} \mathrm{H}_{22} \mathrm{ClO}_{4}, \mathrm{M}+\mathrm{H}\right]^{+}$: 421.1201, Found: 421.1206 .

\section{4-Vinylphenyl}

4-((5S,8R,9S,10S,13R,14S)-10,13-dimethyl-3,7,12-trioxohexadecahydro-1 $H$-cyclopenta[a]phe nanthren-17-yl)pentanoate (P96)

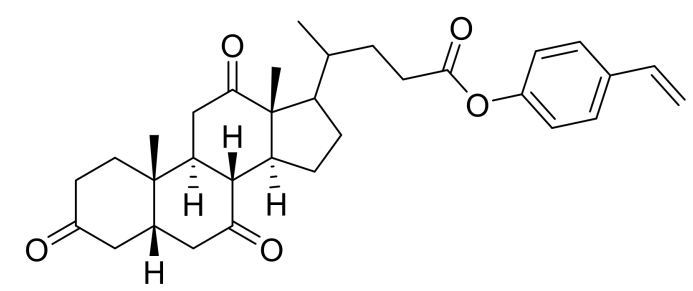

Prepared as described above. Purified by silica gel column chromatography using petroleum ether/EtOAc $=2: 1 \rightarrow 1: 1$ to give $79 \%$ yield $(39.9$ $\mathrm{mg}$ ) of the product as a white solid. ${ }^{1} \mathrm{H}$ NMR (400 $\left.\mathrm{MHz}, \mathrm{CDCl}_{3}\right): \delta 7.41(\mathrm{~d}, J=8.6 \mathrm{~Hz}, 2 \mathrm{H}), 7.04(\mathrm{~d}, J=8.7 \mathrm{~Hz}, 2 \mathrm{H}), 6.70(\mathrm{dd}, J=17.6,10.9 \mathrm{~Hz}$, 1H), $5.70(\mathrm{dd}, J=17.6,0.9 \mathrm{~Hz}, 1 \mathrm{H}), 5.24(\mathrm{dd}, J=10.9,0.8 \mathrm{~Hz}, 1 \mathrm{H}), 2.97-2.82(\mathrm{~m}, 3 \mathrm{H})$, 2.72-2.59 (m, 1H), 2.57-2.46 (m, 1H), 2.39-2.29 (m, 3H), 2.28-1.94 (m, 10H), 1.91-1.81 (m, 1H), $1.62(\mathrm{td}, J=14.2,5.1 \mathrm{~Hz}, 1 \mathrm{H}), 1.56-1.46(\mathrm{~m}, 1 \mathrm{H}), 1.44-1.34(\mathrm{~m}, 5 \mathrm{H}), 1.31-1.23(\mathrm{~m}, 1 \mathrm{H})$, $1.09(\mathrm{~s}, 3 \mathrm{H}), 0.92(\mathrm{~d}, J=6.6 \mathrm{~Hz}, 3 \mathrm{H}) ;{ }^{13} \mathrm{C} \mathrm{NMR}\left(101 \mathrm{MHz}, \mathrm{CDCl}_{3}\right): \delta 211.9,209.0,208.7,172.5$, $150.3,135.9,135.3,127.1,121.6,114.0,56.9,51.7,49.0,46.8,45.6,45.5,45.0,42.8,38.6,36.5$, $36.0,35.5,35.3,31.6,30.4,27.6,25.1,21.9,18.7,11.9$; ESI-HRMS calcd for $\left[\mathrm{C}_{32} \mathrm{H}_{40} \mathrm{NaO}_{5}, \mathrm{M}+\right.$ $\mathrm{Na}^{+}:$527.2768, Found: 527.2768 . 


\section{$(1 S, 8 R, 9 S, 10 S, 13 S, 14 S, 17 S)$-1,10,13-trimethyl-3-oxohexadecahydro-1 $H$-cyclopenta[a]phenan}

thren-17-yl 2-(4-(vinylthio)phenyl)acetate (P97)

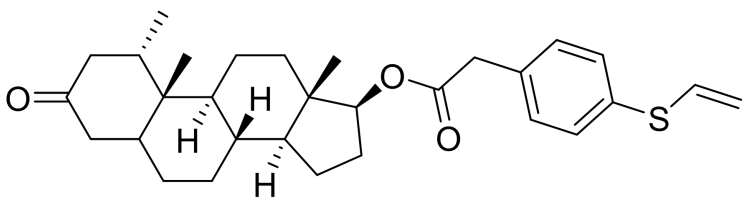

Prepared as described above. Purified by silica gel column chromatography using petroleum ether/EtOAc $=15: 1 \rightarrow 10: 1$ to give

$65 \%$ yield $(31.1 \mathrm{mg})$ of the product as a white solid. ${ }^{1} \mathrm{H}$ NMR (400 MHz, $\left.\mathrm{CDCl}_{3}\right): \delta 7.39-7.33(\mathrm{~m}$, 2H), 7.28-7.24 (m, 2H), $6.54(\mathrm{dd}, J=16.6,9.6 \mathrm{~Hz}, 1 \mathrm{H}), 5.39-5.28(\mathrm{~m}, 2 \mathrm{H}), 4.63(\mathrm{dd}, J=9.2,7.7$ $\mathrm{Hz}, 1 \mathrm{H}), 3.61(\mathrm{~s}, 2 \mathrm{H}), 2.71(\mathrm{dd}, J=14.6,6.0 \mathrm{~Hz}, 1 \mathrm{H}), 2.29-2.20(\mathrm{~m}, 1 \mathrm{H}), 2.19-2.03(\mathrm{~m}, 4 \mathrm{H})$, $1.86-1.75(\mathrm{~m}, 1 \mathrm{H}), 1.73-1.60(\mathrm{~m}, 3 \mathrm{H}), 1.56-1.44(\mathrm{~m}, 3 \mathrm{H}), 1.41-1.25(\mathrm{~m}, 4 \mathrm{H}), 1.20-0.94(\mathrm{~m}, 6 \mathrm{H})$, 0.92-0.80 (m, 4H), $0.75(\mathrm{~s}, 3 \mathrm{H}) ;{ }^{13} \mathrm{C}$ NMR $\left(101 \mathrm{MHz}, \mathrm{CDCl}_{3}\right): \delta 212.0,171.2,133.5,132.7,131.9$, 130.7, 130.0, 115.3, 83.2, 50.6, 48.4, 45.9, 44.9, 42.8, 41.2, 39.8, 39.4, 37.8, 36.8, 35.2, 31.0, 28.6, 27.4, 23.5, 20.0, 14.6, 14.4, 12.1; ESI-HRMS calcd for $\left[\mathrm{C}_{30} \mathrm{H}_{41} \mathrm{O}_{3} \mathrm{~S}, \mathrm{M}+\mathrm{H}\right]^{+}$: 481.2771, Found: 481.2775 .

\section{Supplementary References}

1. Armarego, W. L. F.; Chai, C. L. L. Purification of Laboratory chemicals-Six Edition; Elsevier Inc.: London, 2009.

2. Du, P.; Schneider, J.; Luo, G.; Brennessel, W. W.; Eisenberg, R. Visible light-driven hydrogen production from aqueous protons catalyzed by molecular cobaloxime catalysts. Inorg. Chem. 2009, 48, 4952-4962.

3. Fan, F.; Tang, J.; Luo, M.; Zeng, X. Chromium-catalyzed regioselective Kumada arylative cross-coupling of $\mathrm{C}(\operatorname{aryl})-\mathrm{O}$ bonds with a traceless activation strategy. J. Org. Chem. 2018, 83, 13549-13559.

4. Yang, Y.; Cai, J.; Luo, G.; Tong, X.; Su, Y.; Jiang, Y.; Liu, Y.; Zheng, Y.; Zeng, J.; Li, C. Selective activation of 1,2-dichloroethane for access to $\beta$-chloroethylarenes enabled by nickel-catalyzed Suzuki-type couplings. Tetrahedron Lett. 2019, 60, 1130-1134.

5. Barsu, N.; Kalsi, D.; Sundararaju, B. Site-selective C-H bond carbonylation with $\mathrm{CO}_{2}$ and cobalt-catalysis. Catal. Sci. Technol. 2018, 8, 5963-5969.

6. Myers, E. L.; de Vries, J. G.; Aggarwal, V. K. Reactions of iminium ions with Michael acceptors through a Morita-Baylis-Hillman-type reaction: Enantiocontrol and applications in synthesis. Angew. Chem., Int. Ed. 2007, 46, 1893-1896.

7. Meng, Q.-Y.; Schirmer, T, E.; Berger, A. L.; Donabauer, K.; König, B. Photocarboxylation of benzylic C-H bonds. J. Am. Chem. Soc. 2019, 141, 11393-11397.

8. Motaleb, A.; Bera, A.; Maity, P. An organocatalyst bound $\alpha$-aminoalkyl radical intermediate for controlled aerobic oxidation of iminium ions. Org. Biomol. Chem. 2018, 16, 5081-5085. 
9. Tian, M.; Abdelrahman, A.; Weinhausen, S.; Hinz, S.; Weyer, S.; Dosa, S.; Ei-Tayeb, A.; Müller, C. E. Carbamazepine derivatives with P2X4 receptor-blocking activity. Bioorg. Med. Chem. 2014, 22, 1077-1088.

10. Querner, J.; Wolff, T.; Görner, H. Substituent-dependent reactivity in the photodimerization of N-substitutedDibenz[b,f]azepines. Chem. Eur. J. 2004, 10, 283-293.

11. Chen, W.; Suo, J.; Liu, Y.; Xie, Y.; Wu, M.; Zhu, F.; Nian, Y.; Aisa, H. A.; Shen, J. Industry-oriented route evaluation and process optimization for the preparation of Brexpiprazole. Org. Process Res. Dev. 2019, 23, 852-857.

12. Zhao, M.; Li, M.; Lu, W. Visible-light-driven oxidative mono- and dibromination of benzylic $s p^{3} \mathrm{C}-\mathrm{H}$ bonds with potassium bromide/oxone at room temperature. Synthesis 2018, 50, 4933-4939.

13. Song, Z.-Q.; Wang, D.-H. Palladium-catalyzed hydroxylation of aryl halides with boric acid. Org. Lett. 2020, 22, 8470-8474.

14. Molloy, J. J.; Seath, C. P.; West, M. J.; McLaughlin, C.; Fazakerley, N. J.; Kennedy, A. R.; Nelson, D. J.; Watson, A. J. B. Interrogating Pd(II) anion metathesis using a bifunctional chemical probe: A transmetalation switch. J. Am. Chem. Soc. 2018, 140, 126-130.

15. Cong, F.; Wei, Y.; Tang, P. Combining photoredox and silver catalysis for azidotrifluoromethoxylation of styrenes. Chem. Commun. 2018, 54, 4473-4476.

16. Garcia-Barrantes, P. M.; Lindsley, C. W. Total synthesis of Gombamide A. Org. Lett. 2016, $18,3810-3813$.

17. Gao, Y.; Ou, Y.; Gooßen, L. J. Pd-catalyzed synthesis of vinyl arenes from aryl halides and acrylic acid. Chem. Eur. J. 2019, 25, 8709-8712.

18. Zhang, L.; Zhang, G.; Zhang, M.; Cheng, J. Cu(OTf $)_{2}$-mediated Chan-Lam reaction of carboxylic acids to access phenolic esters. J. Org. Chem. 2010, 75, 7472-7474.

19. Tang, M.; Han, S.; Huang, S.; Huang, S.; Xie, L.-G. Carbosulfenylation of alkenes with organozinc reagents and dimethyl(methylthio)sulfonium trifluoromethanesulfonate. Org. Lett. 2020, 22, 9729-9734.

20. Diehl, C. J.; Scattolin, T.; Englert, U.; Schoenebeck, F. C-I-selective cross-coupling enabled by a cationic palladium trimer. Angew. Chem., Int. Ed. 2019, 58, 211-215.

21. Frye, N. L.; Bhunia, A.; Studer, A. Nickel-catalyzed Markovnikov transfer hydrocyanation in the absence of Lewis acid. Org. Lett. 2020, 22, 4456-4460.

22. Haubenreisser, S.; Wöste, T. H.; Martínez, C.; Ishihara, K.; Muñiz, K. Structurally defined molecular hypervalent iodine catalysts for intermolecular enantioselective reactions. Angew. Chem., Int. Ed. 2016, 55, 413-417.

23. Kos, P.; Savka, R.; Plenio, H. Fast olefin metathesis: Synthesis of 2-aryloxy-substituted Hoveyda-type complexes and application in ring-closing metathesis. Adv. Synth. Catal. 2013, 355, 439-447.

24. Huang, J.-M.; Lin, Z.-Q.; Chen, D.-S. Electrochemically supported deoxygenation of epoxides into alkenes in aqueous solution. Org. Lett. 2012, 14, 22-25.

25. Ke, J.; Wang, H.; Zhou, L.; Mou, C.; Zhang, J.; Pan, L.; Chi, Y. R. Hydrodehalogenation of aryl halides through direct electrolysis. Chem. Eur. J. 2019, 25, 6911- 6914.

26. Arundhath, H.; Damodara, D.; Mohan, K. V.; Kantam, M. L.; Likhar, P. R. Monodispersed and stable nano copper(0) from copper-aluminium hydrotalcite: importance in $\mathrm{C}-\mathrm{C}$ couplings of deactivated aryl chlorides. Adv. Synth. Catal. 2013, 355, 751-756. 
27. (a) Zorba, L.; Kidonakis, M.; Saridakis, I.; Stratakis, M. Cycloisomerization of conjugated allenones into furans under mild conditions catalyzed by ligandless Au nanoparticles. Org. Lett. 2019, 21, 5552-5555. (b) Das, M.; O'Shea, D. F. Z-Stereoselective aza-Peterson olefinations with bis(trimethylsilane) reagents and sulfinyl imines. Org. Lett. 2016, 18, 336-339.

28. Li, K.; Khan, R.; Zhang, X.; Gao, Y.; Zhou, Y.; Tan, H.; Chen, J.; Fan, B. Cobalt catalyzed stereodivergent semi-hydrogenation of alkynes using $\mathrm{H}_{2} \mathrm{O}$ as the hydrogen source. Chem. Commun. 2019, 55, 5663-5666.

29. Asahara, K. K.; Okita, T.; Saito, A. N.; Muto, K.; Nakao, Y.; Yamaguchi, J. Pd-catalyzed denitrative intramolecular C-H arylation. Org. Lett. 2019, 21, 4721-4724.

30. McAtee, C. C.; Riehl, P. S.; Schindler, C. S. Polycyclic aromatic hydrocarbons via iron(III)-catalyzed carbonyl-olefin metathesis. J. Am. Chem. Soc. 2017, 139, 2960-2963.

31. (a) Totland, K.; Alper, H. Hydroformylation of vinyl sulfones and sulfoxides catalyzed by a Zwitterionic rhodium complex. A diastereoselective process. J. Org. Chem. 1993, 58, 3326-3329.

(b) Schmink, J. R.; Dockrey, S. A. B.; Zhang, T.; Chebet, N.; Venrooy, A. V.; Sexton, M.; Lew, S.

I.; Chou, S.; Okazaki, A. Palladium-catalyzed synthesis of aryl vinyl sulfides via 1,3-oxathiolanes as vinyl sulfide surrogates. Org. Lett. 2016, 18, 6360-6363.

32. Bhowmik, A.; Yadav, M.; Fernandes, R. A. Room temperature nickel-catalyzed cross-coupling of aryl-boronic acids with thiophenols: synthesis of diarylsulfides. Org. Biomol. Chem. 2020, 18, 2447-2458.

33. Lin, S.; Lies, S. D.; Gravatt, C. S.; Yoon, T. P. Radical cation cycloadditions using cleavable redox auxiliaries. Org. Lett. 2017, 19, 368-371.

34. Lin, Y.; Lu, G.; Wang, G.; Yi, W. Acid/phosphide-induced radical route to alkyl and alkenyl sulfides and phosphonothioates from sodium arylsulfinates in water. J. Org. Chem. 2017, 82, 382-389.

35. Singh, R.; Raghuvanshi, D. S.; Singh, K. N. Regioselective hydrothiolation of alkynes by sulfonyl hydrazides using organic ionic base-Brønsted acid. Org. Lett. 2013, 15, 4202-4205.

36. Wang, B.-W.; Jiang, K.; Li, J.-X.; Luo, S.-H.; Wang, Z.-Y.; Jiang, H.-F. 1,1-Diphenylvinylsulfide as a functional AIEgen derived from the aggregation-caused-quenching molecule 1,1-diphenylethene through simple thioetherification. Angew. Chem., Int. Ed. 2020, 59, 2338-2343.

37. Palani, T.; Park, K.; Song, K. H.; Lee, S. Palladium-catalyzed synthesis of (Z)-3-arylthioacrylic acids and thiochromenones. Adv. Synth. Catal. 2013, 355, 1160-1168.

38. Matt, C.; Kölblin, F.; Streuff, J. Reductive C-O, C-N, and C-S cleavage by a zirconium catalyzed hydrometalation/ß-elimination approach. Org. Lett. 2019, 21, 6983-6988.

39. (a) Al-Hamdan, N. S.; Habib, O. M.; Ibrahim, Y. A.; Al-Awadi, N. A.; El-Dusouqui, O. M. E. Pyrolysis of azetidinone derivatives: a versatile route towards electron-rich alkenes, $\mathrm{C}-1$ allylation and/or homologation of aldehydes. RSC Adv. 2014, 4, 21023-21031. (b) Iwasaki, T.; Miyata, Y.; Akimoto, R.; Fujii, Y.; Kuniyasu, H.; Kambe, N. Diarylrhodates as promising active catalysts for the arylation of vinyl ethers with Grignard reagents. J. Am. Chem. Soc. 2014, 136, 9260-9263.

40. Yamasaki, R.; Morita, K.; Iizumi, H.; Ito, A.; Fukuda, K.; Okamoto, I. N-ethynylation of anilides decreases the double-bond character of amide bond while retaining trans-conformation and planarity. Chem. Eur. J. 2019, 25, 10118-10122.

41. (a) Bai, X.-Y.; Zhang, W.-W.; Li, Q.; Li, B.-J. Highly enantioselective synthesis of propargyl amides through Rh-catalyzed asymmetric hydroalkynylation of enamides: Scope, mechanism, and 
origin of selectivity. J. Am. Chem. Soc. 2018, 140, 506-514. (b) Mo, X.; Morgan, T. D. R.; Ang, H. T.; Hall, D. G. Scope and mechanism of a true organocatalytic Beckmann rearrangement with a boronic acid/perfluoropinacol system under ambient conditions. J. Am. Chem. Soc. 2018, 140, 5264-5271.

42. Carafa, M.; Distaso, M.; Mele, V.; Trani, F.; Quaranta, E. Superbase-promoted direct N-carbonylation of pyrrole with carbonic acid diesters. Tetrahedron Lett. 2008, 49, 3691-3696.

43. Hayama, K.; Kojima, R.; Kubota, K.; Ito, H. Synthesis of chiral $N$-heterocyclic allylboronates via the enantioselective borylative dearomatization of pyrroles. Org. Lett. 2020, 22, 739-744.

44. Trindade, A. F.; Faulkner, E. L.; Leach, A. G.; Nelson, A.; Marsden, S. P. Fragment-oriented synthesis: $\beta$-elaboration of cyclic amine fragments using enecarbamates as platform intermediates. Chem. Commun. 2020, 56, 8802-8805.

45. Knapp, S.; Yang, C.; Pabbaraja, S.; Rempel, B.; Reid, S.; Withers, S. G. Synthesis and kinetic analysis of the $N$-acetylhexosaminidase inhibitor XylNAc-isofagomine. J. Org. Chem. 2005, 70, $7715-7720$.

46. Lv, X.; Bao, W. A. A $\beta$-Keto ester as a novel, efficient, and versatile ligand for copper(I)-catalyzed $\mathrm{C}-\mathrm{N}, \mathrm{C}-\mathrm{O}$, and $\mathrm{C}-\mathrm{S}$ coupling reactions. J. Org. Chem. 2007, 72, 3863-3867.

47. Lanni, E. L.; Bosscher, M. A.; Ooms, B. D.; Shandro, C. A.; Ellsworth, B. A.; Anderson, C. E. Synthesis of substituted $N$-benzyl pyridones via an $O$ - to $N$-alkyl migration. $J$. Org. Chem. 2008, 73, 6425-6428.

48. Tezuka, N. Shimojo, K.; Hirano, K.; Komagawa, S.; Yoshida, K.; Wang, C.; Miyamoto, K.; Saito, T.; Takita, R.; Uchiyama, M. Direct hydroxylation and amination of arenes via deprotonative cupration. J. Am. Chem. Soc. 2016, 138, 9166-9171.

49. He, Y.; Agarwal, P. K.; Kiran, I. N. C.; Yu, R.; Cao, B.; Zou, C.; Zhou, X.; Xu, H.; Xu, B.; Zhu, L.; Lan, Y.; Nicolaou, K. C. Efficient synthesis of dimeric oxazoles, piperidines and tetrahydroisoquinolines from $N$-substituted 2-oxazolones. Chem. Eur. J. 2016, 22, 7696-7701.

50. Phae-nok, S.; Kuhakarn, C.; Pohmakotr, M.; Reutrakul, V.; Soorukram, D. Convenient synthesis of $\alpha, \beta$-unsaturated $\gamma$-butyrolactones and $\gamma$-butyrolactams via decarboxylative iodination of paraconic acids and $\beta$-carboxyl- $\gamma$-butyrolactams using 1,3-diiodo-5,5-dimethylhydantoin. Org. Biomol. Chem. 2015, 13, 11087-11095.

51. Xiao, Y.; Xu, Y.; Cheon, H.-S.; Chae, J. Copper(II)-catalyzed hydroxylation of aryl halides using glycolic acid as a ligand. J. Org. Chem. 2013, 78, 5804-5809.

52. Patra, T.; Agasti, S.; Modak, A.; Maiti, D. Nickel-catalyzed hydrogenolysis of unactivated carbon-cyano bonds. Chem. Commun. 2013, 49, 8362-8364.

53. Egi, M.; Umemura, M.; Kawai, T.; Akai, S. Heteropoly compound catalyzed synthesis of both $Z$ - and E- $\alpha, \beta$-unsaturated carbonyl compounds. Angew. Chem., Int. Ed. 2011, 50, 12197-12200.

54. Khoobi, M.; Alipour, M.; Zarei, S.; Jafarpour, F.; Shafiee, A. A facile route to flavone and neoflavone backbones via a regioselective palladium catalyzed oxidative Heck reaction. Chem. Commun. 2012, 48, 2985-2987.

55. Yang, F.; Rauch, K.; Kettelhoit, K.; Ackermann, L. Aldehyde-assisted ruthenium(II)-catalyzed C-H oxygenations. Angew. Chem., Int. Ed. 2014, 53, 11285-11288.

56. (a) Yang, W.; Chen, H.; Li, J.; Li, C.; Wu, W.; Jiang, H. Palladium-catalyzed aerobic oxidative double allylic $\mathrm{C}-\mathrm{H}$ oxygenation of alkenes: a novel and straightforward route to a, $\beta$-unsaturated esters. Chem. Commun. 2015, 51, 9575-9578. (b) Trost, B. M.; Hirano, K. 
Dinuclear zinc catalyzed asymmetric spirannulation reaction: An umpolung strategy for formation of $\alpha$-alkylated- $\alpha$-hydroxyoxindoles. Org. Lett. 2012, 14, 2446-2449.

57. Thalluri, K.; Nadimpally, K. C.; Chakravarty, M. P.; Paul, A.; Mandal, B. Ethyl 2-(tert-butoxycarbonyloxyimino)-2-cyanoacetate (boc-oxyma) as coupling reagent for racemization-free esterification, thioesterification, amidation and peptide synthesis. Adv. Synth. Catal. 2013, 355, 448-462.

58. Wu, J.; Xiang, S.; Zeng, J.; Leow, M.; Liu, X.-W. Practical route to 2-quinolinones via a $\mathrm{Pd}-$ catalyzed $\mathrm{C}-\mathrm{H}$ bond activation/C-C bond formation/cyclization cascade reaction. Org. Lett. 2015, 17, 222-225.

59. Kojima, S.; Hidaka, T.; Ohba, Y. Synthesis of $\beta$-monosubstituted $\alpha, \beta$-unsaturated amides with Z-selectivity using diphenylphosphonoacetamides. Heteroat. Chem. 2004, 15, 515-523.

60. Albrecht, D.; Bach, T. Synthesis of 4-substituted 1,5-dihydropyrrol-2-ones and 5,6-dihydro-1H-pyridin-2-ones by Negishi cross-coupling reactions: Short access to the antidepressant ( \pm )-Rolipram. Synlett 2007, 10, 1557-1560. 


\section{NMR Spectra}

\section{2-(4-Ethylphenoxy)pyridine (S13)}

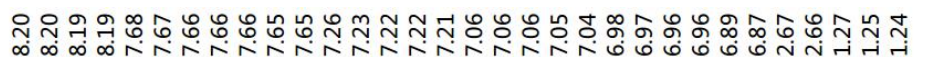

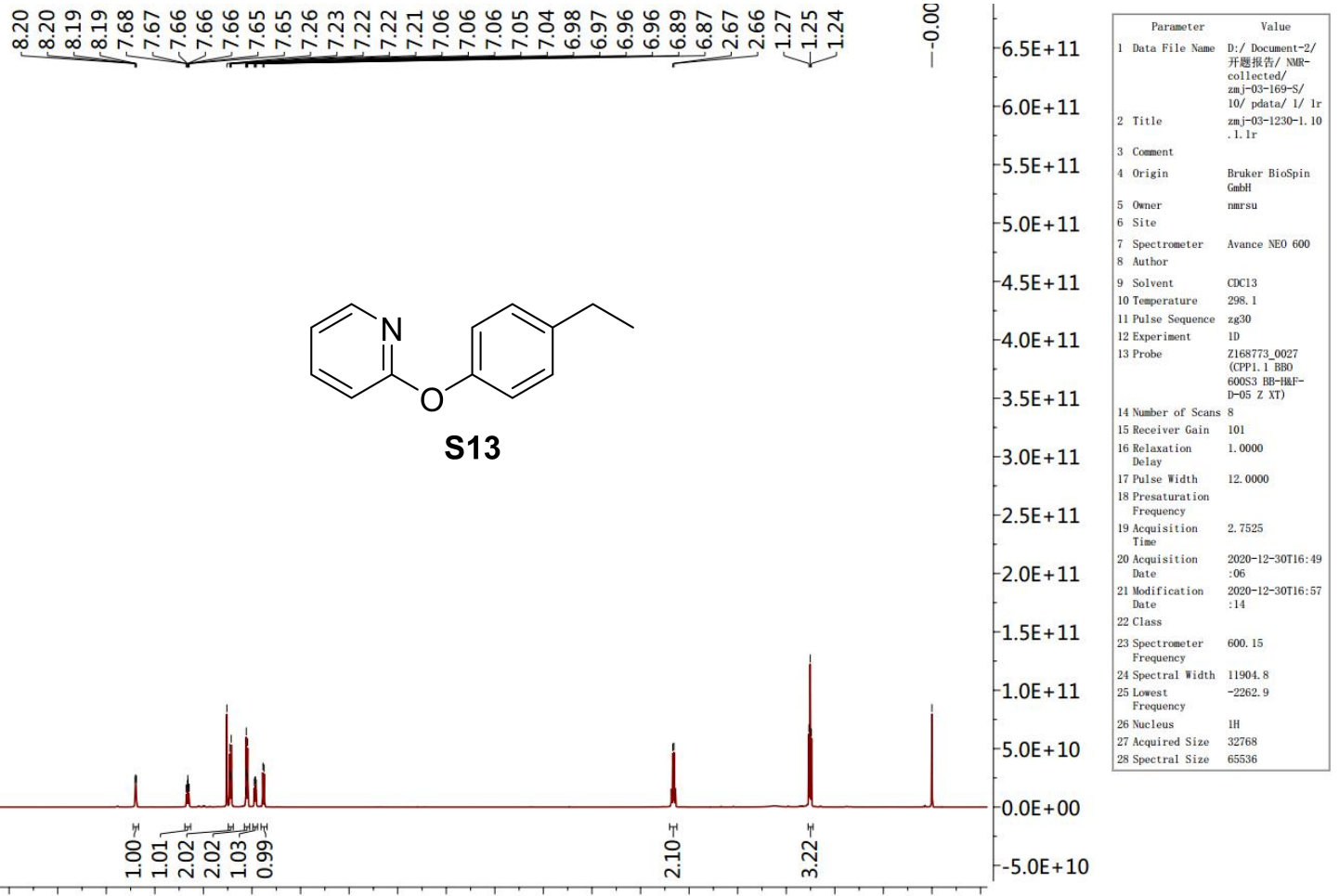

$\begin{array}{lllllllllllllllllllll}9.5 & 9.0 & 8.5 & 8.0 & 7.5 & 7.0 & 6.5 & 6.0 & 5.5 & 5.0 & 4.5 & 4.0 & 3.5 & 3.0 & 2.5 & 2.0 & 1.5 & 1.0 & 0.5 & 0.0 & -0.5\end{array}$

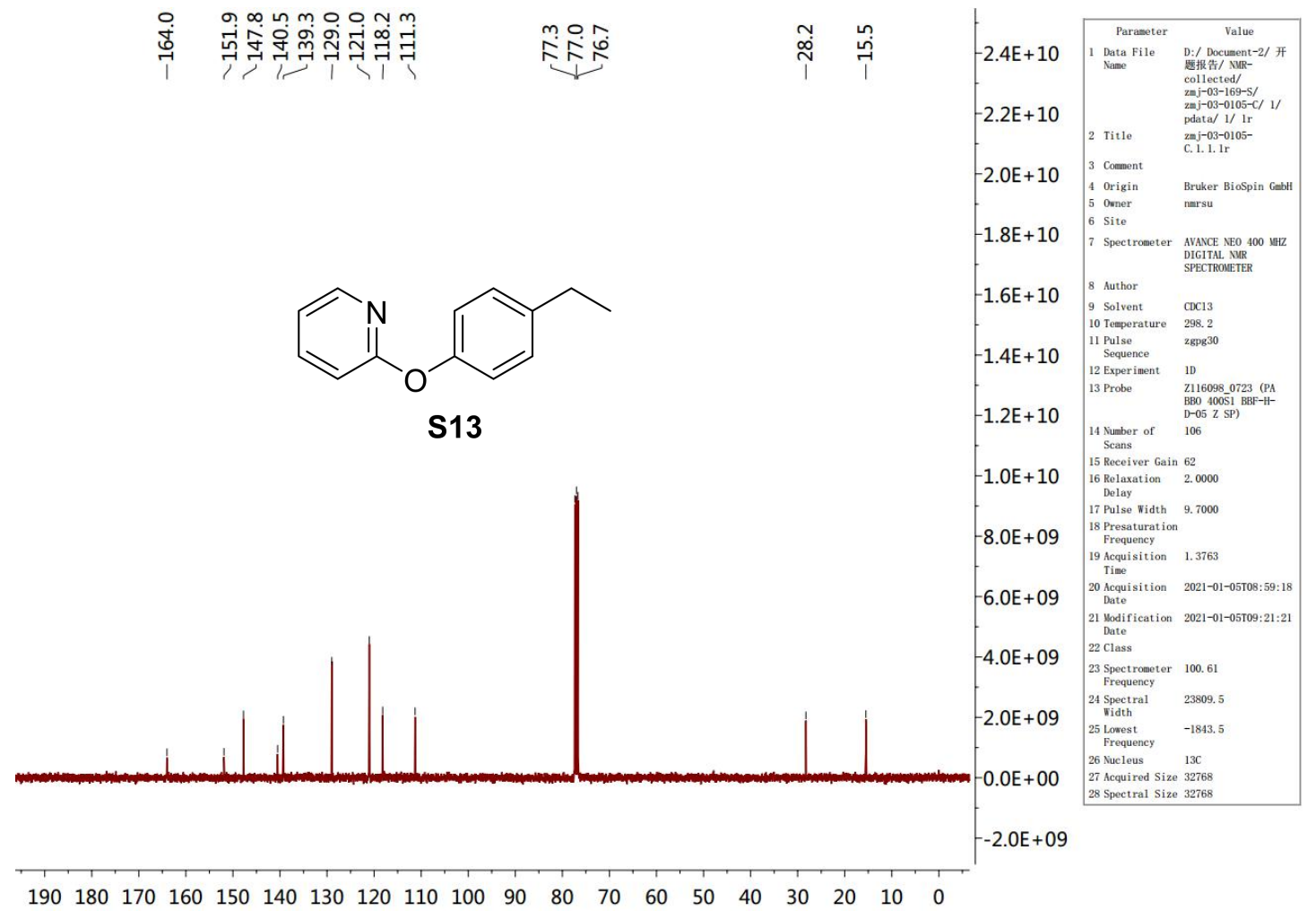


2-(Phenethylthio)pyrimidine (S42)

กิน

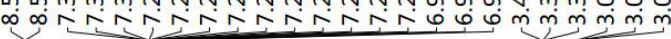<smiles>c1ccc(CCSc2ncccn2)cc1</smiles>

S42

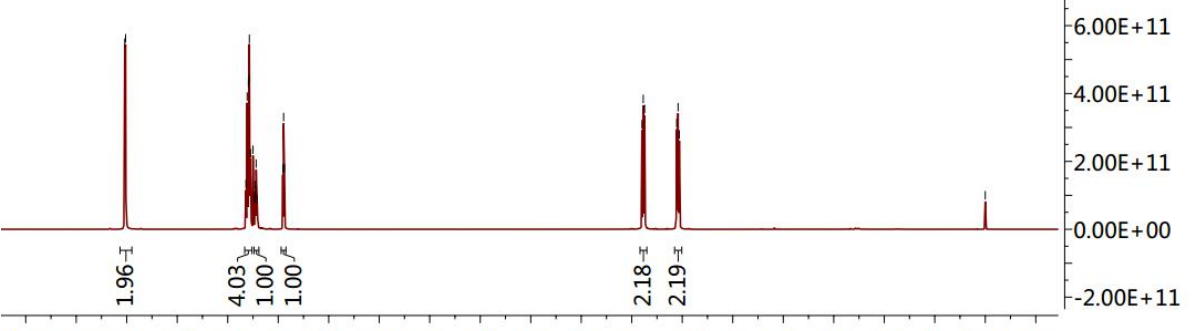

$\begin{array}{lllllllllllllllllllll}9.5 & 9.0 & 8.5 & 8.0 & 7.5 & 7.0 & 6.5 & 6.0 & 5.5 & 5.0 & 4.5 & 4.0 & 3.5 & 3.0 & 2.5 & 2.0 & 1.5 & 1.0 & 0.5 & 0.0 & -0.5\end{array}$

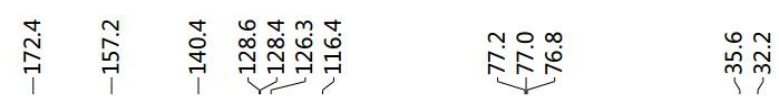<smiles>c1ccc(CCSc2ncccn2)cc1</smiles>

S42

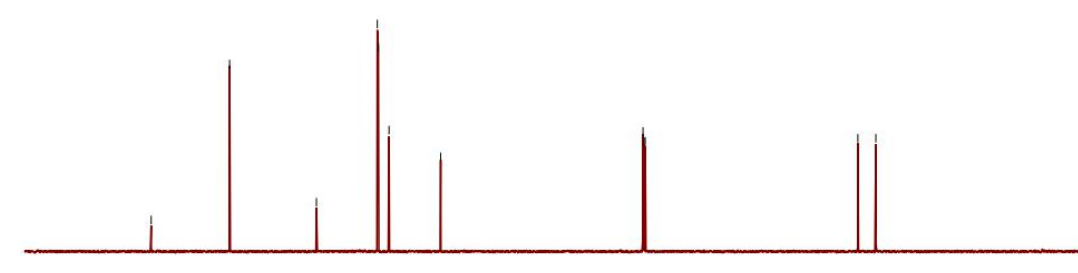

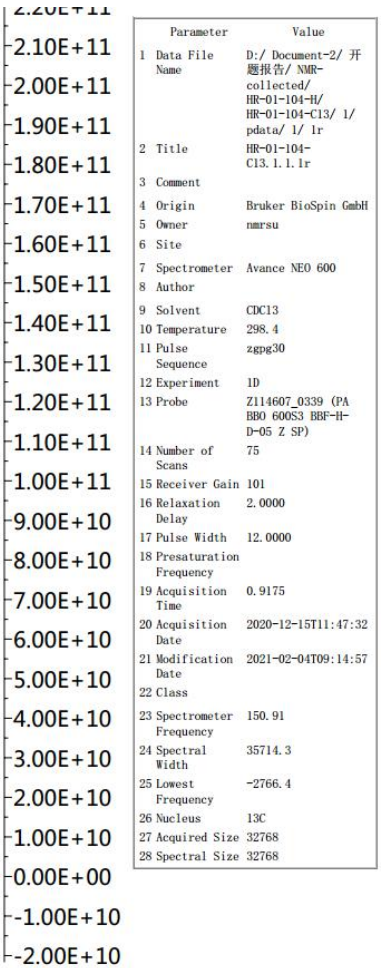

$\begin{array}{llllllllllllllllllll}190 & 180 & 170 & 160 & 150 & 140 & 130 & 120 & 110 & 100 & 90 & 80 & 70 & 60 & 50 & 40 & 30 & 20 & 10 & 0\end{array}$ 


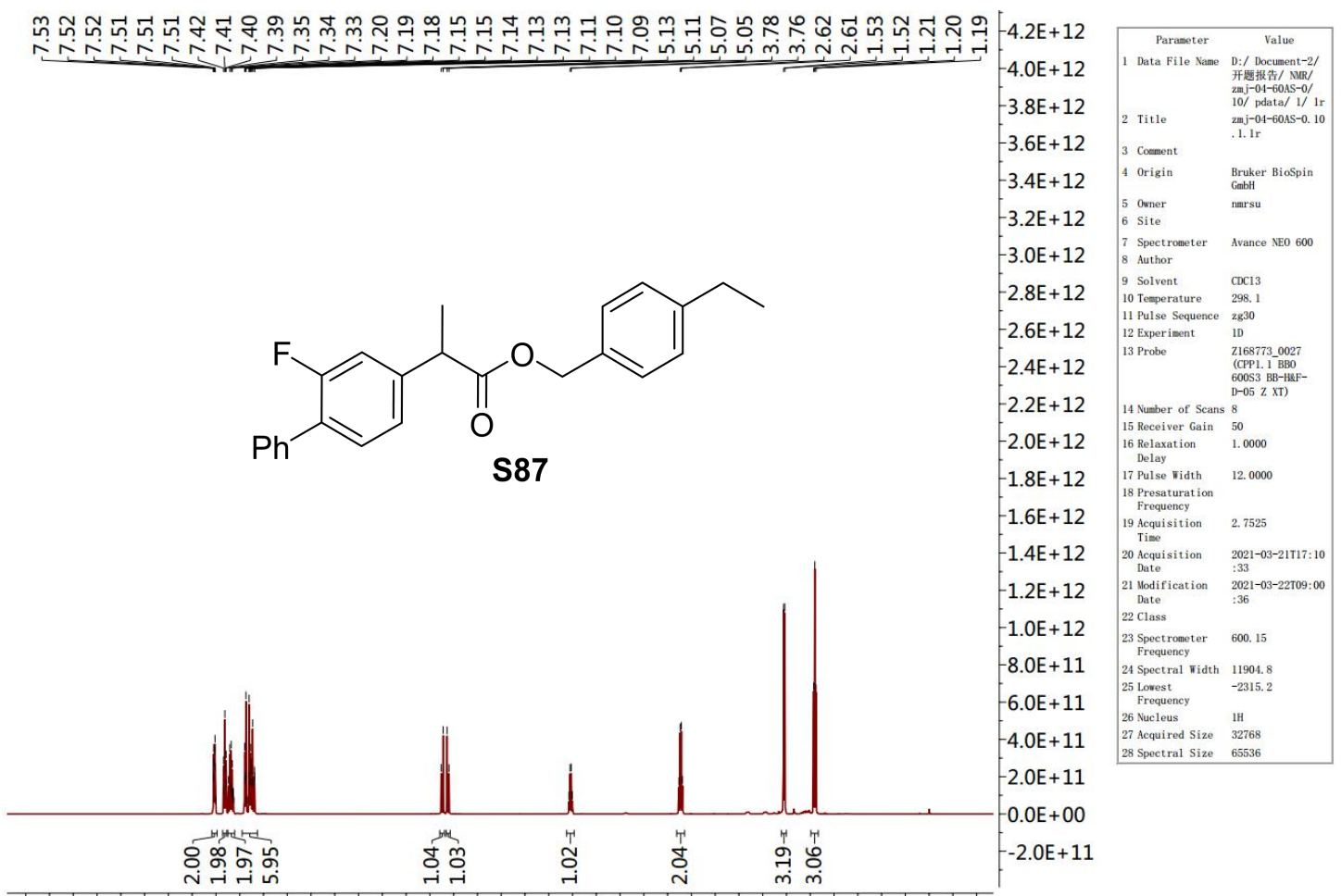

$\begin{array}{llllllllllllllllllllll}9.5 & 9.0 & 8.5 & 8.0 & 7.5 & 7.0 & 6.5 & 6.0 & 5.5 & 5.0 & 4.5 & 4.0 & 3.5 & 3.0 & 2.5 & 2.0 & 1.5 & 1.0 & 0.5 & 0.0 & -0.5\end{array}$

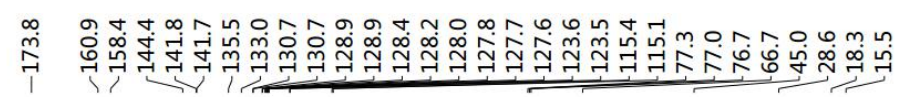<smiles>CCc1ccc(COC(=O)C(C)c2ccc(-c3ccccc3)c(F)c2)cc1</smiles>

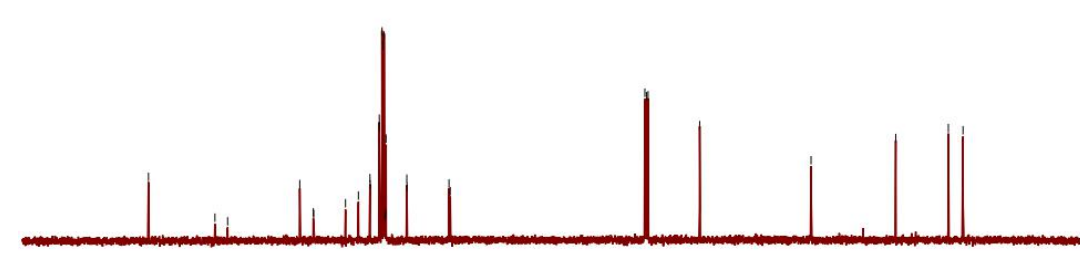

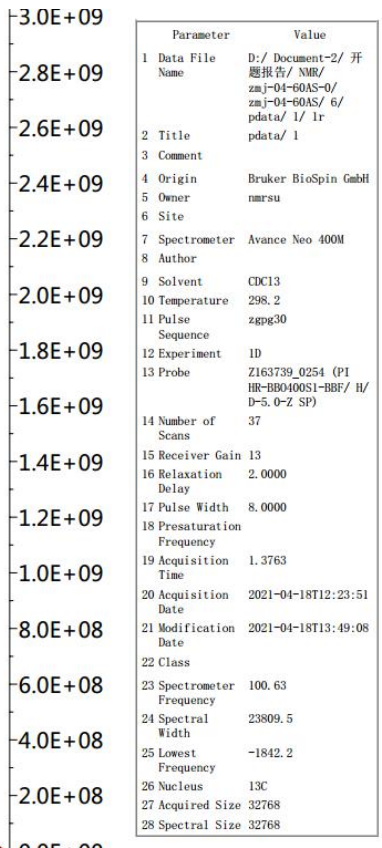

$\begin{array}{llllllllllllllllllll}190 & 180 & 170 & 160 & 150 & 140 & 130 & 120 & 110 & 100 & 90 & 80 & 70 & 60 & 50 & 40 & 30 & 20 & 10 & 0\end{array}$ 


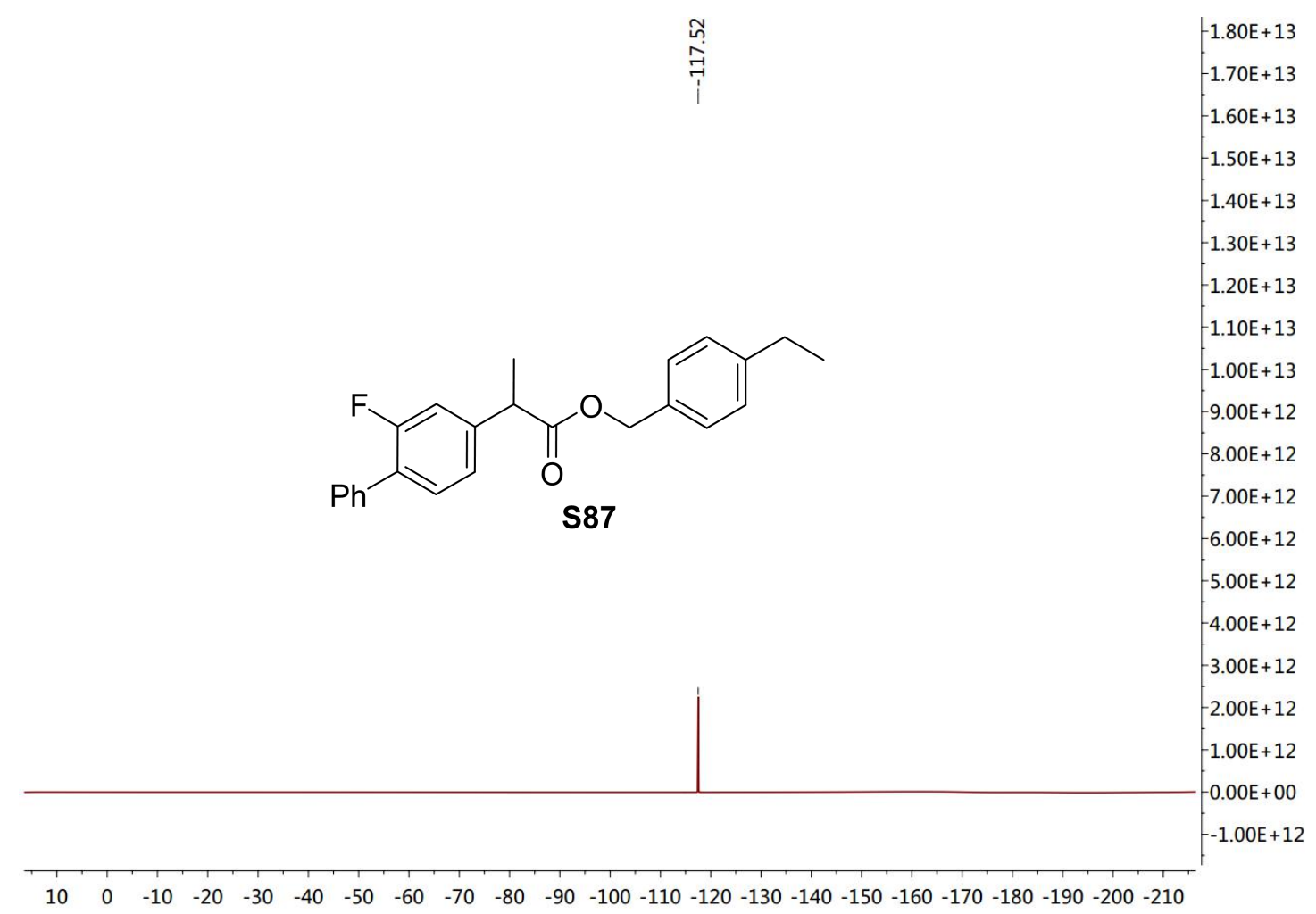

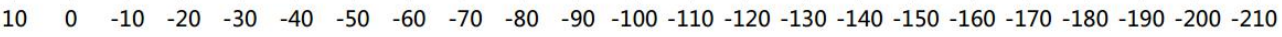

${ }^{19} \mathrm{~F}$ NMR of $\mathbf{S 8 7}$ 
Phenyl 2-(4-((2-oxocyclopentyl)methyl)phenyl)propanoate (S88)

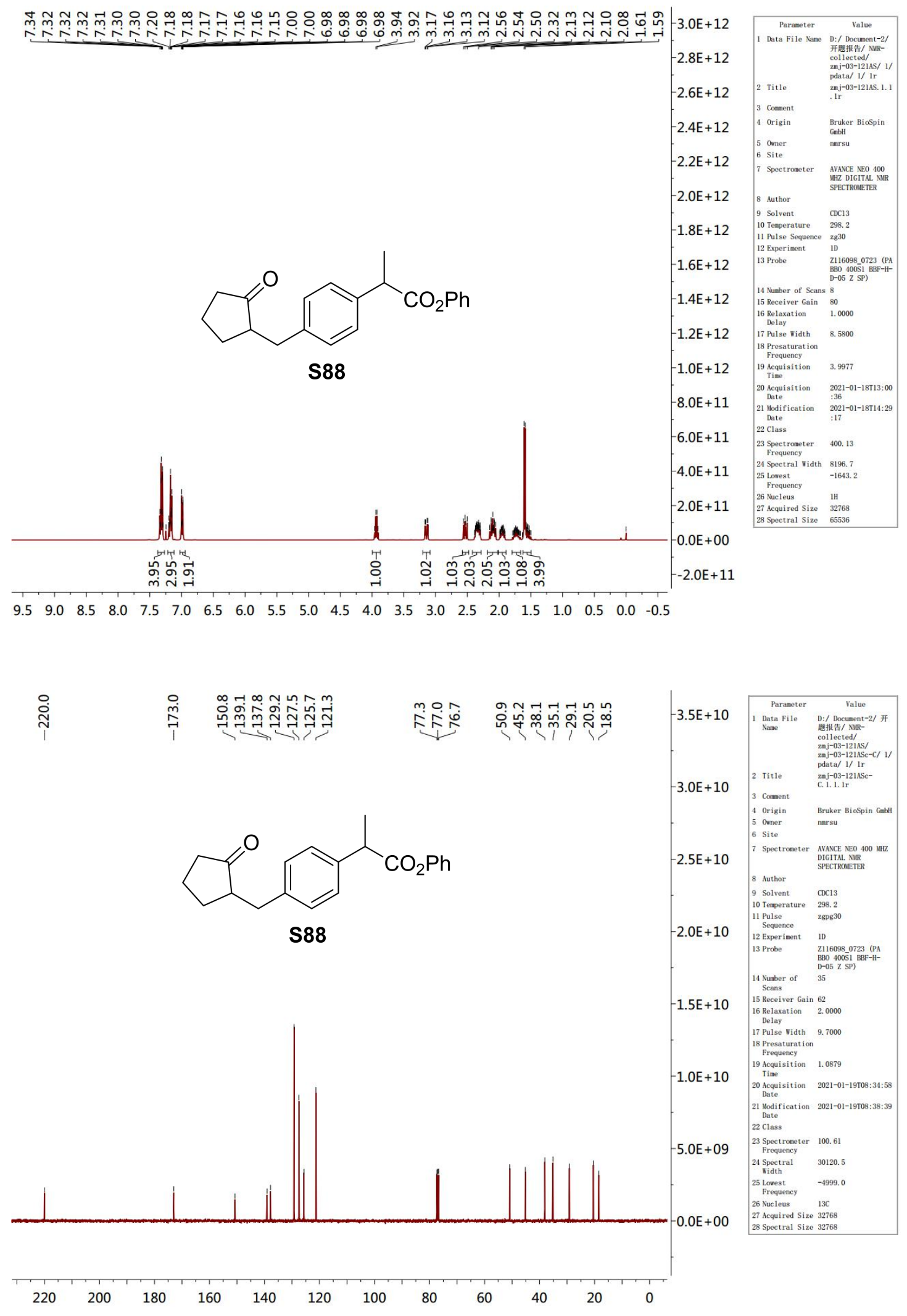


2-(2,5-Dichlorophenoxy)-1-thiomorpholinoethan-1-one (S91)

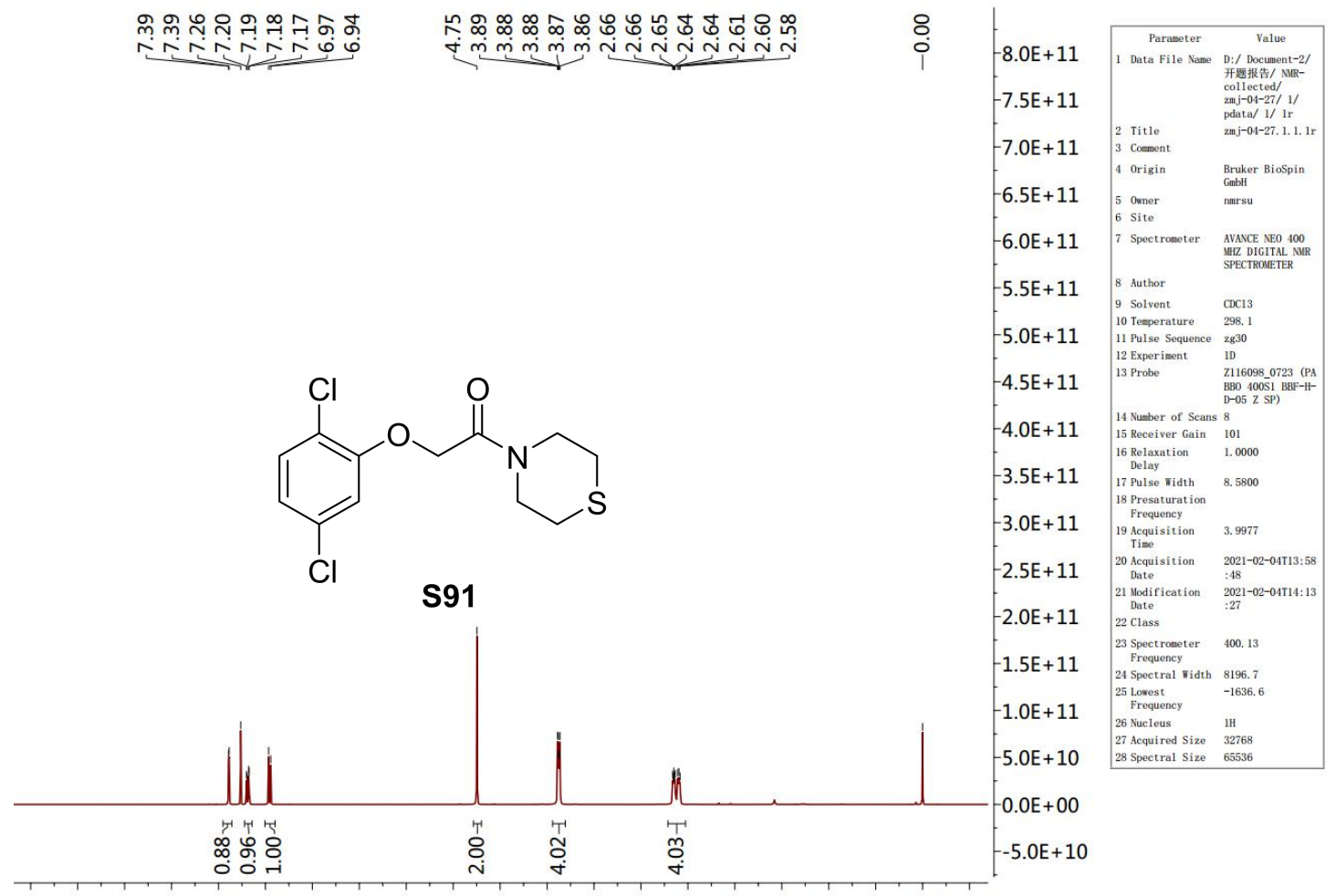

$\begin{array}{lllllllllllllllllllll}9.5 & 9.0 & 8.5 & 8.0 & 7.5 & 7.0 & 6.5 & 6.0 & 5.5 & 5.0 & 4.5 & 4.0 & 3.5 & 3.0 & 2.5 & 2.0 & 1.5 & 1.0 & 0.5 & 0.0 & -0.5\end{array}$

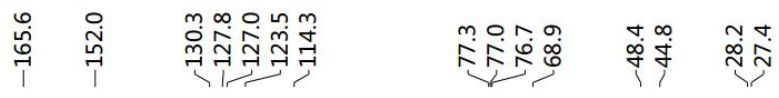

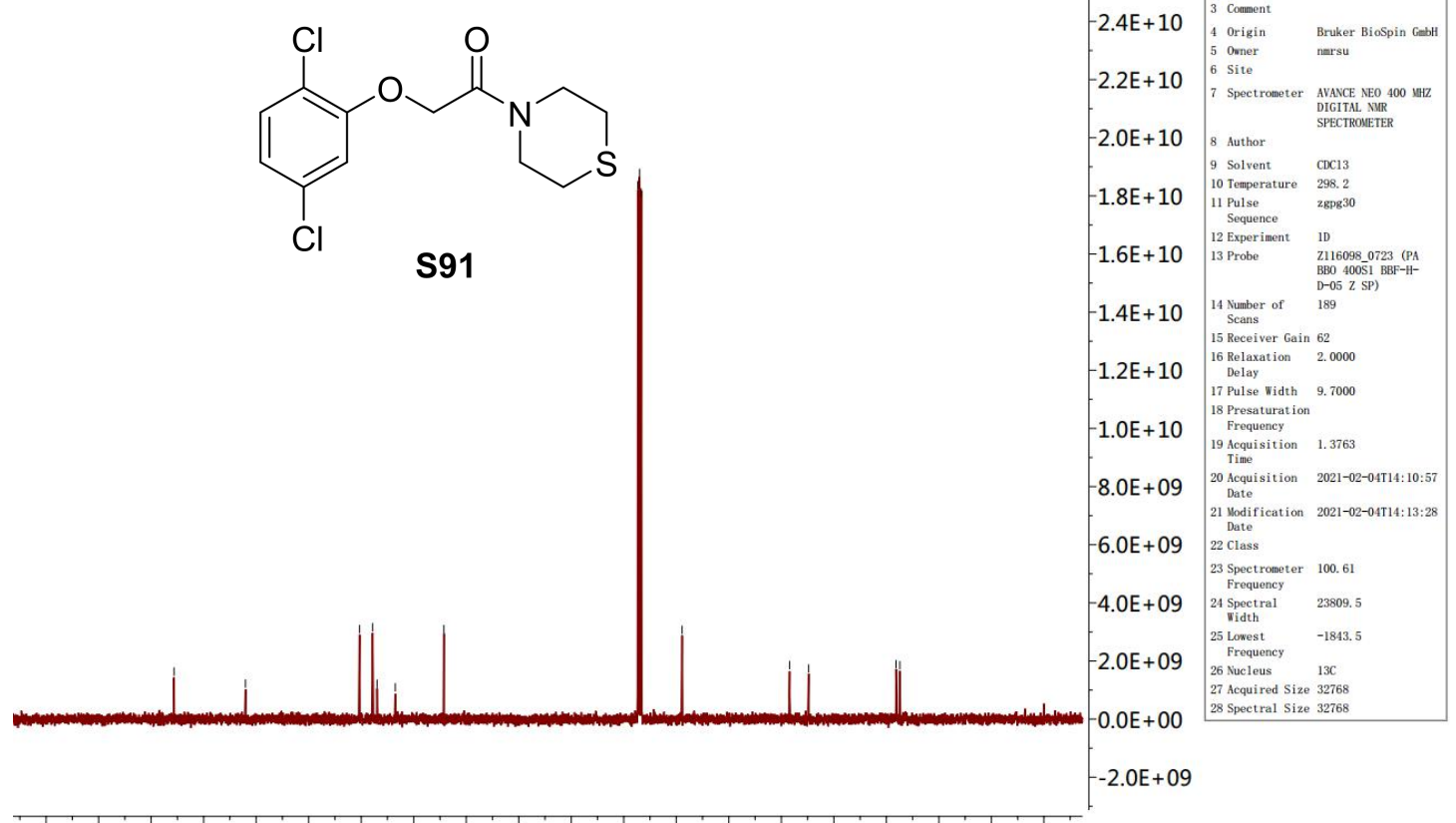

$\begin{array}{llllllllllllllllllll}190 & 180 & 170 & 160 & 150 & 140 & 130 & 120 & 110 & 100 & 90 & 80 & 70 & 60 & 50 & 40 & 30 & 20 & 10 & 0\end{array}$ 
<smiles>O=C(CC1(CN2C(=O)c3ccccc3C2=O)CCCCC1)N1CCOCC1</smiles>

S92

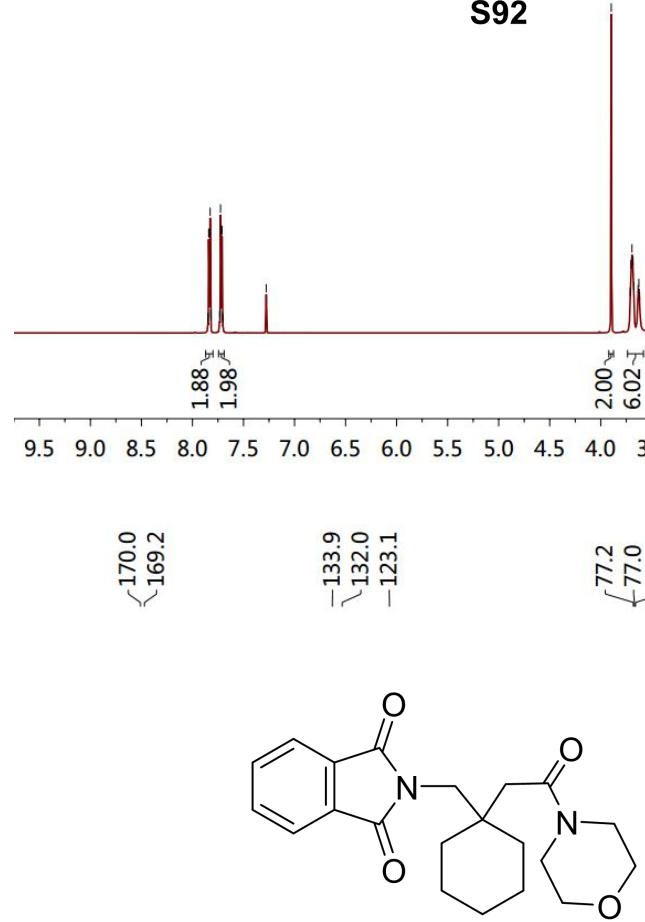

S92

$-1.50 E+12$
$-1.40 E+12$
$-1.30 E+12$
$-1.20 E+12$
$-1.10 E+12$
$-1.00 E+12$
$-9.00 E+11$
$-8.00 E+11$
$-7.00 E+11$
$-6.00 E+11$
$-5.00 E+11$
$-4.00 E+11$
$-3.00 E+11$
$-2.00 E+11$
$-1.00 E+11$
$-0.00 E+00$
$-1.00 E+11$
Parameter
1. Data File 2 Title 3 Coment Origin $\quad \begin{gathered}\text { Brukh } \\ \text { Gublt }\end{gathered}$

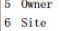
Spectrometer Avance NE0 600 8 . Author 10 Temerature 298. 11 Pulse Sequence zz30 12 Experient $\quad$ ID

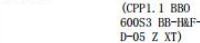

14 Number of Scans 8
15 Receiver Gain 16 Relaxation $\quad 1.0000$ 18 Presaturation 12.0000 $\begin{array}{ll}\begin{array}{l}\text { Freaquency } \\ \text { 19 Acquisition }\end{array} & 2.7525\end{array}$ 2021-03-21112:43 \begin{tabular}{ll} 
Date & :53 \\
21 Nodification & $2021-03-21114: 53$ \\
\hline
\end{tabular} Date
22 Class

23 Spectrometer $\quad 600.15$ 27 Acqui red Size 3276 28 Spectral Size 65536

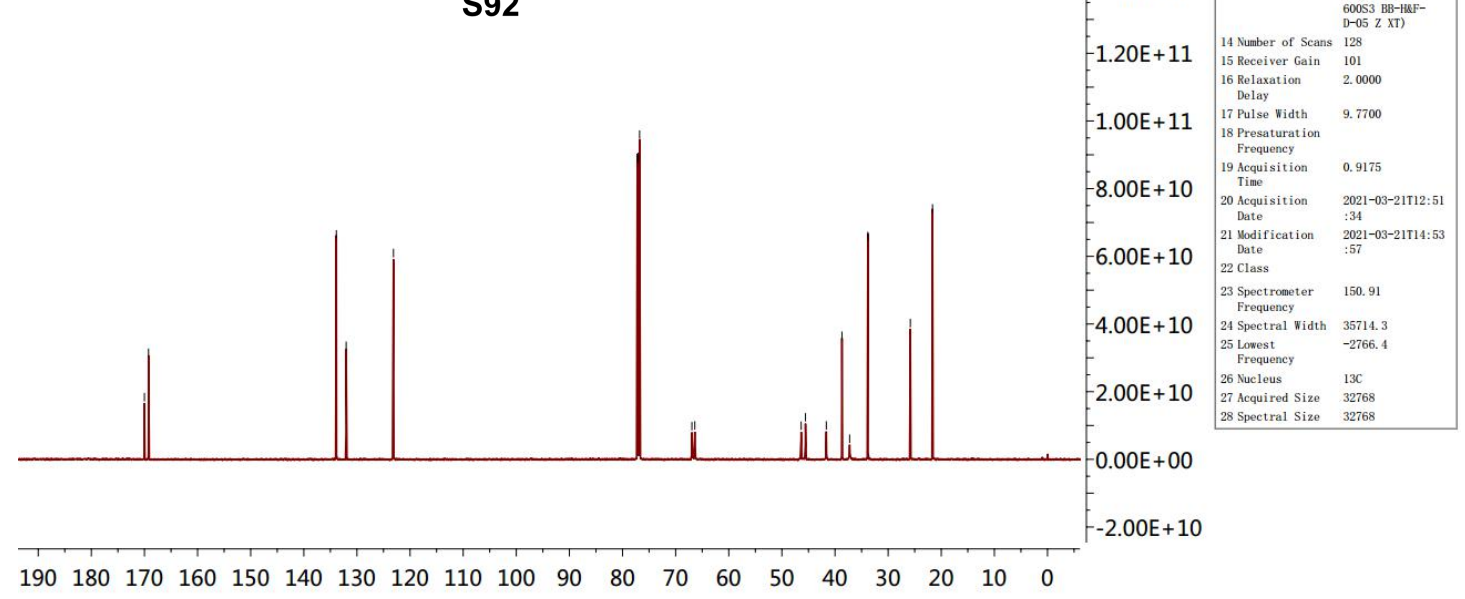


Benzyl 4-(2-((2,4-dimethylphenyl)thio)phenyl)piperazine-1-carboxylate (S93)

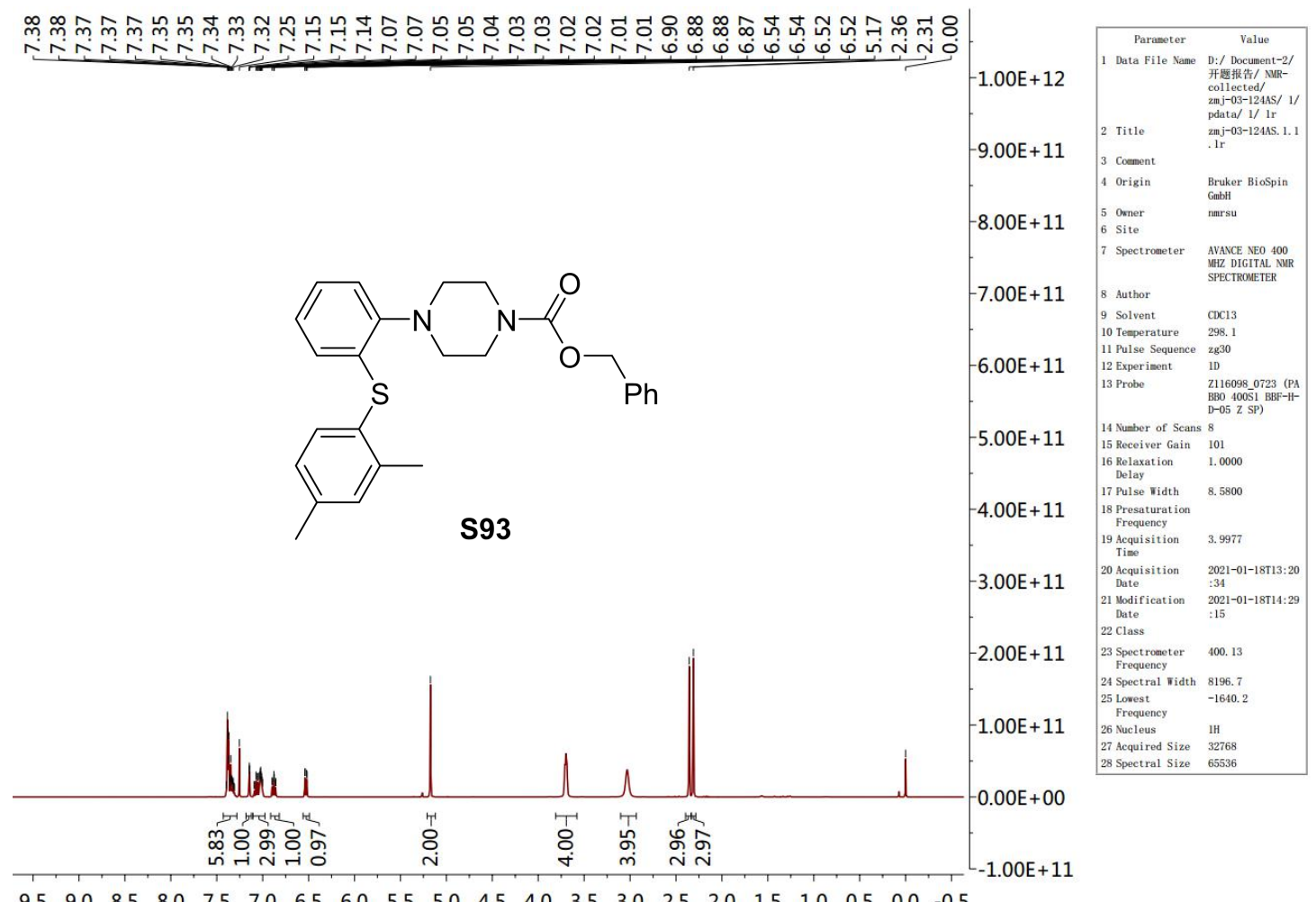

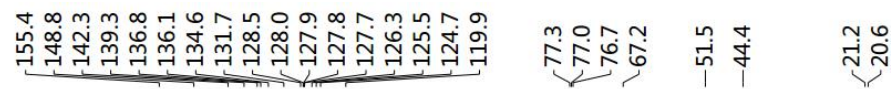

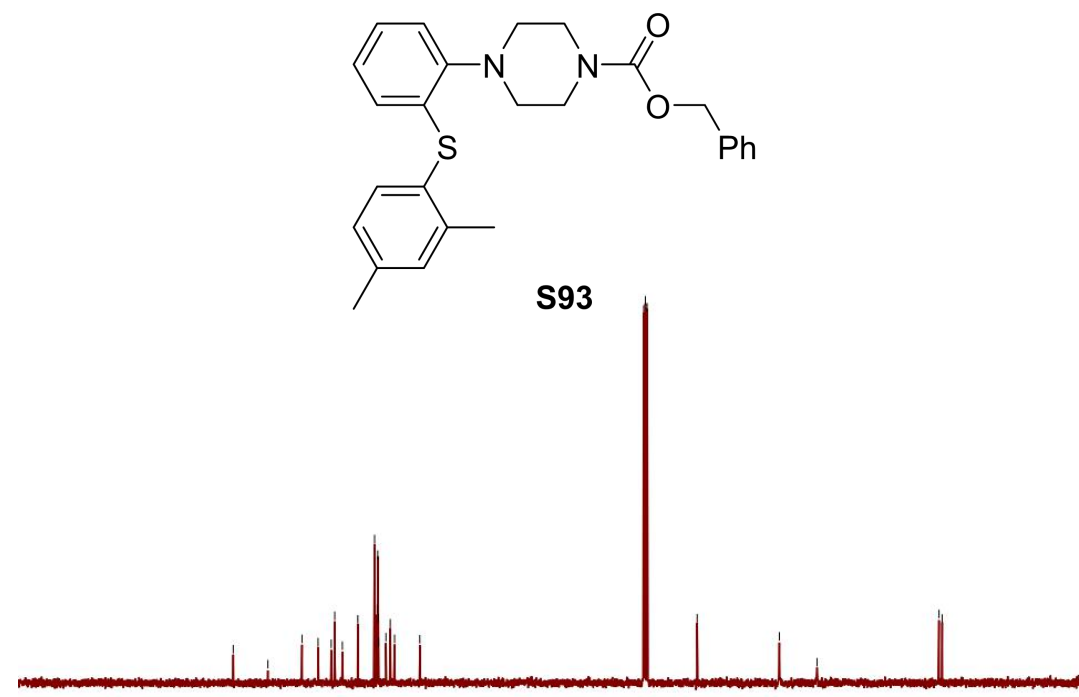

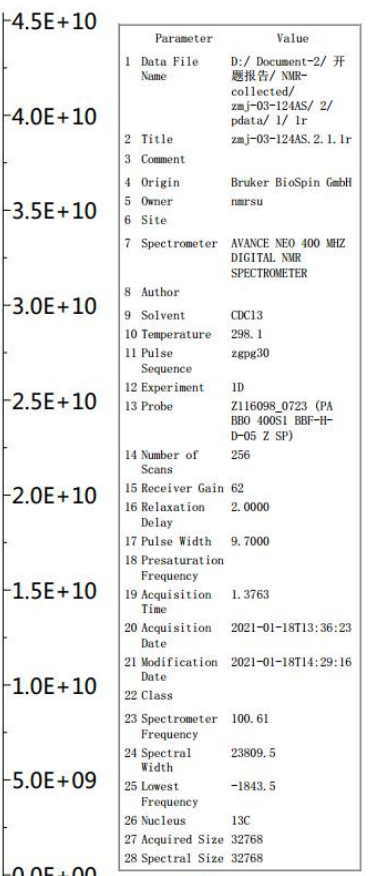

$\begin{array}{llllllllllllllllllll}190 & 180 & 170 & 160 & 150 & 140 & 130 & 120 & 110 & 100 & 90 & 80 & 70 & 60 & 50 & 40 & 30 & 20 & 10 & 0\end{array}$ 


\section{4-Ethylphenyl}

4-((5S,8R,9S,10S,13R,14S)-10,13-dimethyl-3,7,12-trioxohexadecahydro-1H-cyclopenta[a]phe nanthren-17-yl)pentanoate (S96)
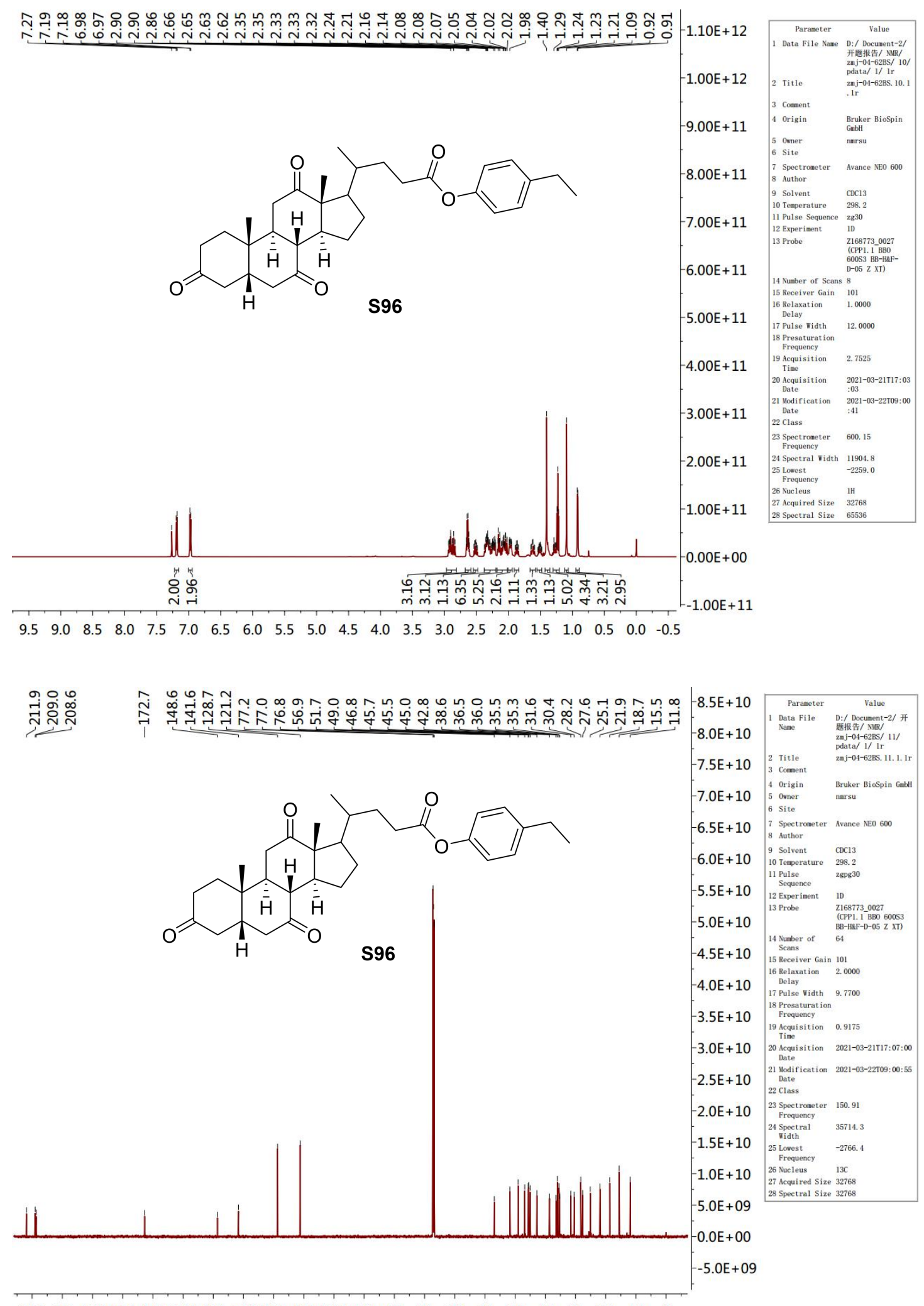

$210200190180170160150140130120110100 \quad 90 \quad 80 \quad 70 \quad 60 \quad 50 \quad 40 \quad 30 \quad 20 \quad 10 \quad 0$ 
$(1 S, 8 R, 9 S, 10 S, 13 S, 14 S, 17 S)$-1,10,13-trimethyl-3-oxohexadecahydro-1H-cyclopenta[a]phenan thren-17-yl 2-(4-(ethylthio)phenyl)acetate (S97)
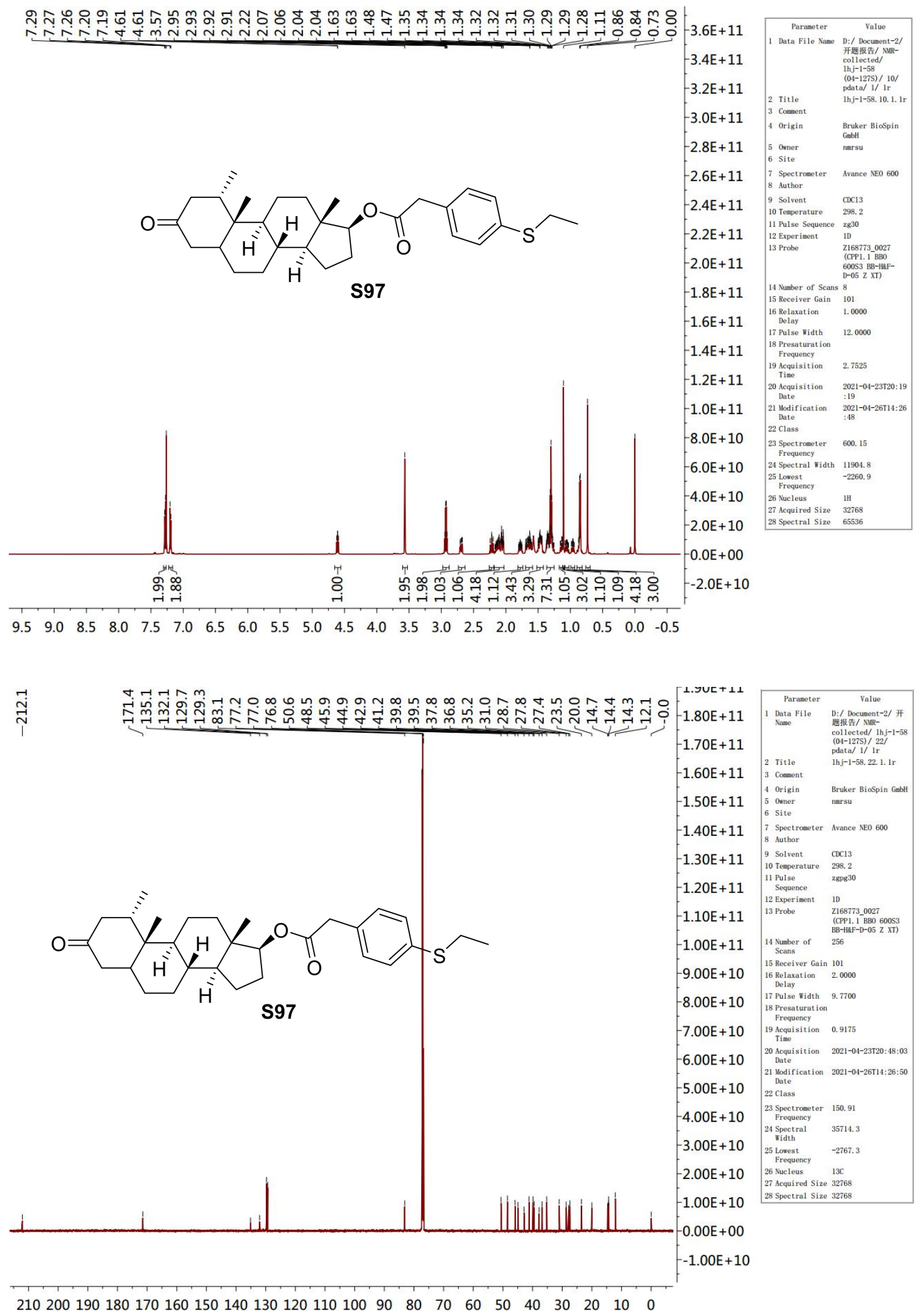
4-(Ethyl-1,1- $\left.\boldsymbol{d}_{2}\right)$ phenyl benzoate $\left(\mathrm{S} 7-\mathrm{D}_{2}\right)$

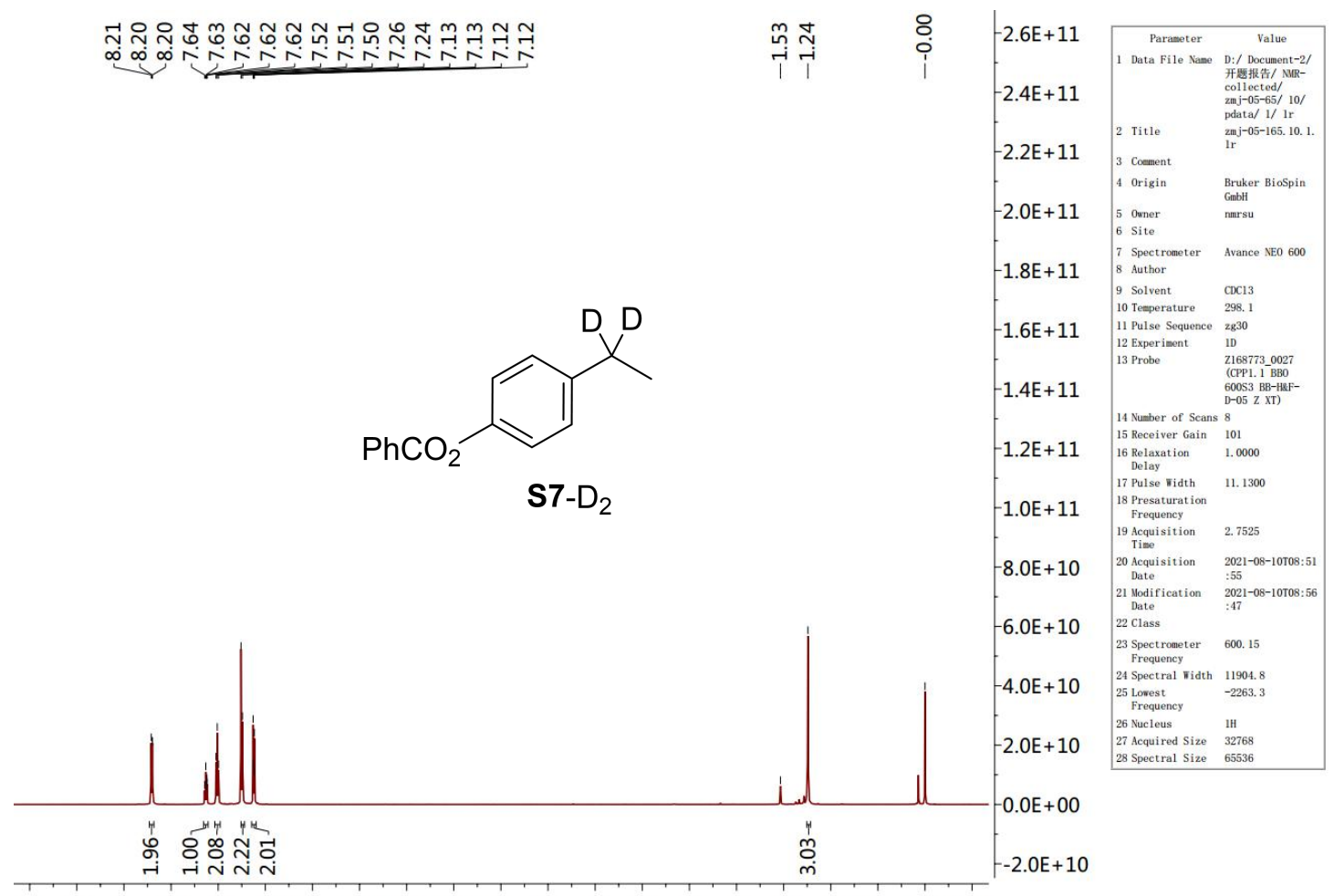

$\begin{array}{lllllllllllllllllllll}9.5 & 9.0 & 8.5 & 8.0 & 7.5 & 7.0 & 6.5 & 6.0 & 5.5 & 5.0 & 4.5 & 4.0 & 3.5 & 3.0 & 2.5 & 2.0 & 1.5 & 1.0 & 0.5 & 0.0 & -0.5\end{array}$

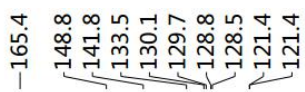
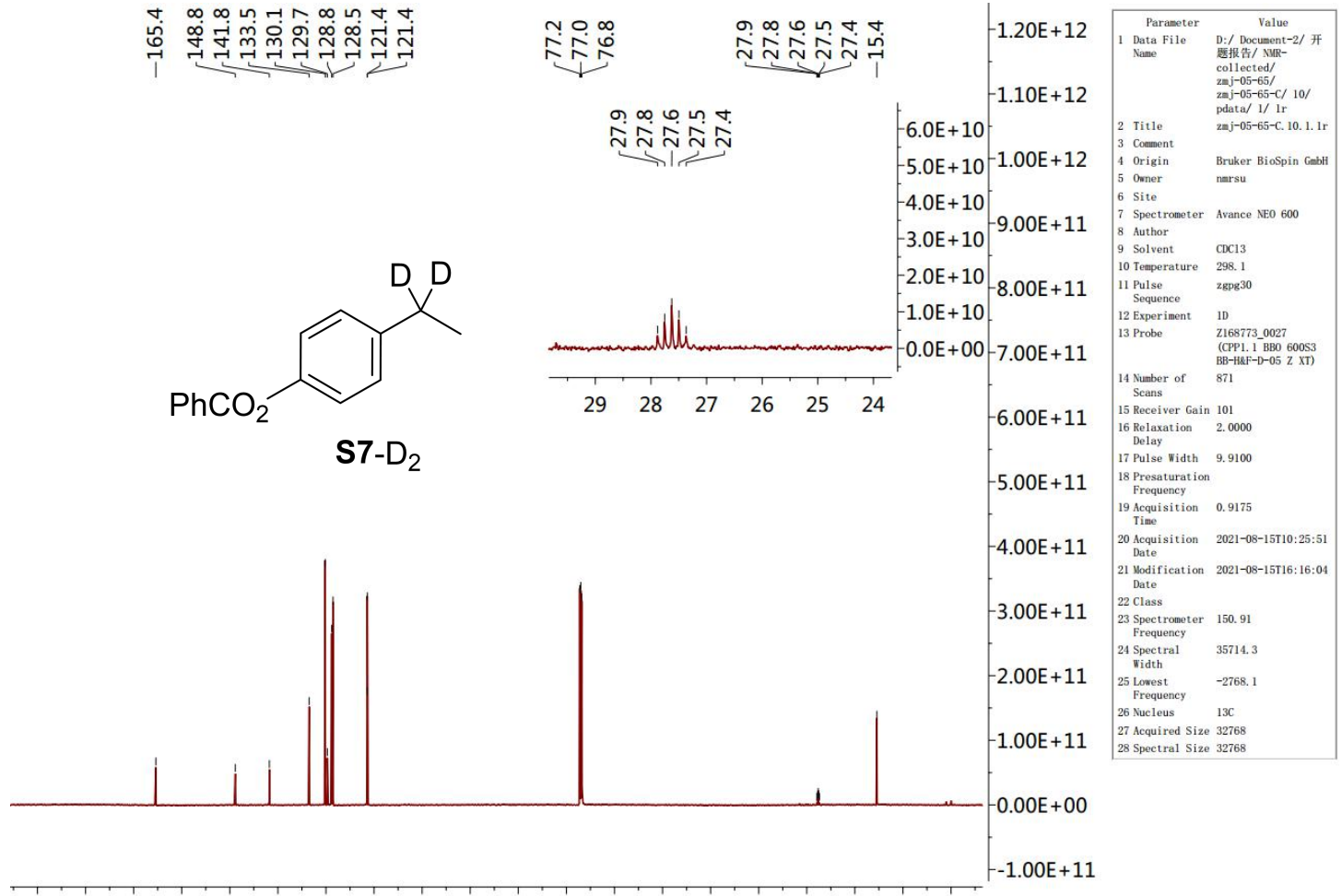

$\begin{array}{llllllllllllllllllll}190 & 180 & 170 & 160 & 150 & 140 & 130 & 120 & 110 & 100 & 90 & 80 & 70 & 60 & 50 & 40 & 30 & 20 & 10 & 0\end{array}$ 


\section{4-(Ethyl-1,1-d 2$)-1,1$ '-biphenyl $\left({\left.\mathrm{S} 9-\mathrm{D}_{2}\right)}^{2}\right.$}

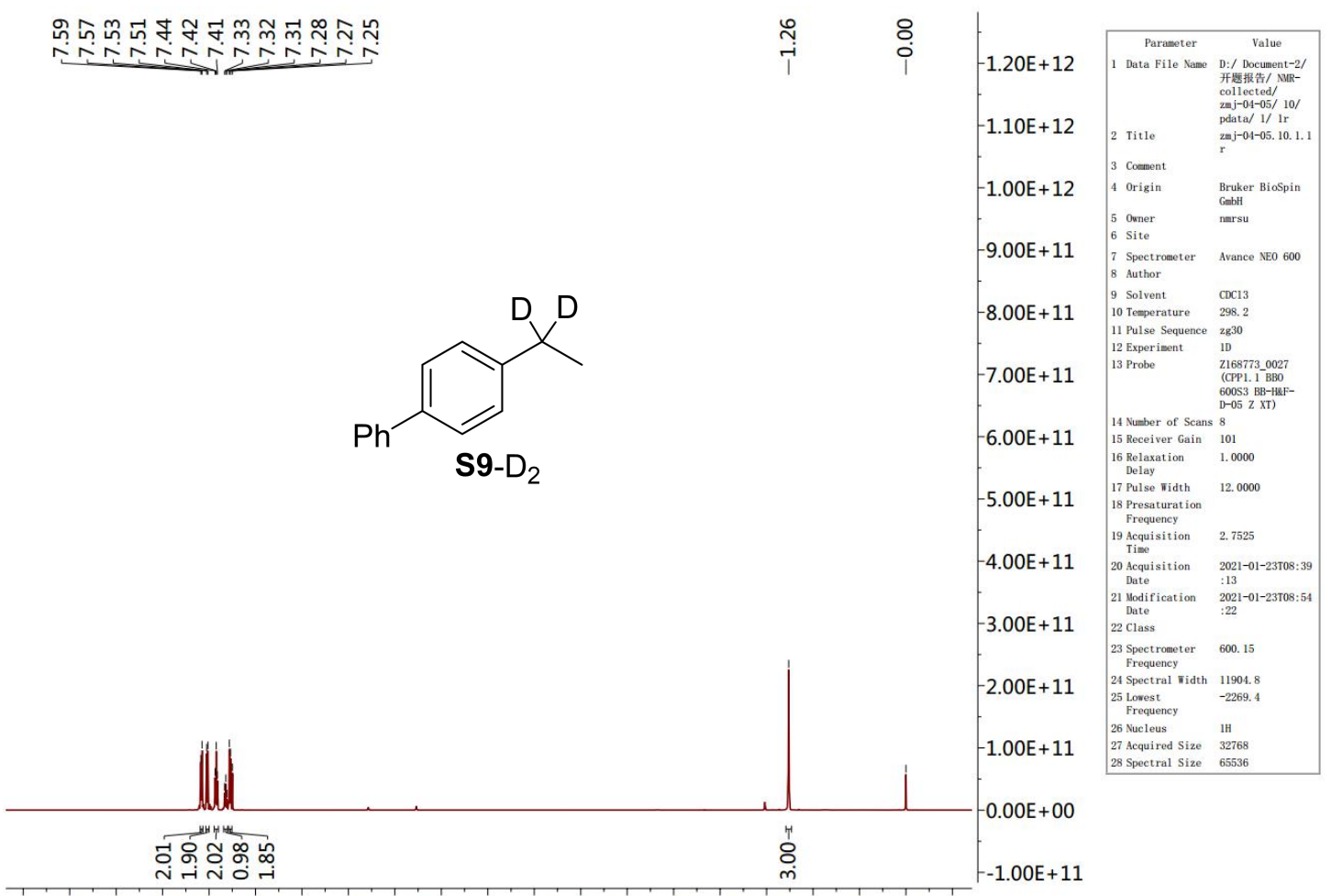

$\begin{array}{llllllllllllllllllllll}9.5 & 9.0 & 8.5 & 8.0 & 7.5 & 7.0 & 6.5 & 6.0 & 5.5 & 5.0 & 4.5 & 4.0 & 3.5 & 3.0 & 2.5 & 2.0 & 1.5 & 1.0 & 0.5 & 0.0 & -0.5\end{array}$
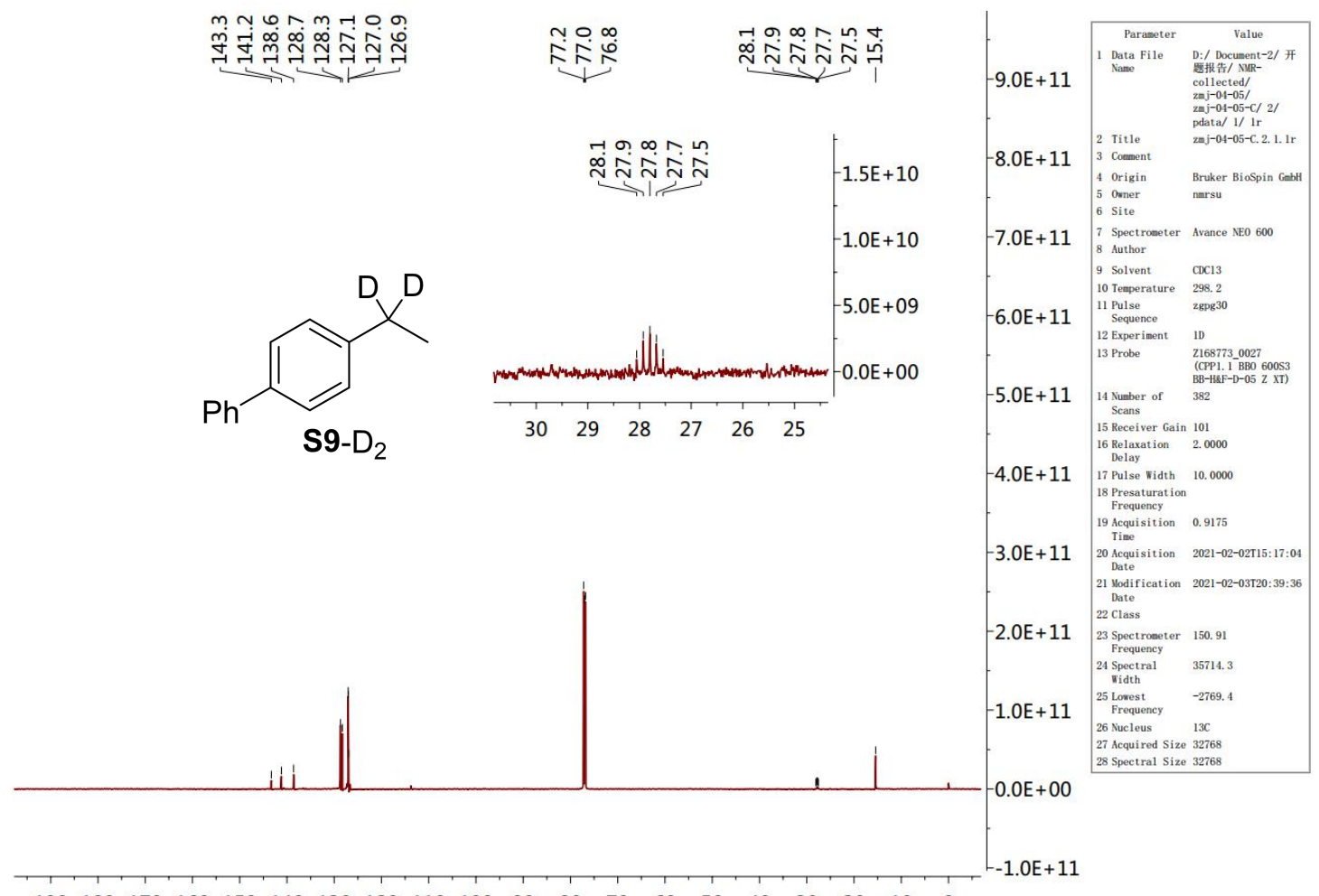

$\begin{array}{llllllllllllllllllll}190 & 180 & 170 & 160 & 150 & 140 & 130 & 120 & 110 & 100 & 90 & 80 & 70 & 60 & 50 & 40 & 30 & 20 & 10 & 0\end{array}$ 
2-Chloroanthracene-9,10-diol (D1)

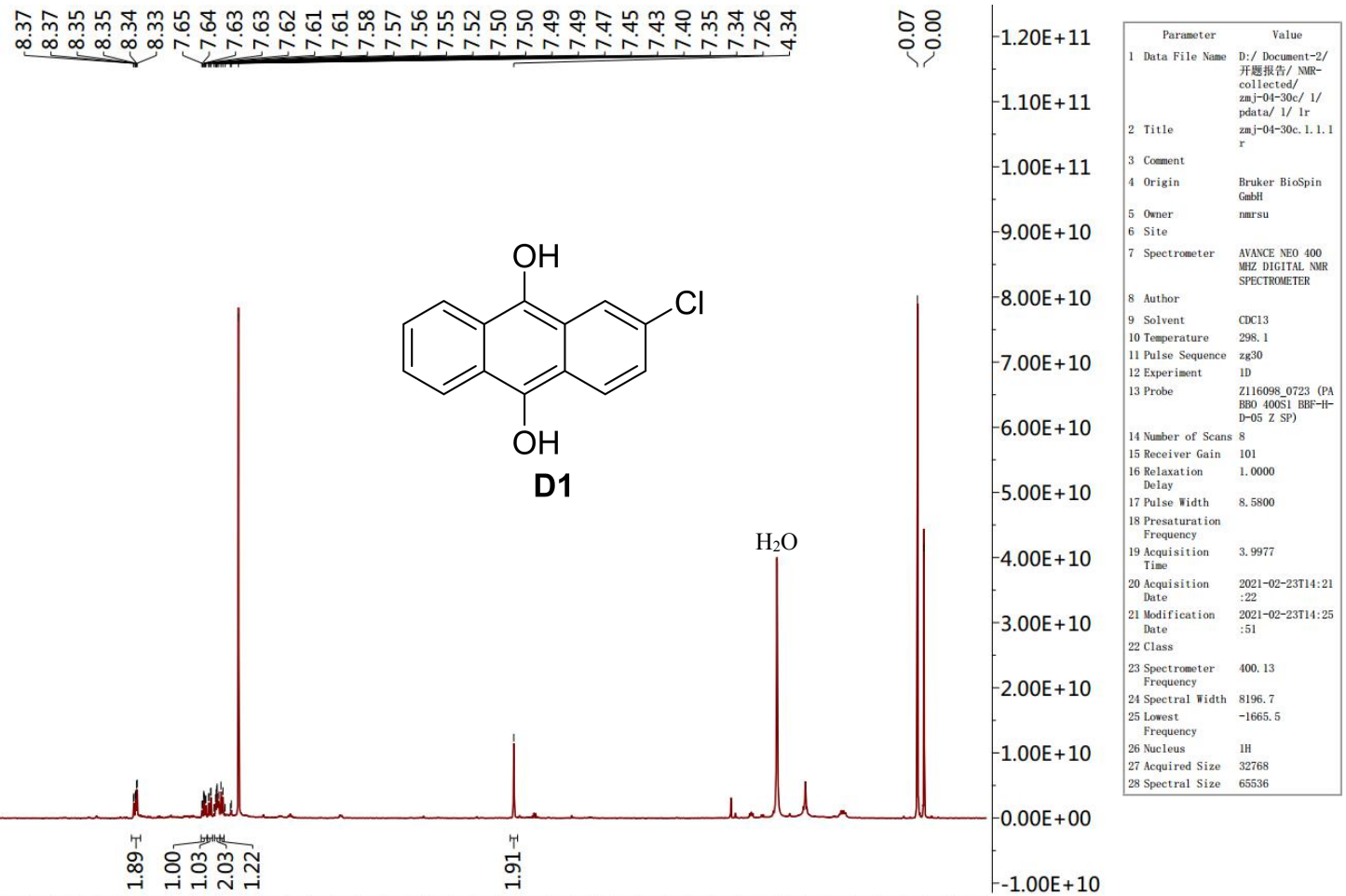

$\begin{array}{lllllllllllllllllllll}9.5 & 9.0 & 8.5 & 8.0 & 7.5 & 7.0 & 6.5 & 6.0 & 5.5 & 5.0 & 4.5 & 4.0 & 3.5 & 3.0 & 2.5 & 2.0 & 1.5 & 1.0 & 0.5 & 0.0 & -0.5\end{array}$ 

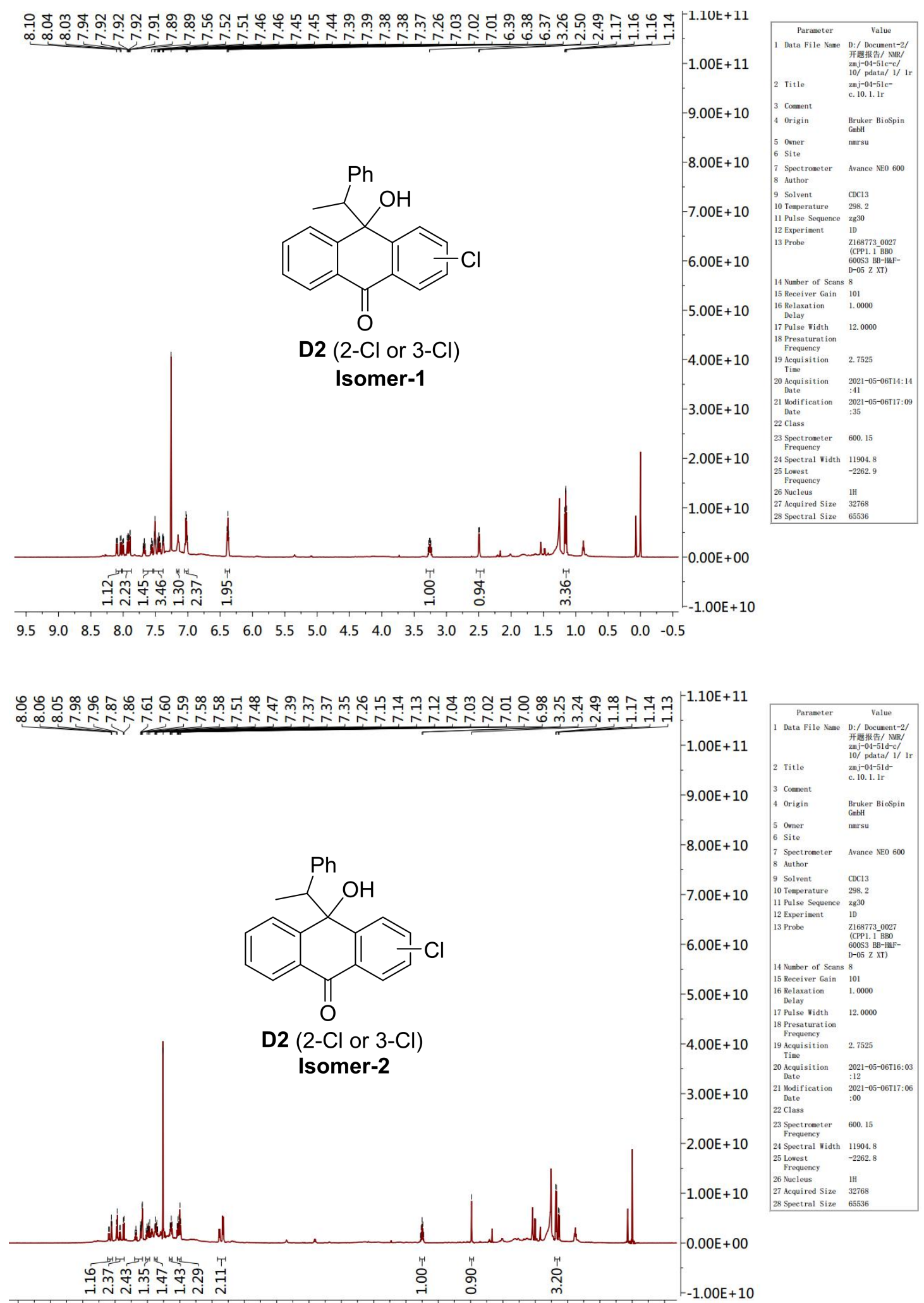

$\begin{array}{llllllllllllllllllllll}9.5 & 9.0 & 8.5 & 8.0 & 7.5 & 7.0 & 6.5 & 6.0 & 5.5 & 5.0 & 4.5 & 4.0 & 3.5 & 3.0 & 2.5 & 2.0 & 1.5 & 1.0 & 0.5 & 0.0 & -0.5\end{array}$ 

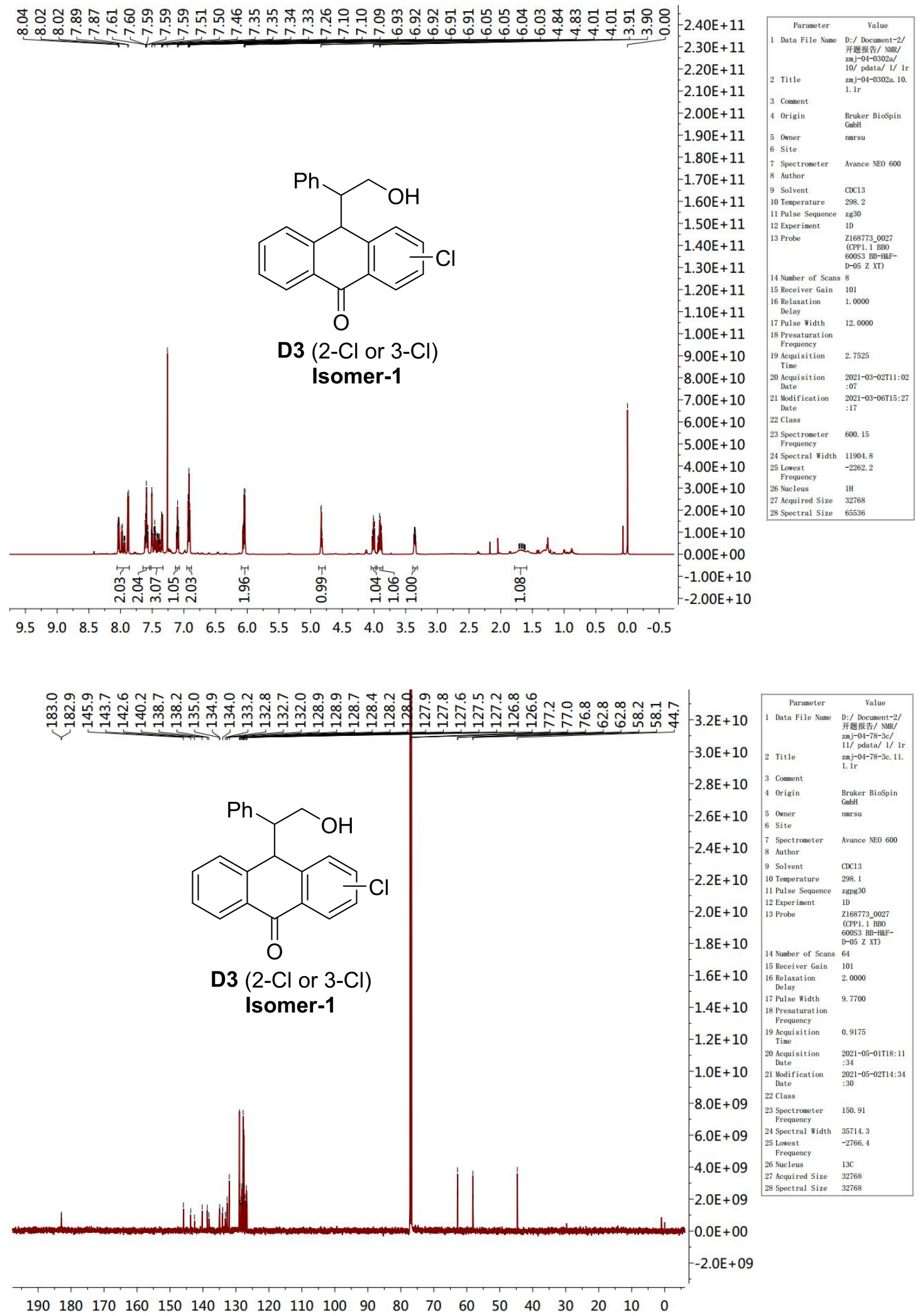

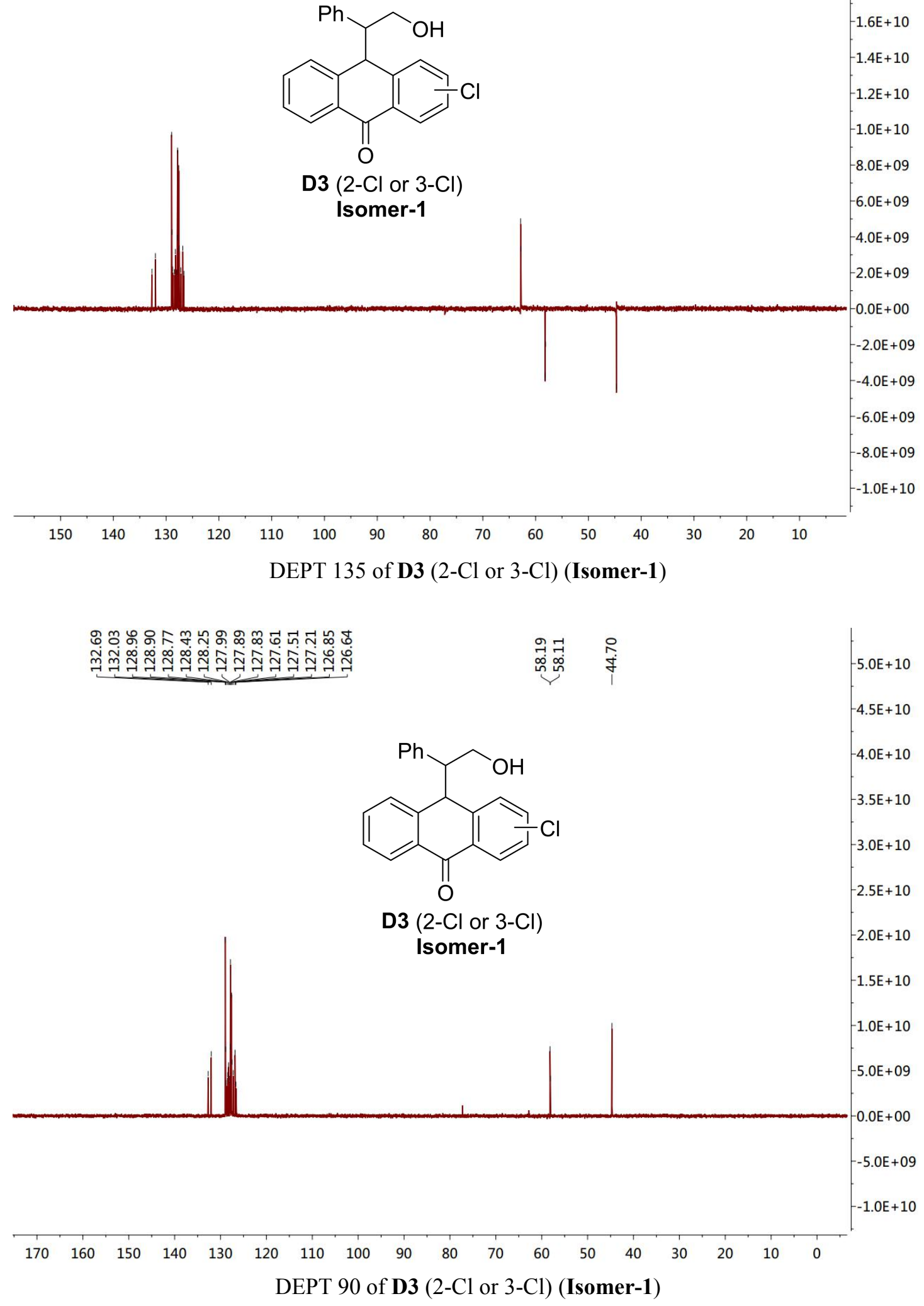
<smiles>CC1(C)C2CCCCC21</smiles>

$1.90 \mathrm{t}+11$

Isomer-2
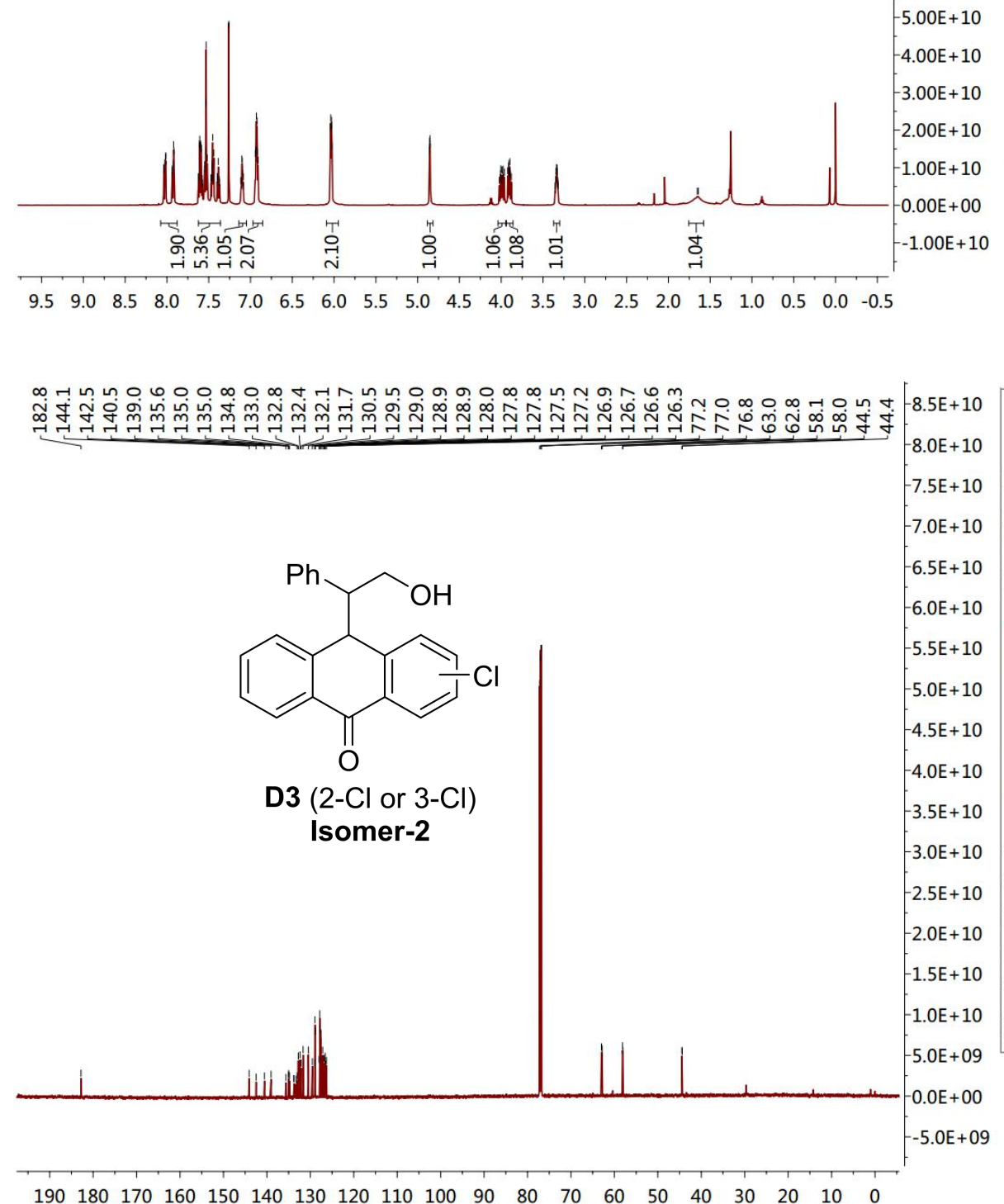

8 Author

$\begin{array}{ll}9 \text { S Solvent } & \text { CDC13 } \\ 10 \text { Temperature } & 298.1\end{array}$

11 Pulse
Sequence

12 Experiment ID

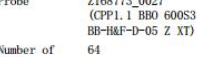

Scans of 04

$\begin{array}{ll}15 \text { Receiver Gain } & 101 \\ 16 \text { Relaxation } & 2.0000\end{array}$

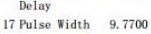

18 Presaturation
Frequency

19 Acquisition $\quad 0.9175$

Time 1 cquis ition 2021-05-01114:41:32

Wodification $2021-05-06719 \cdot 37 \cdot 26$

$.5 \mathrm{E}+10$

$2.0 \mathrm{E}+10$

Spectrometer 150.91

Frequency
Spectral 35714.3

(a) ancy

27 Acquired Size 32768

$\begin{array}{llllllllllllllllllll}190 & 180 & 170 & 160 & 150 & 140 & 130 & 120 & 110 & 100 & 90 & 80 & 70 & 60 & 50 & 40 & 30 & 20 & 10 & 0\end{array}$ 
<smiles>Cc1ccc2c(c1)C(C(CO)c1ccccc1)c1ccccc1C2=O</smiles><smiles>O=C1c2ccccc2C(C(CO)c2ccccc2)c2ccccc21</smiles>

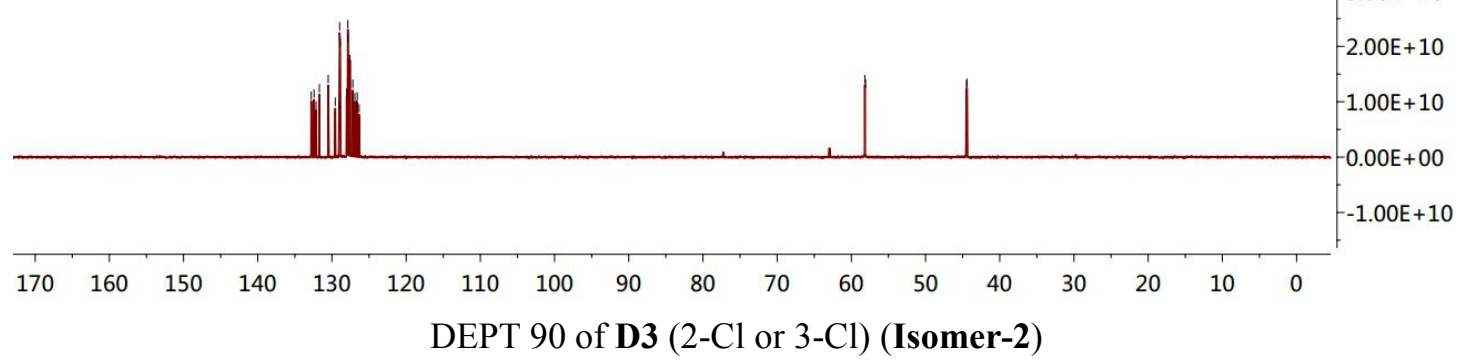




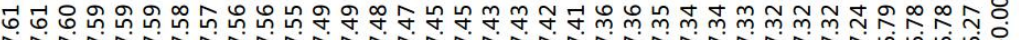

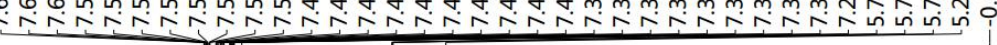<smiles>[2H]C(=C)c1ccc(-c2ccccc2)cc1</smiles>

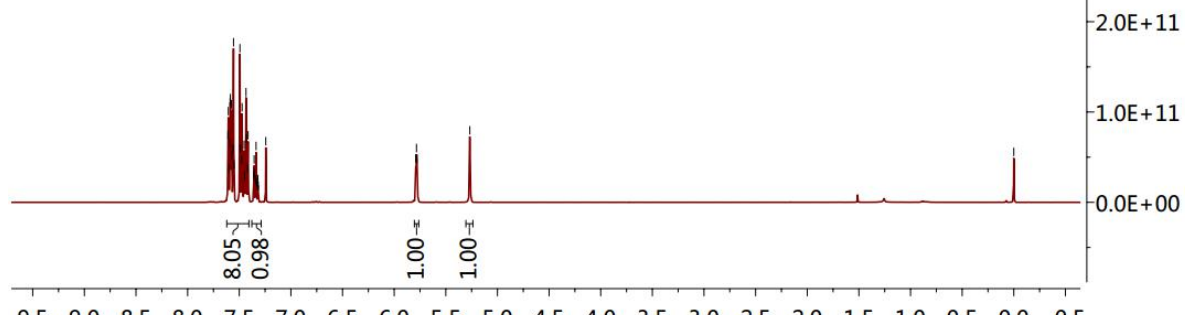

$\begin{array}{lllllllllllllllllllll}9.5 & 9.0 & 8.5 & 8.0 & 7.5 & 7.0 & 6.5 & 6.0 & 5.5 & 5.0 & 4.5 & 4.0 & 3.5 & 3.0 & 2.5 & 2.0 & 1.5 & 1.0 & 0.5 & 0.0 & -0.5\end{array}$

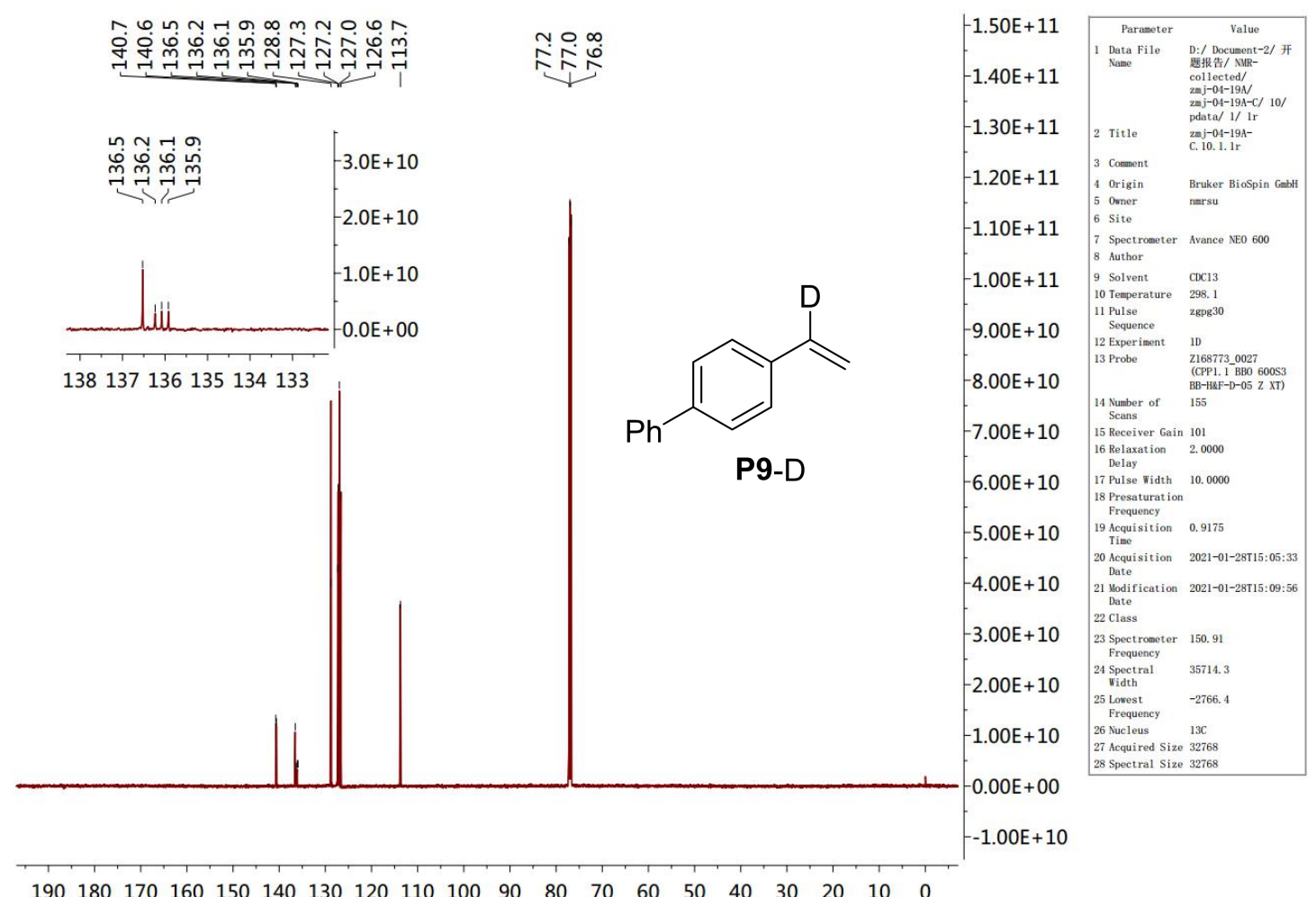




\section{4-Vinylphenol (P2)}

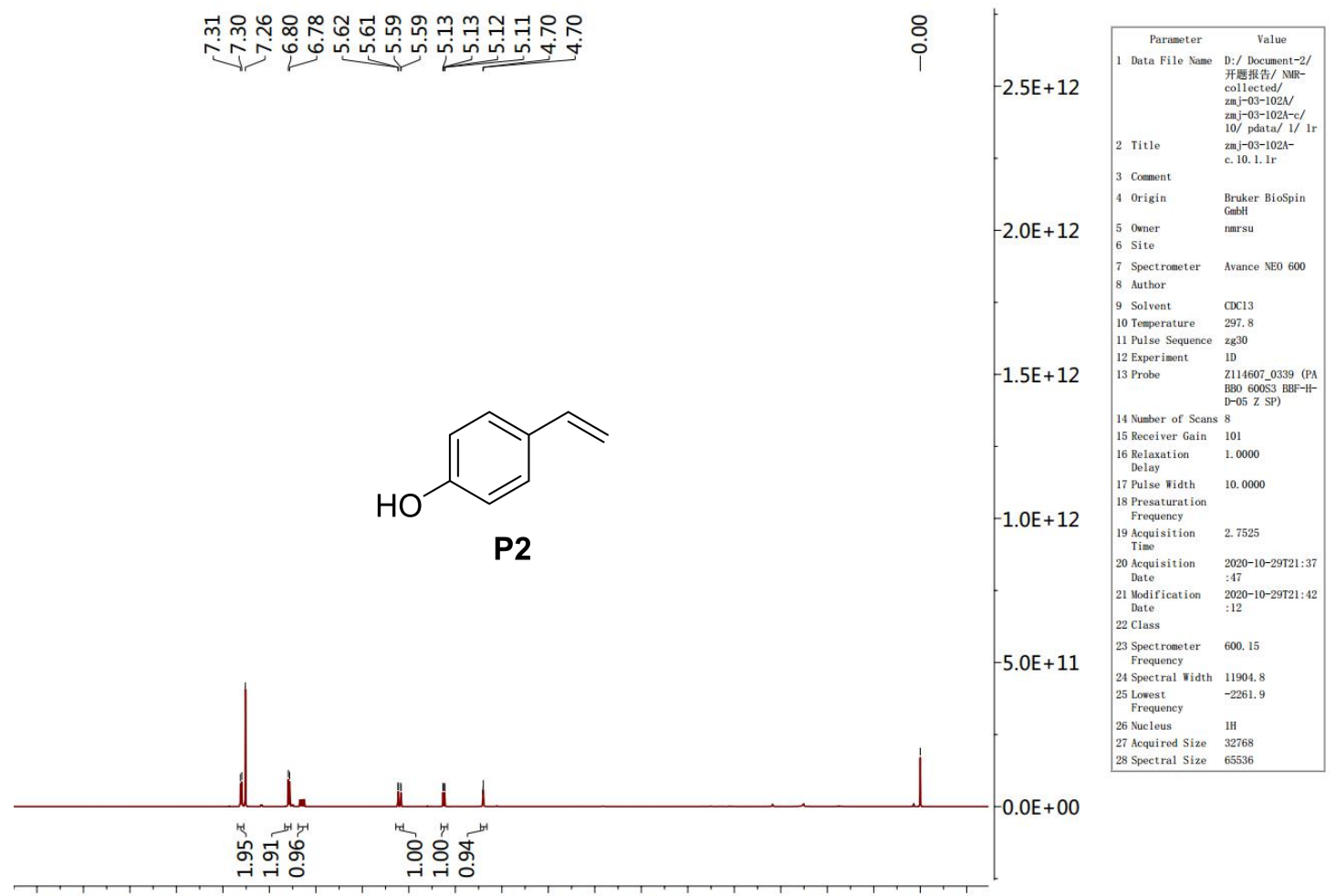

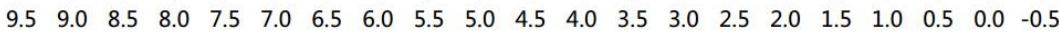

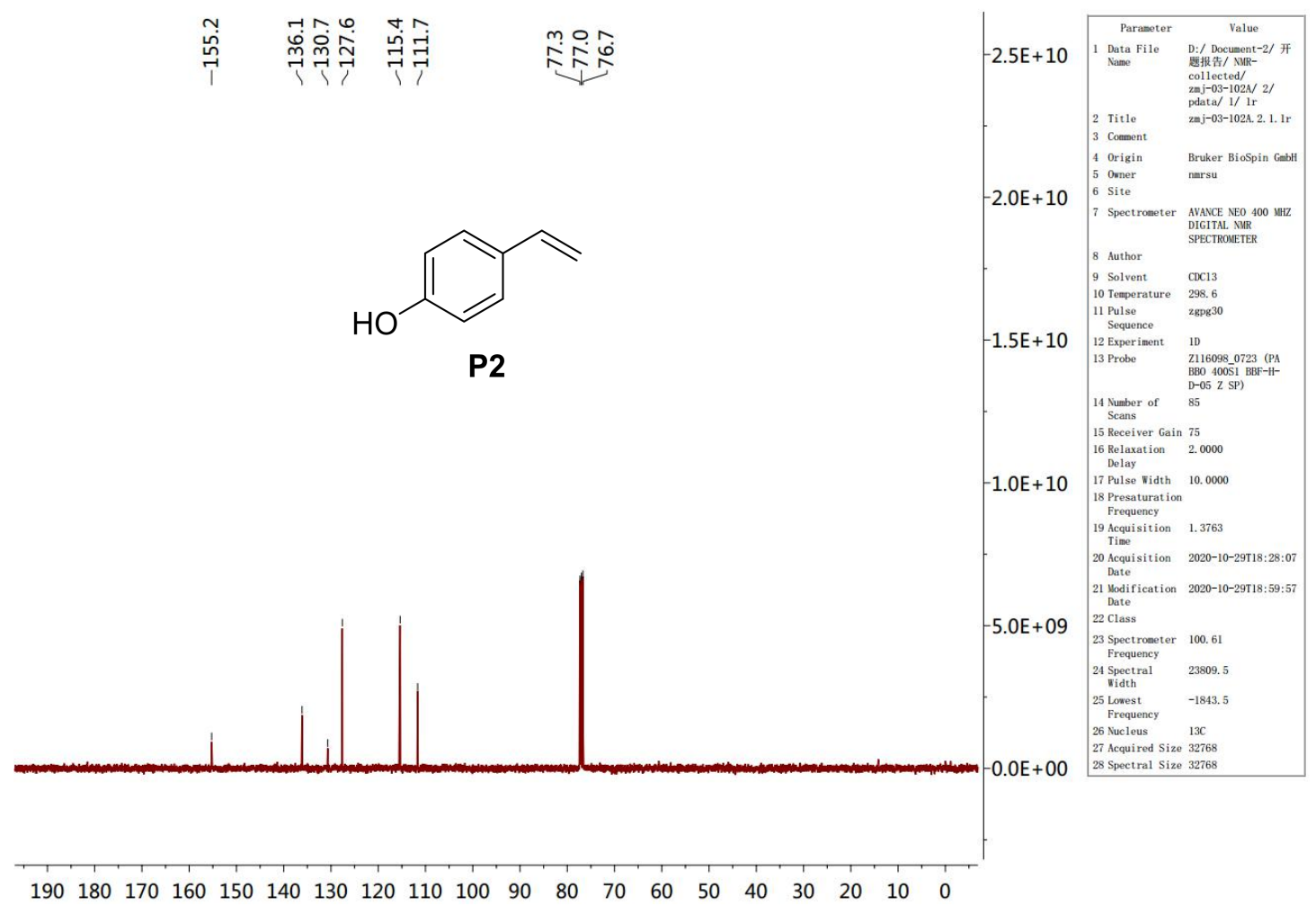


1-Methoxy-4-vinylbenzene (P3)

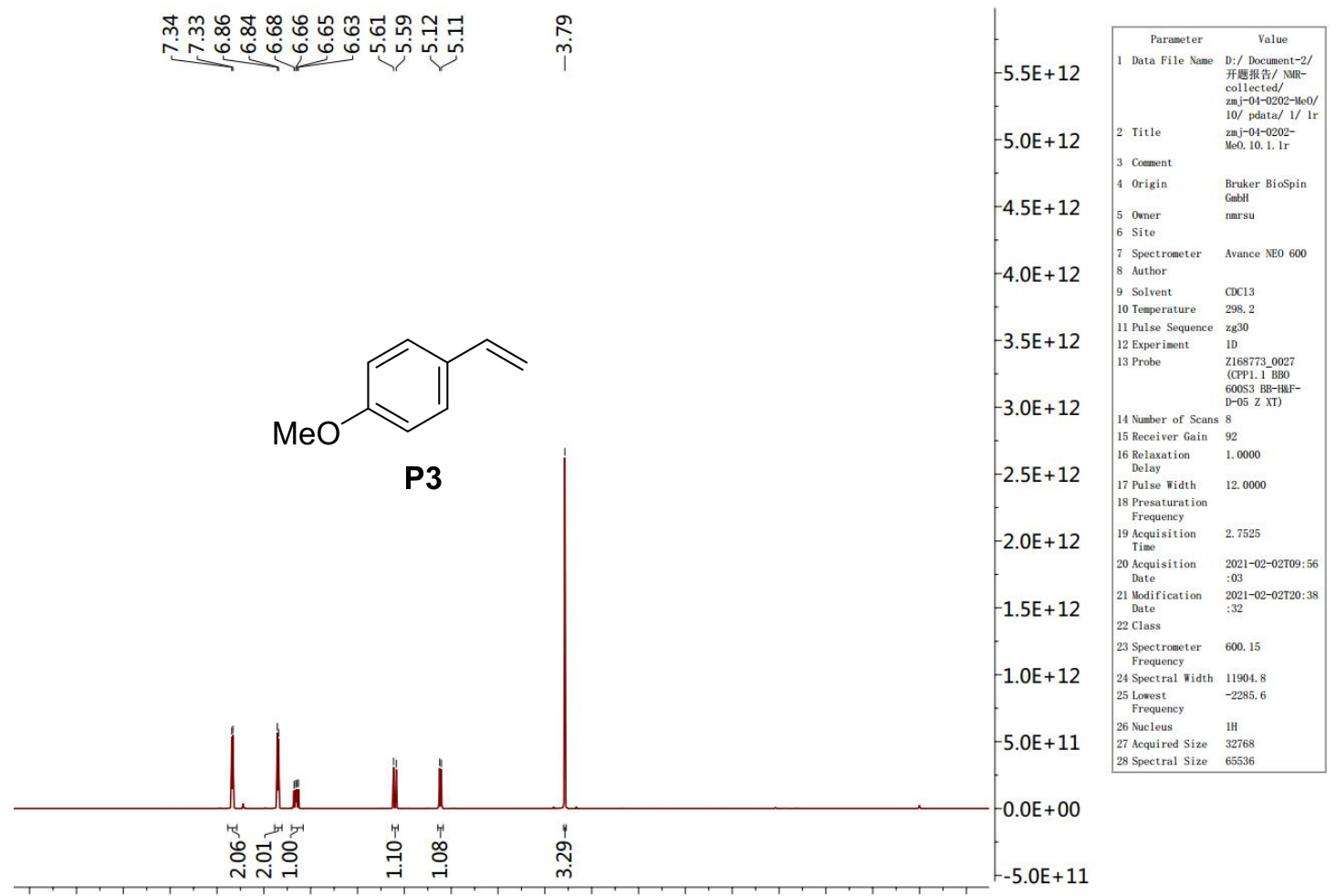

$\begin{array}{lllllllllllllllllllll}9.5 & 9.0 & 8.5 & 8.0 & 7.5 & 7.0 & 6.5 & 6.0 & 5.5 & 5.0 & 4.5 & 4.0 & 3.5 & 3.0 & 2.5 & 2.0 & 1.5 & 1.0 & 0.5 & 0.0 & -0.5\end{array}$

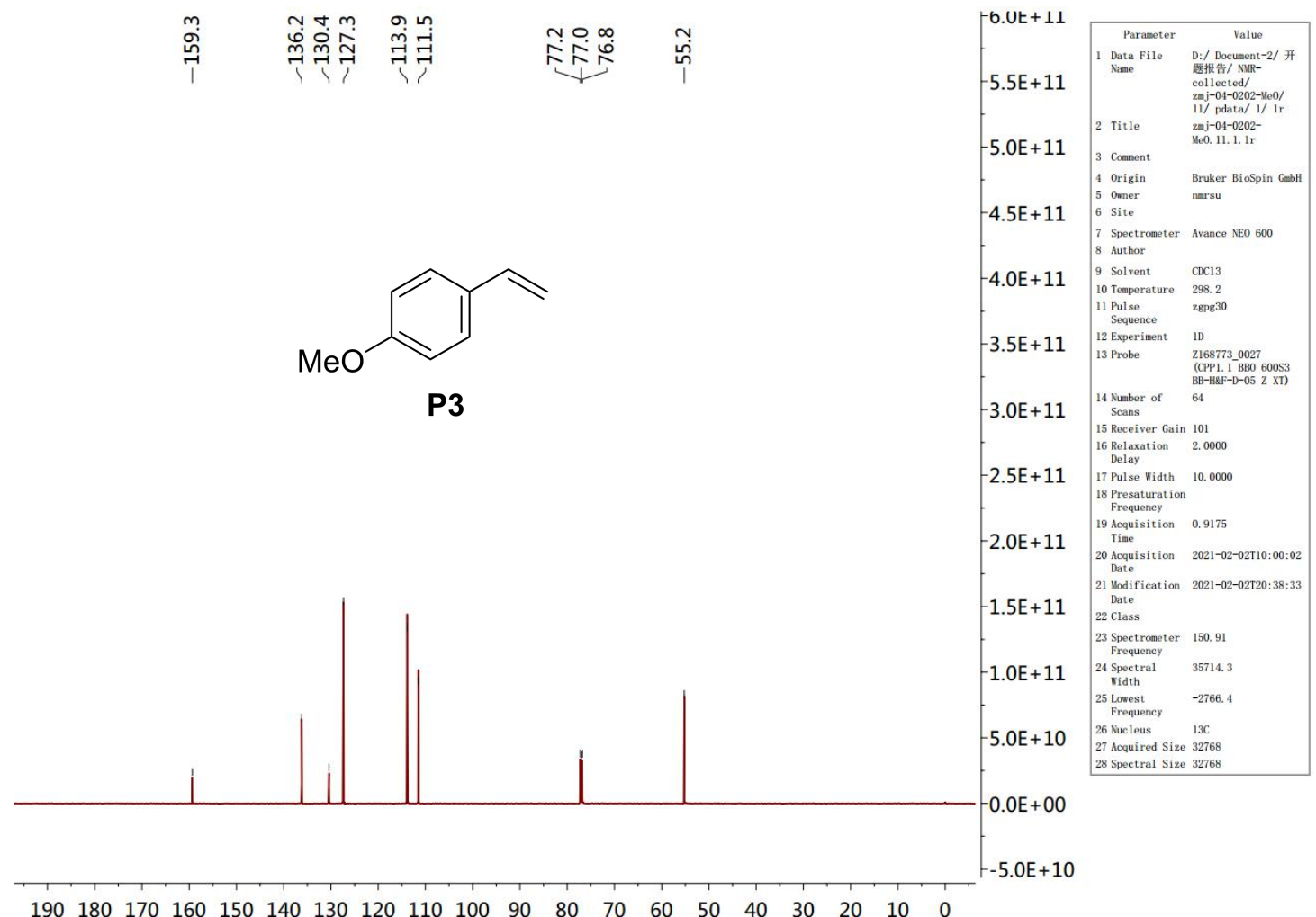

$\begin{array}{llllllllllllllllllll}190 & 180 & 170 & 160 & 150 & 140 & 130 & 120 & 110 & 100 & 90 & 80 & 70 & 60 & 50 & 40 & 30 & 20 & 10 & 0\end{array}$ 

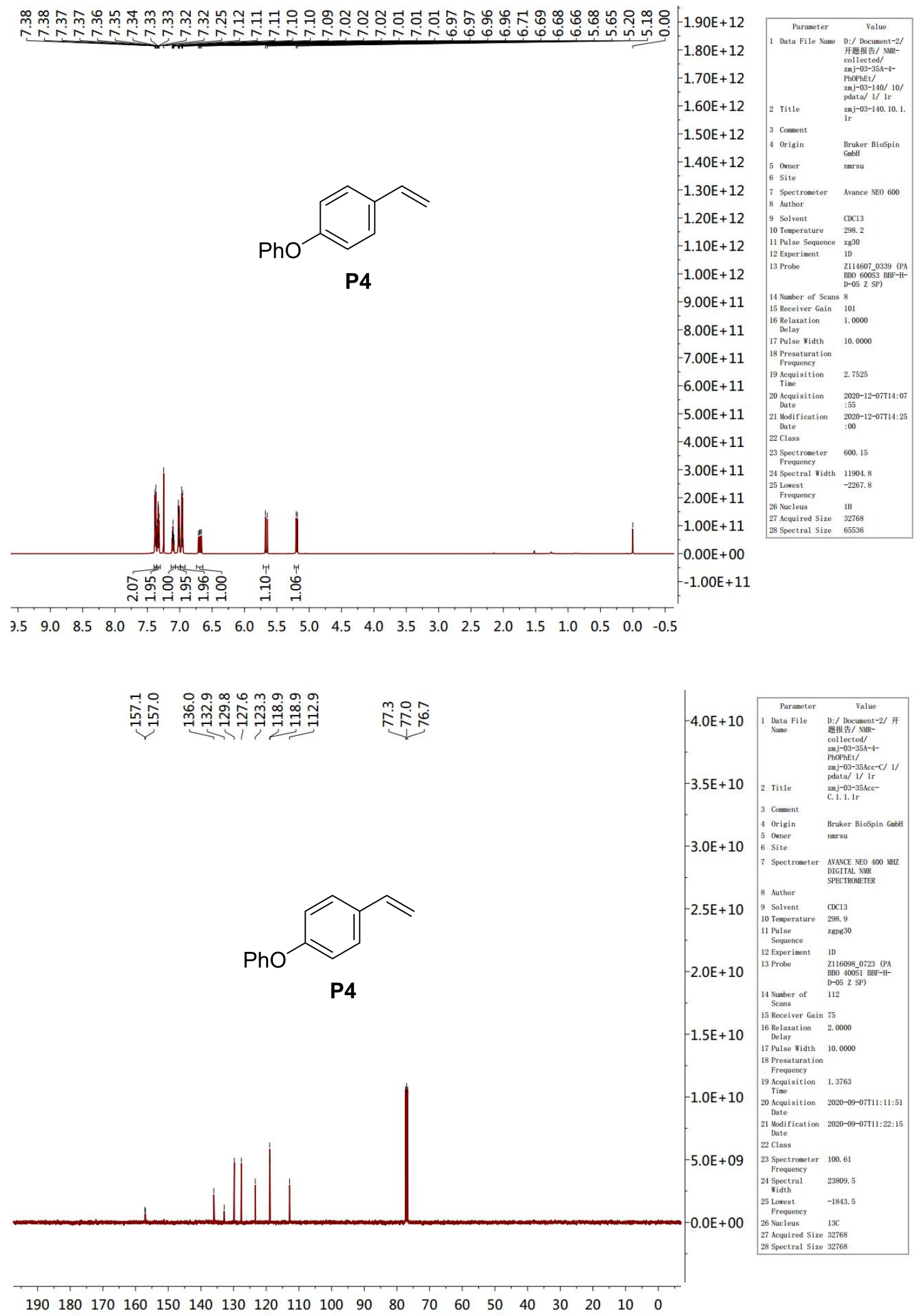
tert-Butyldimethyl(4-vinylphenoxy)silane (P5)

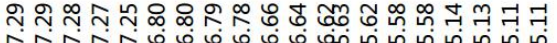

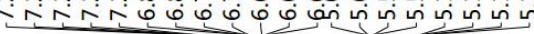

ڤ̊ำ<smiles>C=Cc1ccc(OC(C)(C)C)cc1</smiles>

P5
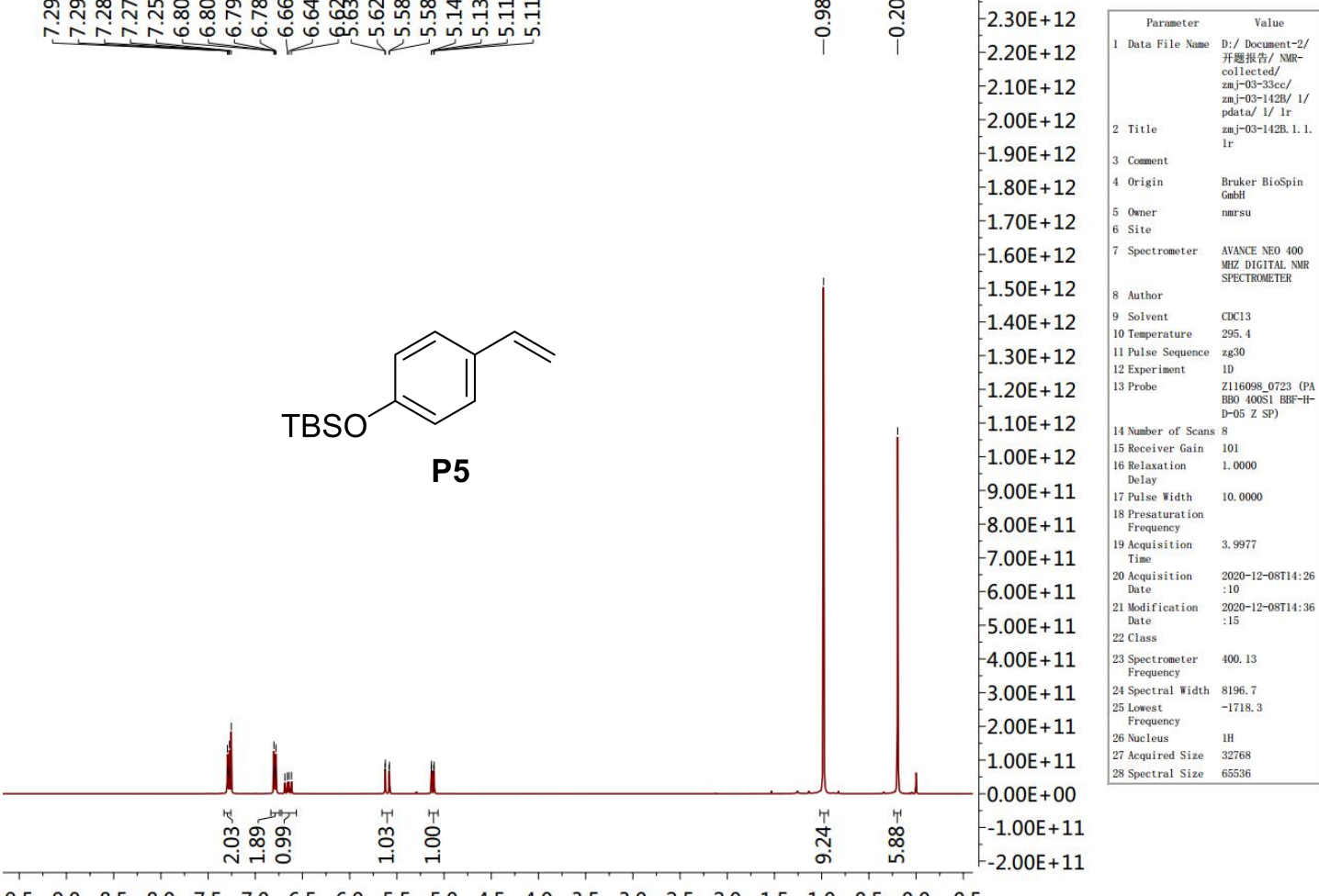

$\begin{array}{lllllllllllllllllllll}9.5 & 9.0 & 8.5 & 8.0 & 7.5 & 7.0 & 6.5 & 6.0 & 5.5 & 5.0 & 4.5 & 4.0 & 3.5 & 3.0 & 2.5 & 2.0 & 1.5 & 1.0 & 0.5 & 0.0 & -0.5\end{array}$

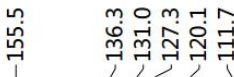

ํㅗㅇํำ

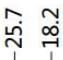

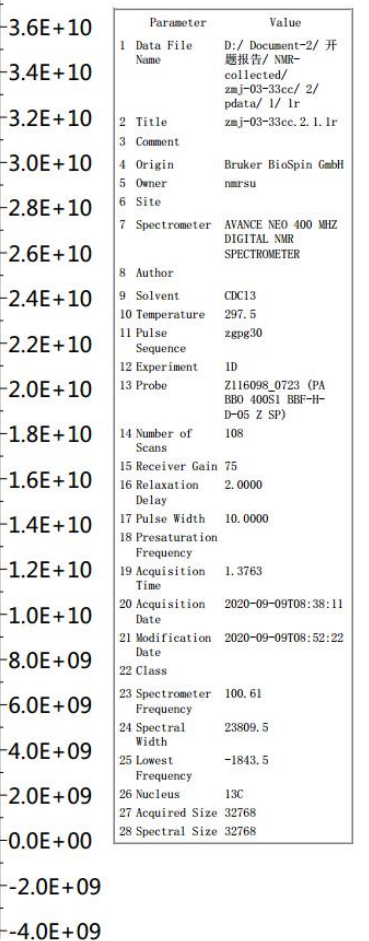

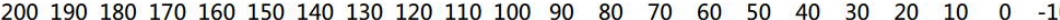




\section{$\mathrm{N}$-(4-vinylphenyl)acetamide (P6)}
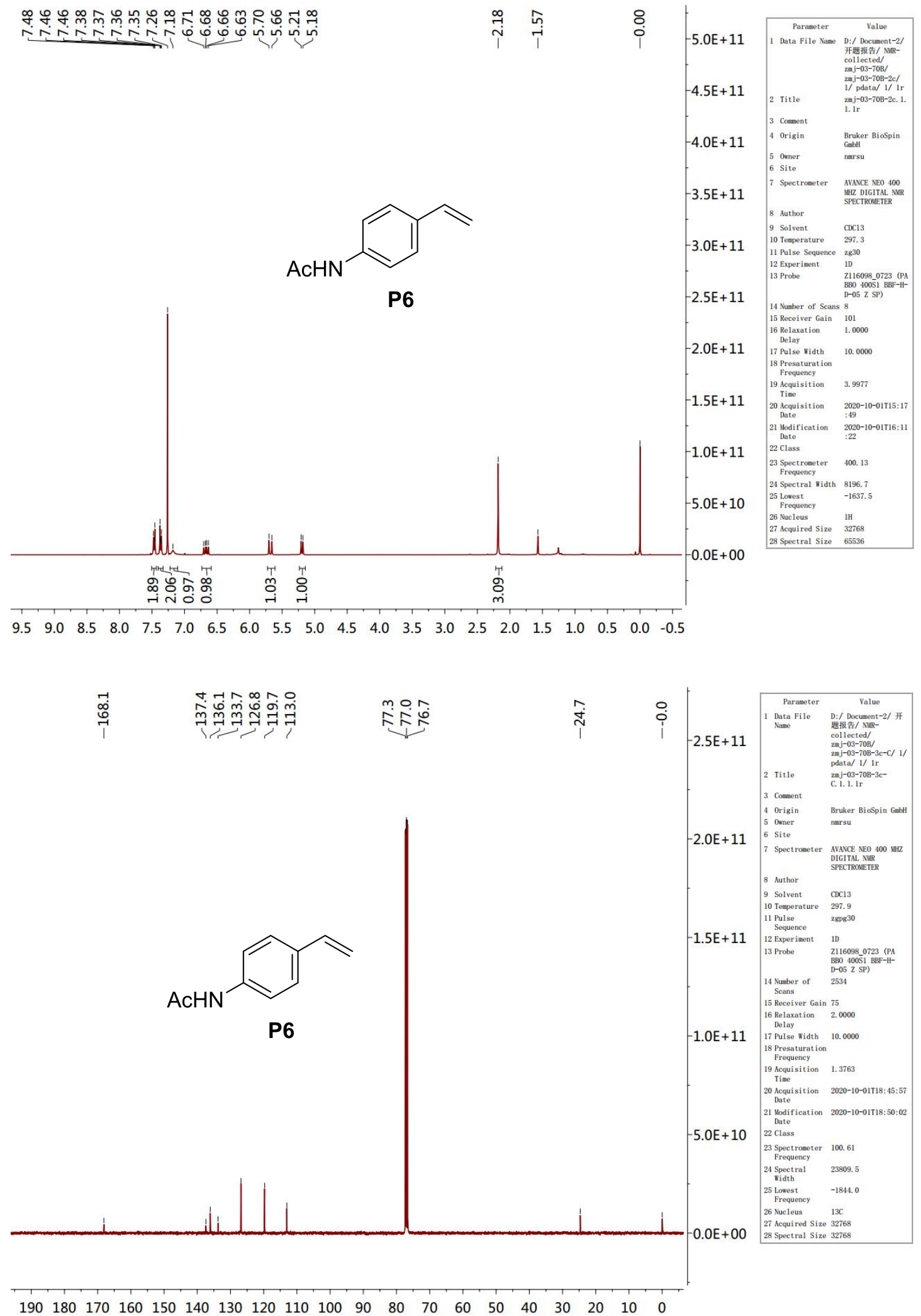


\section{4-Vinylphenyl benzoate (P7)}
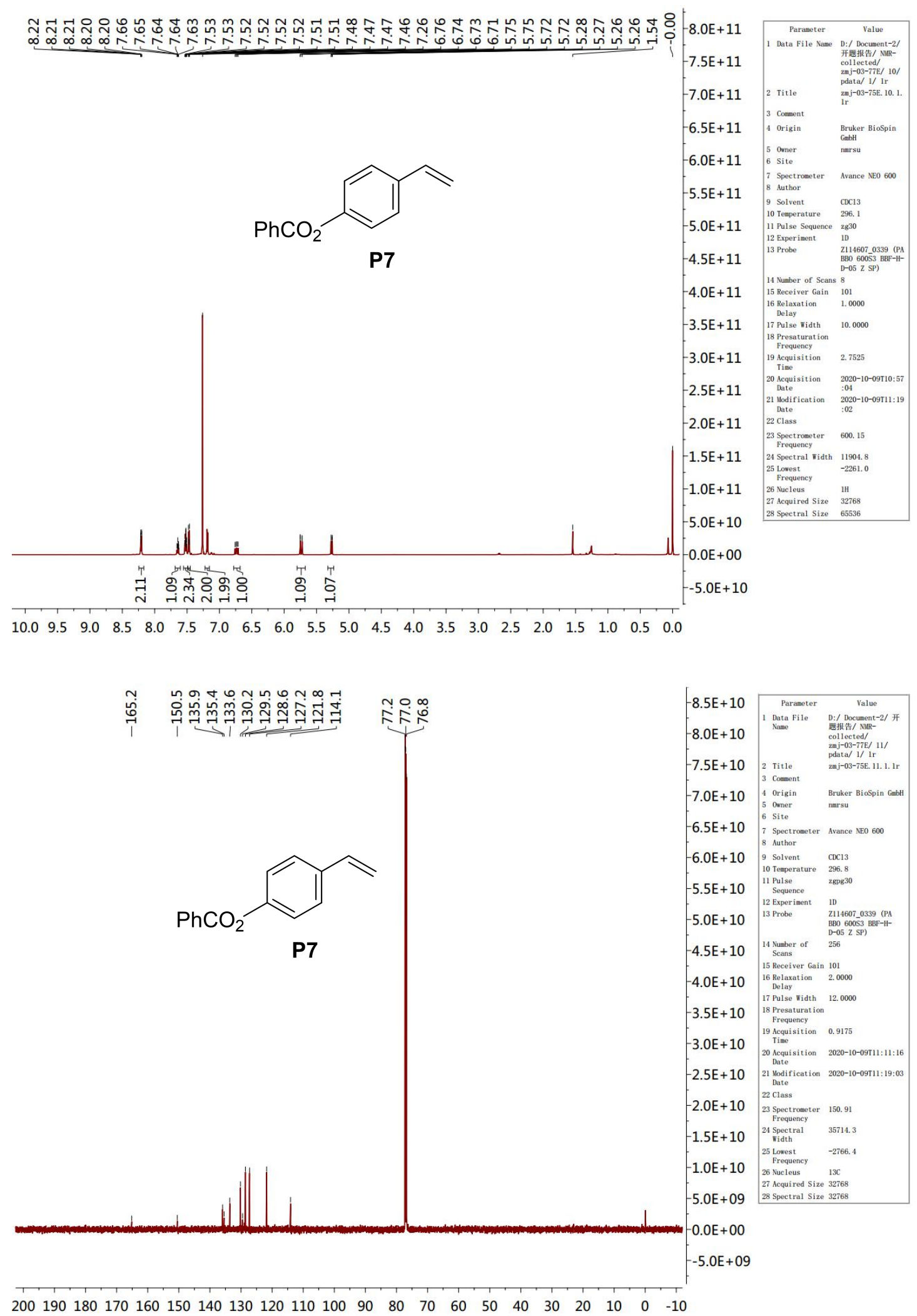


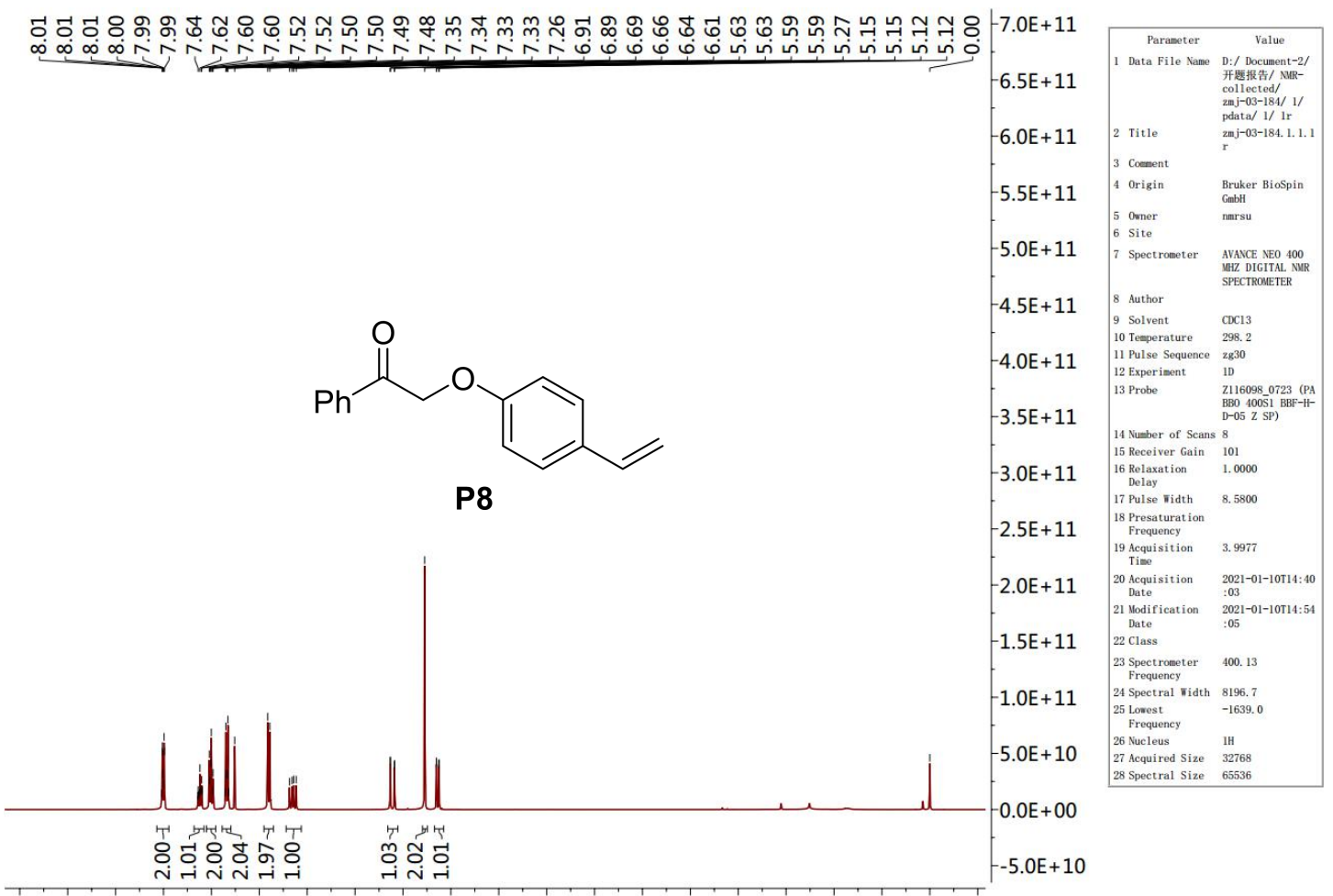

$\begin{array}{lllllllllllllllllllll}9.5 & 9.0 & 8.5 & 8.0 & 7.5 & 7.0 & 6.5 & 6.0 & 5.5 & 5.0 & 4.5 & 4.0 & 3.5 & 3.0 & 2.5 & 2.0 & 1.5 & 1.0 & 0.5 & 0.0 & -0.5\end{array}$

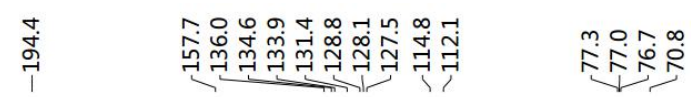<smiles>C=Cc1ccc(OCC(=O)c2ccccc2)cc1</smiles>

P8
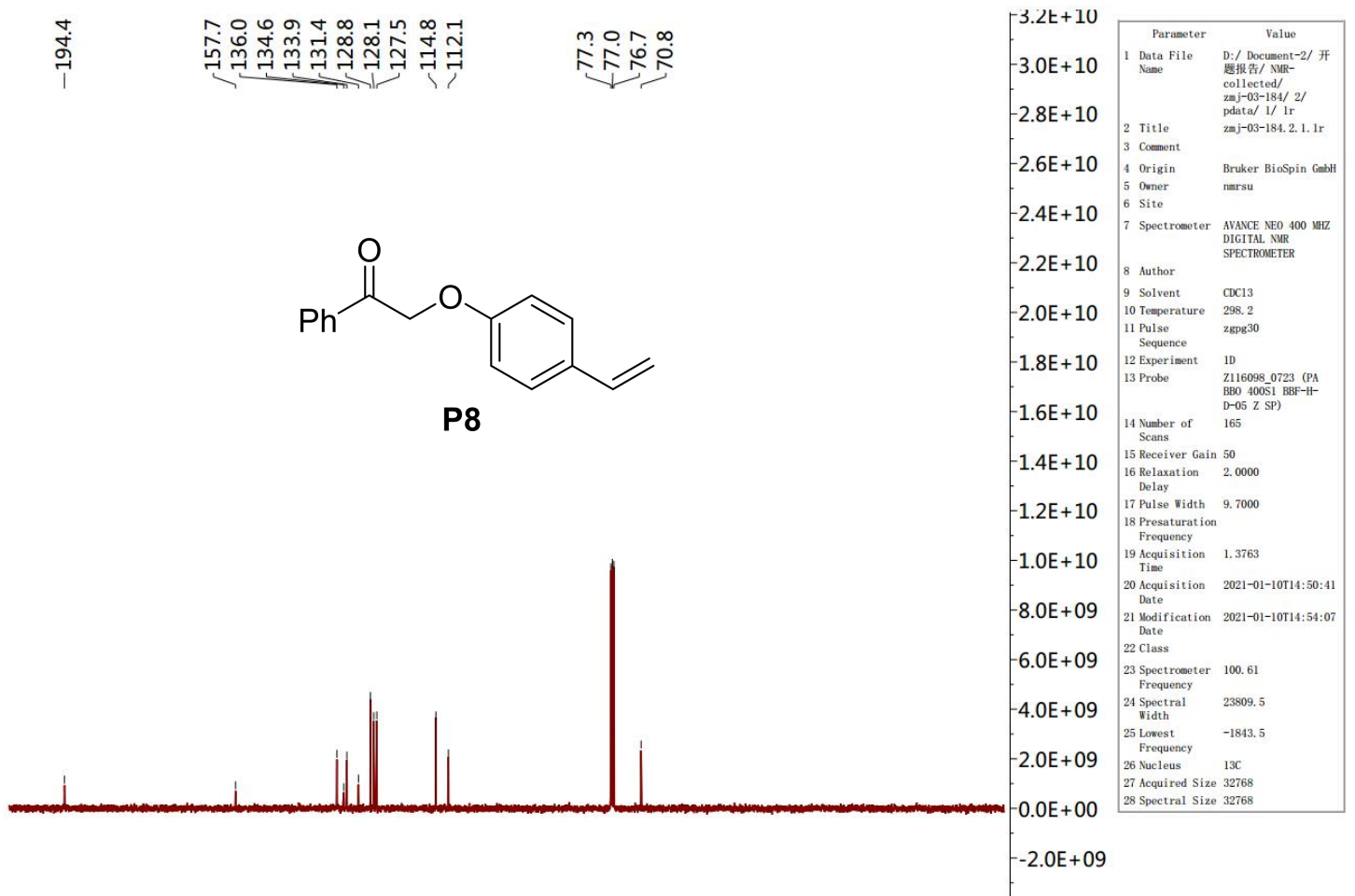

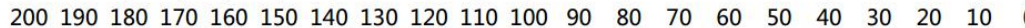




\section{4-Vinyl-1,1'-biphenyl (P9)}

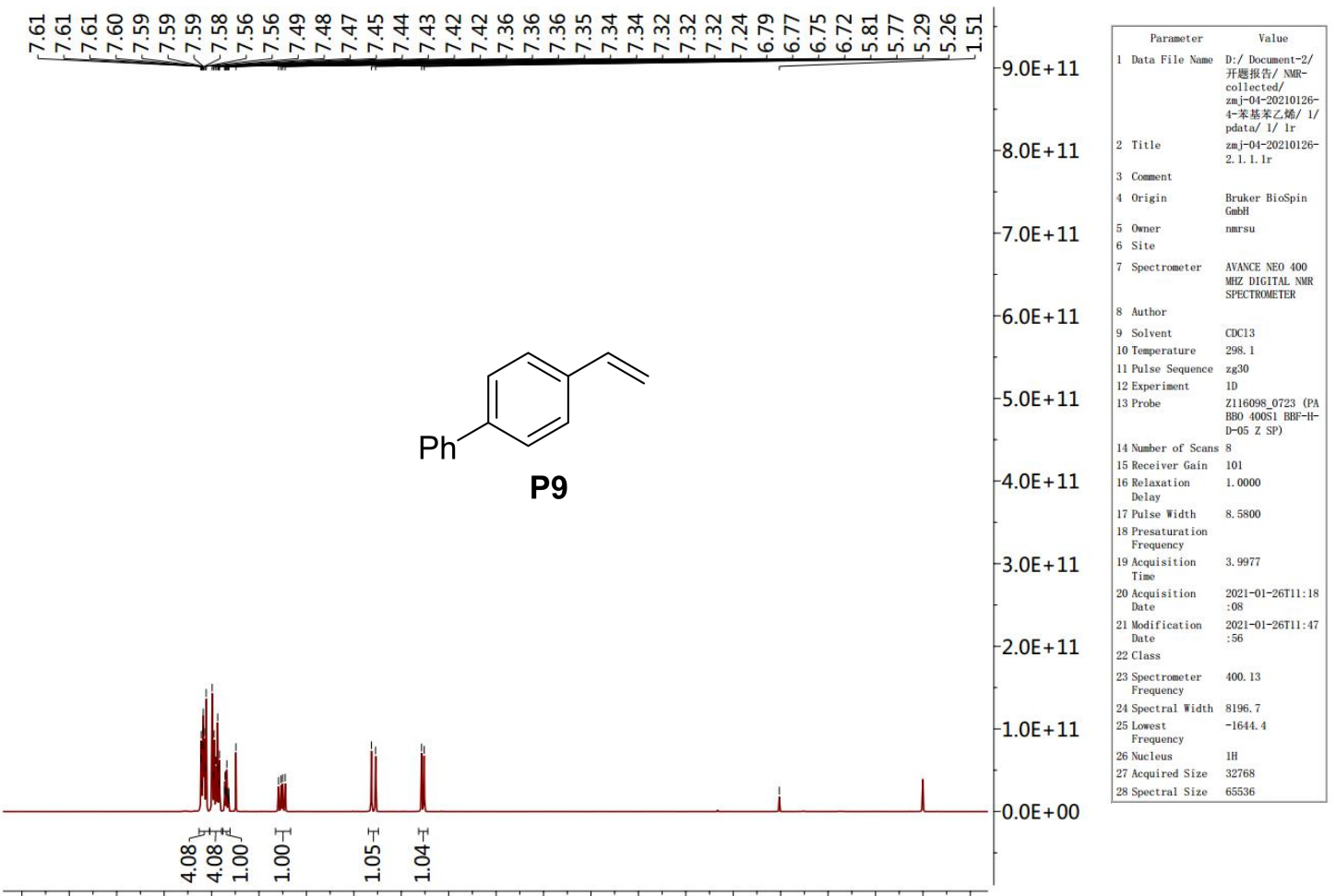

$\begin{array}{lllllllllllllllllllll}9.5 & 9.0 & 8.5 & 8.0 & 7.5 & 7.0 & 6.5 & 6.0 & 5.5 & 5.0 & 4.5 & 4.0 & 3.5 & 3.0 & 2.5 & 2.0 & 1.5 & 1.0 & 0.5 & 0.0 & -0.5\end{array}$

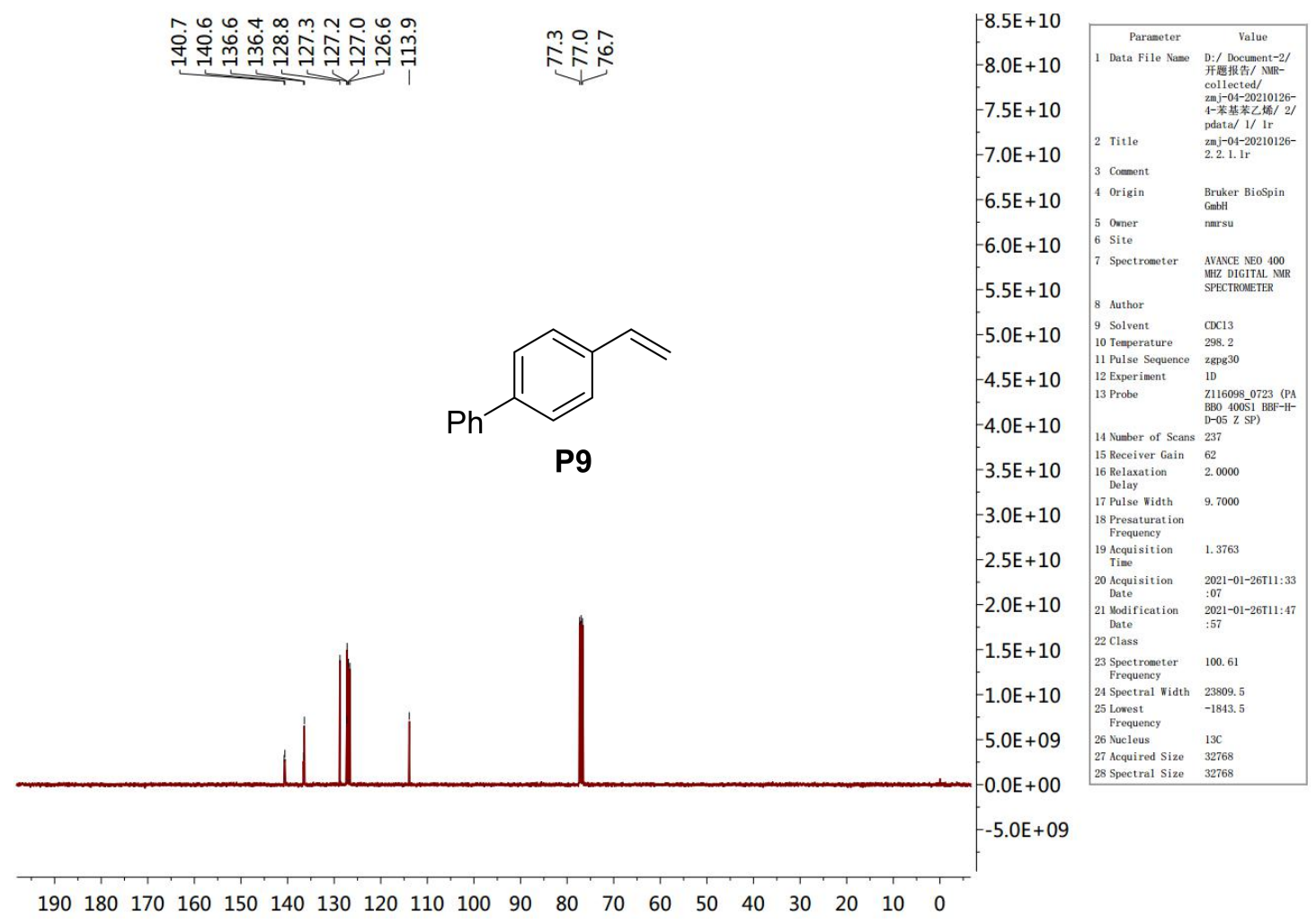




\section{4-Bromo-4'-vinyl-1,1'-biphenyl (P10)}

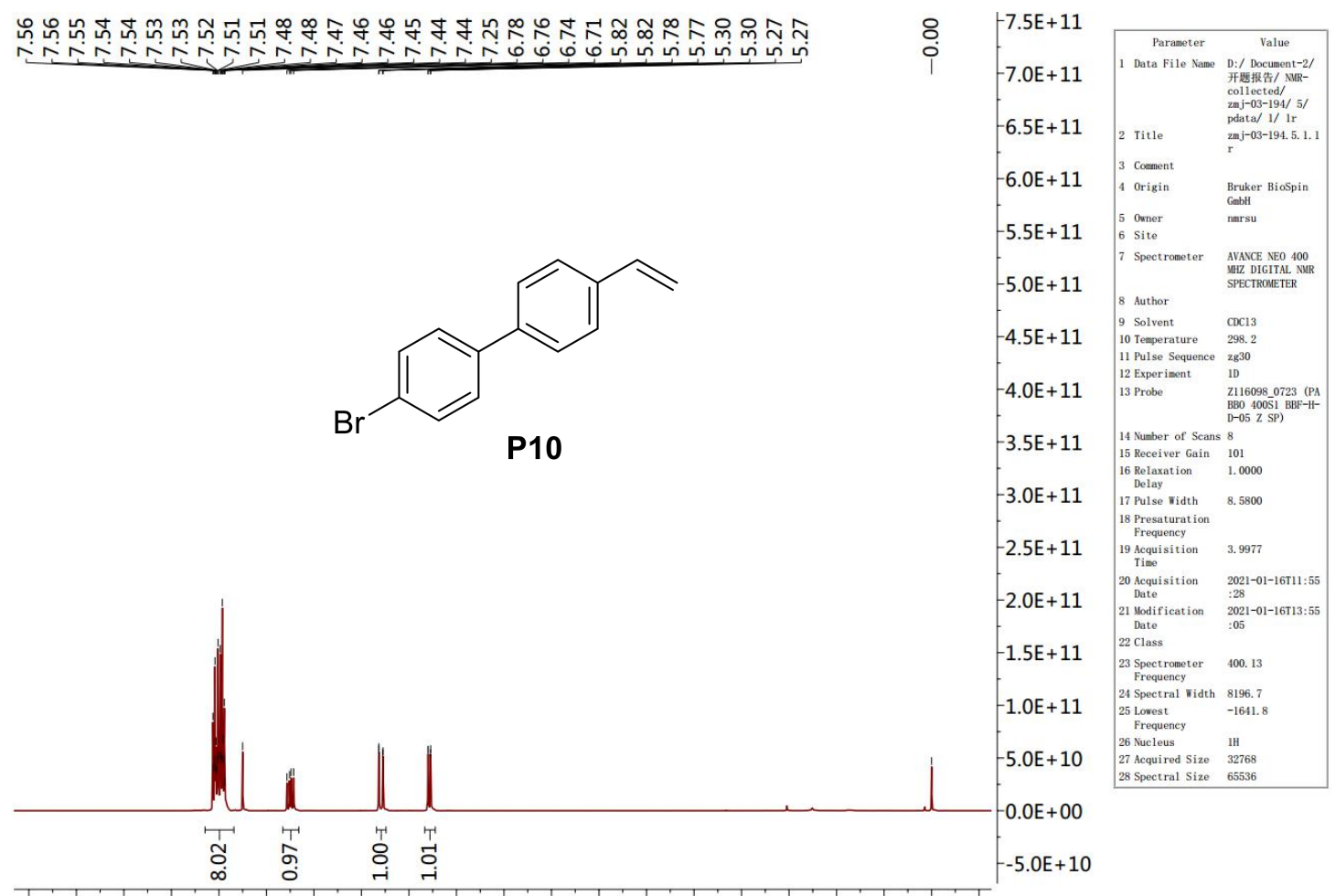

$\begin{array}{lllllllllllllllllllll}9.5 & 9.0 & 8.5 & 8.0 & 7.5 & 7.0 & 6.5 & 6.0 & 5.5 & 5.0 & 4.5 & 4.0 & 3.5 & 3.0 & 2.5 & 2.0 & 1.5 & 1.0 & 0.5 & 0.0 & -0.5\end{array}$

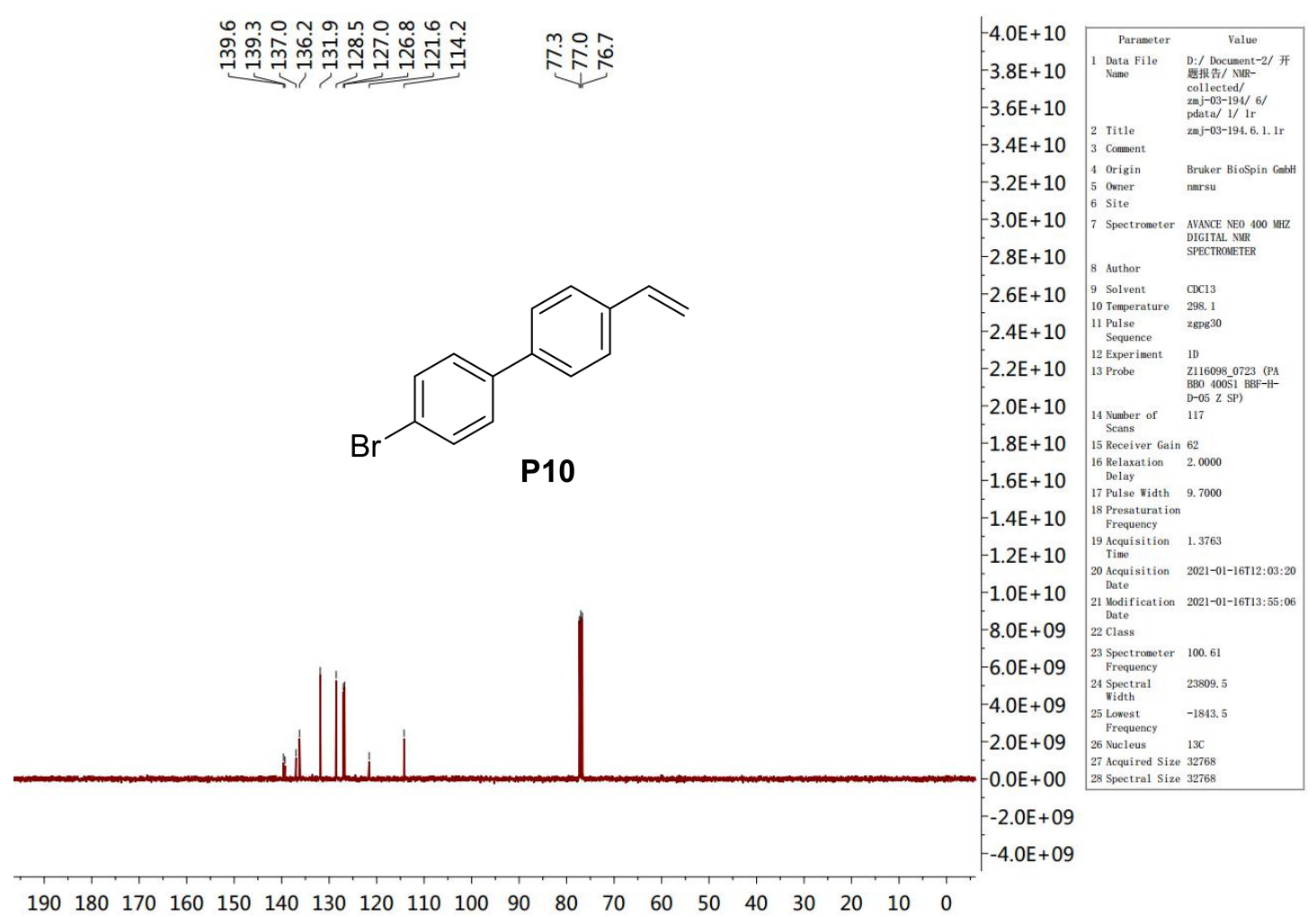



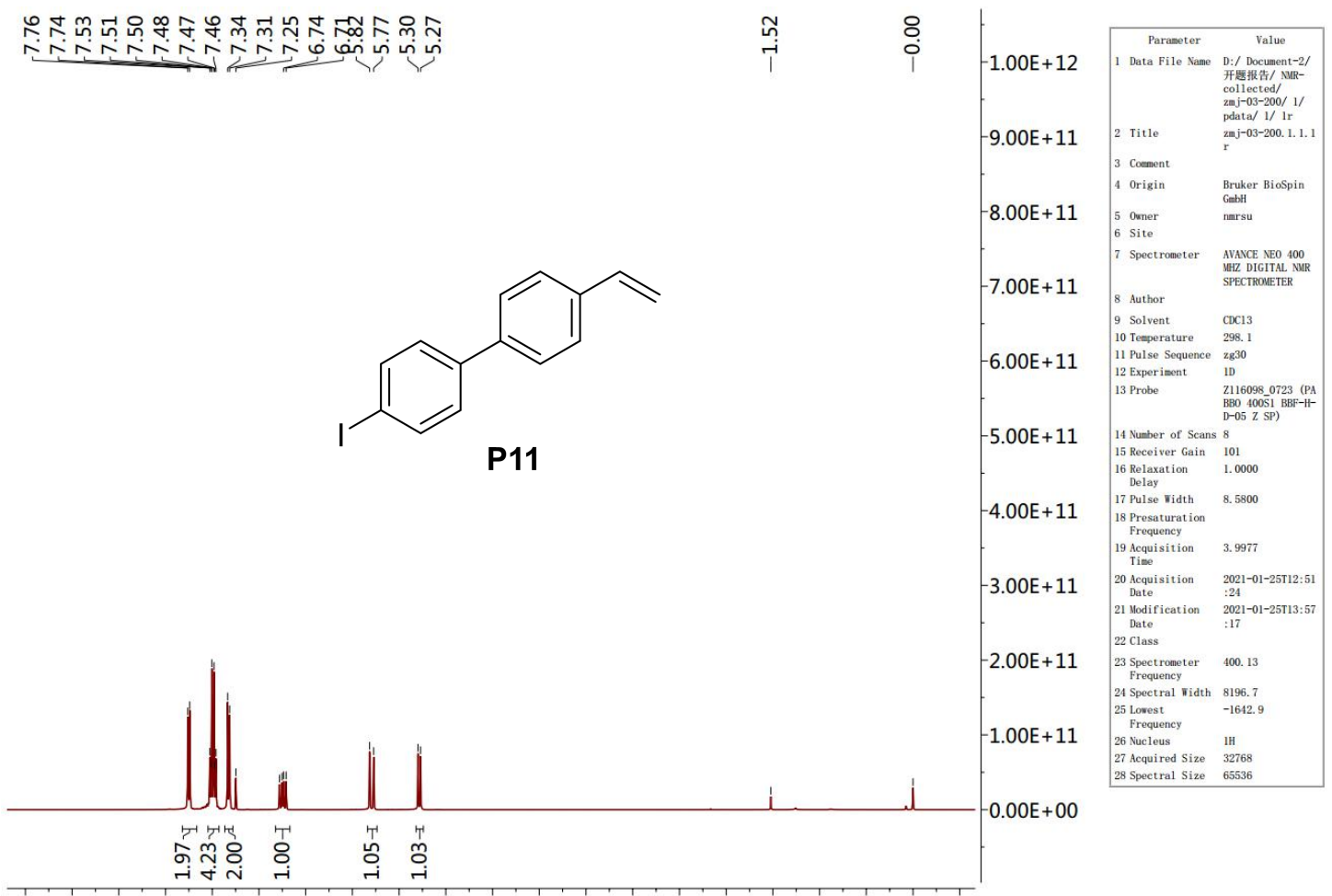

$\begin{array}{lllllllllllllllllllll}9.5 & 9.0 & 8.5 & 8.0 & 7.5 & 7.0 & 6.5 & 6.0 & 5.5 & 5.0 & 4.5 & 4.0 & 3.5 & 3.0 & 2.5 & 2.0 & 1.5 & 1.0 & 0.5 & 0.0 & -0.5\end{array}$

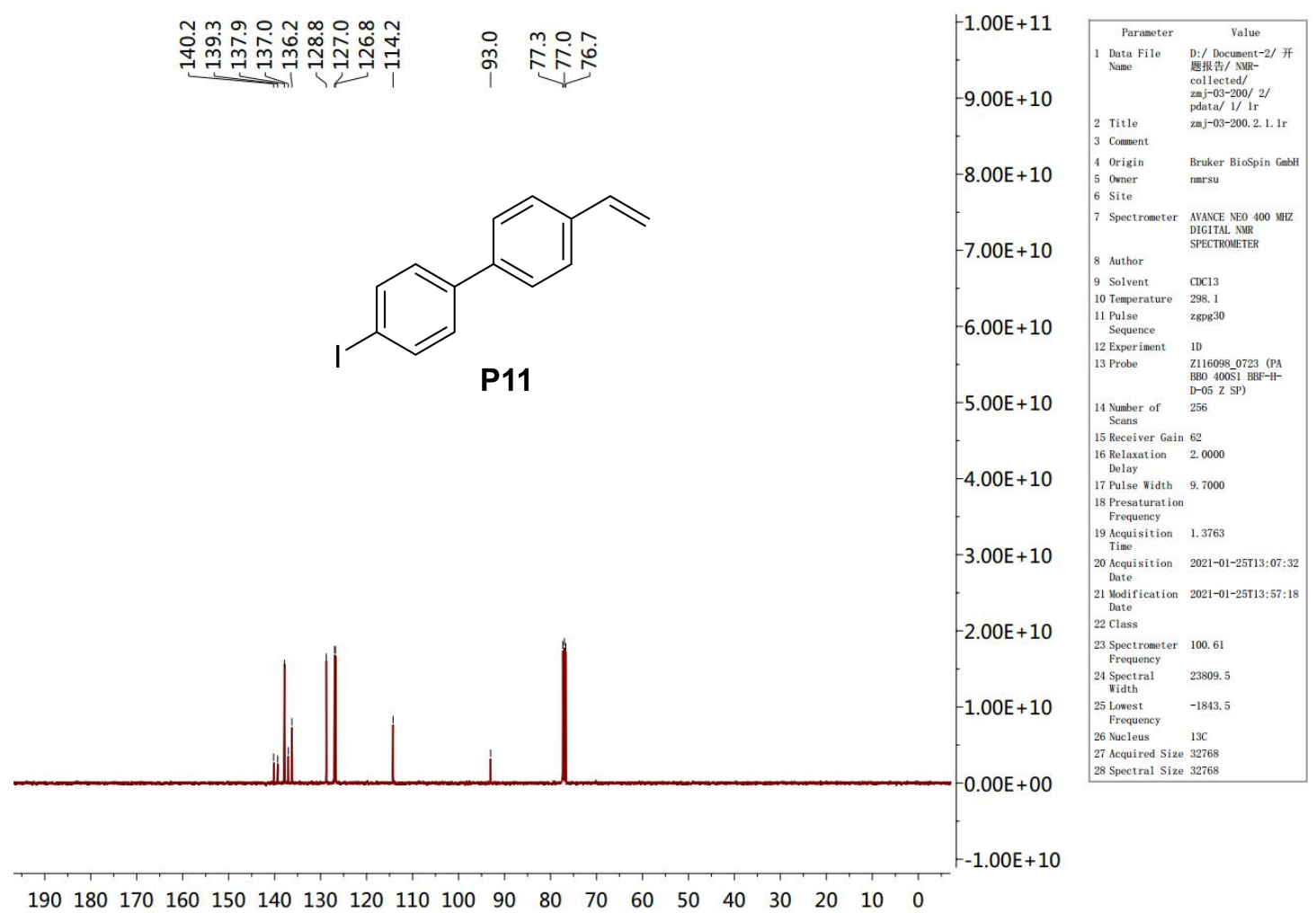


6-Methyl-2-(4-vinylphenyl)-1,3,6,2-dioxazaborocane-4,8-dione (P12)

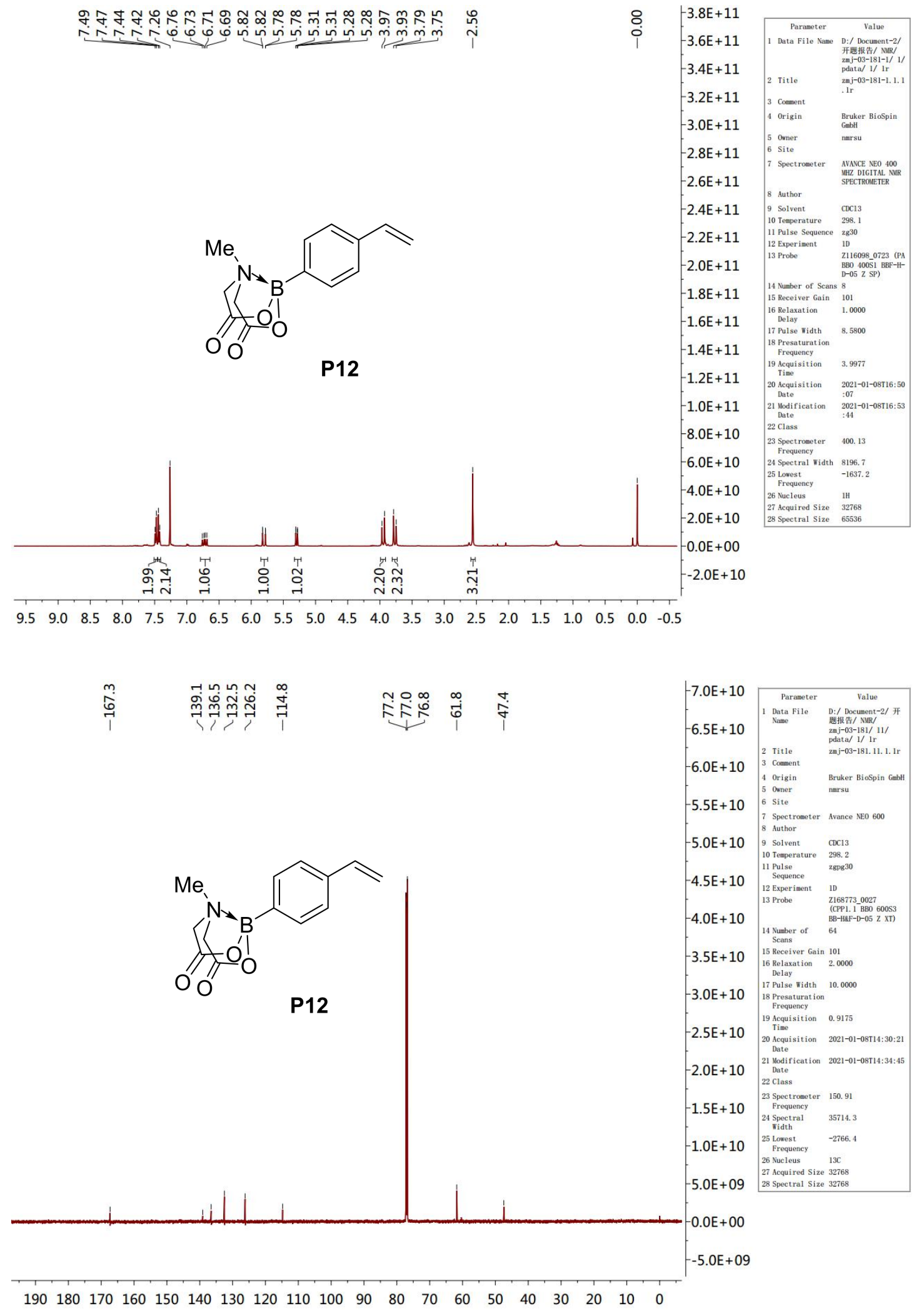




\section{2-(4-Vinylphenoxy)pyridine (P13)}

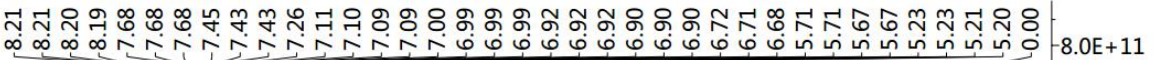

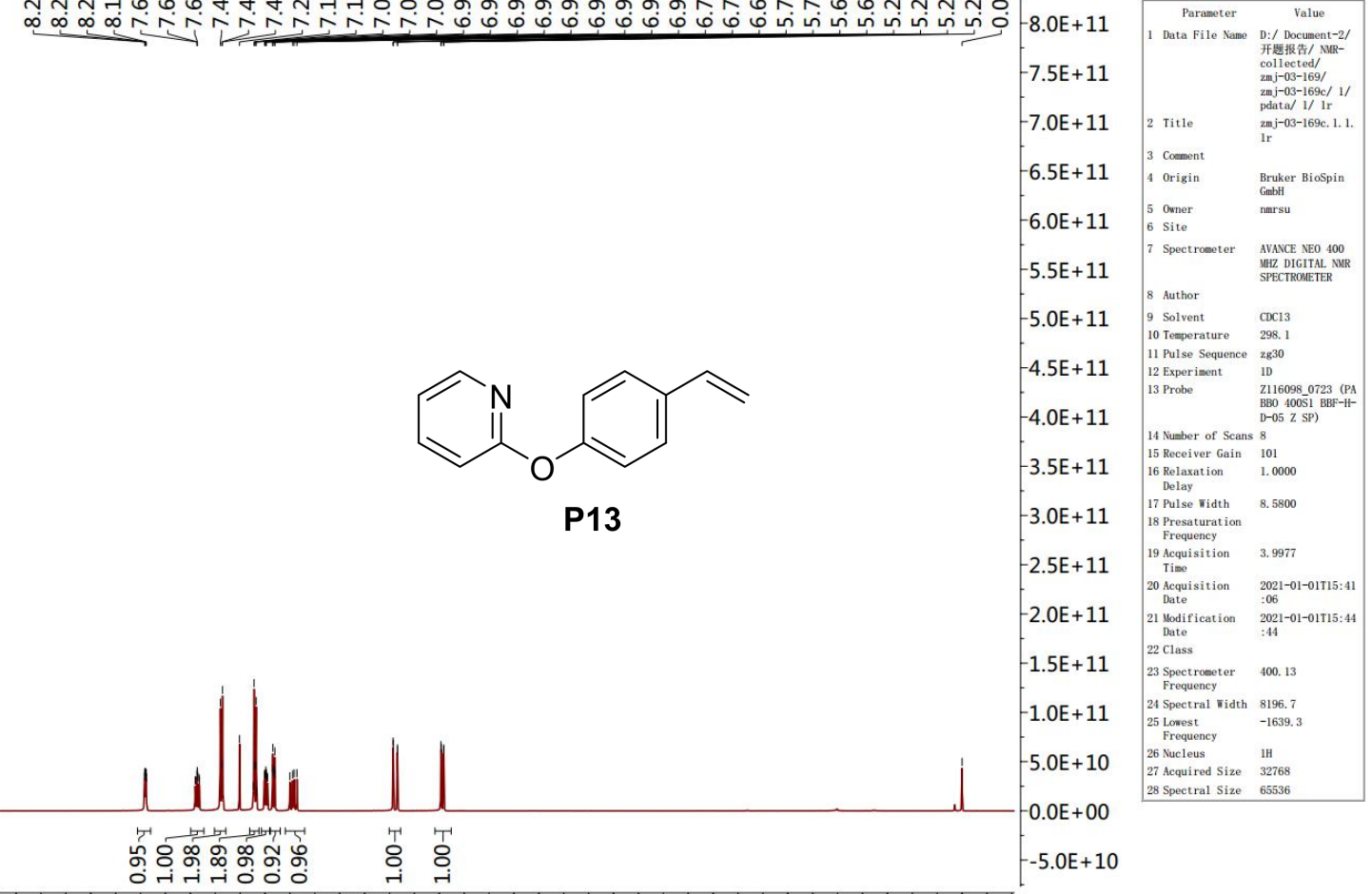

$\begin{array}{lllllllllllllllllllll}9.5 & 9.0 & 8.5 & 8.0 & 7.5 & 7.0 & 6.5 & 6.0 & 5.5 & 5.0 & 4.5 & 4.0 & 3.5 & 3.0 & 2.5 & 2.0 & 1.5 & 1.0 & 0.5 & 0.0 & -0.5\end{array}$

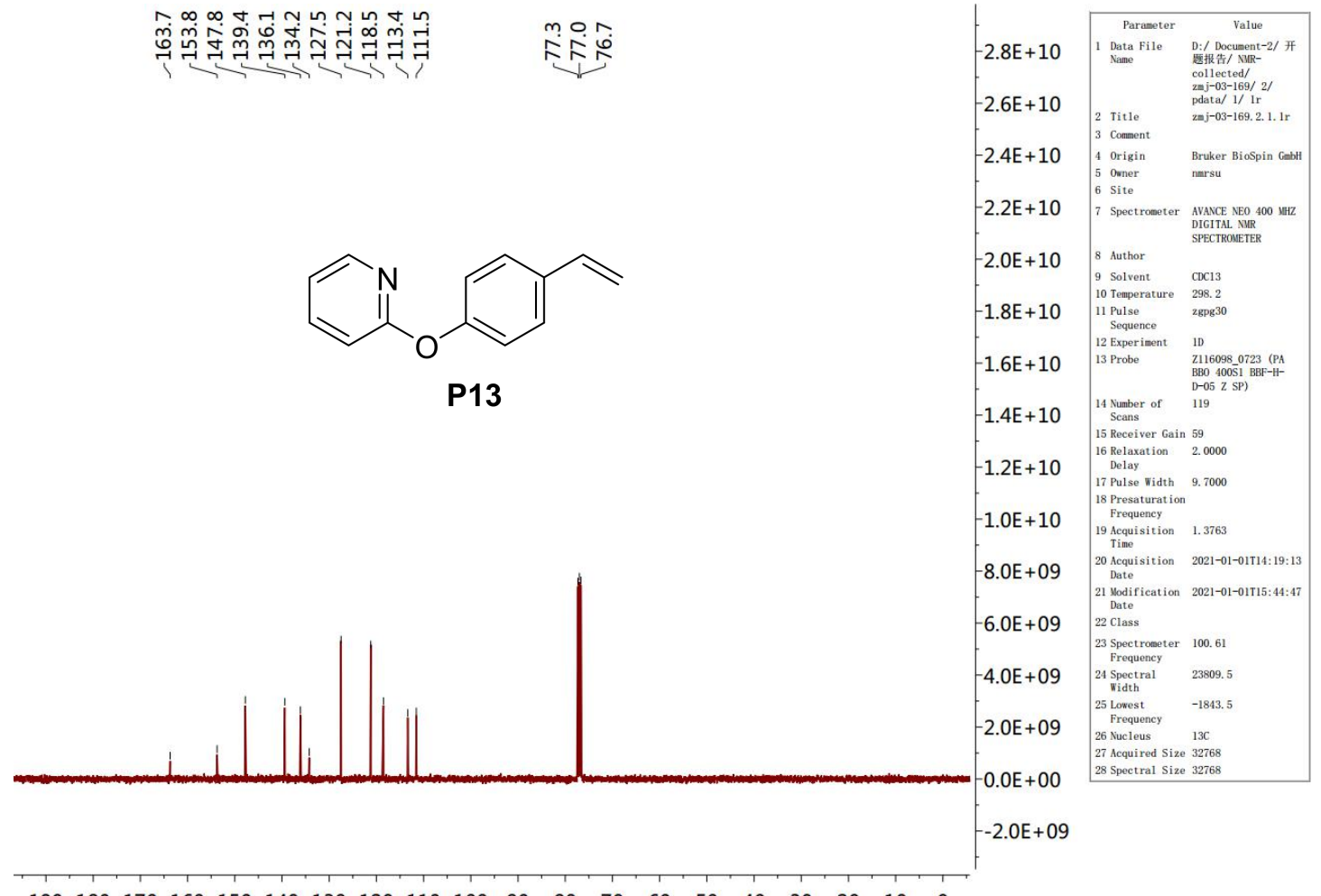

$\begin{array}{llllllllllllllllllll}190 & 180 & 170 & 160 & 150 & 140 & 130 & 120 & 110 & 100 & 90 & 80 & 70 & 60 & 50 & 40 & 30 & 20 & 10 & 0\end{array}$ 


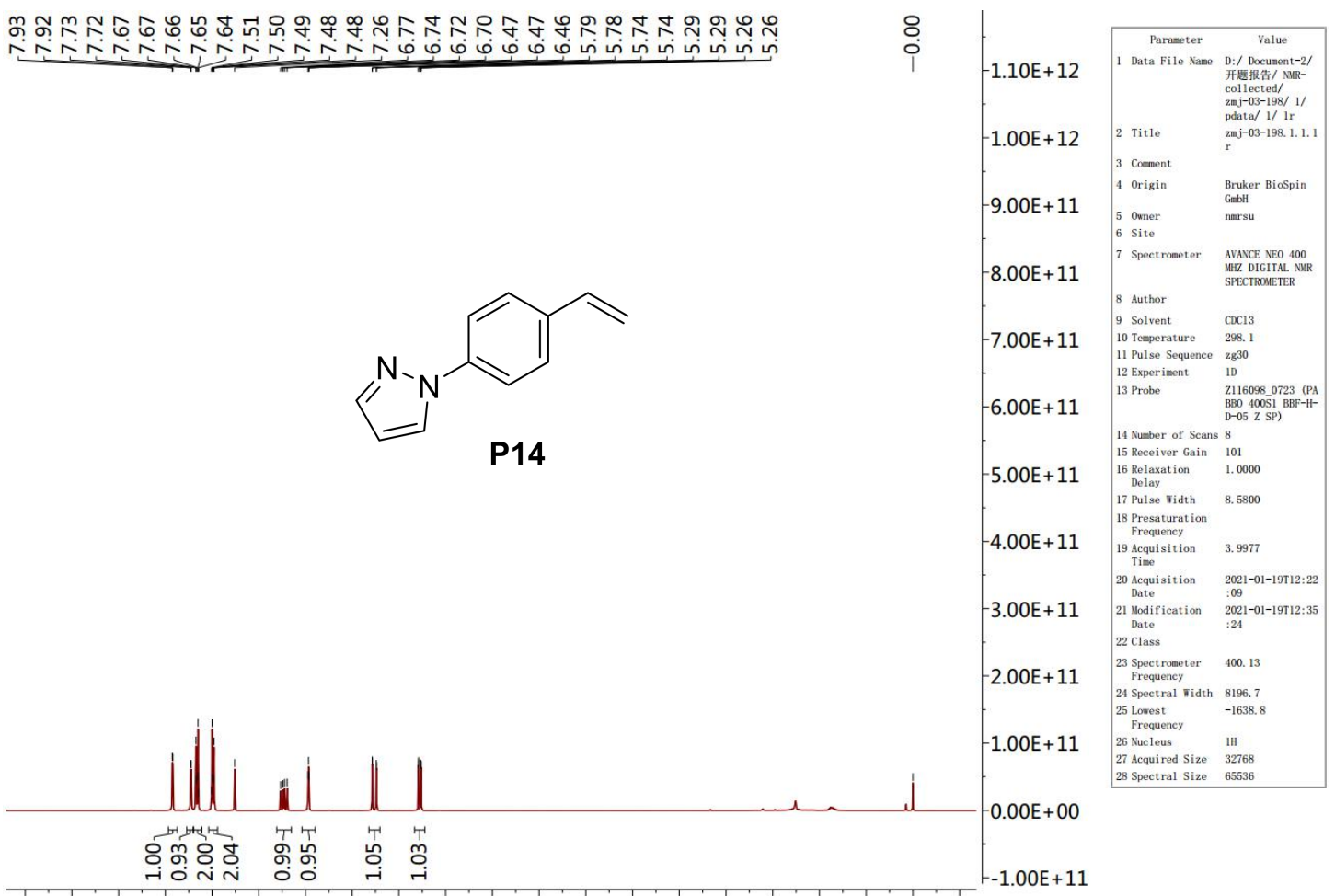

$\begin{array}{lllllllllllllllllllll}9.5 & 9.0 & 8.5 & 8.0 & 7.5 & 7.0 & 6.5 & 6.0 & 5.5 & 5.0 & 4.5 & 4.0 & 3.5 & 3.0 & 2.5 & 2.0 & 1.5 & 1.0 & 0.5 & 0.0 & -0.5\end{array}$

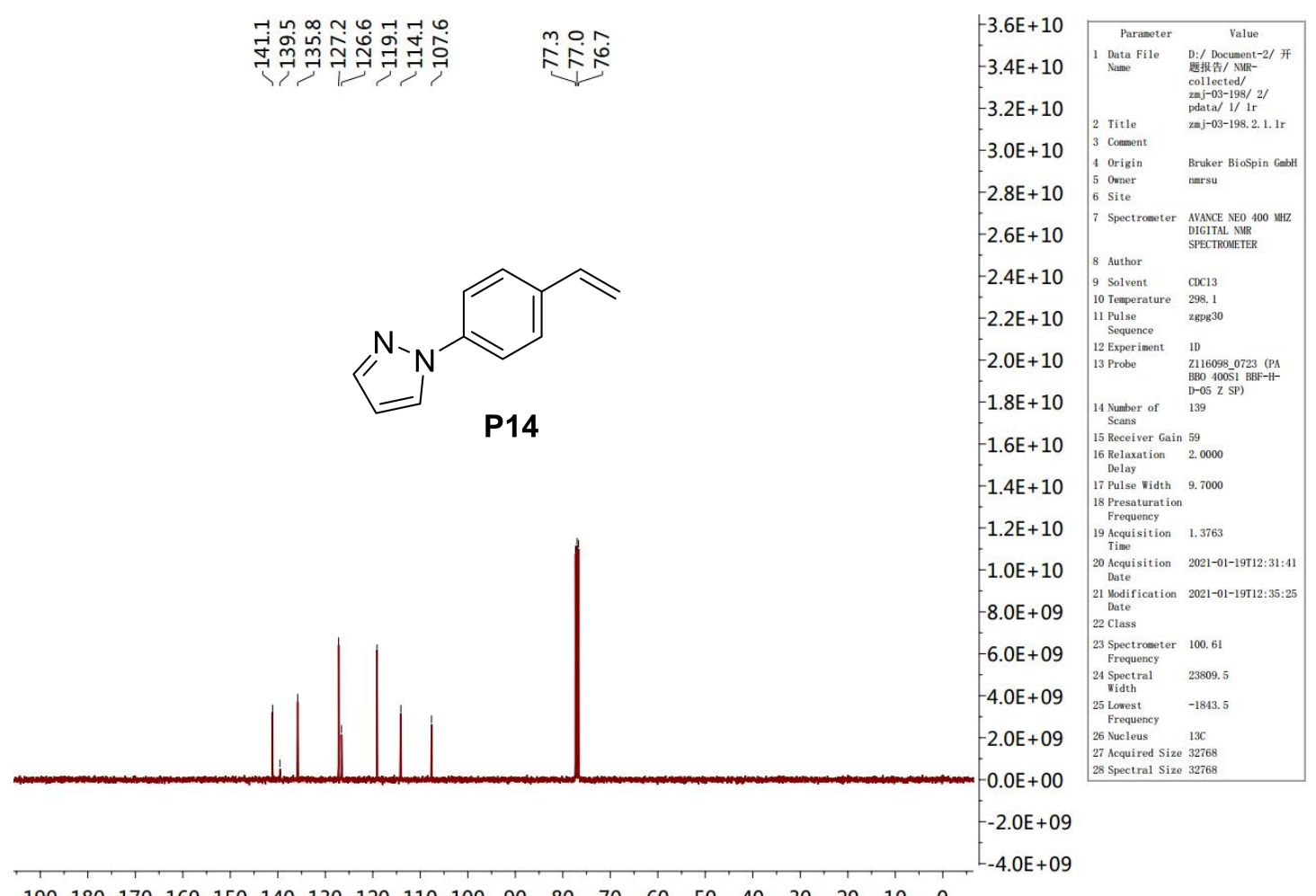

$\begin{array}{llllllllllllllllllll}190 & 180 & 170 & 160 & 150 & 140 & 130 & 120 & 110 & 100 & 90 & 80 & 70 & 60 & 50 & 40 & 30 & 20 & 10 & 0\end{array}$ 
1-Phenoxy-3-vinylbenzene (P15)
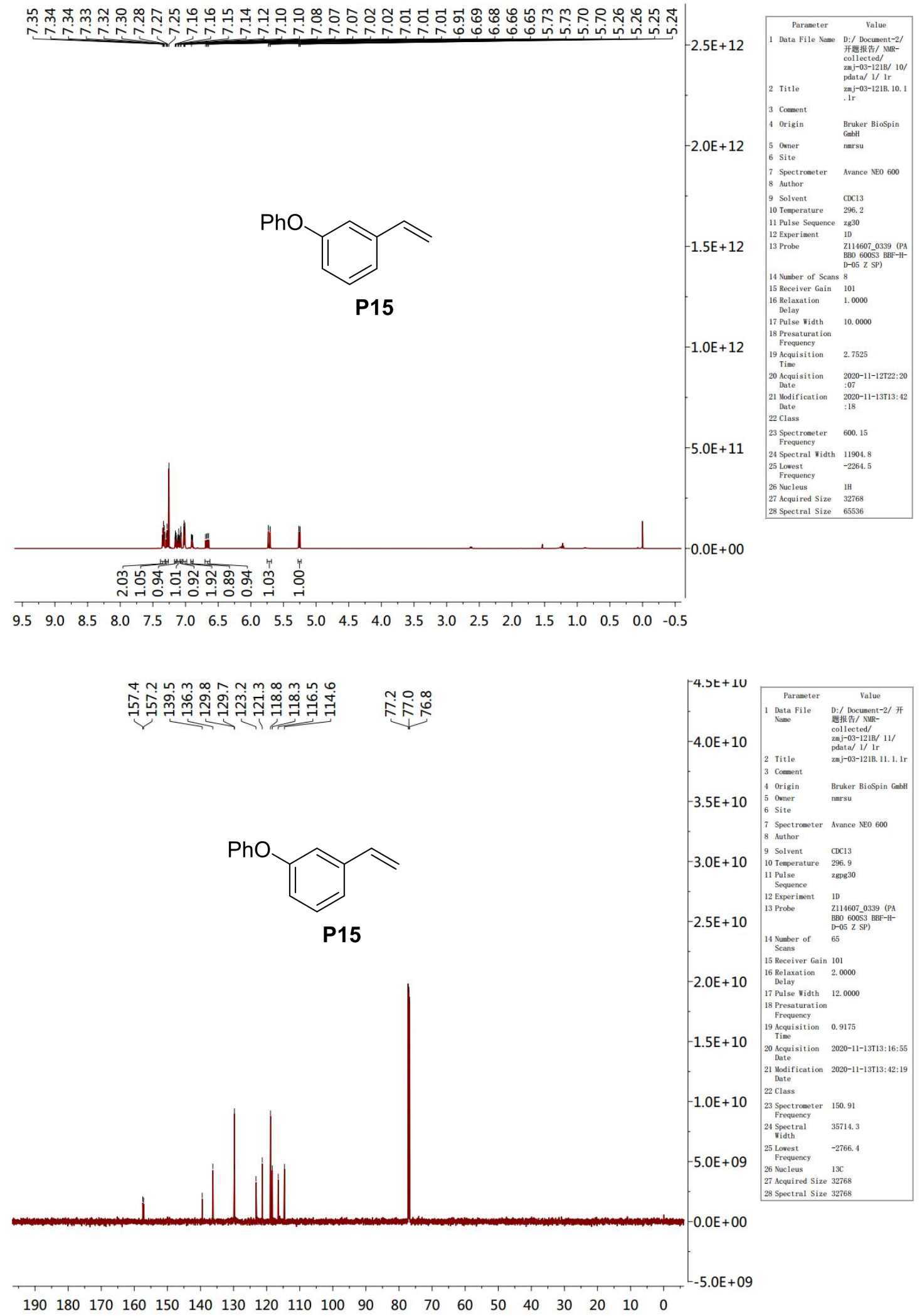

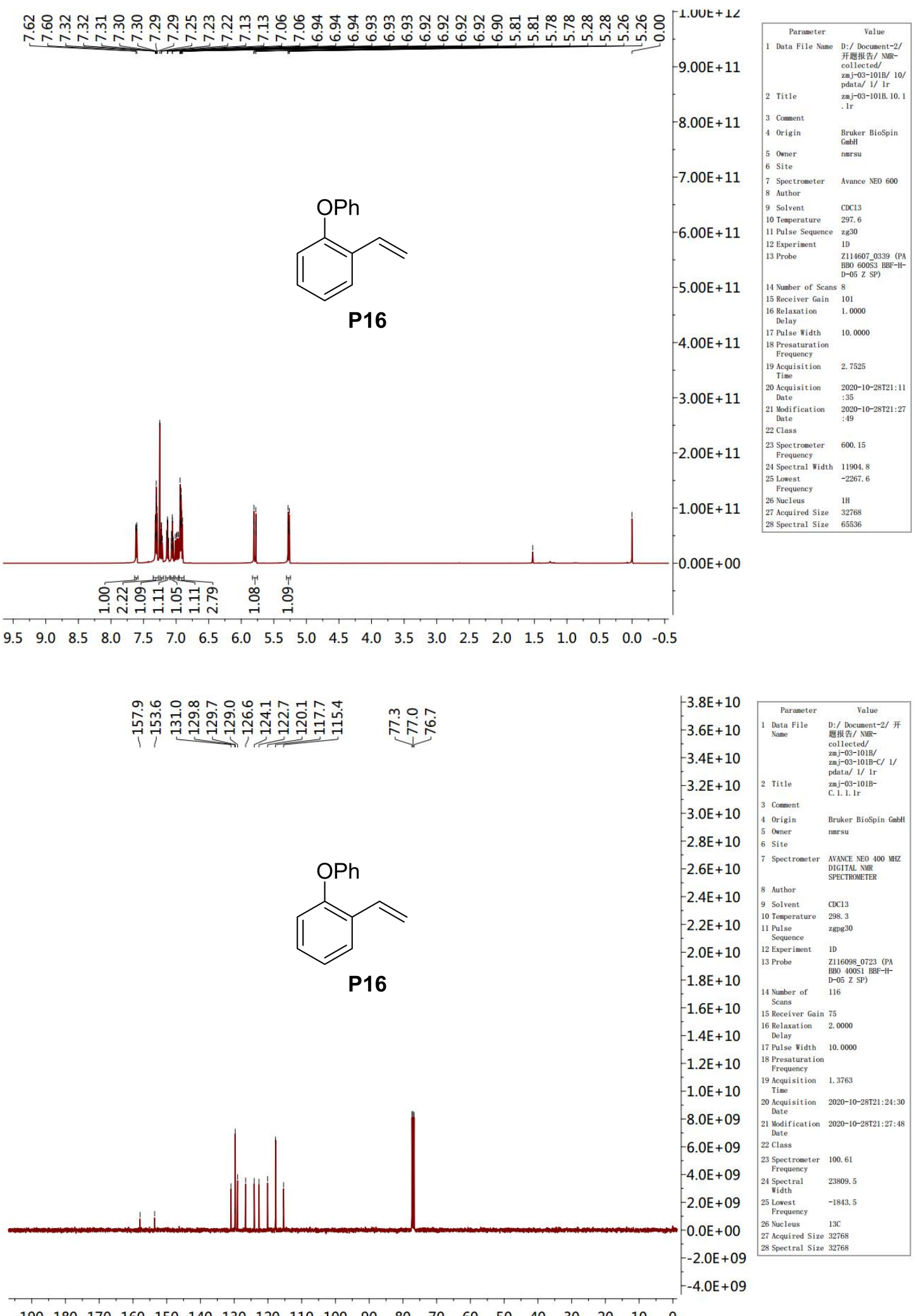


\section{2-Vinylnaphthalene (P17)}

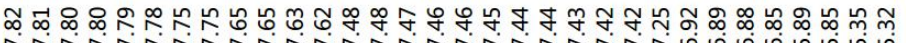

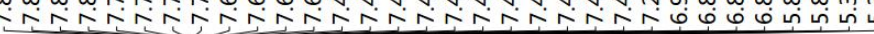<smiles>C=Cc1ccc2ccccc2c1</smiles>

P17

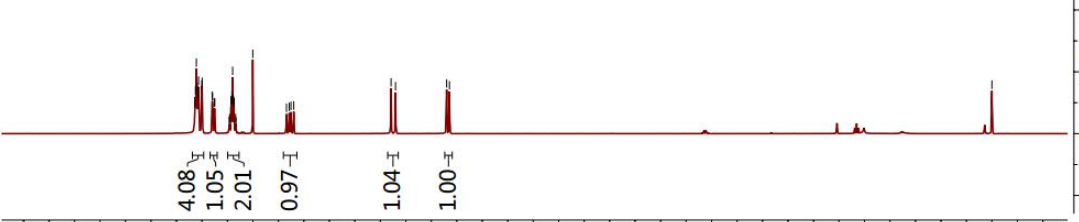

$\begin{array}{lllllllllllllllllllll}9.5 & 9.0 & 8.5 & 8.0 & 7.5 & 7.0 & 6.5 & 6.0 & 5.5 & 5.0 & 4.5 & 4.0 & 3.5 & 3.0 & 2.5 & 2.0 & 1.5 & 1.0 & 0.5 & 0.0 & -0.5\end{array}$

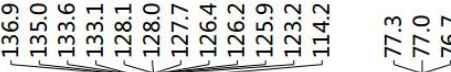<smiles>C=Cc1ccc2ccccc2c1</smiles>

P17

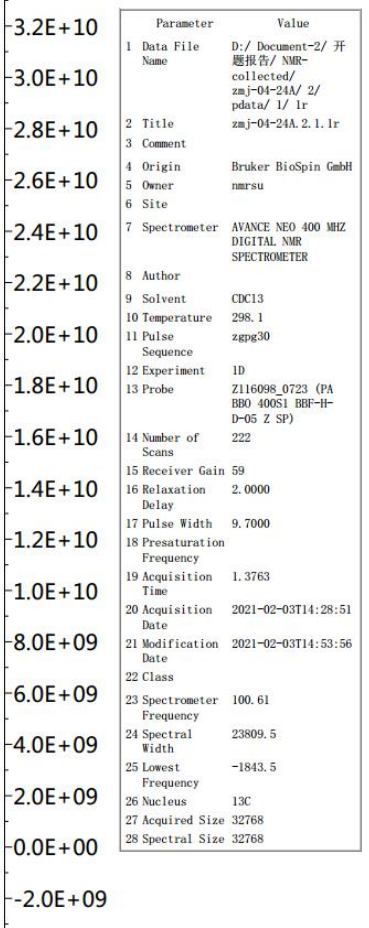

$\begin{array}{llllllllllllllllllll}190 & 180 & 170 & 160 & 150 & 140 & 130 & 120 & 110 & 100 & 90 & 80 & 70 & 60 & 50 & 40 & 30 & 20 & 10 & 0\end{array}$ 


\section{Naphthalene (P18)}

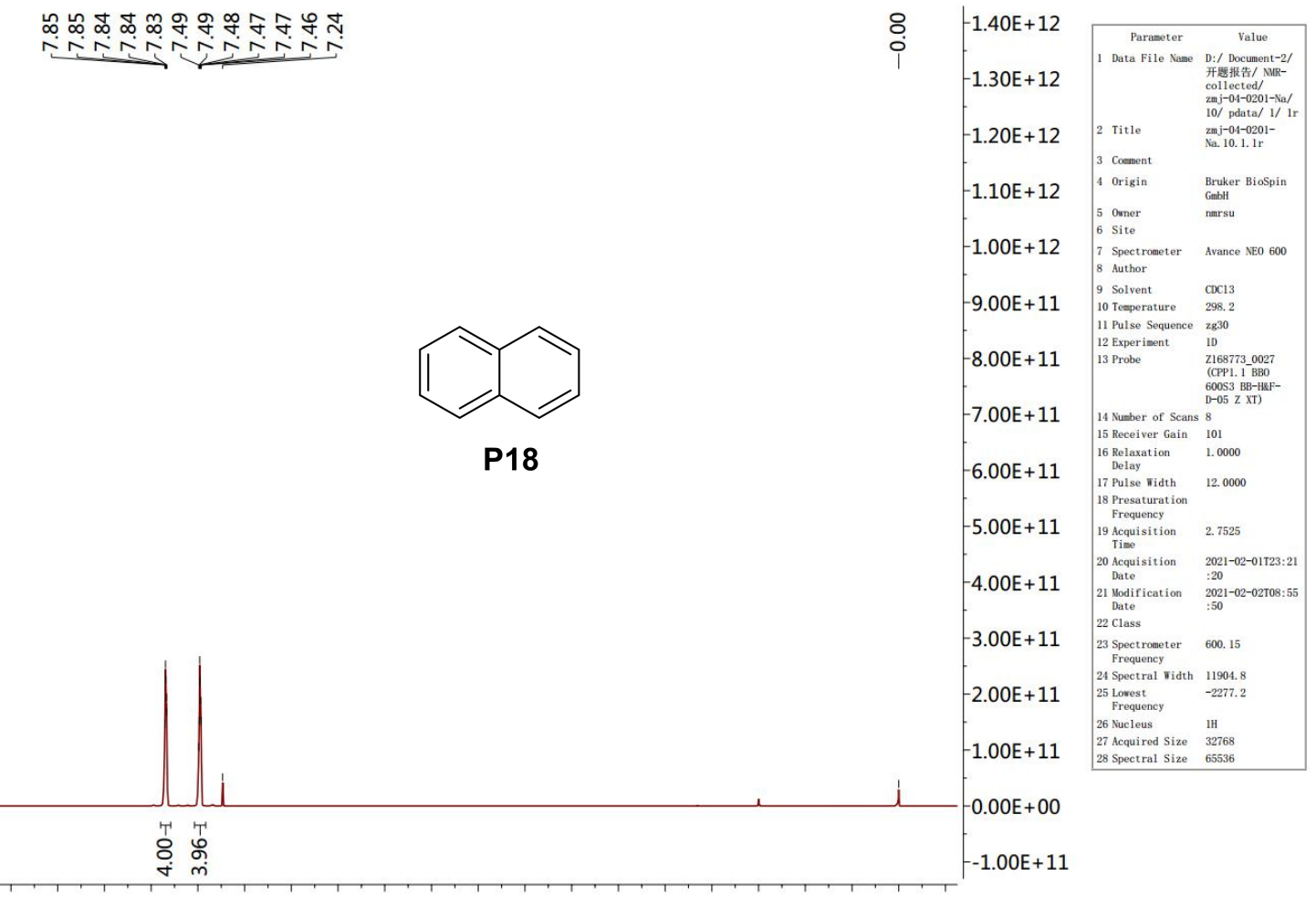

$\begin{array}{lllllllllllllllllllll}9.5 & 9.0 & 8.5 & 8.0 & 7.5 & 7.0 & 6.5 & 6.0 & 5.5 & 5.0 & 4.5 & 4.0 & 3.5 & 3.0 & 2.5 & 2.0 & 1.5 & 1.0 & 0.5 & 0.0 & -0.5\end{array}$

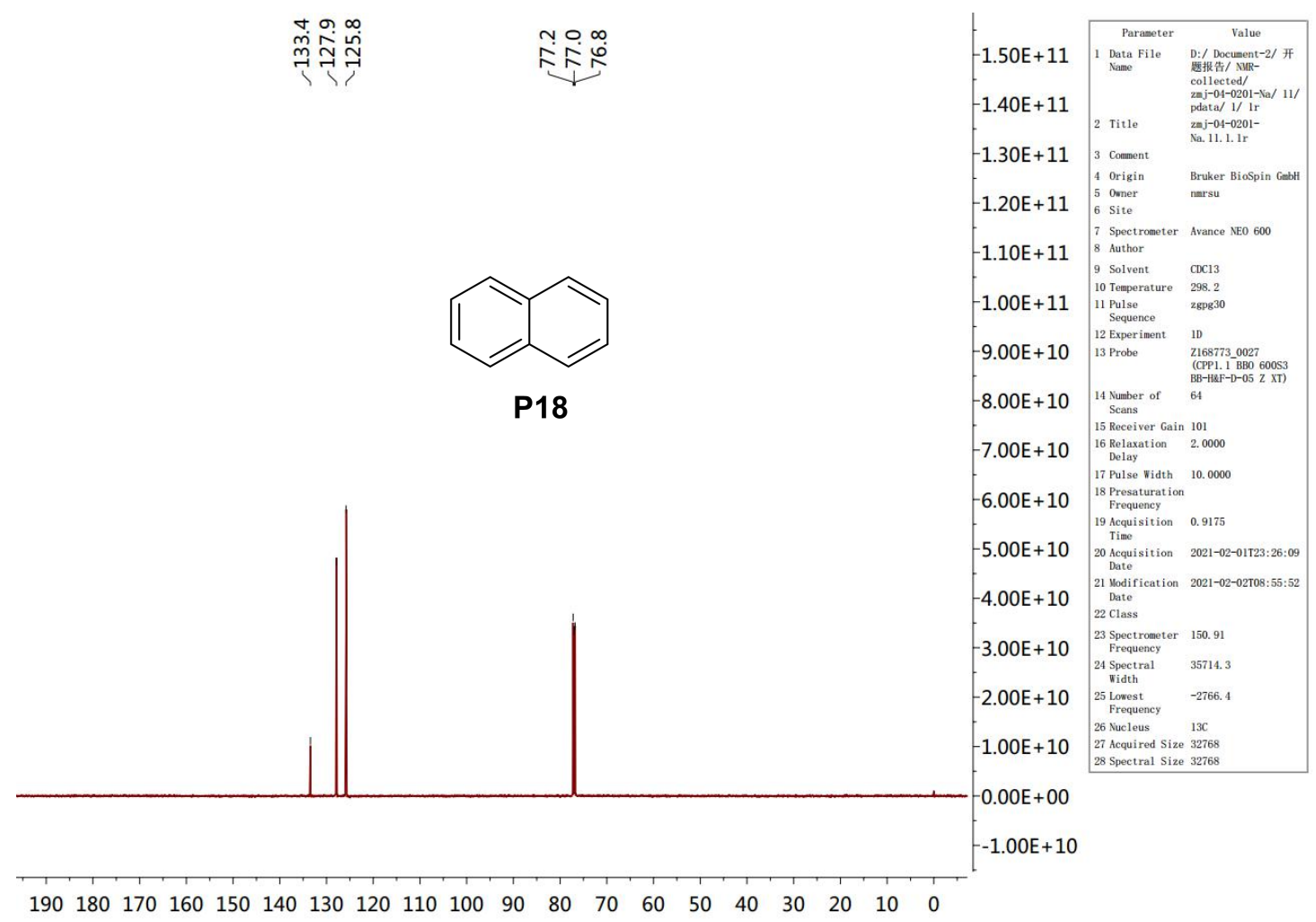




\section{1,1'-Biphenyl (P21)}
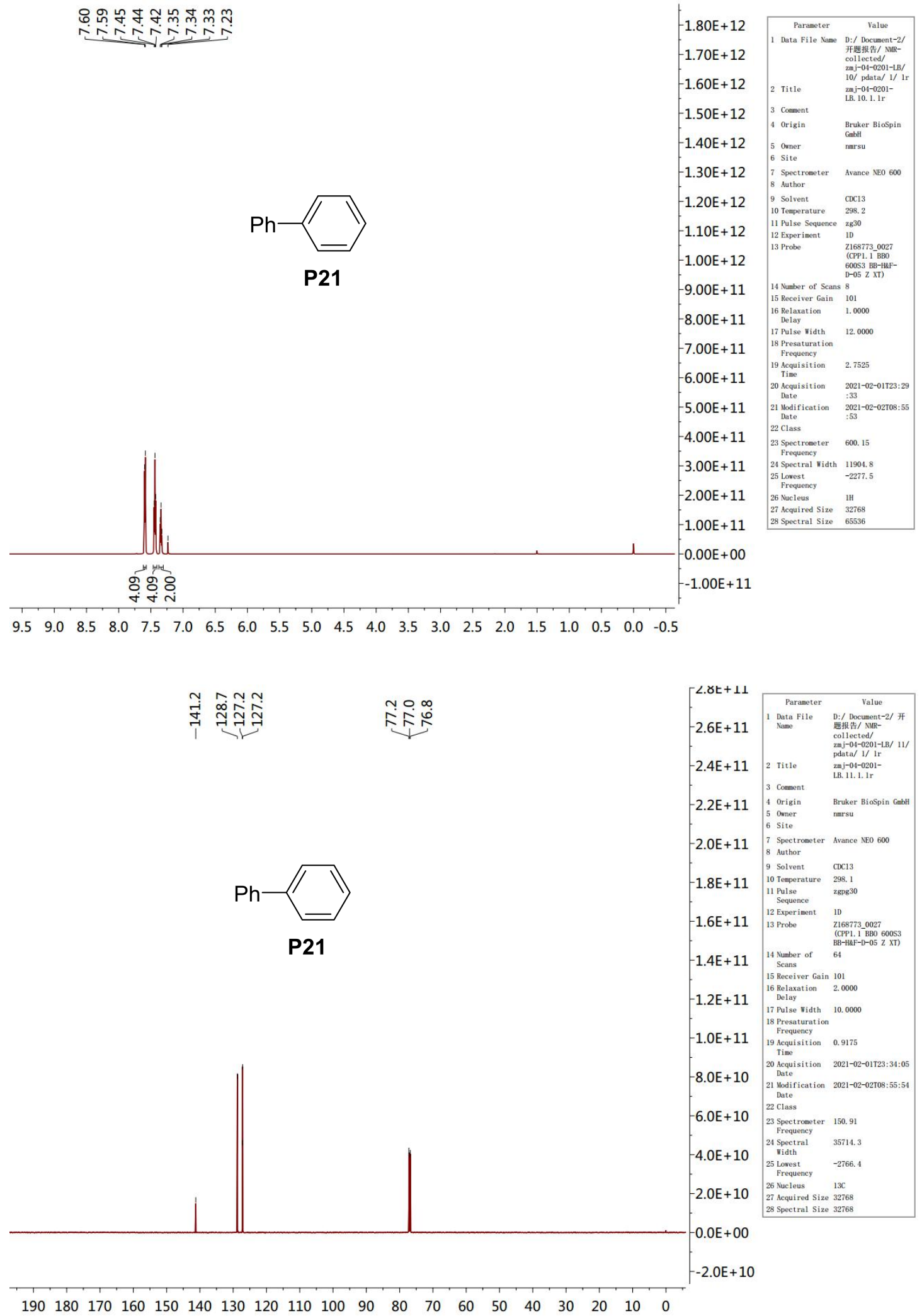


\section{3-Phenylallyl benzoate (P24)}

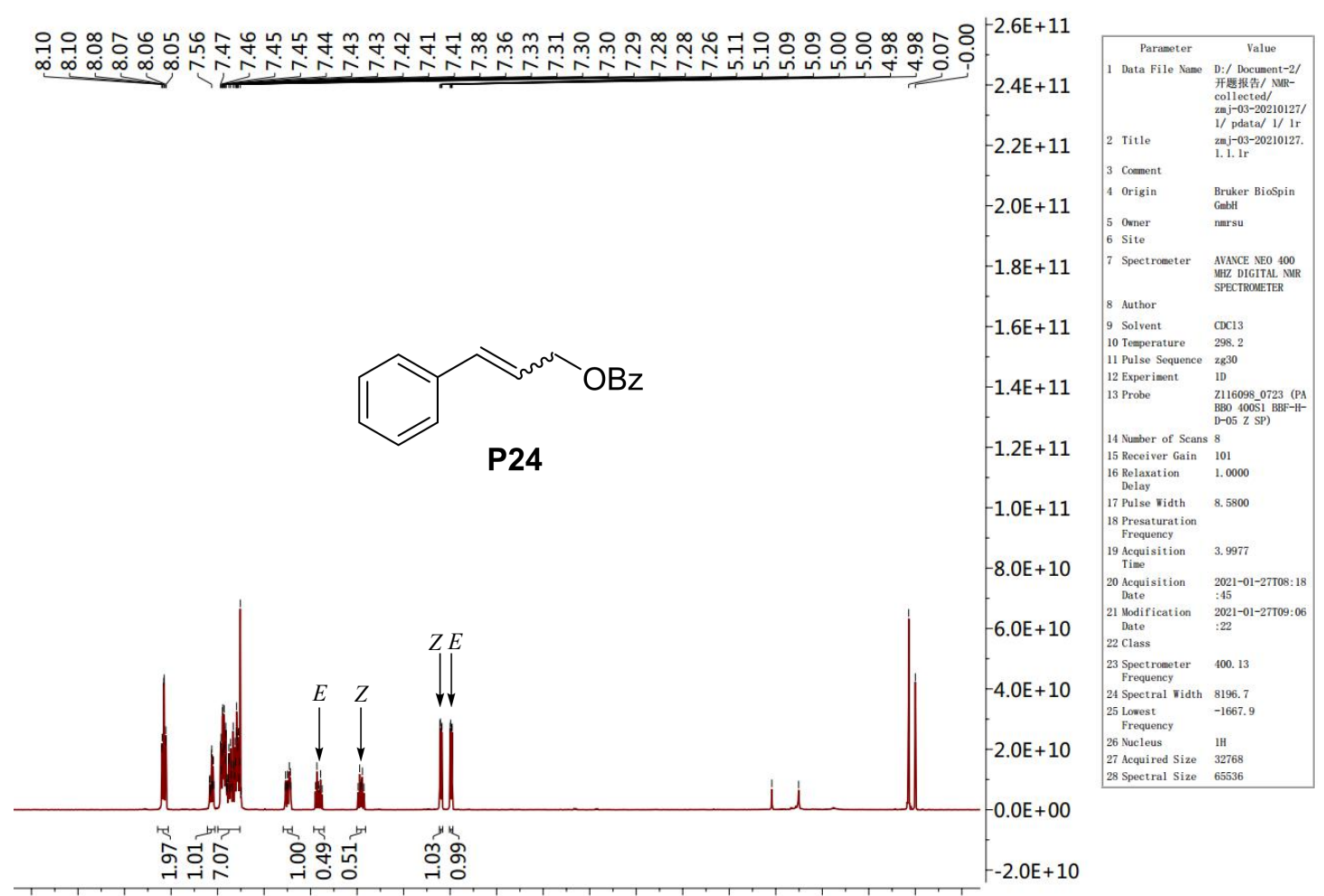

$\begin{array}{lllllllllllllllllllll}9.5 & 9.0 & 8.5 & 8.0 & 7.5 & 7.0 & 6.5 & 6.0 & 5.5 & 5.0 & 4.5 & 4.0 & 3.5 & 3.0 & 2.5 & 2.0 & 1.5 & 1.0 & 0.5 & 0.0 & -0.5\end{array}$

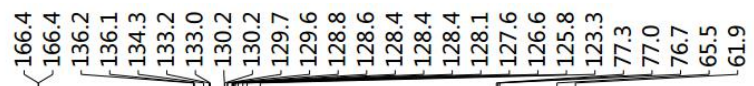

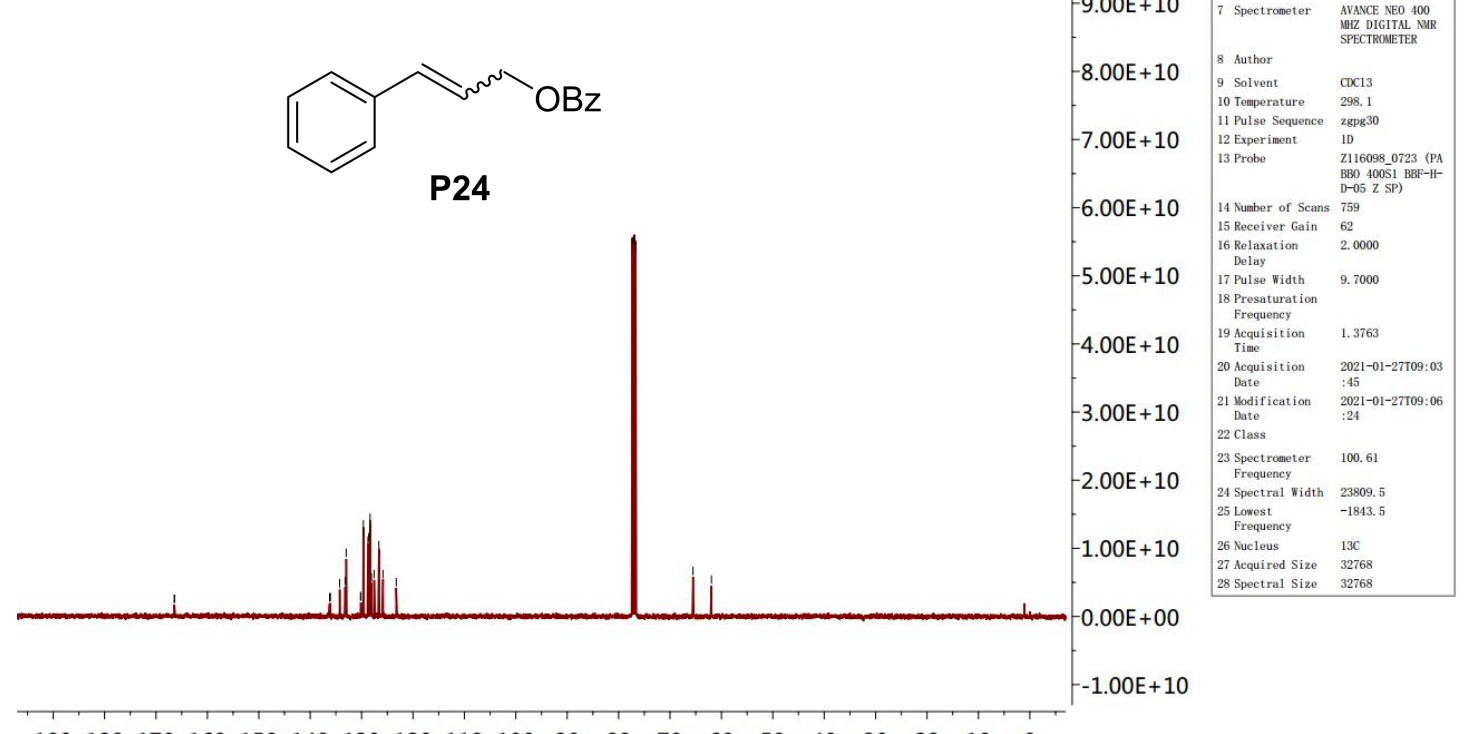

$\begin{array}{llllllllllllllllllll}190 & 180 & 170 & 160 & 150 & 140 & 130 & 120 & 110 & 100 & 90 & 80 & 70 & 60 & 50 & 40 & 30 & 20 & 10 & 0\end{array}$ 


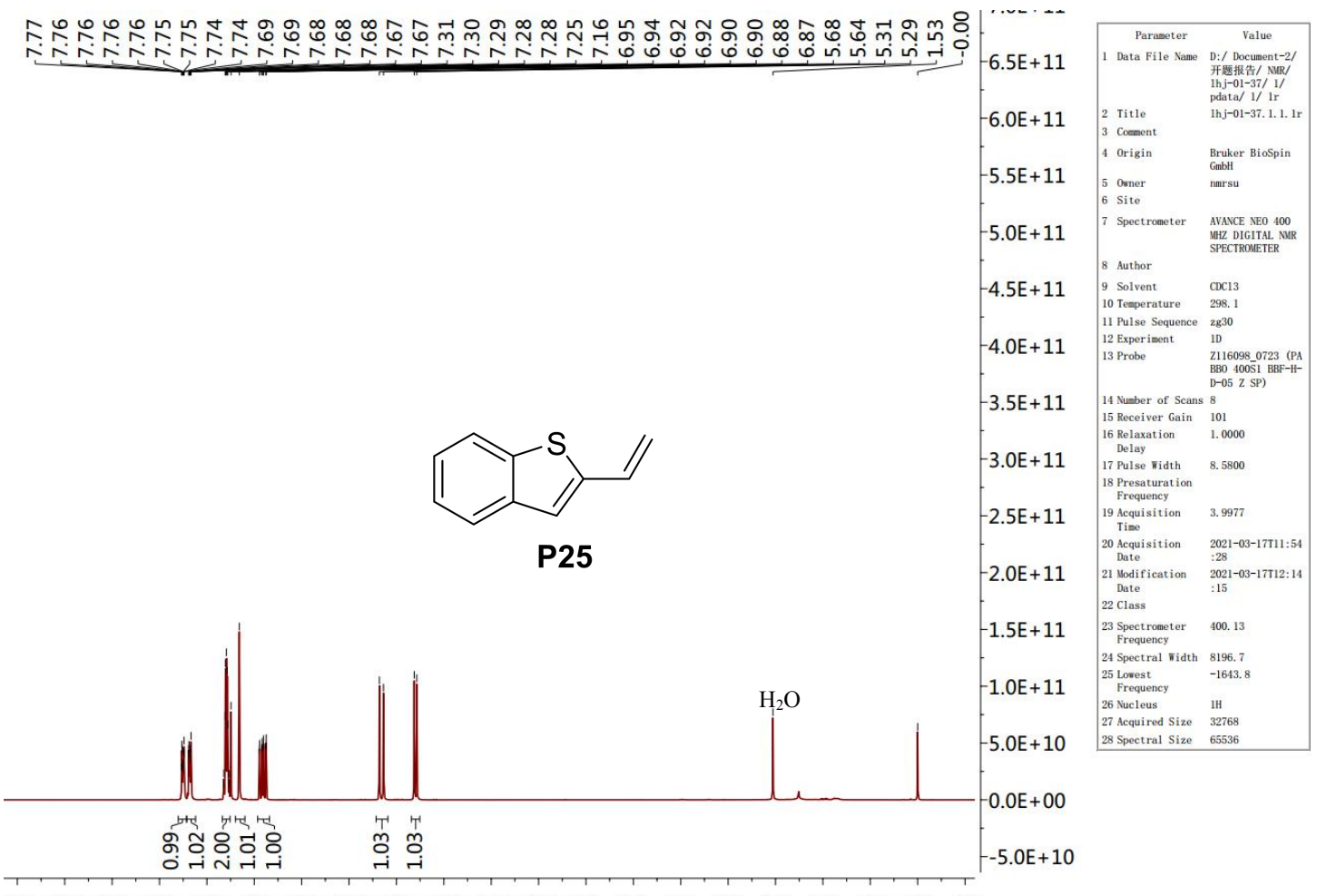

$\begin{array}{lllllllllllllllllllll}9.5 & 9.0 & 8.5 & 8.0 & 7.5 & 7.0 & 6.5 & 6.0 & 5.5 & 5.0 & 4.5 & 4.0 & 3.5 & 3.0 & 2.5 & 2.0 & 1.5 & 1.0 & 0.5 & 0.0 & -0.5\end{array}$

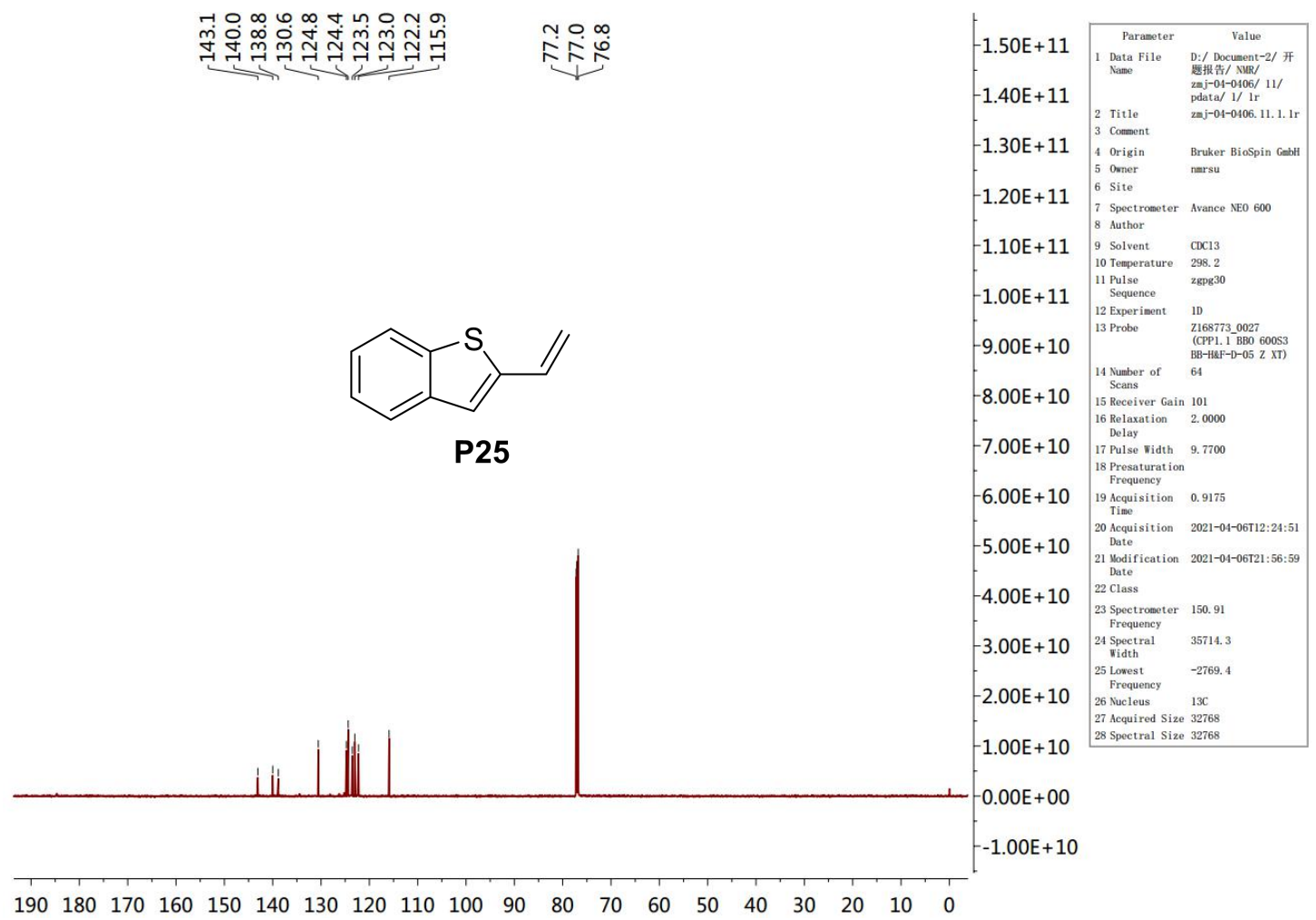




\section{2-Styrylfuran (P26)}

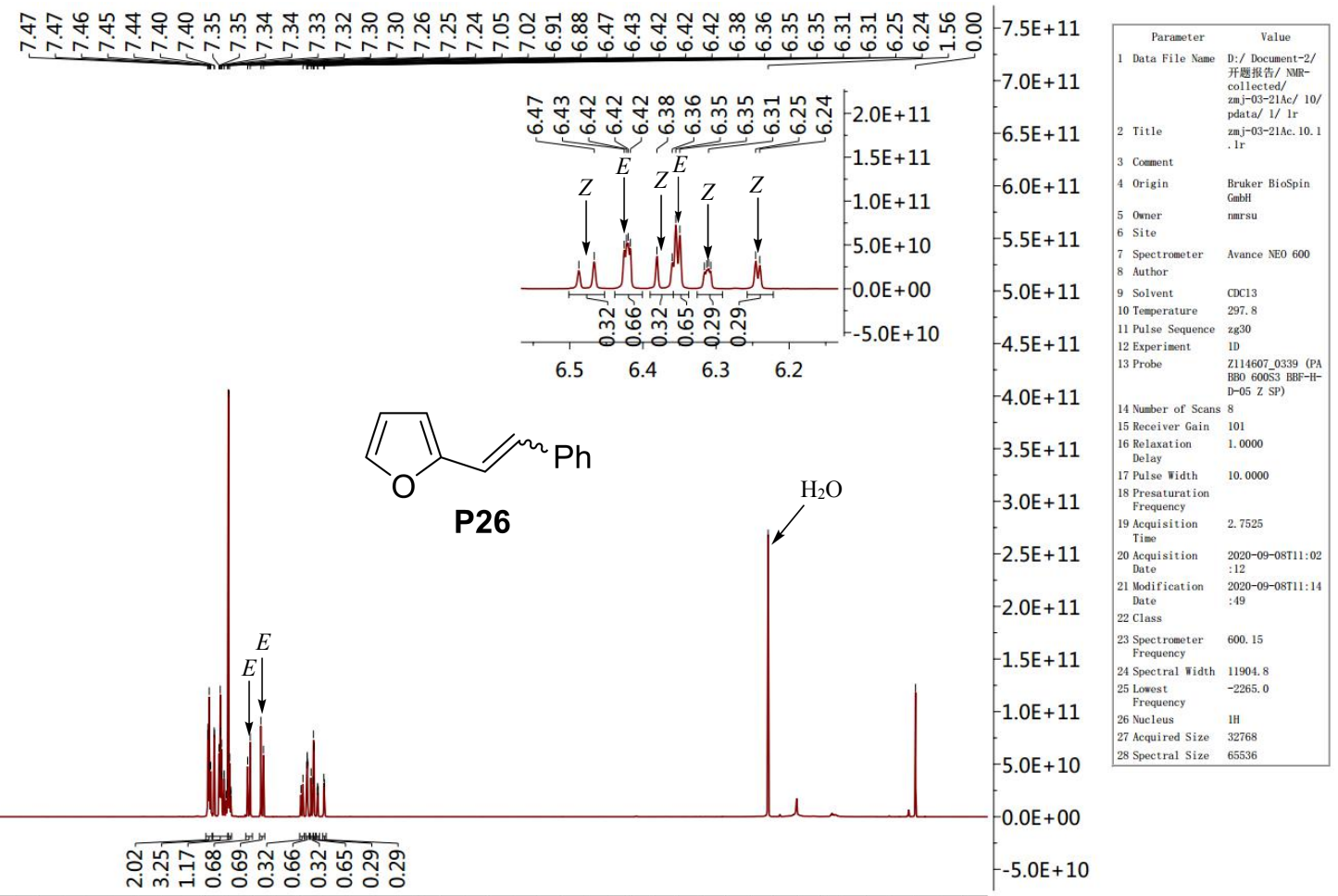

$\begin{array}{lllllllllllllllllllll}9.5 & 9.0 & 8.5 & 8.0 & 7.5 & 7.0 & 6.5 & 6.0 & 5.5 & 5.0 & 4.5 & 4.0 & 3.5 & 3.0 & 2.5 & 2.0 & 1.5 & 1.0 & 0.5 & 0.0 & -0.5\end{array}$

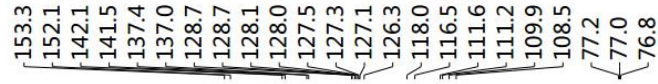

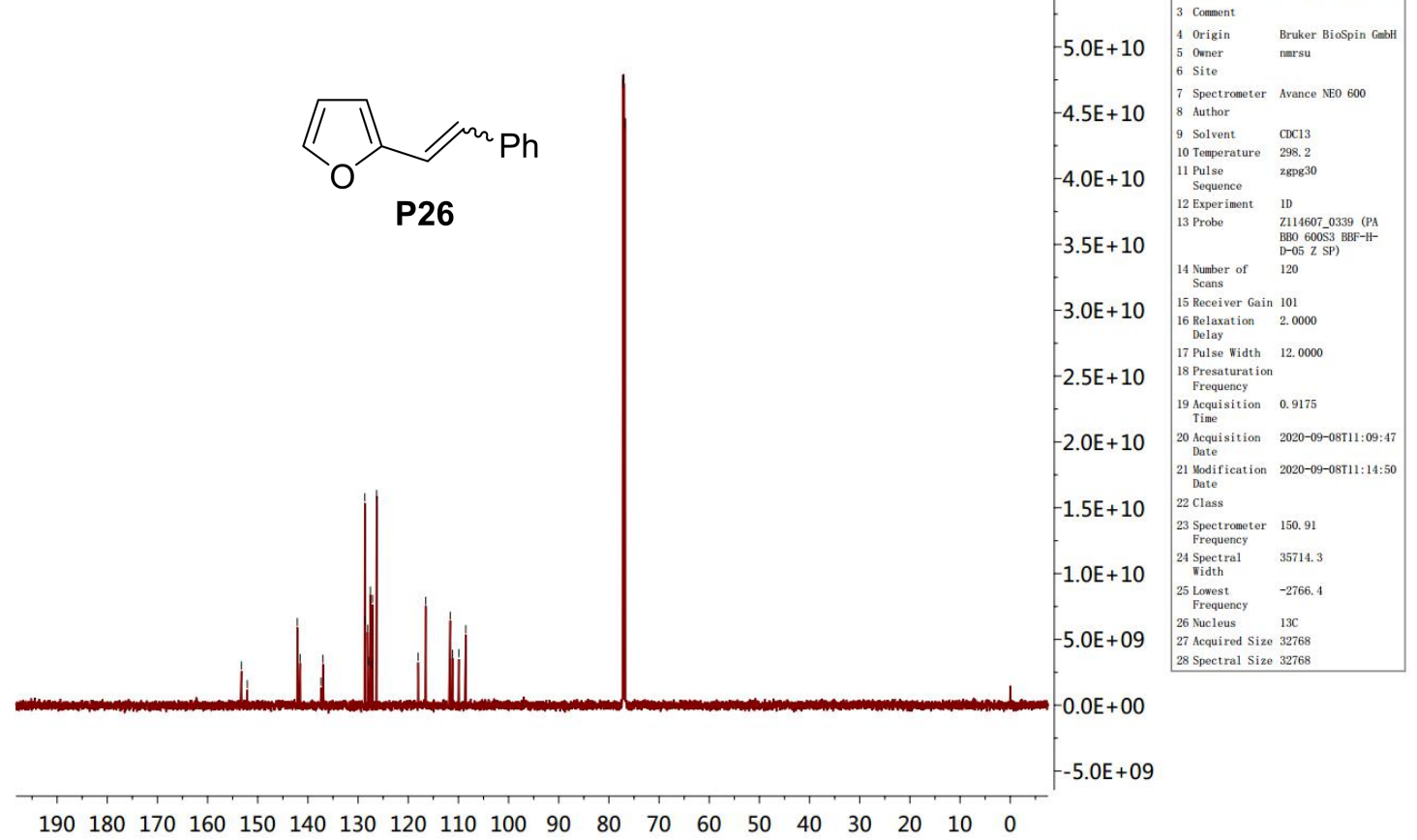




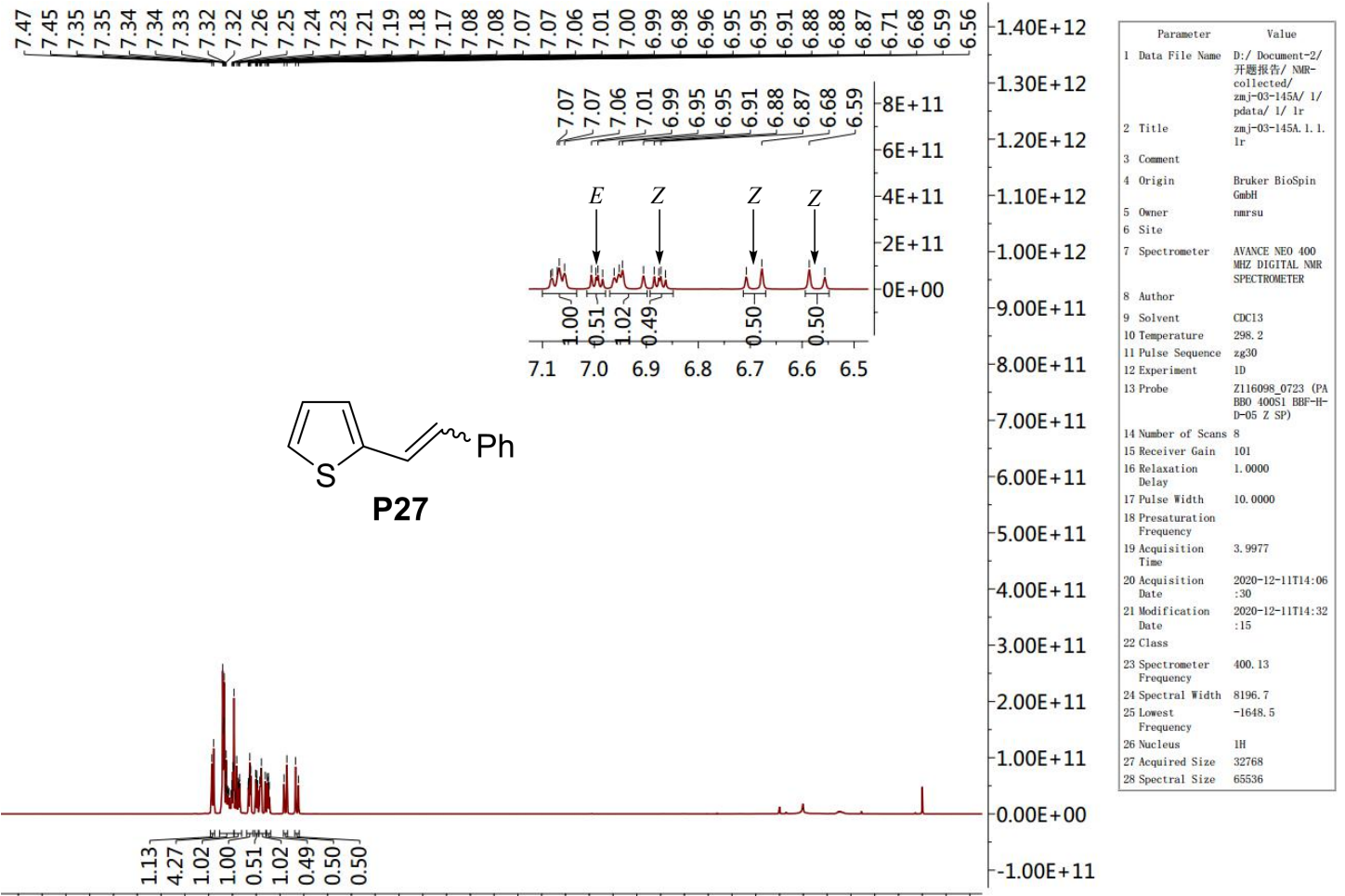

$\begin{array}{lllllllllllllllllllll}9.5 & 9.0 & 8.5 & 8.0 & 7.5 & 7.0 & 6.5 & 6.0 & 5.5 & 5.0 & 4.5 & 4.0 & 3.5 & 3.0 & 2.5 & 2.0 & 1.5 & 1.0 & 0.5 & 0.0 & -0.5\end{array}$

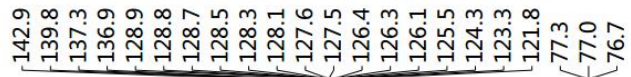

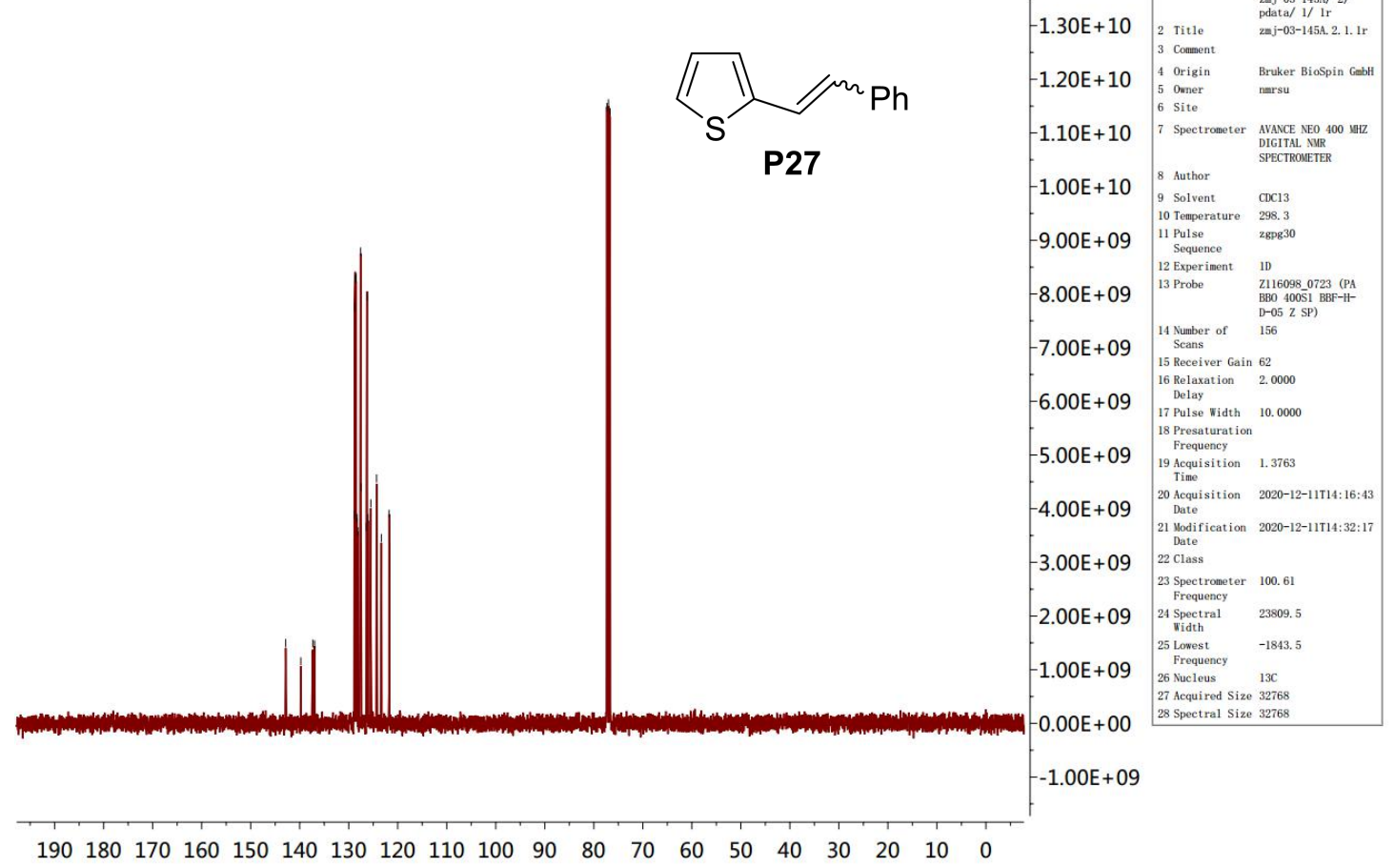



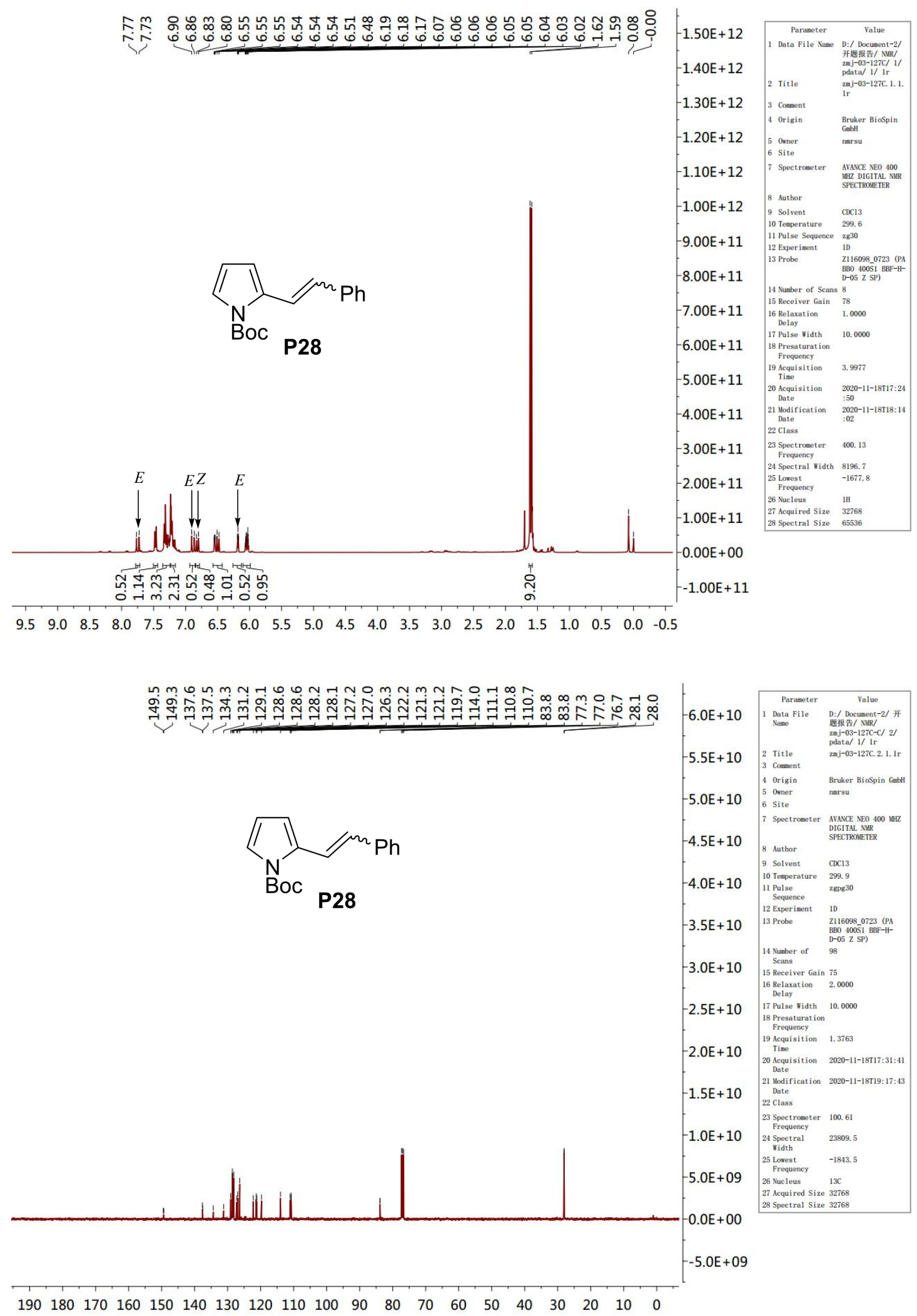


\section{2-Styrylbenzofuran (P29)}

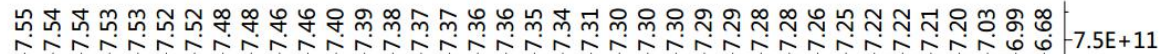

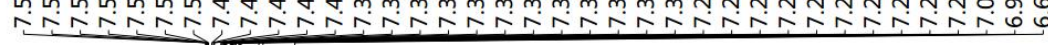<smiles>C(=Cc1cc2ccccc2o1)c1ccccc1</smiles>

P29

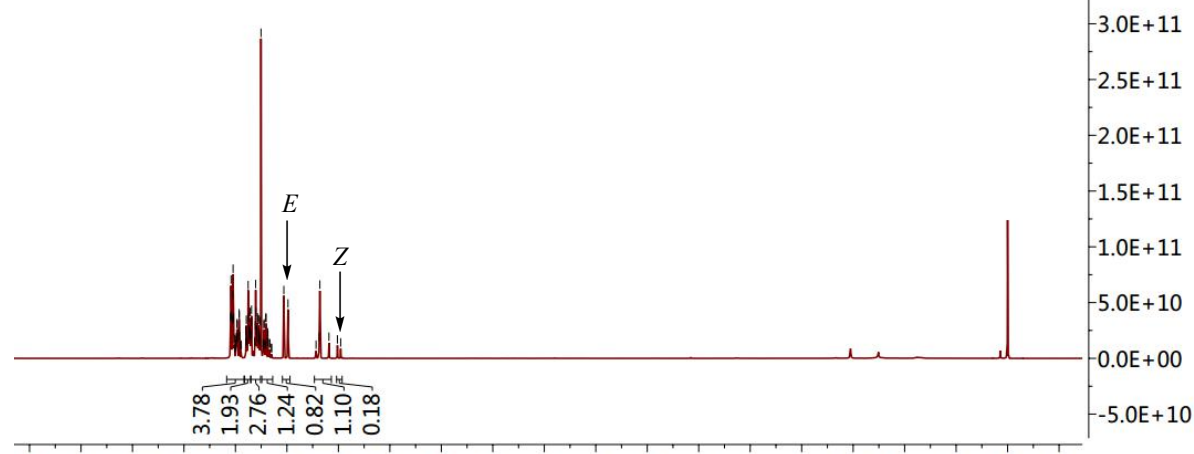

$\begin{array}{lllllllllllllllllllll}9.5 & 9.0 & 8.5 & 8.0 & 7.5 & 7.0 & 6.5 & 6.0 & 5.5 & 5.0 & 4.5 & 4.0 & 3.5 & 3.0 & 2.5 & 2.0 & 1.5 & 1.0 & 0.5 & 0.0 & -0.5\end{array}$

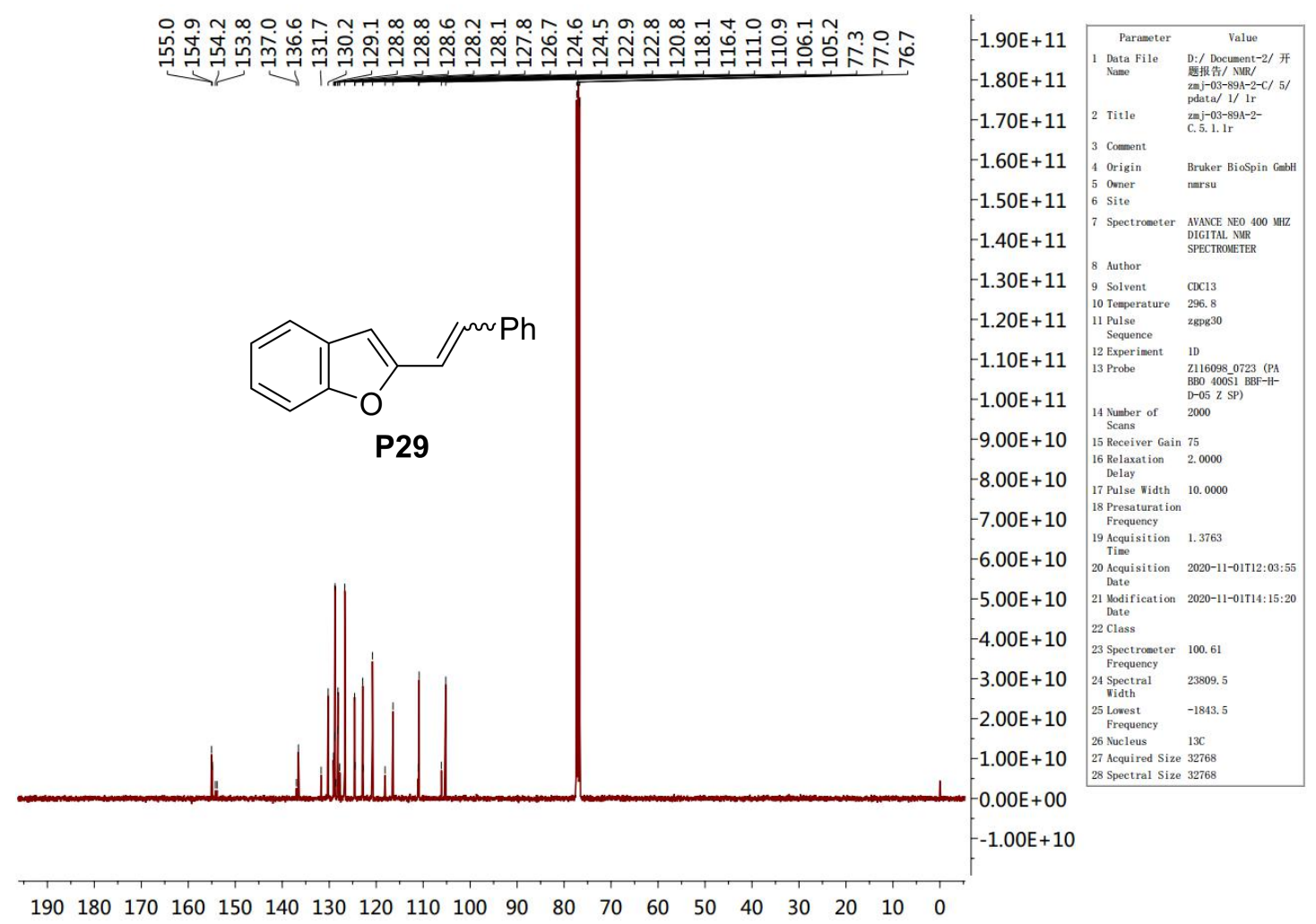




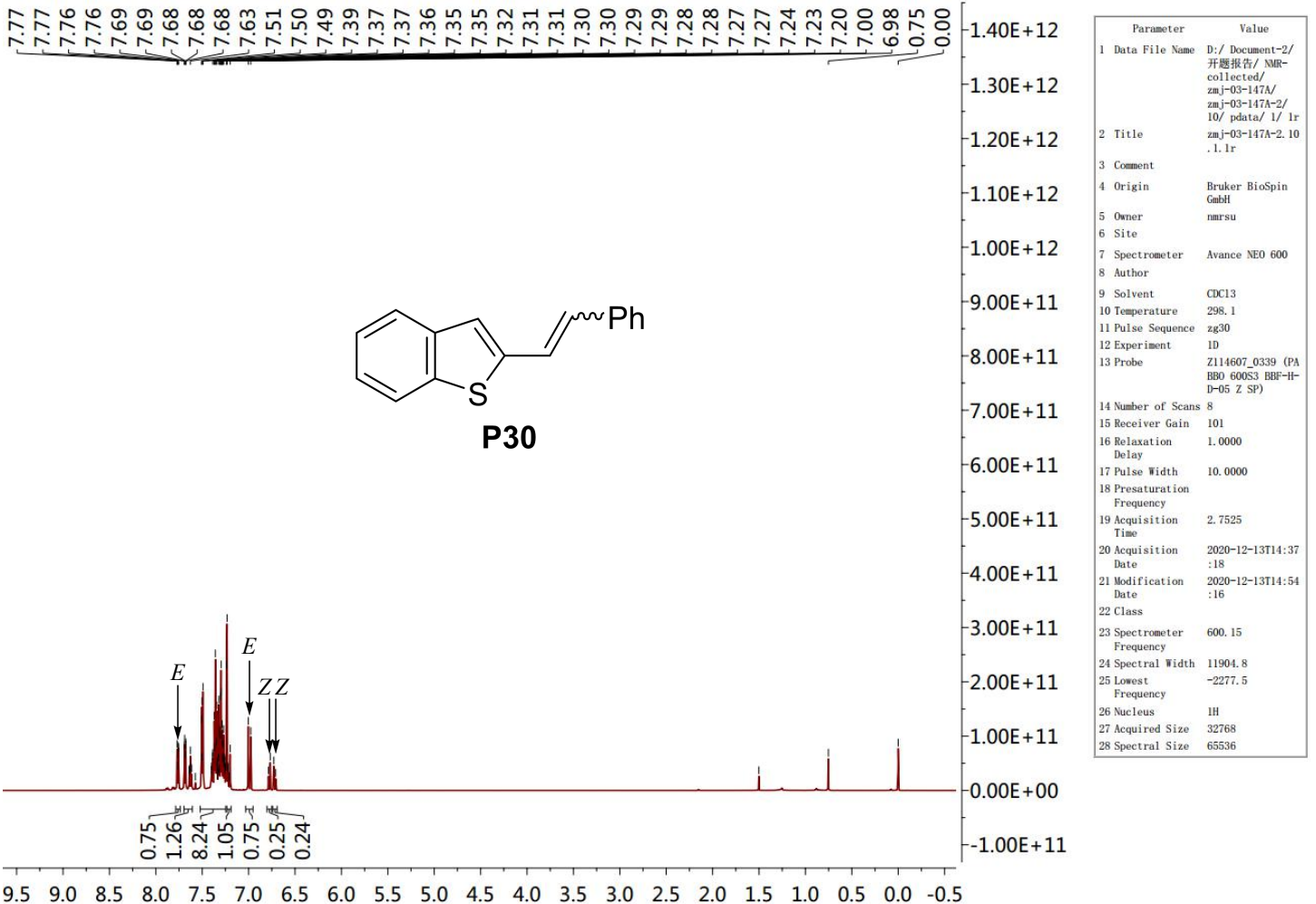

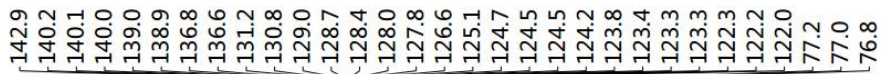<smiles>C(=Cc1cc2ccccc2s1)c1ccccc1</smiles>

P30

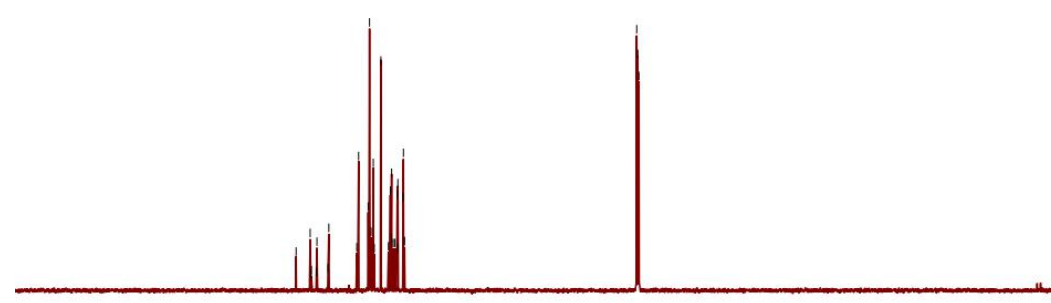

$-2.20 \mathrm{E}+11$ $-2.10 \mathrm{E}+11$ $-2.00 \mathrm{E}+11$ $-1.90 \mathrm{E}+11$

$-1.80 \mathrm{E}+11$

$-1.70 \mathrm{E}+11$

$-1.60 \mathrm{E}+11$

$-1.50 \mathrm{E}+11$

$-1.40 \mathrm{E}+11$

$-1.30 \mathrm{E}+11$

$-1.20 \mathrm{E}+11$

$-1.10 \mathrm{E}+11$

$-1.00 \mathrm{E}+11$

$-9.00 \mathrm{E}+10$

$-8.00 \mathrm{E}+10$

$-7.00 \mathrm{E}+10$

$-6.00 \mathrm{E}+10$

$-5.00 \mathrm{E}+10$

$-4.00 \mathrm{E}+10$

$-3.00 E+10$

$-2.00 \mathrm{E}+10$

$-1.00 \mathrm{E}+10$

$-0.00 \mathrm{E}+00$

$-1.00 \mathrm{E}+10$

$-2.00 E+10$

$\begin{array}{llllllllllllllllllll}190 & 180 & 170 & 160 & 150 & 140 & 130 & 120 & 110 & 100 & 90 & 80 & 70 & 60 & 50 & 40 & 30 & 20 & 10 & 0\end{array}$

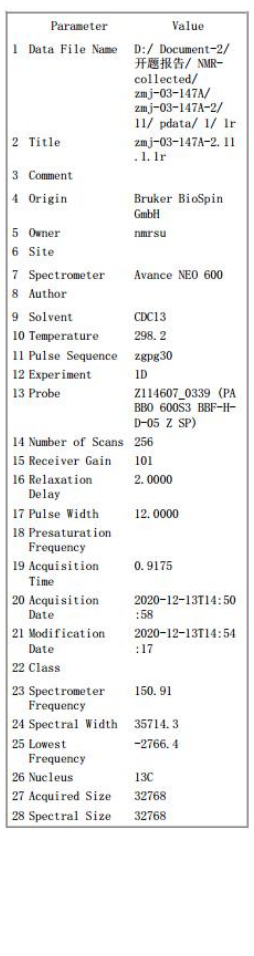




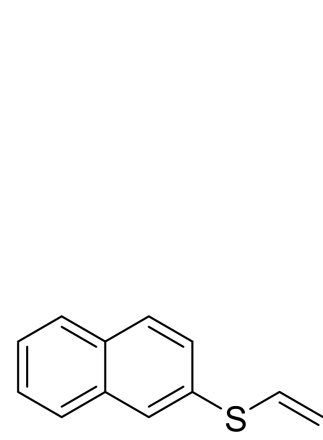

$3.2 \mathrm{E}+12$

$-3.0 \mathrm{E}+12$

$-2.8 \mathrm{E}+12$

$2.6 \mathrm{E}+12$

$2.4 \mathrm{E}+12$

$2.2 \mathrm{E}+12$

$-2.0 \mathrm{E}+12$

$-1.8 \mathrm{E}+12$

$-1.6 \mathrm{E}+12$

$-1.4 \mathrm{E}+12$

P31

$-1.2 \mathrm{E}+12$

$-1.0 \mathrm{E}+12$

$-8.0 \mathrm{E}+11$

$6.0 \mathrm{E}+11$

$4.0 \mathrm{E}+11$
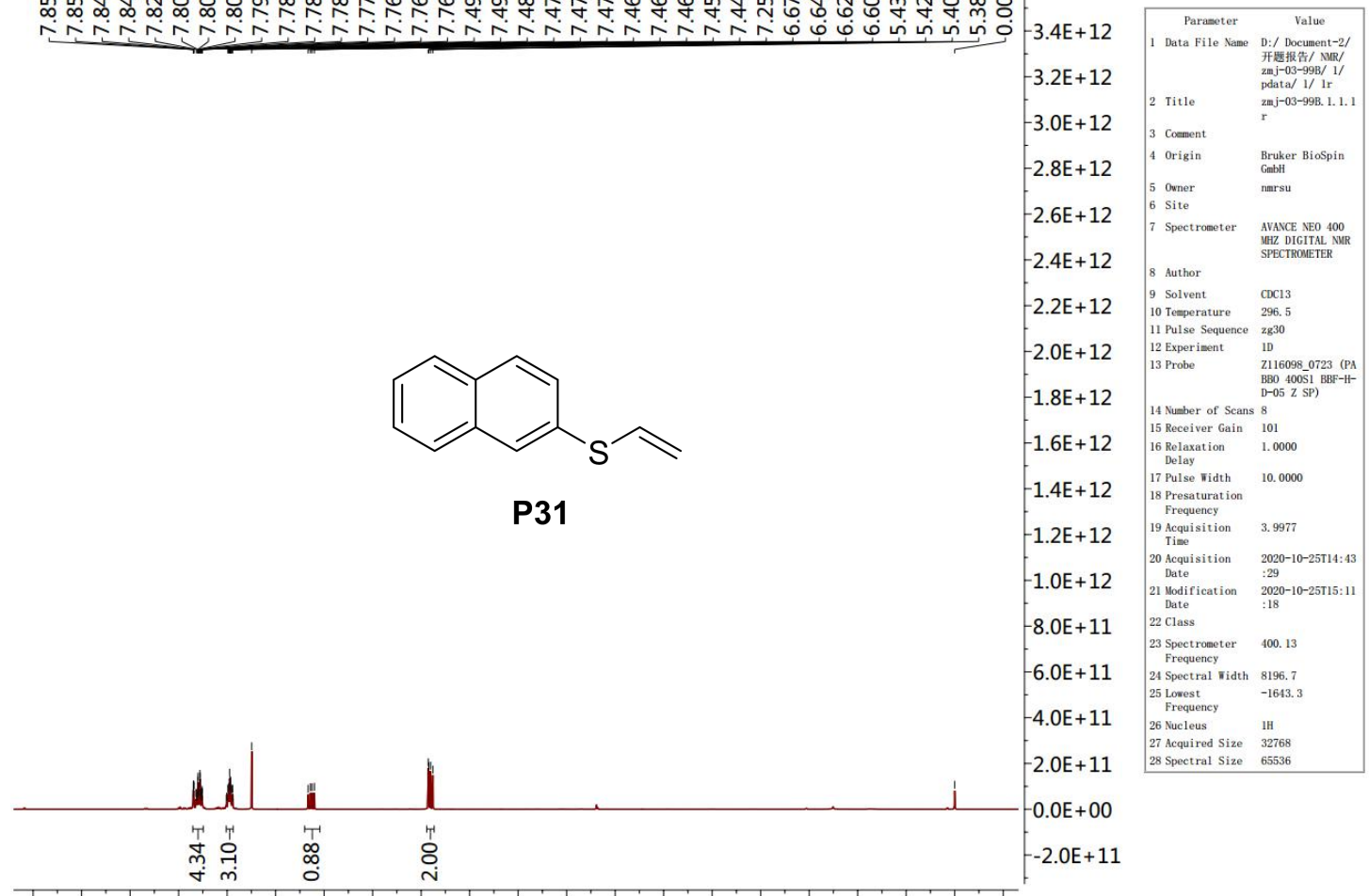

$\begin{array}{llllllllllllllllllllll}9.5 & 9.0 & 8.5 & 8.0 & 7.5 & 7.0 & 6.5 & 6.0 & 5.5 & 5.0 & 4.5 & 4.0 & 3.5 & 3.0 & 2.5 & 2.0 & 1.5 & 1.0 & 0.5 & 0.0 & -0.5\end{array}$
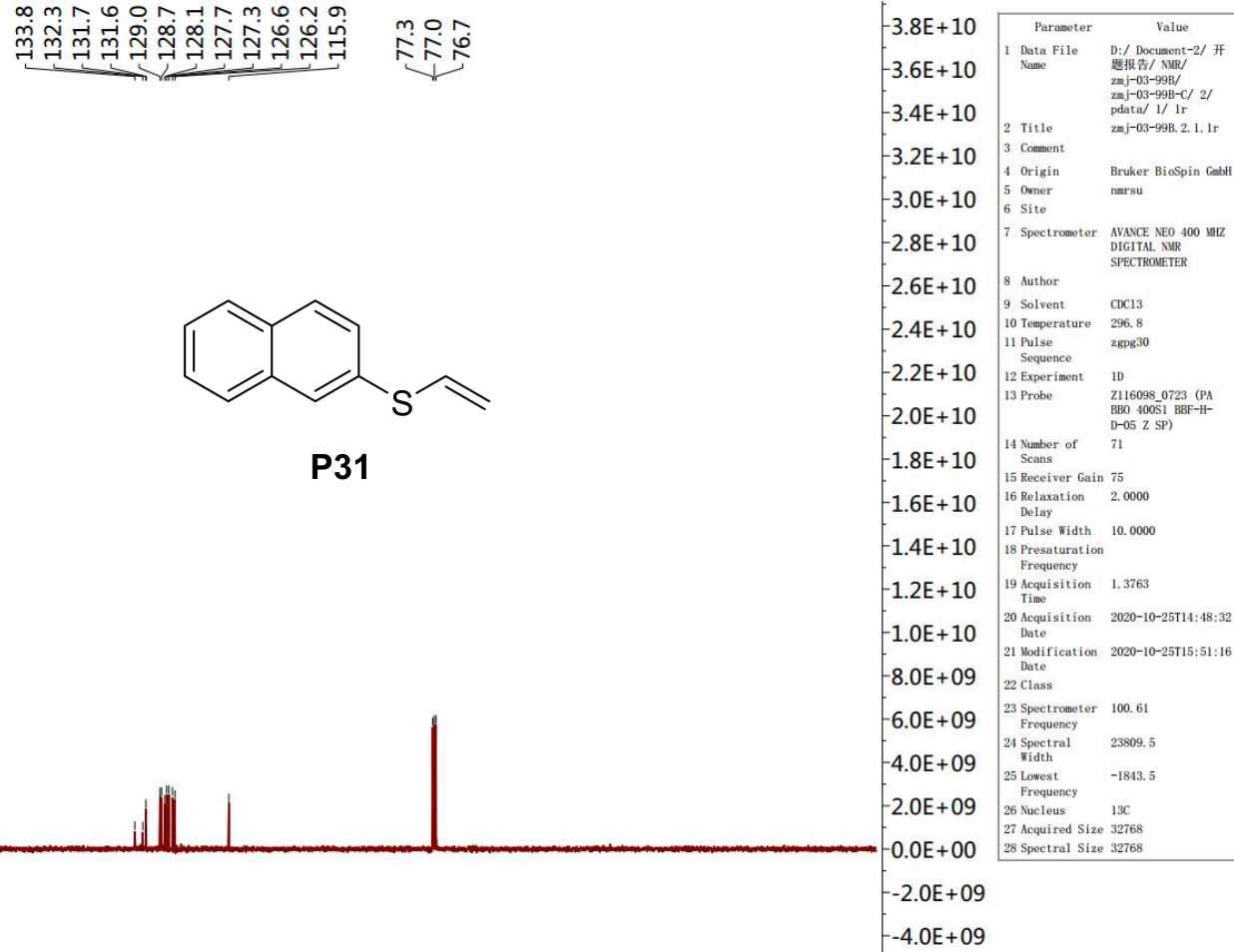

$\begin{array}{llllllllllllllllllll}190 & 180 & 170 & 160 & 150 & 140 & 130 & 120 & 110 & 100 & 90 & 80 & 70 & 60 & 50 & 40 & 30 & 20 & 10 & 0\end{array}$ 
Naphthalen-2-yl(prop-1-en-2-yl)sulfane (P32)

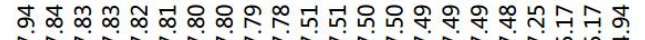<smiles>C=C(C)Sc1ccc2ccccc2c1</smiles>

نู่

P32

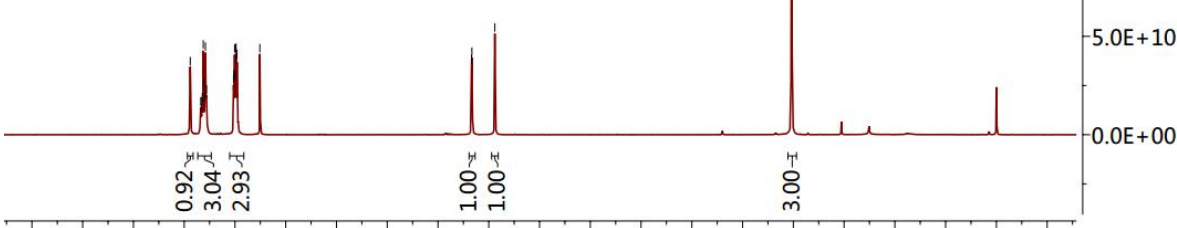

$\begin{array}{lllllllllllllllllllll}9.5 & 9.0 & 8.5 & 8.0 & 7.5 & 7.0 & 6.5 & 6.0 & 5.5 & 5.0 & 4.5 & 4.0 & 3.5 & 3.0 & 2.5 & 2.0 & 1.5 & 1.0 & 0.5 & 0.0 & -0.5\end{array}$

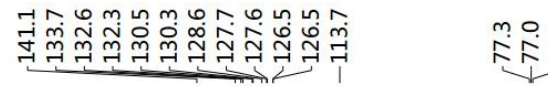<smiles>C=C(C)Sc1ccc2ccccc2c1</smiles> 
Naphthalen-2-yl(prop-1-en-1-yl)sulfane (P33)
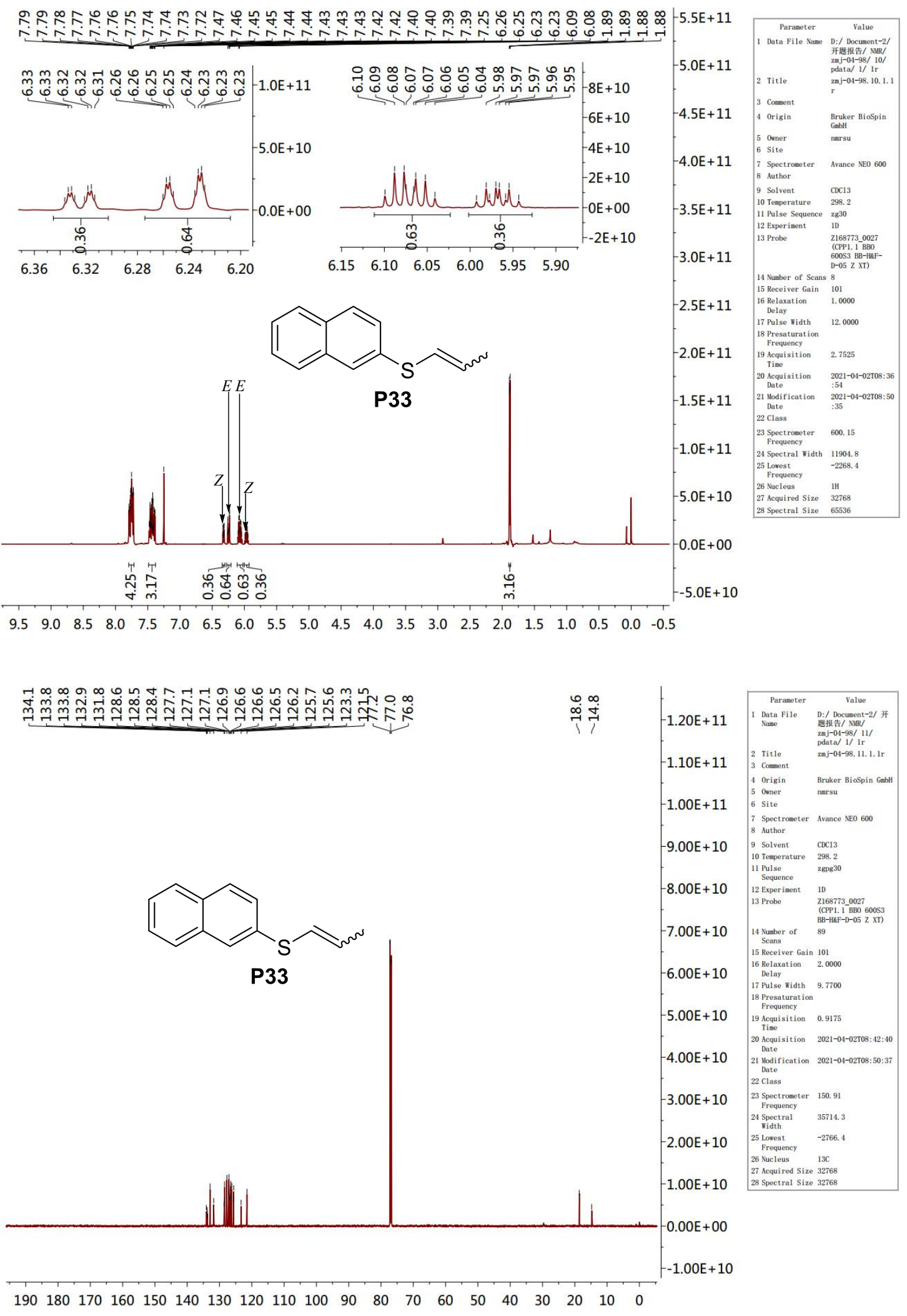
But-1-en-2-yl(naphthalen-2-yl)sulfane (P34)

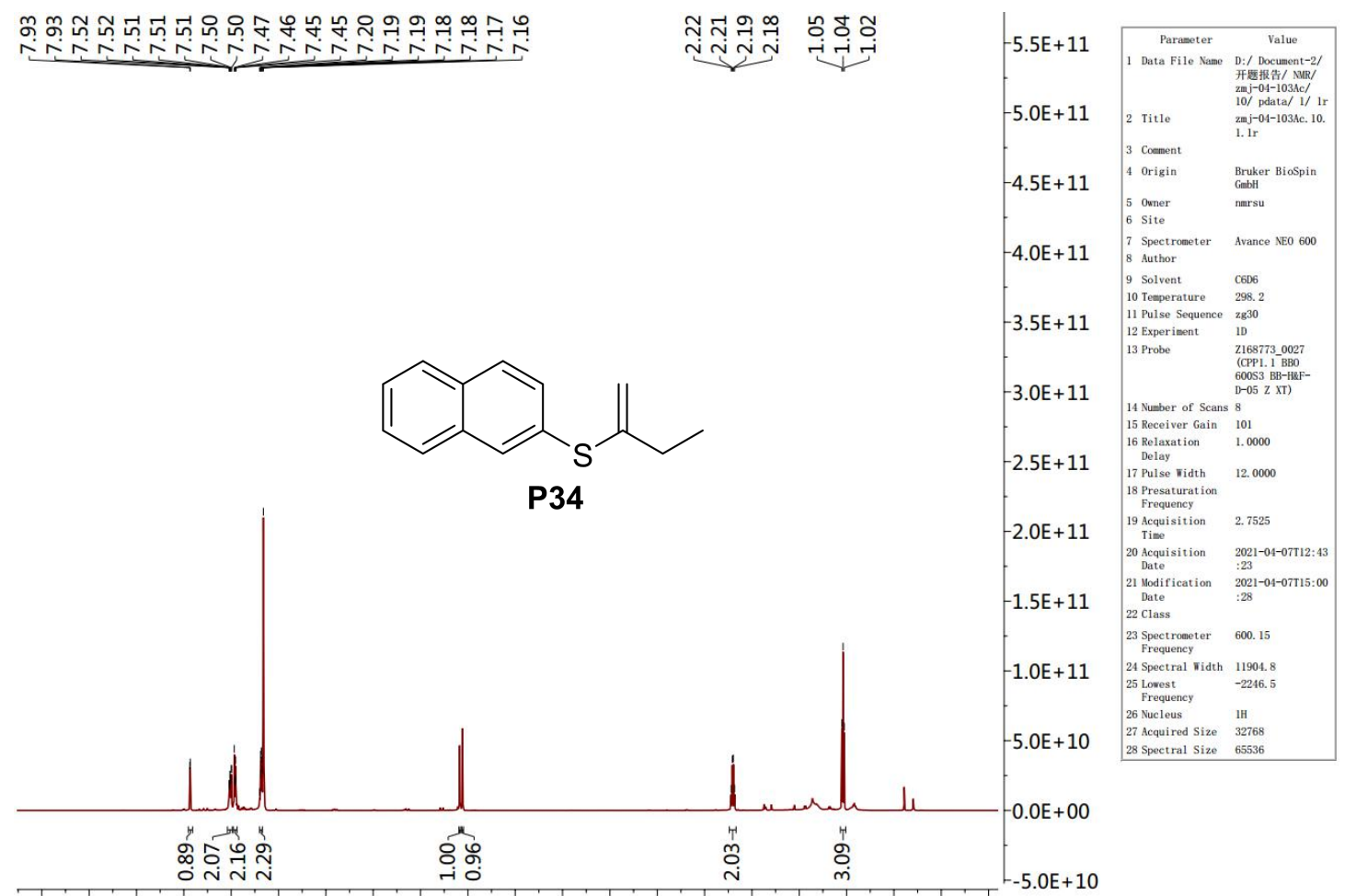

$\begin{array}{lllllllllllllllllllll}9.5 & 9.0 & 8.5 & 8.0 & 7.5 & 7.0 & 6.5 & 6.0 & 5.5 & 5.0 & 4.5 & 4.0 & 3.5 & 3.0 & 2.5 & 2.0 & 1.5 & 1.0 & 0.5 & 0.0 & -0.5\end{array}$

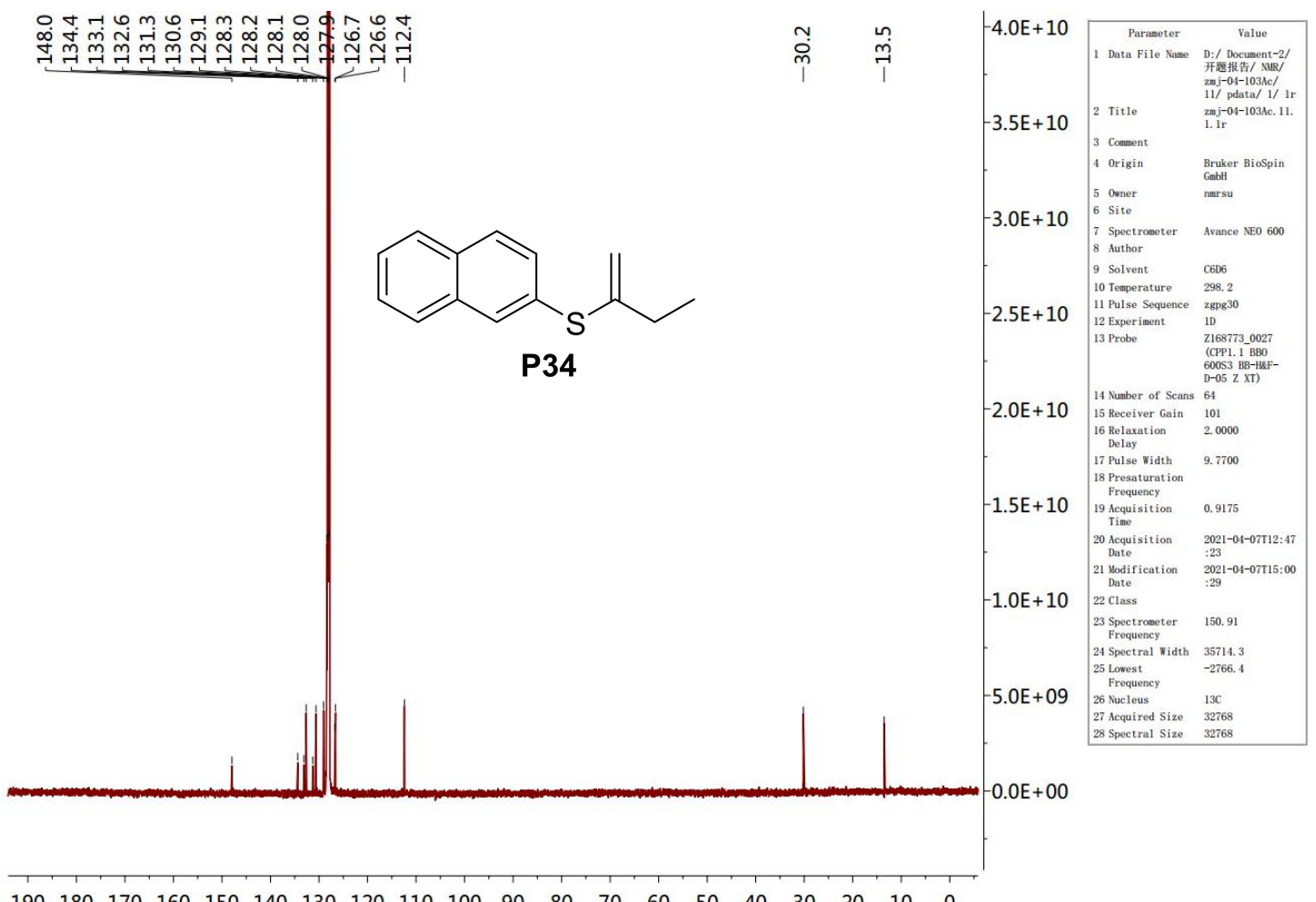

$\begin{array}{llllllllllllllllllll}190 & 180 & 170 & 160 & 150 & 140 & 130 & 120 & 110 & 100 & 90 & 80 & 70 & 60 & 50 & 40 & 30 & 20 & 10 & 0\end{array}$ 
(4-Chlorophenyl)(phenyl)sulfane (P35)
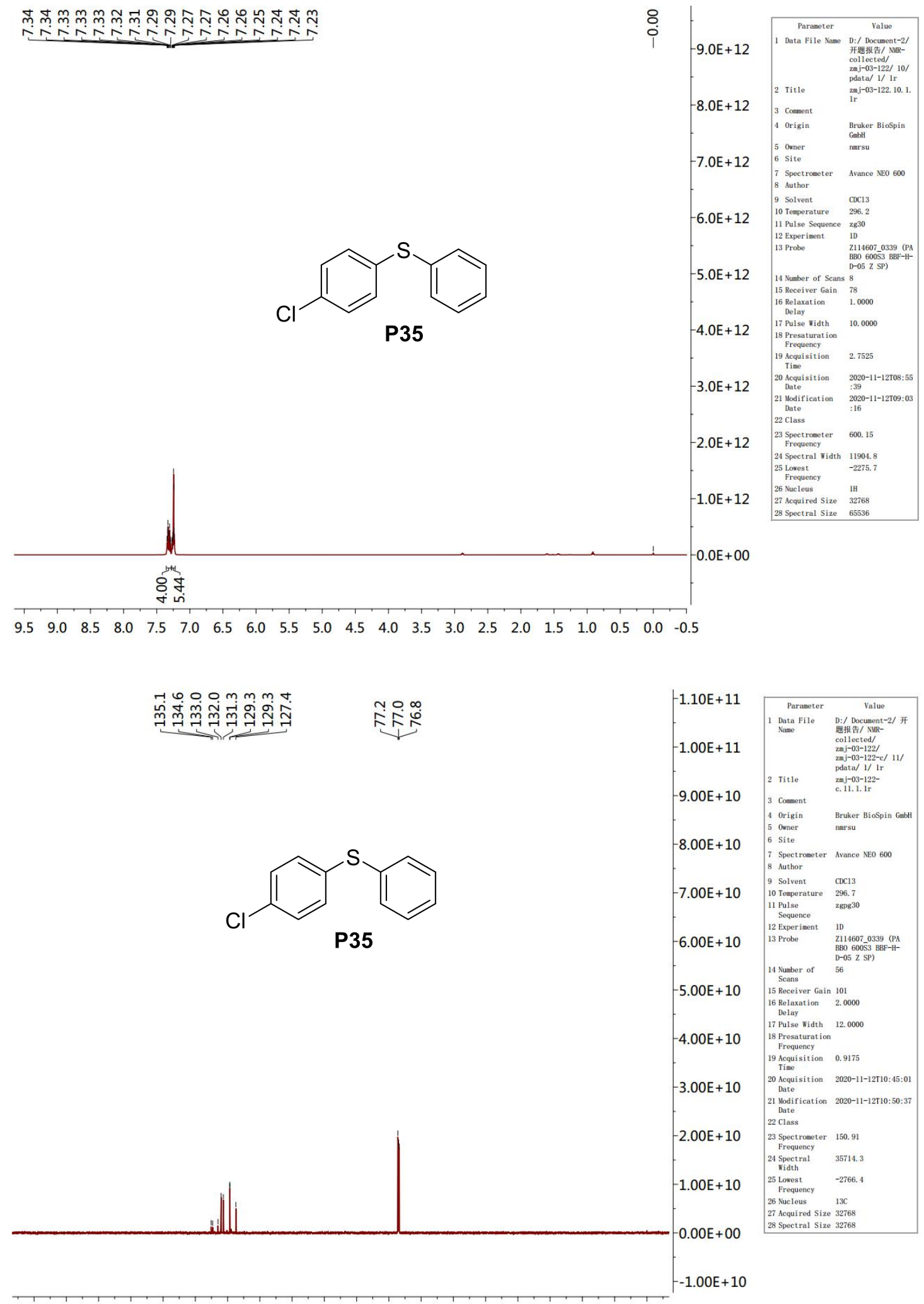

$\begin{array}{llllllllllllllllllll}190 & 180 & 170 & 160 & 150 & 140 & 130 & 120 & 110 & 100 & 90 & 80 & 70 & 60 & 50 & 40 & 30 & 20 & 10 & 0\end{array}$ 


\section{(4-Chlorophenyl)(3-phenylprop-1-en-1-yl)sulfane (P36)}
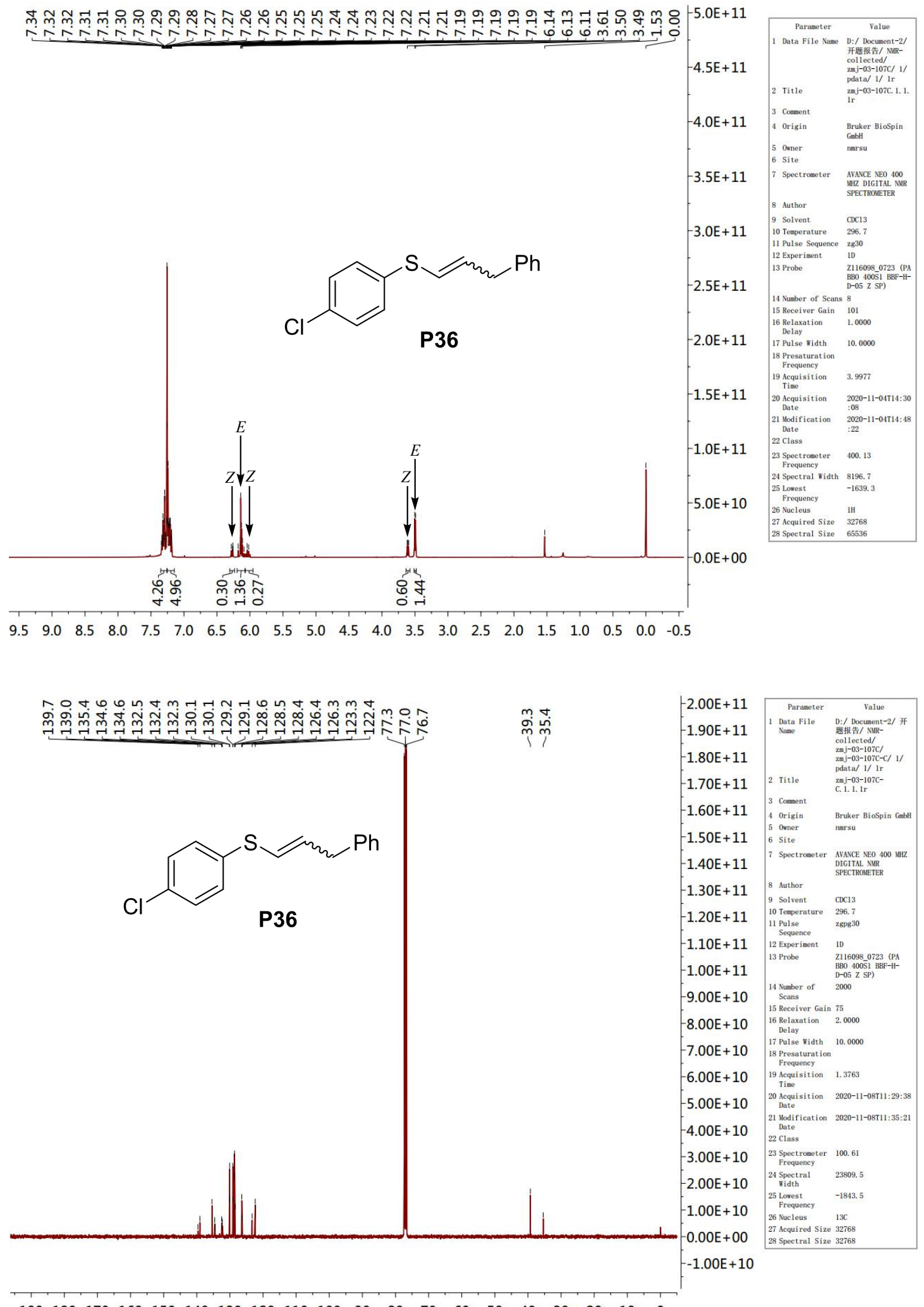

$\begin{array}{llllllllllllllllllll}190 & 180 & 170 & 160 & 150 & 140 & 130 & 120 & 110 & 100 & 90 & 80 & 70 & 60 & 50 & 40 & 30 & 20 & 10 & 0\end{array}$ 


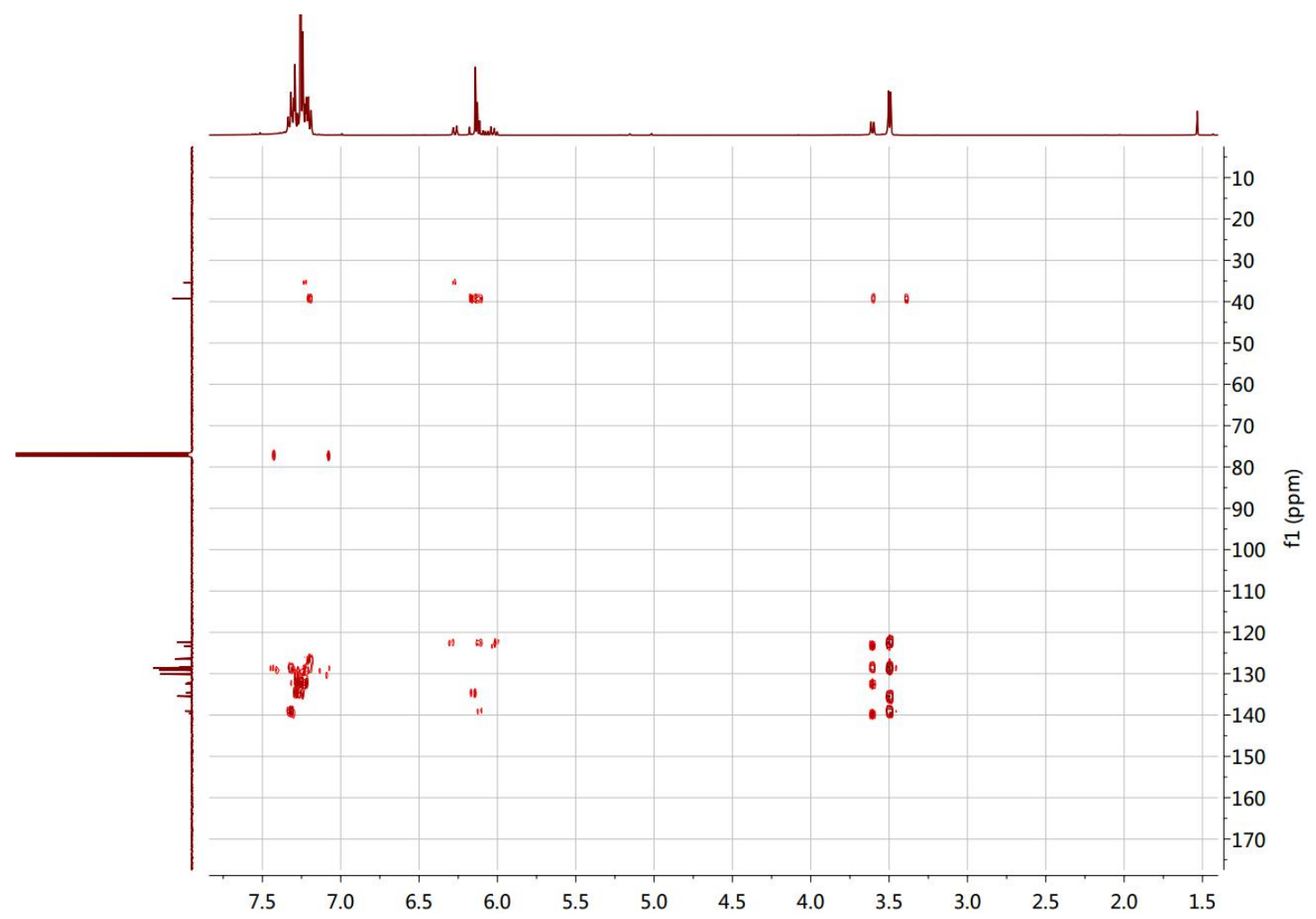

The zoom of HMBC spectrum of $\mathbf{P 3 6}$

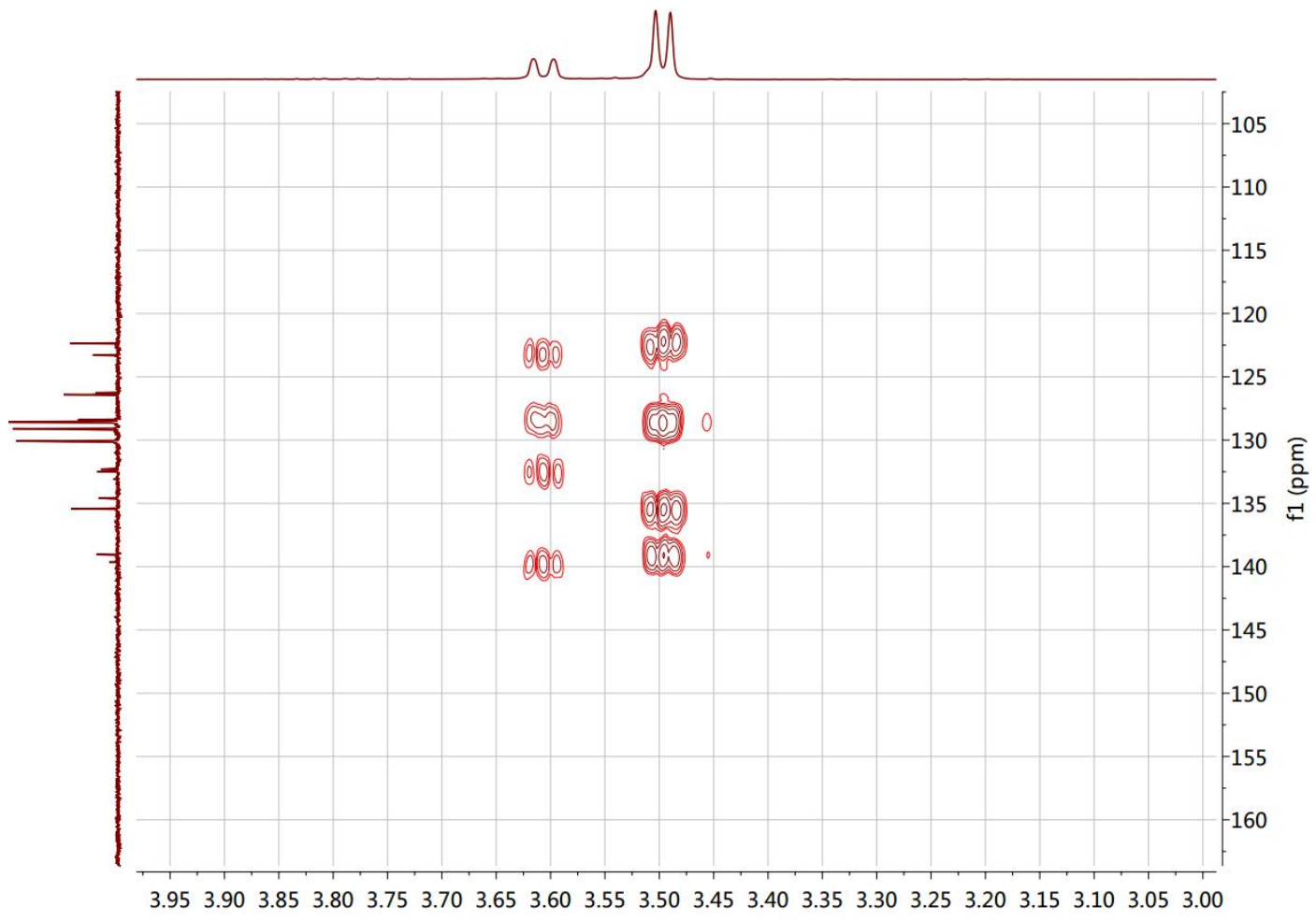

The zoom of HMBC spectrum of P36 
Phenyl(3-phenylprop-1-en-1-yl)sulfane (P37)

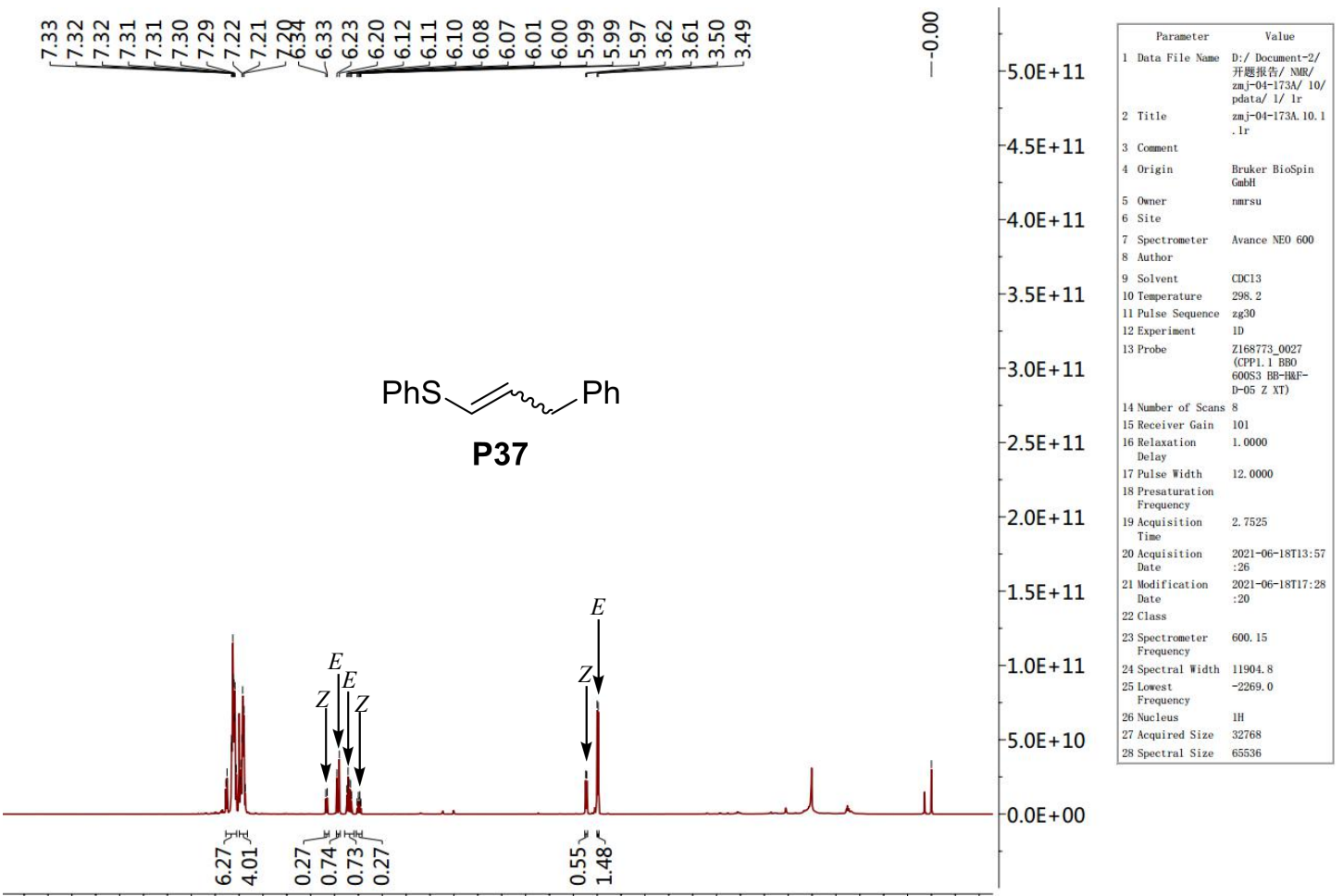

$\begin{array}{lllllllllllllllllllll}9.5 & 9.0 & 8.5 & 8.0 & 7.5 & 7.0 & 6.5 & 6.0 & 5.5 & 5.0 & 4.5 & 4.0 & 3.5 & 3.0 & 2.5 & 2.0 & 1.5 & 1.0 & 0.5 & 0.0 & -0.5\end{array}$

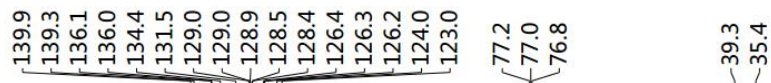

$\mathrm{PhS} \backslash / m_{2}-\mathrm{Ph}$

P37

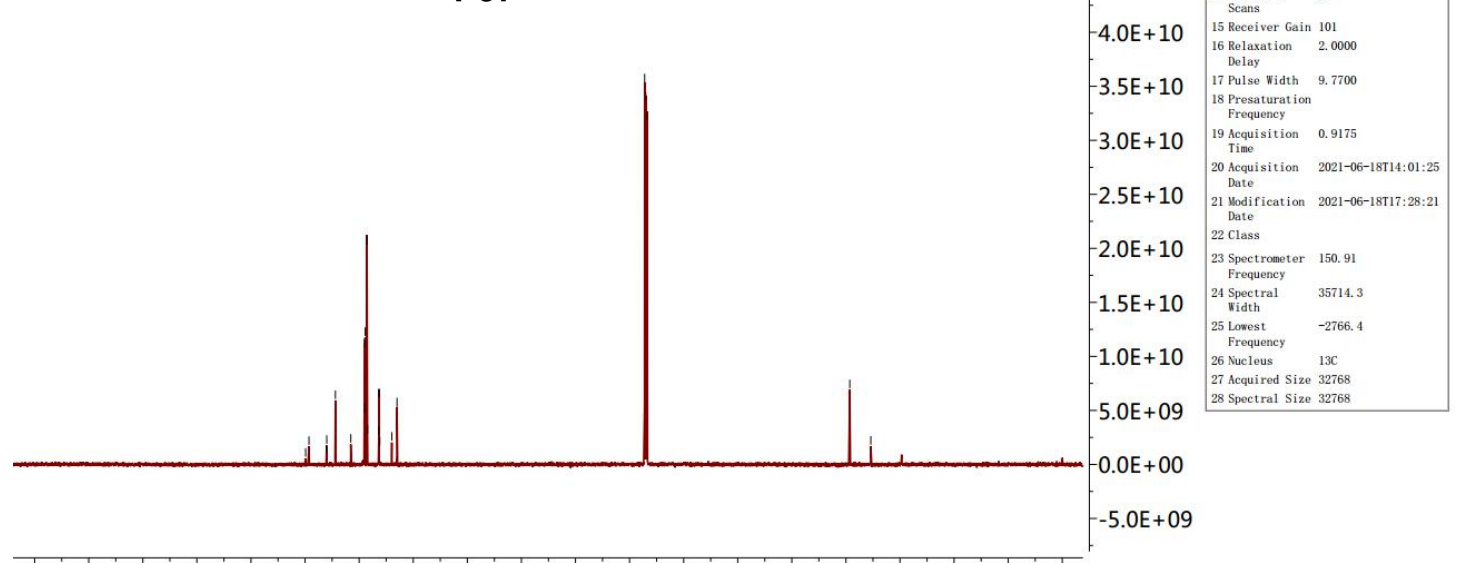

$\begin{array}{llllllllllllllllllll}190 & 180 & 170 & 160 & 150 & 140 & 130 & 120 & 110 & 100 & 90 & 80 & 70 & 60 & 50 & 40 & 30 & 20 & 10 & 0\end{array}$ 


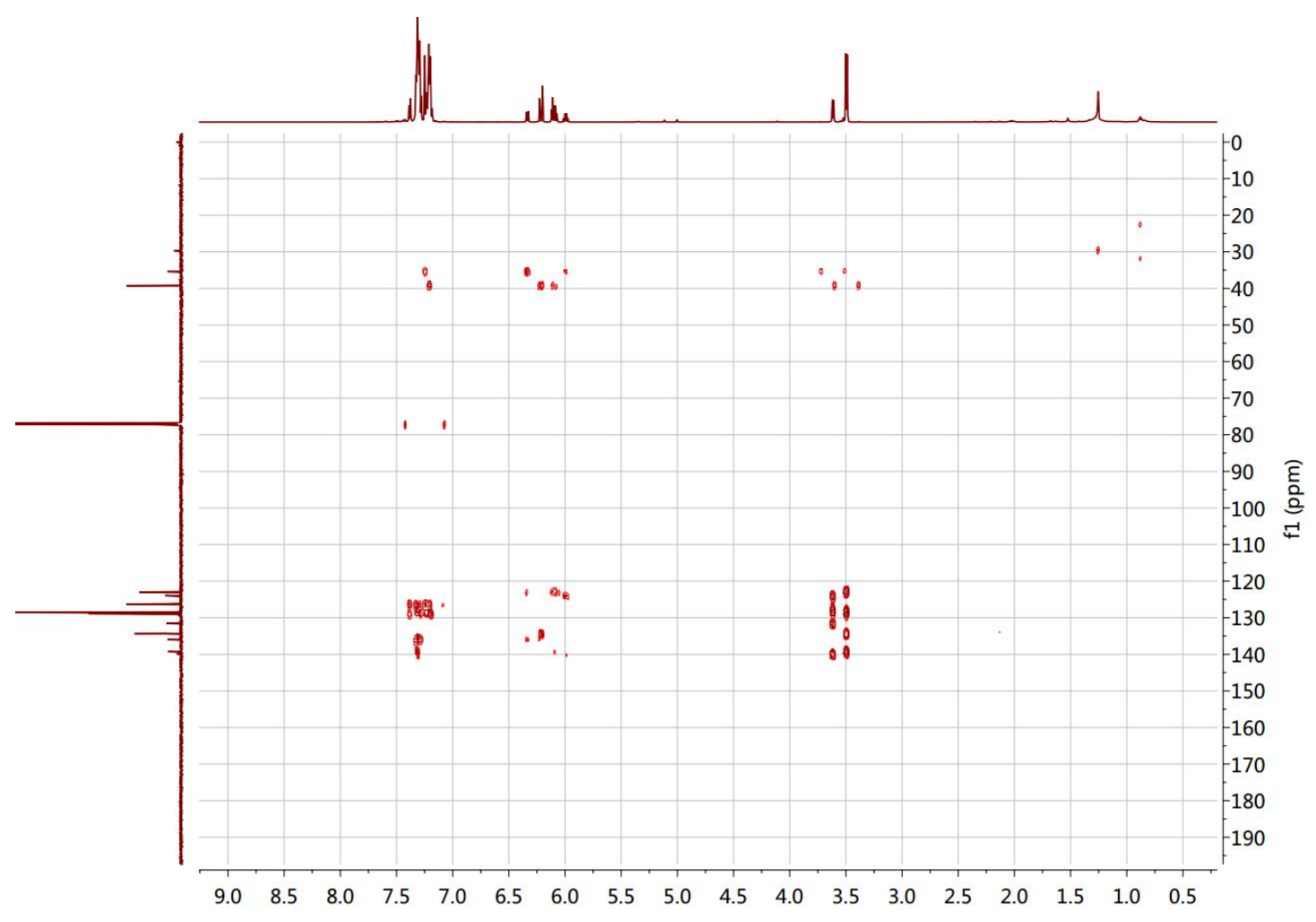

The zoom of HMBC spectrum of $\mathbf{P 3 7}$

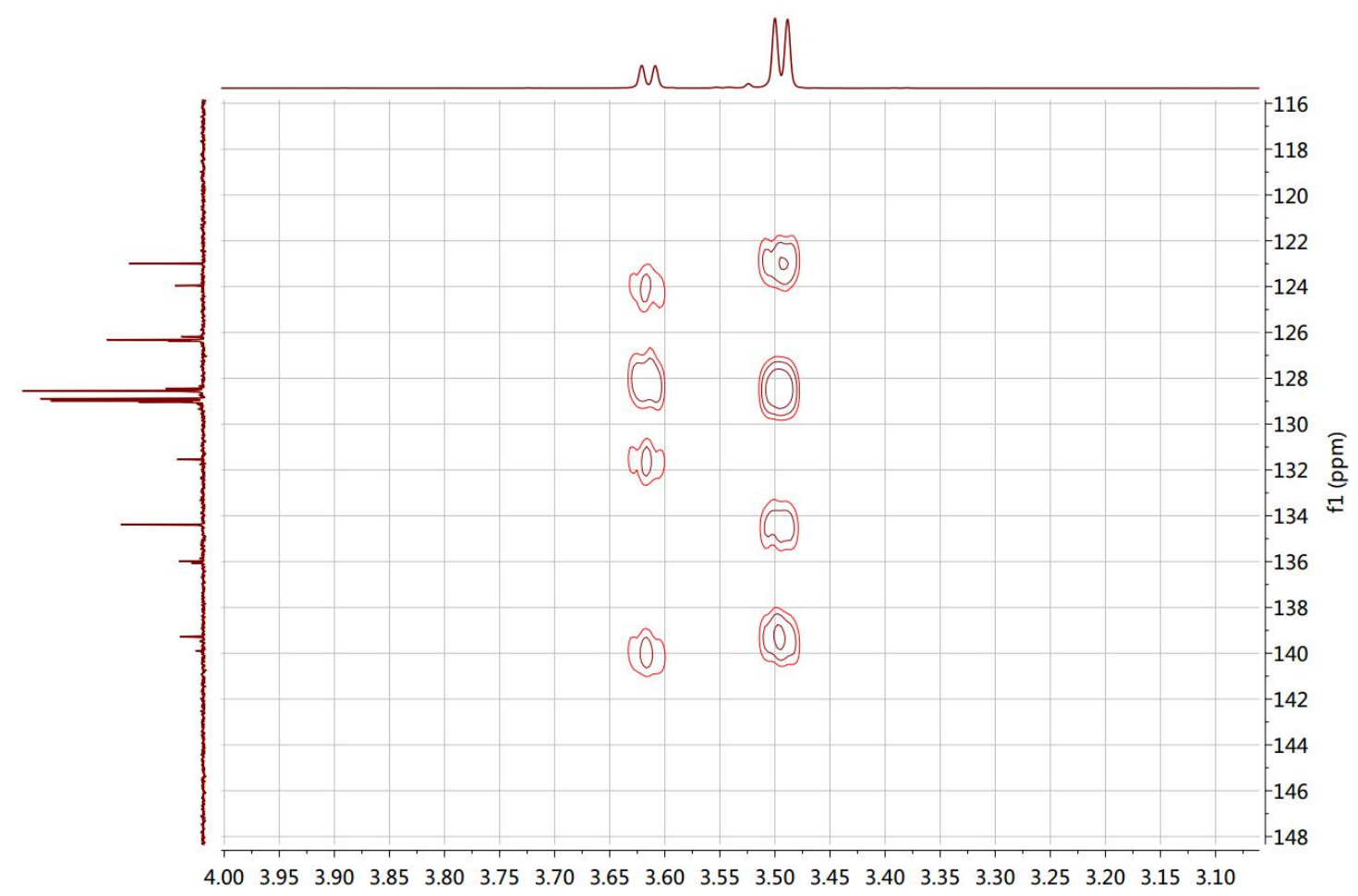

The zoom of HMBC spectrum of P37 


\section{(4-Chlorophenyl)(styryl)sulfane (P38)}

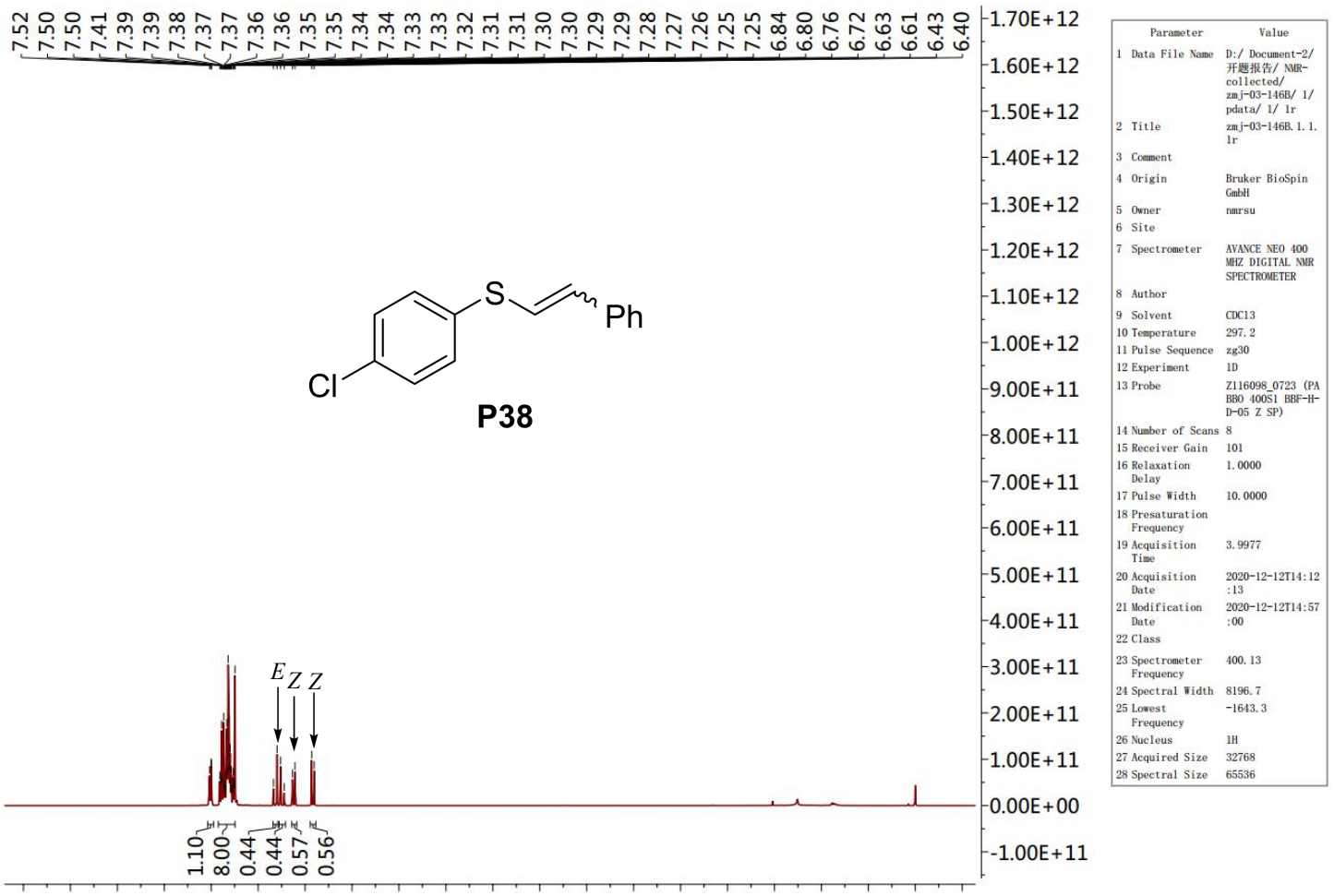

$\begin{array}{lllllllllllllllllllll}9.5 & 9.0 & 8.5 & 8.0 & 7.5 & 7.0 & 6.5 & 6.0 & 5.5 & 5.0 & 4.5 & 4.0 & 3.5 & 3.0 & 2.5 & 2.0 & 1.5 & 1.0 & 0.5 & 0.0 & -0.5\end{array}$

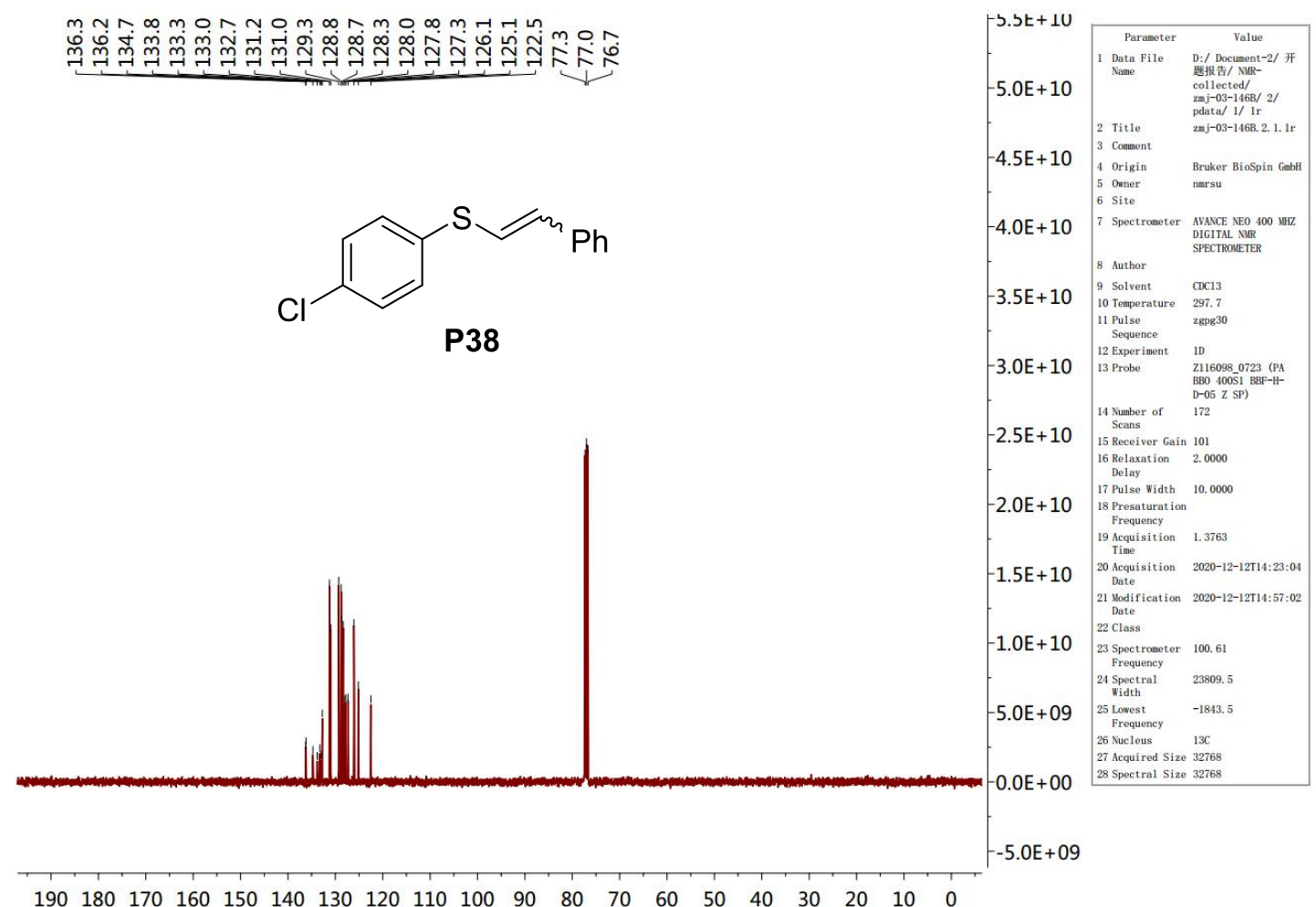




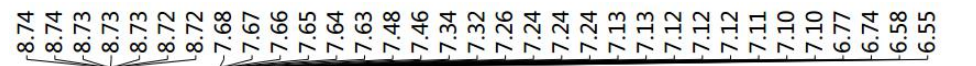

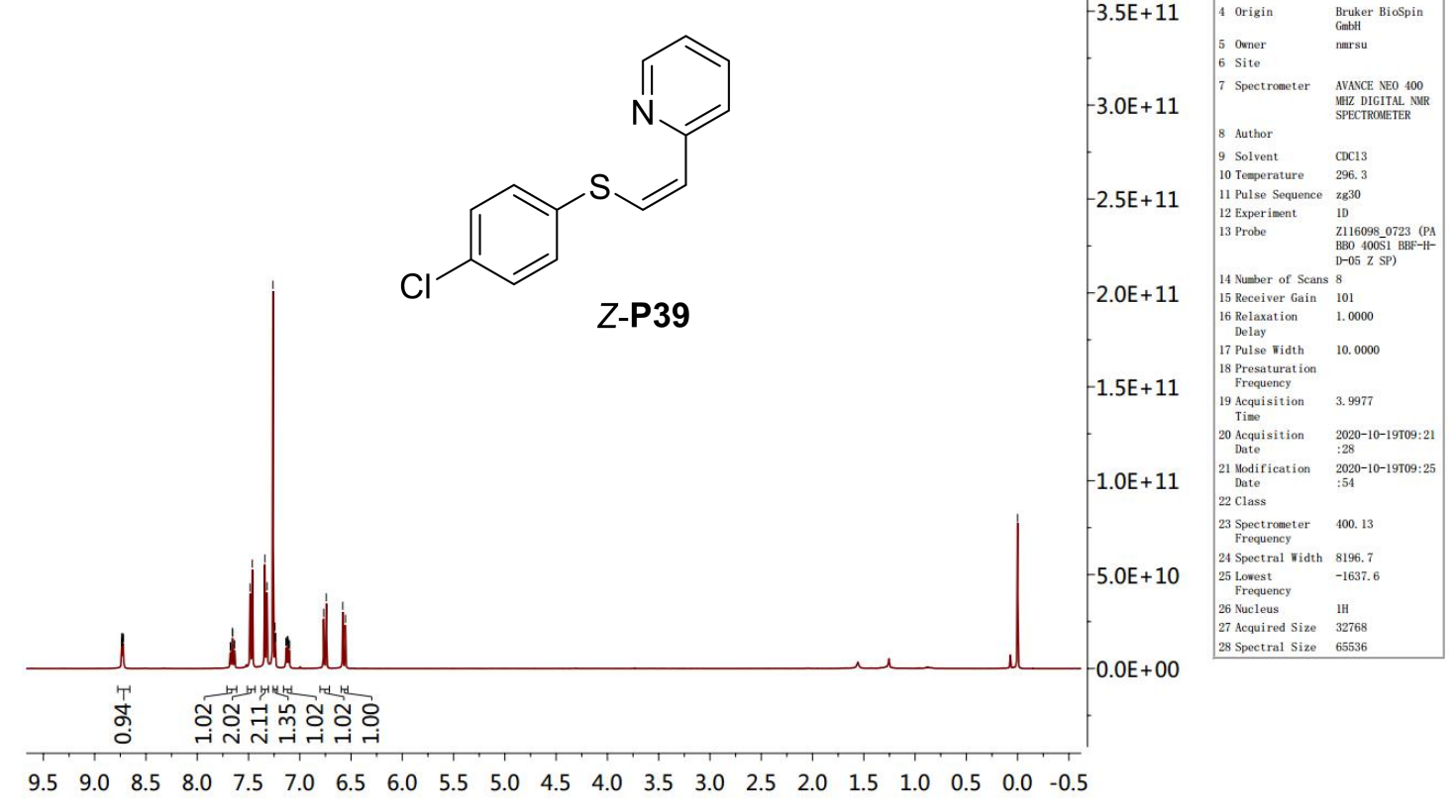

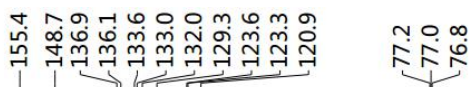
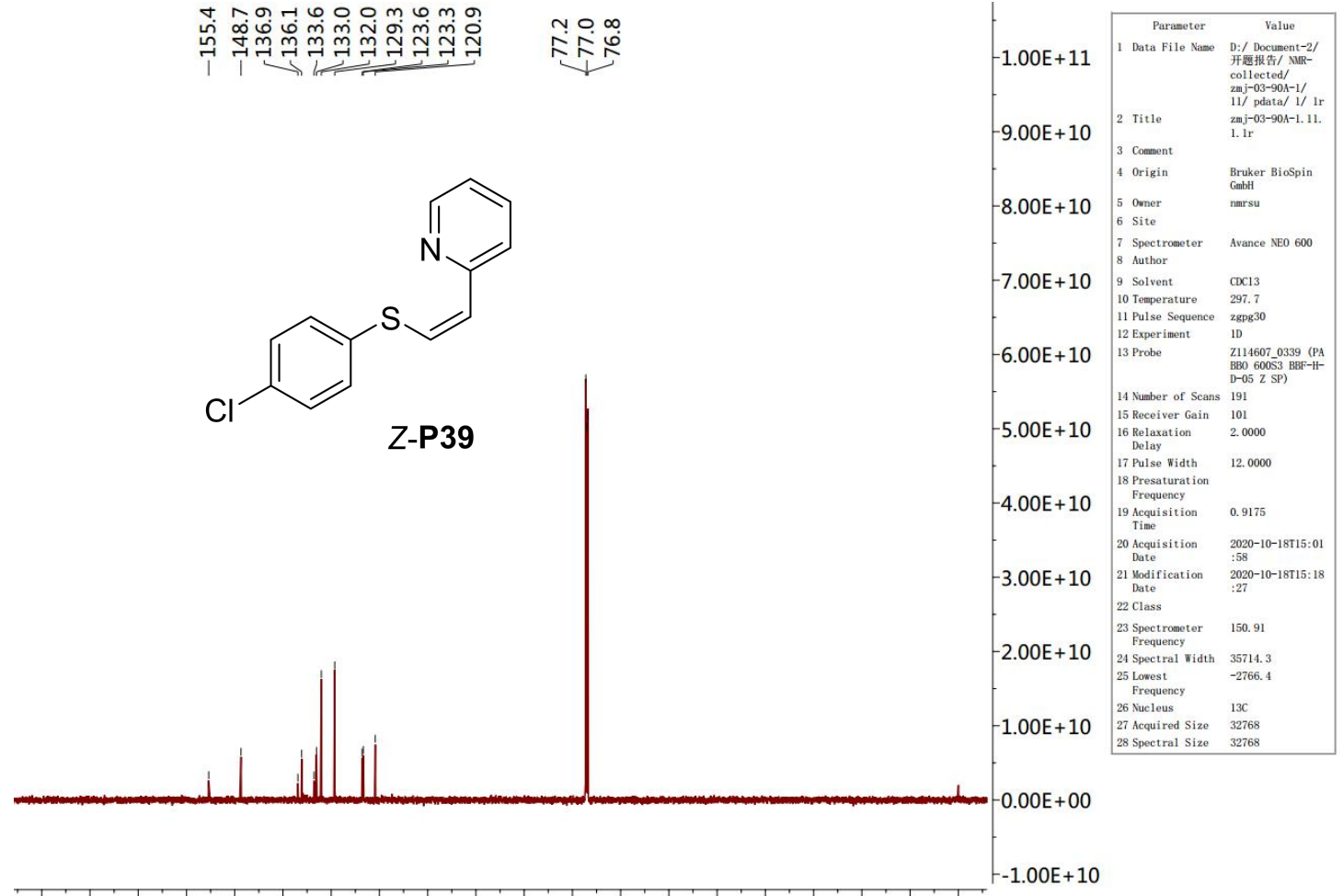

$\begin{array}{llllllllllllllllllll}190 & 180 & 170 & 160 & 150 & 140 & 130 & 120 & 110 & 100 & 90 & 80 & 70 & 60 & 50 & 40 & 30 & 20 & 10 & 0\end{array}$ 


\section{(E)-2-(2-((4-Chlorophenyl)thio)vinyl)pyridine (E-P39)}

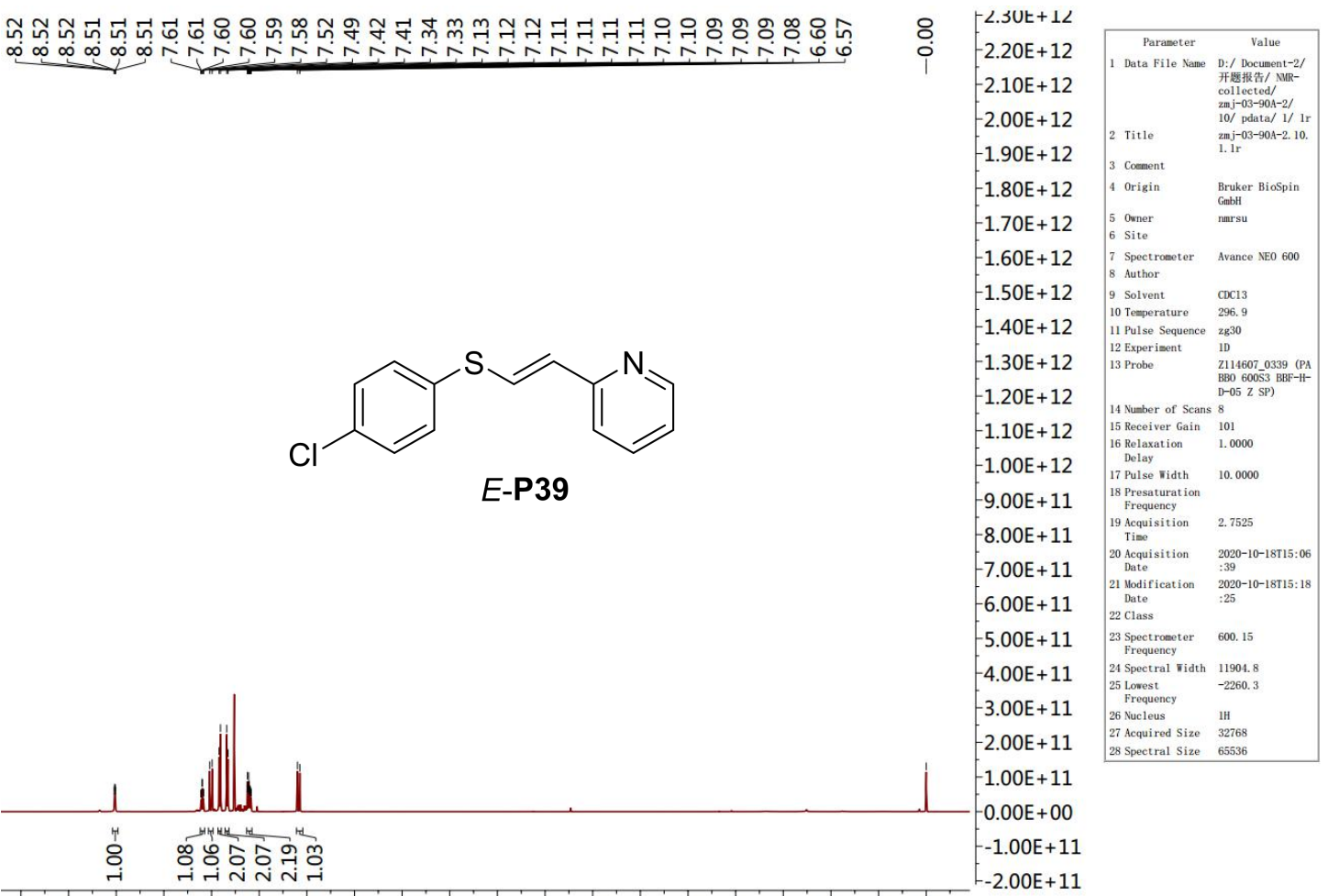

$\begin{array}{llllllllllllllllllll}9.5 & 9.0 & 8.5 & 8.0 & 7.5 & 7.0 & 6.5 & 6.0 & 5.5 & 5.0 & 4.5 & 4.0 & 3.5 & 3.0 & 2.5 & 2.0 & 1.5 & 1.0 & 0.5 & 0.0\end{array}$

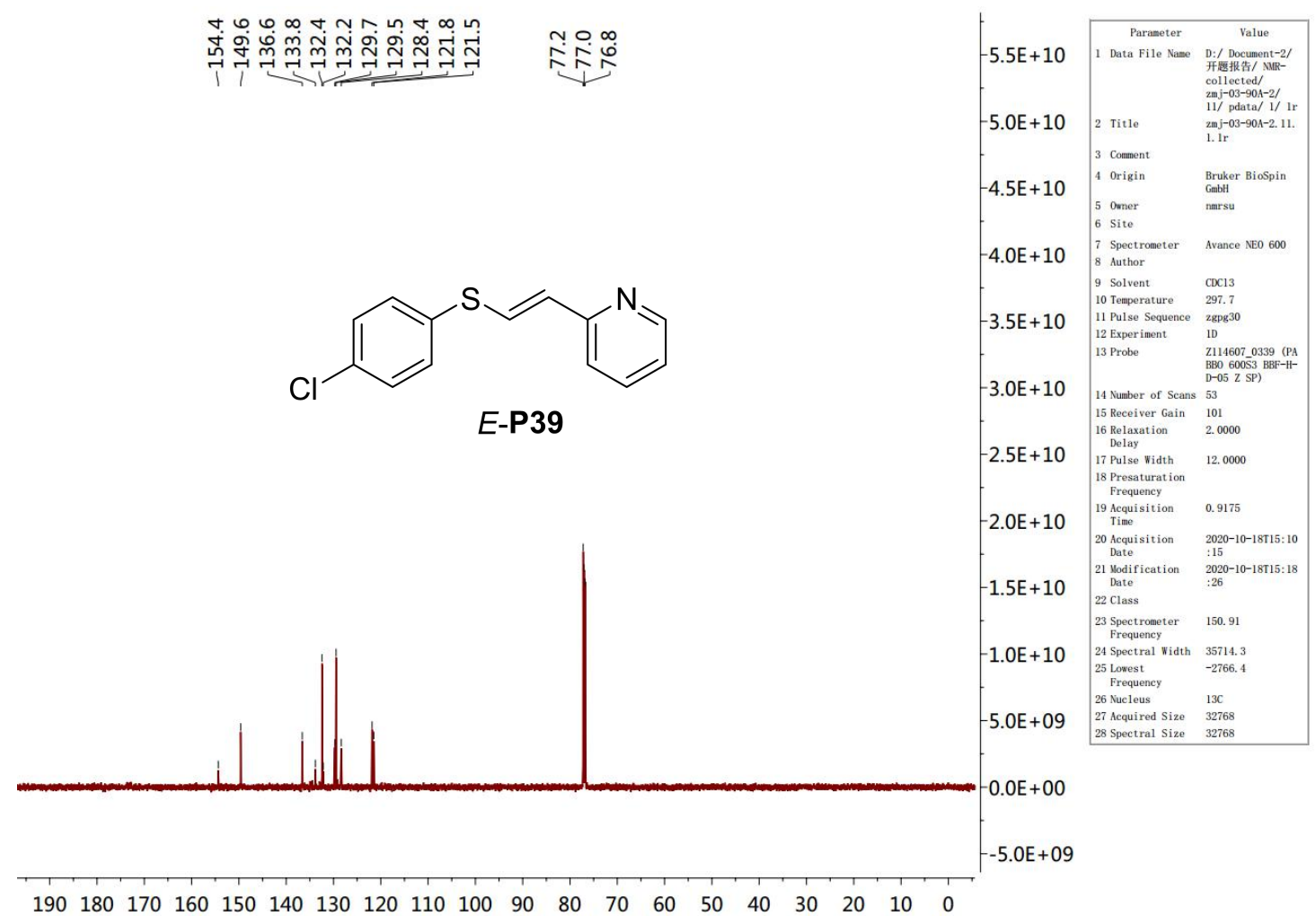




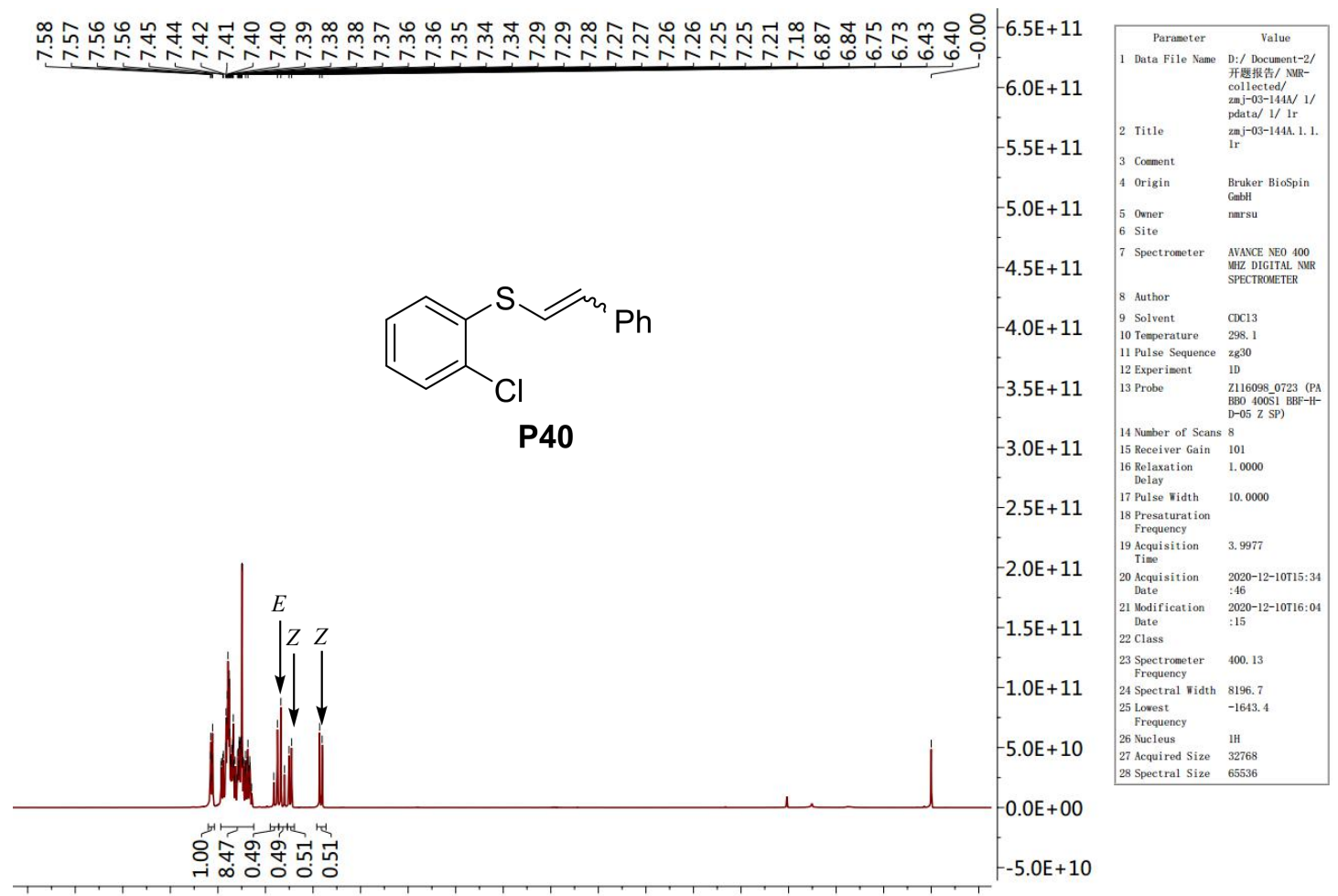

$\begin{array}{lllllllllllllllllllll}9.5 & 9.0 & 8.5 & 8.0 & 7.5 & 7.0 & 6.5 & 6.0 & 5.5 & 5.0 & 4.5 & 4.0 & 3.5 & 3.0 & 2.5 & 2.0 & 1.5 & 1.0 & 0.5 & 0.0 & -0.5\end{array}$

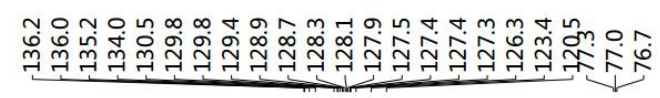<smiles>Clc1ccccc1SC=Cc1ccccc1</smiles>

P40

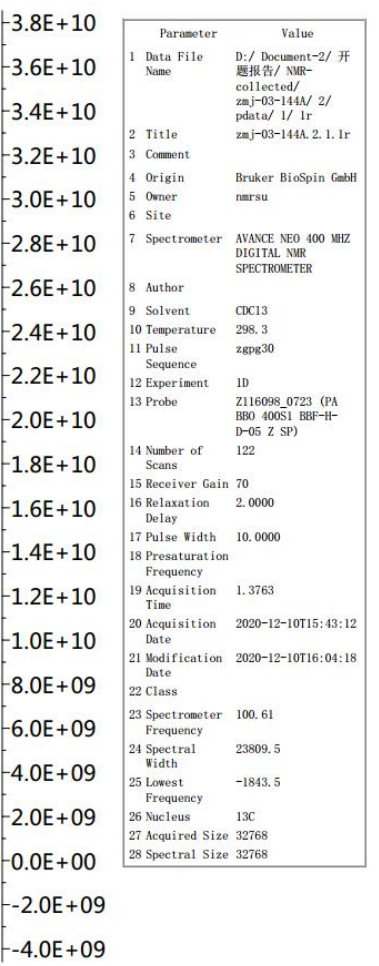

$\begin{array}{llllllllllllllllllll}190 & 180 & 170 & 160 & 150 & 140 & 130 & 120 & 110 & 100 & 90 & 80 & 70 & 60 & 50 & 40 & 30 & 20 & 10 & 0\end{array}$ 
<smiles>CC(C)(C)c1ccc(S/C=C/c2ccccc2)cc1</smiles>

P41

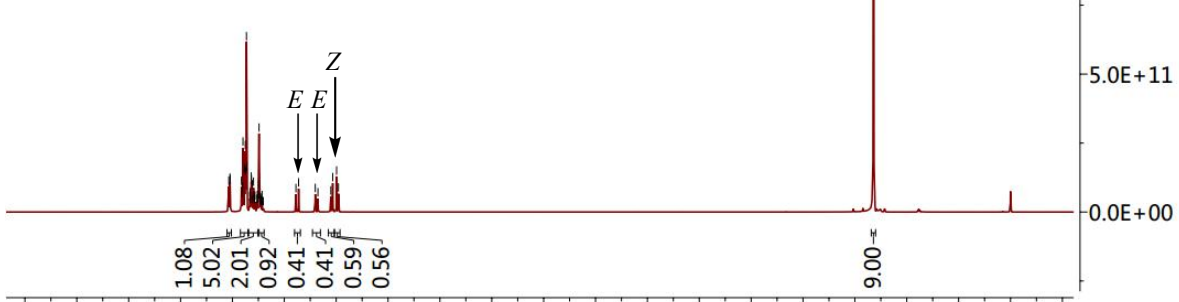

$\begin{array}{llllllllllllllllllllll}9.5 & 9.0 & 8.5 & 8.0 & 7.5 & 7.0 & 6.5 & 6.0 & 5.5 & 5.0 & 4.5 & 4.0 & 3.5 & 3.0 & 2.5 & 2.0 & 1.5 & 1.0 & 0.5 & 0.0 & -0.5\end{array}$

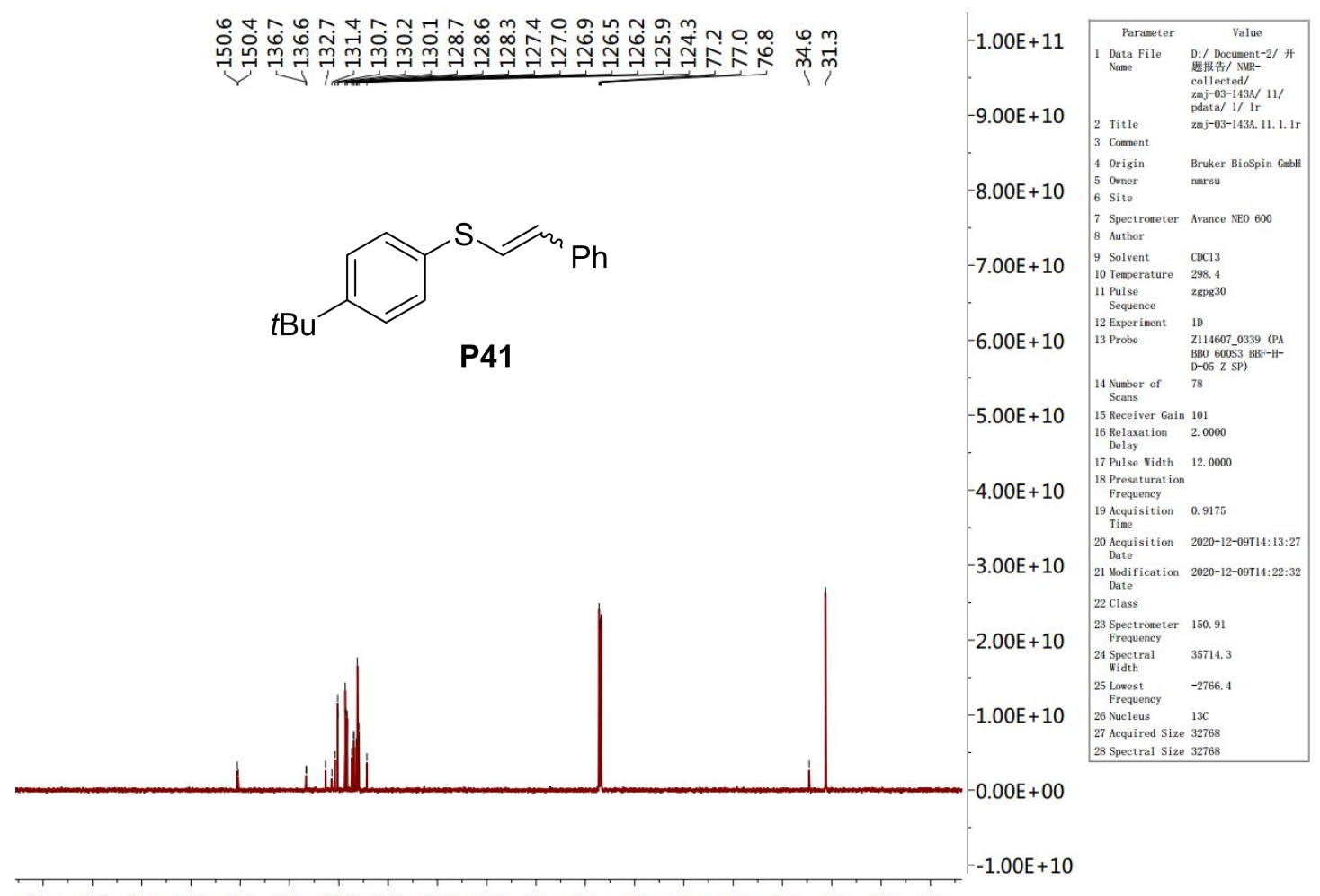

$\begin{array}{lllllllllllllllllll}190 & 180 & 170 & 160 & 150 & 140 & 130 & 120 & 110 & 100 & 90 & 80 & 70 & 60 & 50 & 40 & 30 & 20 & 10\end{array}$ 


\section{2-(Styrylthio)pyrimidine (P42)}

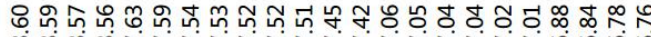

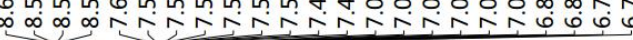<smiles>C(=Cc1ccccc1)Sc1ncccn1</smiles>

P42

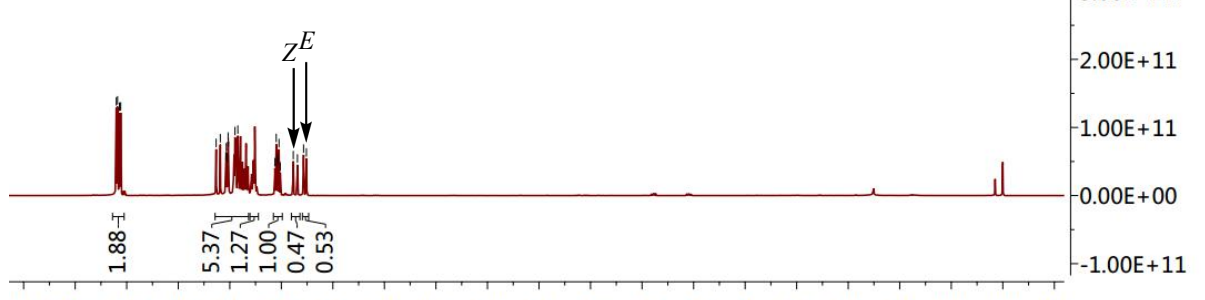

$\begin{array}{lllllllllllllllllllll}9.5 & 9.0 & 8.5 & 8.0 & 7.5 & 7.0 & 6.5 & 6.0 & 5.5 & 5.0 & 4.5 & 4.0 & 3.5 & 3.0 & 2.5 & 2.0 & 1.5 & 1.0 & 0.5 & 0.0 & -0.5\end{array}$

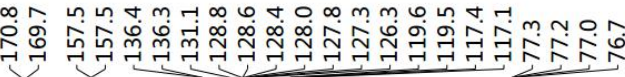<smiles>C(=Cc1ccccc1)Sc1ncccn1</smiles>

P42

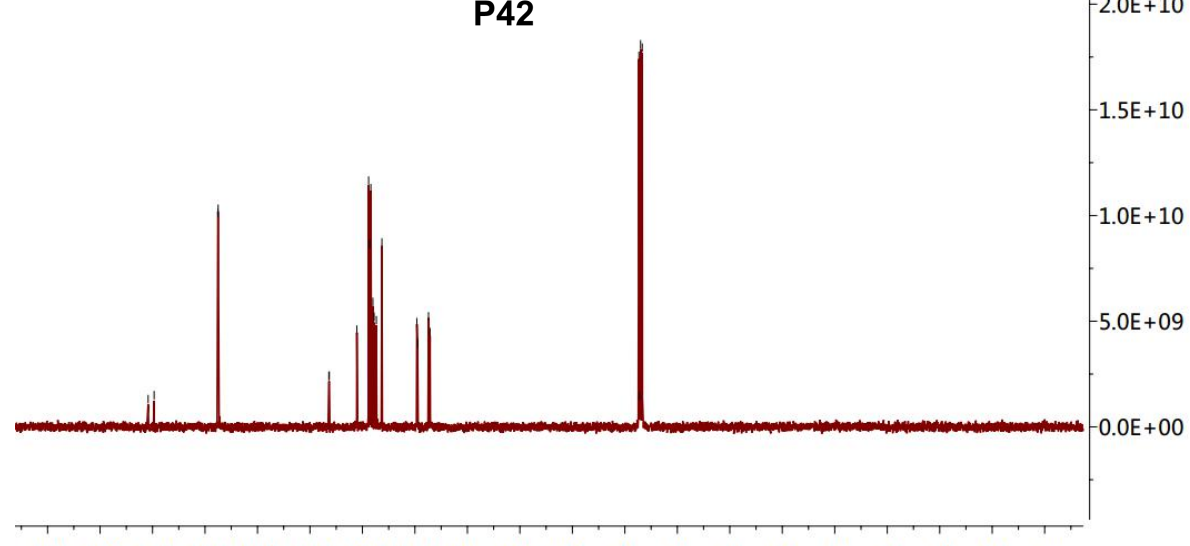

$\begin{array}{llllllllllllllllllll}190 & 180 & 170 & 160 & 150 & 140 & 130 & 120 & 110 & 100 & 90 & 80 & 70 & 60 & 50 & 40 & 30 & 20 & 10 & 0\end{array}$

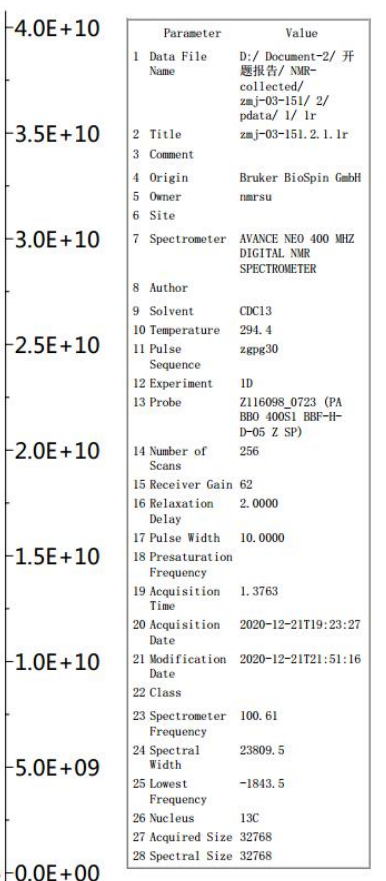

28 Spectral Size 32768 

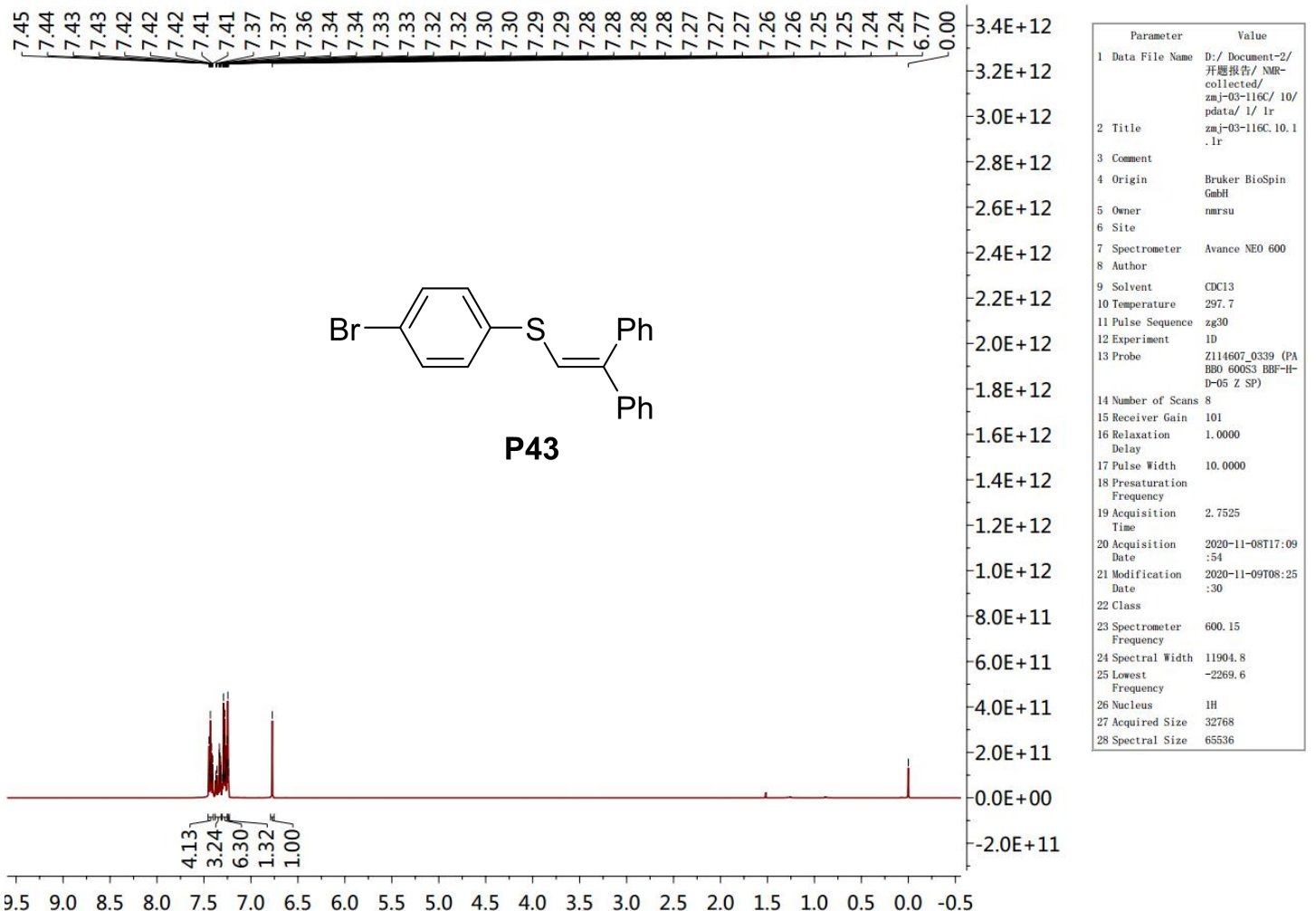

$\begin{array}{lllllllllllllllllllll}9.5 & 9.0 & 8.5 & 8.0 & 7.5 & 7.0 & 6.5 & 6.0 & 5.5 & 5.0 & 4.5 & 4.0 & 3.5 & 3.0 & 2.5 & 2.0 & 1.5 & 1.0 & 0.5 & 0.0 & -0.5\end{array}$
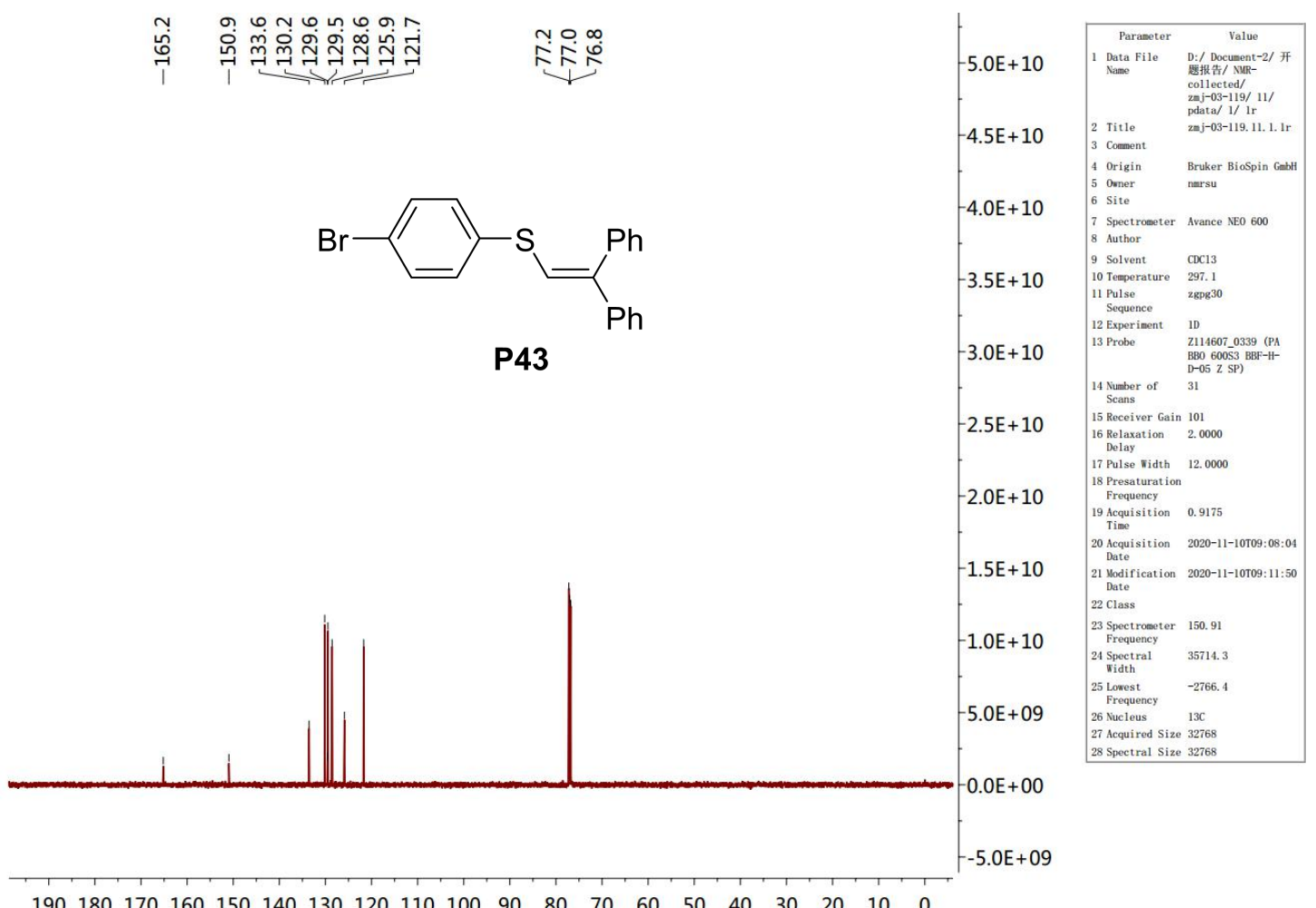

$\begin{array}{llllllllllllllllllll}190 & 180 & 170 & 160 & 150 & 140 & 130 & 120 & 110 & 100 & 90 & 80 & 70 & 60 & 50 & 40 & 30 & 20 & 10 & 0\end{array}$ 

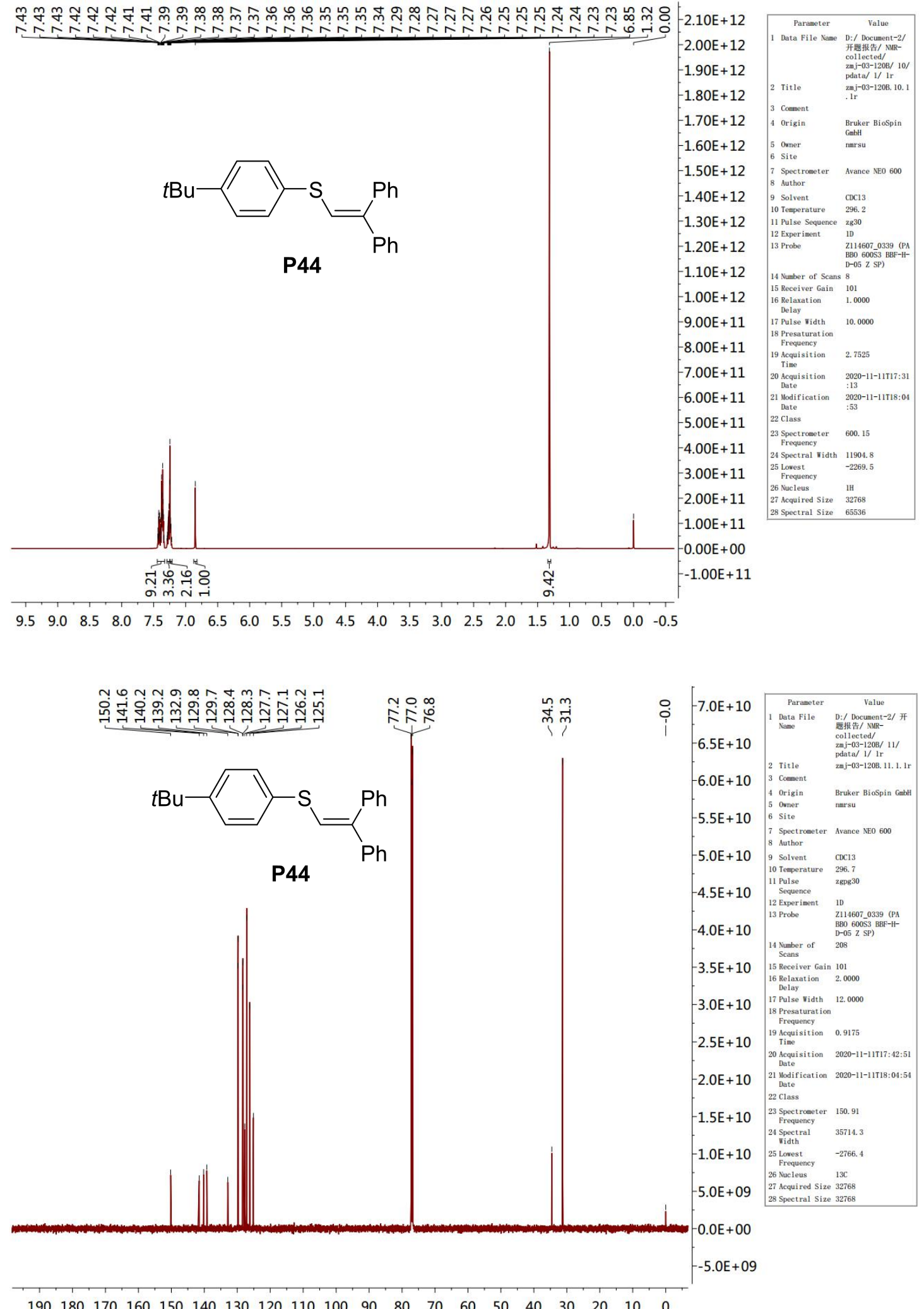

$\begin{array}{llllllllllllllllllll}190 & 180 & 170 & 160 & 150 & 140 & 130 & 120 & 110 & 100 & 90 & 80 & 70 & 60 & 50 & 40 & 30 & 20 & 10 & 0\end{array}$ 


\section{(4-Chlorophenyl)(2,2-diphenylvinyl)sulfane (P45)}

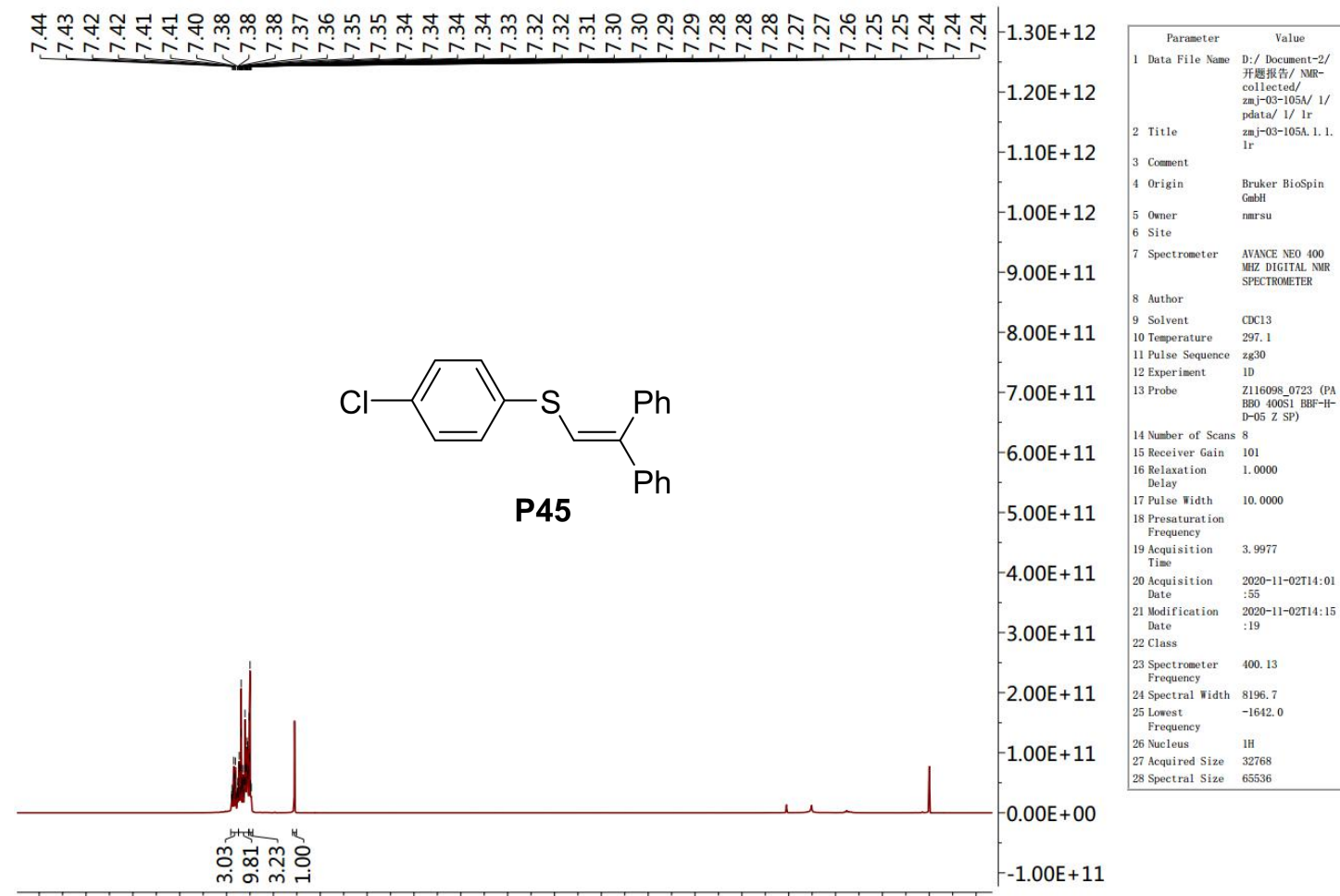

$\begin{array}{lllllllllllllllllllll}9.5 & 9.0 & 8.5 & 8.0 & 7.5 & 7.0 & 6.5 & 6.0 & 5.5 & 5.0 & 4.5 & 4.0 & 3.5 & 3.0 & 2.5 & 2.0 & 1.5 & 1.0 & 0.5 & 0.0 & -0.5\end{array}$

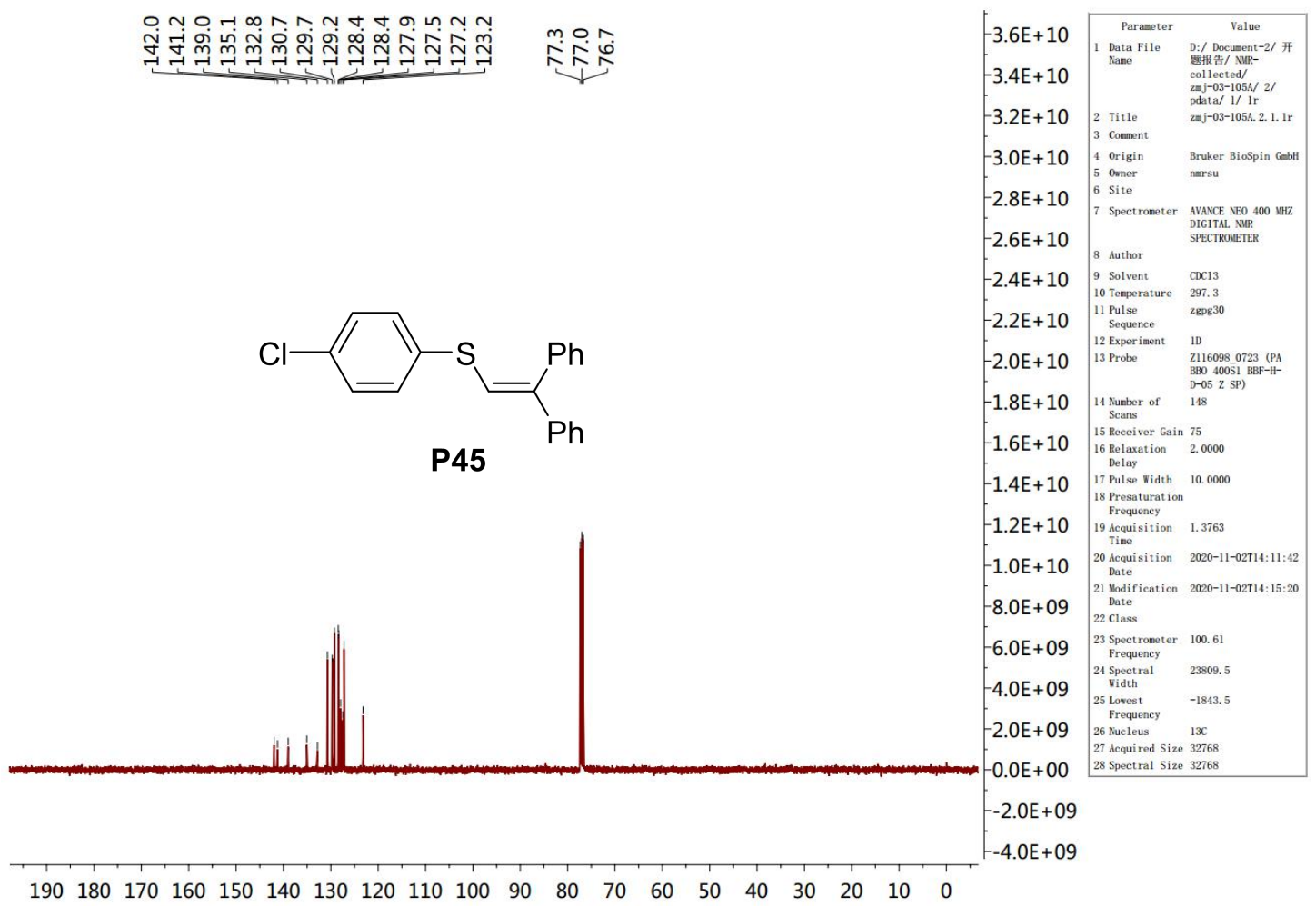


(E)-(4-chlorophenyl)(2-phenylprop-1-en-1-yl)sulfane (E-P46)

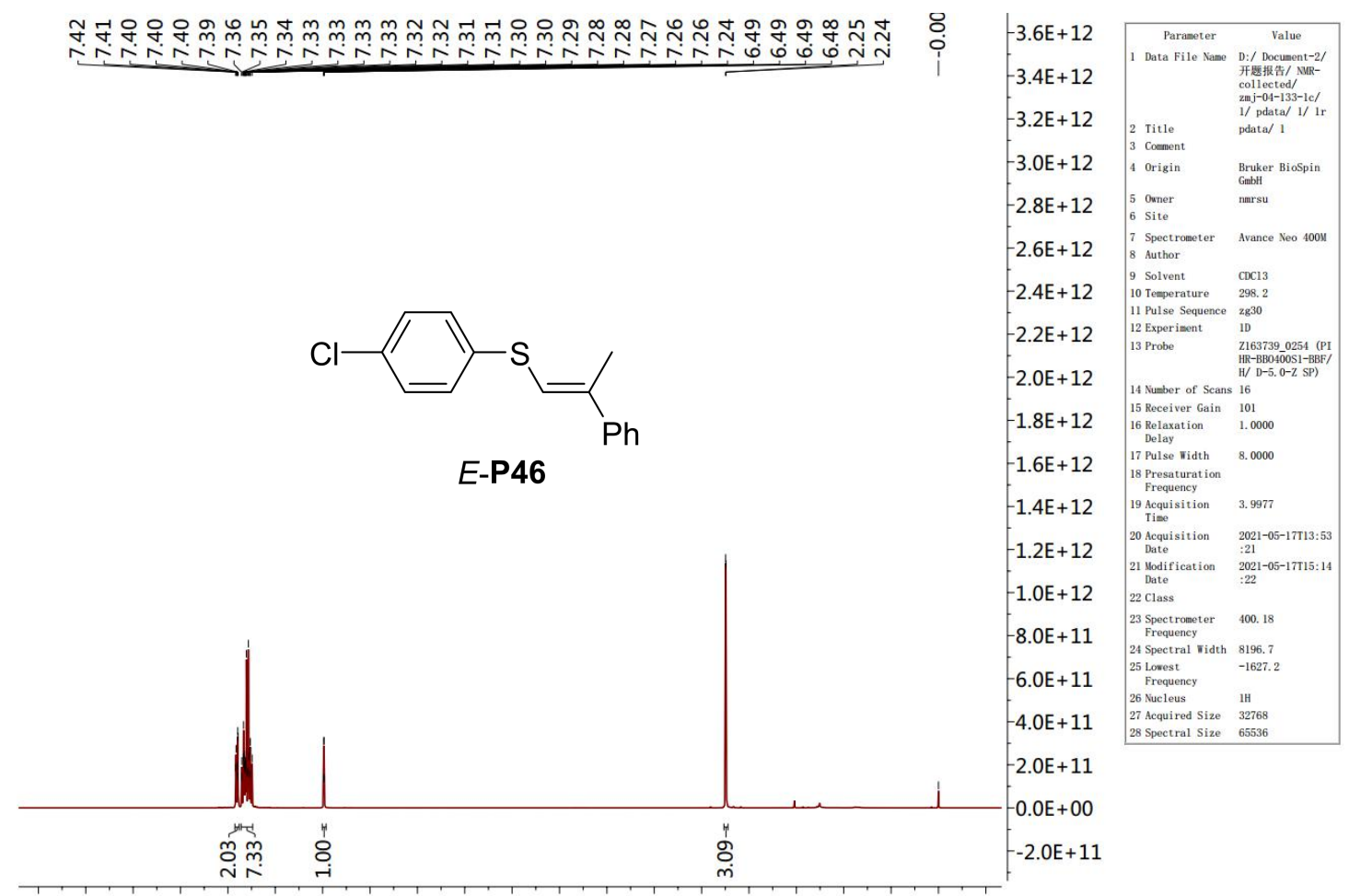

$\begin{array}{lllllllllllllllllllll}9.5 & 9.0 & 8.5 & 8.0 & 7.5 & 7.0 & 6.5 & 6.0 & 5.5 & 5.0 & 4.5 & 4.0 & 3.5 & 3.0 & 2.5 & 2.0 & 1.5 & 1.0 & 0.5 & 0.0 & -0.5\end{array}$

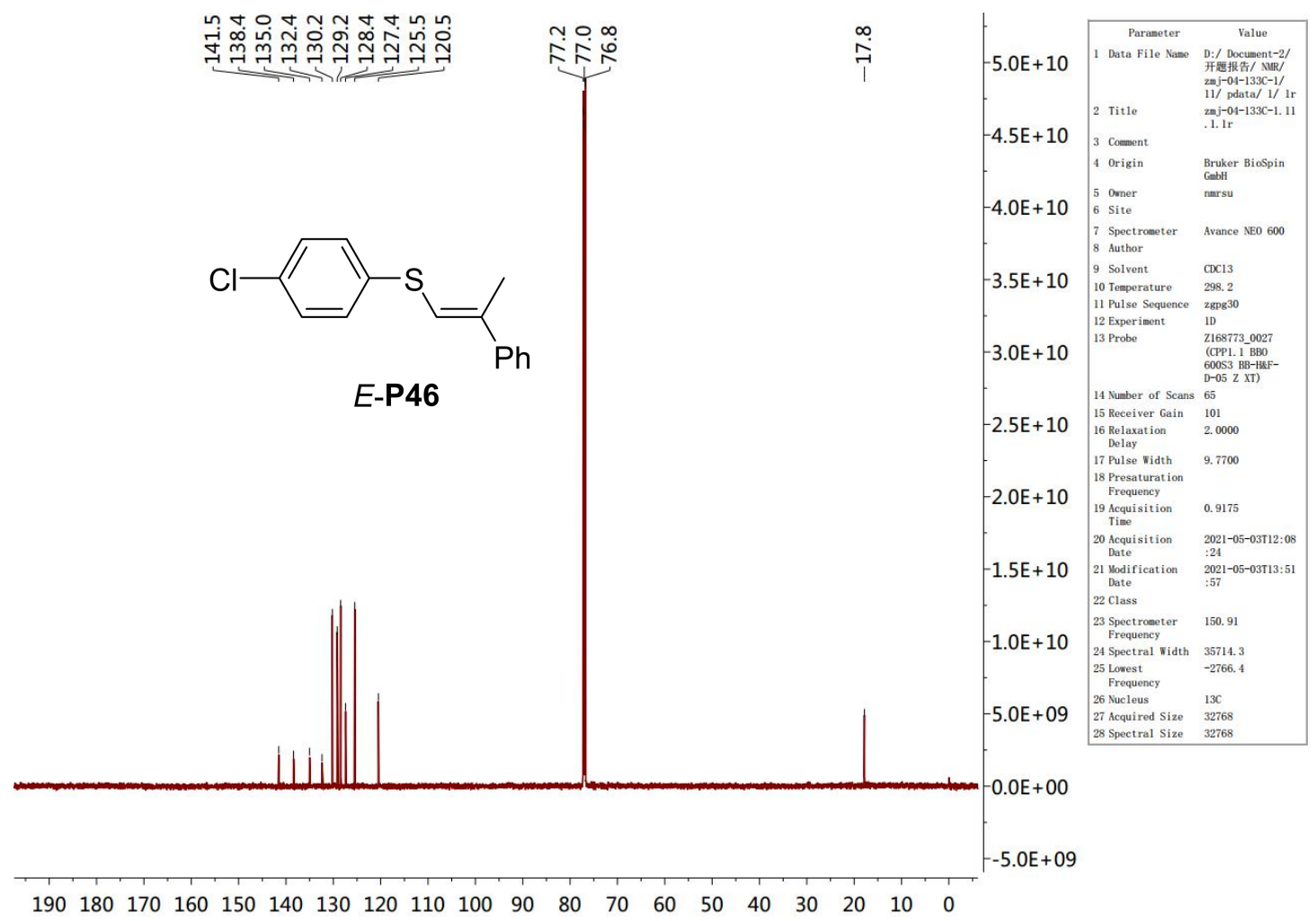




\section{(Z)-(4-chlorophenyl)(2-phenylprop-1-en-1-yl)sulfane (Z-P46)}

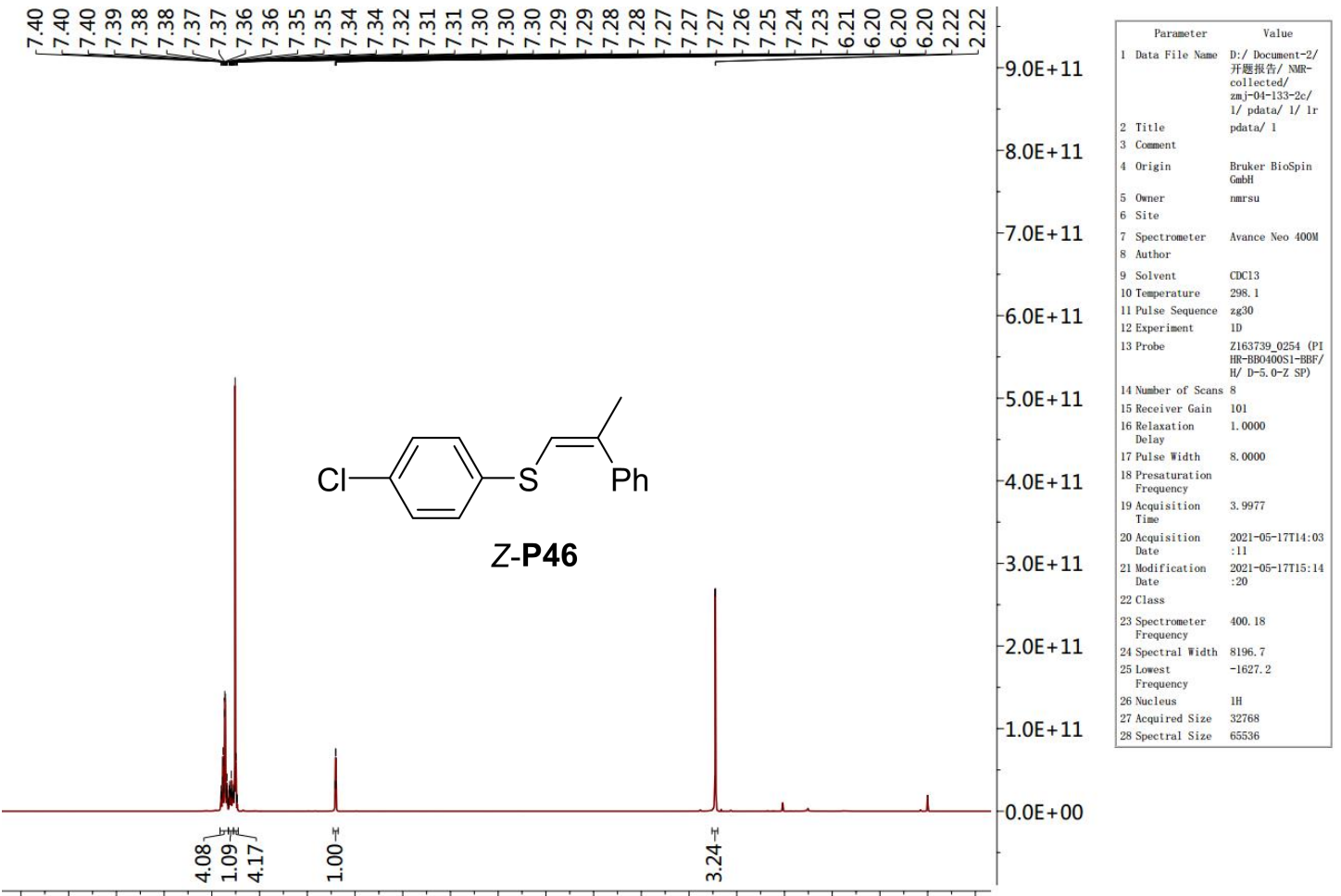

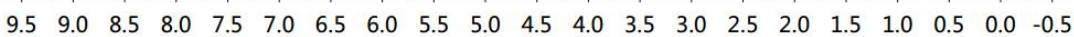

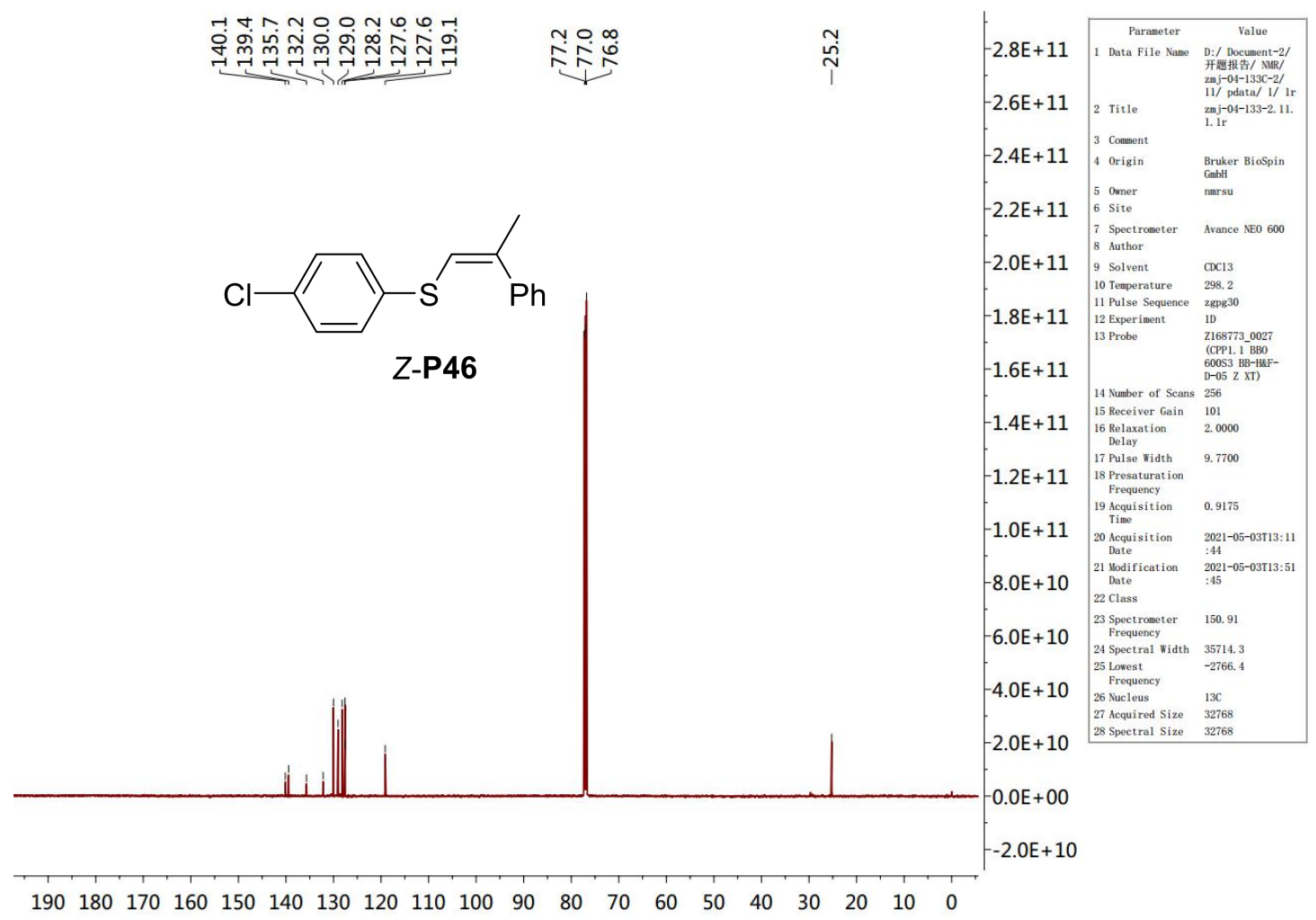




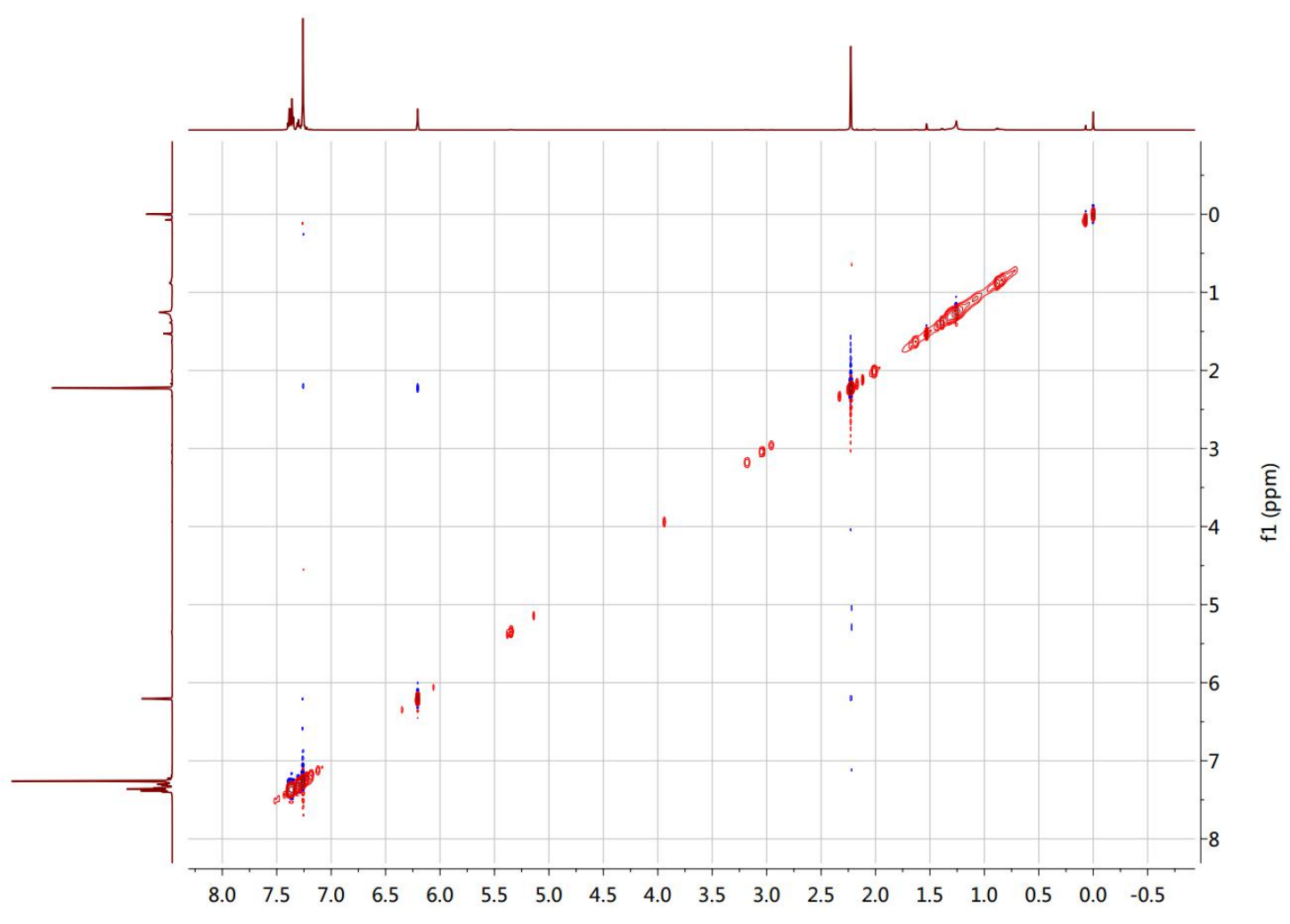

The zoom of NOESY spectrum of Z-P46

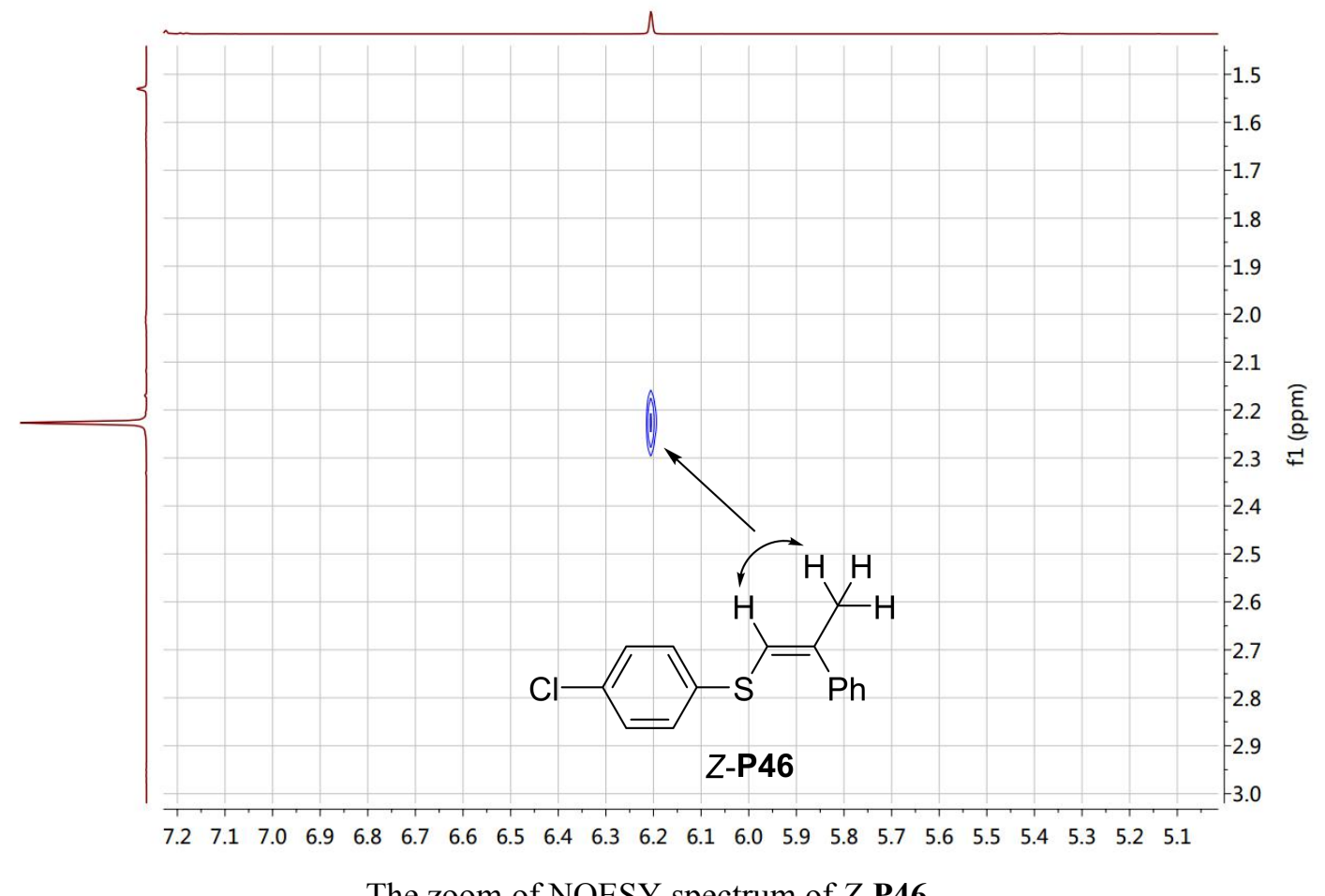

The zoom of NOESY spectrum of Z-P46 

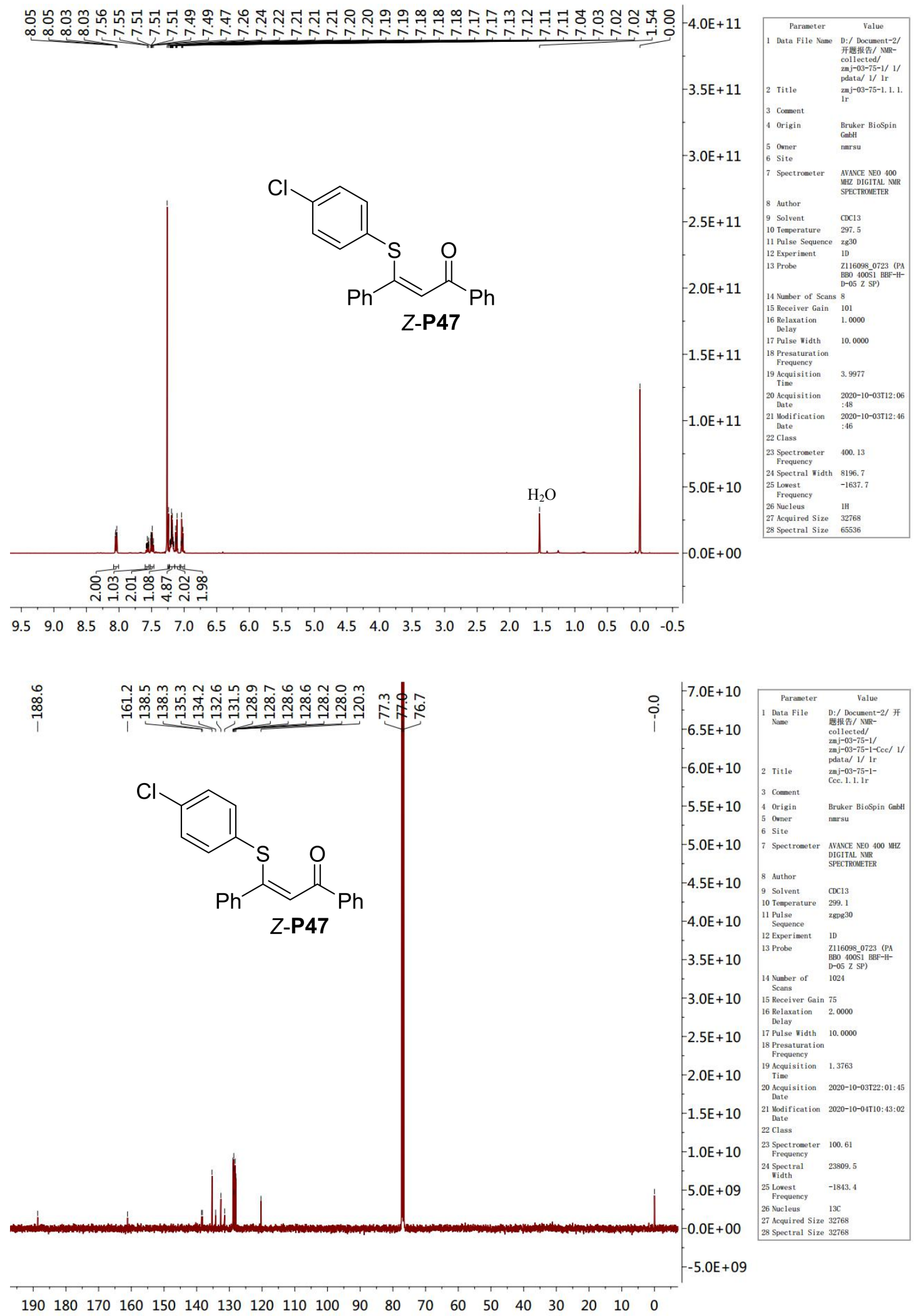
(E)-3-((4-Chlorophenyl)thio)-1,3-diphenylprop-2-en-1-one ( $E$-P47)

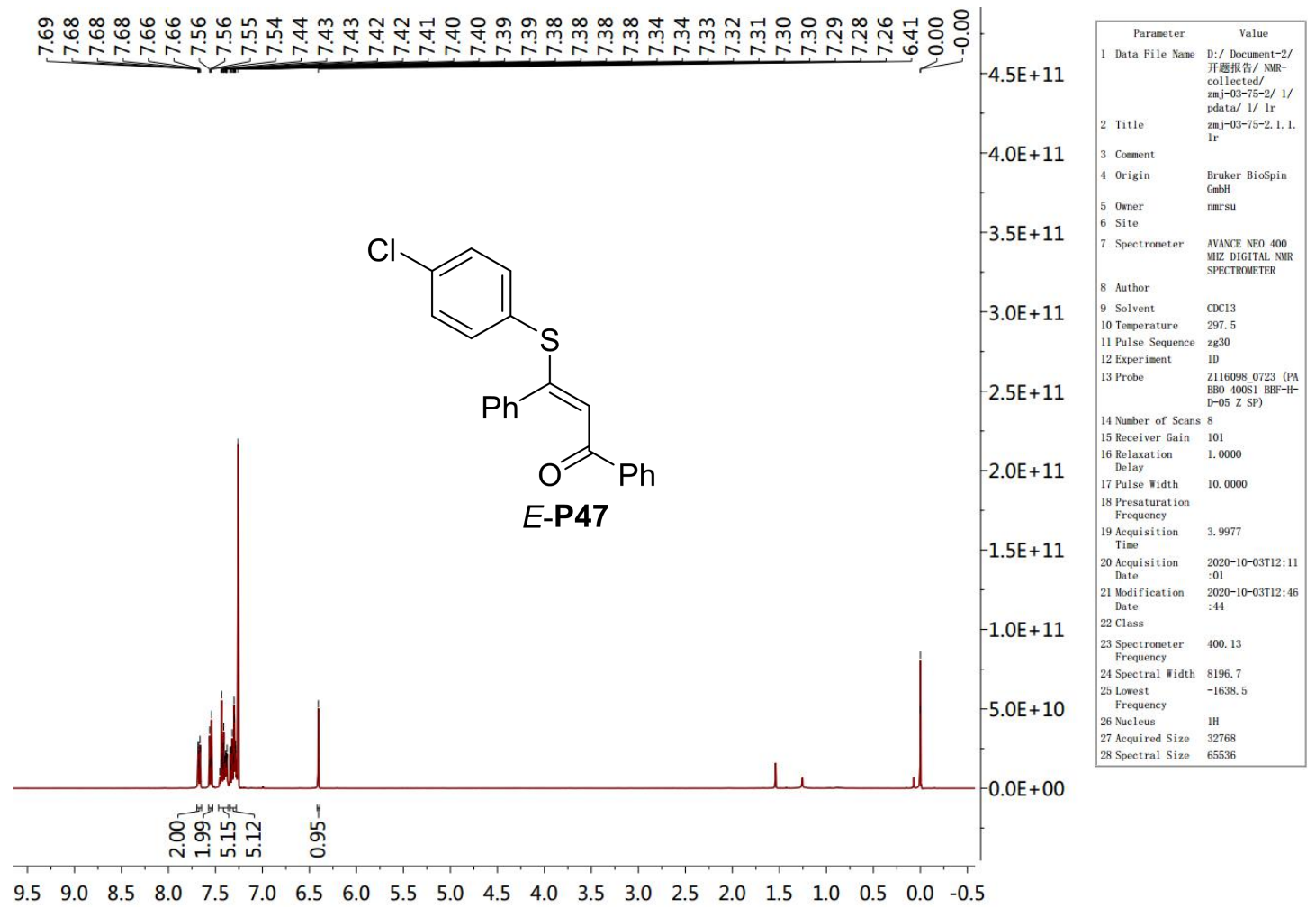

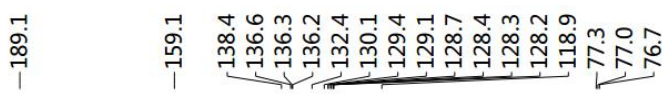

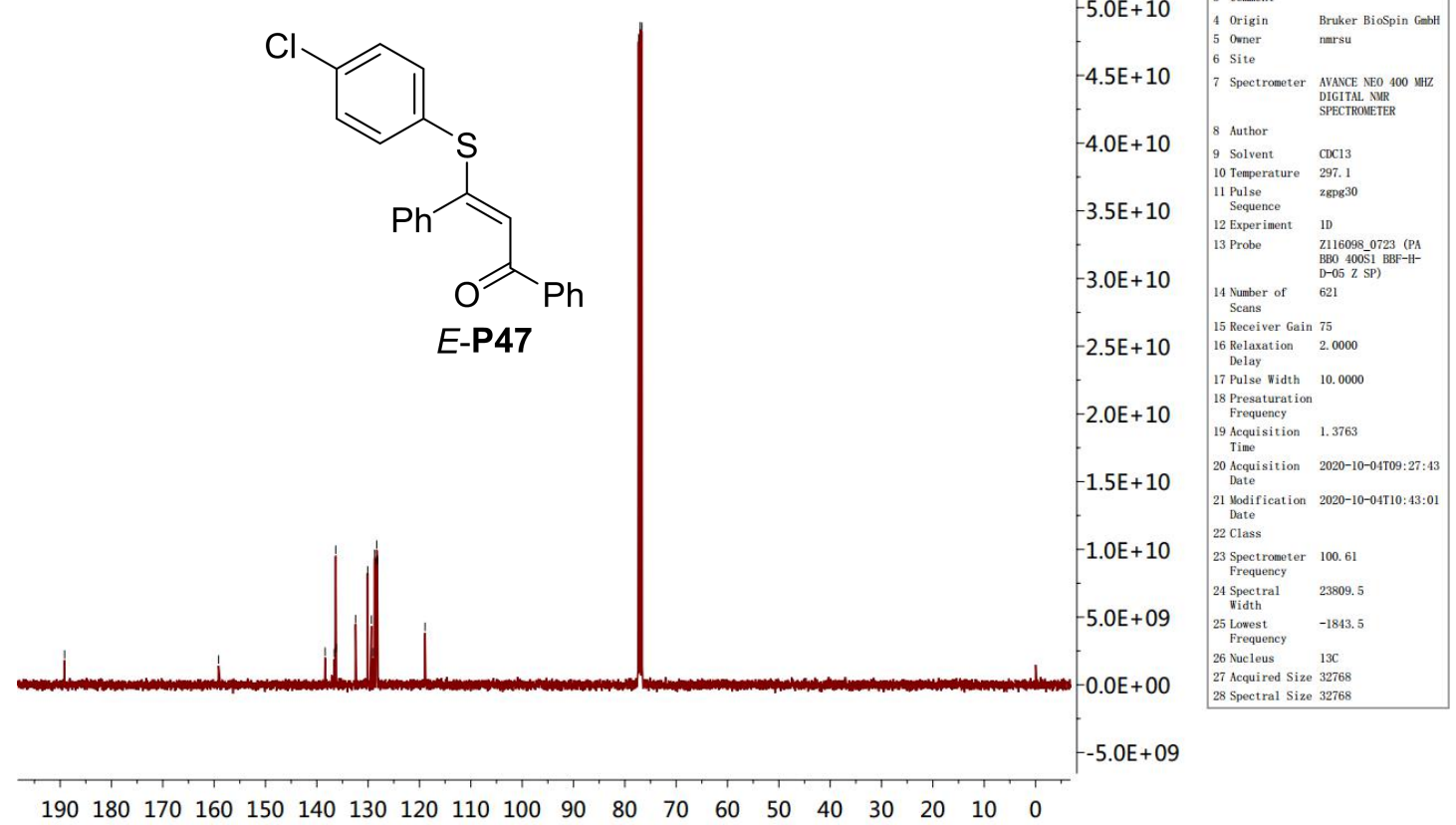


3-((4-Chlorophenyl)thio)cyclohex-2-en-1-one (P48)
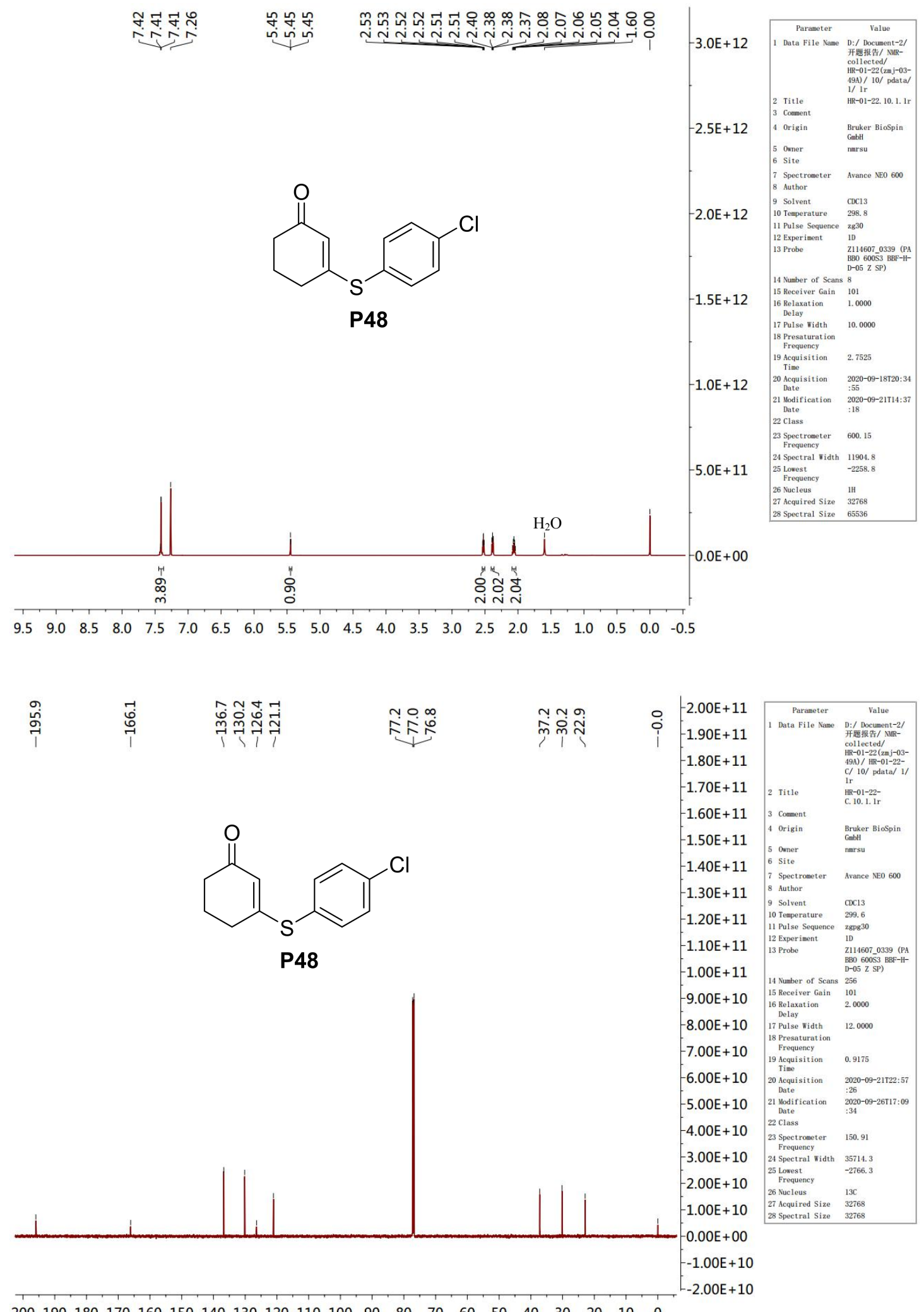

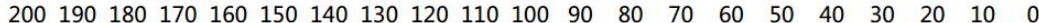




\section{6-Chloro-4H-thiochromen-4-one (P49)}
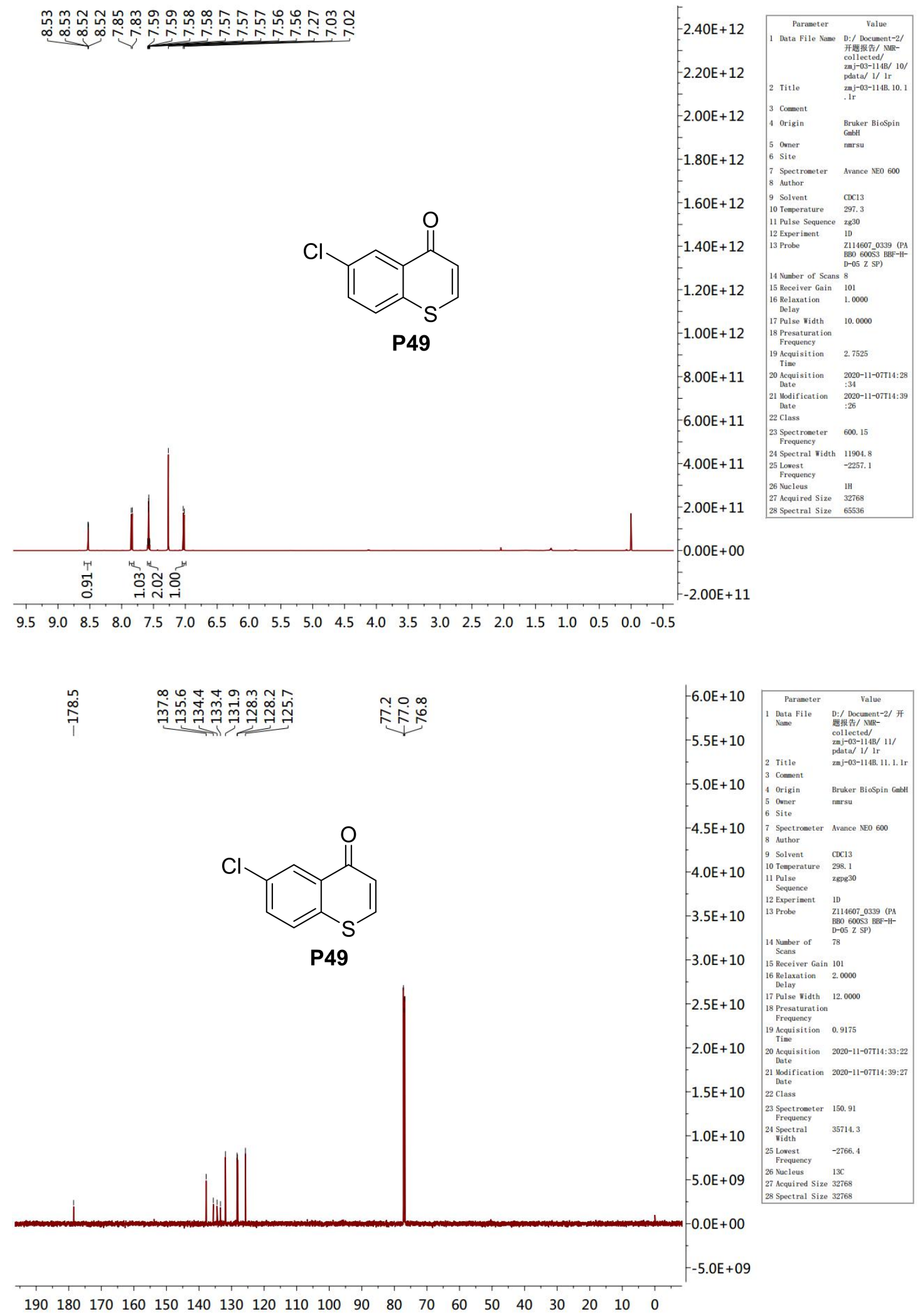
<smiles>C=COc1ccc2ccccc2c1</smiles>

P50

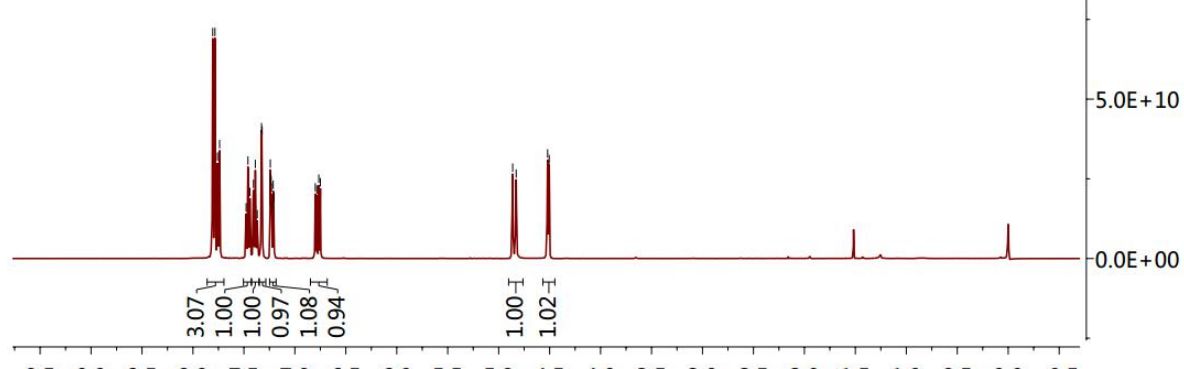

$\begin{array}{lllllllllllllllllllll}9.5 & 9.0 & 8.5 & 8.0 & 7.5 & 7.0 & 6.5 & 6.0 & 5.5 & 5.0 & 4.5 & 4.0 & 3.5 & 3.0 & 2.5 & 2.0 & 1.5 & 1.0 & 0.5 & 0.0 & -0.5\end{array}$

$.0 \mathrm{E}+00$<smiles>C=COc1ccc2ccccc2c1</smiles>

P50

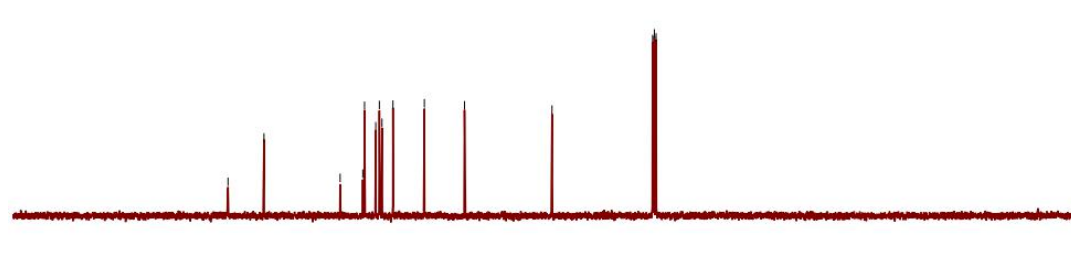

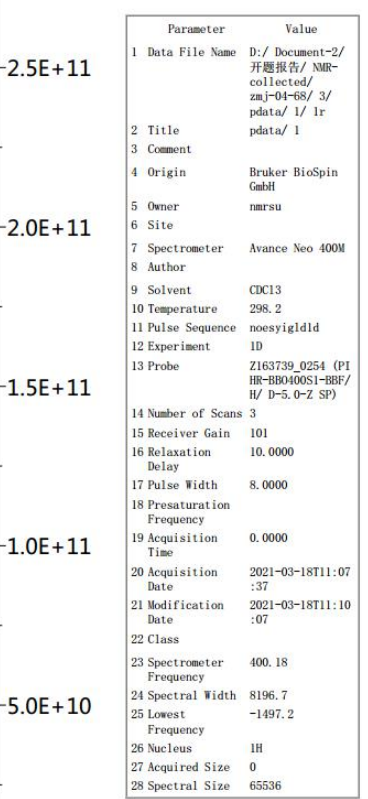

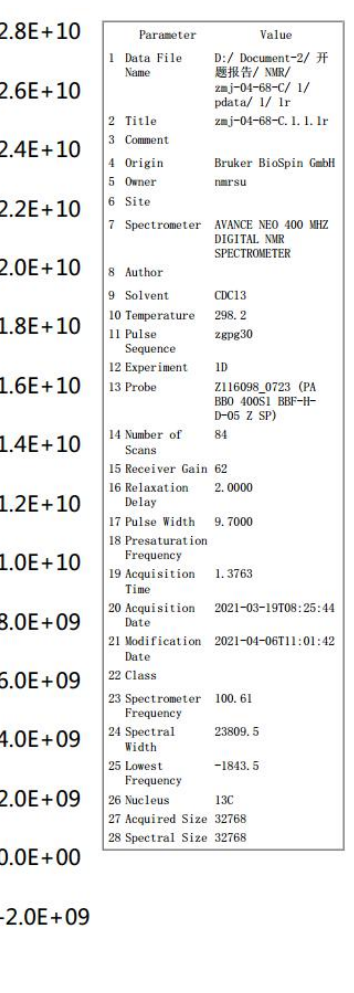




\section{(2-Phenoxyvinyl)benzene (P51)}

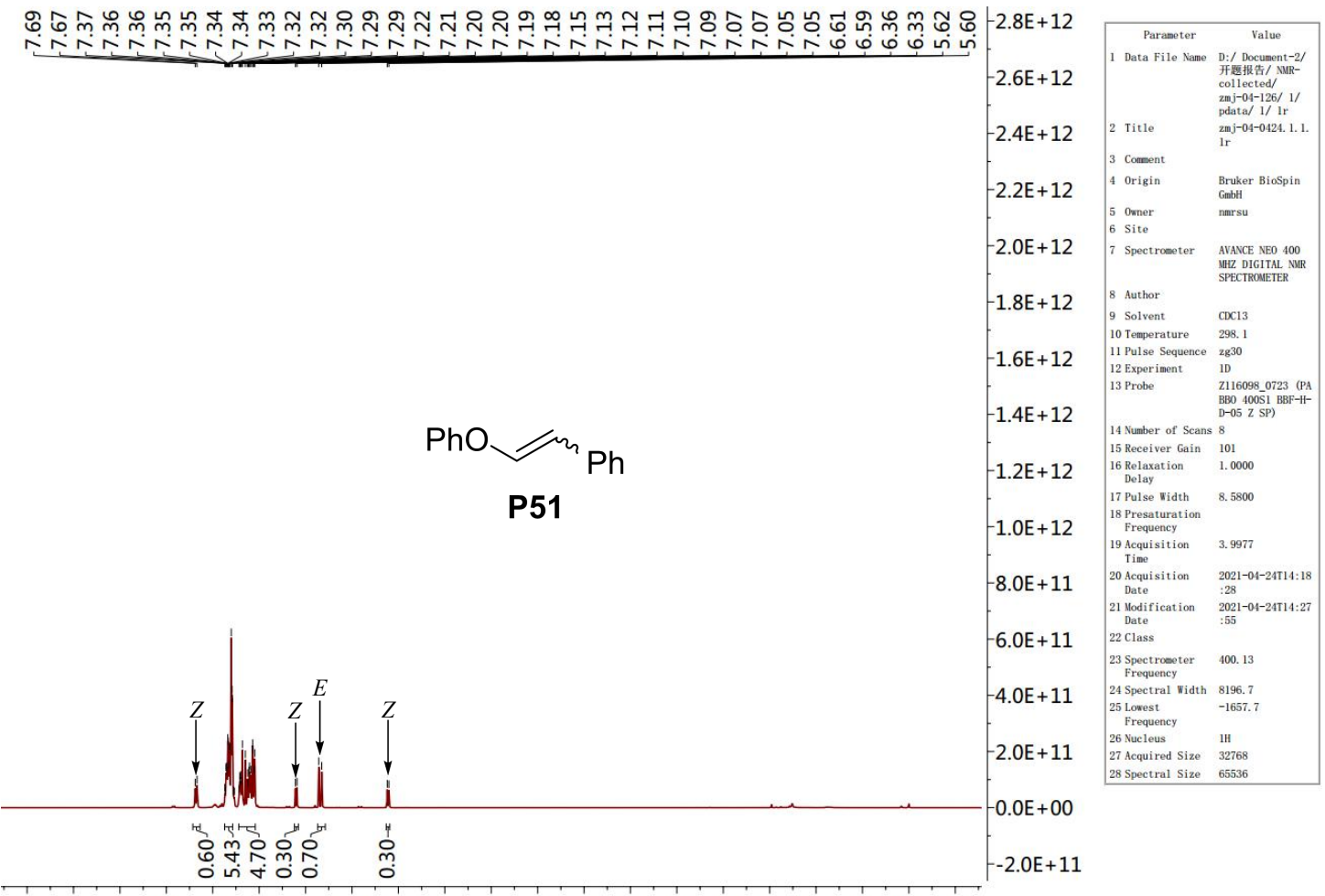

$\begin{array}{lllllllllllllllllllll}9.5 & 9.0 & 8.5 & 8.0 & 7.5 & 7.0 & 6.5 & 6.0 & 5.5 & 5.0 & 4.5 & 4.0 & 3.5 & 3.0 & 2.5 & 2.0 & 1.5 & 1.0 & 0.5 & 0.0 & -0.5\end{array}$

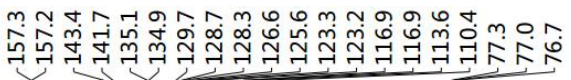

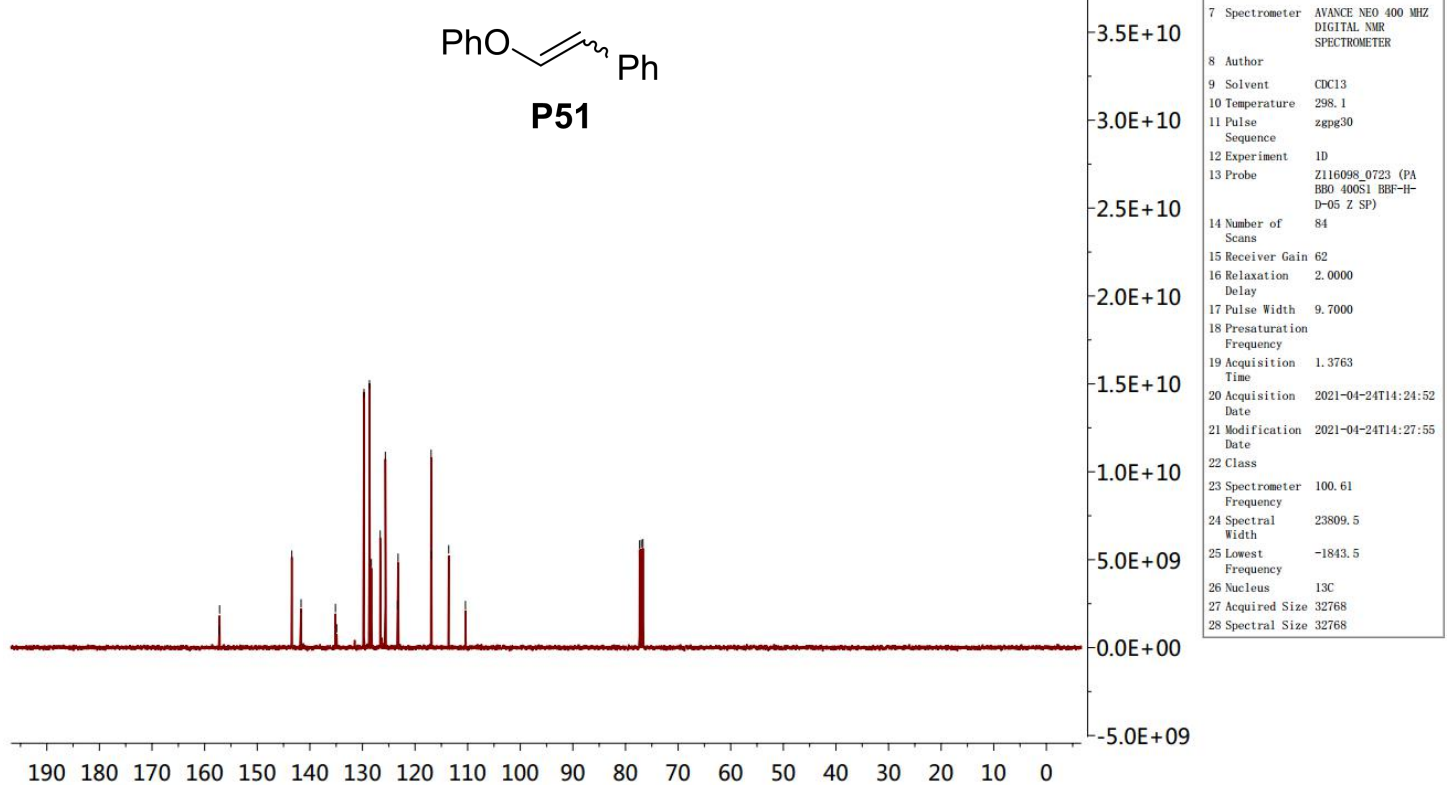




\section{$\mathrm{N}$-phenyl- $\mathrm{N}$-vinylbenzamide (P52)}
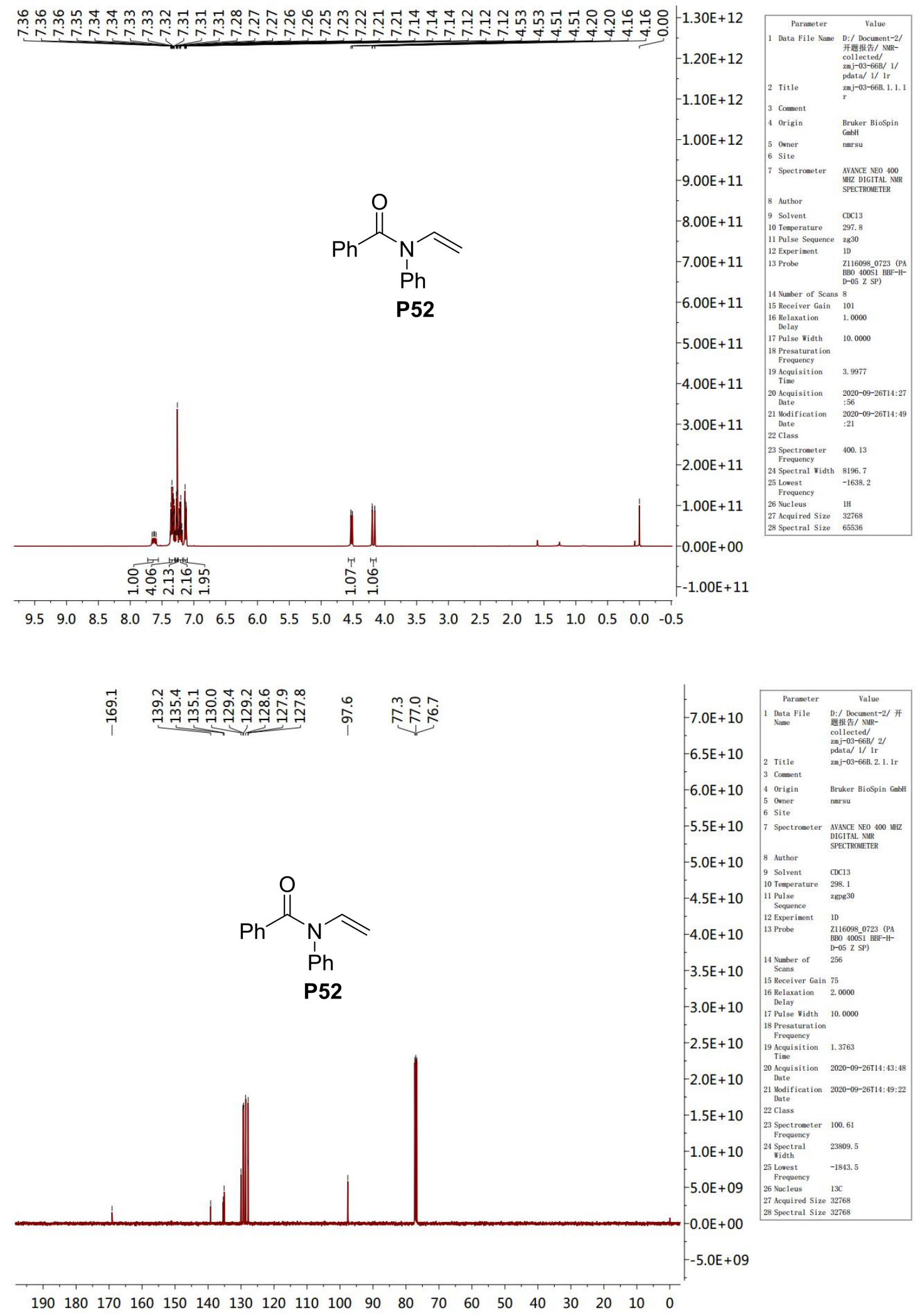


\section{$N$-phenyl- $N$-vinylfuran-2-carboxamide (P53)}

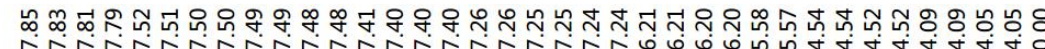

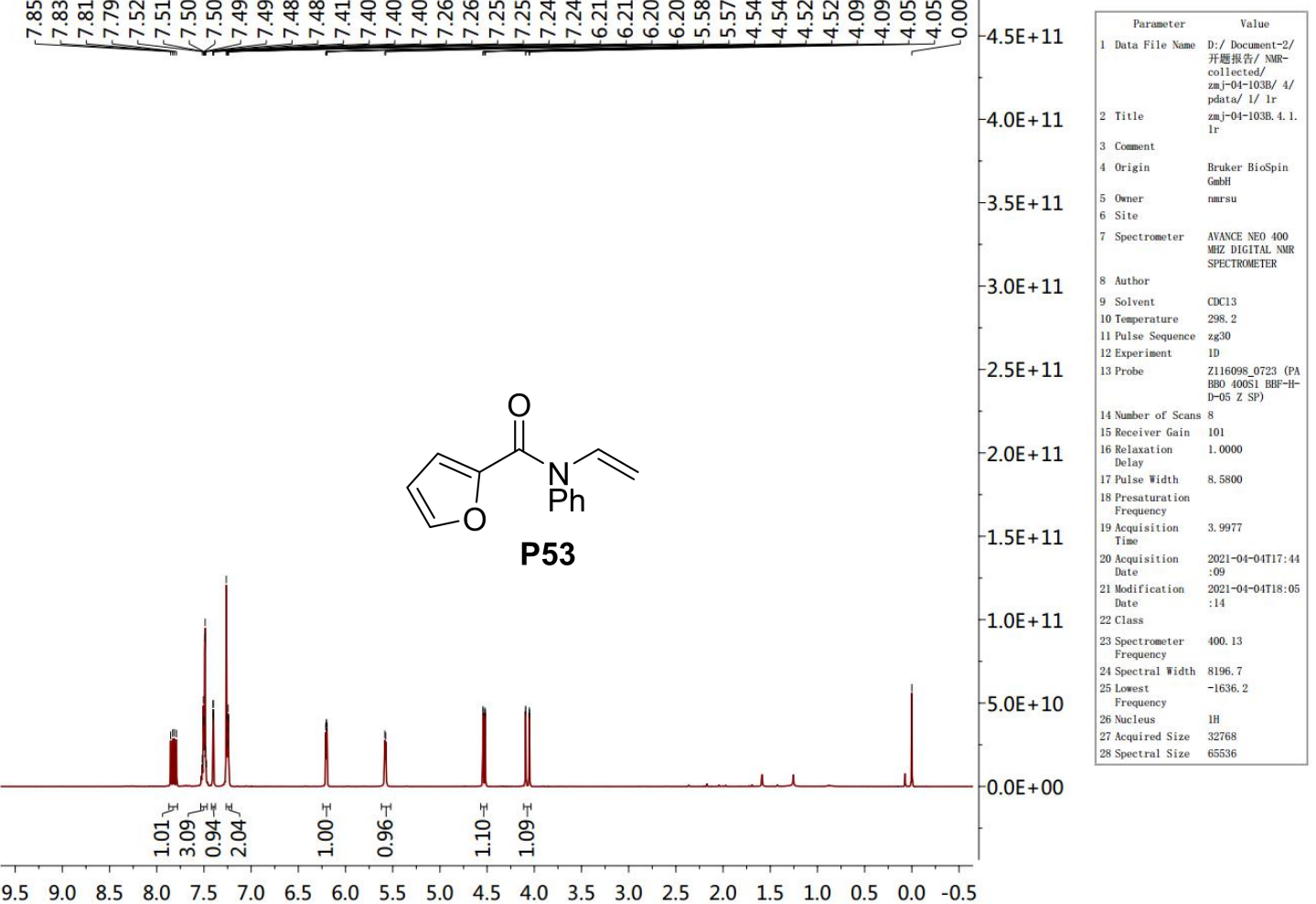

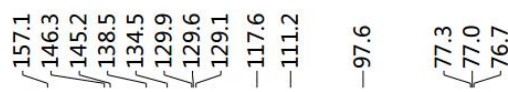<smiles>C=CNC(=O)c1ccco1</smiles>

P53

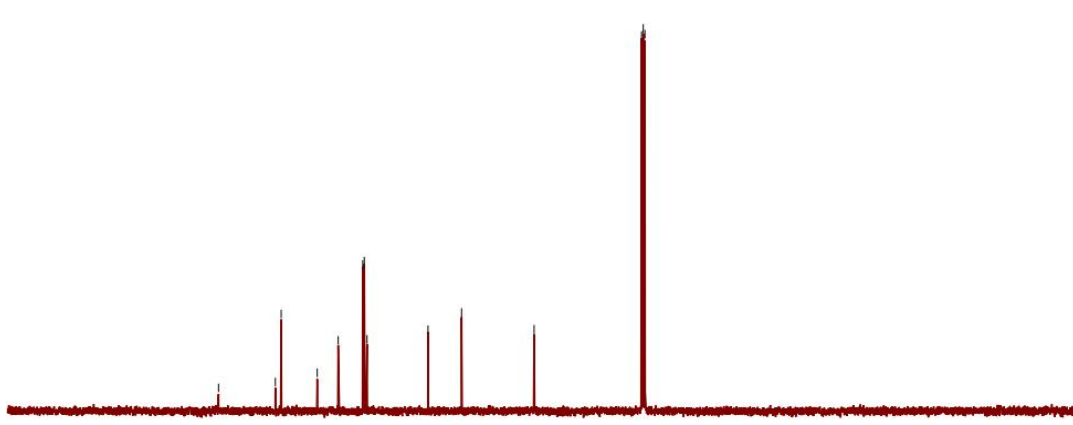

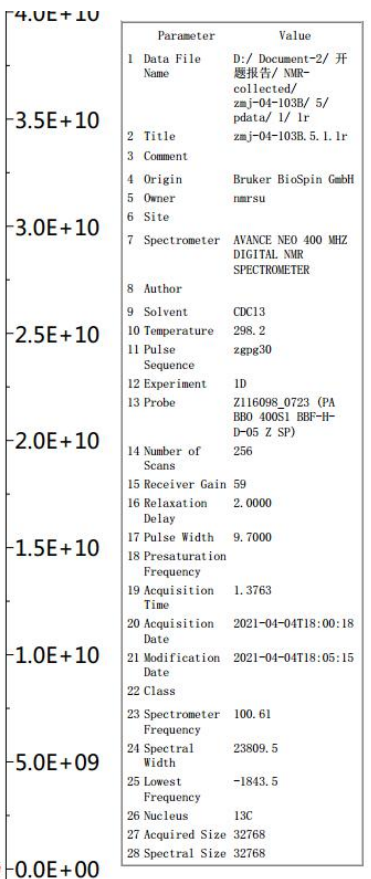

$\begin{array}{llllllllllllllllllll}190 & 180 & 170 & 160 & 150 & 140 & 130 & 120 & 110 & 100 & 90 & 80 & 70 & 60 & 50 & 40 & 30 & 20 & 10 & 0\end{array}$ 


\section{$(E)$ - $N$-styrylacetamide ( $E$-P54)}

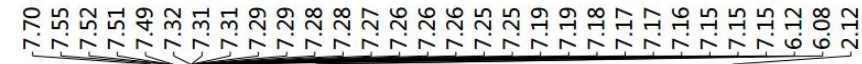<smiles>CC(=O)N/C=C/c1ccccc1</smiles>

E-P54

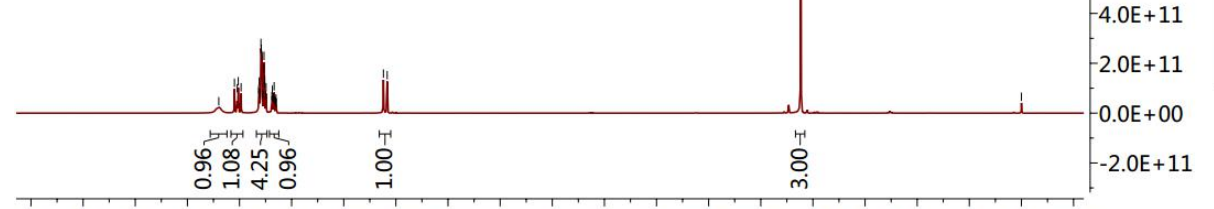

$\begin{array}{lllllllllllllllllllll}9.5 & 9.0 & 8.5 & 8.0 & 7.5 & 7.0 & 6.5 & 6.0 & 5.5 & 5.0 & 4.5 & 4.0 & 3.5 & 3.0 & 2.5 & 2.0 & 1.5 & 1.0 & 0.5 & 0.0 & -0.5\end{array}$

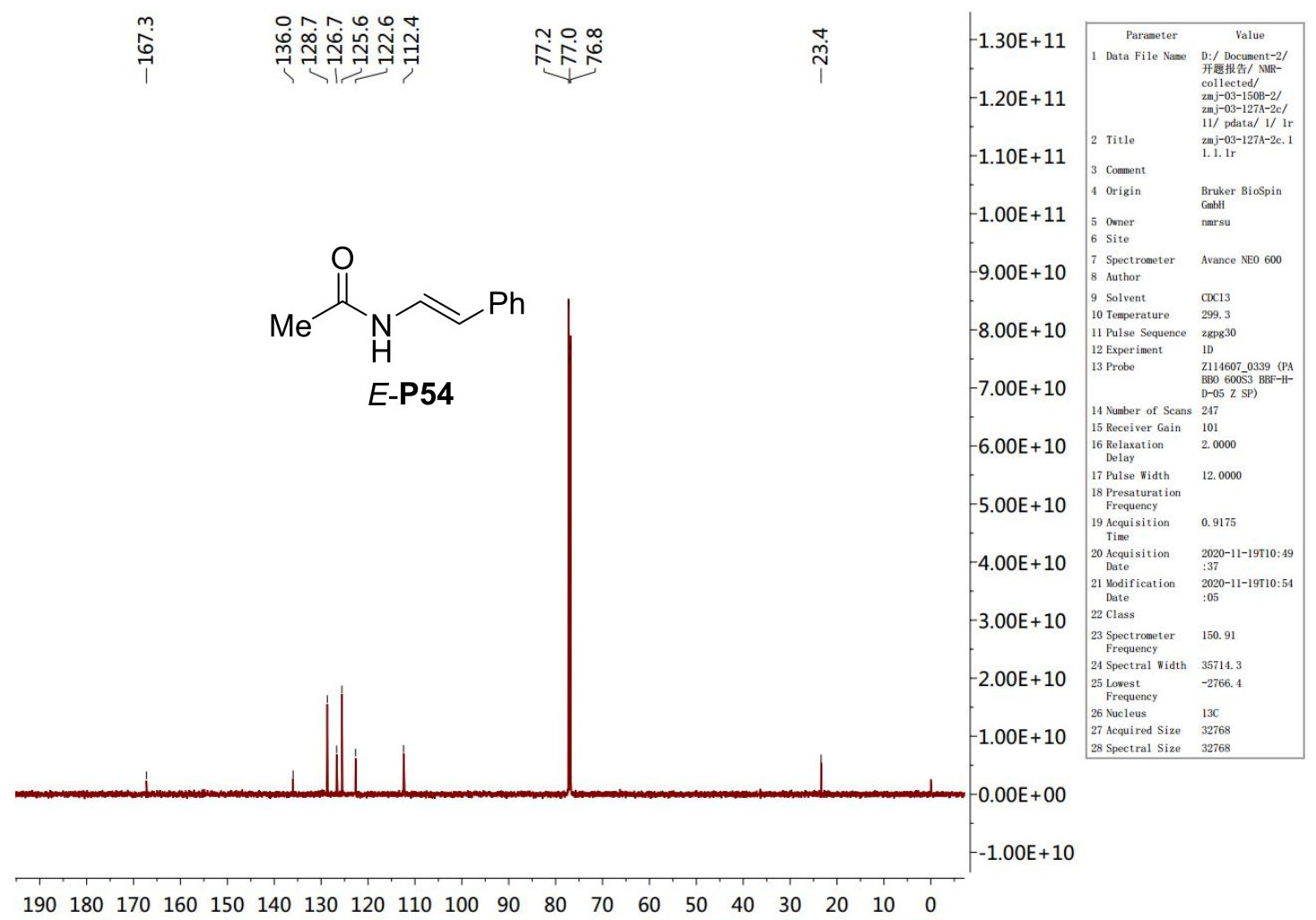


(Z)- $N$-styrylacetamide (Z-P54)

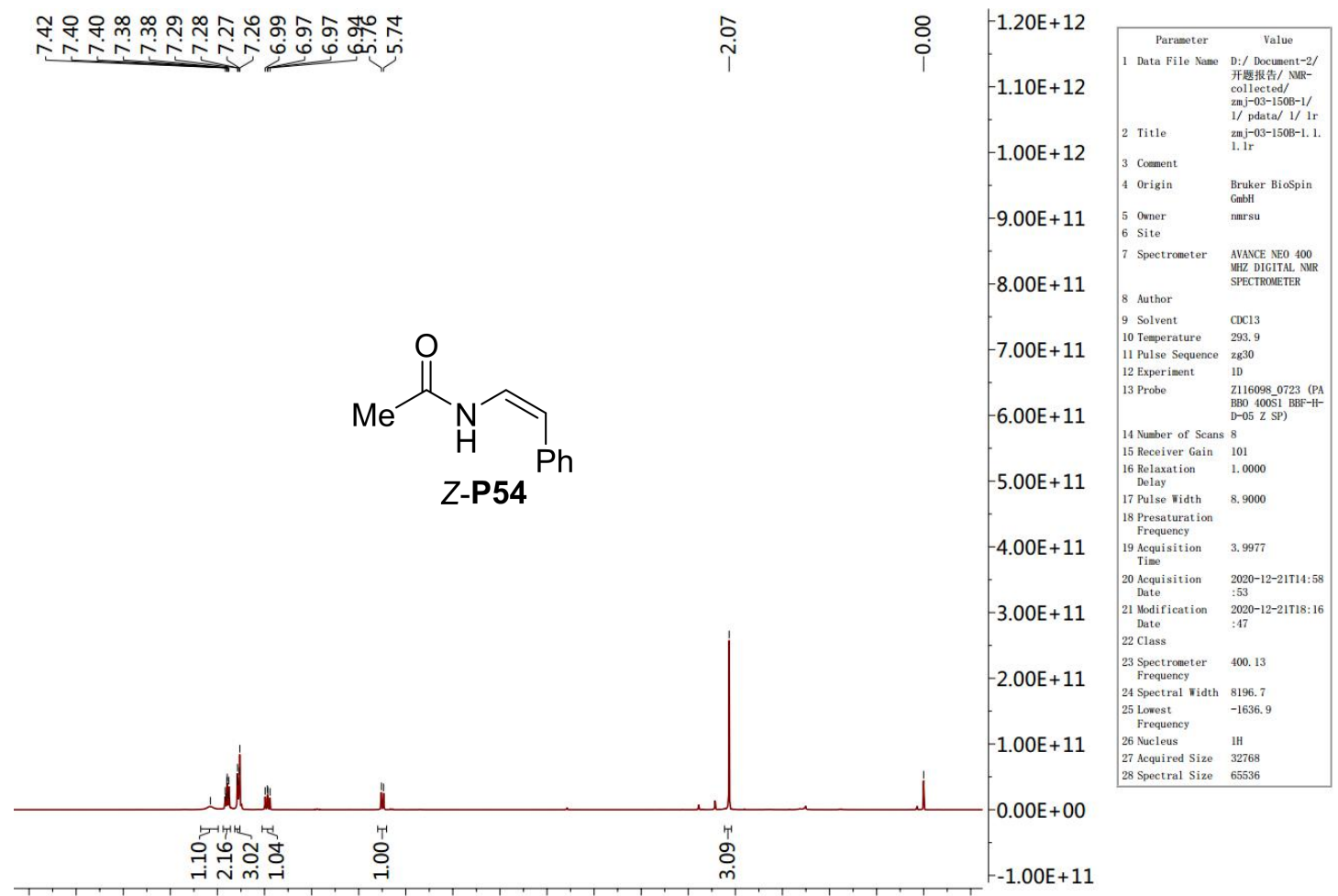

$\begin{array}{llllllllllllllllllllll}9.5 & 9.0 & 8.5 & 8.0 & 7.5 & 7.0 & 6.5 & 6.0 & 5.5 & 5.0 & 4.5 & 4.0 & 3.5 & 3.0 & 2.5 & 2.0 & 1.5 & 1.0 & 0.5 & 0.0 & -0.5\end{array}$

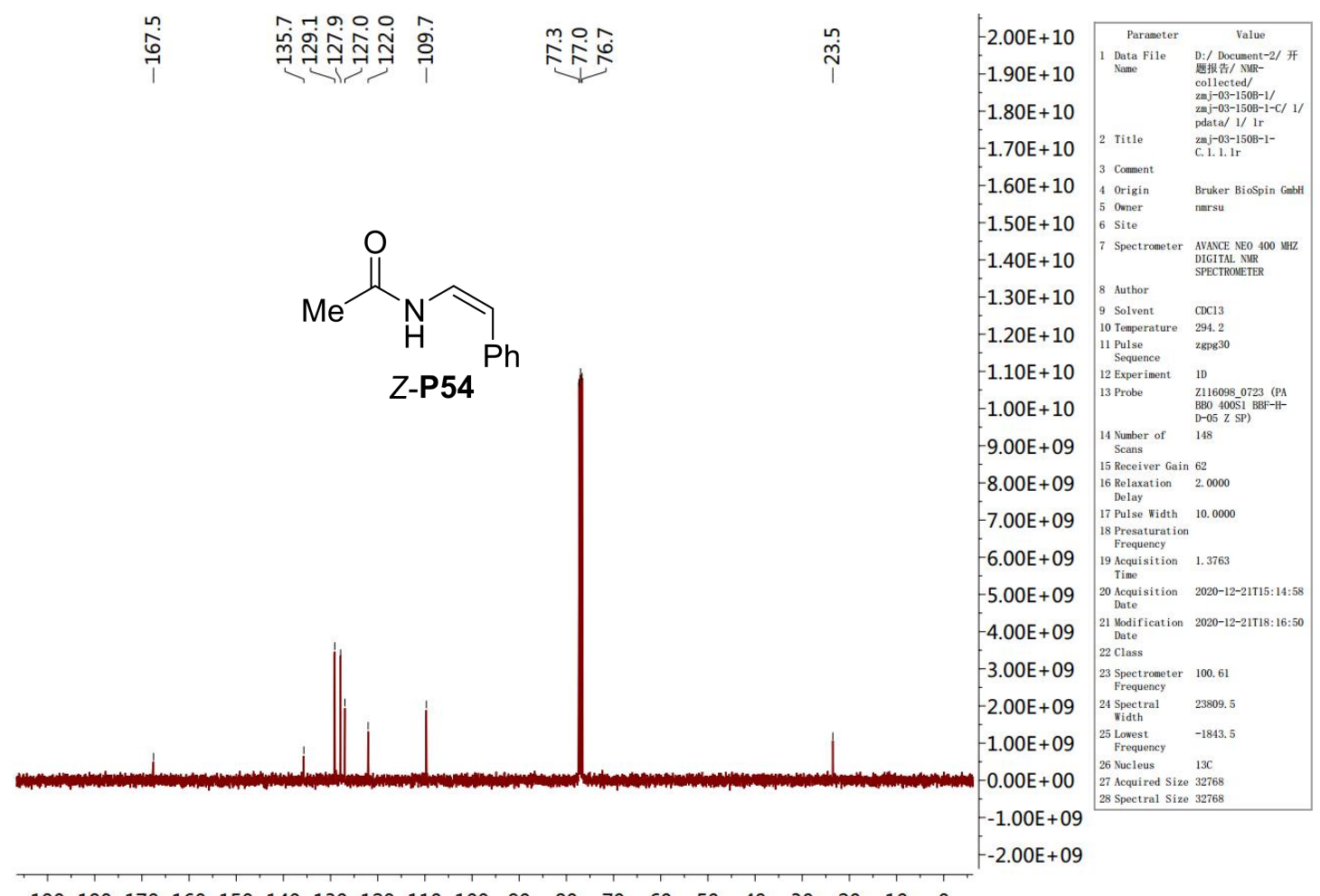

$\begin{array}{llllllllllllllllllll}190 & 180 & 170 & 160 & 150 & 140 & 130 & 120 & 110 & 100 & 90 & 80 & 70 & 60 & 50 & 40 & 30 & 20 & 10 & 0\end{array}$ 
Benzyl 1H-pyrrole-1-carboxylate (P55)

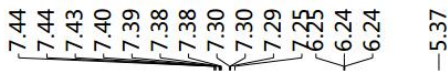

4

$\mathrm{Cbz}$

P55

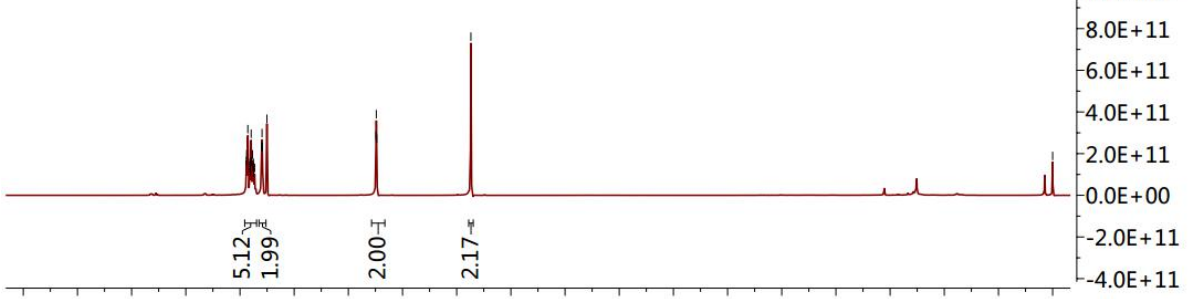

$\begin{array}{llllllllllllllllllll}9.5 & 9.0 & 8.5 & 8.0 & 7.5 & 7.0 & 6.5 & 6.0 & 5.5 & 5.0 & 4.5 & 4.0 & 3.5 & 3.0 & 2.5 & 2.0 & 1.5 & 1.0 & 0.5 & 0.0\end{array}$

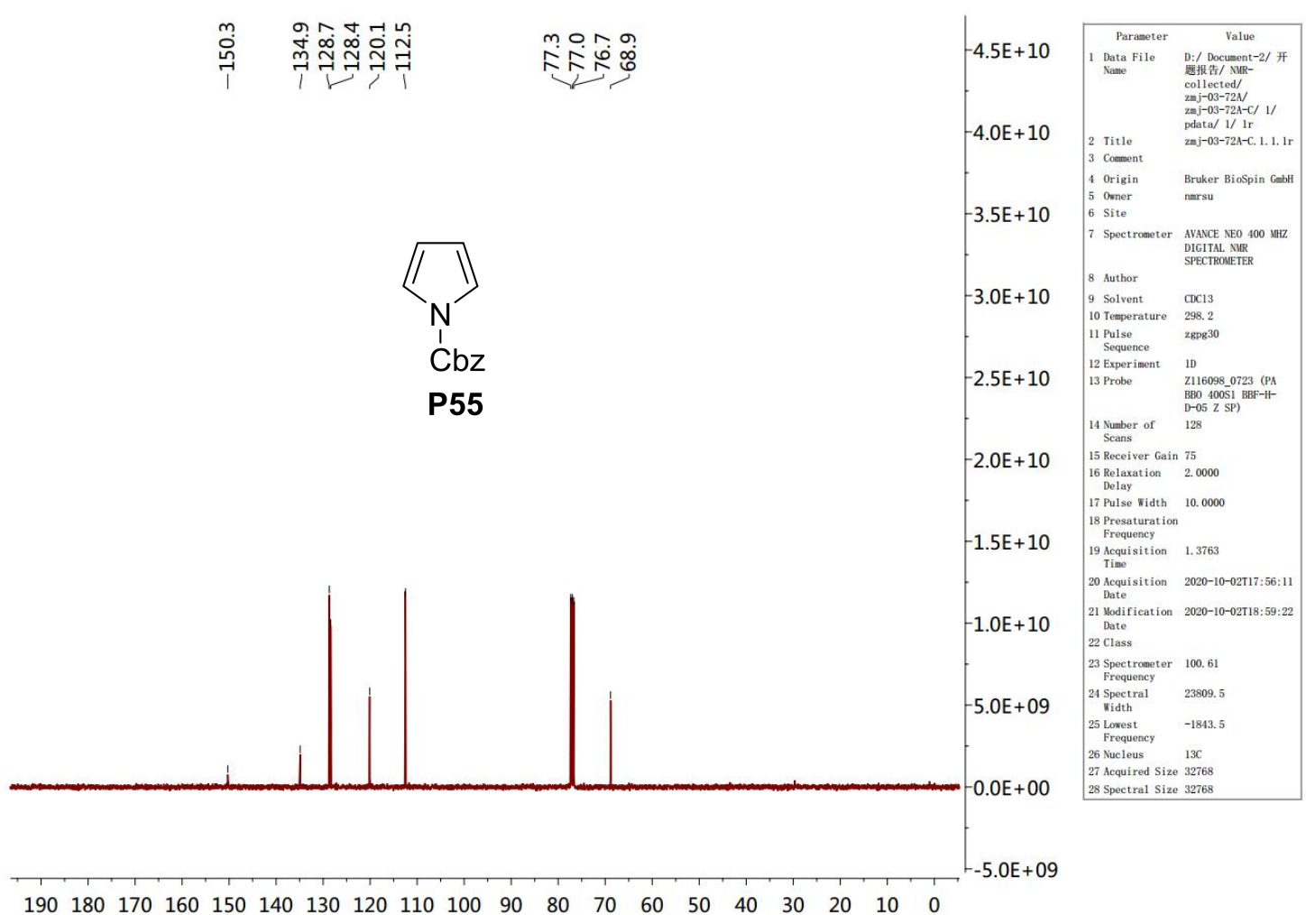

$\begin{array}{llllllllllllllllllll}190 & 180 & 170 & 160 & 150 & 140 & 130 & 120 & 110 & 100 & 90 & 80 & 70 & 60 & 50 & 40 & 30 & 20 & 10 & 0\end{array}$ 
1-Benzyl 2-methyl $1 H$-pyrrole-1,2-dicarboxylate (P56)
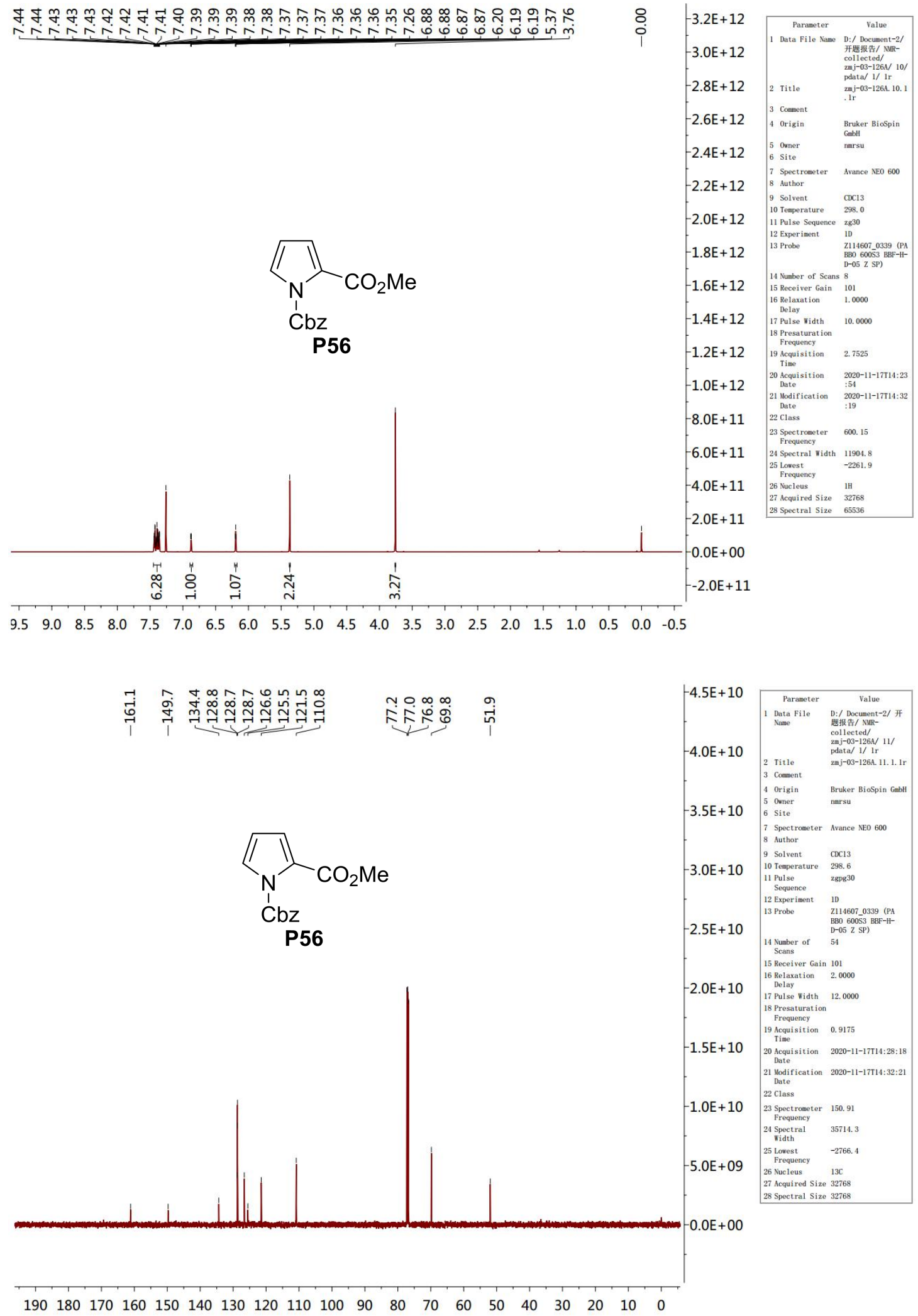
Benzyl 2,3-dihydro-4H-1,4-oxazine-4-carboxylate (P58)

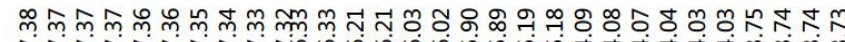

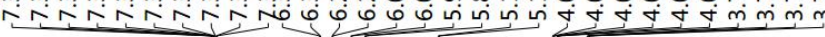
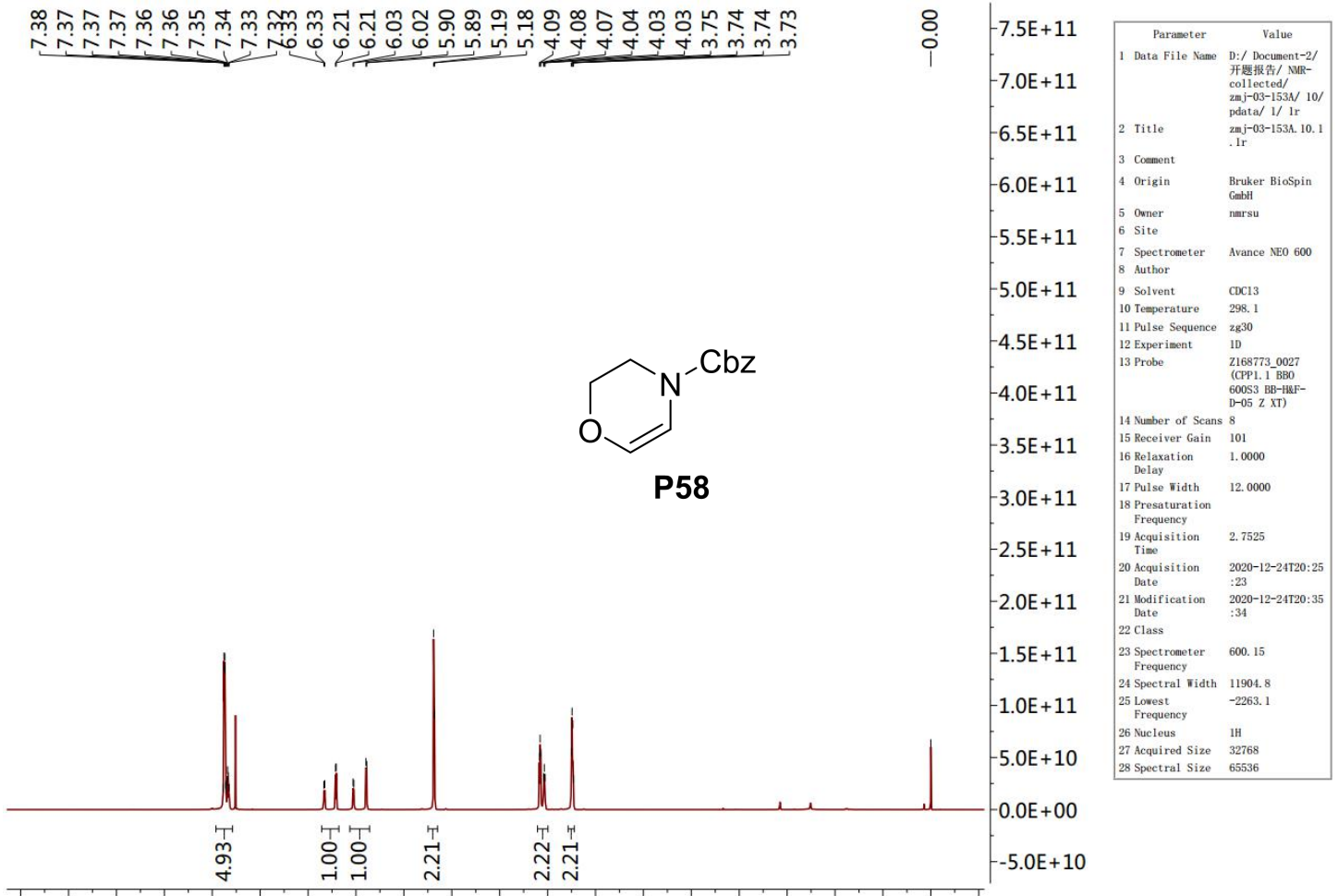

$\begin{array}{lllllllllllllllllllll}9.5 & 9.0 & 8.5 & 8.0 & 7.5 & 7.0 & 6.5 & 6.0 & 5.5 & 5.0 & 4.5 & 4.0 & 3.5 & 3.0 & 2.5 & 2.0 & 1.5 & 1.0 & 0.5 & 0.0 & -0.5\end{array}$

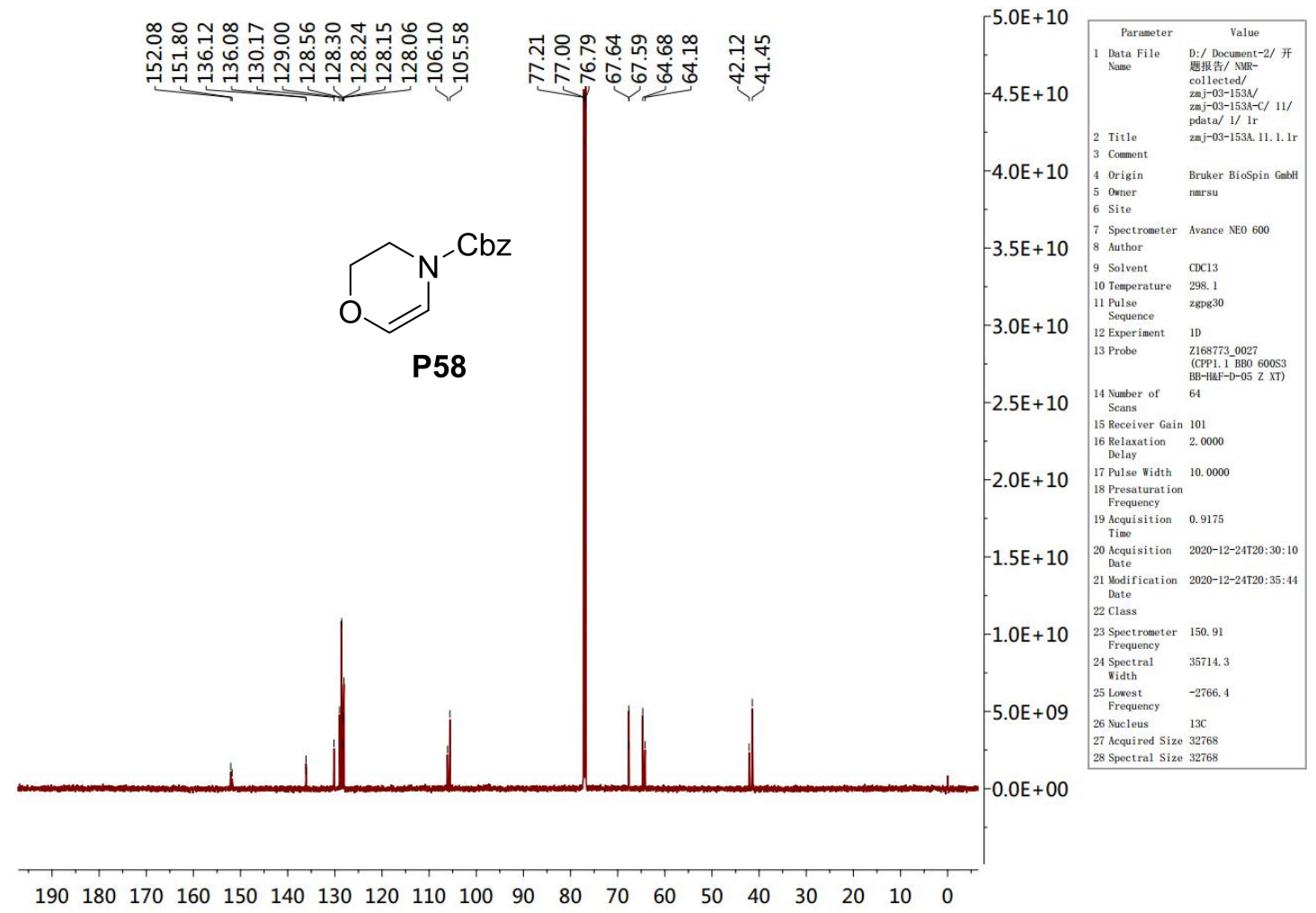


Benzyl 2,3-dihydro-4H-1,4-thiazine-4-carboxylate (P59)

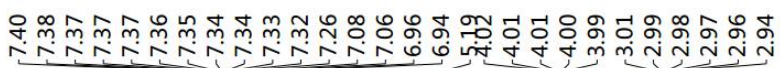<smiles>O=C(O)N1C=CSCC1</smiles>

P59

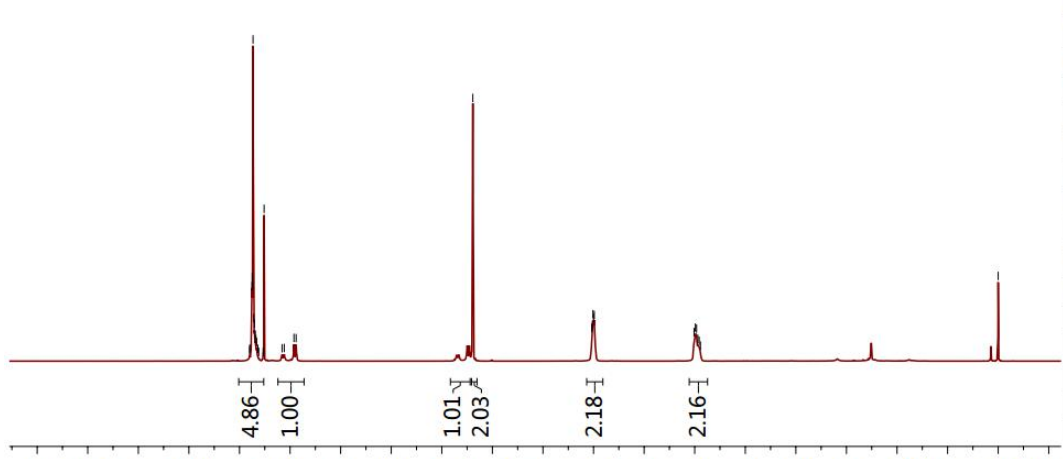

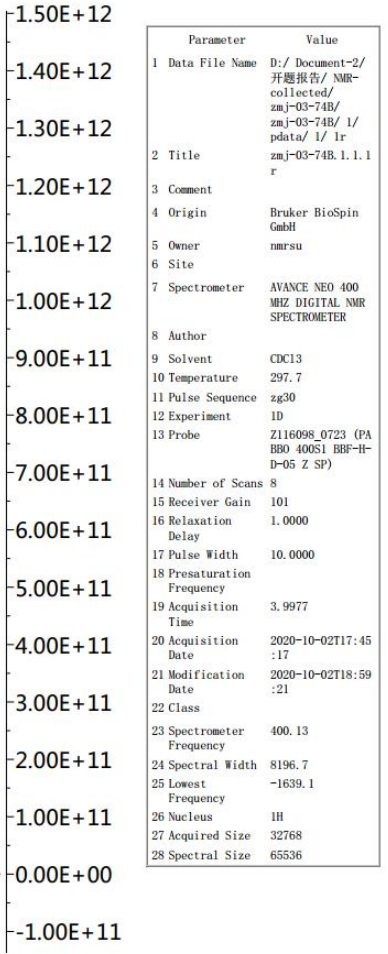

$\begin{array}{lllllllllllllllllllll}9.5 & 9.0 & 8.5 & 8.0 & 7.5 & 7.0 & 6.5 & 6.0 & 5.5 & 5.0 & 4.5 & 4.0 & 3.5 & 3.0 & 2.5 & 2.0 & 1.5 & 1.0 & 0.5 & 0.0 & -0.5\end{array}$

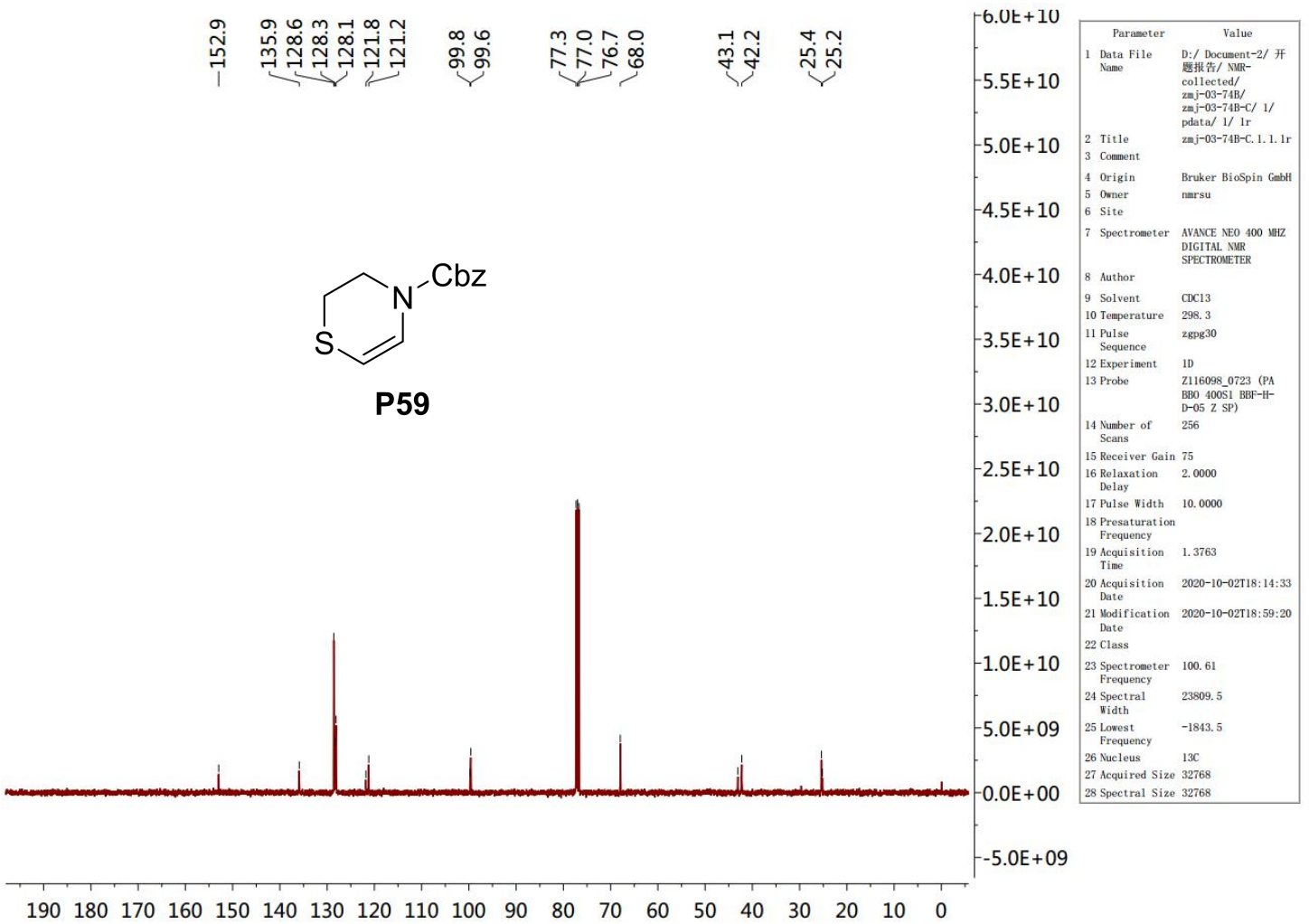


Dibenzyl 2,3-dihydropyrazine-1,4-dicarboxylate (P60)
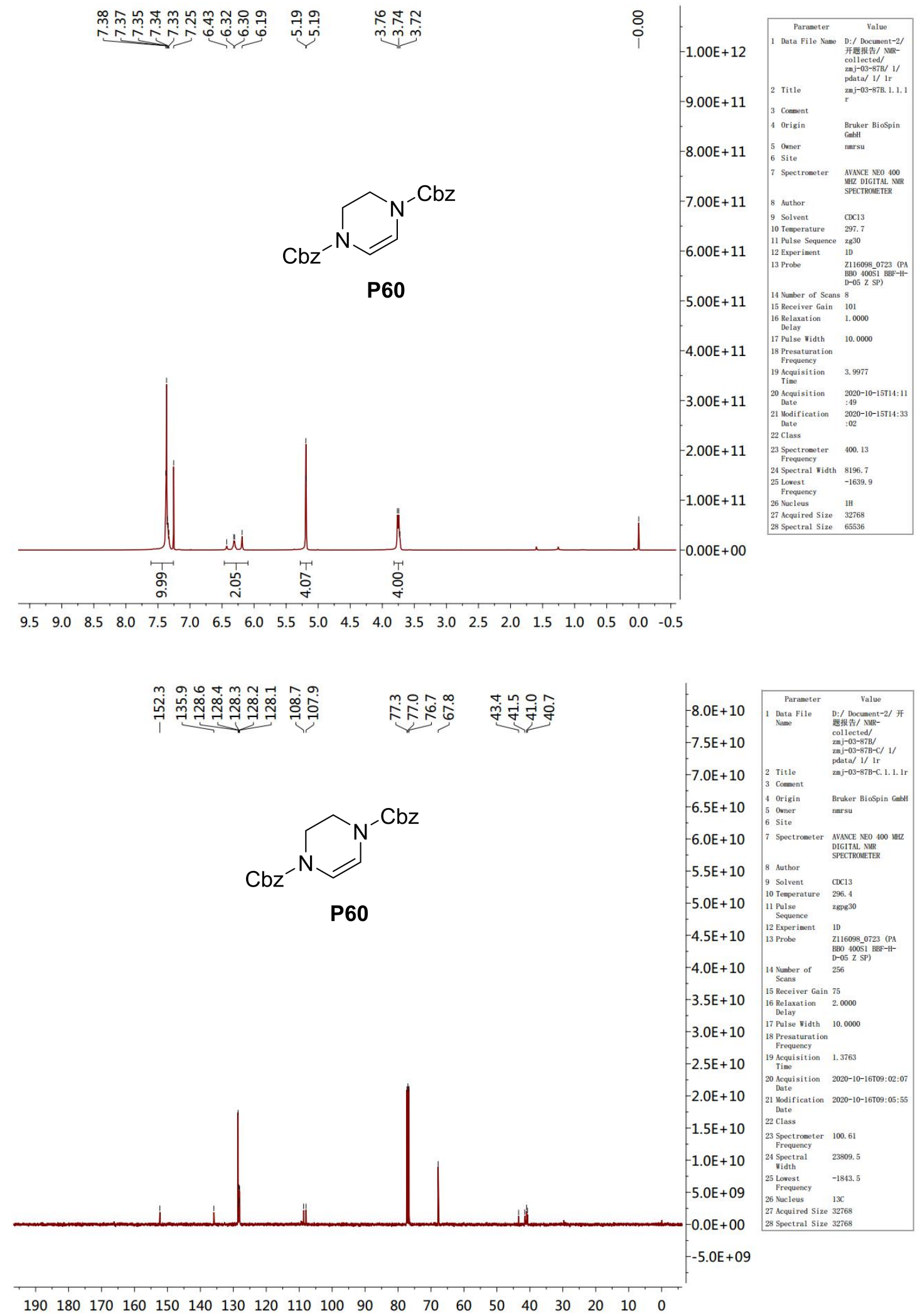
Benzyl 4-0xo-3,4-dihydropyridine-1(2H)-carboxylate (P61)
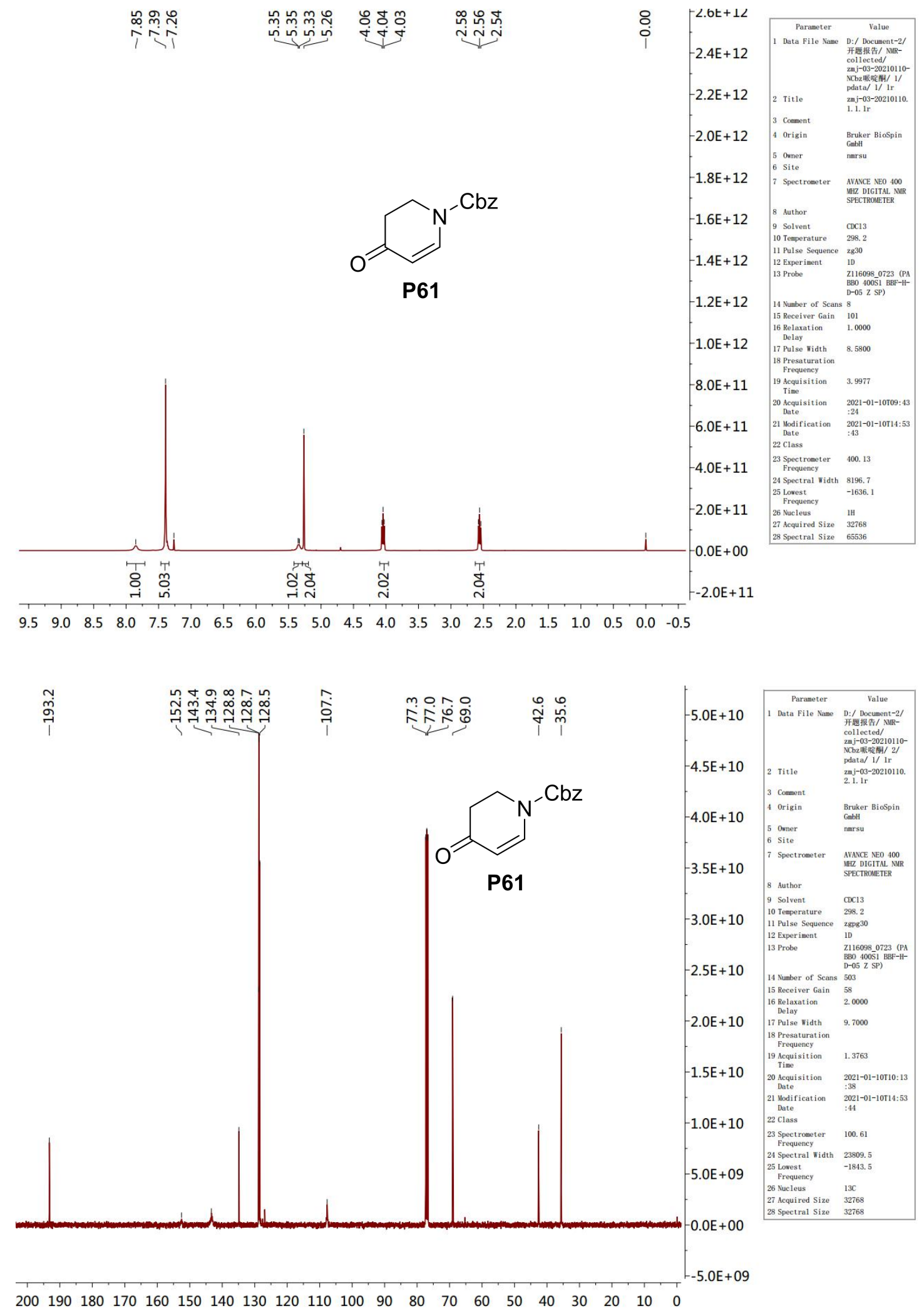


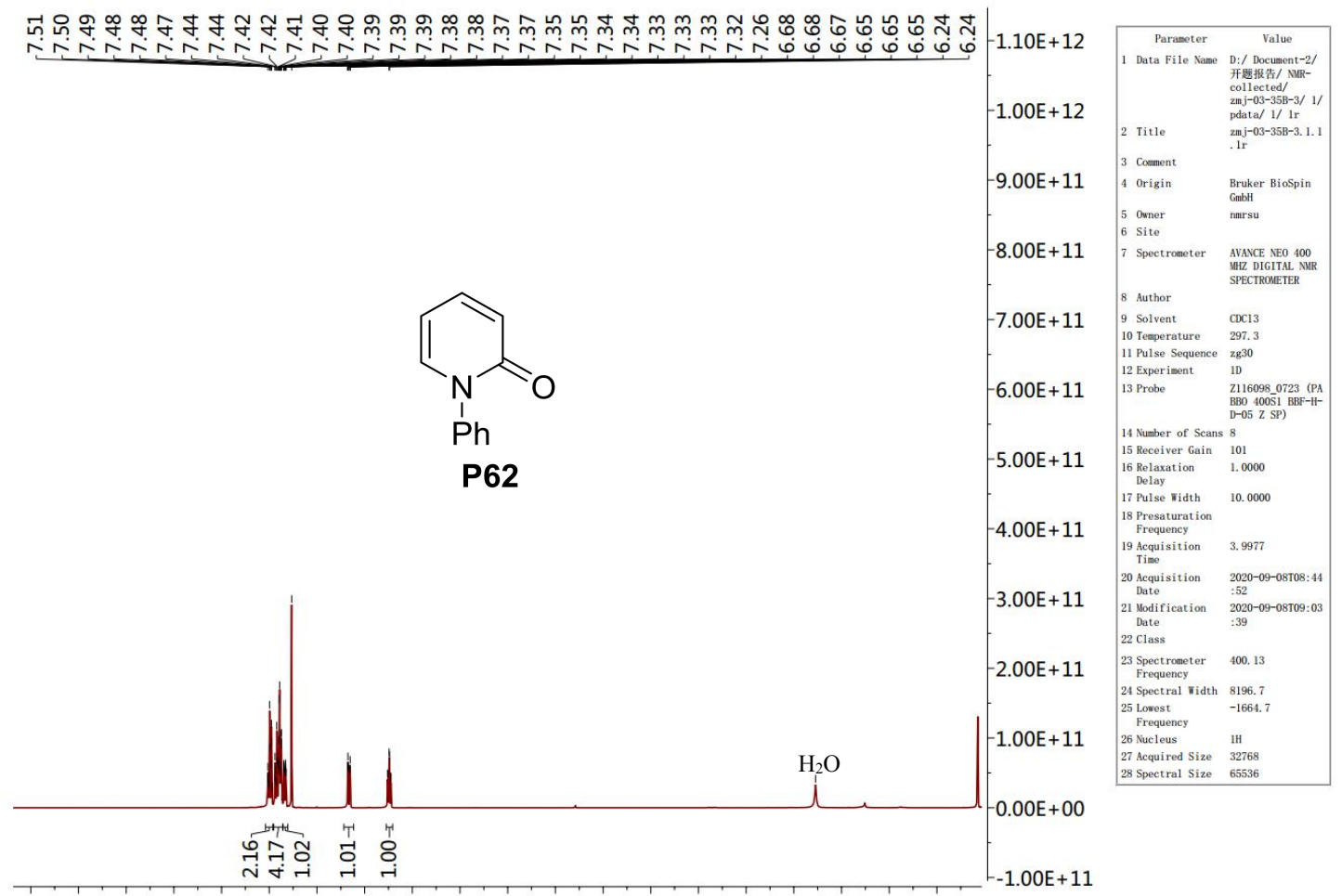

$\begin{array}{llllllllllllllllllll}10.0 & 9.5 & 9.0 & 8.5 & 8.0 & 7.5 & 7.0 & 6.5 & 6.0 & 5.5 & 5.0 & 4.5 & 4.0 & 3.5 & 3.0 & 2.5 & 2.0 & 1.5 & 1.0 & 0.5\end{array}$

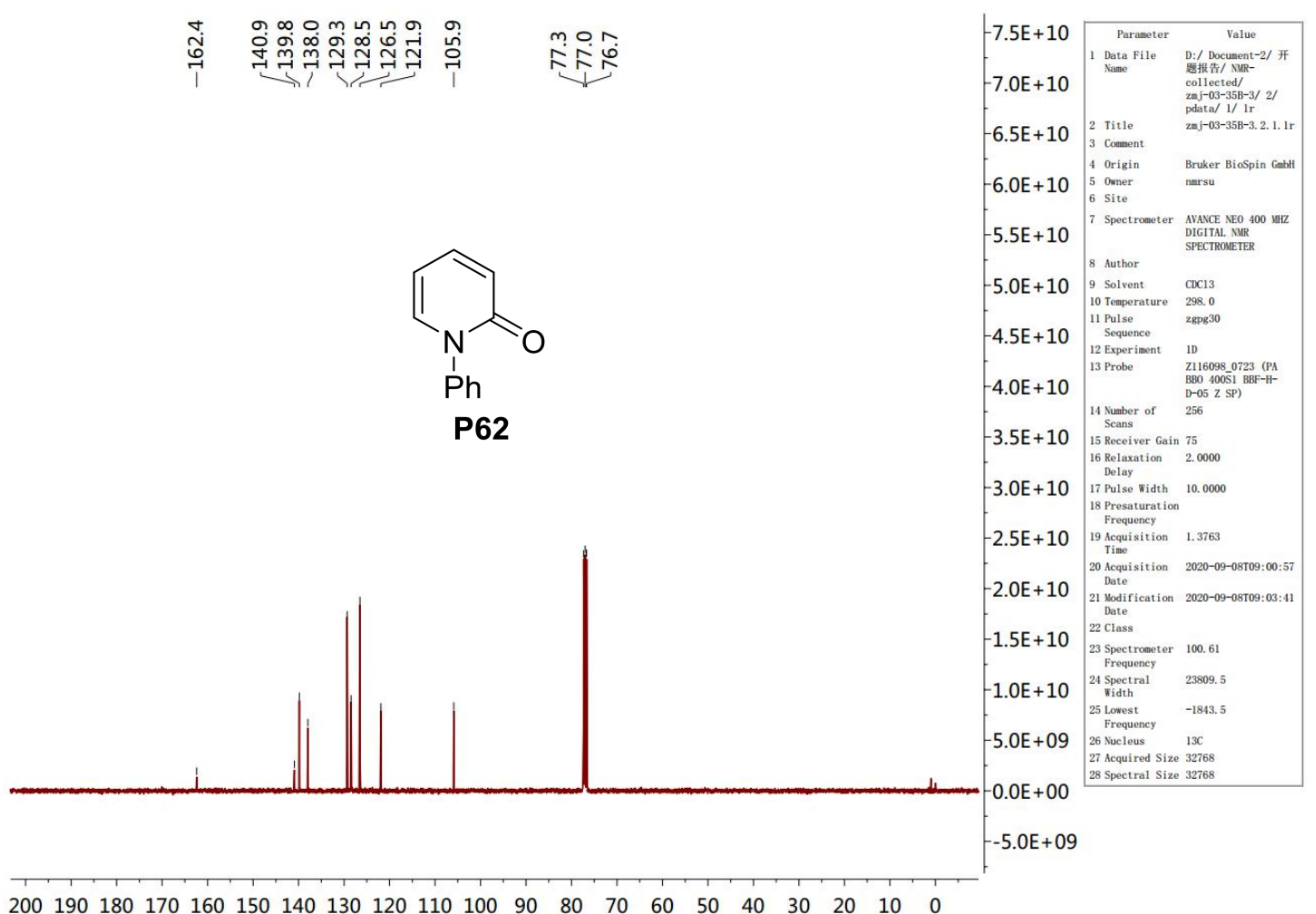

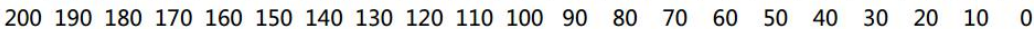




\section{1-Benzylpyridin-2(1H)-one (P63)}

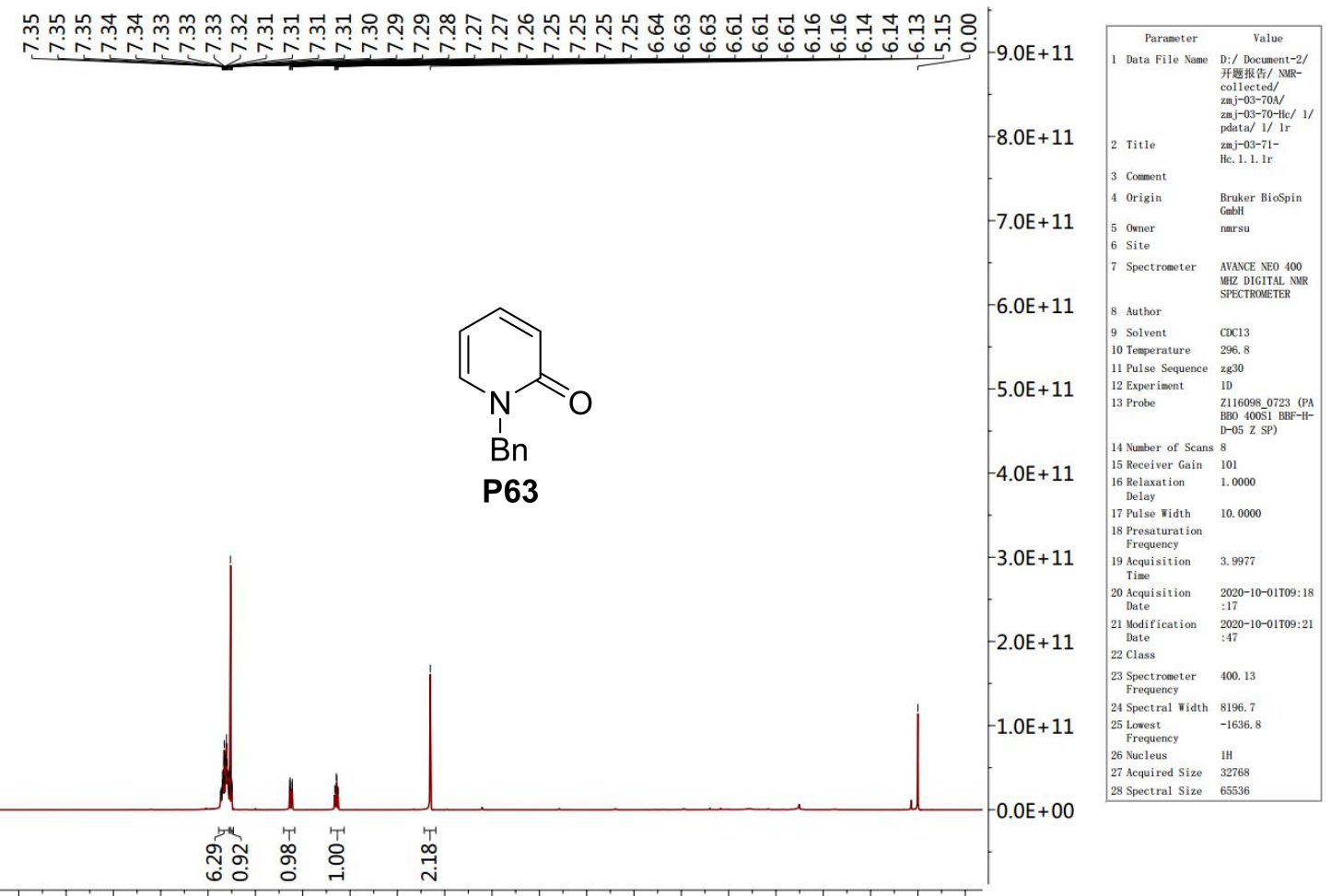

$\begin{array}{lllllllllllllllllllll}9.5 & 9.0 & 8.5 & 8.0 & 7.5 & 7.0 & 6.5 & 6.0 & 5.5 & 5.0 & 4.5 & 4.0 & 3.5 & 3.0 & 2.5 & 2.0 & 1.5 & 1.0 & 0.5 & 0.0 & -0.5\end{array}$

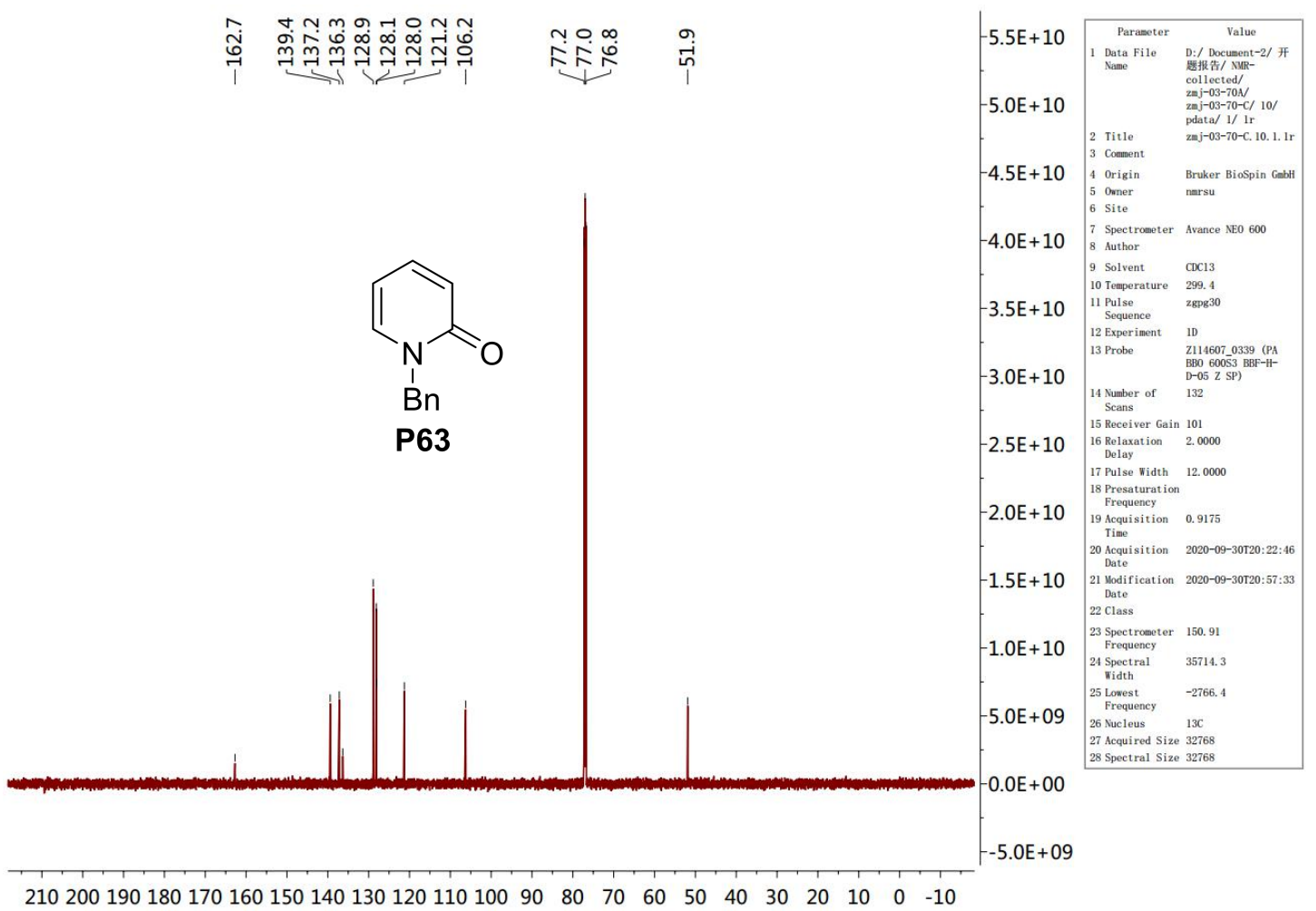




\section{Isoquinolin-1(2H)-one (P64)}

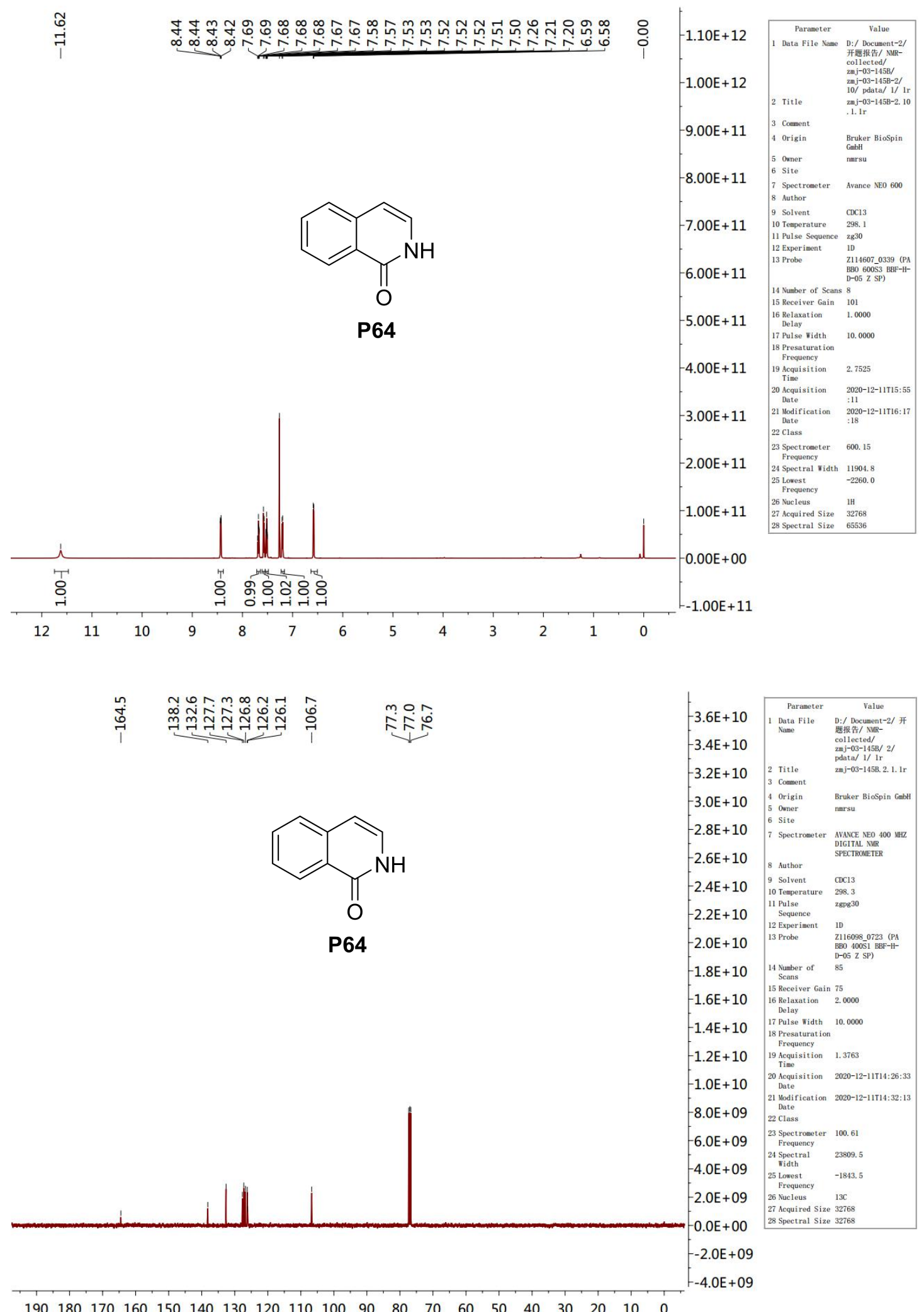




\section{3-Phenyloxazol-2(3H)-one (P65)}

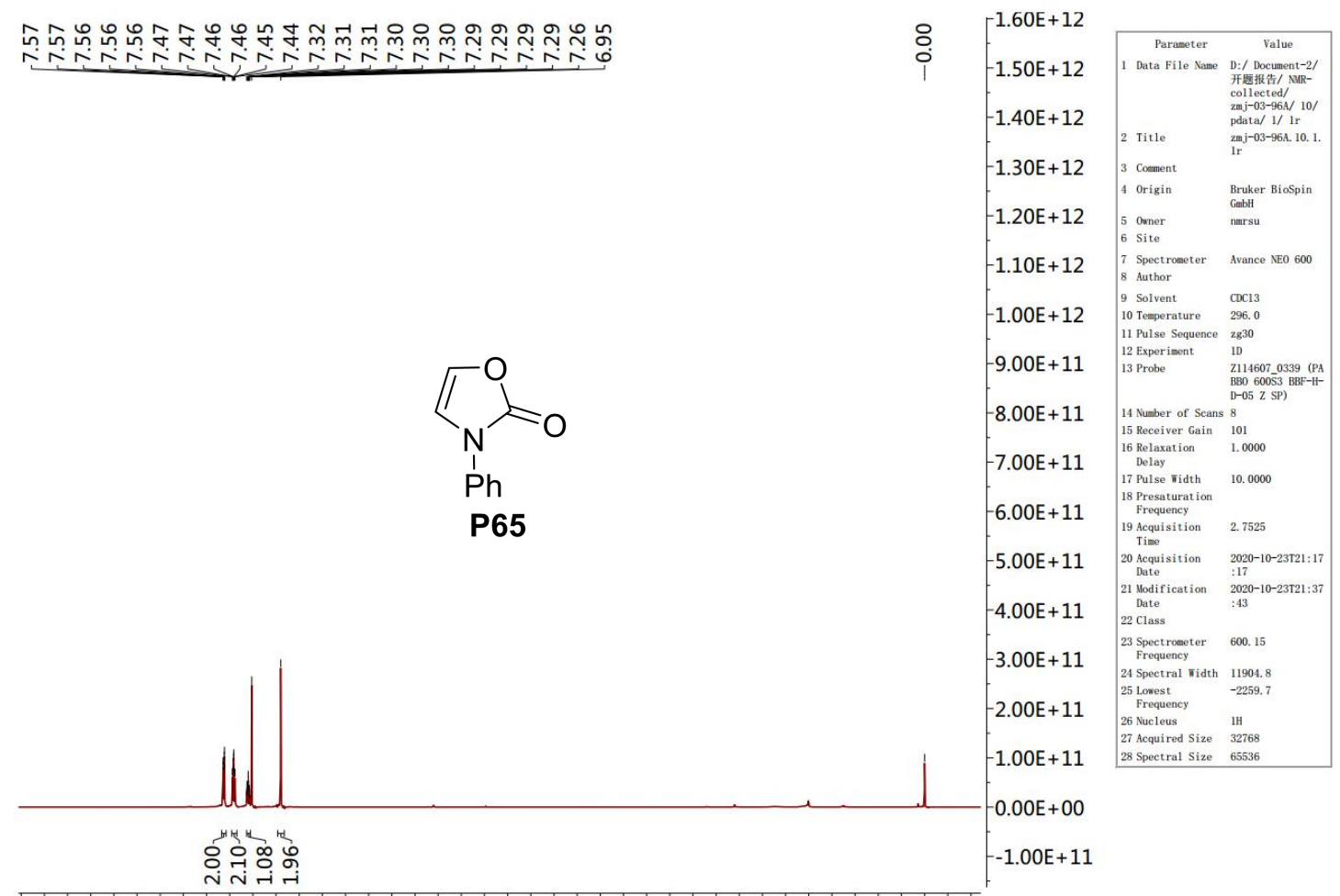

$\begin{array}{lllllllllllllllllllll}9.5 & 9.0 & 8.5 & 8.0 & 7.5 & 7.0 & 6.5 & 6.0 & 5.5 & 5.0 & 4.5 & 4.0 & 3.5 & 3.0 & 2.5 & 2.0 & 1.5 & 1.0 & 0.5 & 0.0 & -0.5\end{array}$

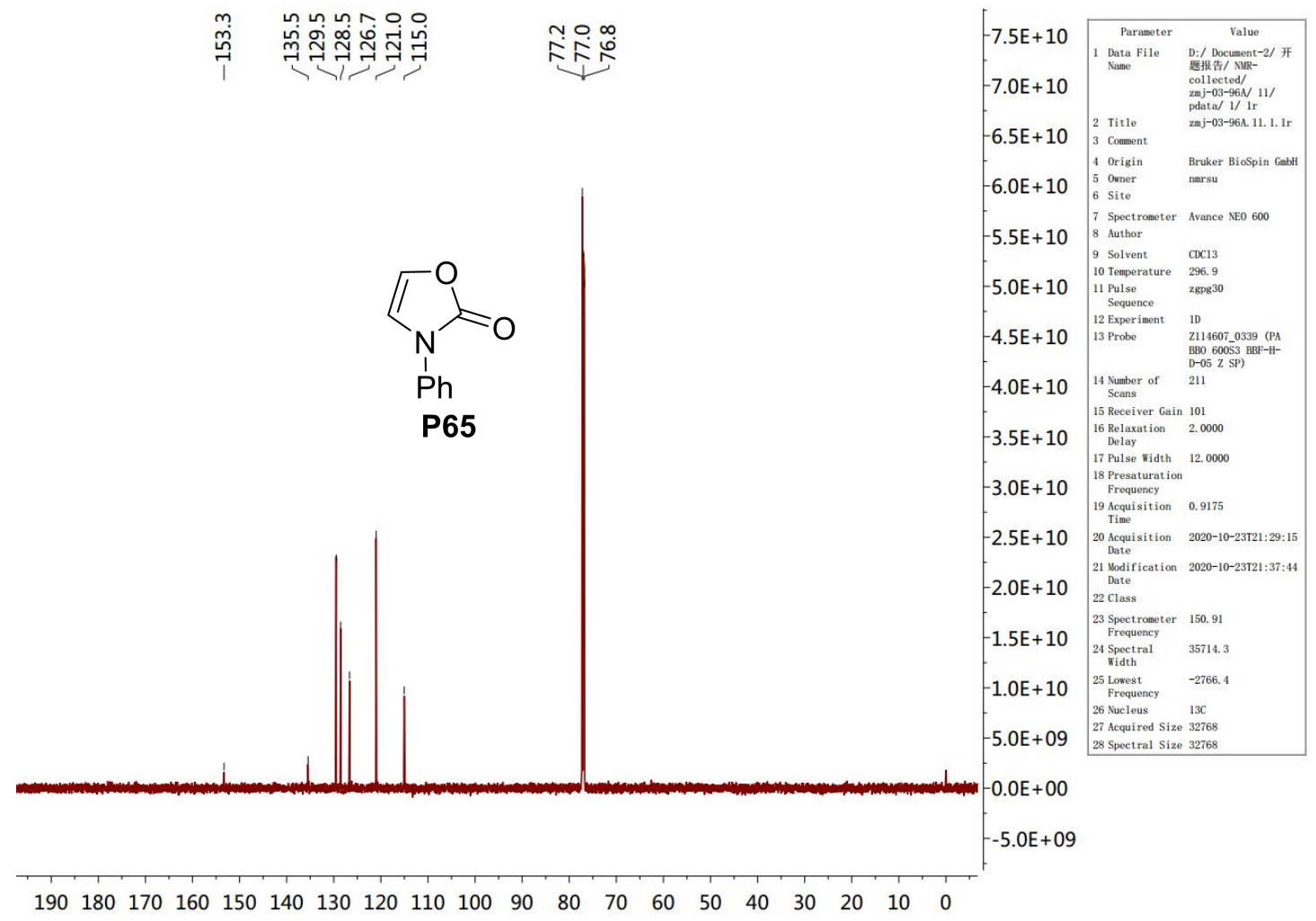




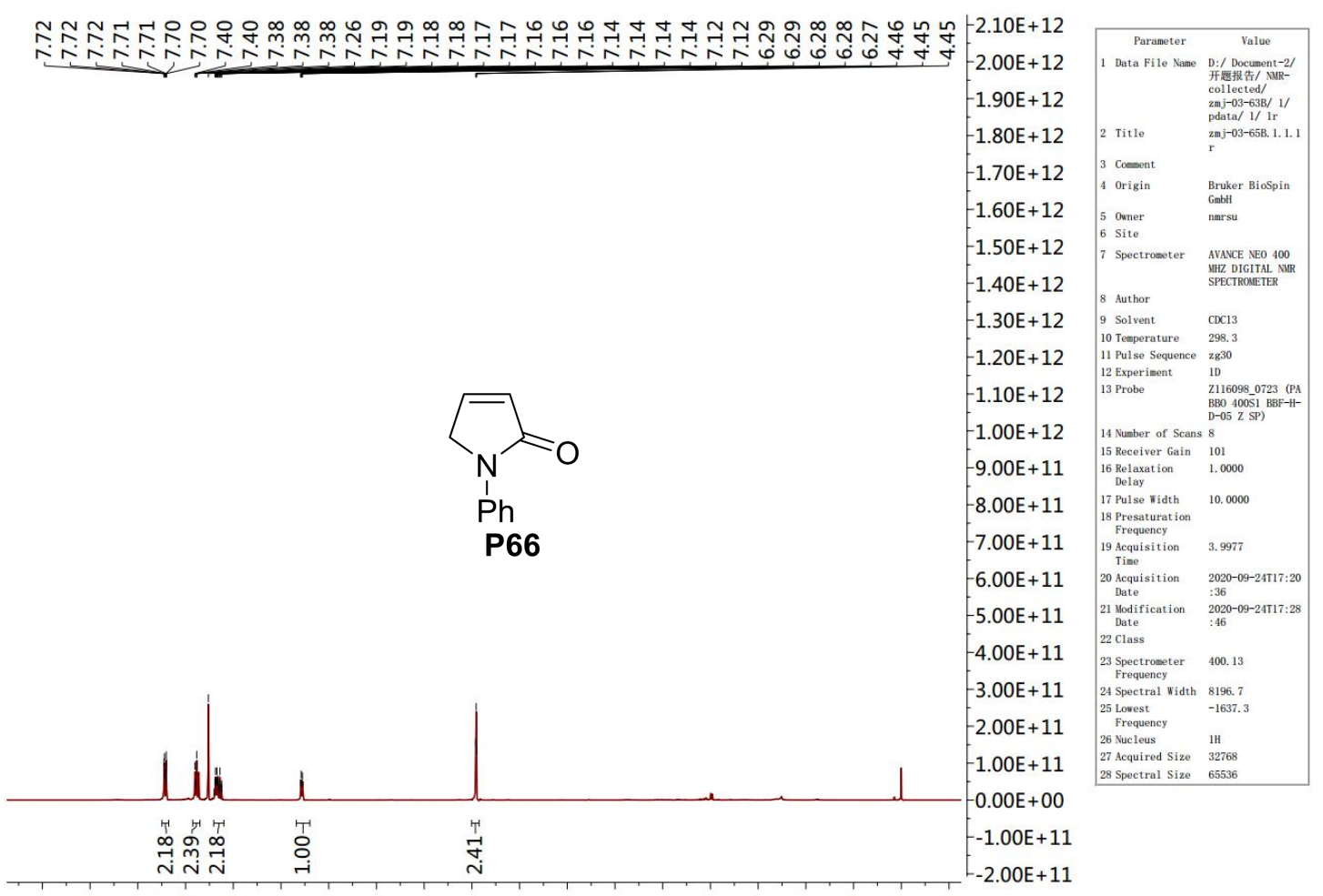

$\begin{array}{llllllllllllllllllll}9.0 & 8.5 & 8.0 & 7.5 & 7.0 & 6.5 & 6.0 & 5.5 & 5.0 & 4.5 & 4.0 & 3.5 & 3.0 & 2.5 & 2.0 & 1.5 & 1.0 & 0.5 & 0.0 & -0.5\end{array}$

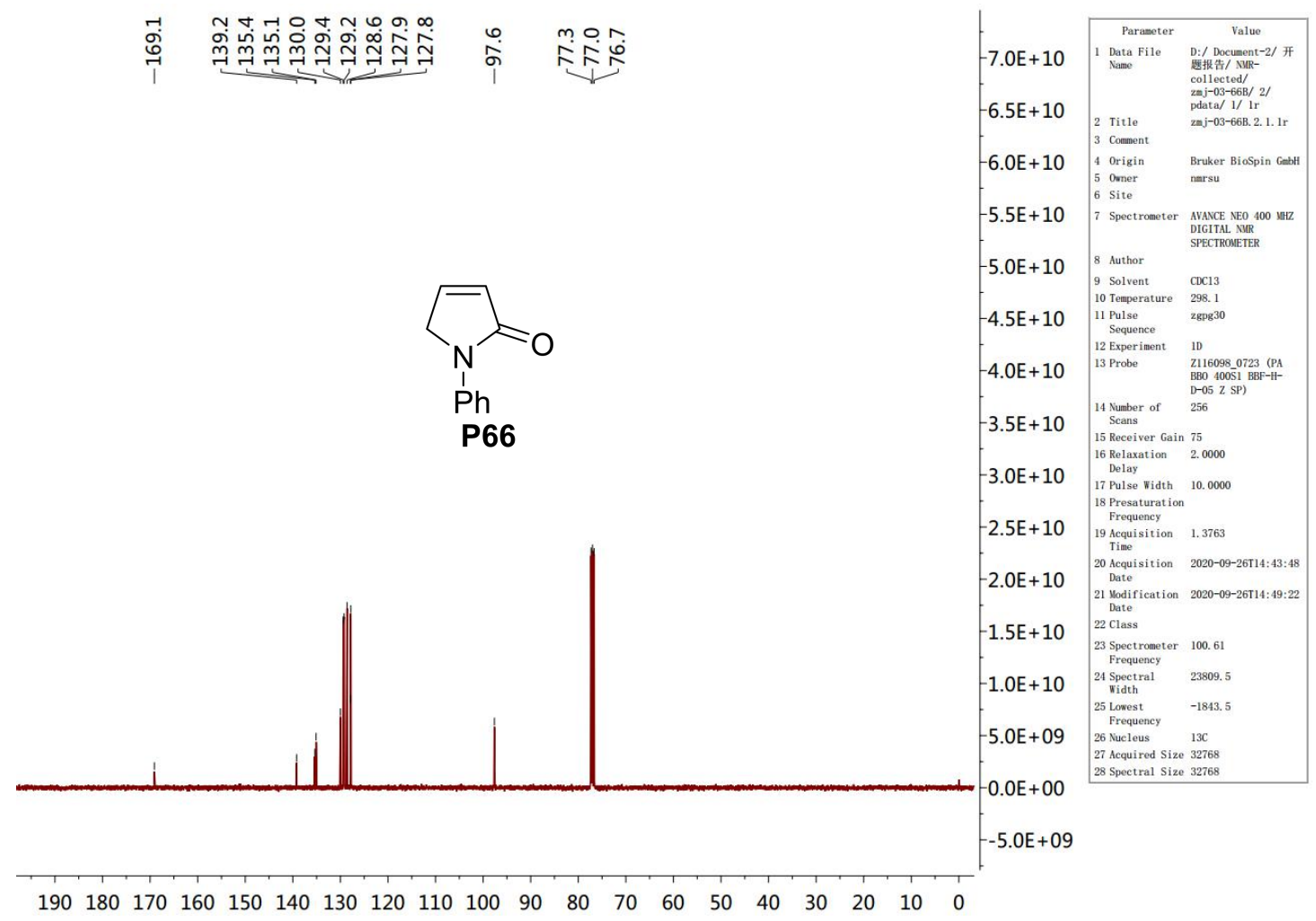


1-Phenyl-1,7-dihydro-2H-azepin-2-one (P67)

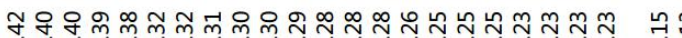

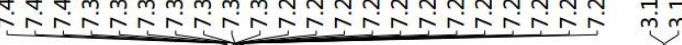<smiles>O=C1C=CC=CCN1c1ccccc1</smiles>

P67

光

กิ
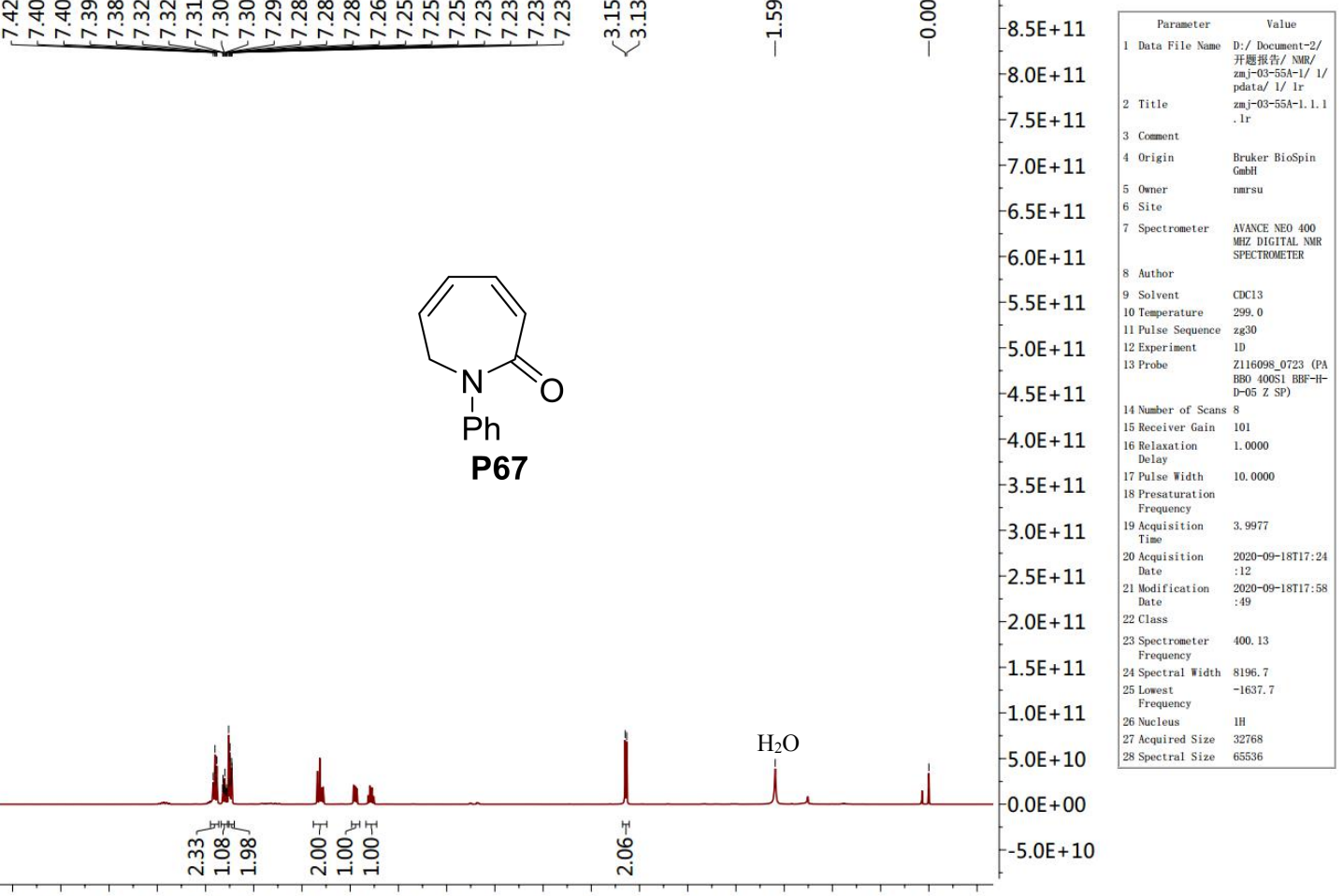

$\begin{array}{lllllllllllllllllllll}9.5 & 9.0 & 8.5 & 8.0 & 7.5 & 7.0 & 6.5 & 6.0 & 5.5 & 5.0 & 4.5 & 4.0 & 3.5 & 3.0 & 2.5 & 2.0 & 1.5 & 1.0 & 0.5 & 0.0 & -0.5\end{array}$

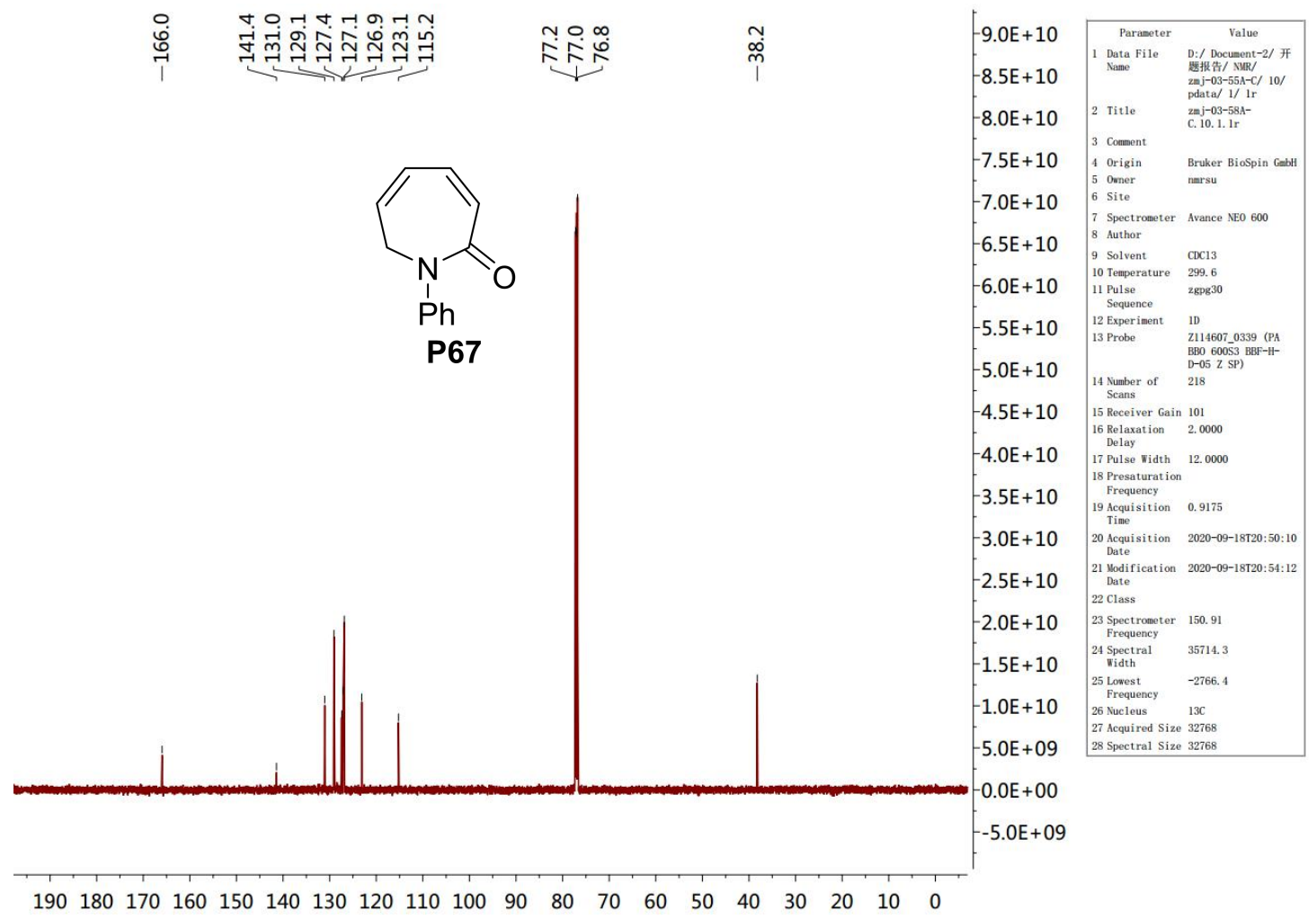




\section{Naphthalen-1-ol (P68)}

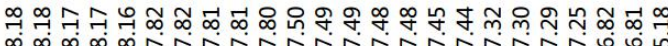

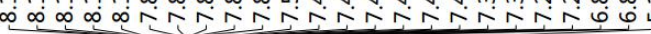

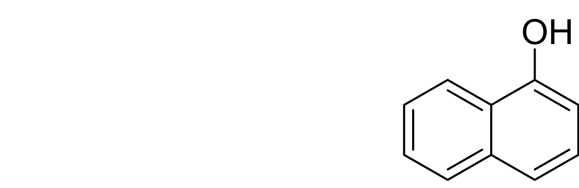

P68
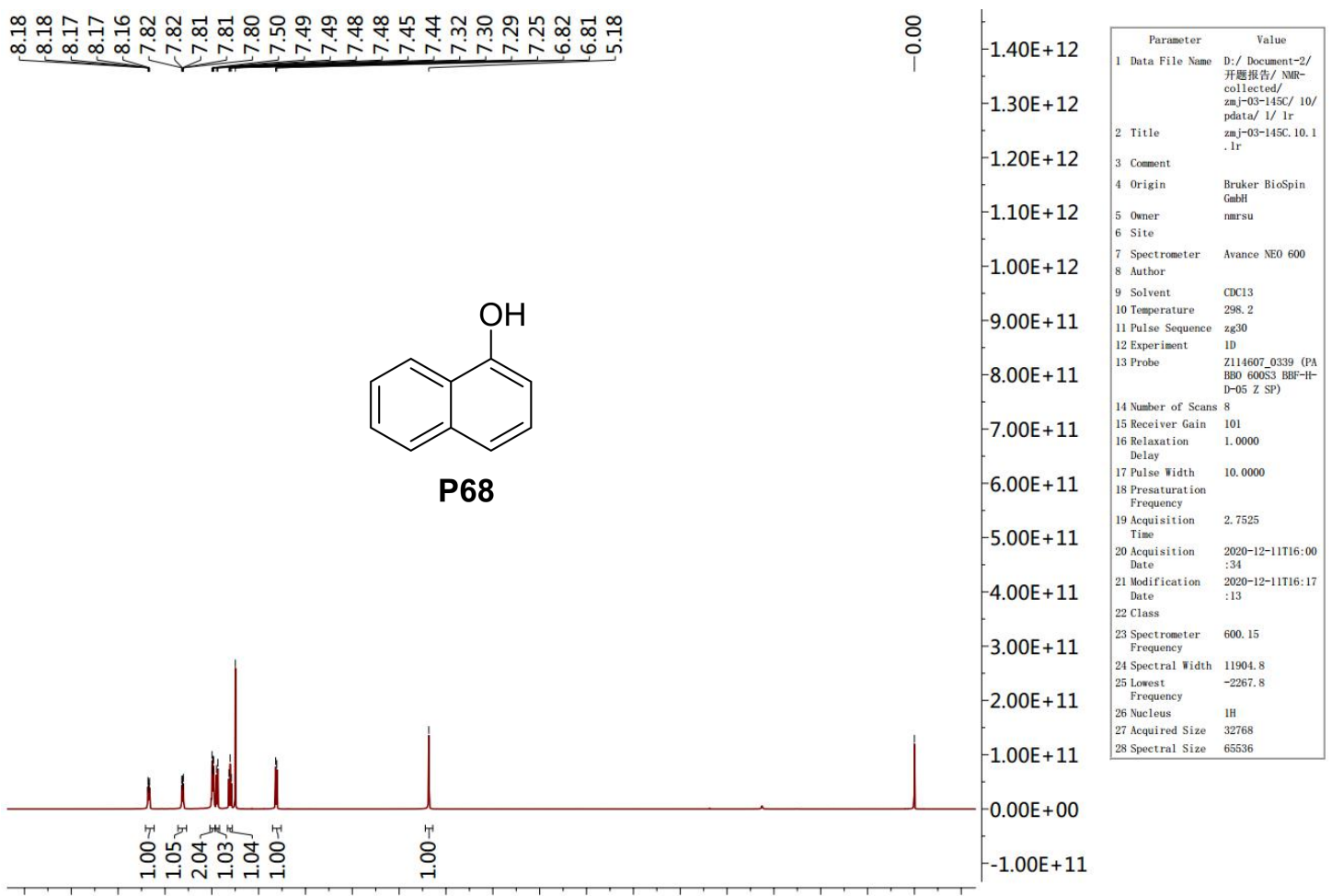

$\begin{array}{lllllllllllllllllllll}9.5 & 9.0 & 8.5 & 8.0 & 7.5 & 7.0 & 6.5 & 6.0 & 5.5 & 5.0 & 4.5 & 4.0 & 3.5 & 3.0 & 2.5 & 2.0 & 1.5 & 1.0 & 0.5 & 0.0 & -0.5\end{array}$

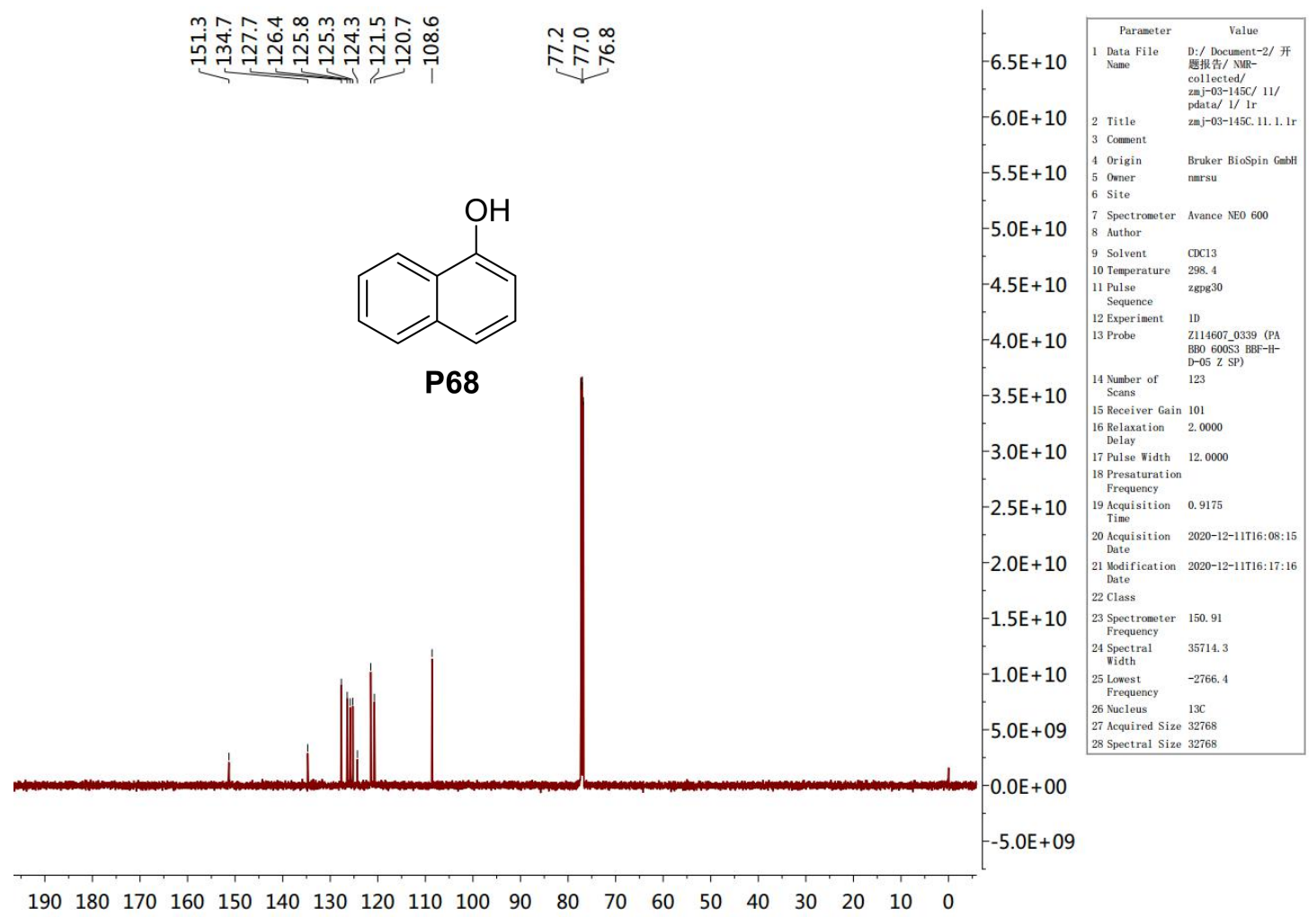




\section{Naphthalen-2-ol (P69)}

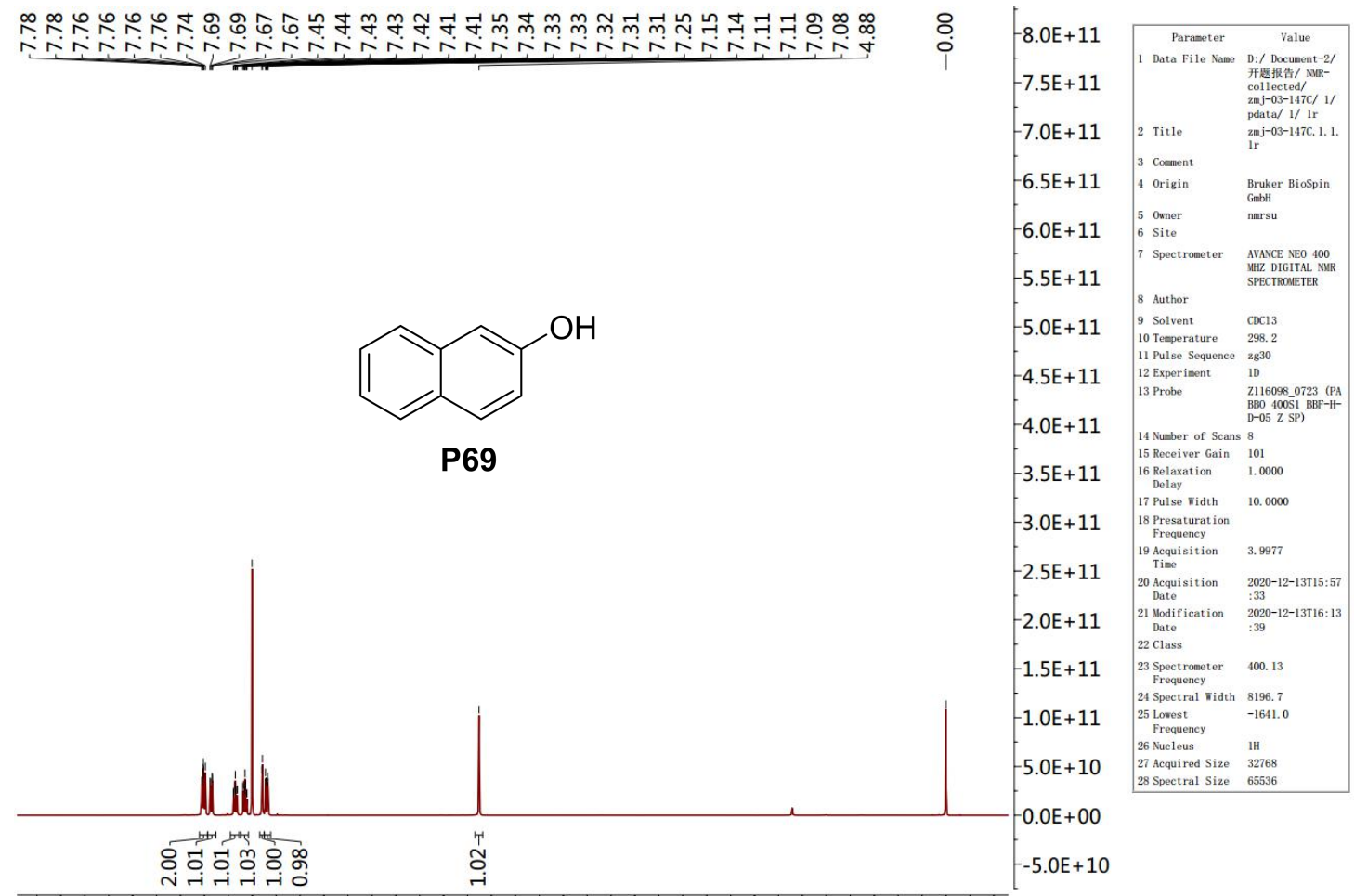

$\begin{array}{lllllllllllllllllllll}9.5 & 9.0 & 8.5 & 8.0 & 7.5 & 7.0 & 6.5 & 6.0 & 5.5 & 5.0 & 4.5 & 4.0 & 3.5 & 3.0 & 2.5 & 2.0 & 1.5 & 1.0 & 0.5 & 0.0 & -0.5\end{array}$

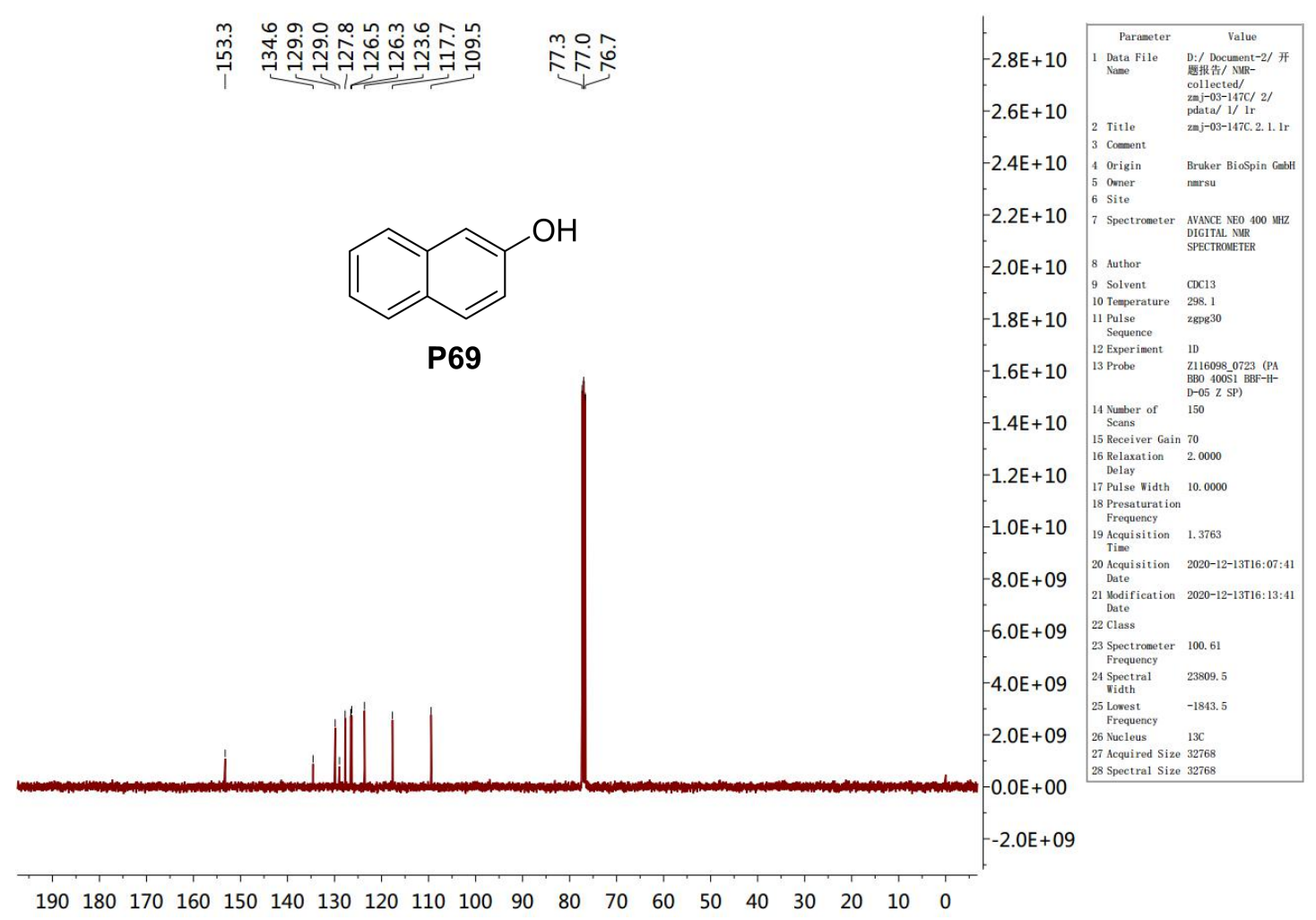




\section{[1,1'-Biphenyl]-4-ol (P70)}

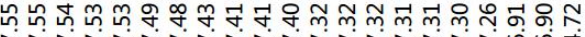

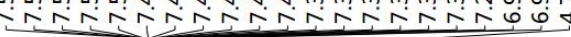<smiles>Oc1ccc(-c2ccccc2)cc1</smiles>
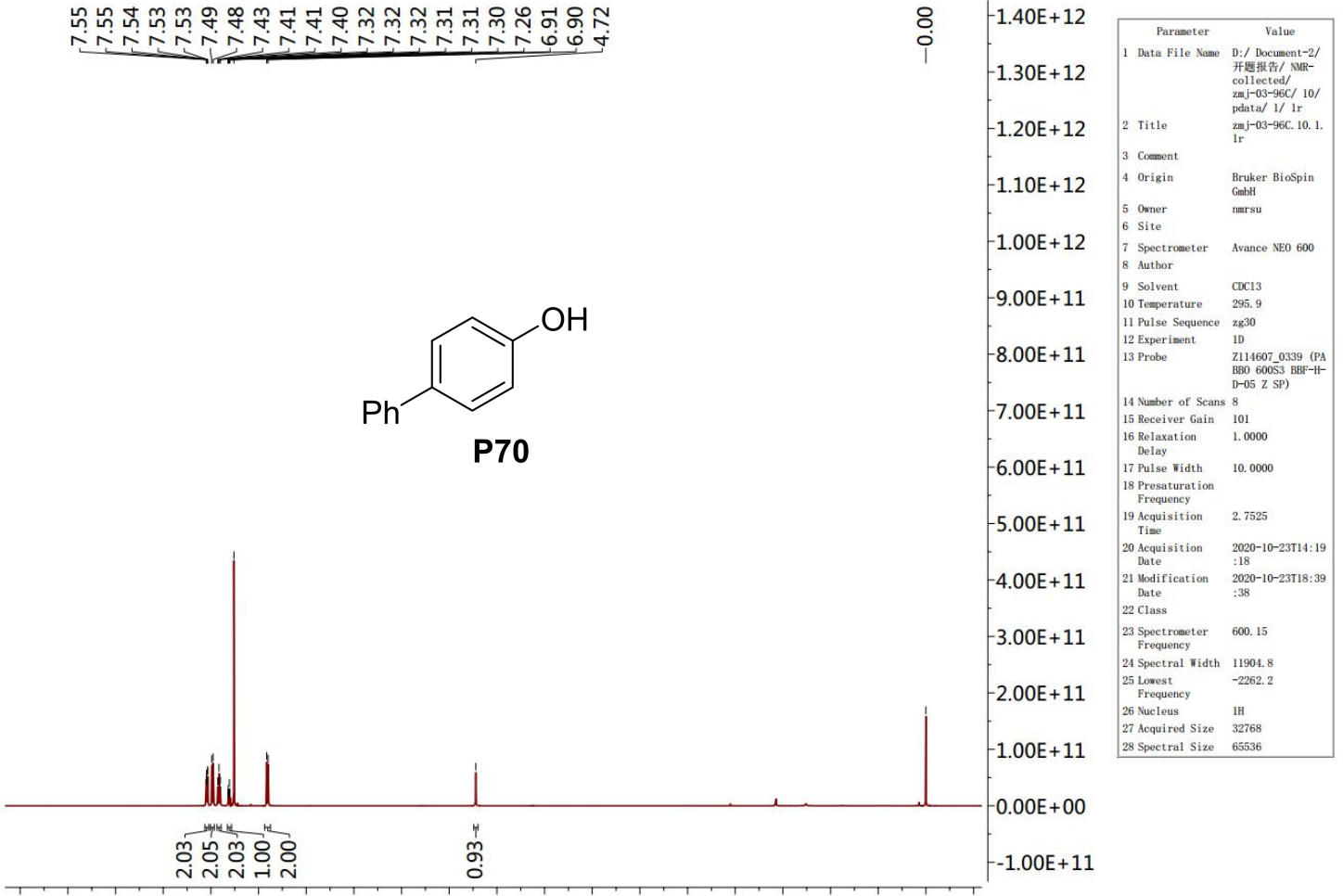

$\begin{array}{lllllllllllllllllllll}9.5 & 9.0 & 8.5 & 8.0 & 7.5 & 7.0 & 6.5 & 6.0 & 5.5 & 5.0 & 4.5 & 4.0 & 3.5 & 3.0 & 2.5 & 2.0 & 1.5 & 1.0 & 0.5 & 0.0 & -0.5\end{array}$

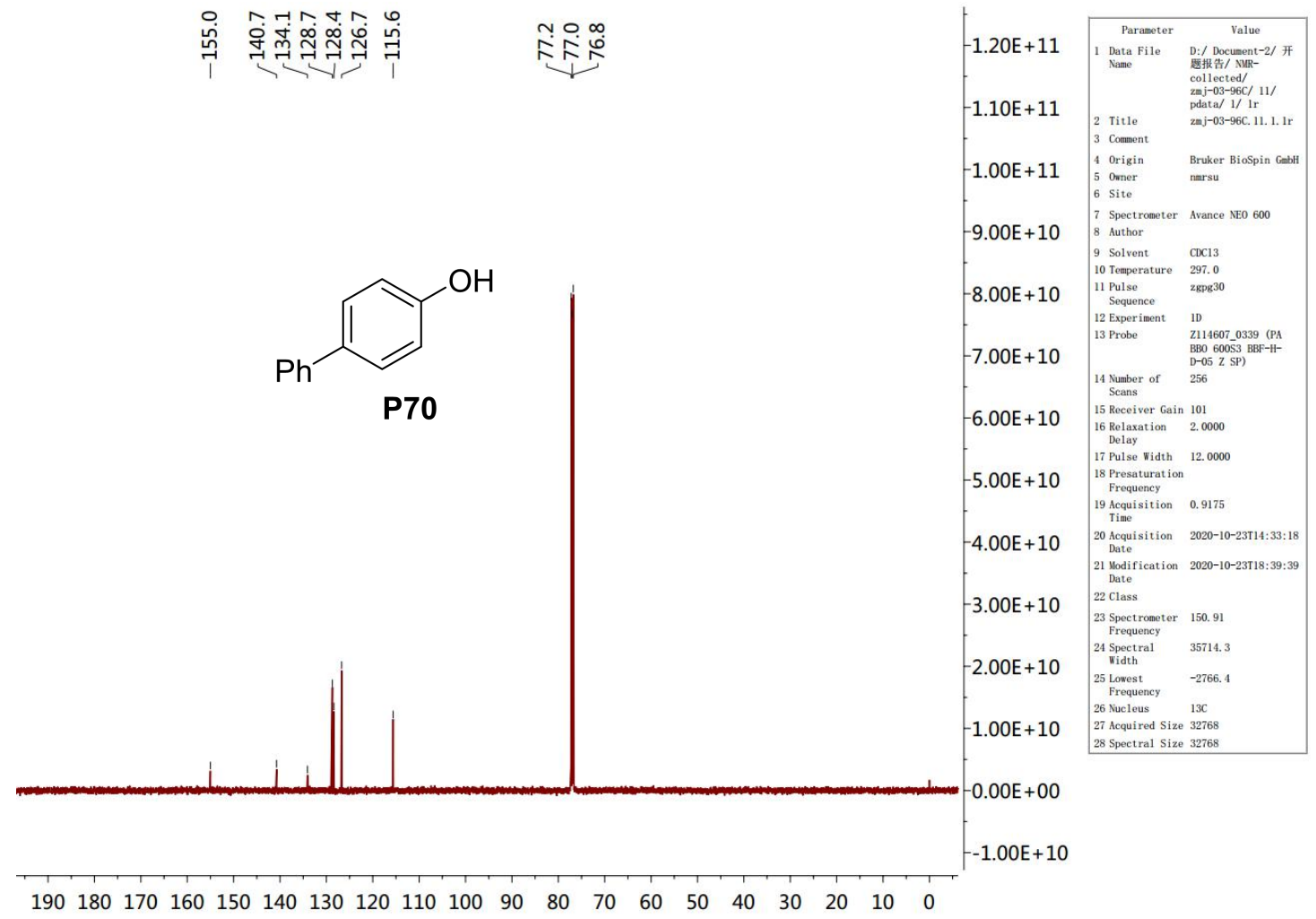




\section{Chalcone (P72)}

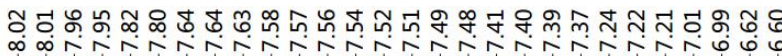
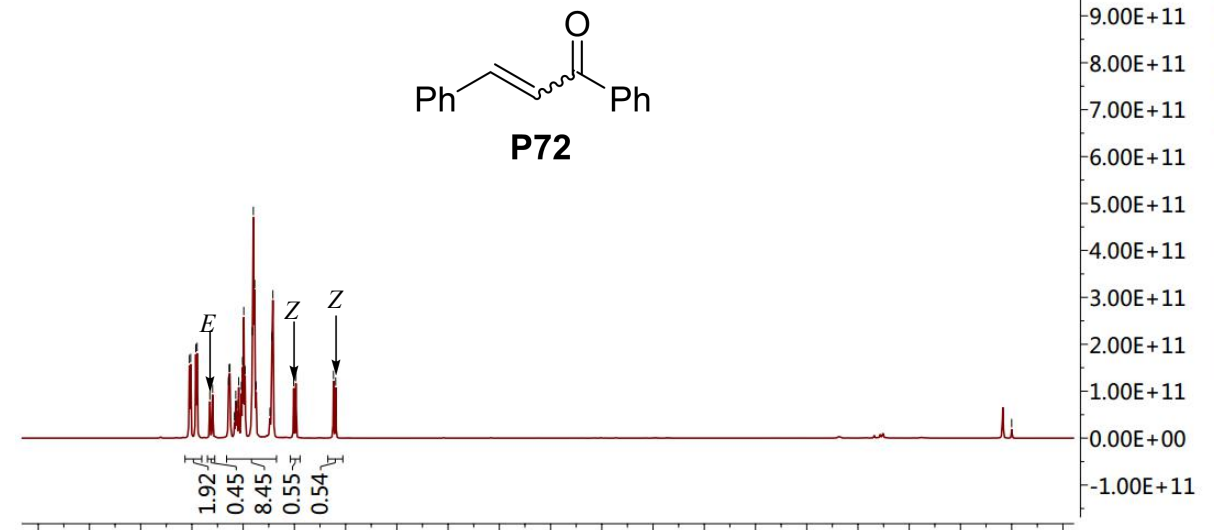

$\begin{array}{lllllllllllllllllllll}9.5 & 9.0 & 8.5 & 8.0 & 7.5 & 7.0 & 6.5 & 6.0 & 5.5 & 5.0 & 4.5 & 4.0 & 3.5 & 3.0 & 2.5 & 2.0 & 1.5 & 1.0 & 0.5 & 0.0 & -0.5\end{array}$

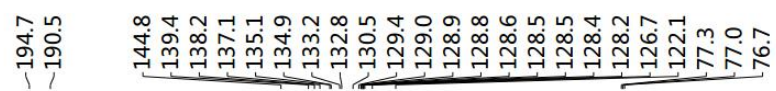<smiles>O=C(C=Cc1ccccc1)c1ccccc1</smiles>

P72

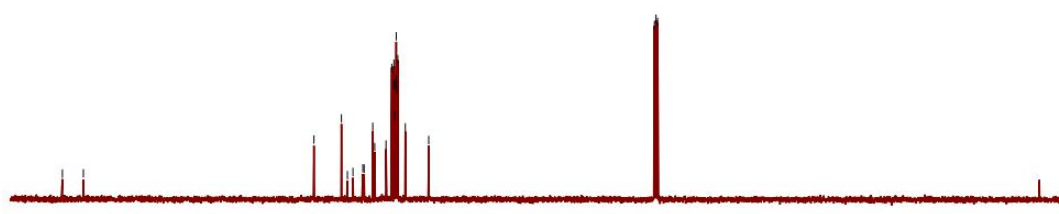

\begin{tabular}{|c|c|c|}
\hline & Parameter & Value \\
\hline$-3.6 \mathrm{E}+10$ & $\begin{array}{l}1 \text { Data File } \\
\text { Name }\end{array}$ & 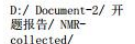 \\
\hline $4 \mathrm{E}+10$ & & 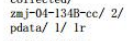 \\
\hline 3. $2 \mathrm{E}+10$ & 2 Title & $\begin{array}{l}\frac{2 \mathrm{j}-04-1348-}{2.2 .1 .1 r} \\
\text { cc. }\end{array}$ \\
\hline $3.0 \mathrm{E}+10$ & $\begin{array}{ll}4 & \text { Origin } \\
5 & \text { Omer }\end{array}$ & $\begin{array}{l}\text { Bruker Biospin GebH } \\
\text { nanrsu }\end{array}$ \\
\hline $2.8 \mathrm{E}+10$ & 6 Site & \\
\hline $2.6 \mathrm{E}+10$ & 7 Spectrometer & 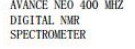 \\
\hline & 8 Author & \\
\hline $.4 \mathrm{E}+10$ & $\begin{array}{l}\text { 9.5olvent } \\
10 \text { Temperature }\end{array}$ & $\begin{array}{l}\text { CDC13 } \\
296.7\end{array}$ \\
\hline $2.2 \mathrm{E}+10$ & $\begin{array}{l}11 \text { Pulse } \\
\text { Sequence }\end{array}$ & zepp30 30 \\
\hline $2.0 \mathrm{E}+10$ & $\begin{array}{l}\text { l2 Experiment } \\
13 \text { Probe }\end{array}$ & 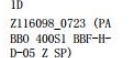 \\
\hline $1.8 \mathrm{E}+10$ & $\begin{array}{l}14 \text { Nubber of } \\
\text { Scans of }\end{array}$ & 102 \\
\hline $1.6 \mathrm{E}+10$ & $\begin{array}{l}15 \text { Receiver Gain } \\
16 \text { Relaxat ion } \\
\text { Delay }\end{array}$ & $\begin{array}{l}n=66 \\
2.0000\end{array}$ \\
\hline$-1.4 \mathrm{E}+10$ & $\begin{array}{l}17 \text { Pulse Width } \\
18 \text { Presaturat ion }\end{array}$ & 9.7000 \\
\hline $1.2 \mathrm{E}+10$ & \begin{tabular}{|l} 
Frequency \\
19 Acquisition \\
Time
\end{tabular} & 1.3763 \\
\hline$-1.0 \mathrm{E}+10$ & $\begin{array}{l}20 \text { Acquisition } \\
\text { Date }\end{array}$ & $2021-05-12720: 27: 12$ \\
\hline $8.0 \mathrm{E}+09$ & $\begin{array}{l}21 \text { lodification } \\
\text { Date } \\
22 \text { Class }\end{array}$ & 2021-05-12т20:31:59 \\
\hline $6.0 \mathrm{E}+09$ & $\begin{array}{l}23 \text { Spect rometer } \\
\text { Frequency }\end{array}$ & 100.61 \\
\hline$-4.0 \mathrm{E}+09$ & $\begin{array}{c}24 \text { Spectral } \\
\text { width }\end{array}$ & 23809.5 \\
\hline$-2.0 \mathrm{E}+09$ & $\begin{array}{l}25 \text { L Lowest } \\
\text { Frequency } \\
26 \text { Nucleus }\end{array}$ & -1843.5 \\
\hline $0.0 \mathrm{E}+00$ & $\begin{array}{l}27 \text { Acquired Size } \\
28 \text { Spectral Size }\end{array}$ & $\begin{array}{l}32768 \\
32768\end{array}$ \\
\hline $2.0 \mathrm{E}+09$ & & \\
\hline $.0 E+09$ & & \\
\hline
\end{tabular}

$\begin{array}{llllllllllllllllllllll}200 & 190 & 180 & 170 & 160 & 150 & 140 & 130 & 120 & 110 & 100 & 90 & 80 & 70 & 60 & 50 & 40 & 30 & 20 & 10 & 0\end{array}$ 


\section{H-chromen-4-one (P74)}

ఇ o<smiles>O=c1ccoc2ccccc12</smiles>

P74

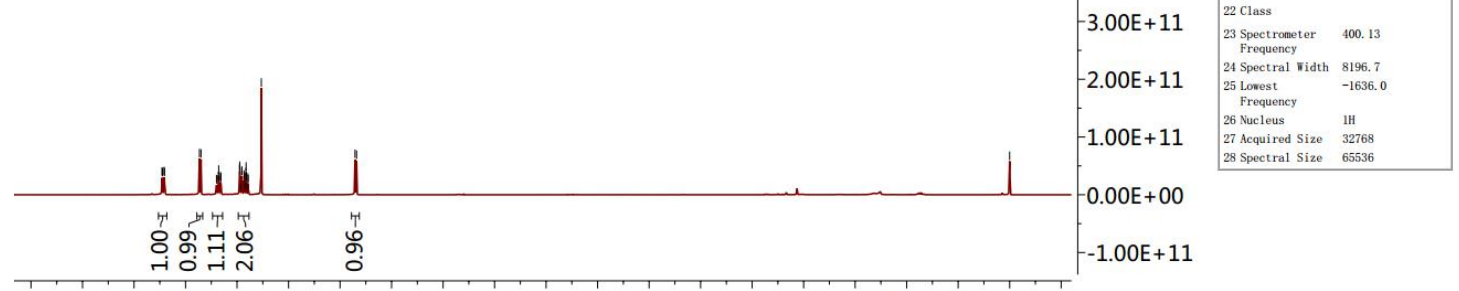

$\begin{array}{lllllllllllllllllllll}9.5 & 9.0 & 8.5 & 8.0 & 7.5 & 7.0 & 6.5 & 6.0 & 5.5 & 5.0 & 4.5 & 4.0 & 3.5 & 3.0 & 2.5 & 2.0 & 1.5 & 1.0 & 0.5 & 0.0 & -0.5\end{array}$

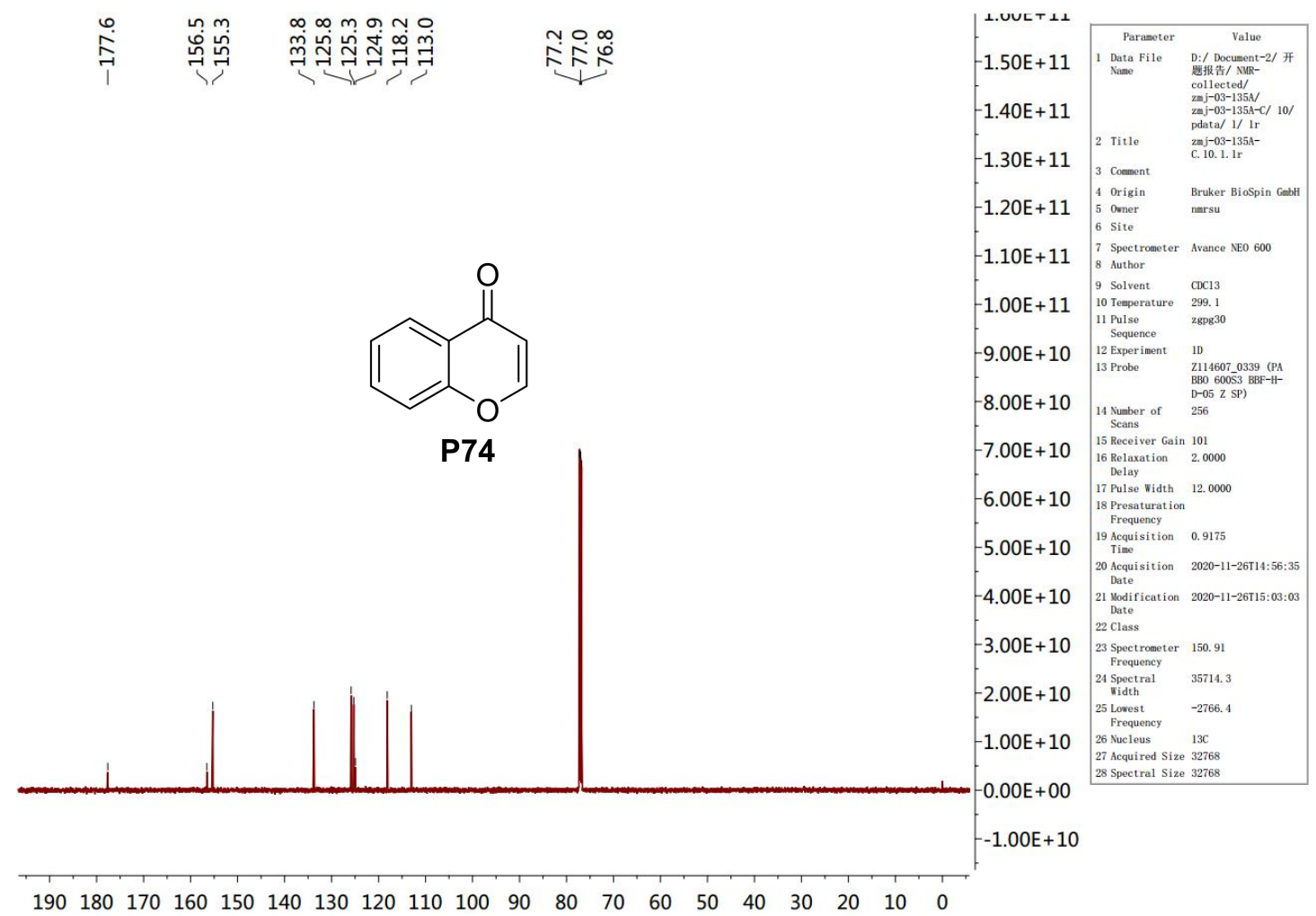




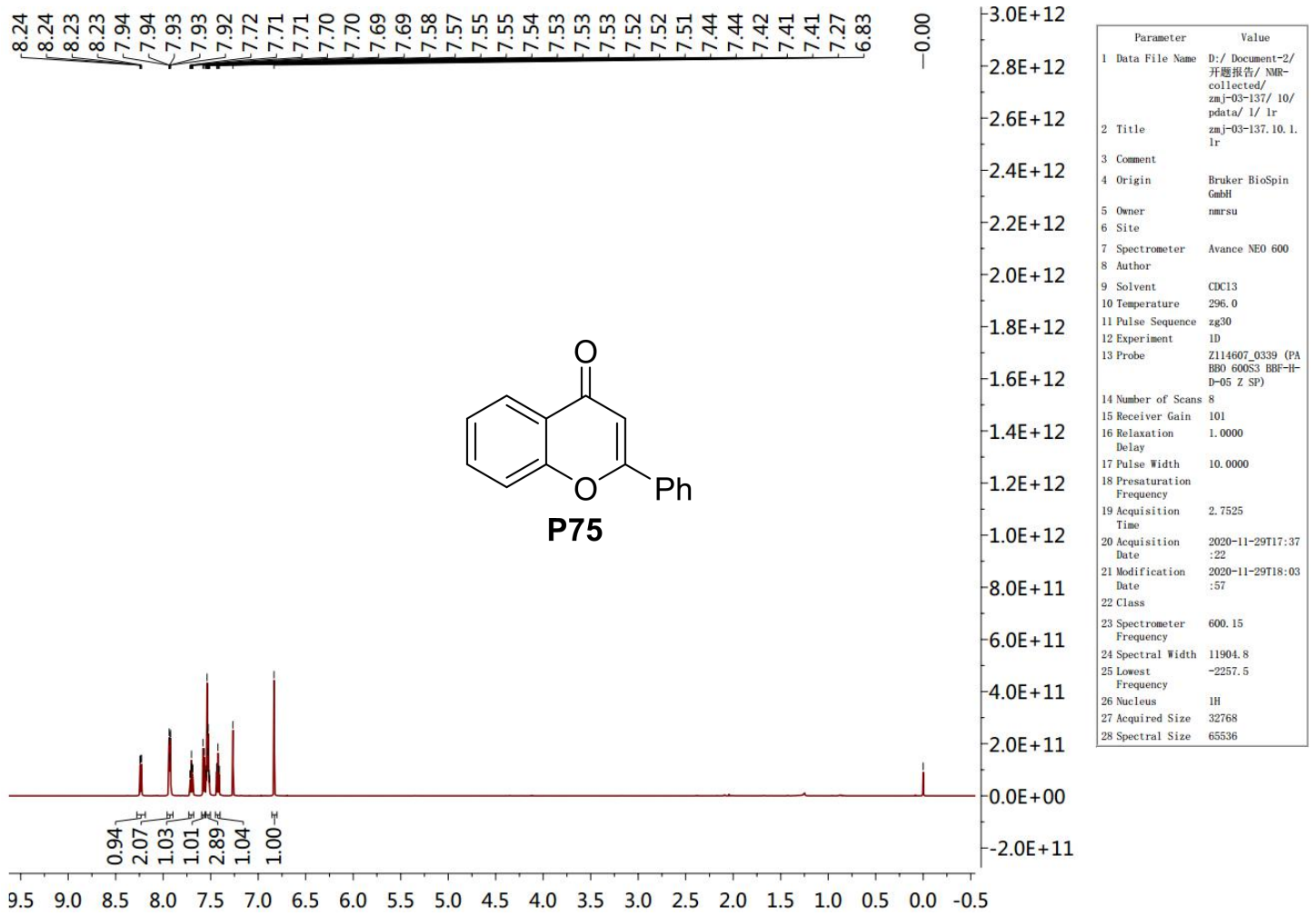

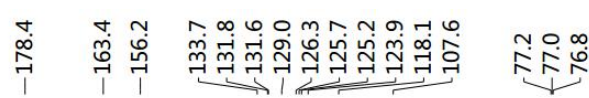<smiles>O=c1cc(-c2ccccc2)oc2ccccc12</smiles>

P75
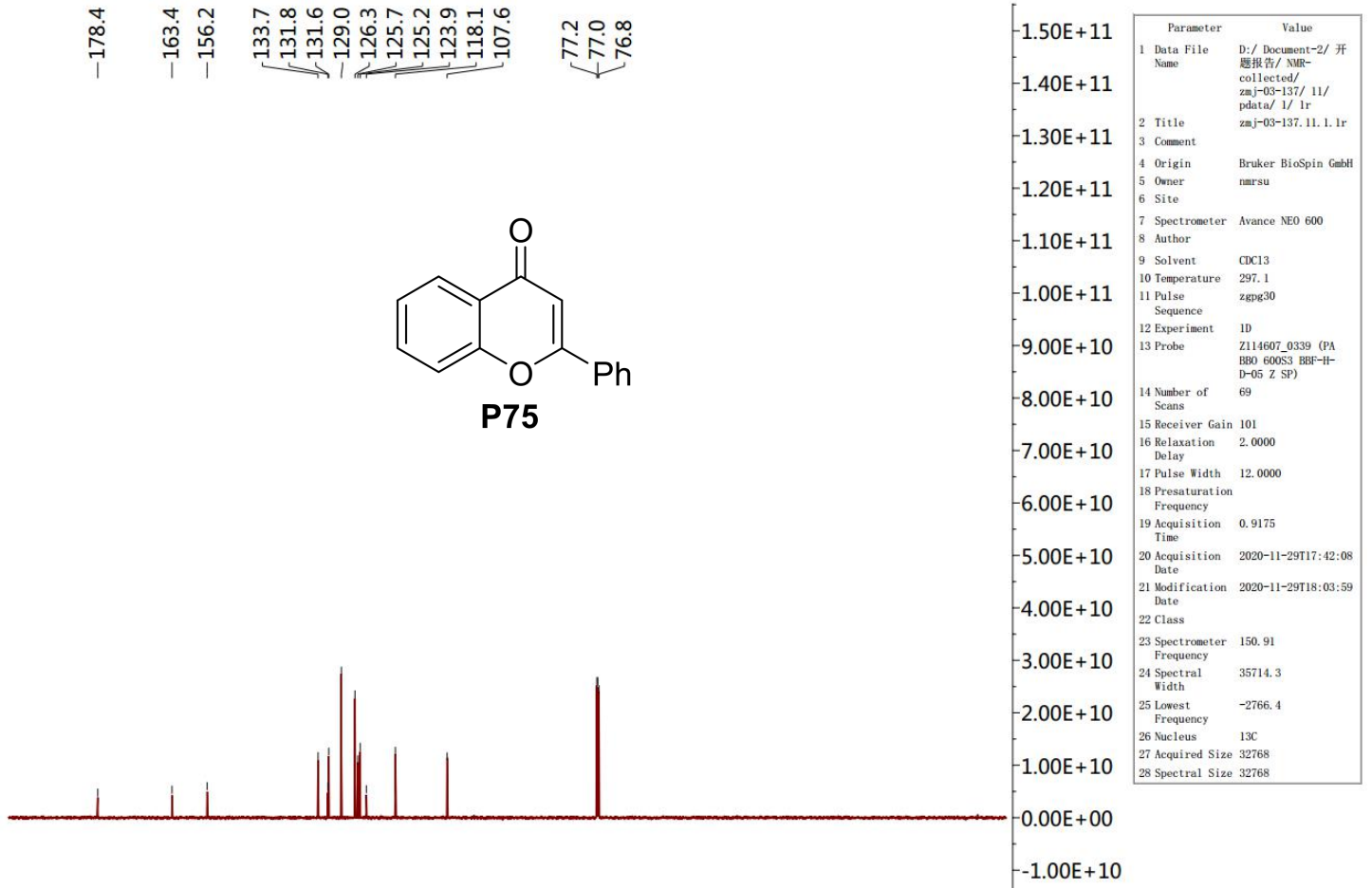

$\begin{array}{llllllllllllllllllll}190 & 180 & 170 & 160 & 150 & 140 & 130 & 120 & 110 & 100 & 90 & 80 & 70 & 60 & 50 & 40 & 30 & 20 & 10 & 0\end{array}$ 
2H-chromen-2-one (P76)

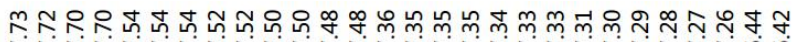

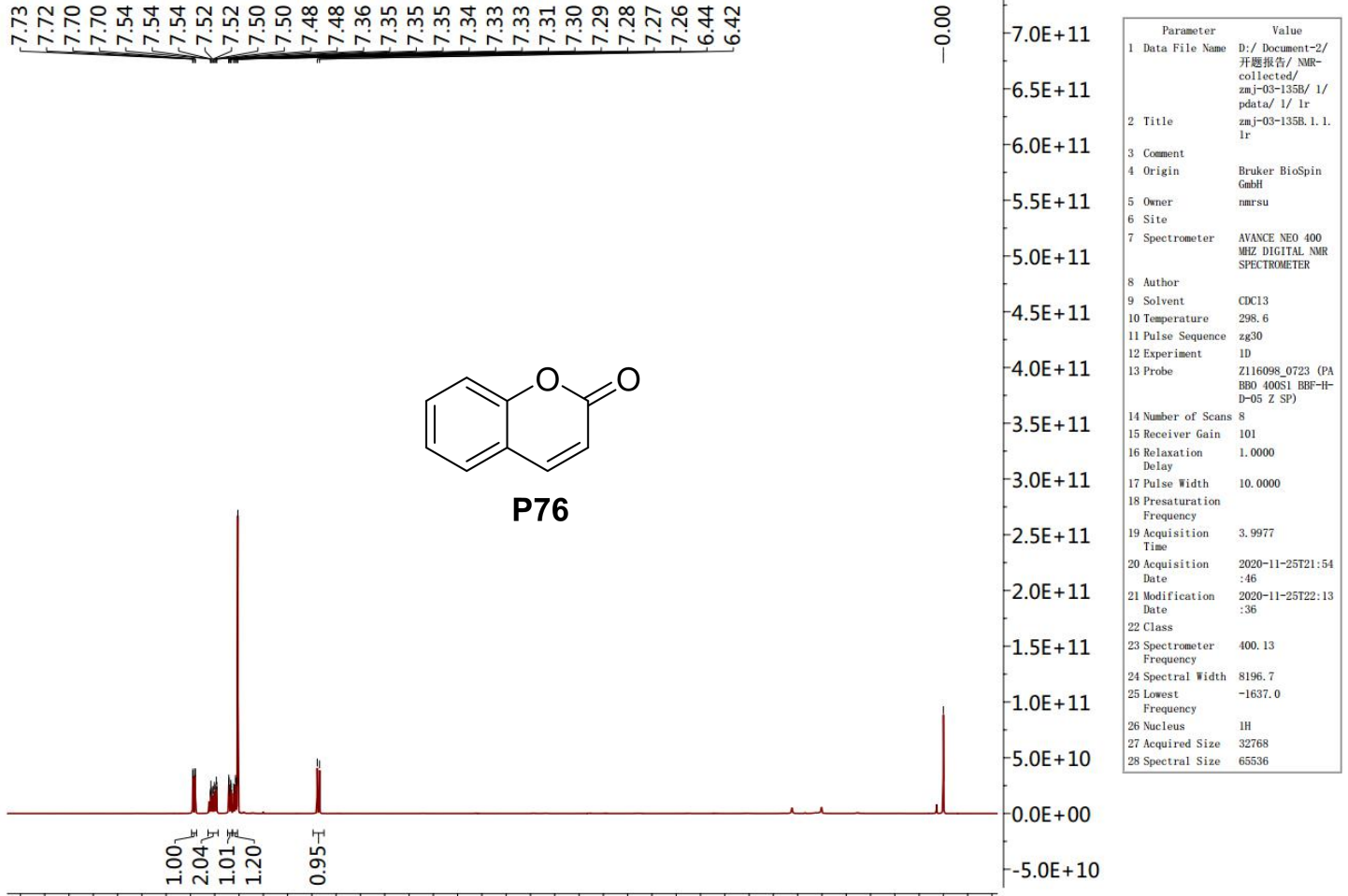

$\begin{array}{lllllllllllllllllllll}9.5 & 9.0 & 8.5 & 8.0 & 7.5 & 7.0 & 6.5 & 6.0 & 5.5 & 5.0 & 4.5 & 4.0 & 3.5 & 3.0 & 2.5 & 2.0 & 1.5 & 1.0 & 0.5 & 0.0 & -0.5\end{array}$

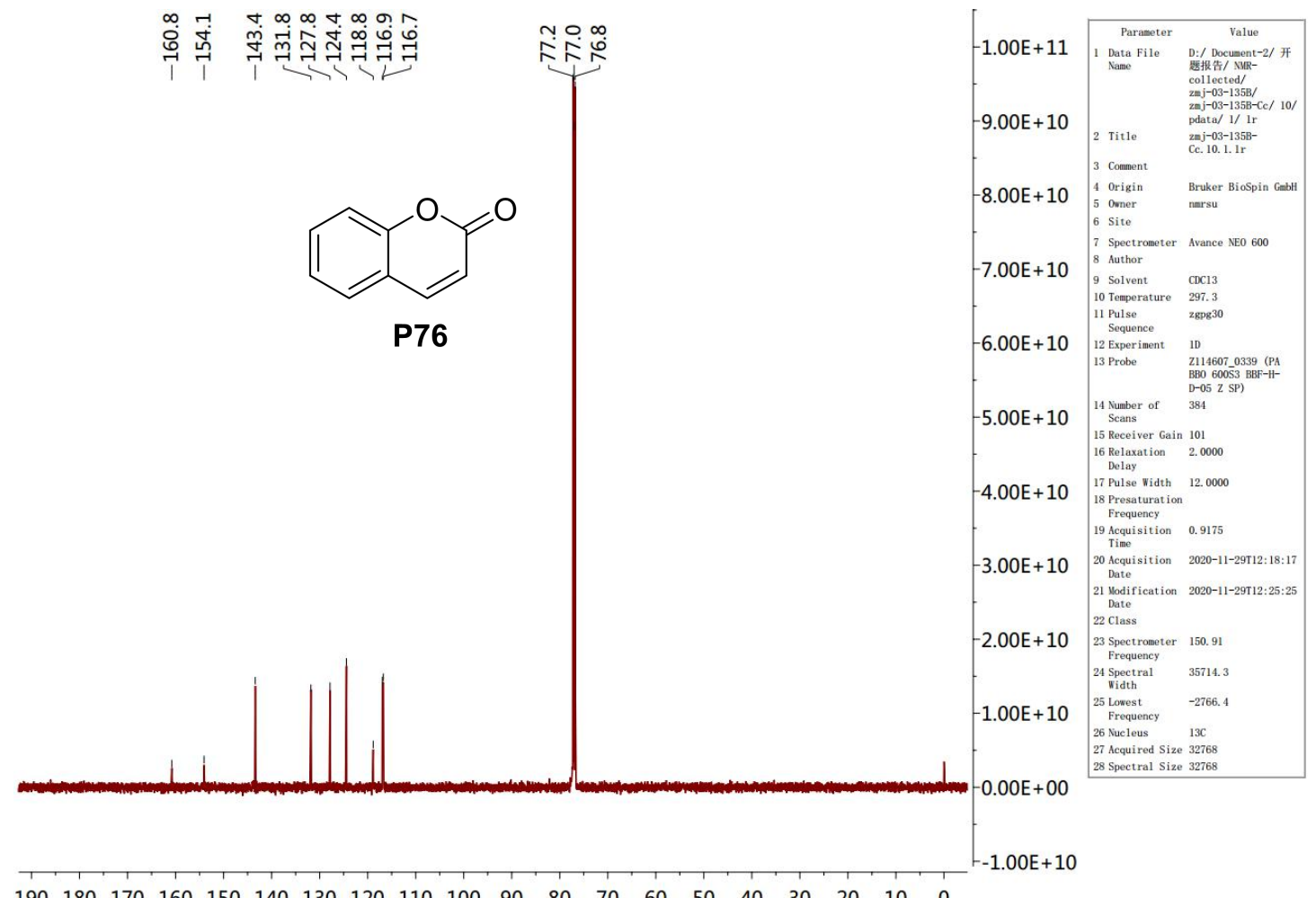

$\begin{array}{llllllllllllllllllll}190 & 180 & 170 & 160 & 150 & 140 & 130 & 120 & 110 & 100 & 90 & 80 & 70 & 60 & 50 & 40 & 30 & 20 & 10\end{array}$ 


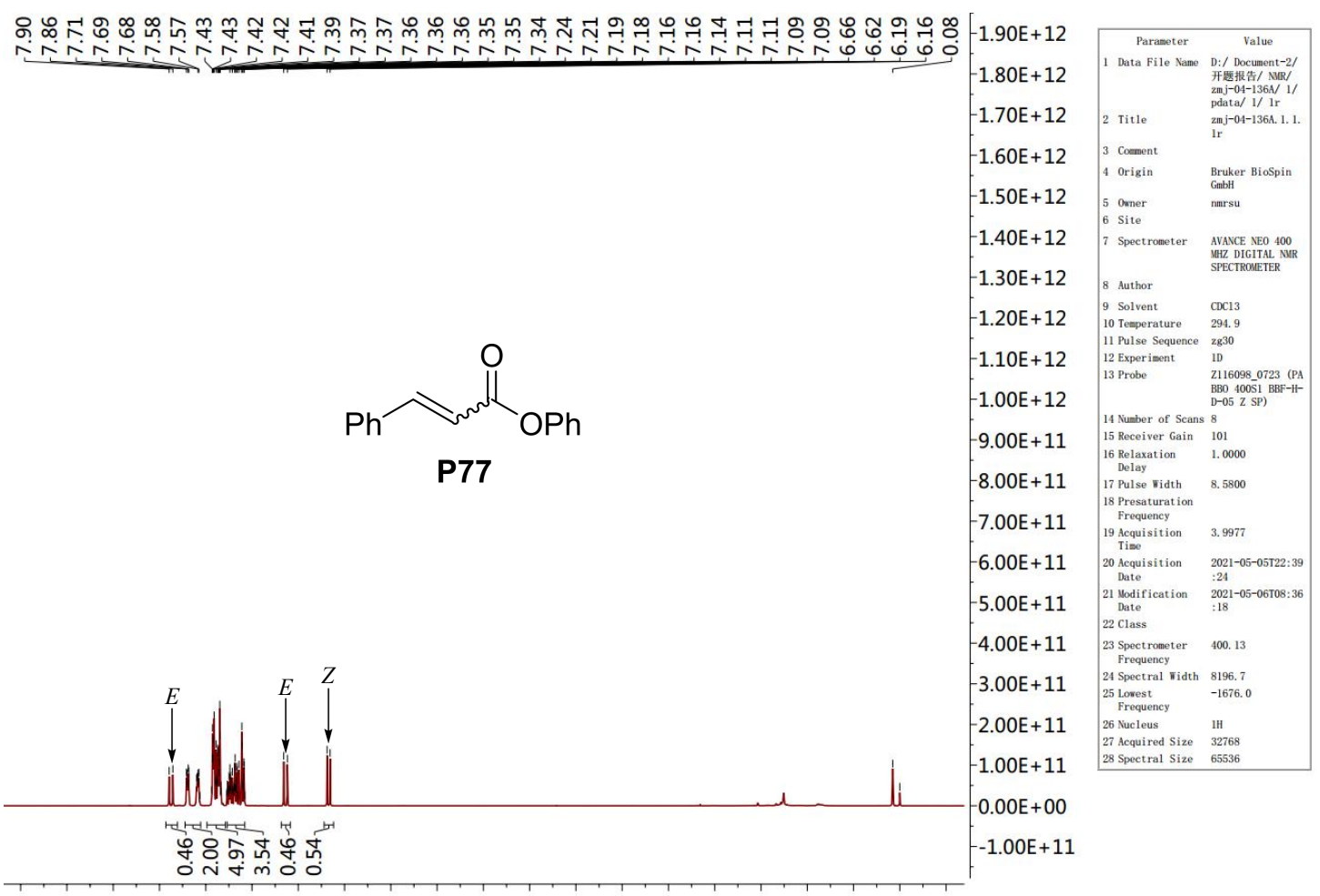

$\begin{array}{lllllllllllllllllllll}9.5 & 9.0 & 8.5 & 8.0 & 7.5 & 7.0 & 6.5 & 6.0 & 5.5 & 5.0 & 4.5 & 4.0 & 3.5 & 3.0 & 2.5 & 2.0 & 1.5 & 1.0 & 0.5 & 0.0 & -0.5\end{array}$

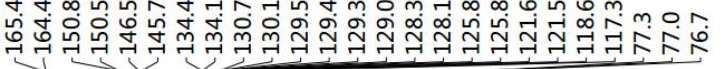<smiles>O=C(/C=C/c1ccccc1)Oc1ccccc1</smiles>

P77

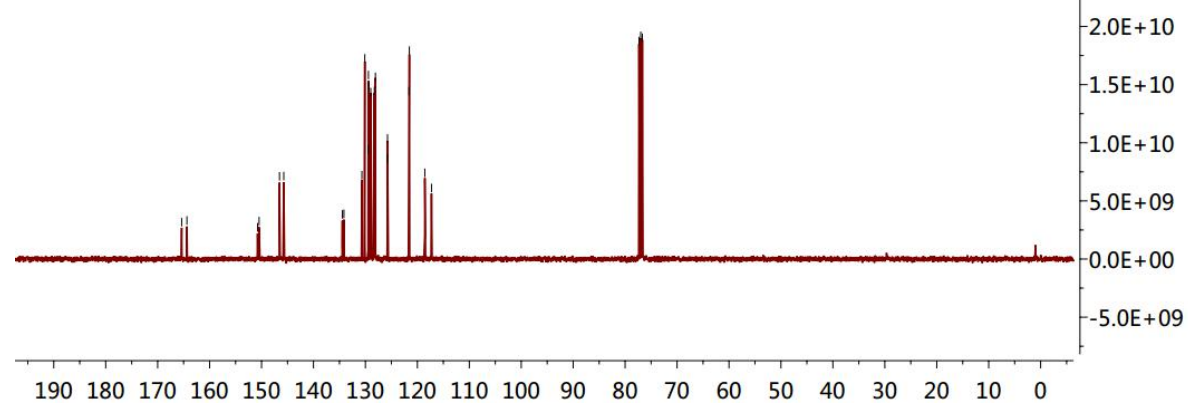

\begin{tabular}{|c|c|}
\hline Parameter & Value \\
\hline $\begin{array}{l}\text { Data File } \\
\text { Name }\end{array}$ & 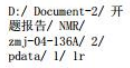 \\
\hline $\begin{array}{l}2 \text { Title } \\
3 \text { Comment }\end{array}$ & $z \mathrm{mj}-04-136 \mathrm{~A} .2 .1 .1 \mathrm{rr}$ \\
\hline $\begin{array}{l}4 \text { Origin } \\
5 \text { Omer }\end{array}$ & 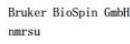 \\
\hline 6 Site & \\
\hline 7 Spectrometer & $\begin{array}{l}\text { NDANCE NEO } 400 \text { UHZ } \\
\text { DIIITIL NRR } \\
\text { SPECTRONETRR }\end{array}$ \\
\hline 8 Author & \\
\hline 9 Solvent & $\mathrm{CDCl}_{3}$ \\
\hline 10 Temperature & 295.4 \\
\hline $\begin{array}{l}11 \text { Pulse } \\
\text { Sequence }\end{array}$ & 2gpg 30 \\
\hline 12 Exper iment & ID \\
\hline 13 Probe & 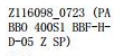 \\
\hline $\begin{array}{l}14 \text { Number of } \\
\text { Scans }\end{array}$ & 256 \\
\hline 15 Receiver Gain & , 62 \\
\hline $\begin{array}{l}16 \text { Relaxation } \\
\text { Delay }\end{array}$ & 2.0000 \\
\hline $\begin{array}{l}17 \text { Pulse Width } \\
18 \text { Presaturation }\end{array}$ & 9.7000 \\
\hline $\begin{array}{l}\text { Frequency } \\
19 \text { Acquisition } \\
\text { Time }\end{array}$ & 1. 3763 \\
\hline $\begin{array}{l}20 \text { Acquisition } \\
\text { Date }\end{array}$ & $2021-05-05522: 55: 31$ \\
\hline $\begin{array}{l}21 \text { Modification } \\
\text { Date } \\
22 \text { Class }\end{array}$ & 2021-05-06708: 36:19 \\
\hline $\begin{array}{l}23 \text { Spectrometer } \\
\text { Frequency }\end{array}$ & 100.61 \\
\hline $\begin{array}{l}24 \text { Spectral } \\
\text { Width }\end{array}$ & 23809.5 \\
\hline $\begin{array}{l}25 \text { Lowest } \\
\text { Freugency }\end{array}$ & -1843.5 \\
\hline 26 Nucleuse & ${ }_{13 \mathrm{C}}$ \\
\hline 27 Acquired Size & 32768 \\
\hline 28 Speetral Size & \\
\hline
\end{tabular}




\section{Phenyl benzoate (P79)}

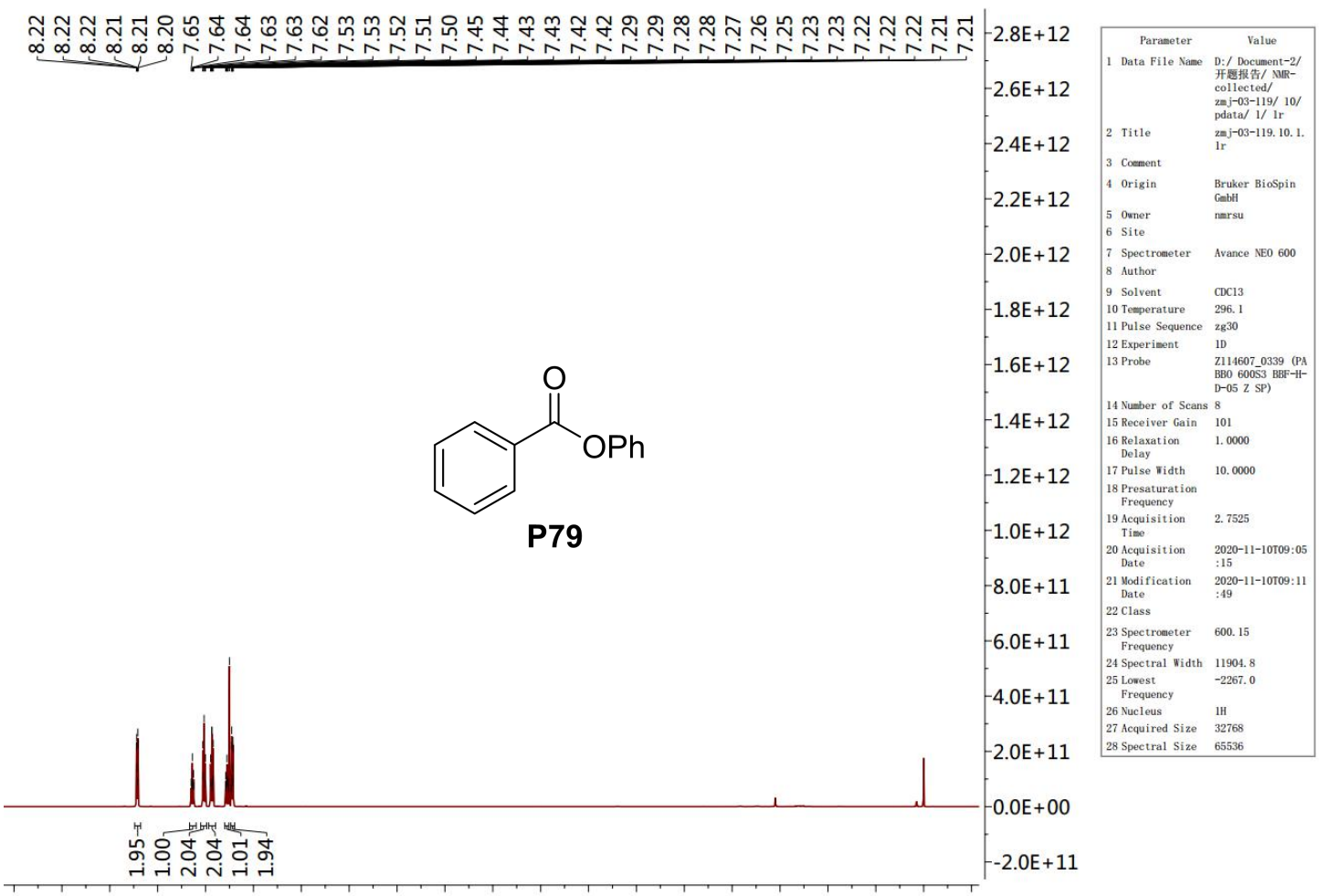

$\begin{array}{lllllllllllllllllllll}3.5 & 9.0 & 8.5 & 8.0 & 7.5 & 7.0 & 6.5 & 6.0 & 5.5 & 5.0 & 4.5 & 4.0 & 3.5 & 3.0 & 2.5 & 2.0 & 1.5 & 1.0 & 0.5 & 0.0 & -0.5\end{array}$

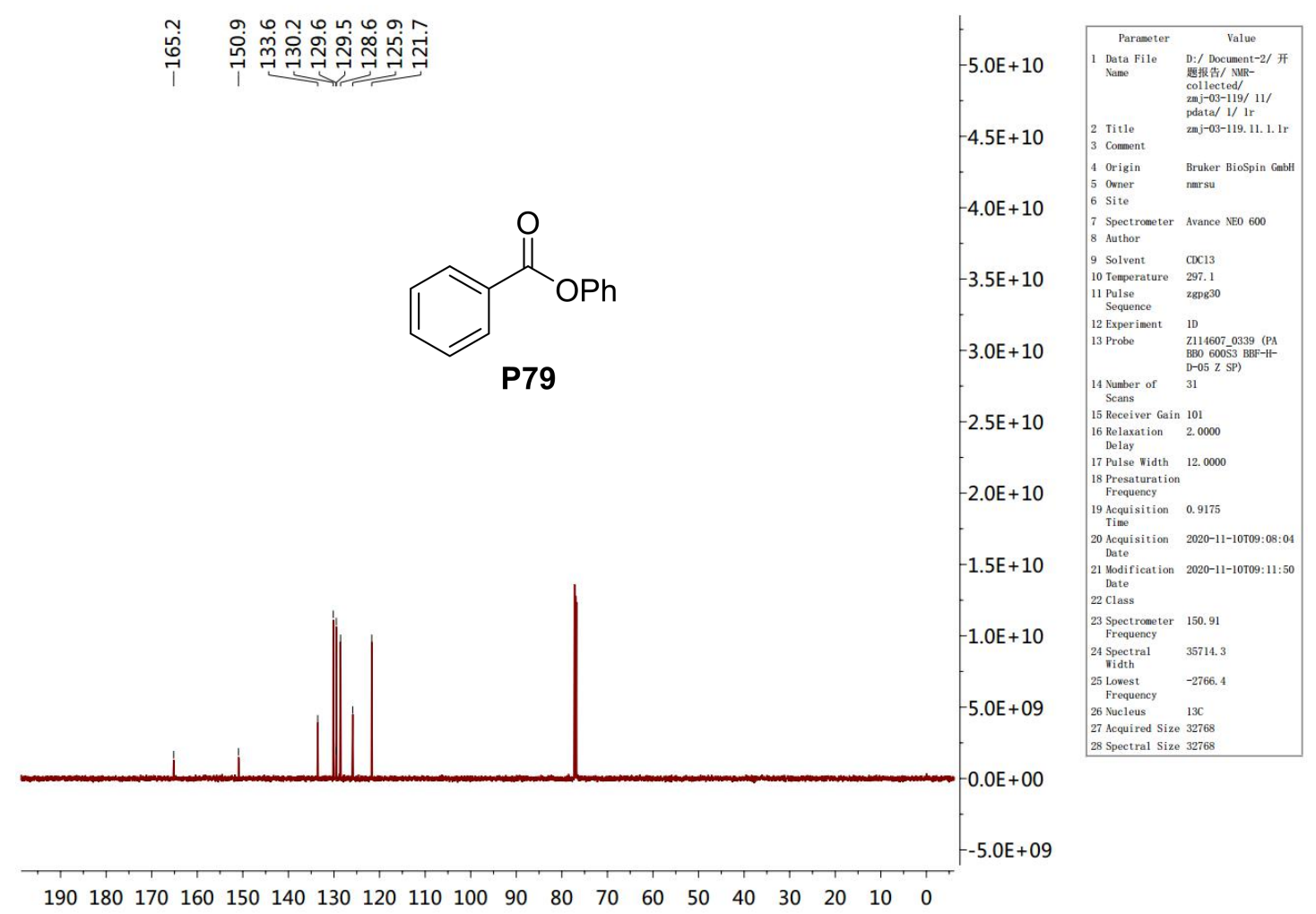




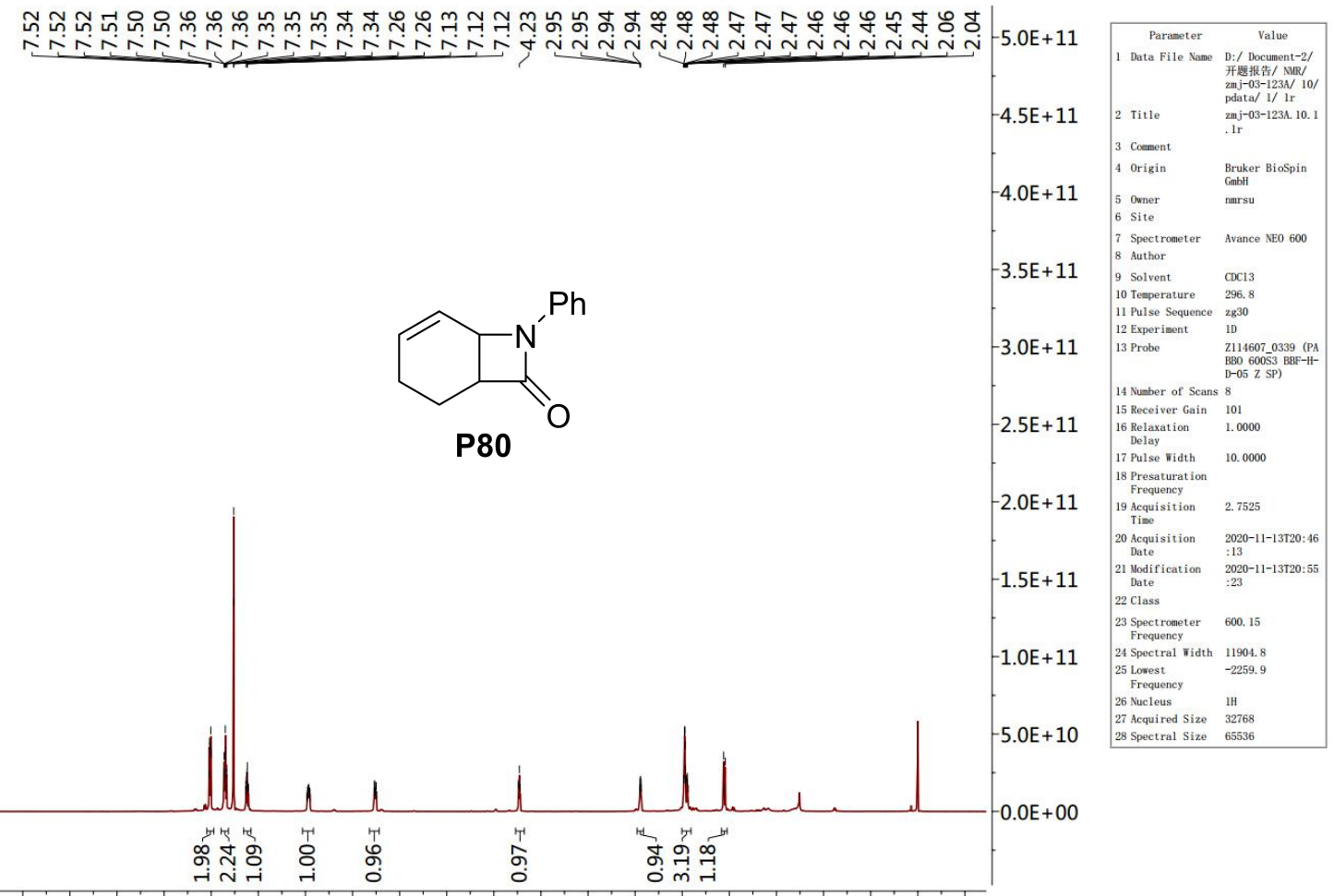

$\begin{array}{lllllllllllllllllllll}9.5 & 9.0 & 8.5 & 8.0 & 7.5 & 7.0 & 6.5 & 6.0 & 5.5 & 5.0 & 4.5 & 4.0 & 3.5 & 3.0 & 2.5 & 2.0 & 1.5 & 1.0 & 0.5 & 0.0 & -0.5\end{array}$

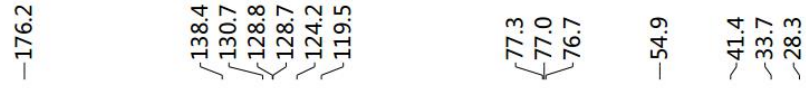

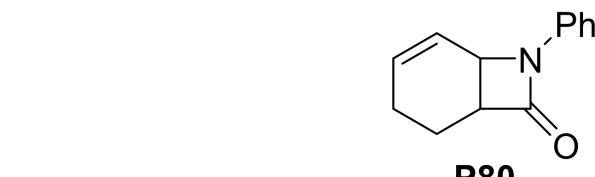<smiles>c1ccccc1</smiles>

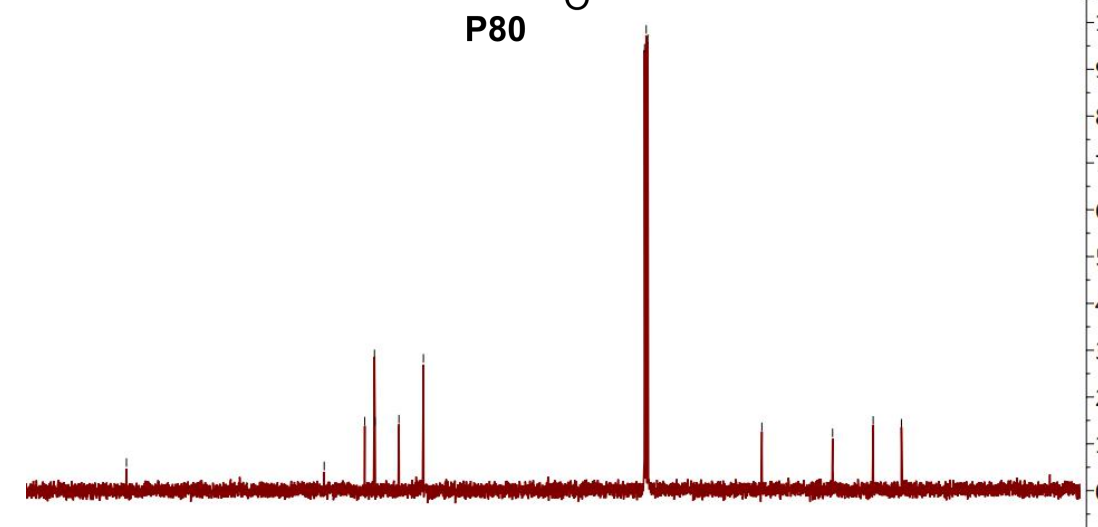

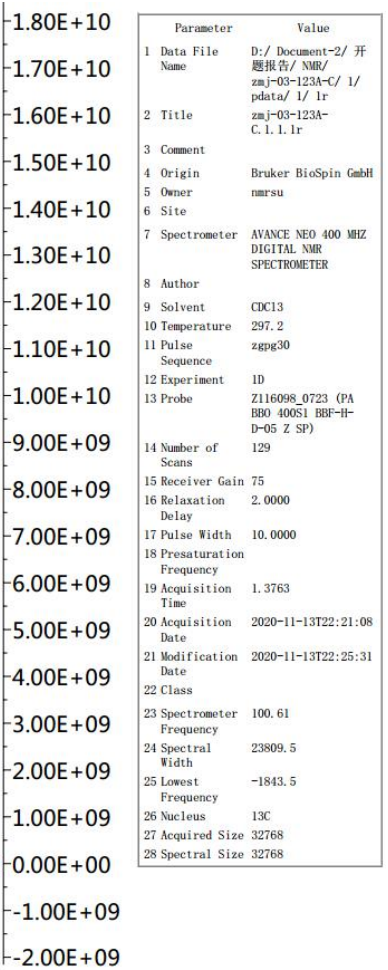

$\begin{array}{llllllllllllllllllll}190 & 180 & 170 & 160 & 150 & 140 & 130 & 120 & 110 & 100 & 90 & 80 & 70 & 60 & 50 & 40 & 30 & 20 & 10 & 0\end{array}$ 
Quinolin-2(1H)-one (81)
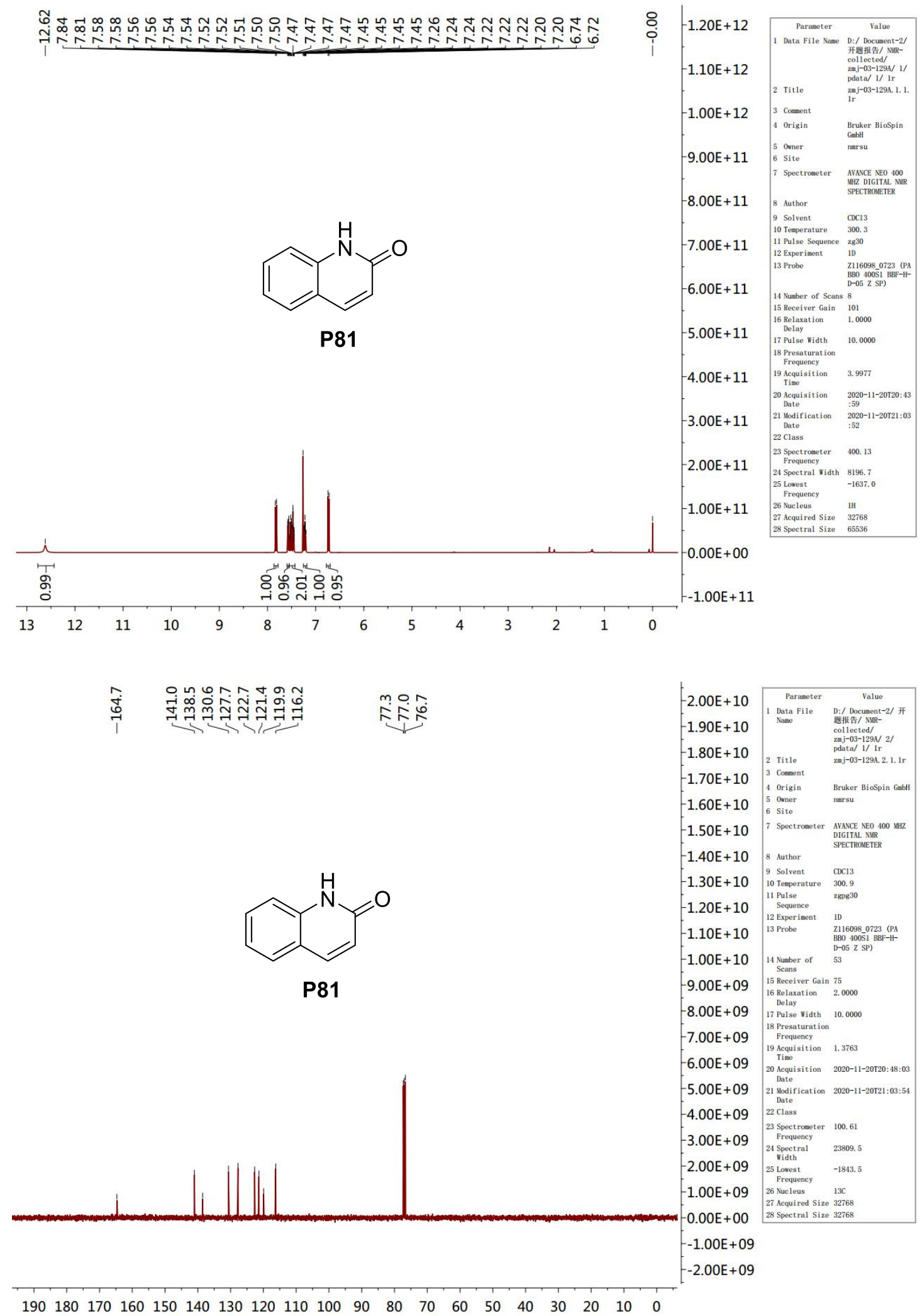


\section{$(E)-N, N$-diphenylcinnamamide ( $E$-P82)}

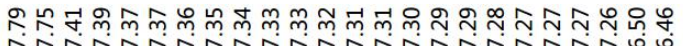

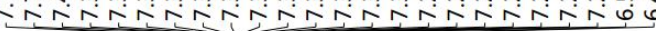
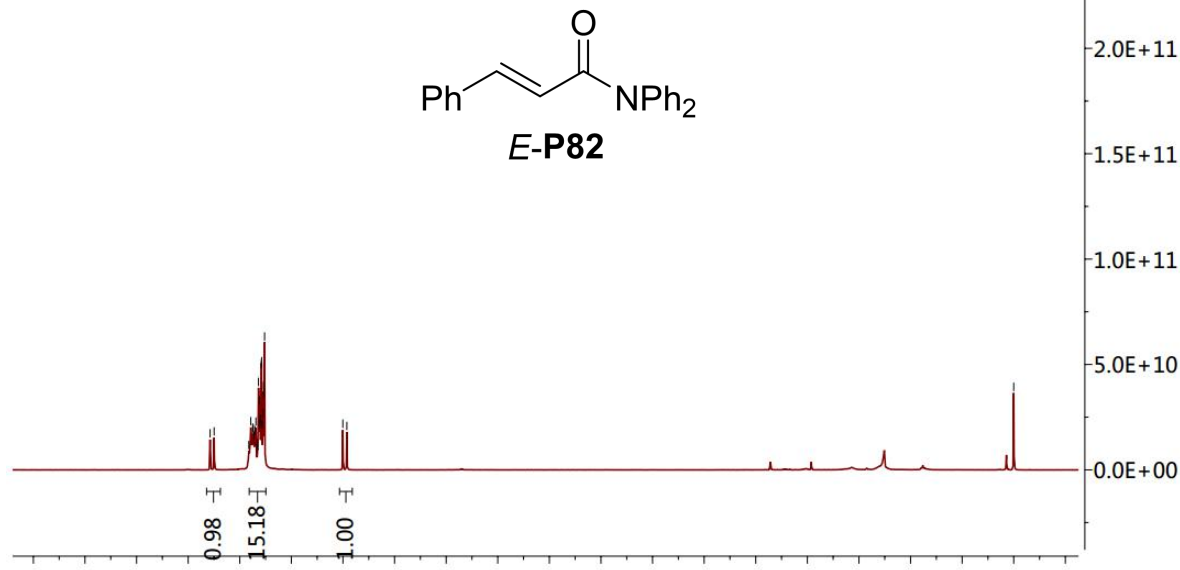

$\begin{array}{lllllllllllllllllllll}9.5 & 9.0 & 8.5 & 8.0 & 7.5 & 7.0 & 6.5 & 6.0 & 5.5 & 5.0 & 4.5 & 4.0 & 3.5 & 3.0 & 2.5 & 2.0 & 1.5 & 1.0 & 0.5 & 0.0 & -0.5\end{array}$

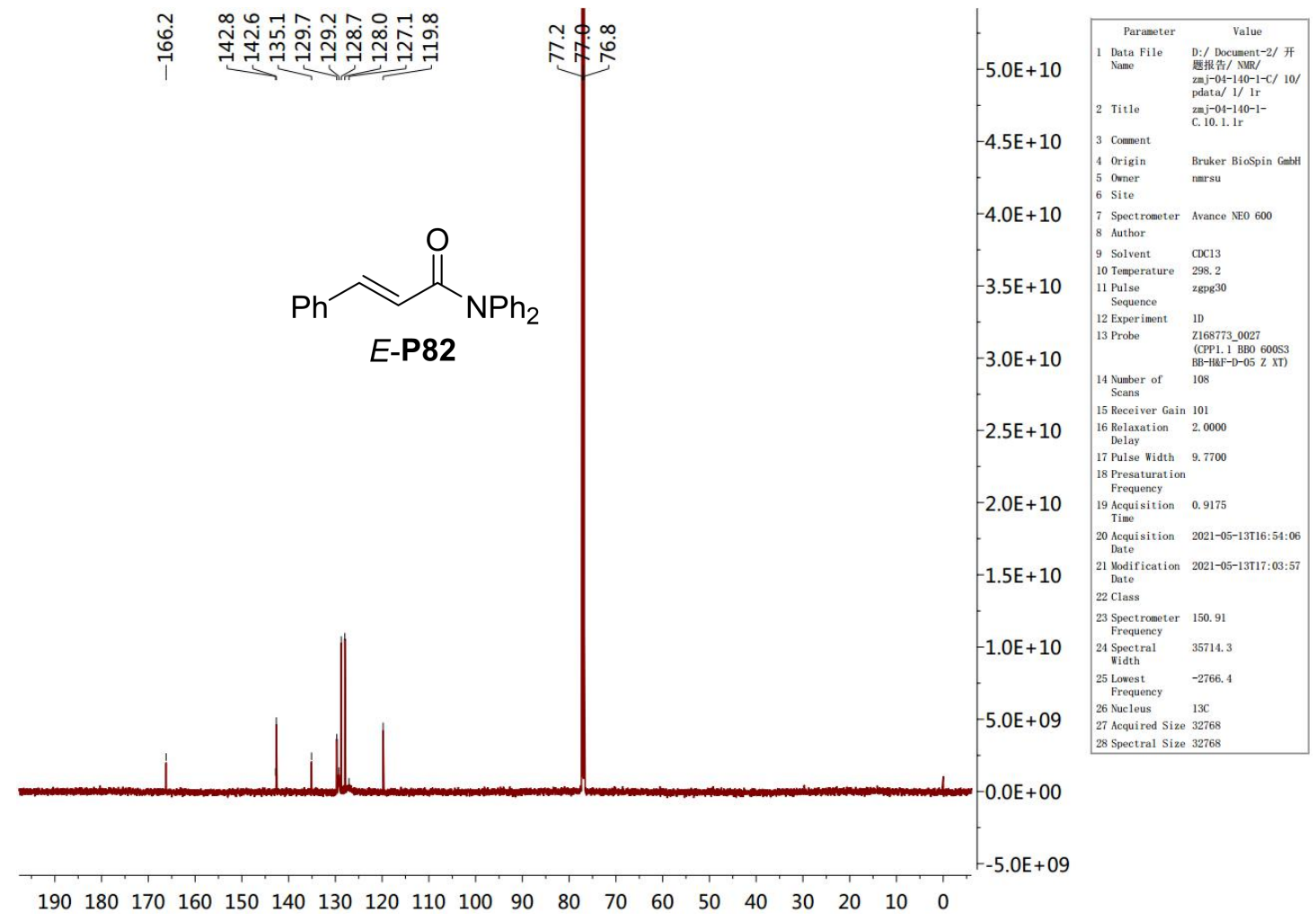


(Z)- $N, N$-diphenylcinnamamide (Z-P82)
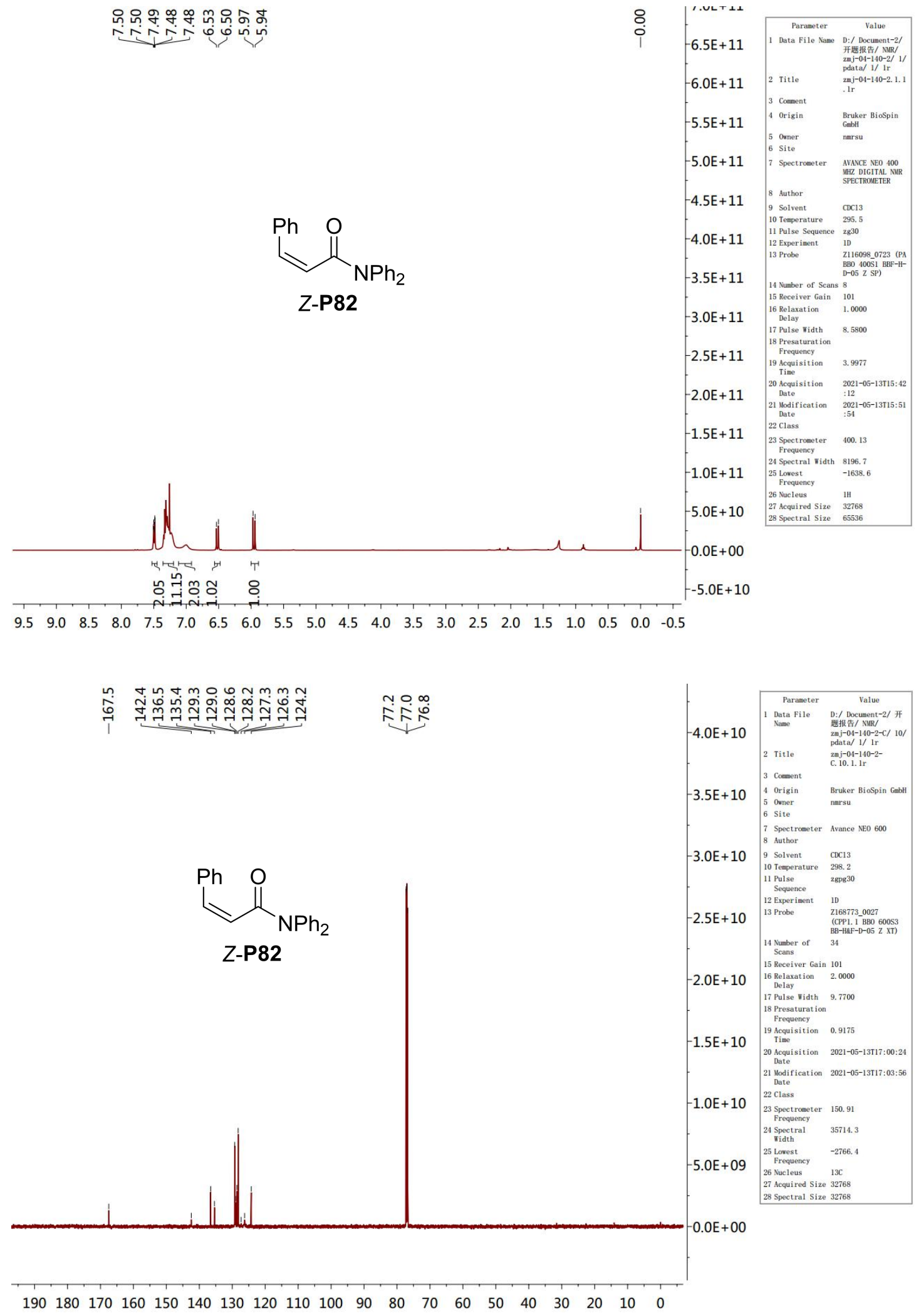


\section{4-Vinylphenyl 3-phenylpropanoate (P83)}

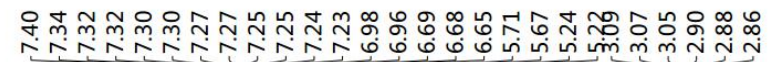

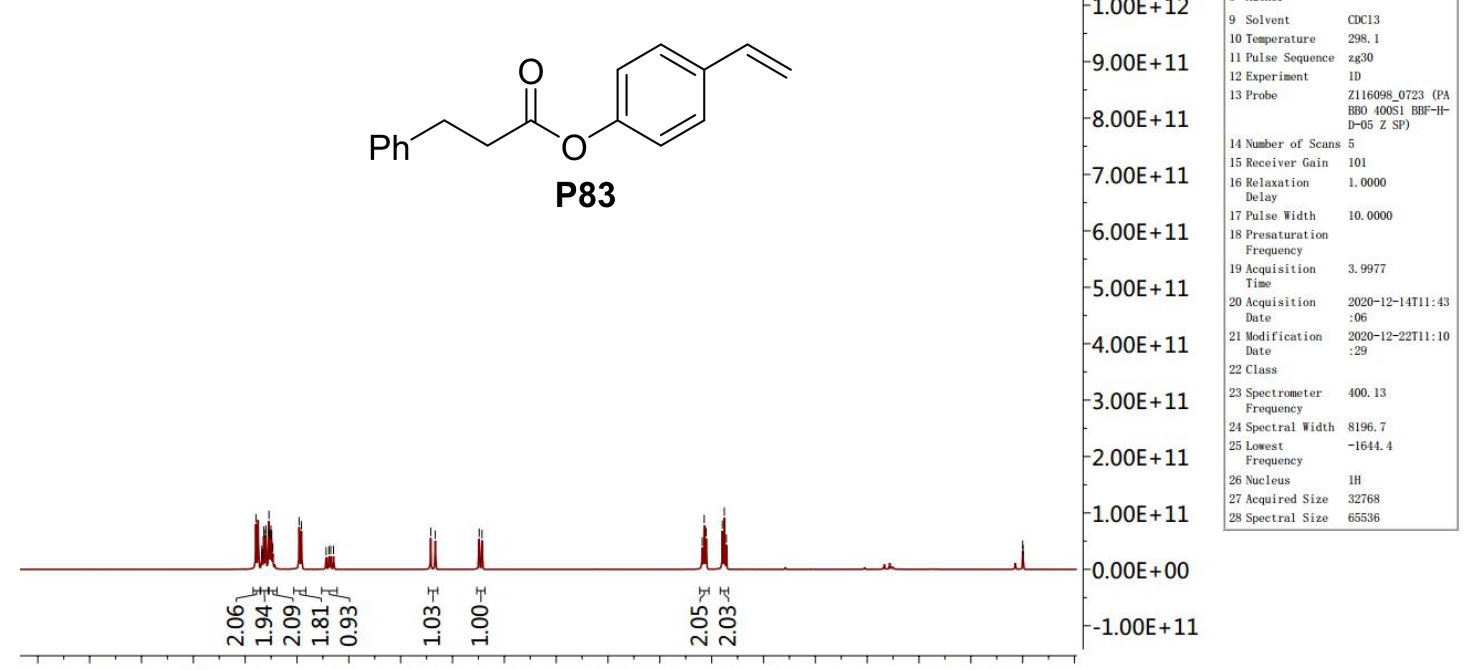

P83

$\begin{array}{lllllllllllllllllllll}9.5 & 9.0 & 8.5 & 8.0 & 7.5 & 7.0 & 6.5 & 6.0 & 5.5 & 5.0 & 4.5 & 4.0 & 3.5 & 3.0 & 2.5 & 2.0 & 1.5 & 1.0 & 0.5 & 0.0 & -0.5\end{array}$

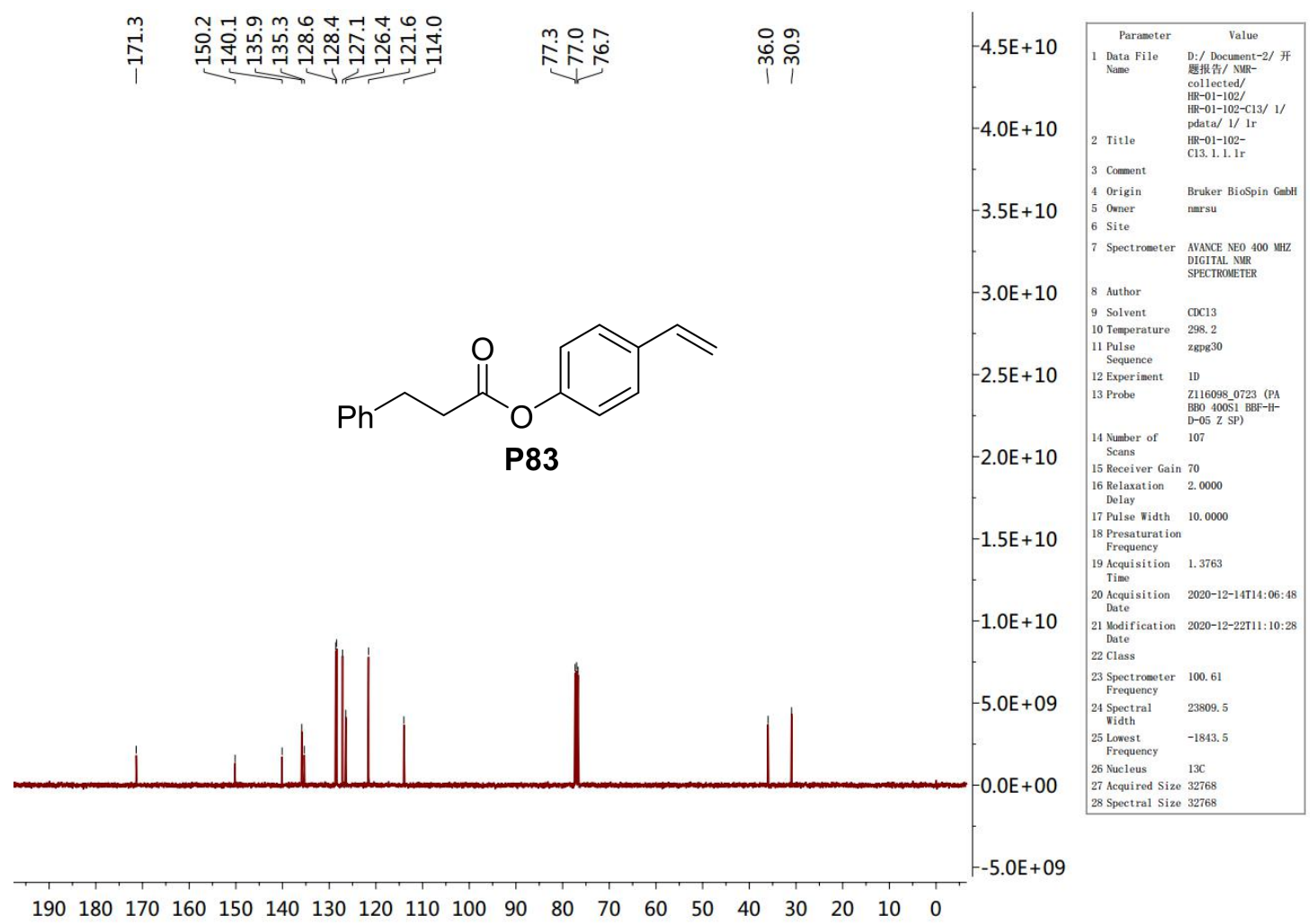


1-Vinyl-1,3,4,5-tetrahydro-2H-benzo[b]azepin-2-one (P85)

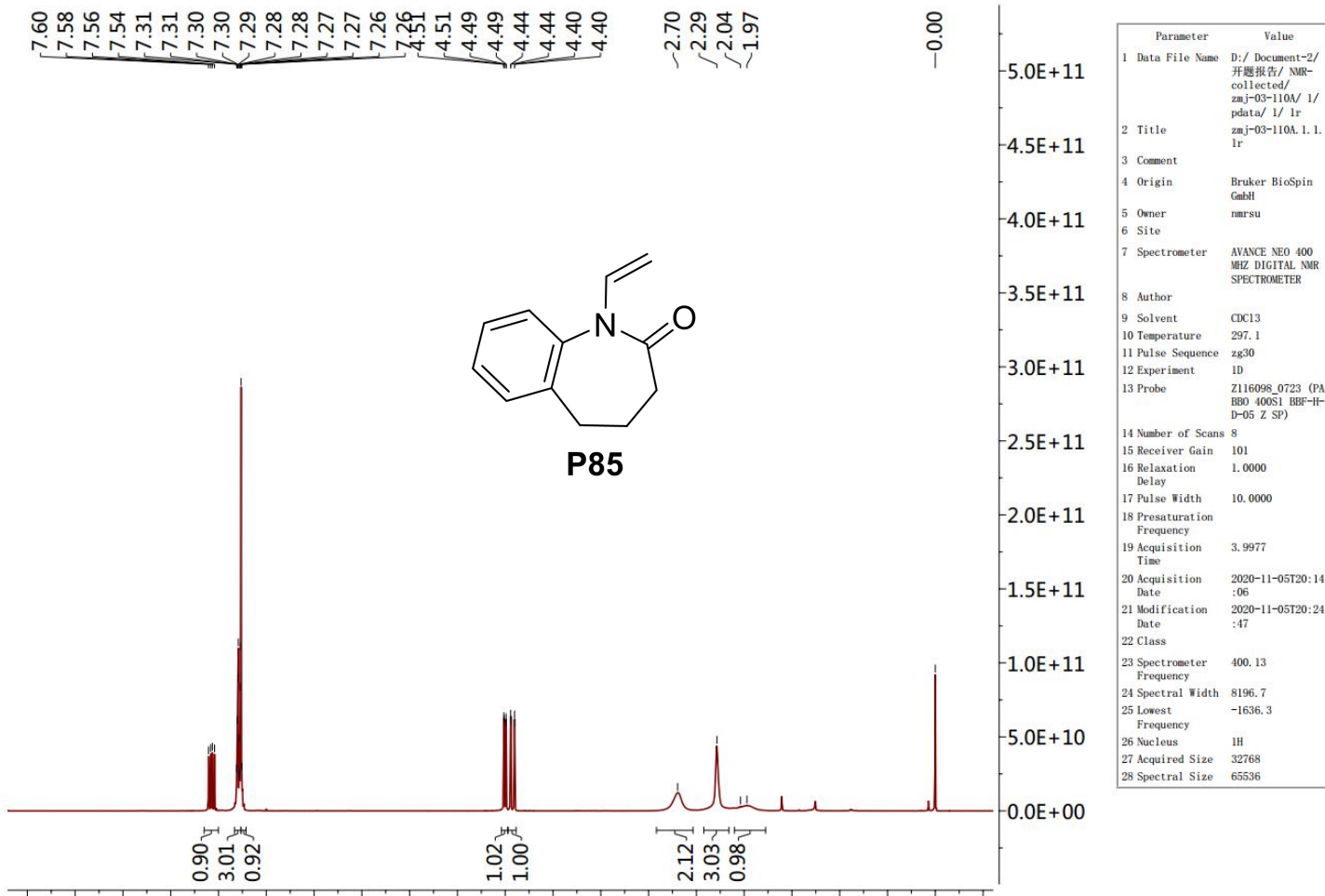

$\begin{array}{lllllllllllllllllllll}9.5 & 9.0 & 8.5 & 8.0 & 7.5 & 7.0 & 6.5 & 6.0 & 5.5 & 5.0 & 4.5 & 4.0 & 3.5 & 3.0 & 2.5 & 2.0 & 1.5 & 1.0 & 0.5 & 0.0 & -0.5\end{array}$
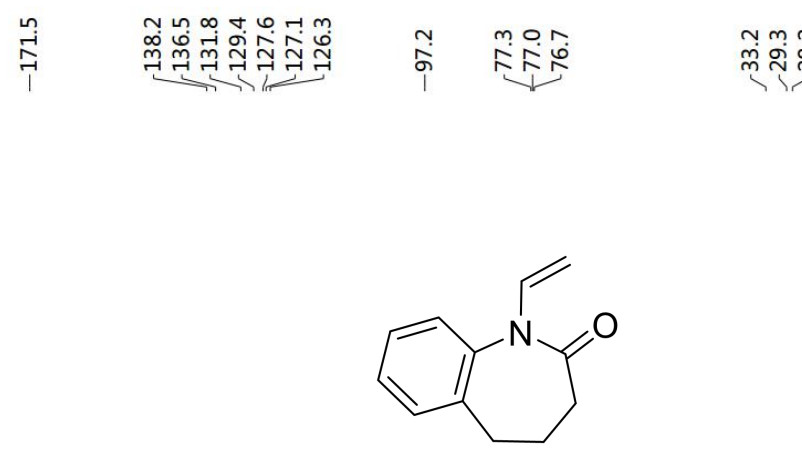

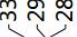

P85

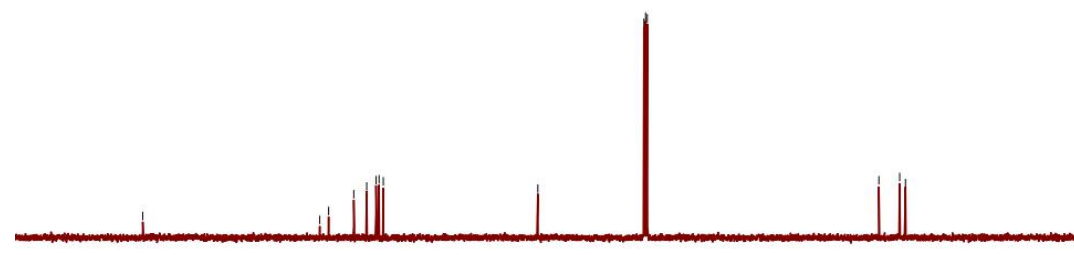

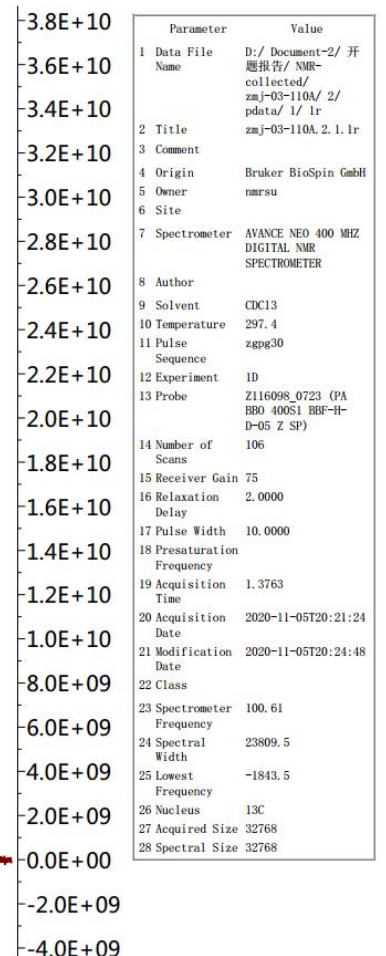

$\begin{array}{llllllllllllllllllll}190 & 180 & 170 & 160 & 150 & 140 & 130 & 120 & 110 & 100 & 90 & 80 & 70 & 60 & 50 & 40 & 30 & 20 & 10 & 0\end{array}$ 


\section{1-Ethylquinolin-2(1H)-one (P86)}

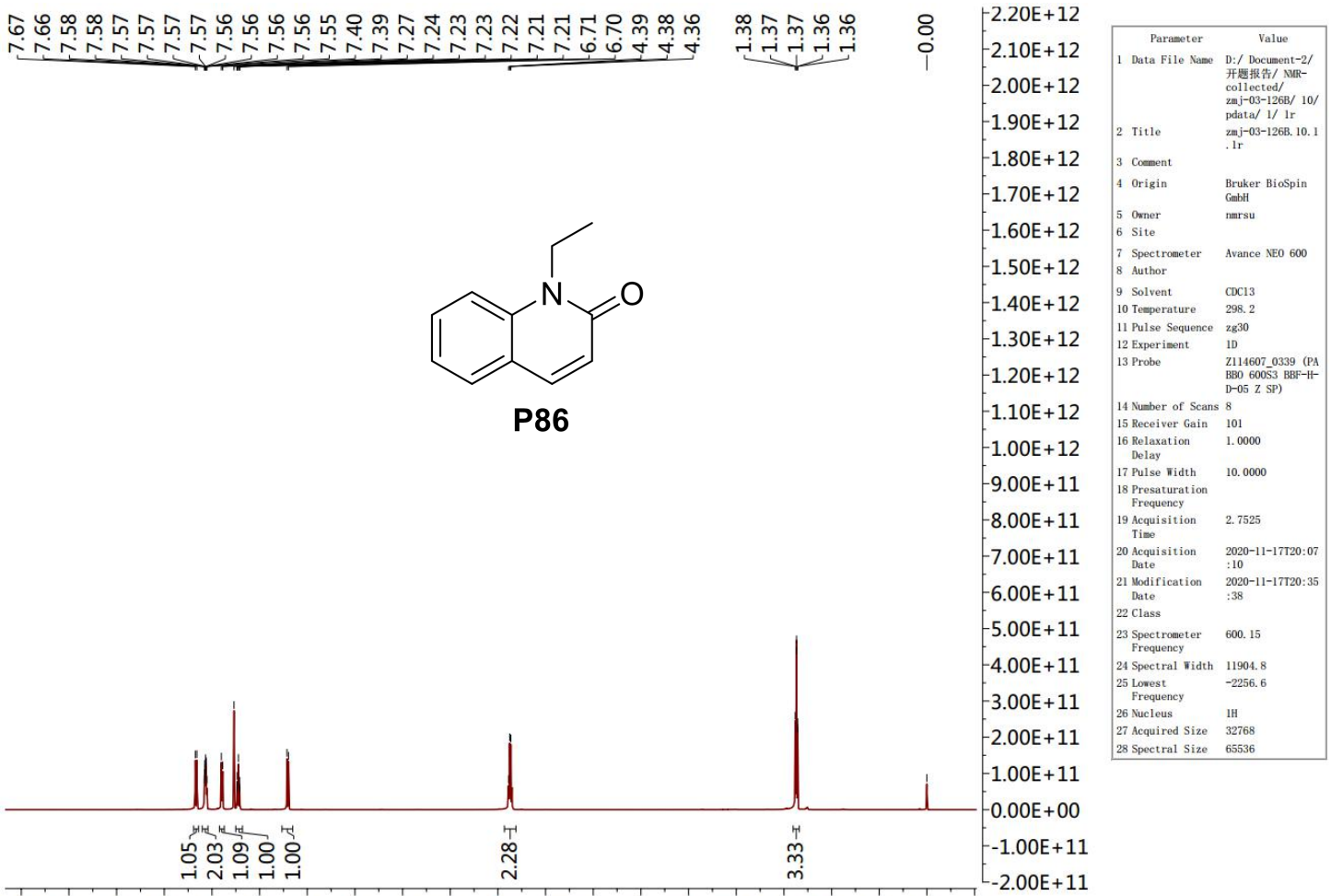

$\begin{array}{lllllllllllllllllllll}9.5 & 9.0 & 8.5 & 8.0 & 7.5 & 7.0 & 6.5 & 6.0 & 5.5 & 5.0 & 4.5 & 4.0 & 3.5 & 3.0 & 2.5 & 2.0 & 1.5 & 1.0 & 0.5 & 0.0 & -0.5\end{array}$

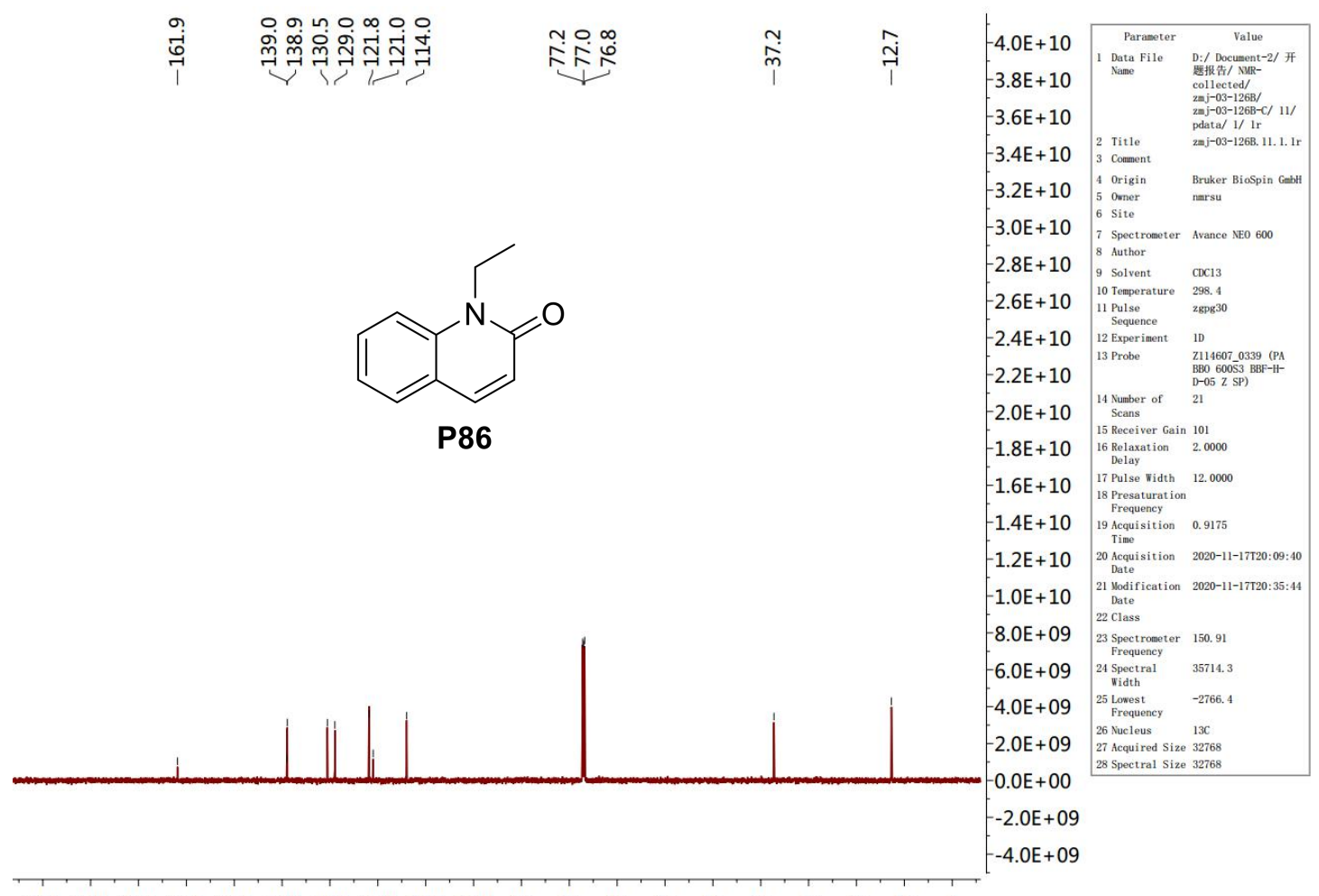

$\begin{array}{llllllllllllllllllll}190 & 180 & 170 & 160 & 150 & 140 & 130 & 120 & 110 & 100 & 90 & 80 & 70 & 60 & 50 & 40 & 30 & 20 & 10 & 0\end{array}$ 


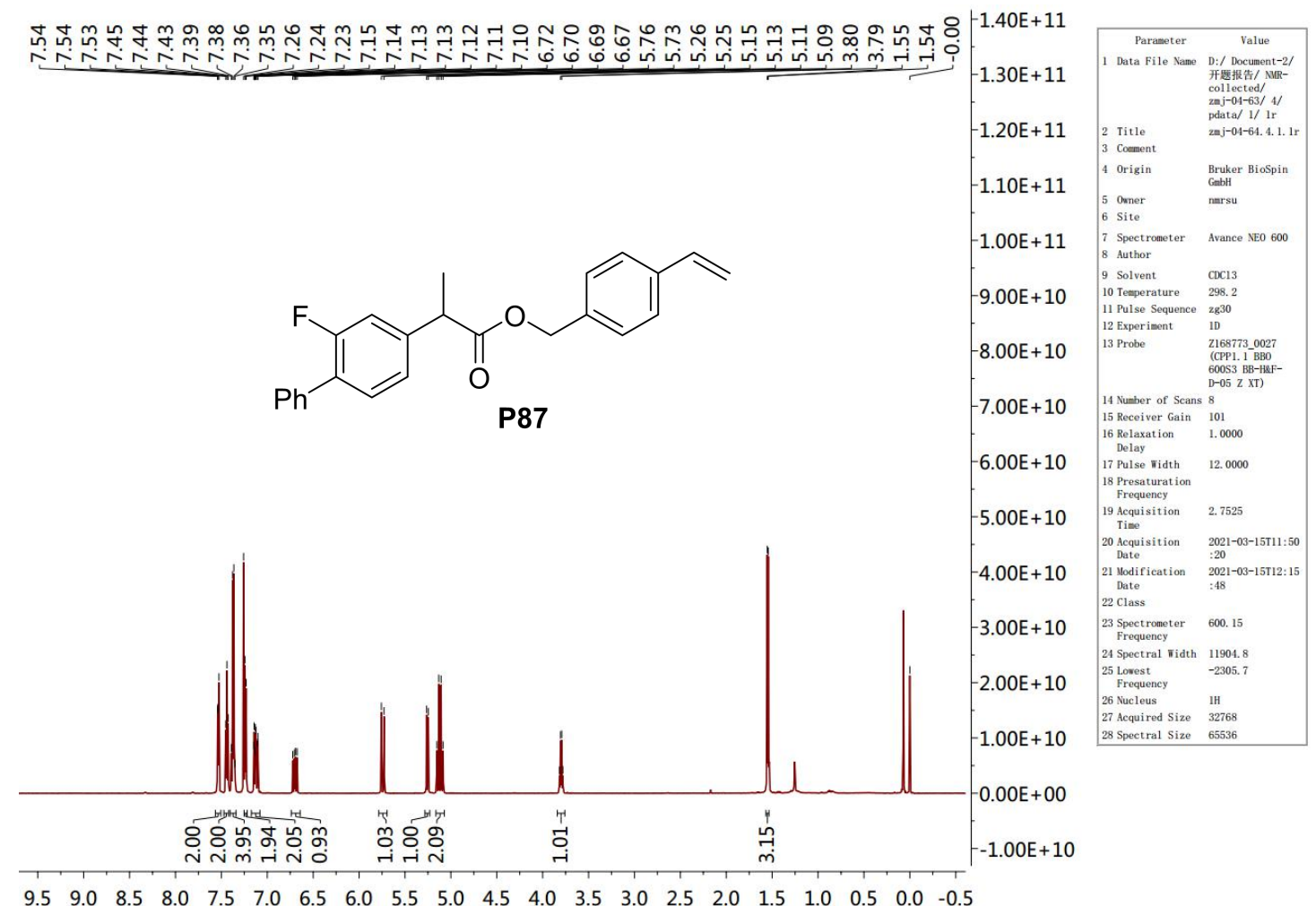

商

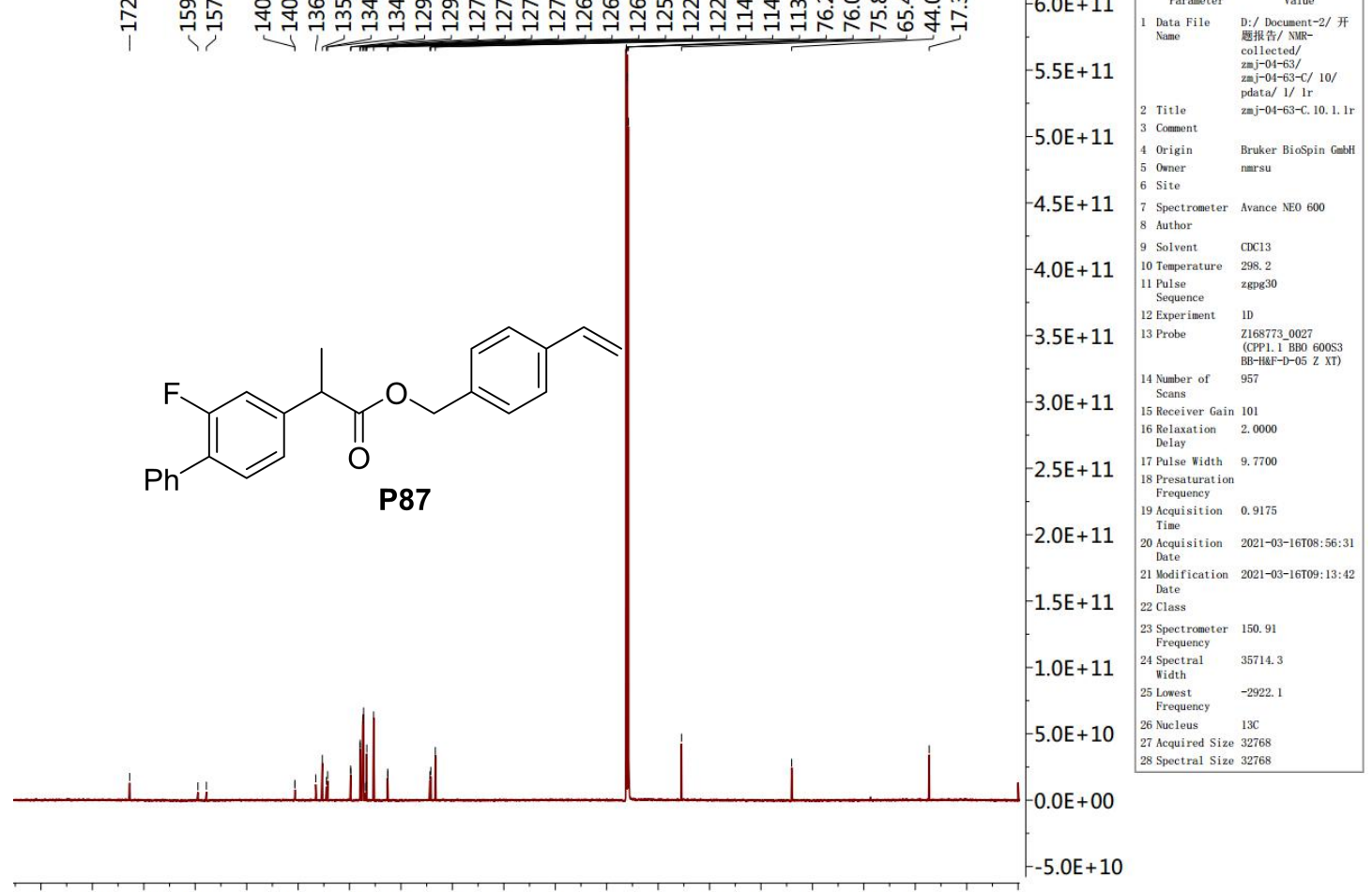

$\begin{array}{llllllllllllllllllll}190 & 180 & 170 & 160 & 150 & 140 & 130 & 120 & 110 & 100 & 90 & 80 & 70 & 60 & 50 & 40 & 30 & 20 & 10 & 0\end{array}$ 


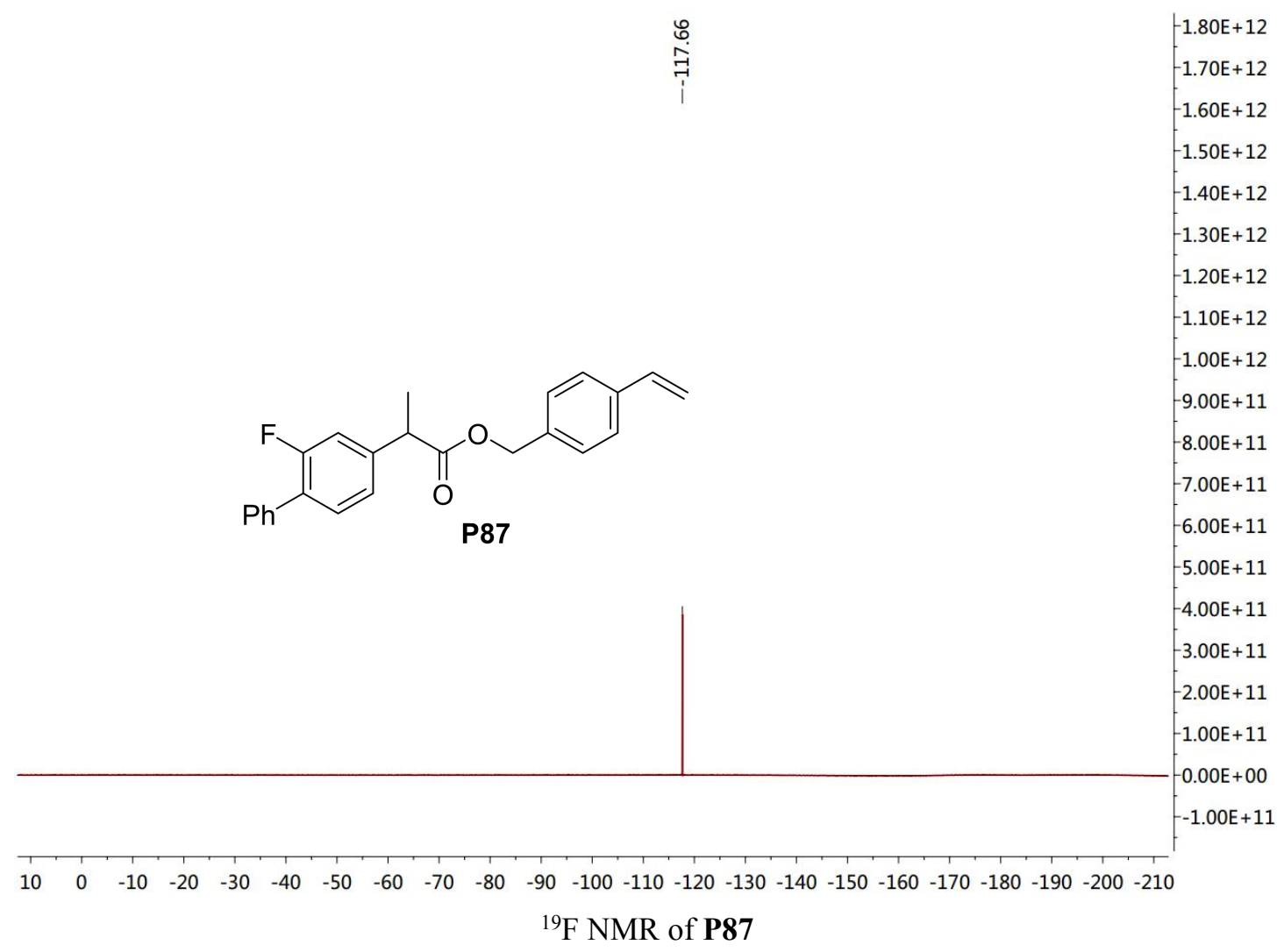


Phenyl (Z)-2-(4-((2-oxocyclopentylidene)methyl)phenyl)propanoate (P88)

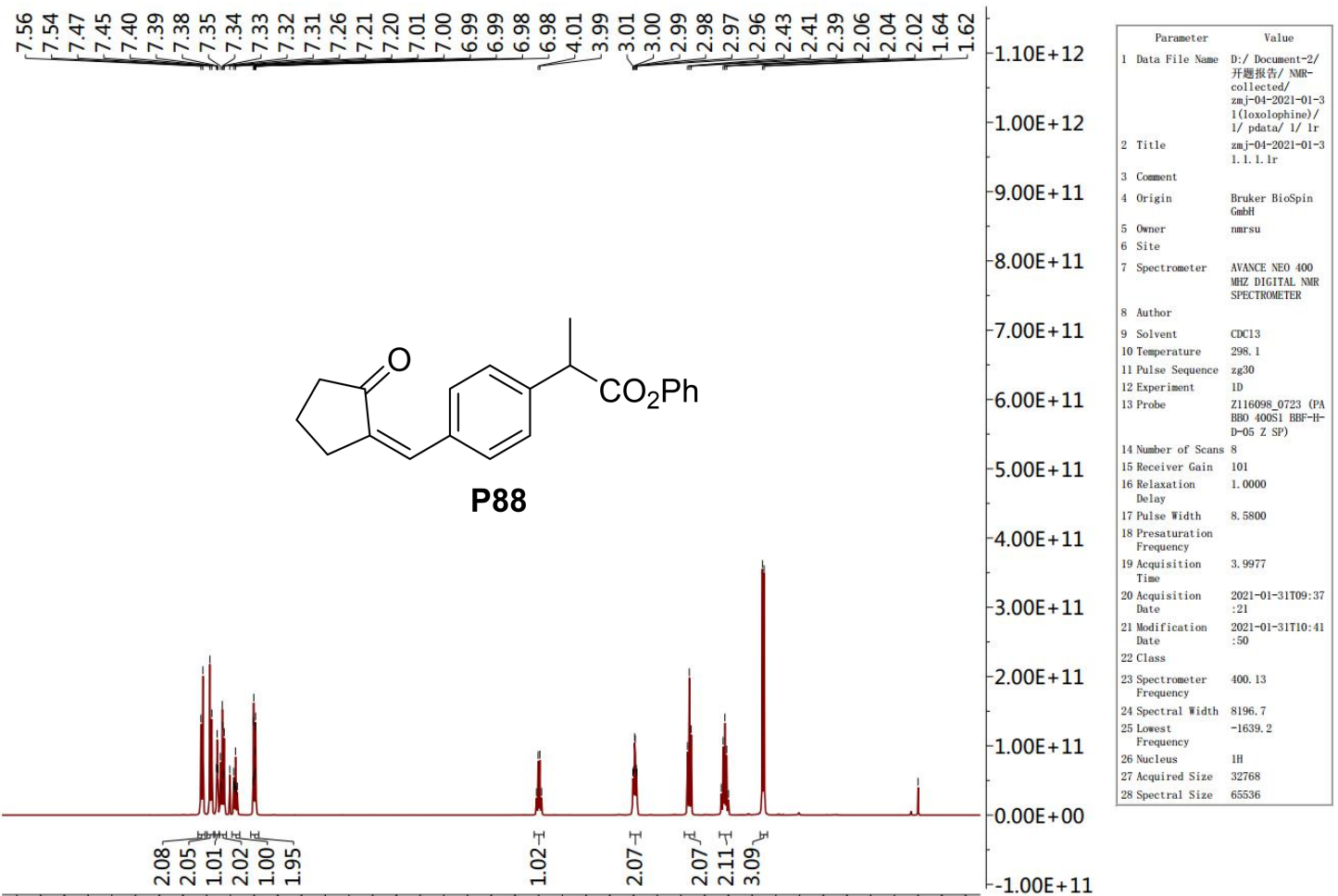

$\begin{array}{lllllllllllllllllllll}9.5 & 9.0 & 8.5 & 8.0 & 7.5 & 7.0 & 6.5 & 6.0 & 5.5 & 5.0 & 4.5 & 4.0 & 3.5 & 3.0 & 2.5 & 2.0 & 1.5 & 1.0 & 0.5 & 0.0 & -0.5\end{array}$

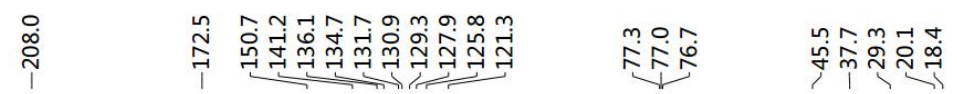<smiles>CC(C(=O)Oc1ccccc1)c1ccc(C=C2CCCC2=O)cc1</smiles>

P88

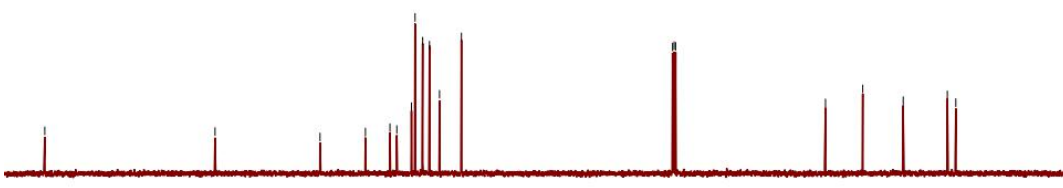

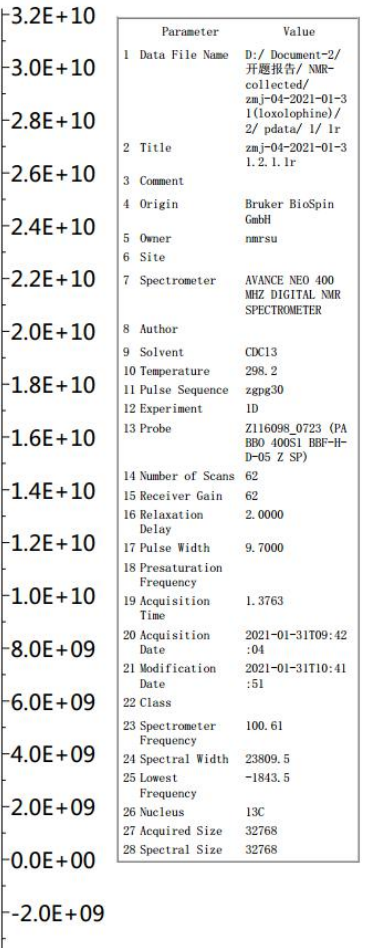

$210200190180170160150140130120110100 \quad 90 \quad 80 \quad 70 \quad 60 \quad 50 \quad 40 \quad 30 \quad 20 \quad 10 \quad 0$ 

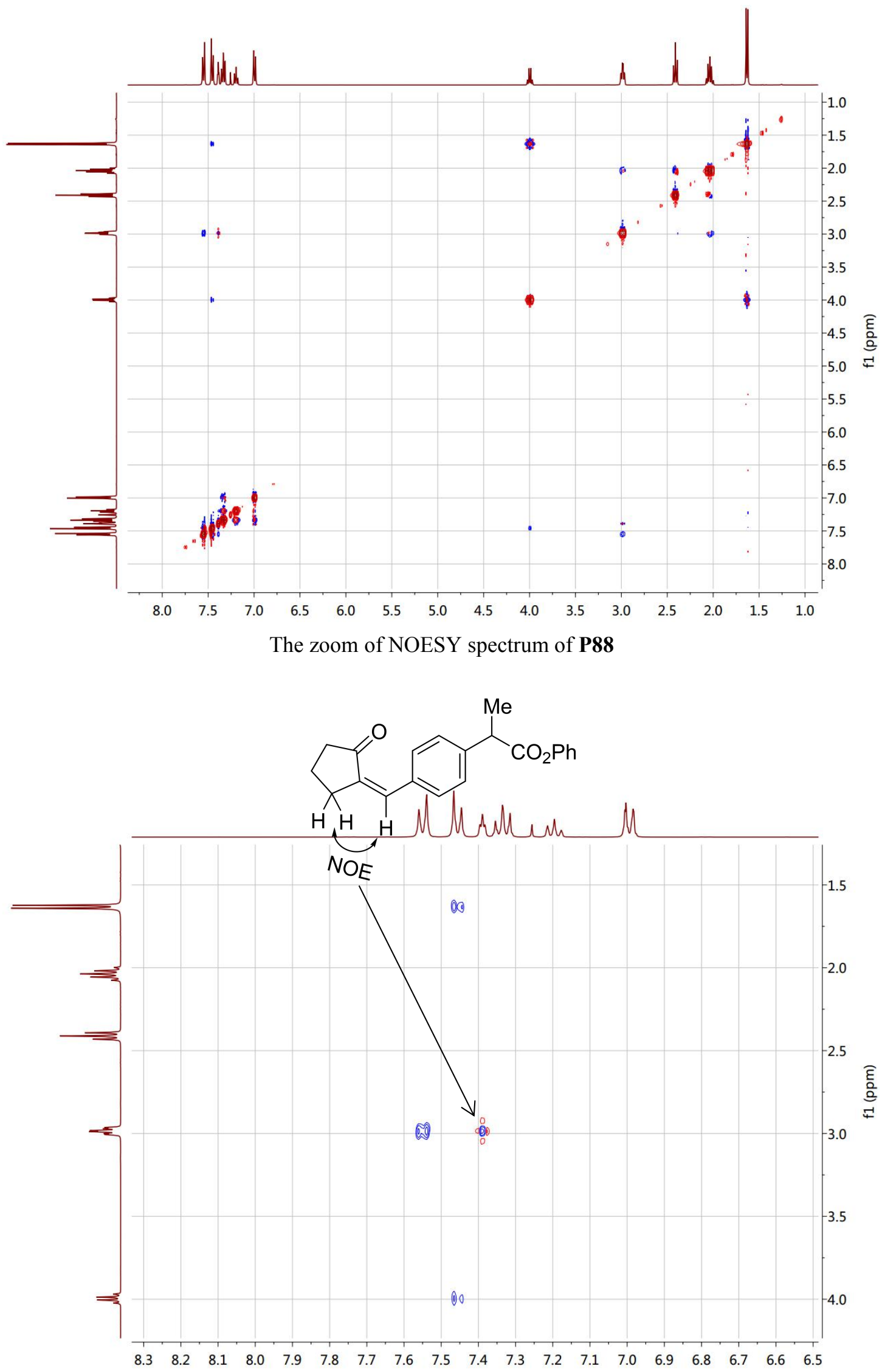

The zoom of NOESY spectrum of $\mathbf{P 8 8}$ 
1-(6-(tert-Butyl)-1,1-dimethyl-1H-inden-4-yl)ethan-1-one (P89)

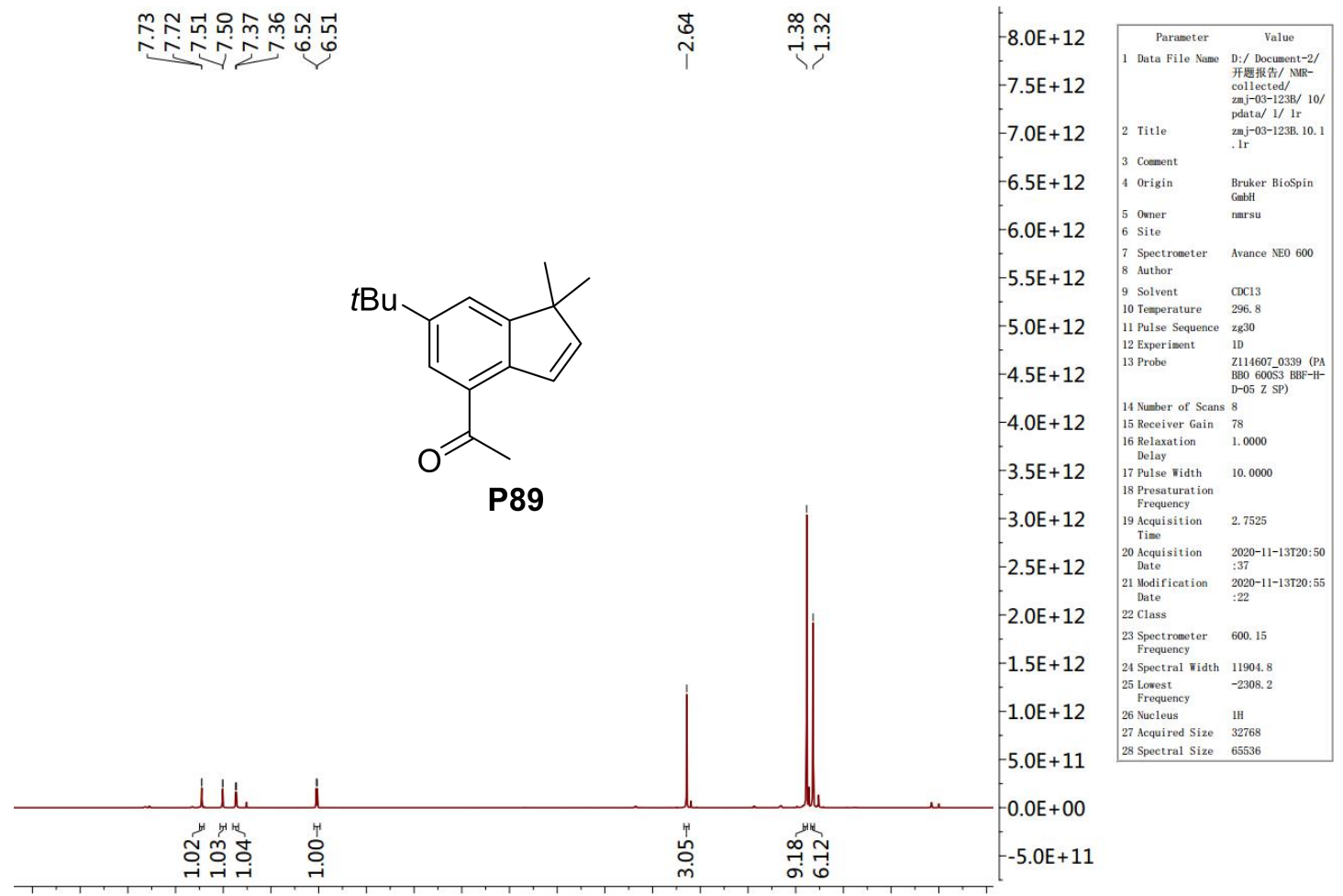

$\begin{array}{lllllllllllllllllllll}9.5 & 9.0 & 8.5 & 8.0 & 7.5 & 7.0 & 6.5 & 6.0 & 5.5 & 5.0 & 4.5 & 4.0 & 3.5 & 3.0 & 2.5 & 2.0 & 1.5 & 1.0 & 0.5 & 0.0 & -0.5\end{array}$
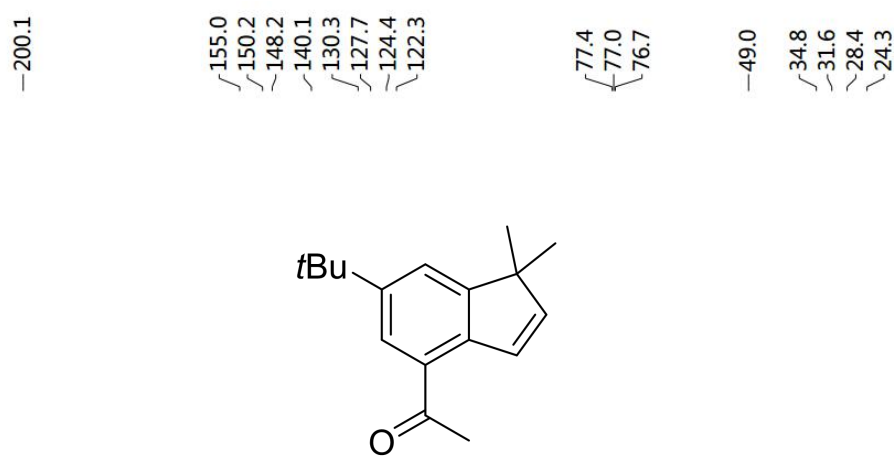

P89

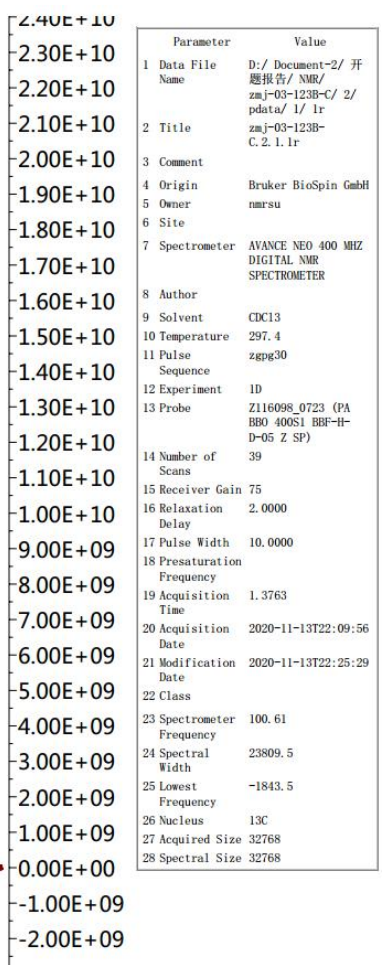

$210200190180170160150140130120110100 \quad 90 \quad 80 \quad 70 \quad 60 \quad 50 \quad 40 \quad 30 \quad 20 \quad 10 \quad 0$ 


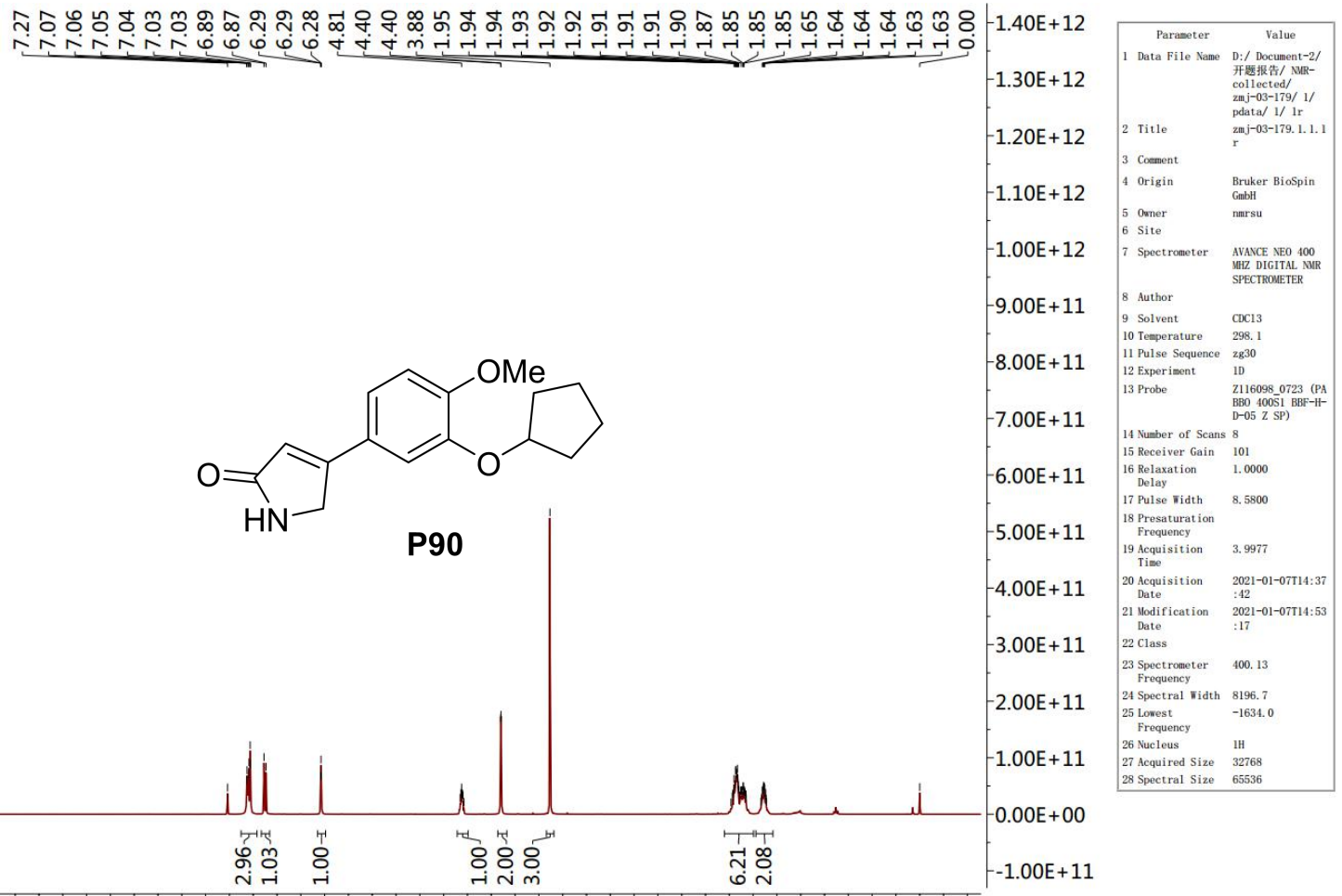

$\begin{array}{lllllllllllllllllllll}9.5 & 9.0 & 8.5 & 8.0 & 7.5 & 7.0 & 6.5 & 6.0 & 5.5 & 5.0 & 4.5 & 4.0 & 3.5 & 3.0 & 2.5 & 2.0 & 1.5 & 1.0 & 0.5 & 0.0 & -0.5\end{array}$

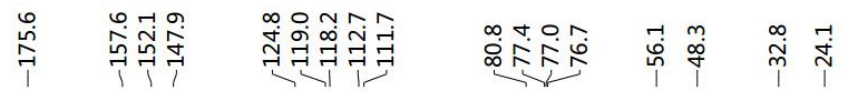<smiles>COc1ccc(C2=CC(=O)NC2)cc1OC1CCCC1</smiles>

\begin{tabular}{|c|c|c|}
\hline $1.50 E+10$ & $\begin{array}{l}\text { Parasecter } \\
\end{array}$ & Value \\
\hline $1.40 \mathrm{E}+10$ & $\begin{array}{l}\text { Data } \\
\text { Name } \\
\text { Nite }\end{array}$ & 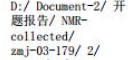 \\
\hline $1.30 \mathrm{E}+10$ & $\begin{array}{l}2 \text { Title } \\
3 \text { Coment }\end{array}$ & $\mathrm{zz}-03-179.2 .1 .1 \mathrm{r}$ \\
\hline $1.20 \mathrm{E}+10$ & $\begin{array}{l}4 \text { Origin } \\
5 \text { Omer } \\
6 \text { Site }\end{array}$ & $\begin{array}{l}\text { Bruker Biospin castif } \\
\text { rarsu }\end{array}$ \\
\hline $1.10 E+10$ & 7 Spectromenter & 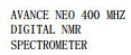 \\
\hline $1.00 \mathrm{E}+10$ & 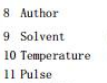 & 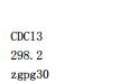 \\
\hline $9.00 E+09$ & $\begin{array}{c}\text { Sequence } \\
12 \text { Experinent }\end{array}$ & \\
\hline $8.00 \mathrm{E}+09$ & 14 Number of & 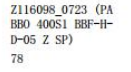 \\
\hline $7.00 E+09$ & $\begin{array}{l}\text { Scans } \\
15 \text { Receiver Gain } \\
16 \text { Relaxat ion }\end{array}$ & $\begin{array}{l}53 \\
2.0000\end{array}$ \\
\hline $6.00 E+09$ & $\begin{array}{l}\text { Delay } \\
17 \text { Pulse width } \\
18 \text { Presaturat ion }\end{array}$ & 9.7000 \\
\hline $5.00 E+09$ & $\begin{array}{l}\text { Frequency } \\
\text { 19.iusisition } \\
\text { Trine }\end{array}$ & 1.3763 \\
\hline $4.00 E+09$ & 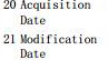 & $\begin{array}{l}2021-01-07714: 43: 44 \\
2021-01-07714: 53: 19\end{array}$ \\
\hline $3.00 E+09$ & $\begin{array}{l}22 \text { Class } \\
23 \text { Spectrounter } \\
\text { Frewerey }\end{array}$ & 100.61 \\
\hline $2.00 E+09$ & $\begin{array}{l}24 \text { Spectral } \\
\text { vidth } \\
25 \text { Lowest }\end{array}$ & $\begin{array}{l}23809.5 \\
-1843.5\end{array}$ \\
\hline $1.00 E+09$ & 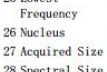 & $\begin{array}{l}13 c \\
13268 \\
32768\end{array}$ \\
\hline $0.00 E+00$ & & \\
\hline$-1.00 E+09$ & & \\
\hline
\end{tabular}

$\begin{array}{llllllllllllllllllll}190 & 180 & 170 & 160 & 150 & 140 & 130 & 120 & 110 & 100 & 90 & 80 & 70 & 60 & 50 & 40 & 30 & 20 & 10 & 0\end{array}$ 
2-(2,5-Dichlorophenoxy)-1-(2,3-dihydro-4H-1,4-thiazin-4-yl)ethan-1-one (P91)

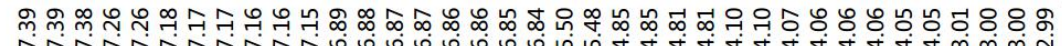

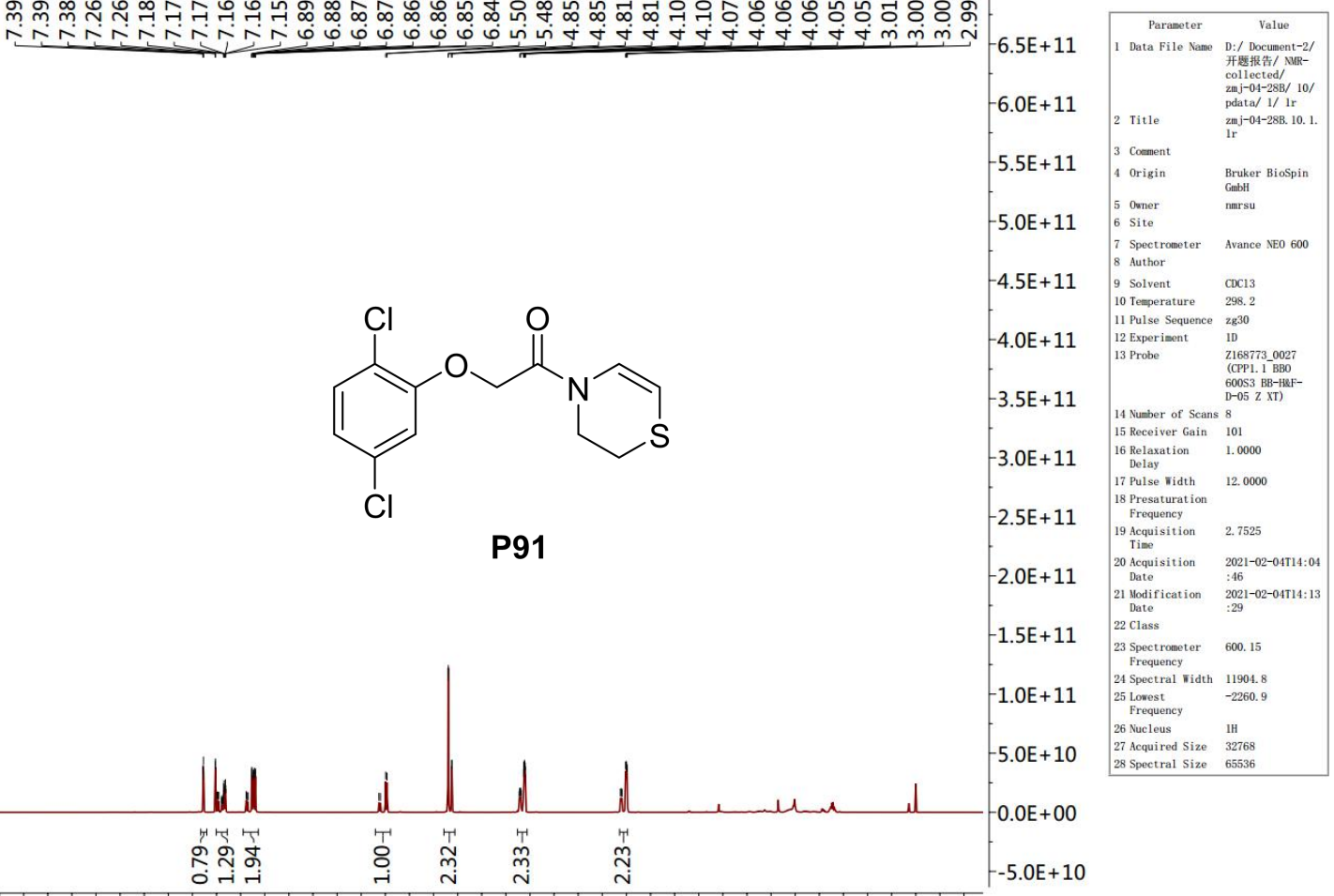

$\begin{array}{lllllllllllllllllllll}9.5 & 9.0 & 8.5 & 8.0 & 7.5 & 7.0 & 6.5 & 6.0 & 5.5 & 5.0 & 4.5 & 4.0 & 3.5 & 3.0 & 2.5 & 2.0 & 1.5 & 1.0 & 0.5 & 0.0 & -0.5\end{array}$

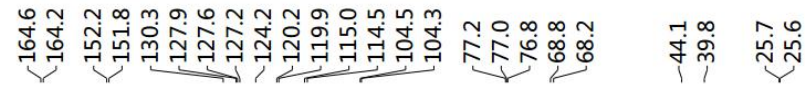<smiles>O=C(COc1cc(Cl)ccc1Cl)N1C=CSCC1</smiles>

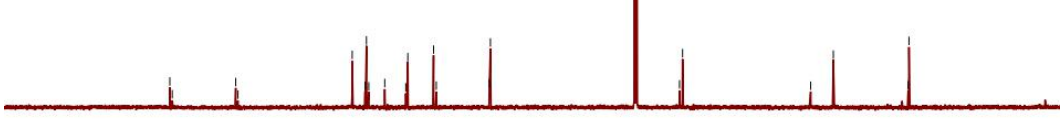

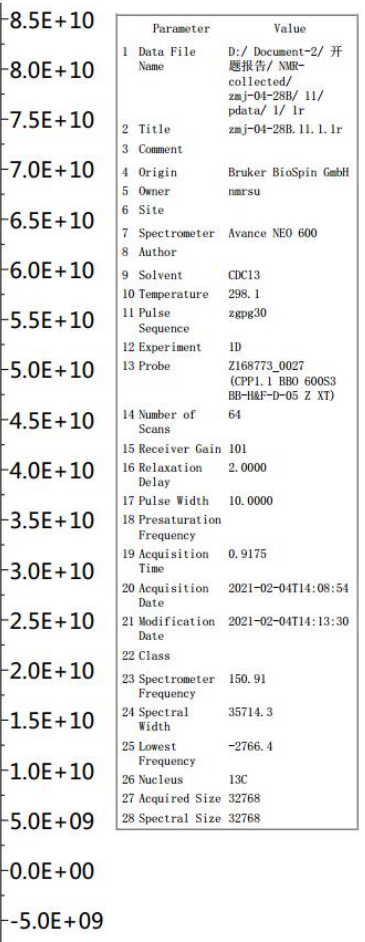

$\begin{array}{llllllllllllllllllll}190 & 180 & 170 & 160 & 150 & 140 & 130 & 120 & 110 & 100 & 90 & 80 & 70 & 60 & 50 & 40 & 30 & 20 & 10 & 0\end{array}$ 
2-((1-(2-(2,3-Dihydro-4H-1,4-oxazin-4-yl)-2-oxoethyl)cyclohexyl)methyl)isoindoline-1,3-dion e (P92)
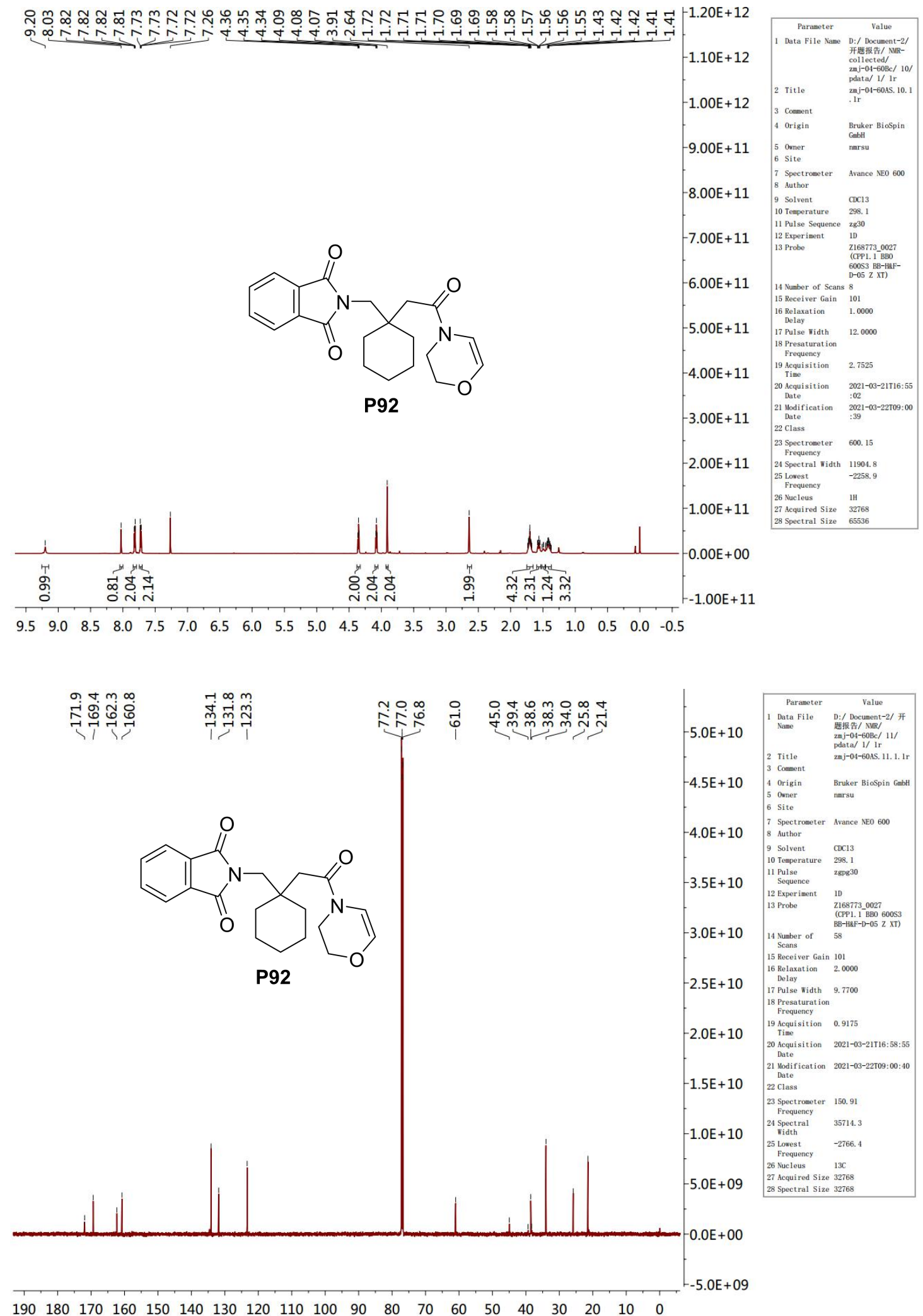
Benzyl 4-(2-((2,4-dimethylphenyl)thio)phenyl)-3,4-dihydropyrazine-1(2H)-carboxylate (P93)

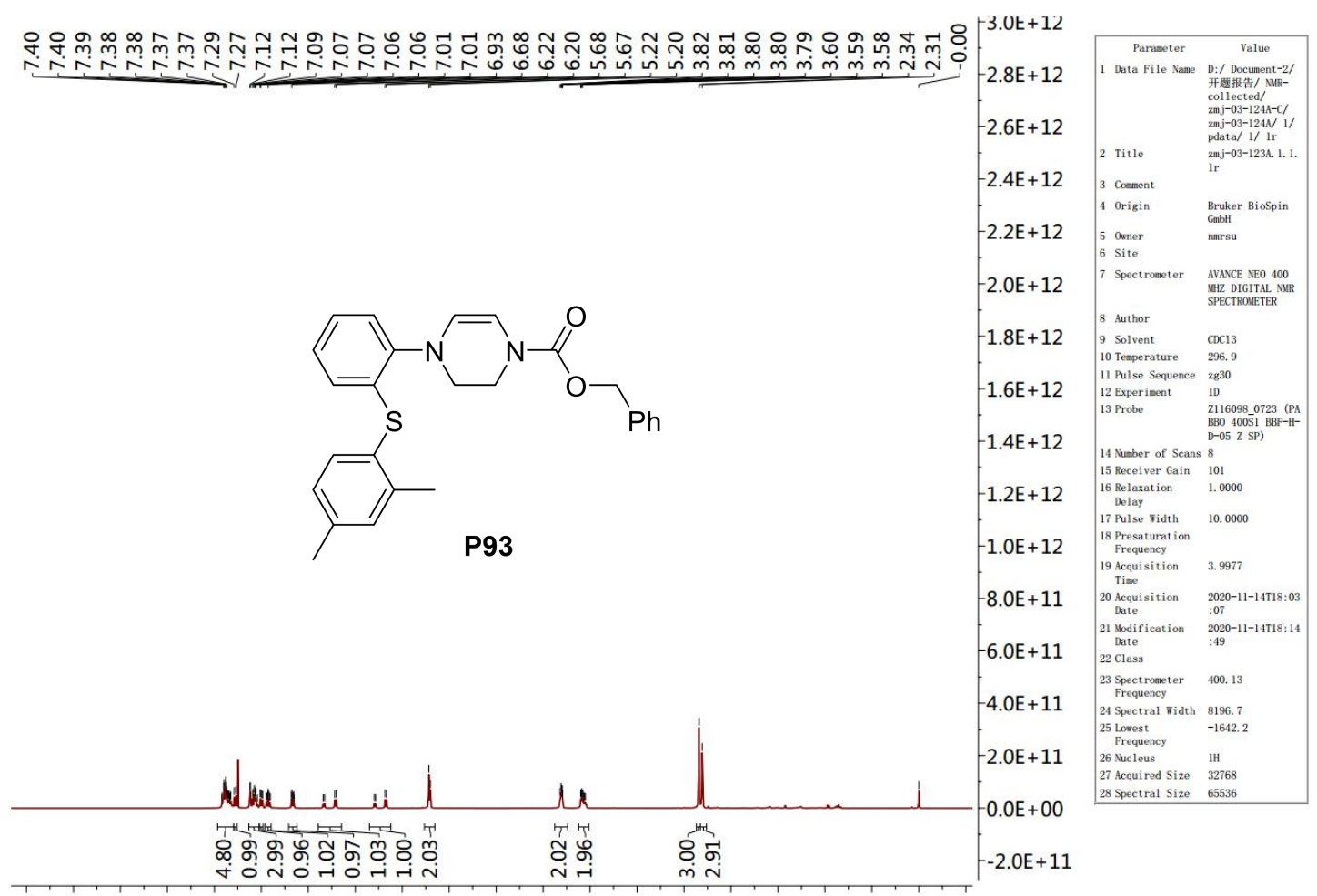

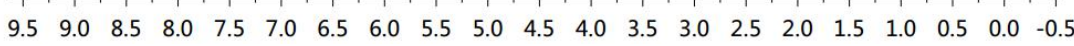

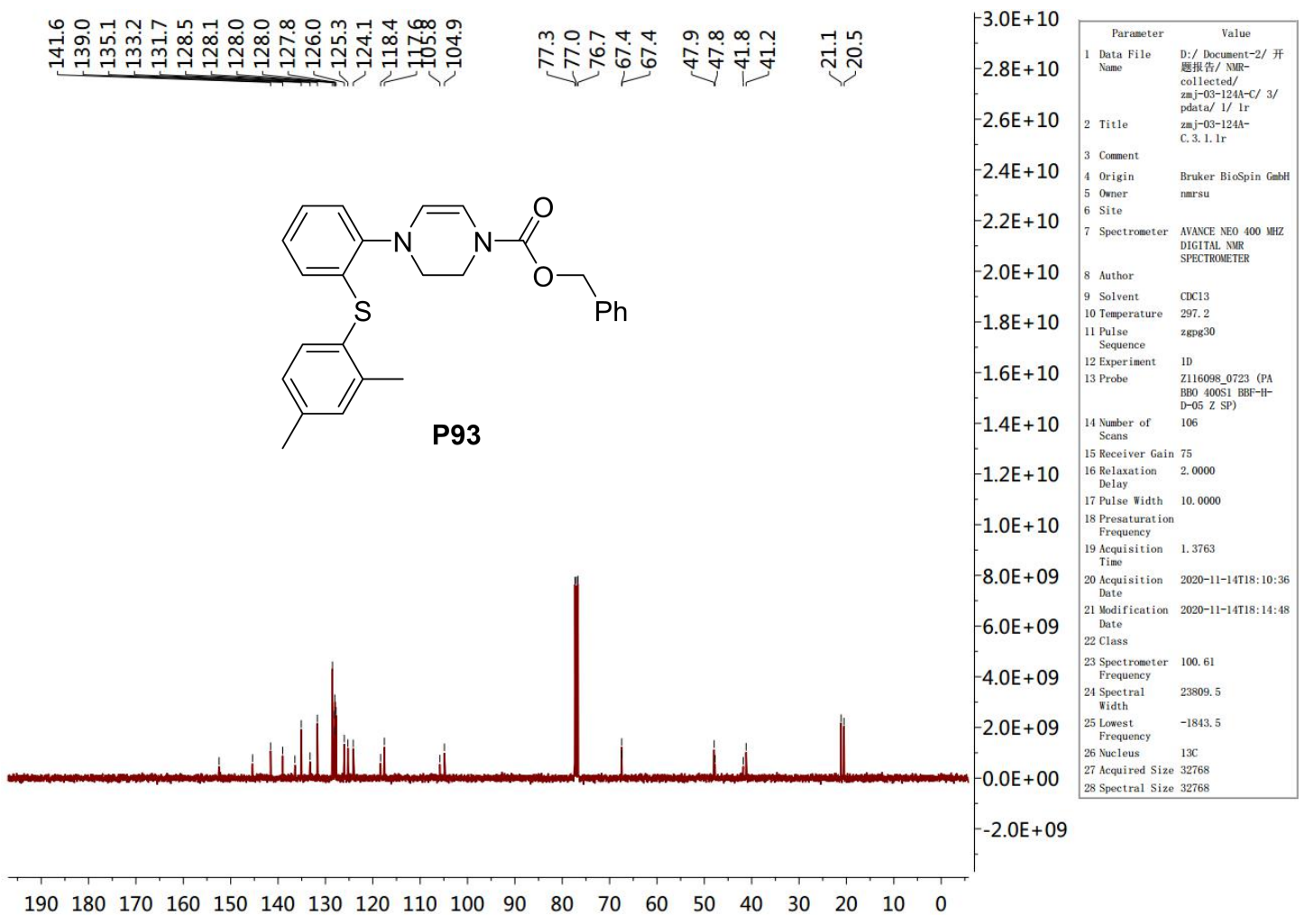


Ethyl-(E)-4-(8-chloro-5,6-dihydro-11H-benzo[5,6]cyclohepta[1,2-b]pyridin-11-ylidene)-3,4-di hydropyridine-1 $(2 H)$-carboxylate

(P94)

and

ethyl

(Z)-4-(8-chloro-5,6-dihydro-11H-benzo[5,6]cyclohepta[1,2-b]pyridin-11-ylidene)-3,4-dihydro pyridine-1(2H)-carboxylate ( $\left(\mathrm{P9}^{\prime}\right)$
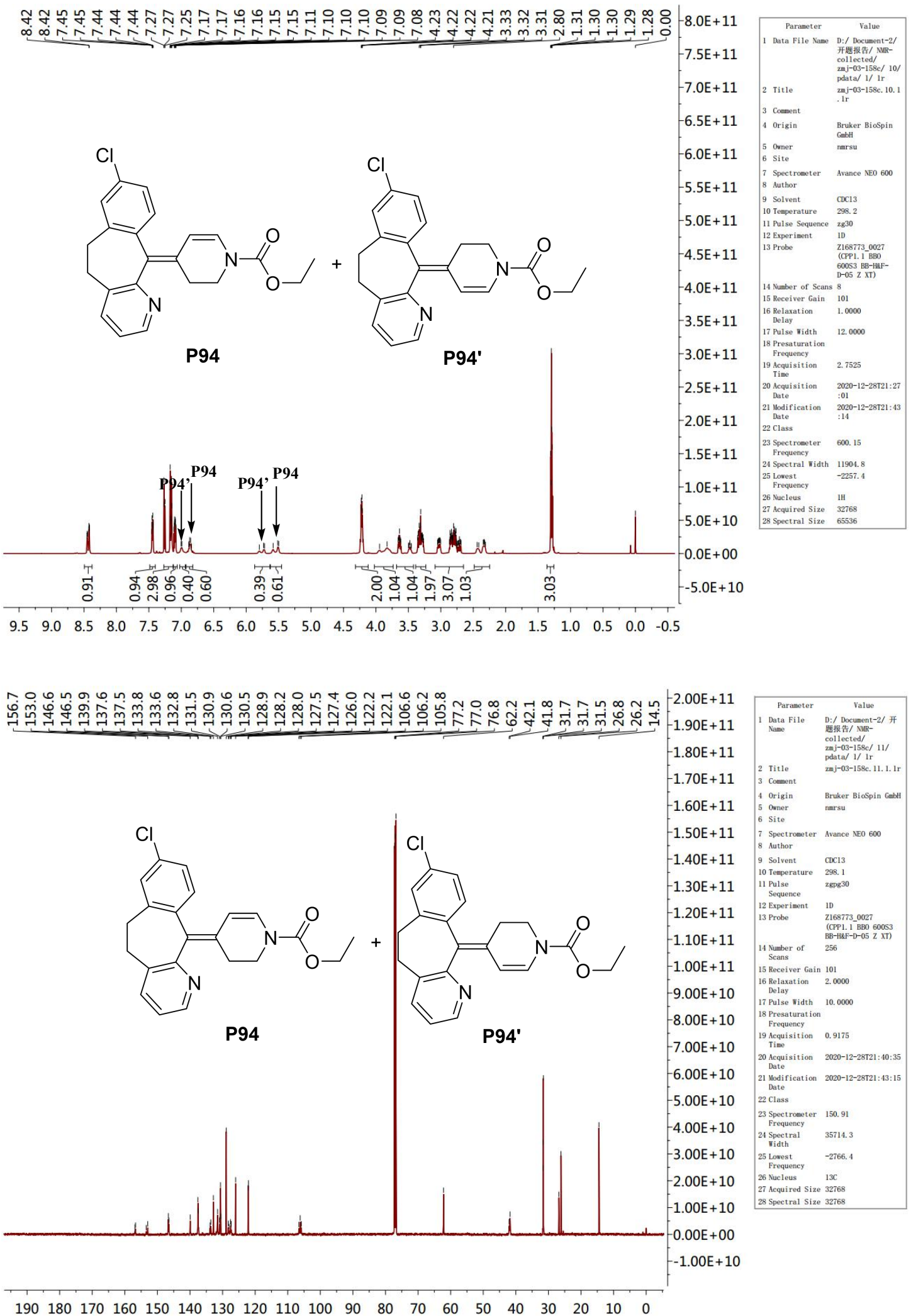
4-Vinylphenyl 2-(4-(4-chlorobenzoyl)phenoxy)-2-methylpropanoate (P95)

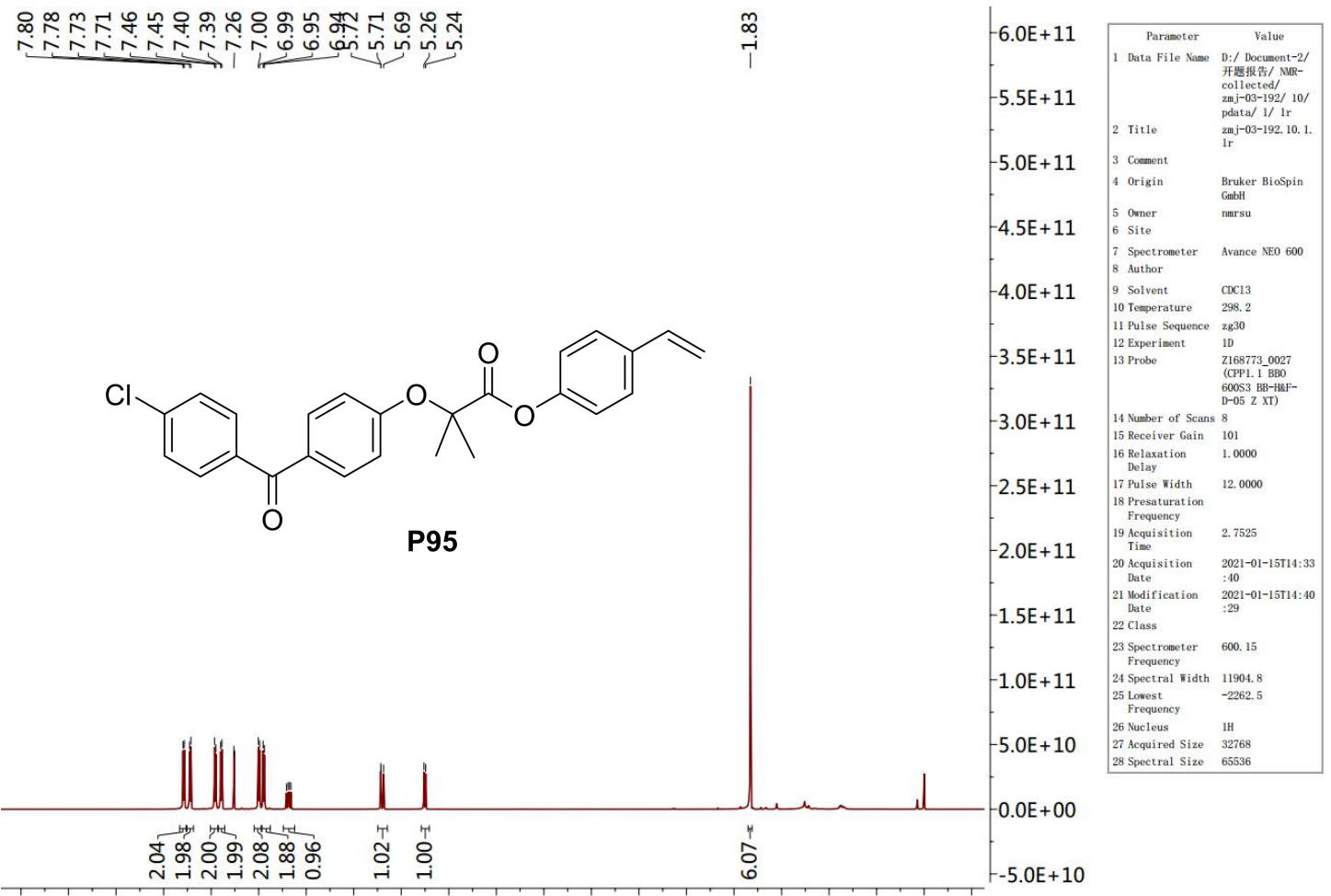

$\begin{array}{lllllllllllllllllllll}9.5 & 9.0 & 8.5 & 8.0 & 7.5 & 7.0 & 6.5 & 6.0 & 5.5 & 5.0 & 4.5 & 4.0 & 3.5 & 3.0 & 2.5 & 2.0 & 1.5 & 1.0 & 0.5 & 0.0 & -0.5\end{array}$

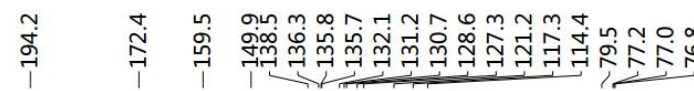<smiles>CC(C)(Oc1ccc(C(=O)c2ccc(Cl)cc2)cc1)C(=O)Oc1ccccc1</smiles><smiles>Cc1ccccc1</smiles>

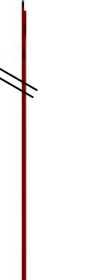

$\underset{\sim}{\stackrel{1}{\sim}}$
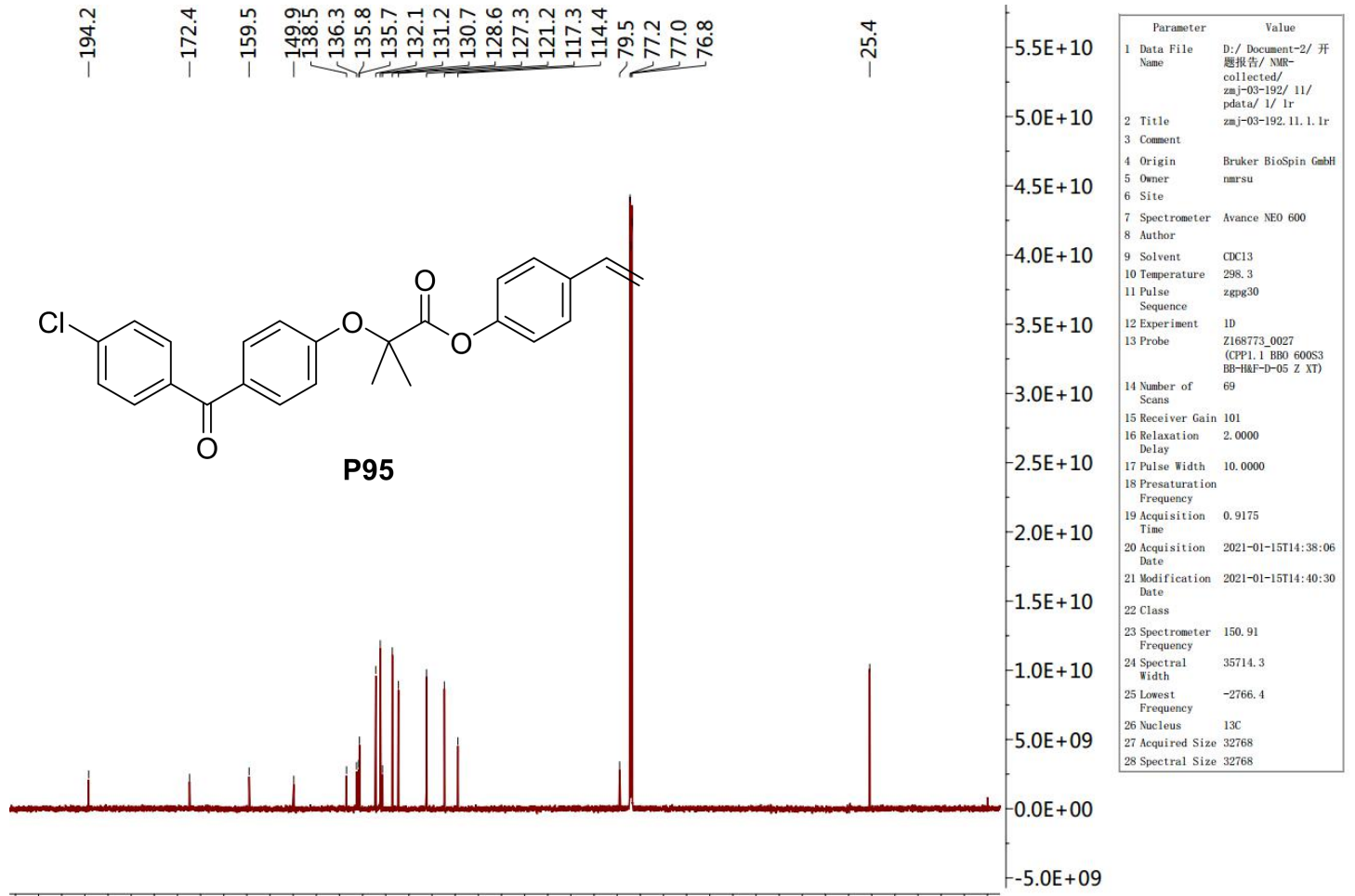

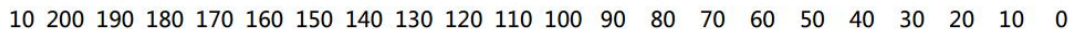




\section{4-Vinylphenyl}

4-((5S,8R,9S,10S,13R,14S)-10,13-dimethyl-3,7,12-trioxohexadecahydro-1H-cyclopenta[a]phe nanthren-17-yl)pentanoate (P96)
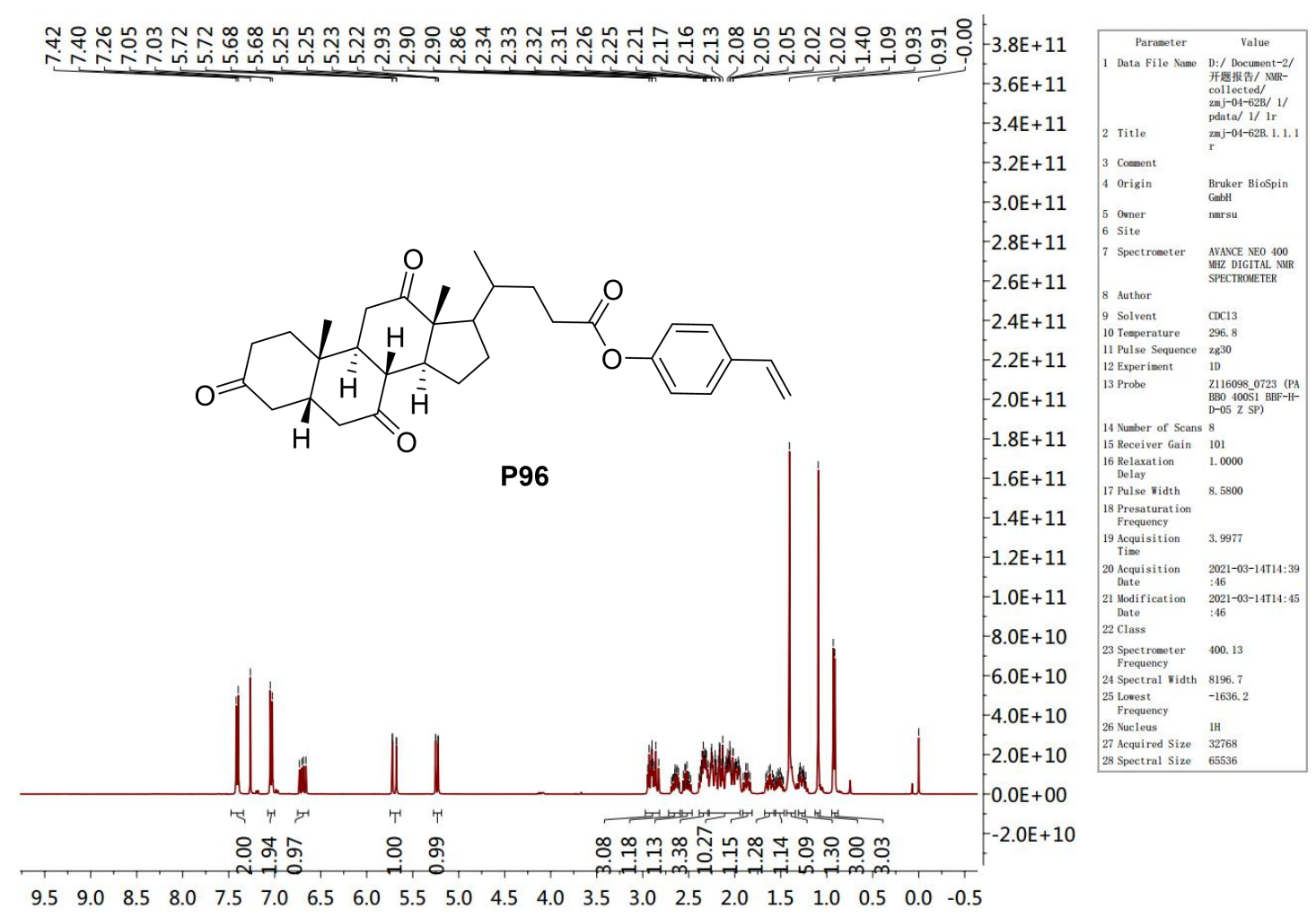

\section{踢}
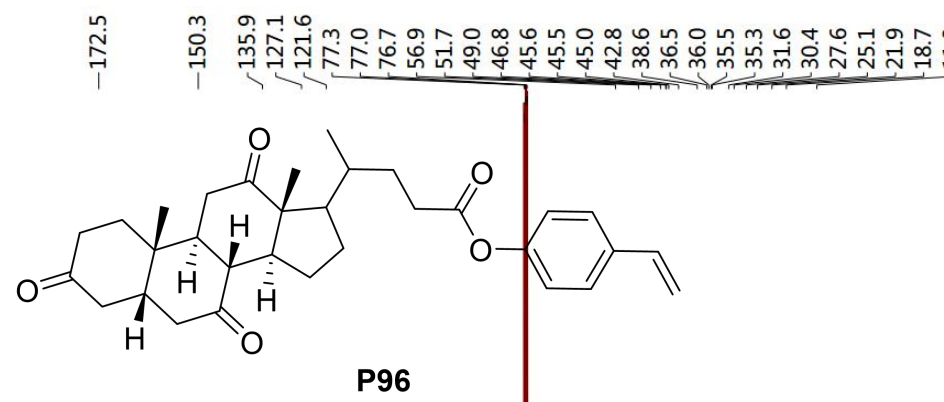

$90 \mathrm{E}+10$

$-1.80 \mathrm{E}+10$

$-1.70 \mathrm{E}+10$

$-1.60 \mathrm{E}+10$

$-1.50 \mathrm{E}+10$

$-1.40 \mathrm{E}+10$

$-1.30 \mathrm{E}+10$

$-120 \mathrm{E}+10$

$-1.10 \mathrm{E}+10$

$-1.00 \mathrm{E}+10$

$-9.00 \mathrm{E}+09$

$-8.00 \mathrm{E}+09$

$-7.00 \mathrm{E}+09$

$-6.00 \mathrm{E}+09$

$-5.00 \mathrm{E}+09$

$-4.00 \mathrm{E}+09$

$-3.00 \mathrm{E}+09$

$-2.00 \mathrm{E}+09$

$-1.00 \mathrm{E}+09$

$-0.00 \mathrm{E}+00$

$-1.00 \mathrm{E}+09$

$-2.00 \mathrm{E}+09$

$21020019018017016015014013012011010090 \quad 80 \quad 70 \quad 60 \quad 50 \quad 40 \quad 30 \quad 20 \quad 10 \quad 0 \quad-10$ 
$(1 S, 8 R, 9 S, 10 S, 13 S, 14 S, 17 S)$-1,10,13-trimethyl-3-oxohexadecahydro-1 $H$-cyclopenta[a]phenan thren-17-yl 2-(4-(vinylthio)phenyl)acetate (P97)

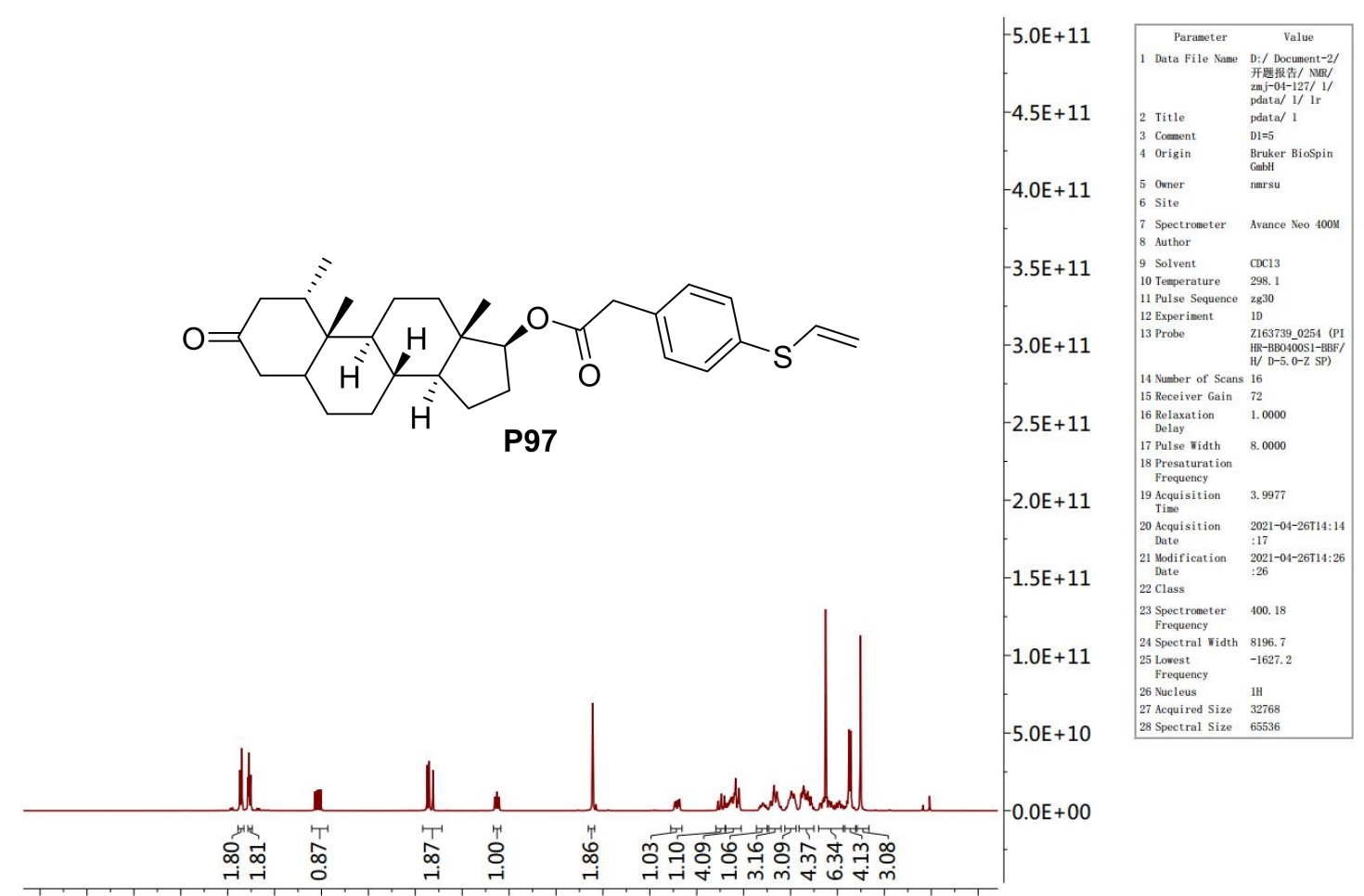

$\begin{array}{lllllllllllllllllllll}9.5 & 9.0 & 8.5 & 8.0 & 7.5 & 7.0 & 6.5 & 6.0 & 5.5 & 5.0 & 4.5 & 4.0 & 3.5 & 3.0 & 2.5 & 2.0 & 1.5 & 1.0 & 0.5 & 0.0 & -0.5\end{array}$

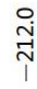

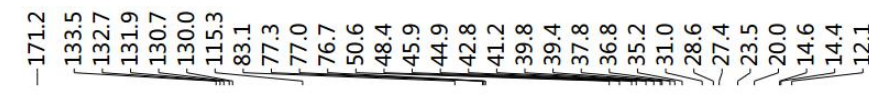

$6.0 \mathrm{E}+09$

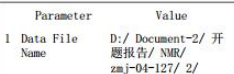

$\begin{array}{lll}2 & \text { Title } \\ 3 & \text { Coment } & \text { pdis } \\ 3 & \text { Dl }=5\end{array}$

$\begin{array}{lll}3 & \text { Comment } & \text { Dl=5 } \\ 4 & \text { Origin } & \text { Bruker Biospin GebH } \\ 5 & \text { Orerer } & \end{array}$<smiles>C=CSc1ccc(CC(=O)O[C@H]2CC[C@H]3[C@H]4CCC5CC(=O)C[C@H](C)[C@]5(C)[C@H]4CC[C@@]23C)cc1</smiles>

P97

9 Solvent CDC13

$\begin{array}{ll}10 \text { Temperature } & 298.3 \\ 11 \text { Pulse } & \text { 2gpg30 }\end{array}$

$4.0 \mathrm{E}+09$

12 Experiment

$3.5 \mathrm{E}+09$

$3.0 E+09$

15 Receiver Gain 13

16 Relaxation 2.0000

$2.5 \mathrm{E}+09$

Frequency
Presation

$-2.0 \mathrm{E}+09$

Pate
Pation 2021-04-26114:22:11

2021-04-26斤14:26:27

$1.5 \mathrm{E}+09$

23 Spectroneter 100.63

100.63

$1.0 \mathrm{E}+09$

25 Lowest -1842,

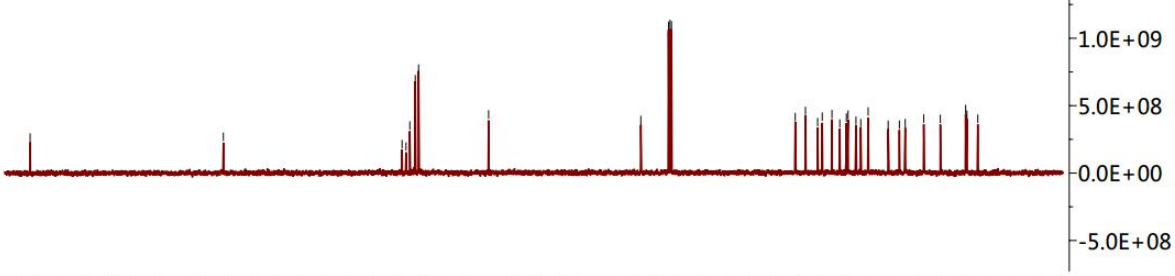

26 Nucleus $13 \mathrm{C}$

27 Acquir red Size 32768

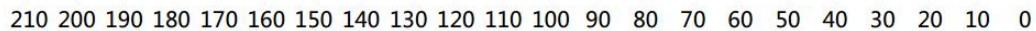



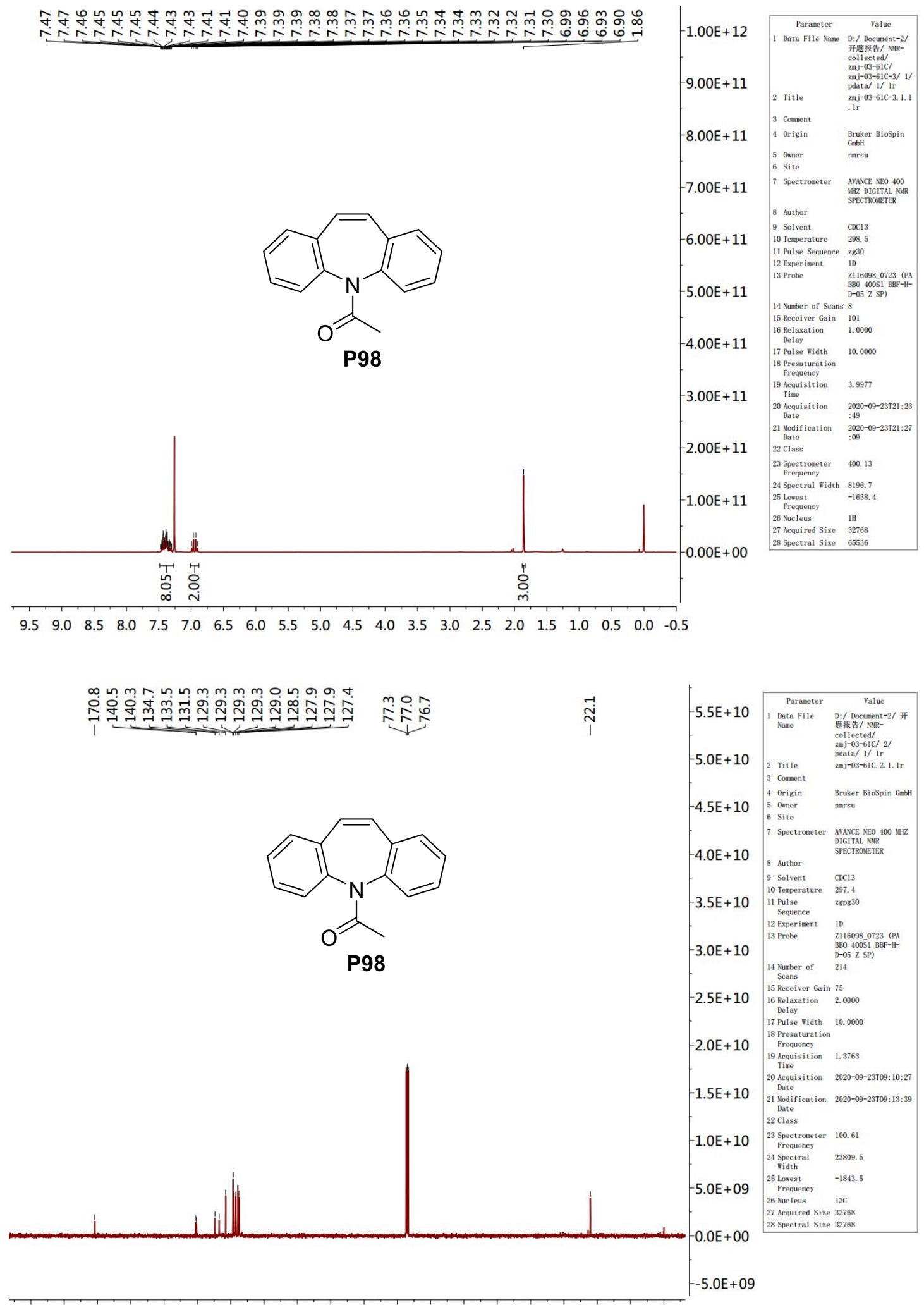

$\begin{array}{llllllllllllllllllll}190 & 180 & 170 & 160 & 150 & 140 & 130 & 120 & 110 & 100 & 90 & 80 & 70 & 60 & 50 & 40 & 30 & 20 & 10 & 0\end{array}$ 


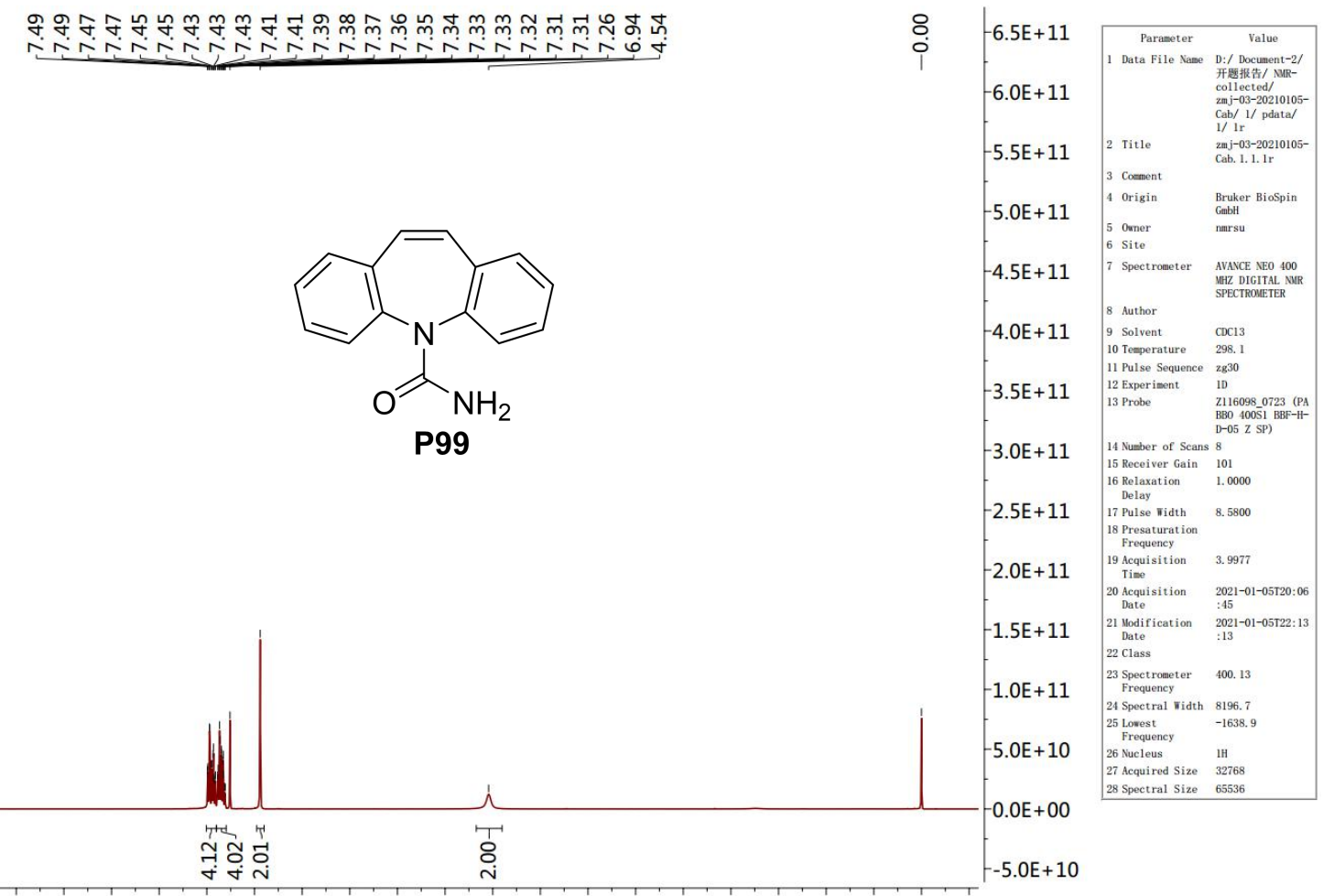

$\begin{array}{lllllllllllllllllllll}9.5 & 9.0 & 8.5 & 8.0 & 7.5 & 7.0 & 6.5 & 6.0 & 5.5 & 5.0 & 4.5 & 4.0 & 3.5 & 3.0 & 2.5 & 2.0 & 1.5 & 1.0 & 0.5 & 0.0 & -0.5\end{array}$

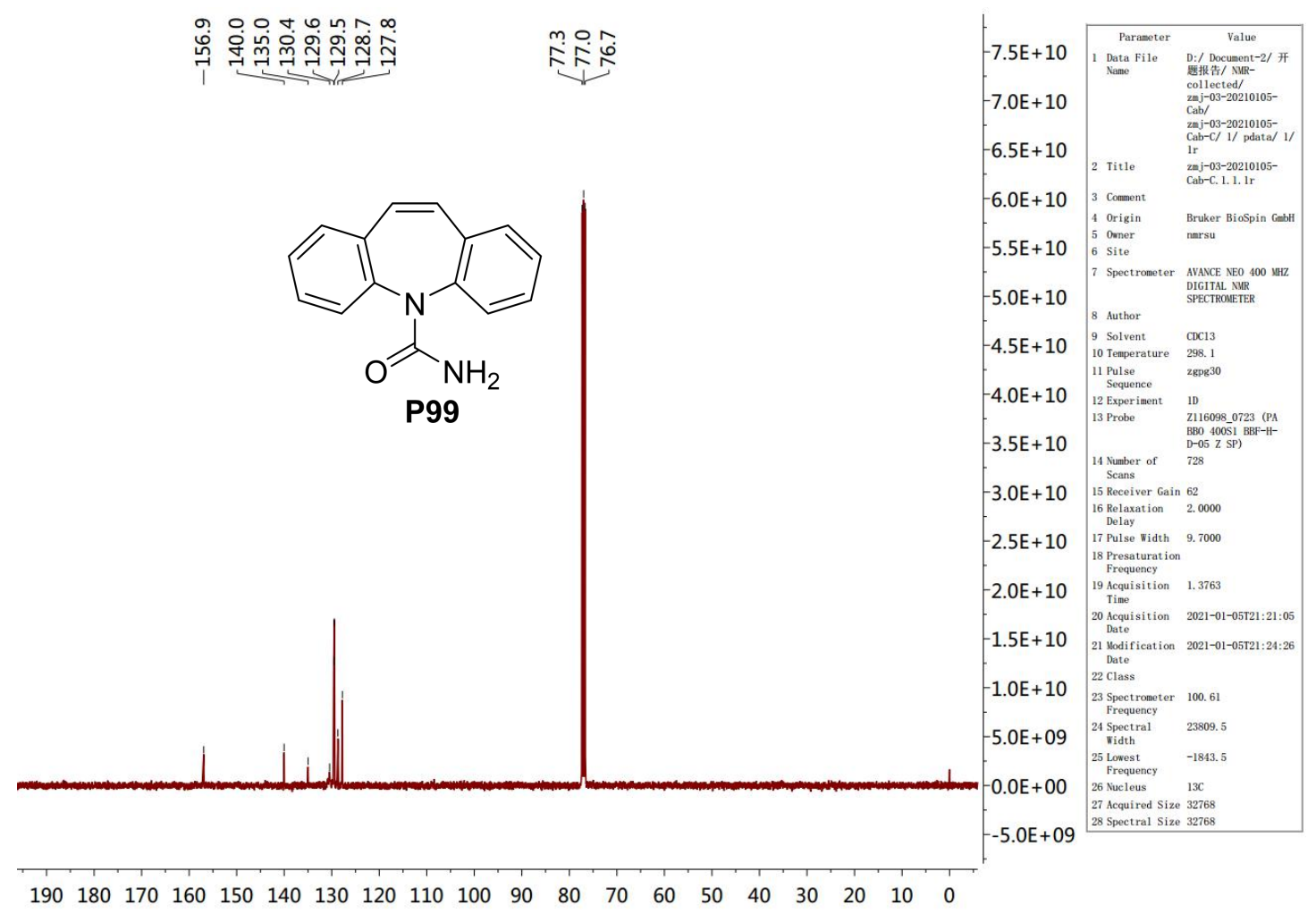


7-(4-Chlorobutoxy)quinolin-2(1H)-one (P100)

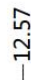

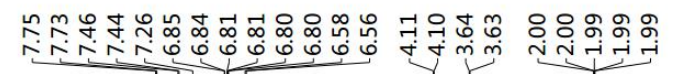<smiles>O=c1ccc2ccc(OCCCCCl)cc2[nH]1</smiles>

P100
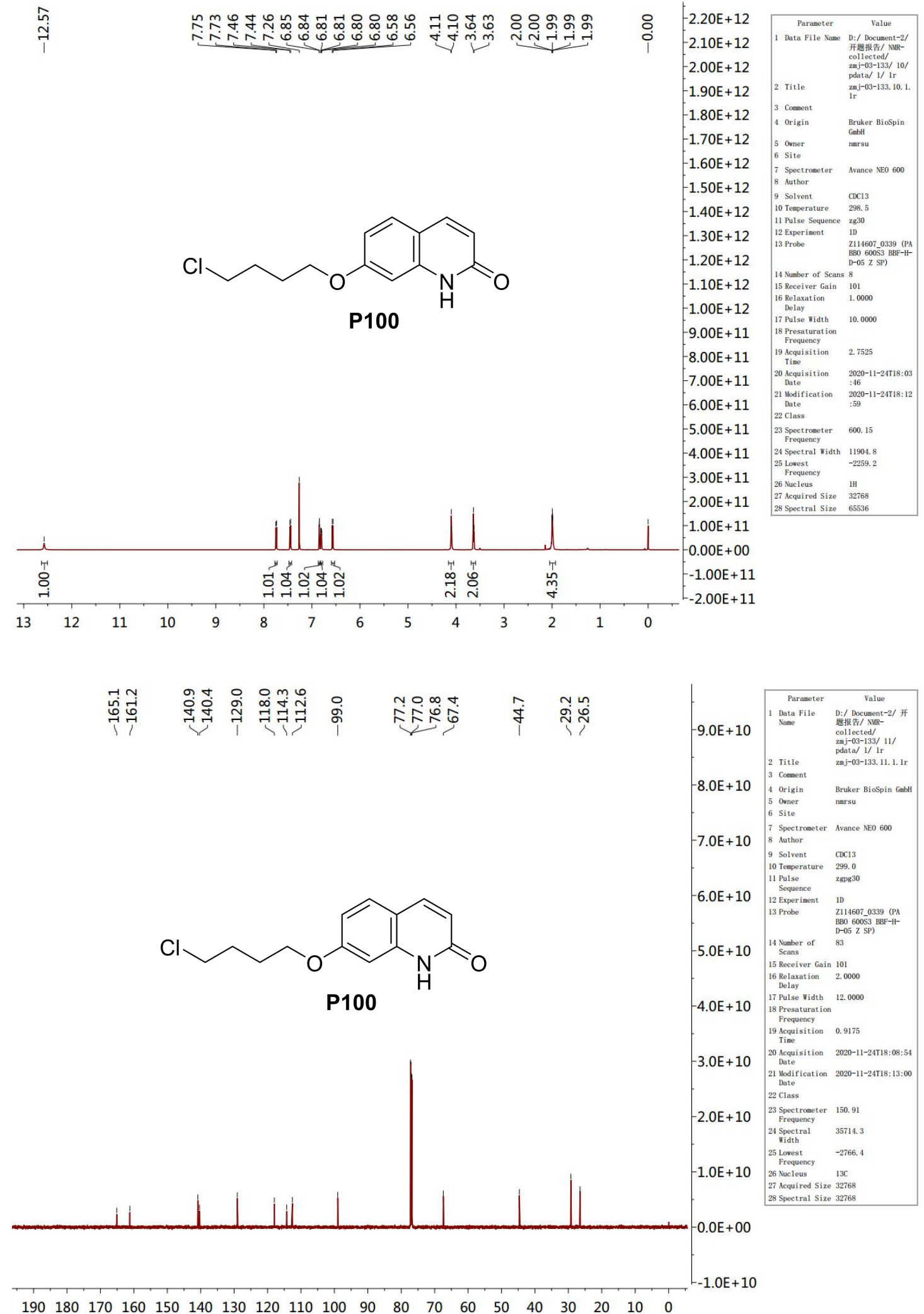